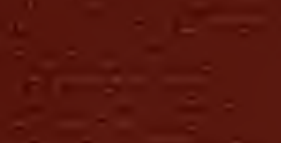




\section{Columbia alniversity}

in the City of $\mathbf{3 e w}$ 思ork

LIBRARY

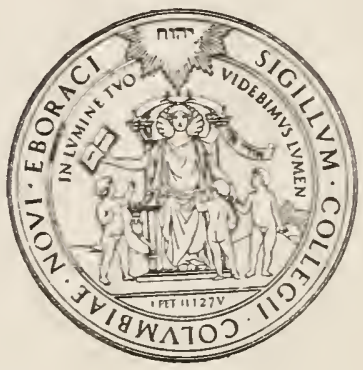








\title{
PHYTOGRAPHIA
}

\author{
OU \\ BOTANICA BRASILEIRA
}




\section{A' VENDA NA MESMA LIVRARIA}

AlMADA PINTO (J. de).-Diceionario de Botanica Brasileira, ou compendio dos vegetaes do Brazil, tanto indigenas como acclimados, contendo: una descripção scientifica de cada familia a que pertencem, e outra vulgar, ao alcance de qualquer intelligencia, seu emprego e differentes denominações nas diversas provincias du Inperio. as propriedades medicas e venenosas, sua utilidade nas artes, industria, economia domestica, e na veterinaria. 1 gresso v.

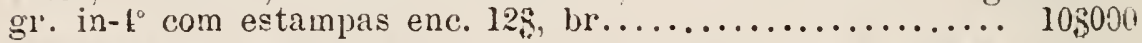

Es W'TOP. ao Dr. A. C. de Miranda Azevedo. $1 \mathrm{v}$. in $-8^{\circ} \mathrm{br} . \ldots \ldots \ldots . .15000$

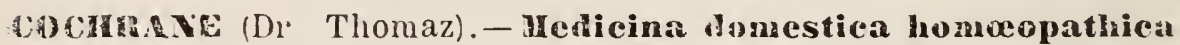
ou Guia pratica da arte de curar ho neopathicamente, contendo tudo quanto de mais util se póde encor: 'ar' nos autores homœopa-

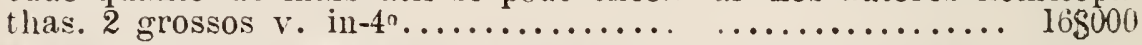

CWr..2 (Eugène). - Mychiene pratica ds. paizes quentes, ou indagações das cousas acerca das causas c tratamento das molestias destas regiöes. $1 \mathrm{v}$. in $-4^{\circ}$ enc. $4 \$, \mathrm{br} . \ldots \ldots \ldots \ldots \ldots \ldots \ldots . \ldots 3100$

faERMON (Emilio). - Manual homoeopathico. $3^{+}$edição correcta e augmentada com um pequeno tratado das molestias de pelle e com a lova materia homcopathica. $1 \mathrm{v}$. in $4^{\circ} \ldots \ldots \ldots \ldots \ldots \ldots . . .49000$

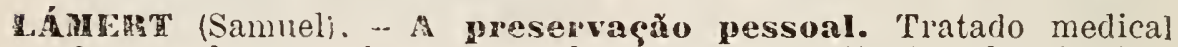
sobre as doenças dos orgãos da geraçâo resultantes dos habitos clandestinos, dos excesos dit mocidade ou do contagio, com observacōes praticas sobre a impotencia prematura. $1 \mathrm{r}$. in- $8^{\circ} \mathrm{br} . . .19000$

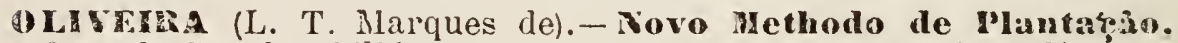
fecundação, durabilidade, estrumação e conservação do café, é extinç̧ăo das formigas. $1 \mathrm{v}$. in-12 br..................\$\$ \$50

MFYriso (D. Alvaro). - Tratado de cultura da Camna de assuear.

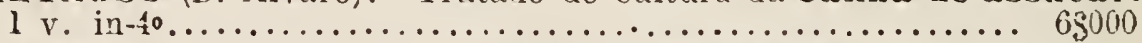

PE.PDD (F. R. Nogueira) - T Tatado de Ifedicina e outros variado= interesses do Brazil e da humanidade. $1 \mathrm{v}$. gr. in $\mathbf{4}^{0}$ enc. $4 \$$, br. 39000

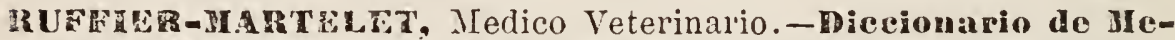
dicina IIomoropatziea Veterinaria, ou tratamento homoopathico das molestias de todos os nimaes domesticos, comprehendendo.o manual operatorio de alguns casos de cirurgia, indispensaveis para a cura de certas atrecióes, a arte dos postos, as regras de irygiene necessarias para a conservaçăo da saude dos animaes. $1 \mathrm{r}$. in-4"................................... 65000

S. dos Voretaes servlares da provincia do Rio de Janeiro e de ou tros pontos do Brazil.

Primeira paite. 1 v. e 1 atlas $1, r . . . \ldots . . . \ldots . . . . . . .45000$

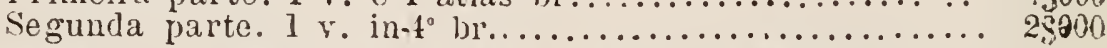

runvap (A.) - Manat do plantados de Mgodio. 1 v. in-4o enc. 6 , br................................. 5,5000

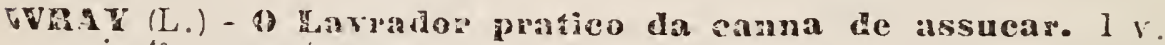
st. in $-4^{\circ}$ com estampas.......................... 123000 
B.Apriel 9, 1898 . 


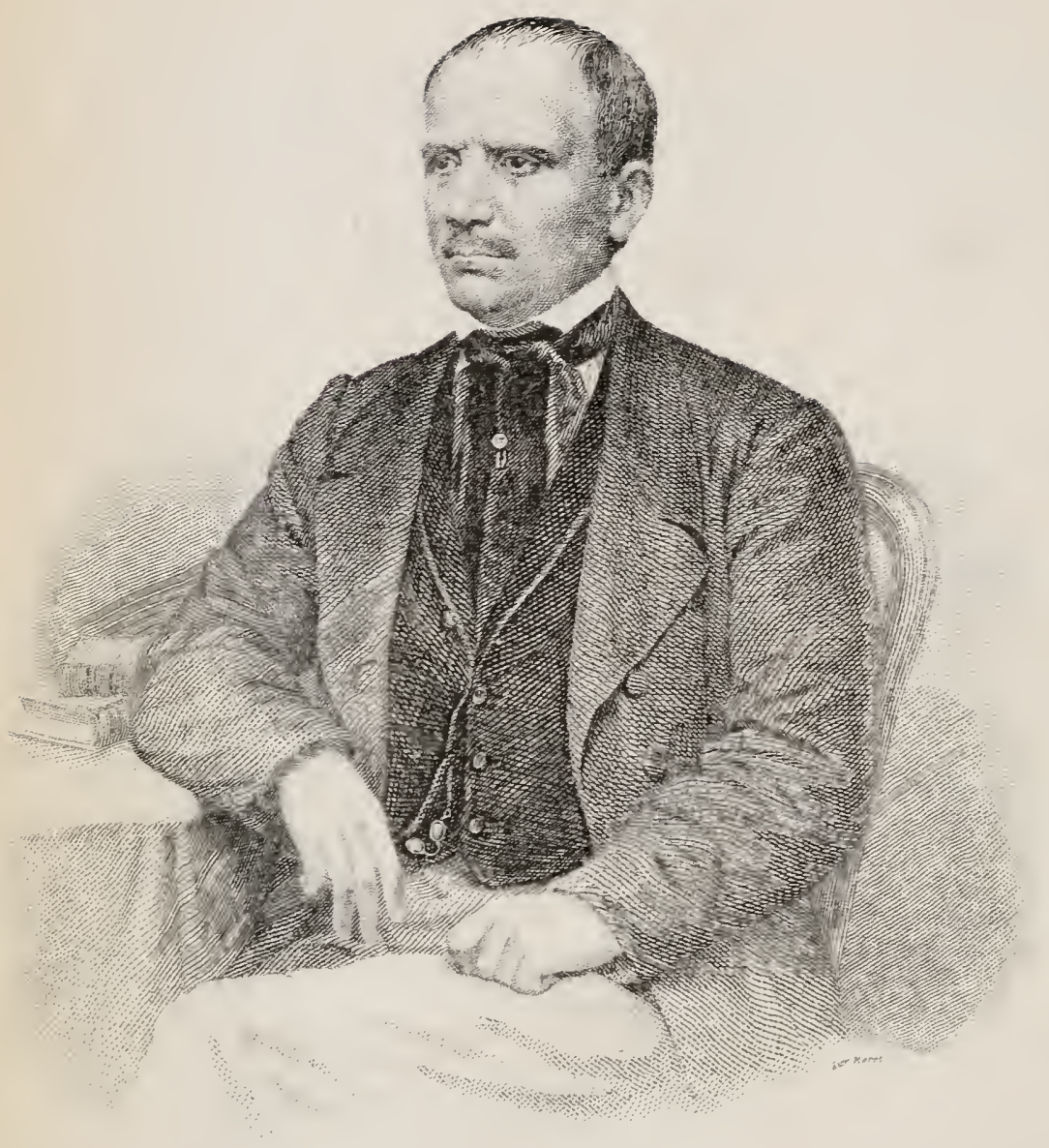

A. F. Lemart:e Cuai de $]^{\prime}$ Horloge $\mathbb{N}^{\circ}: 23$

Li: Alllo clloraers 


\title{
PHYTOGRAPHIA
}

ov

\section{BOTANICA BRASILEIRA}

\author{
APPLICADA
}

\section{a MEDICINA, ÁS ARTES E Á INDUSTRIA}

Séguida de um supplemento de materia medica, inclusive as planias

conhecidas e applicadas pelos indios em suas enfermidades

$$
\text { Drx Melelo Moraes }
$$

(NATLRAL DA CIDADE DAS ALAGÒAS)

EA-DEPUTADO i ASSEMBLEA GERAL LEGISLATIVA DO IMPERIO WO BRASI,

E ALTOR IE MUITAS OBRAS DE MEDICINA,

DE SCIENCIAS, DE HISTORIA DO BRASII, E DE LITTERATTRA

Eu d'esta gloria só fico contente

Que a minha terra amsi e a minha gente.

Ferremsu, Poesius Lusiturus

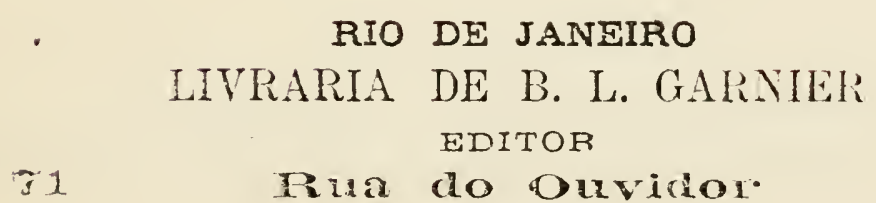

$\overline{1881}$ 


\section{2}

\section{ADVERTENCIA}

Na pag. xxr, ga linha, onde se lè-Lamento-lhe a morte, lear-se - Lamenta-se-lhe a morte, etc. 


\section{A0 LEITOR}

Aproveitando os intervallos que, me ficavam de meus estudos medicos, litterarios, historicos e scientificos, para investigar e colleccionar as riquezas vegetaes da nossa espleadida e prestimosa Flora, reconheci, que só nos falta a mĩo industriosa do homem, para tirar todo o proveito das riquezas naturaes, que a bemfizeja Mão do Altissimo, com benignidade nos dadivou.

o Brasil é, sem contestação, o mais feliz de todos os paizes do globo terraqueo, porque é bafejadı duas rezes em cada anno, pelo pai da creaçĩo, que directamente embebenrlo-lhe os effluvios de seus raios, não só the purifica a atmosphera, como fecunda-lhe - sólo, dando-lhe força para a prorluccĩo. e vigor á natureza rreada.

Sabe-se que, cada uma regiĩo do globo, conforme a latitude, tem os terrenos e climas, differenças sensiveis, devidas ao maior, ou menor dardejamento dos raios solares, seu gráu de calor, e sequidio; mator ou menor deposito de electricidade e magnetismo; maior ou menor abundancia de agoas pluveo-fluviacs. Nestas circumstancias, variaudo a atmosphera em sua humidade ou sequidáo, tambem variam as correntes electricas e magneticas, rirecçĩo dos ventos, e a sua periodicidade.

Em consequencia d'estas circumstancias, a regetação não é do mesmo modo; sendo carda regetal, de propriedlarles differentes, 
tem necessidale de estudos reflectidos, em relação ás vantagens que podem resultar em proveito da humanidade: mórmente em um paiz como o nosso, em que temos plantas, que nos dá:-pão, sul. azeite, leite, para o café, vinho. vinagre, adubos, para as comidas, fructas e agua potavel: pamno para cobrir o corpo, e sabão nutujal, para laval-o; prpel para a escripta; balsamo paracurar as feridas, modicunentos para combater os males, perfumes para os regalos, e cobertura para nos abrigar das inclemencias do tempo.

Não sendo os climas iguaes. a creação vegetal, necessariamente deve experimentar modificações, conforme as circumstancias locaes: todavia, a vegetação do Brasil é a que ostenta mais luxo. mais rida, e mais variados prestimos, sendo cada vegetal um jarlim; mas, infelizmente, é tambem a que tem sido menos estudada, e por isso menos apreciada, e desoracadamente destruida pela ambicão dos homens, e deleixo dos gorernos.

o que se sabe da nossa Fiora, em relação á medicina. com poucas excepçóes é tudo empirico, e foi referido pelo Jesuita Padre José de Anchieta, Gabriel Śaros, e pelo chronista Simão de Vasconcellos. os naturalistas que mais se occuparam l'ella. foram: Guilherne Pison e Jorge Mucgrave, qu acompanharam ao Brasil, o principe Mauricio, conde de Nassau, em 23 de Janeiro de 1637, onde escreveram a sua Historia Natural, e João Vigier, unicos que possuimos, dos tempos primitiros do Brasil, e depois o I)r. Alexandre Rodivigues F'erreira, o Dr. Martius, Saint-Hilaire, e o Di. Lacerda, no Maranhão. (')

o Dr. Lacerda, fez estudos especiaes em si, em relação á therapeutica; e os seus manusuriptos estão na Bibliotheca Publica do Rio de Janeiro, bem conservados. Alli tambem existem muitos trabalhos do benemerit, Dr. Lacerda, a respeito da Zoologia brasileira, e, ben que muitos por acabar, seria de granke ntilidade, se lossem devidamente colleccionados.

Felizmente dos trabalhos botanicos do Dr. Lacerda, eu os aproveitei, em relação á therapautica rulgar.

(1) Devemos ao Dr. Quintanilha, Barão de Paquetá, possuirmos os trabalhos do Dr. Lacerda, que, sem duvida, se perderiam no Marauhão, se não fosse a solicitude d'este amigo nosso, de honrada memoria. 
o Dir. José de Godoy Torres, fez um bonito estudo sobre as virtudes das plantas medicinaes da provincia de Minas-Geraes, que publicou no periodico o Patriota, do Brigadeiro Manoel Ferreira de Araujo, impresso no Rio de Janeiro em 1813, que eu tambem aproveitei. O Dr. Bem udino Antonio Gomes, fez estudos sobre a Ipecacuanha, a Anda-assi, e outras plantas nossas, e de que tenho conhecimento.

o Dr. Manoel Joaquim Henrique de Paiva, deixou um importantissimo manuscripto, sobre a materia medica brasileiro, que se perdeu parte na Bahia e parte no Rio de Janeiro. D'este sabio medico e naturalista, eu possuo os seus escriptos especiaes a respeito da Jalapr, Mucunan, e Guaxima.

José IIonteiro de Carvalho, igualmente se occupou das plantas do Brasil.

o Dr. Arruda da Camara, muitos estudos fez a respeito dos prestimos medicinaes das plantas do Brasil, e particularmente do herbario de Pernambuco, e Alagôas, que felizmente foram aproveitados pelo pharmaceutico Joaquim de Almeida Pinto, no seu interessante Diccionario de botanica brasileira, que não teve no Rio de Janeiro o acolhimento que desejaramos, porque um bom numero de exemplares, foram vendidos a pezo aos taberneiros, como papel de embrulho!!

O Di. Peckolt, intelligente chimico. fez analyse de uma porção de plantas brasileiras, e publicou em 1868 os seus interessantes trabalhos. O 1 ). Cheinoviz no sell Diccionario e formulario medicos, e o $D r$. Langaard no seu Diccionario de Medicina, trátam de inuitas plantas nossas em relação á medicina pratica.

A Flora Fluminense do celebre Franciscano Frei José Marianno da Conceição Vellnso, que se mandon gravar e imprimir em Pariz, por conta do Estado, com cujas estampas se gastaram um milhão de cruzados (mais de dous milhões de francos) pouco se distribuio, porque foram abandonadas em Pariz, e alli serviram para forrar as barretinas dos soldados francezes, e a parte que veio para o Rio de Janeiro, foi atirada no pavimento terreo da Secretaria da Justiça, onde muitas estampas apodreceram, e o resto foi vendido, para com ellas se fabricar papel de embrulho. (Vide adiante Flora Fluminense.) 
O illustrado Dr. Nicolcio Moreira, publicou um interessante livro sobre a materia medic: nacional.

Não obstante o desanimo e a indifferença, que reina entre nós, ainda temos alguns homens estudiosos, como o modesto Dr. Glaziou que investiga com interesse as riquezas da nossa Flora; bem como o Dr. Caminhoca, o Dr. Nogueira da Gaina, o Dr. Ladislau Netto, o Dr. Lacerda e o Sr. Barbosa Rodrigues, a quem o senado brasileiro, negou o auxilio votado pela Camara temporaria, para a impressão da sua magnifica obra, a respeito das orchideas.

Os trabalhos botanicos do meu fallecido amigo, o sabio Conselheiro Freire Allemão Cisneiro, (') estão por imprimir, e mesmo não sei onde elles param. Igualmente acontece com os do sabio $\mathrm{Fr}$. Custodio Alves Serrão, e Fr. Leandro do Sacramento, porque nada entre nós se aprecia, a não ser o papel moeda do thesouro nacional.

Muito deve a materia medica brasileira aos illustrados Drs. Merat e De Lens, que assás a investigaram, para enriquecer o seu Diccionario Universal de Materia Medica.

No entanto o que é digno de reparo é, que tendo nós duas Escholas medicas, e uma Academia de Medicina, todas subven. cionadas pelos cofres publicos, e um grande numero de pharmaceuticos, não se occupem particularmente, com as experiencias da nossa profusa, prestimosa, e admiravel Flora, para se servirem com preferencia das plantas alterarlas, e ás vezes podres, que nos mandam da Europa. ( $\left.{ }^{2}\right)$

o Reverendo Conego Francisco Bernardino de Snuza, aproveitando-se de alguns estudos do Dr. Silva Castro, e de outros, e mesmo esclarecimentos dados por curiosos, nos o Tereceu a noticia de um herbario usado no Pará e Amazonas, no seu precioso escripto Commissão do Madeira, Pará e Amazonas. De todus elles

(1) Vid. a sua Biographia, escripta e publicada por mim.

(2) Felizmente a sociedade medica fluminense, fundada em 7 de Junho de 1833, possue illustracões notaveis, como os Drs. Emilio Joaquim da Silva Maia, Sigeaud, De-Simoni, Paula Candido, Freire Allemão Cisneiro, Meirelles e outros, que creando o Semanario da Saude Publica em 1835, o substituiram pela Revista Hedica Fluminense, ambas impressas na typographia de Paula Brito, na praça da Co:stituição n. 5l, cheia de luminosos escriptos sobre Botanica medica, hygiene e observações medicas, etc. 
me utilisei, em proveito da medicina em geral, e da homœopathia em particular.

o que muito convém, é que se estude o paiz, suas localidades, sua athmosphera nas phases do anno, (1) os ventos, e as molestias proprias dos logares; a natureza, e causas das qui appareceram, desde a descoberta do Brasil, até á ultima epidemia, que tantas vidas levou comsigo; de todas ellas a Historia Patria faz memoria, em suas differentes epochas, mencionando os principaes symptomas de cada uma, e mesmo lembrando os meios therapeuticos de que lançaram mâo os medicos, e curiosos do tempo, em proveito da salvaçãu publica. Nada d'isto se tem feito actualmente, porque no Brasil, em geral, os medicos receitam pelos formularios de Pariz.

No Rio de Janeiro, desde a fundação da Cidade, nos aterrados pantanaes que existiam, grassavam molestias endemicas, e epidemicas, e uma enfermidade conhecida pelo nome de Erysipela, que ás vezes mata em 48 horas: a Camara Municipal, consultou aos medicos em 1798, e estes attribuiam o mal a causas diversas, que convinha removel-as, $\left(^{2}\right)$ e até hoje nada se fez; porque no Rio de Janeiro, ao que menos importancia se dá, é á saude publica, e á segurança individual. $\left({ }^{3}\right)$

Mais tarde, quando esta geração descrente, folgasuna, e indifferente desapparecer, as vindouras, praguejando-a, se empenharão com sincero interesse, pelo engrandecimento d'este abençoado territorio, onde tudo o que é natureza, é admiravel e grandioso, e só pygmeu o homem!

O homem do futuio, contemplando a natureza esplendida, e magnifica do Brasil, procurará pela intelligencia, e pelo trabalho, elevar-se, collocando o Brasil no logar que lhe compete, como o paiz o mais rico, e o melhor aquinhoado das grandezas de Deos.

Eu o espero; porque confio nos homens do futuro...

(1) Vid. o meu Diccionario de Medicina Homœopathica. Artigo - ar atmospherico.

${ }^{(2)}$ Vid. a minha Corographia Hist. tomo 5. ${ }^{\circ}$ pag. 438 e seguintes.

(3) O Brasil com 57 annos de separacão politica, tendo uma alluvião de leis e regulamentos, ainda não possue uma loi de Policia Correccional, para pôr termo á vagabundagem. 



\section{HISTORIA DA FLORA FLUNINES SE}

No Relatorio do ministerio da Agricultura de 1854, se lê:- Flora Fluminense. - O logar distincto, que na republica das latras patrias, occupa com toda a justiça o fallecido monge Fr. Marianno da Conceisano Velloso, foi-lhe principalmente marcado pela sua obra de botanica, que elle intitulou-Flora Fluminensis. - Entretanto esta obra, de incontestavel merito, acha-se em grande parte por imprimir, e a parte impiessa é hoje tão rara, que não perritte aos homens da sciencia obterem facilmente um cxemplar. Ponderando estas e outras ponderasões, que por certo vos não escaparão, dei as providencias, para que se faça uma impressão de toda a obra por conta do governo imperial.

Parece-me que o governo do Brasil, não tem conhecimento da historia do paiz, que dirige, e por isso falla ao corpo legislativo, pelo modo que acima transcrevi. Existindo na Bibliotheca publica do Rio de Janeiro o manuscripto da Flora Fluminense, acabado em 1790, por Frei José Marianno dạ Conceição Velloso, religioso Franciscano, nitural de Minas Geraes, nascido em 1742, pertencente ao convento de Santo Antonio do Rio de Janeiro, onde falleceu do dia 13 á 14 de Junho de 1811, e jaz sepultado em uma das carneiras do claustro do seu convento, em cuja obra collaboraram Fr. Francisco Solano, Fr. Antonio de Santa Ignez, Francisco Manoel da Silva Mello, José Corrêa Rangel, José 
Aniceto Rangel, João Francisco Xaviel, Joaquim de Souza Marcos, Firmino José do Amaral, José Gonçalves e Antonio Alvares, (1) aconteceu que tomando conta da Bibliotheca publica do Rio de Janeiro, $\mathrm{Fr}^{2}$. Antonio de Arrabida, mestre e valido do primeiro Imperador, encontrasse alli, o precioso manuscripto da Flora Fluminense, mandado fazer pelo benemerito vice-rei Luiz de Vasconcellos e Soura, depois visconde de Figueiró, que se empenhara, pelo engrandecimento e esplendor da capital do Rio de Janeiro; o qual prestou ao sabio religioso, e naturalista brasileiro, todos os auxilios, á levar ao fim tão grandiosa obra. $\left({ }^{2}\right)$

Fr. Antonio de Arrabida, enthusiasmado por ter achado o precioso manuscripto, tão gabado pelos sabios, que julgava perdido, depois de o lêr e corrigir, e confial-o á revisão do sabio Dr. João da Silveira Caldeira, conheceu estar completo, quanto ás estampas; porém, vio que lhe faltavam algumas descripções; mas não obstante, reconhecendo que era digno de publicidade, pela importancia do assumpto, e bem acabado do trabalho; aconselhou ao governo imp rial, de mandar imprimir a obra; e muito se empenhou. para que ella apparecesse como desejava; mandando-

(1) Antonio Alvares, habilissimo pintor, toi quem desenhou a bandeira republicana da revolucĩo de 6 de Marco de 181\%, em Pernambuco, cujo desenho original o possui, e tirou os retratos dos antores da revolucão. Este pintor celebre, natural do Rio de Janeiro, estando em Pernambuco, em 1817, passou por uma das maiores decepcões: que foi :- tomando conta do governo de Pernambuco. o famigerado ladião Rodrigo Lobo, chefe das forcas navaes do governo de el-rei, depois de haver saqueado a praca do Recife de Pernambuco, deu ordem para que fussem surrados os mulatos c negios, que se involveram na revolucão; e Antonio Alvares, bem que já mui disfarçado, foi comprehendido na surra, por saber Rodrigo Lobo, ter elle pintado a bandeira. e feito os retratos dos l'evoltosos; e pelo que. sendo prêso, para ser castigado; pôde escapar da surra, por se haver abracado com o retrato de el-rei D. João VI, que por cautela trazia comsigo. Na historia da revolução de 6 de Março, que publiquei no meu Brasil Historico, e que tambem memoro na minha Chronica Geral, que estou impriinindo, fallo sobre este e outros acontecimentos, com documentos originaes iginorados, pela maxima parte, dos brasileiros.

(2) Não aconteceu o mesmo com o Sr Barbosa Rodrigues, a quem o senado brasileiro, negou o auxilio para a impressĩo da sua obra sobre as Orchideas, magnificamente dusenhada. 
se á Pariz os desenhos, para serem lithographados na officina de Lastoyrie, como a mais conceituada do tempo. Emquanto se apromptaram em Pariz as estampas, Fr. Antonio de Arrabida, depois bispo de Anemuria, fazia imprimir ina Typographia Nacional, o texto latıno em 1825 . O que me não resta durida, é que, se mandando as estampas para França, deu-se comeco em Pariz ao trabalho da gravura, montando-se alli, uma repartição, onde o Estado despendeu um mithão de cinsados, (mais de dous milhões de francos). afim de divulgar o precioso monumento, que tanta gloria nos dava.

Acabada a obra, consta-me, que se mandaram para o Rio de Janeiro 500 exemplares; ficando em Pariz 1,500; os quaes, não sendo reclamados, foram entregues, não sei a quem, e dos quaes salvaram-se algumas colleccões; e por fim, se reconlecendo, que essas estampas não eram mais procuradas, foram vendidas ou dadas, ao chapeleiro que fornecia barretinas, para o exercito francez, o qual forrou com as estampas, as que estava fazendo para os soldados do exercito.

Os 500 exemplares, que vieram para o Rio de Janeiro, foram parar no saguão da secretaria de Estado dos negocios da justiça, (em frente do Passeio Publico), onde permaneceram apodrecendo, pela humidade; fazendo-se presente de alguns exemplares, a uma ou outra pessoa, que pedia.-Ninguem subscreveu á obra do famoso religioso, e naturalista mineiro, á excepcão do tenentegeneral Joaquim de Oliveira Alves (ministro da ganerra em 1822.)

D'este mesmo sabio franciscano, vieram para o Brasil, de Lishoa, um grande numero de exemplares da sua importante obra O fazendeiro do Brasil, e outras impressas em Lisboa, na Typographia do Arco do Cego; e consta-me, que por ordem superior, sendo repartida por varias capitanias, á serem distribuidas pelos fazendeiros, nunca sakiram das secretarias dos governos, em modo que se inutilisaram. ou antes foram bem aproveitadas pelos tres famosos litteratos que temos, que são Mrs. Cupin, Trą e Bichá, (isto é, cupm. traça e bicho.)

Memoro estes factos, porque o que tenho visto, e o que sei, depoem extraordinariamente contra as varias administrações officiaes, que tem tido o Brasil, por que tcdas escas administracões do Brasil, tem sido confiadas í Eschola de direito, sem 
experiencia, e nem pratica, que só tem servido para empobrecer, desacreditar e desmoralisar o paiz. Todos os governos estrangeiros protegem as letras patrias, porque conhecem que pelo progresso d'ellas, é que sio coniderados; o governo do Brasil segue outra via. porque só farorece as tretas; e haja rista, o que se tem dado n'estes ultimos trinta annos, em que o thesouro publico tem sido assaltado desapierladamente.

o governo portuguez, não obstante os seus poucos recursos, é sempre o primeiro subscriptor voluntario das obras, que se imprimem no reino; e eu escrevendo a historia do Brasil, com a qual tenho desnendido uma somma avultada, rou assim consumindo o que ganlic, pela minha profissão de medico, emquanto que o governo do Brasil não me subscreveu um exemplar sequer, como expressão de animação. (1) Desejando imprimir o meu ficcionario de Medicina, etc., pedi á Assembléa Geral Legislatira, que me coadjurasse, e passando o meu manuscripto, por todos os tramites, porque passam as cousas nas commissões da assembléa, aconteceu, que se consignando uma somma, para a impressão do livro, na terceira discussăo cahio o projecto; e em seguida passou a Lei, que autorisava o gorerino, a despender vinte e dous contos de réis, para a vinda de camellos, para o Brasil, que de facto vieram e foram para o Ceará, onde todos morreram.

Nĩo me admira o que se pratica com a impressĩo dos livros uteis, quando temos um avi o do ministerio da Fazenda de 18 de Janeiro de 1836. mandando entregar ao da Guerra-, todo o papel impresso, que existia na Typograplia Nacional, para ser aproveitado na filbricacão do cartuxame:- e realniente entregou-se, uma extraordinaria quantidade de arrobas de papel impresso, indo como inutil a Historia do Brasil do sabio Visconde do Cayru, as Memorias do padre Luiz Goncalves, os Annaes do liin de Janeiro do Dr. Balthazar da Silva Lisboa; as Memorias

(1) Recorıi á Camara Municipal de 1878, a Assembléa Geral Lesislativa, aos ministerios do imperio e da agricultura, e, sobretudo ao imperador o Senhor D. Pedro Il, em uma carta, para me abril a Typographia Nacional, afim de contiuuar a imprimir a Chronice do Imperio do Brasil, enviando-lhe o que já estava impresso, nem resposta me deu! 
do Rio de Janeiro de Monsenhor Pizarro; as de Fr. Leandro do Sacramento, sobre a cultura do chá, e outras obras de merecimento, impressas na Typographia Nacional, desde 1808 á 1836 !!!

No dia 14 de Janeiro de 1861, a Typographia Nacional annunciou á venda em leilão de 2,950 arrobas de impressos, indo entre elles alguns exemplares da Flora Fluminense.

Por outro aviso do governo imperial, mandou-se vender, como papel sujo, os exemplares existentes, da Flora Iluminense, á Fabrica de papel de Petropolis, cujo prolucto liquido, não entrou para o Thesouro, segundo constou, porque a fabrica fallio. E' digno de reparo, e contrista o coração dizer-se, que só no Brasil, se manda como papel sujo, pesar-se no Trapiche Mauá, o producto da intelligencia, e da arte, adquirido com tantas fadigas e trabalho, com o qual o Estado gastou um milhão de cruzados, para com elle fazer-se papel de embrulho!!! Um homem de bom senso, estando presente ao pesamento da Flora Fluminense, no mencionado Trapiche Mauá, sito no largo da Prainha, disse penalisado:-N'este largo foi assassinado Racticlif por amar a liberdade, para satisfazer o despotismo feroz de D. Pedro I; no mesmo logar. é assassinado o producto da intelligencia, pela ignorancia dos que governam...

Seria longo memorar factos, que tên passado desapercebidos, porém que os conservo, para justiticar o que escrevo: mas apenas lembrarei o seguinte:- Năo existindo nos Archivos da Secretaria de Estado dos Negocios da Agricultura, um só documento official, sobre as nossas minas de ouro, prata, cobre, diamantes, etc., e nem ácerca dos estabelecimentos mineralogicos, e nem mesmo sobre a Phytographia brasileira: tendo promptas duas obras, relativas a estes assumptos; isto é, a historia da descoberta das minas desle 1693, casas de moeda, fundições, e regimentos d'ellas, desde os tempos coloniaes até agøra, e tudo documentado, com a legislação e providencias respectivas: a historia da nossa arbologia, "em relação a medicina, as artes e a sciencia, (1) mencionallo a creaçĩo do Juizo

(1) É a presente obra que vendi as edicoes a Mr. Garnier, que a edita com todo o interesse. 
conservador das Mattas em 1796, para que as florestas do Brasil não fossem continuadamente devastadas, pelo vandalismo do machado, e nem devoradas nas chammas, atiçadas pela maldade dos homens, todos esses trabalhos, pelos quaes eu não queria paga, mas que fossem impressos á custa do Estado, na Typographia Nacional, os offereci ao ministro de agricultura do gabinete de 25 de Junho de 1876, o bacharel em direito José Thomaz Coelho de Almeida, e teve a petição que lhe dirigi, o descarado e sediço despacho:- Não tem logar!

No entanto gastam-se centenas de contos de réis, com os monstruosos relatorios dos ministros, com uma alluvião de avulsos impressos das camaras, e com memorias de commissões inuteis, e com os descommunaes volumes da estatistica do Imperio, infiel e mal feita, e com a impressão da celebre carta geral to Imperio, e outras bagaceiras iguaes!!! (1)

Entre nós, os homens estudiosos são pobres; quem podia auxiliar as lettras, eram os ricos; infelizmente estes, com poucas excepções, olham para um livro com horror, e não lêm,

(1) Agora (1881) a secretaria da agricultura, commercio e obras publicas acaba de mostrar praticamente, que não conhece a topographia do Rio de Janeiro, porque aventando-se a questão sobre a canalisação das aguas do Rio S. Pedro, que náo são propriedade de ninguem. em proveito da populaç̃o da capital do Imperio, depois de muito barulho, nada produzıo, devendo lembrar-se o ministro, que ainda estando em vigor no Brazil as leis civis portuguezas, sem ir de encontro ao $\$ 22$ do art. 179 da constituicão, a resolução de 17 de Agosto de 1775, fundada no bom senso pratico, expressamente determina que o dominio da agua que nasce em predio particular, pertence ao senhor d'este, que depois de usar d'ella, ñ̃to póde desvial-a do seu curso natural, em prejuizo dos predios inferiores.

Quando en 1761 se arremataram n'esta cidade do Rio de Janeiro as terras pertencentes aos extinctos Jesuitas. nas escripturas de transferencias de propriedade, eram garantidas as aguas que por ellas passavam em beneficio dos proprietarios que as compravam.

Se a secretaria tivesse conhecimento da topographia da pro vincia do Rio de Janeiro. logo que sentisse pressão no proprietario da fazenda, por onde passa o mencionado rio S. Pedro; não querendo tambem fazer effectivo o Alvará acima lembrado, mandaria a serra do Tingua, canalisar as agnas das cachoeiras, que o proprio ministro com os seus proprios olhos vio, abundantissimas em aguas, e trazel-as aos encanamentos geraes da cidade. 
porque o tempo não lhes chega, para cultivar a intelligencia; e como nenhum valor dão a ellas, em vez de livros, atiram-se por todos os meios á leitura dos bilbetes do Thesouro publico, por ser de mais facil e de melhor comprehensão, sem se importarem coin o que disse Filinto Elysio, da riqueza embrutecida:

Não vive o nescio, bem que a vida alongue;

Viver é tomar gosto á formosura

Ao esplendido universo;

E não se gosta o que se não conhece. 



\title{
DE-SE PROTEGgIO I IGREULTURA
}

\author{
Divina Agricultura, eu palpo, en rejo \\ Teus dons celestiacs, o os teis presentes \\ Ingenuos são, da ingenua Natireza: \\ Se ha dias puros, os mortaes t'os devem: \\ $\mathrm{Tu}$ só nos lás riquezas sem remorsos, \\ Sem ancias o prazer; tuas conquistas. \\ Sĩo conquistas de paz, virtude as doiras : \\ Não devidas ao favor das armas, \\ Nem se comprão com lagriras de sangue, \\ Feliz quem póde em solitario asylo. \\ Esquecer-se do mundo, e dos ingratos. \\ Dormir tranquillo á sombra do arvoredo. \\ E tranquillo acordar! Quem ama o campo, \\ Quem ama a Agricultira, ama a virtule.
}

$$
\text { Macedo-Mediluç̃̃o. }
$$

Quando considero o nosso viver social, e politico, en relaçio ac estado prospero das nações da America, e principalmente dos Estarlos-Unidos, onde as sciencias, as artes, a industria, a navegação, e a agricultura florescem espantosamente, rejo que este estado, dependeu da qualidade das sementes, que deixaram plan- 
tadas, os fundarores d'esses Estadns, principalmonte Washington, que lepois de 8 annos de uma guerra sanguinolenta, concluida, pela capitulacĩo de 1781, em Cornwalles, cuja paz, foi assignada, em Pariz, á 3 de Setembro de 1783, reconstruindo o seu paiz, dispoz os negocios do Estado em tal caminho, que começando a sua populaçĩo, com dons milhũes e quinhentos mil habitantes, hoje campêa, com perto de cincoenta e um milhões de almas! Seus campos roteados, suas fabricas, e suas invencões espantosas, admiram ao mundo com o seu progresso!

o Canad ́, com a sua agricultura, abastece de farinha de trigo, á differentes paizes. Isto prova, que os govarnos são estabelecidos para vantagem dos governados, e não (los governantes, como nos tem acontecido, e nos vai acontecendo, e acontecera, porque entre nós do bem publico, e do finturo do paiz, ninguem trata; e por isso antevejo, que não serí n'estas seis oll oito geraçoes, que o Brasil ha de primar como grande Naçĩo. A agricultura, que é a principal riqueza do paiz, vive entre nós amortesida, por falta de estimulos; e o commercio sem ella, não se póde representar; porque não havendo abunlancia de geneios agricolas, para permutar com os productos estrangeiros, obriga o nosso commercio a comprar fiado ao imrortador, para vender a dinheiro ao consummidor. (')

o Sr. Jose Maria da Costa e Silva, no seu instructivo Poema o Passeio, ouvindo a voz la patria, diz que ella se ergue, e assim se exprime :

Do abandono, e oppressão da Agricultura, Naseem em grande parte os meus desastres!

Acudir com desvello aos seus clamores,

E' crime evitar, dispôr virtudes.

Da hedionda pobreza o torvo aspecto,

Faz q ie dos campos ás cidades corram

Os e.xames de Juvens d'ambos os sexos,

Que o probioso pabulo demandam,

Em vil mendicidade, em torpes vicios!

(1) Vide a minha corographia Historica Tomo $5^{\circ}$ ou o tomo $1^{\circ}$ da $2^{2}$ parte, o capitulo Tribunal do commercio. 
Fazei soar bem alto aos pés do Throno, Patriotica voz! Leis previdentes Extingam, pelo menos aligeirem, Encargos, cujo peso o arado quebra;

Tornar os lavradores venturosos, E' felizes tornar as classes todas, Das suas producções a industria vive. Prospéra com ellas o commercio ; vinga, Cresce a população, que onde acha o homem, Os meios de viver, facil propaga, Qual planta, que enfuada em chão mesquinho.

A ubertoso terreno transplantada Subito arreiga, cresce, e fructifica! .. Com permanente Exercito que rouba, Os braços á Lavoura, e que consome Sem produzir, para que é bom ? as armas Nunca estranharam mãos á enchada effeitos;

Se injustos inimigos nos invadem, Todos os cidadãos serão soldados, Mais bravos, mais fieis se a propriedade, Imitarem aos estimulos da gloria.

De Roma as Legiões sempre invenciveis, Defendiam seus bens servindo a Patria; Fora um crime admittir hom?m sem censo A'milicia, então honra, hoje violencias, Como Roma os Guerreiros, finda a lucta, Mandai de novo cultivar seus campos.

As nações mais opulentas, são as que se avantajam na Agricultura, nas Artes, e na Industria, e por isso, são tambem as que mais depressa reparam as suas perdas; e os governos que as protegem, além de tirar d'ellas todo o proveito possivel, dá emprego aos seus concidadãos ( $\left.{ }^{1}\right)$, que por falta de recursos, procuram os logares

(1) Suicidio.-Ante-hontem, pouco depois de escurecer, foi encontrado sem sentidos no Passeio Publico um homem que, a despeito dos promptos soccorros que the prestou logo o Dr. Calvet, falleceu ás 8 horas da noite no hospital da. Misericordia, para onde havia sido remettido. 
publicos da Nação, para terem meios de vida. Prolnovendo a Agricultura, e protegendo a indistria manufactureira, e concorrendo para o aperfeiçoameato d'ellas, serño preferidos os productos nacionaes as estranhos, que nos chegan de fóra. Cromwell, protector rla republica ingleza, depois de fazer decapitar em 1649 a Carlos I, e ahater o poder maritımo da Hollanda, de posse do supremo mando da Inglaterra, l'ez respeitar as leis inglezas, e prosperar o commercio, fazendo apparecer em l(65l, o regulamento (Act de Navegação) relativo á marinha e ao commercio, muitas vezes modificado, e definitivamente abolido em 1847, no ininisterio de Lord J. Russell, porque a Inglaterıa, por conveniencias politicas, não precisava mais d'elle.

Tinhamos, em tempos idon, navegação nacional de long's curso, viveiro de bons marinheiros, e pescaria, onde se empregavam milhares de homens uteis; e hoje nada d'isso temos, porque tirou-se dos nacionaes a navegação, para se entregal ao estrangeiro!

A pescaria, acabrunhada pela capitania do Porto, tem concorrido, para que um grande numero de brasileiros, nĩo tenham do que viver! A pescaria, que seria hoje um manancial de riqueza do paiz, se a tivessemos em grande escala, haveria fartura no povo, e não comprariamos o peixe estrangeiro tão caro, como diariamente nos acontece. A agricultiina prosperava, a ponto de se exportar do Brasil para a Furopa, Africa e Asia, os nossos productos, para abastecer os mercados d'essas regiões; e hoje recebemos do estran-

Suppuzera-se a principio que o iufeliz havia sido accommettido de algum ataque; mas rerificou-se depois que envenenara-se.

Em seu poder encontraram-se as seguintes linhas dirigidas ao Sr. Francisco Moreiri de Carvilho \& C.:

«Chamo-me João Rabello, filho de Perilambuco. Não procurem - motivo de minha morte. Heco apenas que mandem levar dous bahús, que estão na hospedaria d’ rua da Assembléa n. 92 e tem o distico com o meu nome, para Perıambuco, a meu irmão Camillo da Costa Rabello, murador na rua do Imperador n. 3, $2^{\circ}$ andar.

« A miseria do meu paiz é tanta, que um artista morre á fome. As officinas estão cheias de estrangeiros; eu, filho da terra, ou havia de norrer de tome ou suicidar-me, como cheguei a fazer. »

(Do Jornal do Commercio de 27 de Abril de 1881.) 
geiro inilho, farinha de trigo, (') arroz, feijão, fava, leite de vacca condensado, ovos de gallinha, vassoura de varrer casa, colheres de páo, cabıs de enchada e de machado, côco de beber agua, cascas seccas de laranjas, e caroços de marmello, para as pharmacias, pevide de melancia, para emulções, e o que é mais, a nossi mesma tapioca, a pimenta malagueta, e até, Deus Eterno, importanos capim. (alfafa) para alimentar os animaes !!!

Tinhamos industria manufactureira, e tinhamos artes; e liaja vista os inimitaveis tecidos de algodão mineiro, os ricos cobertores e rerles, fabricados nos sertões do Brasil. Os magniticos tem:los da Bahia, e aqui mesmo no Rio de Janeiro, o monumental aqueducto da Carioca, que rivalisa com o das aguas livres de Lisboa, que foram construidos pelos artistas nacionaes. Wos nossos estaleiros, annualmente cahiam ao mar, grande quantidade de embar'cações, emquanto que hojesão comprados na Europa os navios podres e imprestaveis, até para a nossa marinha de guerra!

Os artffactcs de marcenaria, de estatuaria, esculptura, os de pintura, prima vam pela perfeição, acontecendo a alguns dos nossos artistas nacionaes, deixarem escolas, e renomes duradouros. Hoje nada temos, porque se prefere'o que se fabrica no estrangeiro, embora ruim, ao que é trabalhado no paiz, em tudo melhor e mais perfeito ; e haja vista o que agora mesmo a Intendencia da marinha, acaba de pratica $r$, dando uma prova do seu nenhum patriotismo, preferindo o calçado, para os navaes, trabalhado na Europa, de pessimo material, ao da imperial fabrica de calçado de ('athiard, mais bem feito e preferivel em tudo, pela differença de $\left.100 \mathrm{rs.} \mathrm{em} \mathrm{cada} \mathrm{par!}{ }^{2}\right)$

(1) Nos tempos coloniaes, o trigo produzio tanto no Rio Grande do sul, em Santi Catharina, que viıha em grão para o Rio de Janeiro, $i$ ser moido nos moinhos do Andarahy e Carioca (vide os engenhos de moinhos na minha Chronica Geral do Imperio).

(2) O illustrado Sr. Dr. Augusto de Castro, na sua carta do Carpira de 26 de Marco de 1881, 11. 415, referindo o facto do calceado estrangeiro, preferido ao da fabrica nacional diz:

Ora aqui estí no que deu a prosa da Intendencia da marinha !...

Veio com um grande arreganho contestar as minhas asseveracres, firmando-o no parecer de um perito amicissimo, e teve logo depois por barlavento o do Sr. Queiroz (que descobrio tiras de papelão iı tal calçalo), e pela prôa o dos oito profissionaes que con- 
Este facto tão censurado pelo illustrado caipira (Dr. Augusto de Castro) folhetinista do Jornal do Commercio, (1) indignou a todos?

No entanto devendo ser o governo brasileiro, que tome a vanguarda na animacão e protecção á industria manufactureira, e artes brasileiras, éo primeiro que arma a guilhotina para a degolar!

A proposito de calçados, lembro-me, que um especulador, foi offerecer no acampamento do Paraguay, ao invicto e illustre Duque de Caxids, de immorredoura memoria, 6 mil pares de coturnos á 3\$, o par, que trouxe de Pariz, e apezar da grande necessidade que havia de calçado no Exercito, em vista da má qualidade, o nobre Duque, não os quiz por quantia alguma; porém o traficante, não desanimou; foi a Buenos Ayres, procurou protecção, e voltou com os mesmos coturnos para o Rio de Janeiro, eo governo imperial os comprou á $6 \$$, cada par ; os quaes coturnos, apezar de bene. ficiados em banhos de azeite de peixe, foram deitados ao monturo, por imprestaveis, gastando o Thesouro publico 40:000\$000, que, com os coturnos foram para o monturo!!! Em 1812 ou 1813 , houve na Bahia uma fabrica de vidros estabelecida pelo rico commerciante Francisco Ignacio de Siqueira Nobre, que desappareceu pela perseguição. Aqui mesmo no Rio de Janeiro se estabeleceram outras, que cahiram por falta de animação.

Em 1824 appareceu o suisso Meuron, natural de Lachapelle, servente, que havia sido, da fabrica de rapé em Lisboa, com uma receita da fabricação de rapé, que a obteve vendo a manipulação,

sultei, e que declararam que esse calçado é tão ruim, que nas melhores condições não póde ter mais de um mẹ de uso...

E S S. teve de metter a viola no sacco! Sirvam-lhe ao menos de lição para os outros fornecimentos, esses pobres 48:000\$ com que se pagaram, não só os primeiros 8,000 pares de sapatos contratados com a tal casa de Pariz, como os outros 8,000 da renovação do contrato... sem concurreıcia!

Agora, como já foram recebidos todos os 16,000, é aguentar a bucha caladinho! Que remedio!!

O Marquez de Maricá dizia que os moços devoram o futuro, e os velhos ruminam o passado. Vá o Sr. Intendente ruminando este contrato, Honeguer. Martius \& C., emquanto não é aberta a concurrencia, para o novo fornecimento. Sim, meu coração?

(1) Tenho em meu poder duas amostras dos mencionados calçados nacional, e o fabricado em França, que pode ser visto, para se admirar o escandalo dado nas repartições do Estado! 
por se fazer de idiota, mas diligente em cumprir as suas obrigações. Na Bahia fez as experiencias, e obtendo bons resultados, foi estabelecer a sua fabrica de rapé, no süburbio da cidade chamado Arêa Preta, e deu ao rapé a denominação do lugar da fabrica.

Exposto ao mercado agradou, e como não tinha concurrentes, pedio ao governo imperial permissão para usar da estampa, cujo especimen offerecia para involucro dos botes: em 10 de Janeiro de 18:5, o ministro Estevão Ribeiro de Rezende, depois Marquez de Valença, communicou ao presidente da Bahia, a concessão feita a Meuron, sem a comminação da pena por elle exigida, aos falsificadores. A fabrica de rapé Arêa Preta de Meuron, que ainda existe montada em grande escala, não só enriqueceu a Meuron, seu fundador, como aos seus successores.

Quanto ao commercio, elle ainda é o mesmo, que o dos tempos coloniaes, porque a nossa independencia foi uma perfeita farça politica, que deu em resultado continuarmos, como nos tempos coloniaes, á ser Portugal, Brasil e Algarves, porque ficamos pelo tratado de 29 de Agosto de 1825, de cessão voluntaria governamental e reconhecimento, com dous Imperadores pelo artigo $2^{\circ}$; em Lisboa o Sr. D. João VI rei de Portugal, e Imperador do Brasil, pagando o Brasil por isso, dous milhões de libras sterlinas, incluindo todas as pensões que Portugal pagava; e no anno seguinte de 1826, ficarmos no Rio de Janeiro com o Sr. D. Pedro I Imperador do Brasil e rei de Portugal.

No mesmo dia em que foi assignado esse tratado vergonhoso, de cessão voluntaria e reconhecimento da independencia, baixou uma circular, assignada por el-rei D. João VI, ordenando ás alfandegas do reino, e possessões ultramarinas, que os navios de procedencia do Brasil, que entrassem nos portos, e descarregassem nas alfandegas portuguezas, fossem recebidos como nacionaes. Lepols da Abdicação, em 7 de Abril de 1831, que commoveu todo o Imperio, seguiram-se as revoltas de 14 de Abril de 1832, em Pernambuco; a de Pinto Madeira, no Ceará, e os morticinios de Cuyabá ; o de Vicente de Paula, e Torres Galindo, nas Alagoas; o de 20 de Septembro de 1835, no Rio Grande do Sul ; a Vinagrada no Pará, com ramificações no Piauhy; a de 7 de Novembro de 1837, na Bahia, chamada a Sabinada; a Balaiada no Maranhão, em 1839; a de 17 de Maio e 10 de Junho em 1842, em S. Paulo e Minas- 
Geraes (1); e a de 7 de Novembro de 1848 em Pernambuco. O governo da Regencia, que foi de lutas, nada póde fazer, em proveito do commercio nacional, e nem soube aproveitar a declaração que o governo Republicano Francez de 1848, fez a todos os governos, que a republica. franceza, não reconhecia, e nem admittia os Tratados feitos com a Monarchia, para libertar o nosso commercio do art. $2^{\circ}$. do Tratado de reconhecimento da Independencia, feito com a França em 1825, que nos agrilhoou o commercio a retalho, fazendo que elle não fosse exclusivo dos naturaes do Brasil. Os liberaes patoteiros de Pernambuco, ou por ignorancia dos Tratados, com as potencias estrangeiras, no reconhecimento da furça da Independencia, para obterem popularidade, engendraram novo engodo ao povo, com a pretendida nacionalisação do commercio, que só se realisará, com a Lei geral de Nacionalisação. Subindo o Sr. D. Pedro II ao Throno Imperial Brasileiro em 1840, e não sendo, como seu pai, Imperador do Brasil e rei de Portugal, as cousas ficaram como d'antes, sómente com a differença. de ter o nosso commercio unicamente a honra do nome de Nacional, com o pessoal estrangeiro, que retalha no mercado. Como tudo isto é irrisorio e farçante, n'este paiz das pomadas!!

Com a protecção á lavoura, o commercio, a navegação a industria manufactureira, e as artes, os filhos do paiz acharão empregos, e alliviarão o Thesouro Nacional, de tantos individuos que o procuram, por não acharem onde ganhar o pão, para o sustento da vida.

0 governo, que em tudo intervem, sem detrimento dos cofres publicos, pódia convidar aos capitalistas nacionaes e estrangeiros, para estabelecerem fabricas de diversos artefactos, garantindo-lhes a concurrencia, e a protecção ; e como governo do papelorio, devia promover uma fabrica de papel nacional, porque temos materia prima, em tanta abundancia, que podemos fabricar papel, para abastecer os mercados da Europa. Na Bahia em 1840 ou 1841, se estabeleceu, proximoá capital, uma importante fabrica de papel, que manufacturava já tão bem feito, tanto na alvura, como nos de diversas côres, fabri-

(1) A historia d'esta revolta a tenho escripta em vista dos documentos officiaes, nue a $\mathrm{p}$ iblicarei em separado, como a de 7 de Norembro de 1837, na Bahia, e outras. 
cado com os troncos da bananeira, que os jornaes diarios, e os livros eram impressos com o papel da fabrica do Engenho da Conceiç̃̃o. A fabrica de papel cahio. por não ter tido protecção, o pela baixa do papel estrangeiro, com o qual não póde concorrer.

Constantemente estão os jornaes ann unciando correrias de Indios, em diversas localidades, e o nosso governo, que gasta annualmente 200:000\$000, decretados pelas camaras, ou antes tem gasto uma somma f́abulosa, com a decantada cathechese, com a qual nada tem conseguido, porque os 200:000§000 são absorvidos sem resultado algum, se seriamente se empenhasse na civilisação d'esses nossos compatriotas, chamando-os ao seio da nossa sociedade, á torna-los uteis a si, e á sua posteridade (1) encaminhando-os á lavoura e ao mais á que são aptos, principiando a aldeia-los nos logares onde nasceram, e estão acostumados, teriamos tido bracos para nos ajudar, não só no cultivo das terras, como lla marinha de guerra e na de cabotagem ${ }^{(2)}$

Ao passo que se empenha em libertar os Africanos, consente que "stejam á escravisar os Indios no Pará, por dividas por elles contrahidas, a troco de missangas, que não puderam pagar! Os Indios, tèm horror á escravidão; e era por esse horror, que elles preferiram a morte, ao commercio com os primeiros povoadores da America. Se em logar de colonisação de chins, e mesmo de vagabundos e proletarios, cuidasse o governo em aproveitar os indios brasileiros, não teria gasto a somma immensa, que se tem despendido improficuamente com os especuladores, que nos têm logrado. Com a industria fabril, e proteccão á Agricultura, estabelecendo-se nucleos ou pequenas colonias agricolas, com os Africanos e escravos, que se vão libertando, e mesmo os vagabur dos, nas immediações dos

(1) Vide no Ensaro Eronomico sobre o commercio de Portugal e suas colonias, nelo bispo de Pernambuco D. José J. de Azeredo Coutinho. as vantagens que o guverno e a sociedarle podem tirar dos Indios do Brazil.

(2) O Sr. D João VI logo que chegou ao Rio de Janeirn, foi um dos seus primeiros cuidados domesticar e civilisar os Indius Botocudos e Puris, e para o que fez expedrr as cartas regias de 13 de Maio, e 2 de Dezembro de 1808, e 7 de Outubro de 1809 ao governador de Minas Geraes, para que désse premios aos agricultore:: e fazendeiros que melhor tratassem e civilisassem os Indios (vide a Gazeta do Rio de 22 de Septernbro de 1810.) 
povoados, e proximas as vias ferreas, ficaremos abrigados das eventualidades que nos trará uma guerra, com qualquer das grandes po. tencias da Europa, que nos mandarem bloquear os portos, porque do que necessitarmos nada entrará para as Alfandegas do Imperio, e nem o proprio governo terá rendimentos com que fazer face ás despezas do Estado, visto ter o ministro dos Estrangeiros José Maria da Silva Paranhos, depois Visconde do Rio Branco, desarmado o Brasil.

Depois de concluido o Tratado de paz de 30 de Março de 1856, o Congresso reunido em Pariz, proclamou em nome das grandes potencias, que representava, o seguinte: $1^{\circ} 0$ corso fica abolido; $2^{\circ}$ o Pavilhão neutro cobre a mercadoria inimiga, com excepscão do contrabando de guerra: $3^{\circ}$ a mercadoria neutra, com excepção do contrabando de guerra, não pode ser apresada sob o pavilhio ini. migo; $4^{\circ}$ os bloqueios para serem obrigatorios, devem ser effectivos, isto é, mantidos por força sufficiente. para prohibir realmente o accesso ao litoral inimigo.

o governo imperial recebeu dos Agentes Diplomaticos, residentes n'esta côrte do Rio de Janeiro, da Gran-Bretanha, França, Russia, Austria, e Sardenha, o convite para adherir ao convenio; e adherio, por nota de 18 de Março de 1857, dirigida, por José Maria da Silva Paranhos, ministros dos Negocios Estrangeiros, ao cavalheiro de Saint Jorge, Enviado Extraordinario, e ministro plenipotenciario do Imperador dos francezes. (1)

A' esta adhesão, que nenhuma potencia da America quiz, nem mesmo o Paraguay, que a sua navegação é fluvial em canôas, e pequenos barcos, a aceitou o Sr. Paranhos, visconde do Rio Branco, para o Brasil, nação fraca e maritima, invejado de todo o mundo, DESARMANDO-0, e the tirando o melhor, e o mais seguro meio da d zfeza, que é o corso, á custa das Grã-Cruzes que por isso recebeu, e que lhe deviam pezar tanto nos hombros, como o mundo ás costas de Atlas.

Saiba o leitor, que cada Grã-Cruz, que recebe um ministro brasileiro, dos governos estrangeiros, é em recompensa de um grande detrimento, se não sacrificio do paiz.

(1) Veja-se o relatorio dos Estrangeiros de 185i, letra C. paginas 5 e 16 . 
O Brasil, em geral, que não lê, senão as gazetas do dia, e os romances, que ellas publicam, e não estuda, e nem conserva de memoria, como eu, os acoutecimentos historicos e politicos, acompanha sem criterio as toadas dos trovadores das praças, e lamenta a morte do Sr. Visconde do Rio Branco, como um benemerito da Patria: eu sinto-lhe a perda, como um cidadão instruido, talentoso, de palavra facil, e bom chefe de familia; mas como estadista e diplomata, não. Lamento- the a morte, como o autor da Lei de 28 de Septembro de 1871, que libertou o ventre da mulher escrava, e eu com justos fundamentos, nego-lhe a paternidade.

O governo do Brazil, sempre embebido nos enredos da politica eleitoral, e nos arranjos da familia, e sem traquejo em administração, quasi sempre cahe nos laços e engodos, que a politica europea the arma, e isto, por não conhecer a interpretação do monossyllabo нг, explicarlo pelo padre Antonio Vieira, quando comparou a profissãc do pescador, a sciencia do homem politico, e estadista (1) O governo francez, conhecedor da docilidade, e espirito condescendente dos nossos homens politicos, (embora prohiba expressamente 0 art. $6^{\circ}$ e $\$ 1^{\circ}$ da constituição do Imperio), o governo francez

(1) ні A palavra é muito breve, explica o padre Vieira, mas não digna de menor reparo. Vos direis: Estes. E quem não dirá: quem são estes ? Muitos é de crer se embaracariam logo com as redes, e com a barca; mas então longe estou de encalhar n'este baixo (posto que o seja) que antes o exercicio de pescadores me parecia melhor noviciado, que estes apostolos podiam ter, para a profissảo de primeiros ministros. Que é uma barca, senão uma republica pequena? E o que é uma monarchia, senão uma barca grande? Nas experiencias de uma, se aprende a pratica da outra. Saber deitar o leme á um, e á outro bordo, e cerral-o de pancada quando convem, saber vogar, quando ha de ir alliante, e sciar quando se ha de dar volta; suspender ou fincar o remo, quando se ha de ter firme; saber esperar as marés, e conhecer as conjunccões, e observar os carris do céo: saber temperar as velas conforme os ventos, largar a escôta. ou carregar a bolina; ferrar o panno na tempestade, e na bonança içar até os topes. Tão politica como isto é arte do pescador na mareaç̃o e mais ainda na industria da pesca. Saber tecer a malha, e segurar o 110 : saber pesar o chumbo e a cortiça: saber cercar o mar para prover. e sustentar a terra: saber estorvar o anzol, para que o peixe o não corte, e encobril-o, para que o não veja: saber largar a sedela, ou têla, em tezo: saber aproveitar a isca, e desperdiçar o engodo só um defeito reconheço no pescador para os lugares do lado, que é o exercicio de puchar para si. E' o que nos tem acontecido, e rai acontecendo. 
pela convencão de 26 de Abril de 1861, nos tirou a nacionalidade dos filhos dos francezes, nascidos no Brazil. O cavalheiro Saint-Jorge, soube tão amestradamente redigir os artigos da convenção, que com duas virgulas, entregou á Franca is naturaes do Brasil, nascidos de pais francezes.

A França impoz ao Brasil, a libertacão dos nessos escravos, sem nos mandar dinheiro, para indemnisar aos senhores, que os possuem legalmente por compra; e sem indicar os meio spraticos de promover a libertação. I uito antes que a França em 1823, o conselheiro José Bonifacio de Andrade e Silva, tinha escripto uma ILemoria, com um projecto de Lei de emancipação da escravatura no Brasil, serido secundado por João Severiano Maciel da Costa, e outros. (1) As idéas da emancipação servil, sendo adoptadas por muitos brasileiros, o presidente do consello de ministros do Gabinete de 3 de Agosto de 1866, nas duas fallas do throno de 22 de Maio de 1867, e 9 de Maio de 1868. entre os assumptos vagos que apresentou ás camaras, lembrou a necessidade de opportunamente tratar-se do elemento servil; e o gabinete de 16 de Julho do mesmo anno de 1868, opportunamente só tratou dos arranjos da familía; mas a camara dos Deputados, logo n') começo dos seus trabalhos, tomando vivo interesse na questão do elemento servil nomeou de seu seio, uma commissão para estuda-la, cuja commissão deu parecer, e com o projecto da lei, no dia 16 de Agosto de 1870, tendo formulado no capitulo $4^{\circ}$ DA GERACJ̃̃o FCTURA:-Os filhos das escravas nascidos depois da publicaşão d'esta Lei, serüo considerados livres.

Cahindo o gabinete de 16 de Julho, que deu como motivo a discordancia 110 conselho de Estado sobre o elemento servil, votando contra a libertação da escravatura, segundo constou, o Sr. Rio Branco, sendo a principal causa ahafada, subio ao poder o gabi-

(1) Dé se o seu a seu dono:

A ideia da libertacão dos fillhos dos africanos, é do sabio conselheiro José Bonifacio de Andrade e Silva. «E porque continuaram a ser escravos os fillos desses africanos? Commetteran elles crimes Foram apanhados em guerra? Mudaram de clima máo, para outro melhor? Sahiram das trevas do paganismo para a luz do Evangellıo ? ete 》 (Representacão a Assembléa Const. Leg. sobre a escravatura pag 11. Pasiz, Typ. de Firmino Didot. 
nete de 29 de Septembro de 1870, e mezes depois, o de 7 de Março de 1871, com a presidencia do conselho de ministros o Sr. Paranhos, visconde do Rio Branco, existindo o projecto da camara dos Deputados de 16 de Agosto de $18 \% 0$, e no projecto o capitulo $4^{\circ}$ da geração futura, e o art. $7^{\circ}$, que se não discutio antes, por não haver tempo.

O gabinete de 7 de Março, havia recebido ordem do Imperador, para que em sua ausencia, se tratasse com instancia da libertaçĩo dos escravos, e no dia 12 de Maio do mesmo anno de 1871, o Presidente do conselho de ministros, sem nenhuma satisfação ás camaras, atirou no recinto da Temporaria, um parecer com o titulo de Elemento Servil, que não era mais, que um commentario do projecto, que a commissão da camara dos Deputados, havia apresentado, na sessão do dia 16 de Agosto de 1870.

Discutido e bem esclarecido o projecto, passou como Lei do Estado, a libertação do ventre da mulher escrava no dia 28 de Septembro de 1871. Quando o projecto se discutia, declarou no Senado o Sr. Zacarias de Góes e Vasconcellos, Provedor da Santa Casa da Misericordia, que ia mandar fechar a Roda dos Expostos, para não receber as miseras criancinhas, que n'ella fossem postas, sem se lembrar o Provedor da Misericordia, que a Roda dos Expostos não é creação da Santa Casa, e rem os gastos que se fazem com ella, sahem do patrimonio da Misericordia, como provei. (1)

Sanccionada e publicada a Lei de 28 de Septembro de 1871, só no dia 12 de Dezembro, appareceu o regulamento dizendo:- desde a data da Lei, não ha mais escravos nascidos no Brazil ; e no entanto o modelo-G-diz o seguinte: Resumo geral dos escravos desde o dia tantos do mez... do anno de 1872, até Outubro do mesmo anno matricularam-se escravos, sendo do sexo masculino, e feminino: somma até um anno, tantos escravos: de um anno até sete tantos!!!

Como o governo não se empenha pela boa execução das Leis, porque qualquer individuo que possa ser manivella ou instrumento de um organisador de gabinete serve para ministro de Estado, depois de promulgada a Lei de 28 de Setembro de 1871 , e no dia 12

(I) Veja-se o meu livro o Brasil Social e Politico, ou o que fomos e o que somos. 
de Dezembro, ter apparecido o irrisorio regulamento, com o modelo -G-foi annunciada a venda em praça publica do Juiz de Orphãos da côrte, de duas crianças, sendo uma de um anno, e a outra de anno e meio, no mez de Julho de 1874, com tão clamoroso escandalo, que o Caipira (o illustrado Dr. Augusto de Castro) no folhetim do Jornal do Commercio, indignado pelo escandalo, exprobou o procedimento das autoridades, sendo ainda presidente do conselho de ministros, o Sr. José Maria da Silva Paranhos, Visconde do Rio Branco.

o Sr. Visconde do Rio Branco, defendeu a passagem da Lei da liberdade do ventre da mulher escrava, por imposiçr̃o do Imperador, e se ficou convertida em Lei da nação, em 28 de Septembro de 1871, foi pelo meu voto, sem o qual, apezar de enfermo, como me achava, fui á camara dos Deputados, n'esse dia, pelo empenho que tinha da sua passagem, sem o que não existiria a Lei de 28 de Septembro de 1871, n'esse anno, por não haver numero legal de Deputados, para approvação e passagem da mencionada Lei. 


\title{
DESTRUIÇÃO DAS MATTAS E FLORESTAS
}

\author{
E SEUS MALES INGALGULAVEIS
}

Estamos convencidos de que o vasto e uberrimo territorio do Brasil, pela sua posição geographica, no globo terraqueo, e condições astronomicas, ha de ser no rodar continuo, infinito, dos seculos, o emporio da humanidade, e d'onde a civilisação, ha de mandar brilhantes raios de luz aos horisontes da terra, se os que o governarem, tomando no devido apreço os interesses futuros do paiz, olharem como convém, para as riquezas vegetaes com que profusamente o Supremo Creador do universo, engrandeceu o Brasil, prohibindo, por meio de leis penaes, e regulamentos florestaes, a destruição das mattas e bosques, em presença da sua importancia e utilidade.

A nossa esplendida flora, a mais interessante e prestimosa que se conhece, possue para mais de quarenta mil especies de plantas differentes, a qual em muitos logares tem sido destruida, pela mão vandalica do homem, e pela indifferença do ministerio da agricultura, commercio e obras publicas, qụe se não importa com ella!! E como isto não ha de acontecer, se na Secretaria de Estado do ministerio da agricultura, não ha um documento ou memoria manuscripto, ou impresso antigo ou moderno, que trate de agricultura, mattas e florestas do Brasil, e nem cousa alguma a respeito das nossas minas de metaes preciosos, e casas de moedas!!! No emtanto é ao ministerio de agricultura, que se 
vai pedir concessões e privilegios, para minerar, chegando o absurdo, filho da ignorancia, a conceder-se privilegio por 90 annos, a um particular, para minerar em quatro provincias, por se não conhecer a topographia dellas! Este absurdo sahido do ministerio de agricultura, foi confirmado pelas duas camaras, sem que houvesse uma voz, que lembrasse a impossibilidarle em que ficava o proprio governo, de se mecher nos territorios das quatro provincias, durante os 90 annos do privilegio concedido!

Buenos-Ayres. estado pequeno da America do Sul, tem a sua carta topographica geral, e especial de cada uma de suas provincias, com todas as minudencias, e o Brasil nada tem que preste. (1)

No emtanto o papelorio official ronca, e a pomada cheirosa se consome, envolta com a mentira governamental, e a falsa politica, e tudo embrulhado nos rendimentos do Estado, que é o producto do suor do contribuinte, esbanjado pelos que, vivendo do mesmo producto, dão as contas que lhes convém, não aos legitimos representantes dos contribuintes, mas aos prepostos do governo, que chancellam tudo o que o governo lhes apresenta, e a quem o senador Zacarias, appellidou no senado-de confraria de pedintes - e os jornaes de 1878, chrismaram de Fagundes...

A flora brasileira, como disse. sendo a mais rica do mundo tropical, e cada vegetal um iardim, coberto de flores aromacicas, e com regetaes extraordinarios, que se elevam á grandes alturas, em busca de ar e luz, são muitas vezes destruidos pelo machado e pelo fogo sem necessilade imperiosa.

(1) A carta geral do Imperio, com a qual despendeu o thesouro publico muito dinheiro, com o traçado ou delineamento, appareceu lithographala de um modo, que é uma vergonha mostrar-se; e a commissão que a examinou reconheceu, que o trabalho é inservirel, pela desharmonia em que estĩo as quatro folhas impressas, além de todas borradas!!!

() Fagundes é o individuo, commensal dos ministros. sem officio nem beneficio, a quem o governo concedeu o privilegio de inineral ein quatro provincias, e que por espirituosa caçoada, fizeranl-no tomal' assento, com diploma arrunjado, na camara dos deputados na lerislatura de 1878, e della foi expulso. ficando por isso, os deputados com o alcunha de Fagundes. 
A destruição das mattas e dos capoeirões pelas derrubarlas, e pelo incendio, para se fazer plantações, sem leis que as regule, sem methodo e vigilancia policial. mesmo na provincia $d$, Rio de Janeiro, fez desapparecer muitos typos de plantas da flora primitiva, acontecendo não se poder mais encontrar algurnas plantas conhecidas pelos nossos illustres botanicos conselheiro Freire Allemão, Fr. Custodio Alves Serrão e Fr. Leandro do Sacrameato.

Como é sabilo, o vegetal tira a sua nutriç̃o da terra, pelas raizes. que absorvem a agua, que n'ella ha, deslocada pela eleciricidade da athmosphera, e calor luminoso do sol, pelas folhas e partes verles, que indo pela absorpcão para os orgãos vegetaes, já transfurmada em substancia regetal, na arrore se conserva, par:i o seu desenvolvimento, sendo a arvore composta de oxygenio, hydrogenio, carbono e azote.

O vegetal, durante o dia, apodera-se do azot: do ar, e durante a noite, do oxygenio. Durante o dia, na presença da luz, absorve o acillo carbonico, retendo o carvão, e exhala o oxygenio, para purificar o ar, servindo o carvĩo, não só á modificar a acção do calor, como a escurecer-lhe a côr das folhas A luz tem grande influencia n'essas decomposições, para tambem influir na variedade las côres, no sibor e aroma dos vegetaes.

As arrores alsorvem, com a humidade, os miasmas que nadam na athmosphera, e transpiram n'ella agua, que, l'arefeita pela accĩo do calor do sol, passa as regiões superiores, e unida á ontros vapores, cundensa-se, e volta para a terra, em forrina de orvallio, ou de chuva. No equador e tropicos, onde o calor é mais intenso, durante o verão, a funceño transpipatoria é mais activa; e por isso, quanto mais robusta for a arvore, mais abundantes serĩo os vapores aquosos, que elli despejará na athmosphera; e por conseruinte mais chuvas apparecerĩo. purque as arvores espalham mais humidades 110 ar, que o proprio mar.

Ha na provincia das Alagoas, uma arvore, co.lihecidi pelo nome de Mary (Geoffroya), que se póde considerar o hygrometro do sertão, por lue em tempo de secea, cuineça a transpirar pela casca, e verter gottas de agua, que é o sigual certo, do proximo apparecimento das chuvas. 
Queimar as mattas e florestas, é esterilisar as terras, seccar a athmosphera, e fazer o maior mal que é possivel ao territorio, e a agricultura; como o Brasil. que é o mais uberrimo que se conhece no globo. Antigamente, como ainda hoje, em Junho e Julho se faziam as derrubadas, para em Agosto até Setembro, fazerem-se as queimadas, e apezar dos acêiros, o incendio os devorava passando as mattas, engolindo-as á muitas leguas. o horrivel de uma queimada, e os estragos irreparaveis que ella produz, sã̀o tão manifestos, que o poeta (1) a descrevendo assim se exprimio:

Eis (depois que amestrada a juventude Em regras taes, anivelou co'a terra o grande bosque) ás chammas condemnado, Jaz de espessura a magestosa pompa

Os comantes vinhaticos, os cedros As sucupiras de viver eterno, E o, que no Brasil deu nome, util madeira; 0 que em côr o violete representa, A cabiunce mais negra, emula digna Do indico ebano; as pingues copahibas, Que, rota a casca, balsamo gotejam; E com barbaros nomes, que a primaria Nobreza gozam da vetusta selva, Do arboreo reino principaes magnates: Cujo vulto e belleza, e còr perenne, E robustez constante, e as proprias manchas Em preço estão: porém riqueza tanta, Que o optimo paiz facil procrêa, Se o desaso, não sei, dos habitantes, Ou se a mesma abundancia as torna baixas. The novo, pois, ao desolado bosque 0 ferro applicam, as ramagens cortam, Futuro pasto de voraz incendio,

(1) De cultura Radicis Brasilice - poema latino do professor José Rodrignes de Mello, portuense. traduzido pelo professor João Gualberto Ferreira dos Santos Reis. 
E, amontoados em altivas pyras

Acommodando os troncos e os madeiros, Dão, que depois o activo sol os dome,

Té que toda a humidade Ihes deseque

Penetravel calor: entĩo da parte, D'onde mais animoso Euro bafeja, Nas ligneas congestões fogo submettem.

Com o vento reforça-se Vulcano, $\mathrm{E}$ de fumo e de chammas altos globos Mandando aos astros, com faminta bocca o raro bosque, crepitando engole, etc.

O togo nas mattas e campos, é a morte dos terrenos, porque destruindo lhes o humus, e o reduzindo a cinzas, que a ignorancia crè bom adubo, em 3 annos deixam de produzir. O agricultor queima as arvores derrubadas, para abreviar a plantação, sem conhecer o immenso damno que o fogo lhe causou. As mattas virgens e florestas onde não penetrou o incendio, o solo está coberto de follhas seccas, que conservam as humidades procedentes das chuvas, e favorece o embebimento d'ellas, não só para fornecerem mais alimento aos vegetaes, como escorrendo para os logares inclinados, entrarem nos corregos, augmentando-lhes as aguas, que tambem, despejando nos rios, engrossam-lhes os cabedaes. Nos logares onde as mattas são destruidas, os terrenos se tornam seccos, pela falta da humidade, que os vegetaes desprendem; e se tem observado, que uma arvore de mediana grandeza, transpira, em forma de vapores, para mais de 20 litros de agua por dia.

o fogo, como já lembrei, é a morte da agricultura; e as seccas que têm apparecido, não têm outri causa senão a destruição das arvores, pelas derrubadas e incendios. O Ceará muito tem soffrido, pela falta da vegetação de suas estensas planicies, que foram destruidas para convertel-as em pastagens de gados, começando a provincia a padecer as consequencias do mal feito, desde 1724, e com algumas interrupções em 1778, seguindo-se em 1785, 1845, até a horrorosa secca de 1875, que terminou em 1880, que além de desgraçar a milhares de familias, matou a dezenas de pessoas devoradas pela fome e pela sêde. 
A grande e devastadora secc $九$ de Pernambuco de 1791 e 179?, que obrigou ao governador D. Thomaz José de Mello, á pedir soccorro a D. Fernando José de Portugal, governador e capitão general da Bahia, em 26 de Maio de 1792, narrando-Ihe os estragos do norte, moveu ao governo de Lisboa á prohibir o córte das mattas.

Sem duvida é pela falta de estudos botanicos, e principal. mente da physiologia vegetal, que se destroem as arvores, porque ellas influem directamente sobre os climas, as estações, e sobre a fertilidade dos terrenos; e tanto é poderosa a sua influencia, que escasseando as aguas, pela falta de vegetação, instinctivamente o povo agricola, reconhecendo a perturbação atmospherica diz: - os tempos estão mudados,- sem ter consciencia que foi elle, a causa d'essa mudança, por ter destruido o grande regulador da atmosphera, que são as mattas e bosques, tanto dos valles e estensos chapadões, como as do cume das montanhas e serranias, que mantêm as humidades, tão necessarias á fertilidade das terras adjacentes.

Deus creou as mattas para conservar a uberdade da terra. e manancial da producção; e sempre que o homem destroe as arrores, os castiga com as seccas, e esterilidade d'ella, por ter desmanchado a obra da natureza. Os logares proximos ás mattas são ferteis, porque são favorecidos de chuvas; e se ha de notar que, desde que se principiaram com as derrubadas, as chuvas foram escasseando. Se de agora em diante forem as florestas conservadas, e novos bosques se forem creando, as chuvas hão de apparecer com regularidade; e ao governo compete cuidar na conservação das mattas e das florestas, afim de que não sejam destruidas, attende:ado ao futuro grandioso, que está reservado á este abençoado paiz. 


\title{
FLORESTAS E MATTAS VIRGENS DO BRASII.
}

\author{
E SEUS BENEFICIOS EM PROVEITO DA HUMANIDADE
}

Troncos varios em côr e qualidade, Que interiças nos fazem as canoas, Dando á grossura tal capacidade, Que andam, remos quarenta, e cem pessoas; E ha por todo o Brasil em quantidade Madeiras para fabricas tĩo boas, Que trazendo-as ao mar por varios rios; Póde encher toda a Europa de navios.

(Durão-Caramumi-Cant. 7 Est. 53 )

A vida sobre a terra começou pelo vegetal, encarregando-se o oxygenio, o hydrogenio, o azote e a electricidade positiva e negativa, em combinaçĩo, formarem a primeira cellula germinativa das plantas, disseminadas pela superficie da terra, (') contendo o principio elementar da vida, que, se desenvolvendo, tirou da terra, da agua, e da luz, os materiaes para se fortificar, e

(1) Vide a minha memoria sobre o Fluido Universal artigo vegetal. 
crescer, cobrindo a face do globo, com a vida vegetativa; com generos, especies, e familias mui differentes, sendo esta creação produzida mui lentamente.

Nas regiões tropicaes e equatoriaes, em consequencia da luz ser mais clara, e haver mais calor e humidade no ar, a vegetação cresceu mais, e se tornou mais corpulenta e mais rica, sendo a flora brasileira, por estas causas, possuidora de mais de quarenta mil especies de vegetaes differentes. As espessas e estensas mattas virgens do Brasil, com vegetaes que se elevam a 200 e mais pés de altura, em busca de ar e luz, mostra a fertilidade, e opulencia vegetativa do mundo tropical, sendo cada vegetal um jardim, devendo a sua magnificencia esplendorosa, á humidade de uma atmosphera sempre morna, sempre suave, e amorosa, origem da corpulencia das arvores, e mais ainda, embalsarnada pelos aromas das flôres, fragrancia das resinas, e balsamo que distillam.

Sabe-se que as arvores por meio das folhas, e de todas as partes verdes, absorvem e decompoem no seu interior o ar, a agua, e o acido carbonico, existentes na atmosphera Do ar, ellas se apoderam do azote, durante o dia; e do oxygenio durante a noite. Do acido carbonico, ellas retem o carbono, e exhalam o oxygenio, na presença da luz, que tambem tem grande influencia sobre a côr, sabor, e cheiro dos vegetaes.

Nadando no ar os miasmas, que se desprendem da fermentação de elementos organicos vegetaes e animaes, são absorvidos pelas arvores, e neutralisados pelos aromas das flôres, e balsamos, que distillam as arvores. Ellas têm igualmente a propriedade de attrahirem á si a electricidade, sendo uma especie de páia-raios naturaes. Além d'estas influencias chimicas e physicas, ellas exercem outra, puramente mecanica, que é moderarem, ou diminuirem a intensidade dos ventos, e das tempestades, tendo por tanto as mattas e as florestas, immensa influencia sobre os climas, as estações, e sobre a fertilidade e salubridade das terras.

o reino vegetal é o verdadeiro poder moderador dos climas, dos meteoros, e da atmosphera.

As mattas e bosques do cume das montanhas, attrahem a si as nuvens, e as chuvas que regam as terras, e diminuem a intensidade das tempestades e dos furacãos, protegendo a habitação do homem, e a agricultura dos campos. 
Tem-se reconhecido que os paizes privados de suas mattas, têm experimentado alterações em sua temperatura, como aconteceu em Cayenna, e nos vai acontecendo pela destruição das nossas mattas, com a talta de chuvas, e trovoadas regulares.

o celebre Francklin, nos Estados-Unidos da America do Norte, era oppostn á destruição das arvores, por concorrerem ellas á purificação do ar atmospherico. Cortar arvores, sem necessidade real, é um crime de leza creação; e as seccas que têm apparecido, não têm outra origem. Além d'este mal, accresce o apparecimento das epidemias, devidas ás emanações deleterias paludosas, desprendidas dos charcos e pantanos descobertos, e sem a sua vegetação primitiva, que o Creador fez apparecer ao redor d'elles, para antidoto dos males que produzem.

A conservação das mattas, e a plantaç̃o das arvores, não só nos fornece bom ar, para a respiração, ( $\left.{ }^{1}\right)$ como abastece-nos de todo o necessario, para uma longa existencia.

O governo francez, mesmo muito antes de 13 de Agosto de 1669, se empenhou pela conservação das suas florestas; e para bem regular a permanencia d'ellas, fez publicar em 31 de Julho de 1827 um regulamento florestal, para a França.

Nos tempos coloniaes do Brasil, o governo de Lisboa. voltando suas vistas para a conservação das mattas e dos bosques, expressamente as recommendou aos corregedores de comarcas, e ás camaras municipaes, no livro Io das Ordenações do Reino; e nas Extravagantes de 30 de Março de 1623, e de 29 de Maio de 1833. Os Decretos de 23 de Septembro de 1713, e de 11 de Março de 1716, mandam conservar as mattas e bosques, por utilidade publica, e proveito real.

A Sra. D. Maria I, ou antes o Principe Regente o Sr. D. João VI, para a conservação das mattas do Brasil, e regular o corte das madeiras, por carta régia de 17 de Março de 1796, creou uma nova magistratura, com a denominação de Jui conservador das mattás; e por aviso de 6 de Agosto de 1798, ordenoủ ao vice-rei do Rio de Janeiro, que nomeasse o Intendente Geral da Capitania, para occupar o cargo do Juiz Conservador das mattas, em conformidade

(') Vide o meu Dicc. de med. art.-Ar atmospherico, e a minha Memoria sobre as epidemias. 
da carta régia de sua creação; e com o fim de regular os córtes das madeiras enviou-lhe o regulamento de 11 de Julho de 1799. Por Alvará de 26 de Julho de 1813, em que concede terras para formação de povoados, reserva mui especialmente as mattas, que estão sobre as montanhas, recommerdando a sua conservação.

Não obstante estas providencias em proveito das mattas do Brasil, em 1815 o nosso sabio naturalista, o conselheiro Dr. José Bonifacio de Andrade e Silva, escreveu uma memoria, aconselhando o governo á mandar plantar arvores e formarem-se novos bosques, em proveito da sociedade.

No entanto, na capital do Imperio do Brasil, nem o ministerio de Agricultura, commercio e obras publicas, nem a camara municipal, e nem a policia hygienica, se importam com a vegetação, porque não ha vigilancia sobre as mattas e bosques, visto como são ellas, de vez em quando, presas dos incendios lançados pela maldade humana.

As proprias autoridades toleram, que se derrubem arvores seculares, para o fabrico do carvão, sem obrigar o destruidor, á plantar no mesmo logar outra arvore, em substituição á cortada. Quantos annos ou mesmo seculos não foram precizos, para crear essa arvore, que foi destruida pela ganancia de meia duzia de patacas !

Todo o páo Brasil da provincia das Alagoas desappareceu, até mesmo as raizes, para vendel-o ao estrangeiro, chegando o destruidor do páo Brasil, a mandar buscar uma machina de extractal-o, que ficou sem uso, porque quando a machina chegou á provincia, já não havia páo Brasil que extractar, devido á demora que teve na Europa o encarregado da encommenda....

A esse mesmo potentado e influencia eleitoral das Alagoas, em 1841 ou 1842 o presidente da provincia, deu-lhe licença para tirar das mattas, duzentas duzias de pranchões de vinhatico! Um destruidor d'essa força, autorisado como estava, contentar-se-hia com as duzentas duzias somente d'esses famosos gigantes das mattas das Alagoas? Lembra-me de um facto assás reprehensivo. que me foi communicado por um encarregado da vigilancia das florestas da Tijuca, no Rio de Janeiro. Um ministro du imperio, foi passar o verão nas Paineiras, e consentio, quando se retirou, que se cortassem arvores seculares da floresta do Estado, e as reduzissem a lenha, e 
fossem conduzidas em carroções das obras publicas, para a cozinha do Sr. ministro, no Andarahy !!!

o Rio de Janeiro em tempos passados, muito soffreu por causa da destruição dos mangues da cidade nova, e de outros logares, alagados e pantanosos, porque appareceram febres de máo caracter, que mataram a muitas pessoas; hoje, que os pantunos da cidade nova estão aterrados, desappareceram essas febres.

Todas as nações, reconhecendo a utilidade dos vegetaes, sob todos os pontos de vista, não só procuram conservar as suas florestas, como formar outras, em proveito geral; no Brasil, ao contrario, se destróe as mattas pelo abandono, sends o proprio governo. que dá o triste exemplo, de consentir que nas obras do Estado, se empregue o pinho da Suecia, em substituição ás nossas riquissimas madeiras.

Os Estarlos-Unidos da America, apezar da sua grande população, devida á emigração Européa, possuem immensas mattas. e cuidam d'ellas, porque a cultura das terras, é feita com methodo intelligente.

Sendo a America abundante de vastas florestas, se forem conservadas, será a parte do mundo muito feliz, porque em vez de estensos areaes, e desertos seccos, como possuem a Africa e a Asia, será sempre o paiz da Promissão, onde nada lhe ha de faltar. ( $\left.{ }^{1}\right)$

(1) E' incrivel dizer-se que o ministerio da Agricultura, que absorve das rendas do Estado cerca de 20.000:000\$, por anno, comprehendendo á sua secretaria de Estado, onde se gastam 236:000\$, e com a decaritada cathechese 200:000\$, que nada tem produzido, e outras fontes de mamata, nada possue que trate de Ágricuitura!!!

Os archivos estào cheios de relatorios, impressos na Typographia Nacional, dos commissionados do governo, que nem para papel de embrulho nas confeitarias e tabernas servem, porque n'esses estabelecimentos não se vende, como em outros tempos, um ou dous vintens, e sim kilos e meios kilogs, dos generos que possuem; e com os impressos da secretiria da Agricultura, não os póde embrulhar; e já se vê, que tudo alli ficou perdido.

E' para lamentar o nosso estado sucial agricola, e o viver do povo, quando se olha para o brilhantismo dos Estados da America do Norte, que está hoje com quasi 51 milhões de habitantes, e vê metade de sua populacão empregada na lavoura, produzindo uma somma fabulosa de dollars; e nós com um territorio uberrimo, que dí seis centos por um, com um clima amoroso e doce, sem 
O governo, que creou os Juizes Municipaes, magistratura desconhecida na Constituição do Imperio, porạue, em vez d'essa magistratura, não crea Juizes conservadores das mattas?

população sem agricultura, sem industria e sem nada e para maior vergonha importando não só o pão do estrangeiro para alimentaça do povo como capim, (alfafa) do Rio da Prata, para o sustento dos burros! E somos Nação! E temos governo! Ora boa noite...

Lamento dentro d'alma, o estado lastimoso do meu paiz, onde já a miseria invade o seio das familias, pela falta de recursos para a vida porque não acham emprego honesto em que ganhem o pão, visto que o governo, absorvendo tudo, não promove as artes, a industria, e nem a cultura dos campos, para facilitar o viver do povo. Só cuida de eleicões, para arranjos de familia, com o thesouro, sendo a Lei n. 7,981, de 29 de Janerro de 1881, tão complicada, que o filho do povo que contribue para o thesouro publico, e vai derramar o sangue na guerra pela patria, é excluido do rotar em quem julga digno de o representar nos congressos da Nação.

o Brasil espere, e confie no futuro; e creio que não será n'essas 6 ou 8 gerações, que o Brasil será Nação, para occupar o logar que lhe está destinado. 


\section{NOTAS BIOGRAPHICAS}

NOTAS BIOGRAPHICAS DE FR. JOSÉ MARIANNO DA CONCEIÇ̃̃O VELlOSO EXTRAHIDAS DO LIVRO DO TOMBO DO CONVENTO DE SANTO ANTONIO DO RIO DE JANEIRO.

Fr. José Marianno da Conceição Velloso, que no seculo se chamara José Velloso Xavier, é natural e baptisado na freguezia de Santo Antonio, da villa de S. José, comarca do Rio das Mortes, Bispado de Marianna, filho legitimo de José Velloso Carmo, natural e haptisado na freguezia do Carmo, Cout. de Tibaens, Arcebispado de Braga, e de sua mulher Rita de Jesus Xavier, natural da freguezia de Santo Antonio do Rio das Mortes, Bi pado de Marianna. Foi acceito á Ordem pelo Rvm. Provincial Fr. Manoel da Encarnação. Tomou o habito no Convento de S. Boaventura, da villa de Macacú, sendo Guardião o Irmão Prégador Fr. José da Madre de Deos Rodrigues, aos 11 de Abril de 1761. Professou no mesmo Convento, com o mesmo Guardião aos 12 de Abril de 1762. Entrou no curso philosophico aberto n'este Convento do Rio, pelo Rvm. Provincial Fr. Manoel da Encarnação, e teve por mestre o Irmão, ex-leitor de theologia Fr. Antonio da Annunciação.

Recebeu Ordens n'esta Cidade, por imposição de mãos do Exm. Diocesano Bispo D. Fr. Antonio do Desterro, com Lettras do Rvm Fr. Ignacio da Graça, no anno de 1766.

Sahio eleito Prégador na Congregação de 23 de Julho de 1768. 
Foi instituido Confessor de Seculares, e Passante de geometria da Cidade de S. Paulo, á 27 de Julho de 1771.

Sahio eleito lente de rhetorica para o Convento de S. Paulo, na Congregação de 8 de Maio de 1799.

Por ordem do Vice-Rei Luiz de Vasconcellos e Souza, intimada ao Rrm Provincial Fr. Josí dos Anjos Passos, percorreu o littoral e se entranhou pelas serras, em qualidade de botanico, em cujo tempo compoz uma volumosa Flora, trazendo em sua companhia Fr. Anastacio de Santa Ignez, escrevente das definições herbarias, e a Fr. Francisco Solano, e outros, delineneador das plantas, que o dito botanico descubria e mandava pintar para se estamparem na dita Flora, que concluio e a apresentou mesmo em pessoa na côrte de Lisboa, com admiração dos mesmos professores de historia natural. Residio em Lisboa em qualidade de socio da Academia, e não cessou de fazer grandes serviços ao Estado.

Na Congregação intermedia de 25 de Janeiro de 1786, toi eleito em mestre de historia natural.

No anno de 1801 foi instituido Padre da Provincia, por ordem de S. A. Real, em recomp nsa de seus avultados serviços. Voltou para o Rio de Janeiro no anno de 1809. Falleceu na enfermaria do Convento do Rio de Janeiro, á meia noite do dia 13 para 14 do mez de Junho de 1811 , tendo recebido o Sagrado Viatico, e jaz sepultado na quadra, em que é costume enterrar os Religiosos que alli fallecem. (')

(1) Procurando em 1868 os ossos d'este celebre religioso, me disce o meu amigo Guardião do convento. Fr. João Baptista de Santa Rosa, que não se tinha exhumado, purque na mesma sepultura, que me mostrou. haviam sido sepultados outros religiosos, e que, portanto, estaram confundidos. 


\section{ACTAS DO CONVENTO DE SANTO ANTONIO DO RIO DE JANEIRO}

LIVRO DAS ACTAS E ELEICOÕES DO DEFINITORIO DA PROVINCIA FRANCISCANA DO RIO DE JANEIRO A FL. N. 49 V. E 50.

Termo da concessão de privilegios de Padre da Provincia co Irmão ex-leitor Fi. José Marianno da Conzeição Velloso, conforme a ordem de Sua Altesa Real, expedida pelo sen Ministro de Estado o Sr. D. Rodrigo de Souza Coutinho.

Aos 19 de Dezembro de 1800, estando nós legitimamente congregados em mesa Definitorial, apresentou o Irmão Ministro Provincial uma carta do Ministro de Estado, em que nos ordena Sua Alteza Real, que o Irmão ex-leitor Fr. José Marianno da Conceição Velloso fosse contemplado como Padre d'esta Provincia, em razão do grande zelo e desinteresse com que tem servido ao Estadc. 0 que nós, em consequencia de nossa fiel vassallagem, concedemos ao sobredito l'adre, e desde agora o reconhecemos e havemos por Padre d'esta Provincia, com todas as preeminencias annexas a este titulo. o que tudo para que mais constasse fizemos este termo, por nós assignados, no mesmo dia, mez e anno ut supra.-Fr. Antonio de S. Bernardo Monsão, Ministro Provincial. - Fr. Antonio Agostinho de Sant'Anna, Custodio.Fr. José Carlos de Jesus Maria Desterro, Definidor.-Fr. Victorino de S. José Marianno, Definidor.-F1. João de S. Francisco Mendonca, Definidor.-Fr. Fernando Antonio de Santa Rita, Definidor.

REgistro DAS PASTORAES DOS REVERENDISSIMOS PRELAdOS E ACTAS Capitulares A FL. 44 v. E 45.

Fr. Antonio de S. Bernardo Monsäo, Pregador, ex-Definidor e Ministro Provincial da Provincia da Conceição do Rio de Janeiro, etc.:

A' todos os Religiosos da mesma Provincia, assim prelados como subditos, saude e paz em Nosso Senhor Jesus-Christo, que de todos é verdadeiro remedio e salvação. Fazemos ver a VV. CC. 
que por carta do Illm. e Exm. Sr. Secretario de Estado D. Rodrigo de Souza Coutinho, nos foi ordenado que o Augusto Principe Nosso Senhor era servido que o Irmão lente Fr. José Marianno da Conceição Velloso, fosse contemplado Padre d'esta Provincia em remuneracão dos avultados progressos que tem feito nos inventos e observações relativos á historia natural, de que tem resultado não vulgares serviços ao Estado e á Nação. Pelo que, desejando nós dar á Sua Alteza Real, um sincero testemunho da nossa obediencia, que serí sempre invariavel a respeito das suas soberanas e sagradas determinaçōes, e querendo tambem concorrer quanto nos é possivel, para distinguir um sujeito d'esta nossa humilde corporação, a quem o mesmo Soberano se digna favorecer, empregando no seu real serviço do que recebemos uma bem assignalada e incomparavel honra, havemos por bem eleger, nomear, instituir ao dito Irmão lente Fr. José Marianno da Conceiç̃o Velloso em Padre d'esta Provincia, ficando de hoje em diante gosando de todas as preeminencias, privilegios e isencões que são annexas aos que gosam d'este predicamento na Nossa Ordem, e ao dito Irmão lente Fr. José Marianno da Conceição Velloso, assim nomeado e instituido queremos e mandamos a VV. CC. reconheçam Padre da Provincia, respeitando-o e guardando-lhe em todos e em cada um dos Conventos, onde estiver morador, as dispensas e privilegios que pelos nossos Estatutos são concedidos aos Reverendos Padres da Provincia. E para que se faca publica esta nossa resolução e prompta subordinação ás Ordens e Mandamentos de Sua Alteza Real mandamos passar a presente Encyclica, que será lida em plena communidade, transcripta no Livro competente, remettida de Convento em Convento, com certidão dos respectivos Prelados locaes e Discretos, e por ultimo remettida á nossa Secretaria. Dada n'este Convento de Santo Antonio do Rio de Janeiro, aos 28 de Setembro de 1807, sob nosso signal e sello maior da Provincia.-Fr. Antonio de S. Bernardo Monsão, Ministro Provincial por M. D. S. Paternidade Reverendissima.-- Fr. Antonio da Natividade Carneiro, ex-Definidor e pro-Secretario. 
NOTAS BIOGRAPHICAS DE FR. FRANCISCO SOLANO.

Fr. Francisco Solano, que no seculo se chamava Francisco José Benjamin, é natural e baptisado na freguezia da villa de Santo Antonio de Sá de Macacú, Bispado do Rio de Janeiro, filho legitimo de Jorge Antonio Costa Soares, natural e baptisado na mesma freguezia, e de sua mulher Anna Maria Furtado de Mendonça, natural de Itamby, e baptisada na freguezia de S. João de Itaborahy, ambos do Bispado do Rio de Janeiro

Foi acceito á Ordem pelo Rvm. Provincial Fr. José de Jesus Maria Reis Tomou o habito no Convento de S. Boaventura da villa de Macacú, sendo Guardião o Irmão Pregador Fr. José de Santa Ursula Pacheco aos 31 de Outubro de 1778 Professou no mesmo Convento com o mesmo Guardião no $1^{0}$ de Novembro de 1779. Entrou no estudo de philosophia aberto n'este Convento pelo Rvm. Provincial Fr. José dos Anjos Passos, no mez de Outubro de 1781, sendo mestre o Ir. ex-leitor de theologia Fr. Antonio de Santa Ursula Rodovalho.

Ordenou-se de Sacerdote a 5 de Julho de 1780. Foi nomeado Pregador na Congregação intermedia de 25 de Fevereiro de 1786 , dispensando-se-lhe o resto do tempo que lhe faltava para encher o triennio de theologia em attenção ao serviço de Sua Magestade Fidelissima, á que estava addido por ordem do Exm. Sr. Luiz de Vasconcellos e Souza, Vice-Rei do Estado.

Foi instituido Con"essor de Seculares na Congregação de 28 de Fevereiro de 1789. Foi eleito presidente do Convento da Ilha a 21 de Setembro de 1796, e confirmado na presidencia do mesmo Convento na Congregação intermedia de 21 de Março de 1798. Foi eleito presidente do Convento da Senhora do Amparo, no Capitulo de 28 de Setembro de 1799. Foi eleito Guardião do Convento de Santa Clara da villa de Taubaté, por fallecimento de um Guardião e pela permuta que se fez de outra Guardiania no Capitulo de 2 de Outubro de 1802.

$\mathrm{Na}$ Congregação de $\tau$ de Abril de 1804, sendo Provincial o Nosso Carissimo Irmão Fr. João de S. Francisco Mendonça, foi eleito Porteiro para o Convento de S. Paulo.

Na Congregação de 11 de Abril de 1807 ficou confirmado no 
mesmo emprego. No Capitulo Provincial celebrado a 8 de Outubro de 1808 foi eleito Guardião do Convento de Taubaté.

$\mathrm{Na}$ Congregaçĩo de 14 de Abril de 1810 sahio eleito Guardião do Convento de S. Sebastião.

No Capitulo Proviıcial celebrado a 12 de Outubro de 1811. foi eleito Deinnidor.

No Capitulo celebrado a 15 de Outubro de 1814, no qual presidio o N. R. P. ex-Definidor e Visitador Geral Fr. Joaquim de Santa Rosa Congonhas, foi eleito Ministro Provincial.

Falleceu a 10 de Dezembro de 1818, com todos os Sacramentos, na enfermaria d'este Convento, e nos seus ultimos dias foi um exemplar de paciencia, sofrendo com grande resignaçĩo a molestia de que morreu. Jaz na quadra em que se costumam sepultar os Religiosos. 


\section{GLIMA DO BRASIL}

\section{Opinião dos antigos e a do Padre Simão de Vasconcellos, chronista da Companhia de Jesus, sobre a bondade do clima do Brasil.}

o Padre Simão de Vasconcellos que conheceu praticamente - Brasil, e mesmo pelas noticias daulas pelo Patle José de Anchieta, e por todos os Missionarios la Companhia de Jesus, e mesmo baseiando-se nas razões philosophicas da Summa Astrologia, fallando do clima deste abençoado continente, diz:- « as estrellas quanto mais de perto predominam, e quanto com raios mais directos, tanto mais purificam os ares do clima, (quanto em si é): e a razão é natural; porque, quanto mais de perto, e direito obram os raios, taato com maior efficacia consomem as nevoas e os vapores, entre nuvens; e por conseguinte purificam os ares, e os toriam vitaes e suaves.

O sol, a lua e as principaes estrellas do Céo predomiilan sobre o Brasil, como sobre as mais partes da zona torrida, mais de perto e com raios mais direstos, que subre alguma untra terra; é força logo, que tornem os ares do clima do Brasil, mais puros e vitaes, que os das demais partes do mundu. $E$ que o sol, a lua e as principaes estrellas do Céo predominem sobre o Brasil mais de perto, e com raios mais direitos, não pode duvidar-se; porque o sol, a lua e os Signos do Zodiaco, que sĩo as estrellas principaes do governo do mundo, tern entre si e a região desta zona, dous elementos - fogo e al': e em qualquer 
outra regiăo, fớra da zona torrida, tem entre si e ella, (além dos elementos fogo e ar) a parte da terra, que vai demais á mais, até qualquer dos climas, com quem fizermos comparação. E' fundamento este efficaz; e claro está, que sendo a zona do Zodiaco, o palacio commum daquelles principes das luzes, e assentando alli o seu throno do governo do Universo, que sempre dentro da esphera delle, devem as causas de ir mais regulares; como com effeito vão os tempos, o verão, o inverno, os dias e as noites, o frio e a calma, e o mais que pertence a um perfeito clima, não sendo assim nas outras partes da terra.»

Em nenhuma parte do mundo, as aguas são mais puras, cristalinas, e doces, que as aguas das fontes, e dos innumeros rios do vastissimo continente do Brasil, e por isso é mui provavel que no futuro, o Brasil seja o grande emporio da humanidade.

\section{CLIMA DO RIO DE JANEIRO}

o clima do Rio de Janeiro varía de temperatura, porque o estado elestrico da athmosphera, o calor e a humidade do ar, dependente da evaporação das aguas do mar, das exhalações miasmaticas, das substancias organicas em decomposição, a immensa poeira que nelle se imbebe, tornam o perimetro da capital do Imperio as vozes, um pouco doentio.

o solo é de primeira formação, composto de granito micaceo, e a cidade circulada de altas montanhas deste mesmo granito, sendo a causa do grande calor nos seis mezes de verão: a privação da livre circulação do ar, que as altas montanhas de granito, algumas, sem vegetação, que a embaraçam, e a reverberação dos raios do sol, que lhes cahe perpendicularmente sobre o solo e sobre alguns pantanos em fermentação, estagnando a athmosphera, c elevando a temperatura, havia necessariamente desenvolver as febres, como as de Macacú em 1829, e mesmo na cidade, como as de 1833, e muitas outras como tem acontecido.

O meio de melhorar as condições hygrienicas da cidade e seus suburbios, é a dissecação de alguns pantanos que ainda existem, e plantar por toda parte arvores e conserval-as. Se isto acontecer serí a capital do Imperio do Brasil, uma das mais salubres do mundo. 


\section{SOCIEDAUE AUXILIADORA DA INDUSTRIA NACIONAL}

A Sociedade Auxiliadora da Industria Nacional foi uma inspiração patriotica, que fermentando por alguns annos, se realisou no Rio de Janeiro, celebrando a sua primeira sessão no dia 28 de Feve. reiro de 1828, sendo os socios fundadores, o visconde de Alcantara, o brigadeiro Francisco Cordeiro da silva Torres, João Fernandes Lopes, João Francisco de Nedeiros Pará, conselheiro José Rodrigues Pereira de Almeida. Reunidos para um fim tão util e proveitoso, mais tarde principiou a publicar o periodico, A uxiliador da Industria Nacional, para conservar a memoria do pensamento da insti. tuição ; cujo primeiro numero appareceu no dia 15 de Janeiro de 1833, escripto por differentes illustrações da época, que eram o conego Januario da Cunha Barbosa, José Silvestre Rebello, José Xavier, Monsinho da Silveira (correspondente em Portugal), tenente general José Aranche de Toledo Rendon, Manoel de Vasconcellos de Souza Bahiana (rico senhor de engenho em Santo Amaro, na Bahia), José Henrique Ferreira, Joaquim de Amorim Castro, José Carneiro, Domingos Borges de Barros, visconde da Pedra Branca, Dr. Emilic Joaquim da Silva Maia, Manoel José Pires da Silva Pontes, J. C de Barros, Fructuoso Luiz da Motta, (industrial, com fabrica de galões á rua do Hospicio, no Rio de Janeiro), conse. lheiro José de Rezende Costa, padre Aguiar, Oscar Lechoc Thouin, Manoel José Onofre, F. C. S. F., Dr. J. B. S., brigadeiro Manoel Ferreira de Araujo, e outros. 
Este periodico scientifico e industrial, creado para o progresso do Brasil, contem artigos preciosissimos a respeito de Agricultura, machinas, fabricas, invenções, manufacturas e outros assumptos de rerdadeira utilidade. Ha 16 annos que o periodico Auxiluador da Industria Nacional, está confiado ao illustrado Dr Nicolau Joaquim Moreira, que o redige, com profisciencia e patriotismo. o illustrado Dr. Nicolau Moreira, reconhecendo ter-se esgotado todos os tomos dos primeiros annos do periodico Auxiliador da Iudustria Nacional, e na impossibilidade de serem reimpressos, procurou sinthentisar as principaes materias contidas nelles, e sob o titulo de Excarasõos historicas, conta o tempo da fundação da Sociedade Auxiliadora, e memora os importantes artigos que elles contêm. Falla do que escreveu o sabio conego Januario da Cunha Barbosa, a respeito da destruiçio das mattas; do cultivo do linho canhamo ; das parasitas do pão ; das machinas e model los ; do bagaço da canna, dos trabalhos do illustre brasileiro Vicente Coelho Seabra, sobre as diversas especies de Abelhas; do compendio de Agricultura escripto pelo conego Januario da Cunha Barbosa, publicado no Auxiliador; do curso de Agricultura e de Economia por A. J. Raspail, traduzido e anotado pol A. J. de Figneiredo e Silva, em 1842; observações sobre a Agricultura no Brasil pelo coronel de engenheiros Reinaldo Oudinot, em 1800; sobre o plantio do algodoeiro e suas especies, e o modo de o descaroçar por J S. Rebello, em 1834; sobre a cultura do Anil, por J.S Rebello, en 1834; sobre a Ortiga do Busque; sobre o ensino agricola nos Estados-Unidos; - assucar de Pernambuco; o carvão de pedra; a fabricação rapida da manteiga ; a mecanica agricula, e machinas de debulhar, e joeirar a luzerna, o trevo, e a lupulina; sobre o preço da carne rerde no Canadá; os productos agriculas do Brasil em differentes annos; sobre o fabrico do assucar na ilha Bourbon, cultura dos cereaes e a sua estatistica, 0 azeite das sementes do algodoeiro e do girasol, por Fr. José Mariano da Conceição Velloso, o plantio das batatas inglezas, e doces, sobre a filação da bananeira, o ersino agricola na Prussia, sobre a população escrava ao encerrar-se a matricula geral em virtude da Lei de 28 de Septembro de 1871, a area do territorio do Brasil, noticia sobre o cafeseiro por José de Rezende Costa, 1834; um verme que ataca o café, pelo padre João Joaquim Ferreira de Aguiar, o 
conde de Gestás e suas estufas de seccar o café; o café, sua composição, propriedades e usos; a plantação do café no Rio de Janeiro por Luiz da Silva Alves Suzano; a plantação do café, por Luiz Torquato Marques de Oliveira; arte da cultura, e preparaçáa do café, por Agostinho Rodrigues Cunha; a revolução do globo, sobre o corpo humano, sobre o queijo gigantesco ; memorias sobre canaes e sua utilidade, por José Silvestre Rebello; observações a respeito da canella do Rio de Janeiro, por Bernardino Antonio Gomes; a canna do assucar, por V. Ribeiro da Silva, sobre a carnauba, e seu cultivo; a mina de carvão de pedra do Camaragibe nas Alagoas, pelo Dr. Manoel Joaquim Fernandes de Barros; o carvão de pedra de Santa Catharina, por Miguel de Souza Mello e Alvim; os primeiros ensaios da cultuıa do chá no Rio de Janeiro; o chá, por Fr. Leandro do Sacramento; sobre o cambio, os diamantes, sobre a guaxima para a cordoaria, o linho, os jardins, por Manoel Arruda Camara; a hydrographia, pelo brigadeiro Cunha Mattos; a amostra do cobre de Jaurú, em Cuyabá, analysado por Fr. Custodio Alves Serrão ; os chapéos de pennas que em 1837 fabricou no Rio de Janeiro José Julio de Barros; o golphão no tratamento da elephantiases. dos gregos pelo conselheiro Dr. Tavares; as madeiras de Santa Catharina, por Almeida Couto; o mate, ou cha de congonlıa, pelo Dr. Sigaud; a fundição de ferro; memorias sobre as industrias no Rio de Janeiro, pelo conde de Gestís; memorias sobre estradas, por J. S. Rebello; fabricas de vidros nos Estados-Unidos; carta régia sobre o corte das mattas e defeza dellas; a gomma elastica, o guaraná; o arroz da India; o tabaco, o urucú; as velas de espermacete, pelo Dr. Nicolau Moreira; a ametysta; a mandioca; memoria sobre a mandioca; memoria sobre as lunaç̃es e mudanças atmosphericas em relação no corte das madeiras, pelo conde de Gestás, e outros muitos escriptos de importancia real para o Brasil. 



\section{JARDIM DO GAMPO DA AGGLAMACGÃO}

CONFIGURACG̃̃o DO CAMPO DE SANT'ANNA, E dE 1822 PRACG DA ACClama-

Ç̃̃o DA CIDADE DO RIO DE JANEIRO, CAPITAL DO IMPERIO DO BRASIL.

o Campo de Santa Anna depois Praça da Acclamação foi mandado aterrar, bem como a do Rocio hoje Praça da Constituição e regularisar, pelo Conde de Resende, em 1793 á 1794, ficando quasi quadrilongo, dividindo a Cidade Velha da Nova Cidade, tendo 286 braças N. sul, e 155 braças de largura. Nesta Praça desembocam as ruas, Larga de S. Joaquim, de S. Pedro, do Sabão (hoje do General Camara), da Alfandega, do Senhor dos Passos, do Hospicio, dos Ciganos (hoje da Constituição), a rua do Conde da Cunha (hoje do Visconde do Rio Branco), Invalidos, travessa do Senado, a rua do Conde da Cidade Nova (hoje do Conde d'Eu), a rua do Areal, a casa da Moeda, a travessa da rua do Sabão da Cidade Nova (hoje do Visconde de Itaúna), a rua de S. Pedro da Cidade Nova (hoje do Senador Euzebio), a rua Nova de S. Diogo (hoje do General Pedra), a rua de Sant'Anna (hoje do Dr. Norberto), e a rua de S. Lourenço.

Com o augmento da população o ministro do Imperio conse. lheiro João Alfredo Corrêa de Oliveira, julgou mandar ajardinar - Campo da Acclamação, para logradouro publico. Este ajardinamento foi incumbido ao illustrado e modesto botanico o Dr. Glaziou, dando começo á obra no dia 17 de Fevereiro de 
1873, e a demolição do Theatro Lyrico a 13 de Setembro de 1875, que ficou de todo arrasado no dia 17 de Dezembro do mesmo anno, e o Jardim do Campo da Acclamação de todo acabado, e inaugurado no dia 7 de Setembro de 1880.

N'este campo houve um chafariz, uma feira, e um jardim que foi destruido no dia 26 de Abril de 182l; um palacete, que foi incendiado, e o Theatro Lyrico Provisorio, edificado em 1852 e demolido em 1875. 


\title{
CORTES DAS MADEIRAS
}

\author{
Officio do Dezembargador Francisco Nunes da Costa, \\ inspector dos reaes córtes
}

Illm. e Exm. Sr.-Tendo a honra de me ser commettido, por Provisão Règia, a inspeccão dos reaes córtes das madeiras, debaixo das ordens de V. Ex., incumbe ao meu officio o proporthe tudo, que possa dirigir a boa administração e utilidade desta importante commissão.

Governando esta Capitania o Exm. Sr. Manoel da Cunha Menezes, e multiplicando-§e n’esse tempo as encommendas de madeiras, manduu o dito Governador fabricar uma grande barca, que servisse do seu transporte e conducção, entendendo que assim se evitavam as grandes despezas dos fretamentos. Não verificou a experiencia este projact, pelo erro com que foi fabircada a referida embarcação, pois pela sua construcção demasiadamente pregueira, era incapaz de entrar nos rios de pouco fundo, e por consequencia morosa nas cargas, pela dependencia das aguas vivas n'umas paragens, e precisar n'outras de conservar-se ao largo, onde recebia por baldeação as madeiras: pela sua mesma armação á redonda demandava doze homens de companha, mestre e pratico, pannos dobrados, cabos de linho, e outros importantes apparelhos. e por ultimo não podendo entrar e sahir pela barra de Jaguaripe, esperara no Morro 
virações do sul para com ellas navegar, e entrar pela barra desta Capital, depois de dous, e as vezes tres mezes de demora. Por toda esta deducção se conhece quanto cresciam as despezas, e que se fazia o transporte mais dispendioso para a Fazenda Real, do que seria, pagando-se os fretes á particulares. N'esta figura se conservou este rrejudicial transporte, até que o Exm. Sr. D. Rodrigo José de Menezes applicou á barra outro destino, dando-lhe nova construcçâo, como é notorio.

Ha mais de 3 annos que está a Fazenda Real pagando importantissimos fretes de todas as madeiras, que se tem conduzido, e extrahido dos reaes cortes para as remessas de Lisboa, e para as fragatas construidas n'este arsenal: fretes, cuja importancia é avultadissima, por serem ordinariamente regulados pela terça parte do valor das peças conduzıdas, e cujo producto tem feito a grande utilidade, e posso seguramente dizer, a riqueza de alguns mestres, que nas suas lanchas, razas, veleiras, armadas á latina, e pouco dispendiosas, fazem o transporte para esta Cidade. Termos em que por beneficio da Real Fazenda, e animado do zelo, que V. Ex. á todos inspira, me vejo obrigado a propôr, que a exemplo e a imitação d'estes mesmos particulares, deve Sua Magestade ter duas lanchas proprias, iguaes em tudo ás que actualmente fazem o transporte, para se costearem da mesma forma, e pelo mesmo methodo, que o fazem us mencio. nados particulares: estas lanchas devem ter mestres e marinheiros, pagos por viagens, vencendo salurios certos e de tarifa, afim de que o seu interesse consista em fazerem viagens regulares e breres: devem ser naturaes da villa de Cayrú, por serem praticos dos rios e das entradas, homens costumados a esto serviço, e sobretudo com grande experiencia da barra de Jaguaripe, por onde entram estas lanchas, ainda no rigoroso inverno.

Posto que as vantagens, que tenho representado, sejam por si mesmo manifestas, posso assegurar a V. Ex. por ultima demonstração, que proximamente Gonçalo Gomes Corrêa recebeu perto de $300 \$ 000$ dos fretes das madeiras, que conduzio na sua lancha; não passaram de $40 \$ 000$ as d spezas feitas no costeamento, e á esta proporção tem sido o lucro das mais viagens.

Avista do que tenho exposto, V. Ex. resolverd o que fôr 
mais util ao Real Serviço. Bahia, 19 de Outubro de 1789.o Dezembargador Inspector dos reaes córtes, Francisco Nunes da Costa.

\section{Regimento dos córtes das madeiras em virtude da Carta Régia de 11 de Julho de 1799}

Eu, a Rainha, faço saber aos que este Alvará virem, que tendo em consideração a necessidade que ha de se formar um Regimento, que não só regule a direcção do serviço dos córtes das madeiras de construccão já abertos nas Capitanıas de Pernambuco e Bahia, ou que para o futuro se houverem de abrir, de tão grande importancia aos interesses da minha Real marinha e da mercantil; mas que tambem cohiba a indiscreta e desordenada ambição dos habitantes, que com o pretexto das suas lavouras, têm assolado e destruido preciosas mattas a ferro e fogo, de tal sorte que, a não acudir eu com as mais energicas providencias, ficarão, em poucos annos, reduzidos a inutilidade de poderem fornecer os páos de construccão, de que tanto abundaram, e já hoje ficam em distancias consideraveis dos portos de embarque: hei por bem, e sou servida estabelecer um Regimento para este fim, prescievendo juntamenle as obrigaçoes do Juiz conservador, que fui servida criar, para os córtes das Comarcas dos Ilheos e das Alagoas, como das mais pessoas empregadas na administração delles, como abaixo se declara.

TITULO I

\section{Do Juiz conservador}

1.0-Declarando ser de propriedade da minha Real Corôa, todas as mattas e arvoredos a borda da costa ou rio, que desembıque immediatamente no mar, e por onde em jangadas, se possam conduzir as madeiras cortadas até as praias; ordeno que jámais se dêm estas de sesmarias. 
2. ${ }^{\circ}$-Attendendo, porém, que algumas já se acham dadas, e que as mattas a borda d'agua estão quasi todas destruidas por se terem situado os habitantes juito as costas e rios, sendo muitas pela sua quantidade e grandeza diguas da minha real attenção, por não haverem outras de semelhante naturiza para as reaes coustrucções, e a não occorrer eu com efficaz providencia, se consumirĩo de todo aquella:s que existem jí apartadias dos rios e costas, pelo interior do paiz, 3, 4, 5, 6 e 7 legoas, como manifestam as mattas das Alagoas, P'ernambuco e Parahyba, e ainda uma grande parte das da Comarca ćos Ilhéos. Ordeno que o Juiz conservador mande notificar a cada um dos proprietarios para que hajam de conservar as madeiras e páos reaes, debaixo das penas que abaixo se declara, emquanto os Governadores e Capitães-generaes daquellas Capitanias me não informarem dos meios porque se poderão restituir a miuha Real Corôa as sesmarias já dadas com terras equivalentes, ou como mais conveniente se julgar, segundo toi declarado na Carta Régia de 13 de Março de 1797, que the dirigi.

$30^{\circ-E}$ querendo para o futuro acautelar os prejuizos que a indiscreta ambição dos habitantes continuam a causar nas mattas, reduzindo-as á cinzas pelo ferro e fogo, mando que sejam vedadas ao uso commum com os seus fundos todas as em que houverem madeiras de construcção, ficandu reservadas para á minha real rnariuha da Comarca dos Ilheos, as mattas du rio Tahipe, desde aqui até Commandatuba, Canuavieiras e Rio Graide de Belmonte, por um e outro lado, e as da corda da terra firme da parte do sul, desde Pinaré até Mapindipe: na Comarea das Alagóas, as do principio do rio de s. Mliguel com o rumo do norte até ao engenho da Aldeia nas cabecerras do Rio Formoso, e deste logar correndo o rumo do NO. até ao lundo das mattas do páo amarello do rio Pilaugy Grande, que contina com as campestres ou catingas do sertĩo, e deste logar correndo o rumo de 0 . pelos fundos das mattas Jacuipe, serras de Manguaba, Mariqueta, Carimam. Barriga, Gravatí, Banaual, Taipú, Principe, até finalizar nas cabeceiras do rio de S. Miguel di tante da sua foz 15 a 17 leguas.

$40^{\circ}$ - Em todas as mais mattas da comarca dos Ilhéos ficarão conservados os proprietarios nas capoeiras e terras lavradas, e - mesmo se entenderí em todas as terras da Comarca das 
Alagoas, que se acharem em capoeiras ao longo da costa do mar para servirem estas a agricultura do paiz, como tambem todas aquellas costaneiras de mattas, que pela demarcação se julgarem improprias para construcção.

5.- Como porém na extenção das mencionadas mattas, se acham estabelecidos alguns engenhos em terras proprias: permetti $\in m$ tal caso aos proprietarios dellas só poderem fazer uso das mesmas mattas, para a conservação de suas importantes fabricas, não podendo com tudo cortar as madeiras proprias para a construcção, que as devem conservar debaixo das penas ao diante declaradas.

6. - E porque é da minha real intenção proteger e animar a marinha mercantil, e os meus reaes arsenaes poderão nem sempre abundar de madeira de construcção, que possa vender, permitto aos particulares mandarem cortal-as na Comarca dos llhéos, nas mattas que existem nas ilhas della e em todas as outras da terra firme, que não forem contempladas no $\$ 3$. debaixo da inspecção e faculdade do Juiz conservador, a quem devem ser apresentadas as relaçōes, e na Comarca das Alagoas debaixo da mesma inspecção nas mattas do Lago do Pescoço oito leguas ao N. da Villa do Penedo até ao Rio de S. Miguel, em que se comprehendem as mesmas mattas do Pescoço, Riacho Secco, Cororipe, Poxi, Jequiá de Cima, e todas as mais, até o referido Rio de S. Miguel.

7. - Attendendo porém a que nos fundos das referidas rnattas das Alagoas, se acham alguns ramos de páu Brasil, ainda que pela má admiiistração do seu córte destruidas, que poderão comtudo pelo tempo adiante restabelecerem-se: Ordeno, que fiquem as sobreditas inteiramente vedadas e fechadas a todo e qualquer uso dos particulares, debaixo das penas estabelecidas contra aos que cortam e extraviam semelhantes madeiras e pela mesma razão ficarão vedadas e fechadas as mattas da cachoeira do Rio Patipe na Comarca dos Ilhéos, e outrosim ficarăı privadas ao uso commum as perobas amarellas nas Alagoas nas mattas declaradas no paragrapho antecedente. Na Cumarca de Pernambuco, permitto aos usos e serventias particulares as mattas do Engenho da Aldeia nas cabeceiras do Rio Formoso 
até ao Cabo de Santo Agostinho, com as mattas de Serinhaem, Pepica e Cabo de Santo Agostinho.

8. - E para que me seja presente quaes são as mattas reservadas ao meu real dominio, ordeno ao Juiz conservador, faça um Tombo das mesmas demarcando, não só as que ficain absolutamente tiradas a) uso commum em um livro para esse fim destinado, pelos rios, mares e configuração da costa, levantando mappas como tambem designando as possessões em que ficam as particulares comarcas caracteristicas que as fixam; emquanto com informação dos Governadores das respectivas capitanias, não dou outras providencias, precedendo comtudo na dita demarcação, sem suspensão de quaesquer embargos, dando appellação e aggravo para o Juiz dos Feitos da Fazenda da Relação da Bahia.

9. - Pelo que toca as mattas que existem no districto da Tarze na comarca de Porto Seguro e as da Capitania do Espirito Santo, margens do Rio Doce, ou em outras quaesquer partes da capitania em que ainda se não tenham aberto córtes por conta da minha real fazenda. Ordeno ao Governador $\mathrm{Ca}$ pitão-general, que tomando a respeito destes as informações veridicas e necessarias, e achando conterem em si madeiras de construcção, que interesse a minha real fazenda. faça observar a respeito dellas as disposições dos $\$ \S 1,{ }^{\circ}, 2.0^{\circ}, 3 .^{\circ}$ e $4 .^{\circ}$ deste Titulo, encarregando entretanto a sua excellentissima pessoa que julgar mais habil de desempenhar tão grande objecto.

10. - Em todas as mattas declaradas no $\S 30^{\circ}$ se farão os córtes pela administracão da minha real fazenda, e só o poderão fazer os particulares debaixo da inspecção e e licença do Juiz conservador, quando se ajustarem por preços convenientes, que prevaleça a utilidade da minha real fazenda.

11. - Considerando por outra parte a necessidade, que os povos tem de madeiras para edificarem casas, engenhos e quaesquer outras obras, permitto que nas mattas excluidas aos particulares possam desfructar os que nellas habitarem aquellas madeiras, que forem necessarias para o seu uso tão sómente, não sendo das de construcção, e em todas as outras lhes faculto, não só as que carecem para os seus particulares usos como tambem 
para venderem e exportarem com licença do Juiz conservador para onde lhes convier, dando das mesmas entradas nos respectivos arsenaes da marinha com as suas guias, qué declarem o que trazem e as licenças que conseguiram para aquelle fim.

12.-Quanto aos taboados de Vinhatico, Potumujú, Tapinhoan e Oiti, tão indispensaveis p:lra o forro das embarcacõ 's e outras obras, supposto que pertençam ao meu real dominio, ordeno em beneficio commum de meus vassallos, que os possam cortar e extrahir, não os vendendo comtudo senão para os meıs reaes arsenaes, ajustando o Juiz conservador com os fabricantes um preço racionavel, que contentando-se utilize a minha real fazenda, destinando o intendente da marinha armazens em que se guardem para veriderem-se aos particulares, que os quizerem por preços porporcionados.

13. - Não obstante pertencer o termo do Jequiriçá a comarca da Cidade da Bahia, e o Rio Grande de Belmonte, a de Porto Seguro, attendendo comtudo a ficarem contiguas a Comarca dos Ilhéos, no principio e fim della, ordeno que o Juiz conservador das mattas dos Ilhéos, o seja tambem das mattas do Jequiriçá e das do Rio de Belmonte, o que pela mesma razão o Juiz conservador das Alagoas o seja tambem nas cinco leguas do $\mathrm{N}$. do Riacho Parassininga, onde termina a mesma cumarca até ao engenho da Aldeia, supposto que as ditas cinco leguas pertençam a comarca das Alagoas.

14.-E para que senão disfraudem as minhas reaes determinações pelus particulares que se atreverem a cortar, e utilizaremos das madeiras vedadas ao uso commum, ordeno, que todas as mateiras fabricadas nos meus reaes córtes, tenham além da marca real uma letra iddicativa do córte donde forem extrahidas, que será posta na cabeceira do páo, para que haverá os ferros competentes, numerando-se em cada anno no acto de se ombarcarem desde o n. 1 por diante para com facilidade se saber tambem a todo tempo os páos remettidos para o real arsenal, com os seus comprimentos, larguras, grossuras e qualidades e os que forem ashados sem as ditas marcas serão tomados para a minha real fazenda, ficando aquelles em cujo poder se acharem incur'sos nas penas impostas aos que sem licença minha os cortarem, o que se observará inviolavelmente 
ainda naquelles lugares em que o Juiz conservador julgar conveniente encarregar aos particulares o azerem madeiras do construcções reaes debaixo da sua vista e fiscalização por convenientes preços, ser o interesse publico o maior augmento das reaes construcçós, a conservação dos povos que tiverem aquelle genero de occupação exigir semelhantes concessões.

15.- Sou outrosim servida ordenar, que todas as madeiras remettidas dos subreditos córtes venham ao real arsenal conforme se pedirem pelos Governadores e Capitães-generaes, junta da real fazenda das respectivas capitanias, intendentes da marinha, acompanhadas de uma relação ou relações feitas pelo escrivão dos córtes, rubricadas pelo Juiz conservador ou pelo administrador dos mesmos córtes no seu impedimento, das quaes mandarão os mesmos intendentes passar conhecimento em fưrma.

16. - - Juiz conservador fará annualmente uma vistoria em cuda uma das mattas, dando a conta do resultado ao Governador e Capitão-general, - tirará além da devassa geral, uma para conforme as denuncias que tomar contra os que transgredirem as disposições deste Regimento, cortando ou queimando páos nos lugares defeøos, e procederí contra os culpados dando appellação e aggravo as partes de quaesquer quantias e penas em que forem condemnados para o Juiz dos Feitos da Fazenda da Relaç̃o.

17.-Toda a pessoa de qualquer qualidade que seja, que for comprehendida em cortar pios de algumas das sobreditas mattas sem apresentarem licença do Juiz conservador pague da cadêa pela primeira vez $20 \$$, e da segunda $40 \$$, além dos dous annos de degredo para fóra da comarca, e sendo impostas as ditas condemnacós pecuniarias por denuncias se applicar'i metade pari o denunciante, e a outra para as despezas dos meus reaes córtes em todo o caso perderão as alfais, bois, carros e escravos achados nas mattas carregando ou cortando madeira julgando-se por provado o delicto todas as vezes que se encontrarem dentro das mattas os bois com os carreiros, ou outros signaes anuunciativos do extravio e córte de madeiras.

18.-Determino outrosim, que todas as pessoas, que fizerem derruhadas nas grosaas mattas destinadas sómente para as reaes construccões e contempladas do $\$ 3 .^{\circ}$, lançando-lhe fogo nãu só 
paguem pelos seus bens tudo o prejuizo, que tiver causado a minha real fazenda com a queima dos píos, segundo a avaliação a que immediatamente procerlerí o Iuiz conservador, mas pagará além disto 40\$. pela primeira vez com 30 dias de cadêa, e da segunda 803, pagos da mesma cadêa, e dinas annos de degredo para fora la comarca, tudo debaixo das applicações do paragrapho antecedente.

19.- Sendo a madcira torta e de leame de maior valor e necessidade para as construcçoes das embarcaçoes, e de que regularmente ha maior falta nos meus reaes arsenaes, talvez por señ̃o terem feito as precisas deligencias, ordeno que o Juiz conservador tenha mais por cuidado em mandar cortar as sobreditas madeiras como sejam cavernas, curras e enximentos, $1^{05}$, 2.os e 3 us bracos e outras desta natureza, apezar das difficnldudes, que repetidas vezes se tem representado em as encontrar nas mattas da Capitania da Bahia, assim como se encontram nas da comarca das Alagoas, que espero se desvaneção, aproveitzudo-se as raizes, troncos, galhos e pernadas das mesmas arrores.

20)-Para que se possa guardar e executar como convém pelo Juiz conservador as disposiçues deste Regimento, hei por bom, que elle tenha um meiriaho geral com seu escrivĩo e dous homens de vara, vencendo de ordenado o meirinho geral 100 e escrivito $80 \$$ e os dous homens da vara 50 s cada um. os quaes servirão tambeñ de cuuteiros, e serão obrigados a fazerem as diligencias, que the forem i.ıcumbidas pelo Juiz conservador e de correrem us mattas nos lugares, que elles lhes apoutar e ordenar.

21.-E cono é summammente necessario, que o Juiz conservador tenha conhecimentos da physica das arrores, para que nĩo aconteça fizel-se $\dot{0}$ córte em terrpo incompetente ou em occasiós de que os pios estejam em principio de ruina, que desenvolvida fará a rla peca, ou peças empregadas nos meus navios de guerra, ordeno que o mesmo Juiz conservador faça uma descripção de todas as arrores de construcção, seus usos e utilidade, e por repetidos exames combinaudo o estade do maximo augmento de cada uma dellas e a sua sezão, que a experiencia tem mostrado ser do mez de Outubro atś Fevereiro, 
devendo preferir para os leames os Sepepirasmirins, Jatahis, Angelins, Arnagozos, Pátos de arcos e Pequiz e para as direitas não só aquellas, como tambem as Sapucaias e Jataubás, e para os taboados, Vinhaticos, Potumujús, Tapinhoans, Oiti e Jatahi e para alcaixas pequenas o Cédro vermelho; e para se ter um exacto conhecimento de tão importante materia enviará annualmente ao Governarlor e Capitão-general, um extracto das suas observaçaes e experiencias com tudo que tiver a este respeito descoberto para subir a minha real presença pela secretaria de estado dos negocios de marinha e dominios ultramarinos.

22.-Para a boa arrecadação dos fundos destinados para as despezas desta administração, mando que se estabeleça um cofre na Villa de Cayrú Comarca dos Ilhéos e outro na Villa das Alagoas pertencente a comarca deste nome, com tres chaves das quaes terá uma o Juiz conservador, outra o escrivão dos córtes e a terceira o almoxarife delles, atim de que todos os pagamentos, que forem relativos a uma administraçio depois de legalisados e correntes com os competentes despachos do Juiz conservador, sejam feitos immediatamente a booca do cofre.

23.-Considerando muito conveniente ao meu real serviço, que todas as madeiras dos meus reaes córtes sejam exportadas nas minhas proprias embarcações, ordeno que se fação para aquelle fim todas quantas forem precisas accommodadas as barras dos lugares aonde devem ir carregar sendo encarregalo aos intendentes dos meus departamentos de marinha o venderem aos particulares aquellas de que precisare!n por justos valores, em maneiras que senão prejudique a real fazenda com aquellas vendas, antes a mesma tique utilisada com os lucros proporcionaes as despezas dos córtes, para o que se farí nas ditas intendencias uma breve escripturação para se conhecer a sahida das madeiras vendidas, e que em todos os semestres se vejam nas juntas das respectivas capitanias os avancos da real fazenda os quaes se devem carregar sobre o thesoureiro geral dellas.

24.-E para os meus intendentes da marinha procederem acertadamente na venda das referidas madeiras, hei por bem, que o Juiz conservartor procure todos os meios de calcular o valor em que fica cada um dos páos que se extrahirem dos meus reaes córtes, segundo as distancias em que estiverem da 
borda d'agua para que as remessas que fizerem ao real arsenal, sejam acompanhadas das relaçies, que mostrem os preços porque sahiram os ditos páos.

25.-E porque a experiencia tem mostrado ser absolutamente impraticavel que o Juiz conservador execute o que neste Regimento lhe é determinado, occupando o lugar de Ouvidor da comarca, sendo tantas e de tão grave importancia as incumbencias, que the ficam pertencendo, que pedem o maior exforço e actividade para se conseguir, como é necessario uma regular disposição e economia dos córtes, o maior augmento e propagação dos bosques, e fazer particulares e pessoaes diligencias nas mattas, das quaes resultarão novos conhecimentos e immensas vantigens aos interesses de uma e outra marinha e a minha real fazenda, com o que occupado o Juiz conservador ficarão os povos por outro lado sem terem quem lhes administre justiça, e as differentes villas sem correcções, e até a minha real fazenda prejudicada por não poderem fazer as diversas arrecadaçoes a que é obrigado, motivos que me moveram neste reino a creação de um magistrado particular para as mattas de Leiria, não. sendo estas tão extensas, como as da Capitania da Bahia e Pernambuco, hei por bem desannexar de Ouvidoria das comarcas o lugar de Juiz conservador, e crear separadamente Juizes conservadores para as mattas das comarcas dos Ilhéos e Alagoas, com plena privativa e ordinaria jurisdicção, que exercerão nas sobreditas comarcas nas materias e objectos conteudos neste Regimento, vencendo carla um de ordenado annualmente 1:000\$000.

TITULO II

\section{Do administrador}

1.0-Haverí para os córtes abertos estabelecidos na comarca dos Ilhéos e Alagoas um sú administrador, com o ordenado annual de 500乡, se a ne.essidade não exigir, conforme as distancias dos córtes e augmento das construcçces, a creação de outros mais, o qual assistirá no matto ao córte em que se trabalhar, regulando o serviço e economia delle, e participará ao Juiz 
conservador todos os mezes as novidades do inesmo córte o o seu estado com todas as circumstancias acontecidas; fari conduzir para o porto do embarque as madeiras cortadas, segundo as ordens que receber do sobredito Juiz conservador, como tambem vigiari que os píos se não embarquem sem serem numerados, marcados e medidos na forma do $\$ 14$ titulo 1."

2.0-E porque póde acoitecer ado 'cer o dito administrador. ou ter algum legitimo impedimento, hes por bem que se lhe nomẻe $\mathrm{um}$ ajudante, com o ordeiado annual de 200\$000, para serrir com elle e nos seus impedinentos, sendo a mesmo tempo encarregado de fazer o ponto de toulos os officiaes jornaleiros que se occuparen no dito córte, que entregara no fim da semana ao administrador, o qual enviarí logo ao escrivio para formalizar a feria, e tèl-a prompta no fin de cada mez.

3.0-Serí o administrador encarragado a vigiar sobre o mestre, contramestre, carpinteiros, estradeiros e praticos das mattas, e de informar ao Juiz conservador a respeito dos carpinteiros que melhor se distinguem uas suas obrigaçẽes, para serem attendidos com os jornaes que the furem competentes até o vencimento de 480 rs., e outrosim assignari as reliçoes das madeiras que vierem ao real arsenal, feita pelo escrivito dos cortes na ausencia do Juiz conservador, na feria prescripta no $\$ 16$ titulo 1.0

$4 .^{\circ}$-Prohibo ao sobredito admini-trador e a todas as pessoas enpregadas nesta alministração, o negociar em malleiras, ou encarregar-se de encommendas de particulares, e no caso de trans:gressão deste paraglapho, serĩo pelo mesmo ficto suspensos e inhabilitados para mais turuarem a oceupar os mesmos empregos, alérn de incorrerem nas penas impostas no $\$ 17$ titulo $1^{\circ}$, rerificando-se que cortaram ou extraviaram pios dos córtes da sua administração.

TITLLO III

\section{Do mestre e contramestre}

1. - Da mesma fórma haverá nos referidos córtes um mestre carpinteiro e um contramestre, os quaes serão habeis e intel!igentes, da construcçio de quaesquer vasos. alinharĩo todos os 
páos derribajos, conferindo com o administrador as peças que dos mesmos se podem tirar, vigiando outrosim se os carpinteiros os falquejam com intelligencia e cuidado.

$2^{\circ}$. Estarão promptos no córte no tempo de verão desde ás 6 horas da manhã até ao meio dia, e das 2 da tarle até ás 6 , em cujas horas se principiara e finalizará o trabalho diario dos córtes. Além do referido, será da indispensavel obrigação do contramestre marcar, medir e numerar, na occasião do embarque, todas as peças de que se fizerem remessas para o real arsenal da Bahia, a cujo acto assistirá o Juiz conservador com o respectivo escrivão, e na sua ausencia o administrador, como fica determinado no $\$ 16$ titulo $1^{\circ}$, vencendo de salario, nos dias ('m que trabalharem, o mestre $1 \$ 200$ e o contramestre 800 rs, sem alguma outra ajuda de custo.

TITLLO IV

Do escrivão

1. ${ }^{\circ}$-Haverá um escrivão para fazer a escripturação, não sómente de tudo que entrar em receita, e de que se fizer carga ao almoxarife, mas tambern para formalizar as ferias no fim de cada mez peios pontos, que semanariamente the forem remettidos pelo alministrador, afim de que no principio do mez seguinte se possa fazel pagamento a todos os operarios do córte, a cujo acto assistirá o dito escrivão, passando certidão em como os sobielitos receberam o pagamento, processando outrosim uma folha, que terí prompta no principio do anno, para por ella, com o mandado do Juiz conservador, se pagar os quarteis de tres em tres mezes a cada uma das pessoas que vencerem ordenados certos.

2. ${ }^{\circ-}$-Registrará igualmente nos livros competentes as ferias dos respectivus córtes, 'olhas dos arrastos, relaçzes das madeiras remettidas para o real arsenal, as ordens que forem dirigidas ao Juiz conservador, e d'este para o administrador.

$3 .{ }^{\circ}$-Para a boa ordem da escripturação haverão os livros seguintes, um para a receita e despeza do dinheiro, outro para as despezas dos arrastos, outro para registro das ferias, outro 
para registro das relações das madeiras que se remetterem ao arsenal, onde se averbarão os conhecimentos em fórma que comprovarem as ditas remessas, outro para registro das ordens e correspondencia geral da administração dos córtes, outro para o tomho das mattas que se hão de demarcar, e outro, finalmente, de conta corrente do almoxarife, com cada uma das pessoas a que tiver feito supprimento com generos para se lhe descontar no pagamento das ferias, os quaes serão todos rubricados pelo Juiz conservador.

$4 .^{\circ}$-0 sobredito escrivão se regulará na escripturação dos referidos córtes e pagamento segundo as instrucções, que pelas juntas das competentes capitanias lhe forem dadas, não effectuando pagamento algum sem despacho ou mandado do Juiz conservador, na fórma já determinada no $\$ 22$ titulo $1^{\circ}$ deste Regimento, e haverá além do dito escrivão um ajudante escripturario para o ajudar a servir nos seus impedimentos, vencendo o escrivão annualmente $300 \$ 000$ e o escripturario $150 \$ 000$.

TITULO V

\section{Do almoxarife}

1. ${ }^{\circ}$-Haverá outrosim urn almoxarife, ao qual será commettida a receita e guardas de todo o dinheiro e generos, que pela junta da fazenda real e armazens reaes se remetter para as despezas dos córtes e supprimento dos trabalhadores, e ao mesmo competirá pagar não só as ferias e folhas dos referidos trabalhadores, e mais officiaes empregados nos córtes, mas tambem outra qualquer despeza relativa a esta administração, que pelo Juiz conservador the fôr determinado, o qual será pessoa estabelecida, e tal que mereça o conceito e credito publico, e vencerá annualmente $200 \$ 000$.

$2 .^{\circ}$-Considerando a necessidade que occorre de prover aos trabalhadores e mais pessoas empregadas nos ditos córtes dos generos assim comestiveis, como vestuario, indispensaveis a sua subsistencia, cuja necessidade os obriga de ordinario a largarem o serviço e virem aos povoados, sou, outrosim, servida ordenar que pelos armazens reaes das respectivas capitanias se forneçam 
effectivamente os ditos córtes daquelles generos que se julgarem mais necessarios, para serem suppridos os trabalhadores por conta dos seus vencimentos, sem prejuizo da minha real fazenda.

Hei por bem que esta fórma de administração se guarde invio-

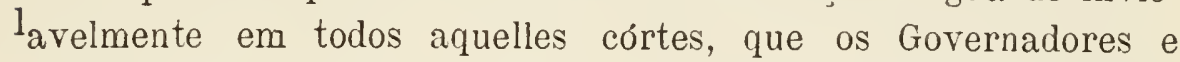
Capitães-generaes das competentes capitanias houverem por bem mandal-os abrir e laborar em beneficio e interesse da minha real marinha, sendo por elles providos os respectivos empregos, e amoviveis a meu real arbitrio.

\section{Sobre o regimento para o córte das madeiras}

Illm. e Exm. Sr.-O disvelo com que me proponho sempre a quanto é do real serviço, e ao desempenho dos meus deveres, são bastantes motivos para levar á presença de V. Ex. o que me parece necessario respectivo aos córtes das madeiras das comarcas dos Ilheos e das Alagoas, em melhoramento d'elles, fazendo este esboço ávista dos artigos do Regimento daquellas conservatorias para que, quando V. Ex. o considere digno de attenção, e queira dignar-se pôl-o na real presença, se sirva de quanto parecer util ao mesmo real serviço, e a bem do honroso ministerio de V. Ex.

Nũo obstante as ordens estabelecidas nos $\$ \S 1^{\circ}$ e $2^{\circ}$ do titulo $1^{\circ}$, foram dadas muitas sesmarias, bem como a do sitio da Lage nas cabeceiras de Jequiriçá, a cinco annos pouco mais ou menos, do que emanou grave prejuizo e damno, nãis só aos moradores daquelle districto, como a conservação dos taboados de vinhatico e potumujú, que só n’elle os havia em abundancia.

A permissão facultativa do $\$ 6^{\circ}$ tez com que se tenham destroçado todas as mattas d'aquelles sitios, porque não sendo só as madeiras exceptuadas nas da terra firme as precisas para as construcções, a ambição dos fabricantes particulares as tem desolado, bem como as de Jequiriçá, pois que ordenando Sua Magestade, no $\$ 12$, em beneficio commum de seus vassallos, se podessem cortar os taboados de vinhatico, potumujú e oiti, não os vendendo elles, comtudo, senão para os reaes arsenaes, ajus- 
tando-os o Juiz conservador com os fabricantes por um preço racionavel: que contentando-se, utilisasse a real fazenda, destinando o intendente da marinha armazens em que se guardassem para se venderem aos particulares, que os quizessem por preços proporcionados, o que parece decide para que sú o arsenal os tenha, e disponha a quem d'elles carecer, afim de suavisar o preço dos que se exceptuarem para as obras reaes; porém assim não acontece, antes de tão benefica concepção emanou o abuso e monopolio com que tem sido gravada grandemente a real fazenda.

Recommenda mais o $\$ 19$ que o Juiz conservador tivesse mais particular cuidado em mandar cortar madeiras. como curvas, cavernas, enchimentos, primeiros, segundos e terceíros braços, e outros desta natureza, bem como no $\$ 21$, que é summamente necessario que o mesmo Juiz conservador tivesse conhecimentos da phyica das arvores para que não acontecesse fazer-se o córte em tempo incompetente, ou em occasião que os páos estivessem em principio de ruina, que desenvolvida fizesse a da peça ou peças empregadas nos navios de guerra; assim como mais especifica o $\$ 23$, que todas as madeiras dos ditos reaes córtes seriam exportadas nas proprias embarcações de Sua Magestade, e que para esse fim se fizessem quantas fossem precisas accommorladas as barras dos logares onde fossem carregar, sendo encarregado aos intendentes dos departamentos de marinha o venderem aos particulares aquellas de que precisassem, por justos valores, em maneiras que se não prejudicasse a real fazenda com aquollas vendas, antes a mesma ficasse utilisada com os lucros proporcionaes as despezas dos córtes, para o que se faria nas ditas intendencias uma breve escripturação para se conhecer a sahida das madeiras vendidas, e que em todos os semestres se vissem nas juntas das respectivas capitanias os avanços da real fazenda, os quaes se deviam carregar sobre o thesoureiro real d'ella.

No $\$ 25$ se vè que Sua Magestade foi servido desannexar a vara dos Corregedores das ditas comarcas da da conservatoria das madeiras, por ser impossivel poder um só magistrado operar nas funcções inherentes a cada uma das ditas varas, sem que padecesse o real serviço, creando, portanto, um Juiz conservador, e um administrador com o ordenado annual, aquelle de 1:000\$ 
e este de 500000 , se a necessidade não exigisse, conforme as distancias dos córtes e augmento das construcções, a creaçĩo de outros mais, o qual assistiria no matto ao córte em que se trabalhasse, regulando o serrico e economia d'elle. participando au Juiz conservador. torlos os mezes, as hovidades do mesmo córte e o seu estalc, com todas as circumstancias acontecilas; e que faria conduzir para o parto do embarque as maleiras cortadas, segundo as ordens que re ebesse do sobredito Jujz conservarlor, como tambem vigiaria que os pios se não embarcasem sem serem numerados. marcados e medidos na tórma lo $\$ 14$ do titulo $1^{\circ}$

Igualmente assim, que houvesse mais um ajudante do ariministrador com o ordenarlo de ¿00\$000, para sorvir com elle e nos seus impedinentus, os quaes serian obrigados a vigiar sobre o mestre, contramestre, carpinteiros, estradeiros e praticos das mattas, e de informar ao Juiz conservador a respeito dos carpinteiros que mellon se distinguirem has suas obrigaçöes, para serem attendirlos com os jolnaes que the fossem competentes ate o vencimento de 480 rs., e que tambem asimnaria as relações das madeiras que fusem para o arsenal feitas pelo escrivão dos cortes. na ausencia do Juiz conservalor, na fórma prescripta no $\$ 16$ do titulo $1 .{ }^{\circ}$

Determina mais no $\$ 1^{\circ}$ do titulo $3^{\circ}$, que haveria nos córtes un mestre carpintciro e un contramestre habeis e intelligentes, da construccão de quaesruer vasos que alinhassem todos os páos derribados, conferindo com o administrador as pecas rue dos mesinos se porlesse tirar, vimiando, outrosim, se os carpinteiros os falquejavam com intelligeneia e cuidado. Finalmente expressa, que o mestre venceria nos lias de trabalho 19200 e o seu contramestre sog rs, sem alguma outra ajuda de custo, sendo vedado ao admiiistrarlor e a todas as pes:oas empregadas na dita administracĩo o negociarem em maleiras, ou encarrear-se de enconmendas particulares, como declara o $\$ 4^{\circ}$ do titulo $2 .{ }^{\circ}$

Tenho gravalu todos os pontos, que formam a base do Regimento da conservatoria, e pela linwa experiencia, tanto dos cortes como da construccia de todos os rasos, julguei ser do meu dever ser o orgĩo que levasse o éco da rerdade aos ouvidos de $\mathrm{V}$ Ex. sobre seme!hante objecto. 
Digne-se V. Ex. reflexionar primeiramente por um pequeno espaço, que não tendo o Juiz conservador todos os conhecimentos theoricos e praticos de construcção, sejam quaesquer que forem os seus grandes estudos, como poderá conhecer a qualidade das arvores, prestimos e configuracões das madeiras, e destinos para onde ellas se devem applicar? E assim sem estes e outros estudos, que possa ser um bom administrador outro qualquer homem, que não seja um constructor perito, e com as qualidades referidas? Colligindo-se, por tanto, que a creação deste segundo logar, despido das precisas circumstancias, parece que foi mais pari proteger certos homens desgraçados, que para a boa ordem do serviço e proveito da real fazenda.

Deixo tambem á sabia e luminosa consideração de V. Ex. o reflexionar qual será o mestre ou constructor habil. com os conhecimentos de todos e quaesquer rasos, que se queira sujeitar a uma vida tão laboriosa, sobrecarregada de perigos e trabalhos para vencer $1 \$ 200$ nos dias em que trabalhar. que contandose-lhe pelo mais, segundo as épocas em que se deve fazer o serviço, poderá vencer no fim do anno $160 \$$ ou $180 \$ 000$.

Parece-me, pois, á vista de tantos e tão justos motivos, lembrar a V. Ex. que todas as sesmarias em que houverem madeiras de construcçĩo, assim como vinhaticos e potumujús, fiquem de nenhun effeito, ainda quando houressem de pagar grandes pensões ou fóros, aquelles que n'ellas estĩo empossados, procedendo-se sem perda de um momento na sua reivindicação, como recommenda $0 \$ 2^{\circ}$ e titulo $1^{\circ} \mathrm{E}$ assim mais, que se abram córtes em todos os logares das ditas comarcas em que houverem madeiras, fazendo-se promptamente todas as diligencias e indagações que para esse fim forem necessarias, como recommenda o $\$ 19$, creando-se para administrador e mestre dos córtes um constructor habil, intelligente e capaz, e igualmente assim um contramestre por elle escolhido para coadjuvar os seus trabalhos e exercer igualmente nos seus impedimentos, vencendo o mestre administrador $2 \$ 400$ diarios, e o contramestre 1\$200, unicos meios que a razĩo offerece para convidar homens benemeritos, e prosperar um ramo de tanta consideraç̃o para Sua Magestade, como para os seus reaes interesses. sem cuja reunião já nais se poderí conseguir. 
Antes da creação da conservatoria serviram os mestres de administradores dos trabalhos dos córtes; encarregados unicamente das carreadas, conducções e embarques certos homens abastados, que tambem pagavam as ferias dos jornaleiros, e cobravam depois, quando a fazenda real fazia pagamentos áquella inspectoria, e unicamente eram compensados pelos Exms. Srs Governadores com patentes milicianas, com o que se davam sobejamente por pagos e contentes, e o serviço se fazia com grande actividade e economia, o que provo com dizer a V. Ex. que pedindo-se da côrte de Lisboa 50 páos, como fossem mãos de trincaniz, ditas de dormentes, taboas da bocca, etc., isto em relação de 27 de Maio de 1788, importaram os ditos 50 páos $103 \$ 000$, e hoje tres ou quatro d'essas dimensões excedem em valor a todos os outros pela má administração e desgraça dos córtes, especialmente da comarca dos Ilhéos.

Foi o primeiro administrador pago João Pedro de Perné e seu ajudante Pedro Gomes, aquelle mestre de sumacas em Pernam. buco, e este arraes do barco de Sua Magestade. Falleceu este administrador a 15 annos pouco mais ou menos, e ficou interino até agora o dito seu ajudante. E' até onde póde chegar a desgraça, contiando-se de semelhantes individuos um tão importante negocio, que devendo por todas as razões ser interessantissimo a Sua Magestade, assim não tem acontecido, antes tem feito balancear té agora sobre os meios de se evitar as suas ruinas, sem que bastem as providencias que se lhe tem applicado.

Como de um absurdo nascem mil, tambem se creou a marinhagem dos barcos de Sua Magestade com pagamentos a mezes, vindo por este modo a sahirem maiores as despezas das soldadas, que se se pagasse frete das madeiras, estando no caso do que hia fazer a barba á Cacilhas por 10 rs., e pagava 40 rs. a falua que o levava e trazia. Accresce mais serem os mestres negociantes, bem como o actual, que trazendo madeiras e taboados, tem a animosidade de entrar com ellas em seu proprio nome, as quaes embarca, conduz e descarrega com os marinheiros a quem Sua Magestade paga, sem que receba frete, nem utilize a real fazenda cousa alguma, quando para este negocião deixa o barco de conduzir a sua competente carga, o que tudo se vê distinctamente nos livros da receita do almoxarifado, e folhas na respectiva contadoria da junta. 
Lembro tambem a V. Ex. ser de uma indispensavel necessidade que a permissão facultativa do $\S 6^{\circ}$ aos fabricantes de Jequiriçá seja de todo immediatamente extincta, por quanto os ditos fabricantes não só têm abusado de uma tão especiosa graca, como armado do mais escandaloso monopolio, pondo socios "e atraversadores nas mattas, entre os quaes são dous clerigos, valendo-se das mais engenhosas astucias, de modo que a continuar essa permissão, seguro a V. Ex. que em menos de 10 annos uma taboa infima não custarái menos de $16 \$$ e $20 \$ 000$, e que as mattas ficarão de todo reduzidas a nada, o que testefico até pelo exemplo dos dias 27 de Agosto, e 10 de Setembro d) presente anno, em que entraram por compra no arsenal 33 pranchões, e 131 taboas por 2:330\$200, isto porque não tem o freio da conscrvatoria, e esta a devida fiscalidade, comprando as falcas nas mattas por conta da real fazenda, e remettendo-as para o arsenal.

Tambem pela liberdade que se tem dilatado, mesmo pela conservatoria aos fabricantes e contratadores de madeiras, já hoje é difficultosissimo achar-se uma enteria ou mastro para as fragatas e náos de Sua Magestade, e a não cohibir-se a dita liberdade com graves penas, ou com as de:criptas no $\$ 17$, affirmo a $\mathrm{V}$ Ex. que em menos de 6 ou 7 annos não haverá um só d'estes páos, ou ainda mesmo para as de cotellos de qualquer galera, pelo que entendo serí tambem muito conveniente á real fazenda, que todos páos de oleo, sapucaia, olandis, carvalhos e louros que sirvam para mastros, entenas, velgas, etc., só possam ser cortados por conta de Sua Magestade, e vendidos aos particulares (exigindo estes competente licenca dos Exms Srs. Governadores) com $20 \%$ sobre o seu custo, sejam comprados no arsenal ou na conservatoria, fazendo-se de tudo as competentes claresas.

E assim mais, que substada a liberdade dos fabricantes dos taboados os irem atravessar nas mattas, se construam duas serras d'agua nos rios de Jequiriçá e Valença (que tem para isso as melhores proporções) e comprando-se as falcas nas mattas por conta da real fazenda," se serem alli, e marcados os pranchões e taboados, assim como $\mathrm{gtambem}$ carimbados com suas verdadeiras importancias, se remettam para o arsenal, o que a effe- 
ctuar-se, seguro a V. Ex. 25:000\$ ou 30:000\$000 em favor da construcção de qualquer fragata, ficando só reservados para os particulares os que se façam desnecessarios para Sua Magestade, quando não pareça justo, como entendo. ser só o arsenal quem os possa vender, impondo- e-lhe para isso tambem a pena do \$ 17. unico meio por que se poderá aiuda salvar os restantes d'aquellas mattas, o que se deve pratical tambem com as de Jequié ou Nova Boipeba. Quando, porém, fique aos particulares a liberdade de comprarem, ou negociarem em taboados d'essa natureza, depois mesmo da escolha. devem pagar 45000 por duzia de pranchões que fizerem, e $2 \$ 000$ pela de taboas, seja barcal ou soalho, cujo imposto serí recullitlo no cofre da conservatoria, e todos os quarteis remettiros á real fazenda, a qual no fim de cada um anno deverí fazer ver nessa secretaria da marinha o que produzir este ramo de negocio.

A' vista das grandes vantagens que tiram os marleireiros nos páos de machado e taboas de louro, cedro e oitis, parece que deverão pagar í real fazenda $590 \mathrm{rs}$. por duzia de vigras, 320 pela de frechaes, 160 pela de vigotas e enx mes, e $200 \mathrm{rs}$. pela dos ditos taboados, procedendo-se ua sua arrecadaç̃̃o e remessa tudo na fórma do artigo supra.

Todns as serras d'agua se reputam pelas fabricas mais iaterešsantes e vantajosas, ainda quando serre so madeiras de partes, porque estas pagam o terço de tudo quanto nellas serram; logo, se uma lancha paga 12\$\$00, uma canoa e uma pequena taberna, por que nio ha de pagar o proprietanio de carla uma serria tambem $12 \$ 800$ annualmente?

Sendo, como é, toda a marinha da pos essĩo e dominio real, estão edificados n'ella todos os estaleiros particulares, impondo estes, que se chamam donos ou mestres d'elles, uma pensĩo aos negociantes que alli mandam construir qualquel embarcacão, 603 de cada uma ; e isto mesmo aconteceu com a construccũo do bergantim Real Pedro, que não obstante ser de Sua Magestade, levou Pedro Francisco a José da Costa de Carvalho, que o construio, tambem 60 do local do seu estaleiro. Logo em termos taes parece năo ser violencia fazer com que todos os mestres dos estaleiros paguem annualmente $70 \$$ e os das comarcas $20 \%$, pena de serem evazuados e tomados para a real fazenda. 
A energia da lei é sempre quem coopera para o acerto e bom fim de todas as cousas, aliás se deveria considerar por um simples escripto; portanto é necessario por ella providenciar o presente, $\theta$ acautelar o futuro, e de uma absoluta necessidade que depois de postas as regras que lembro, se proceda no mais que passo a expender, applicando-se uma rija fiscalidade sobre tão dignos e importantes objectos, adquirindo-se homens habeis e probos para execução de quanto se faz necessario naquelles repartimentos dos córtes reaes.

Como se fosse reunida em 1810 a vara da conservatoria outra vez a da corregedoria, está assás provada a impossibilidade dos Juizes conservadores, ponderadas no $\$ 19$, poderem desempenhar com satisfação e um exacto dever aquellas commissões tendentes aos reaes córtes; e, portanto, lembro a V. Ex. não ser deslocado eleger constructores hajeis e provectos, pagos na fórma já dita, e que estes mesmos sejam administradores do serviço, sujeitos tão sómente ao Juiz conservador, obrando sempre de intelligencia com este; e demais que se admittam até o numero de 50 aprendizes, com o vencimento de $80 \mathrm{rs}$. nos dias de trabalho, sejam escravos ou libertos, despedindo-se daquelle serviço os que se couhecerem inhabeis, e augmentando-se proporcionalmente os que melhor se applicarem e distinguirem no trabalho, sendo os libertos exemplos das tropas de linha, para assim se animarem e aproveitar-se tanta mocidade perdida e ociosa que existe por aquelles 10gares.

Que posto tudo isto em ordem, se abram córtes em todos os lo. gares onde houver madeiras nos districtos da comarca, e que estes sejam sempre feitos desule o $1^{\circ}$ de Março até o ultimo de Julho, de maneira que fiquem píos derrubados quantos bastem para se falquejarem nos outros mezes em que as arvores se revestem de folhas novas, e tem o seu maior viço, succedendo portanto abrirem os páos no falquejo, e terem muito pouca duração nos vasos em que se empregam, a respeito do que ha infinitos exemplos, além dos por mim experimentacos nas mattas e nas construcções.

Outrosim acho ser de grande utilidade, que nos logares dos portos onde se fizerem os córtes, se façam tamhern corvetas, bergantins e escunas de guerra, sendo este um meio de illustrar aquelles povos, augmentar os logares, de se evitar as grandes 
despezas de fretes e conducções, e de crear muitos officiaes em beneficio e augmento da marinha real e suas construcçós.

E' lacto visto a todos os momentos, que os páos da con servatoria (especialmente a de Ilhéos) sempre trazem o valor de $5,6,7,8,12,50,75$ e $80 \$$, etc., etc. (não fallo dos seus grandes deffeitos) mas só sim, que sem offender nem levemento a autoridade d'aquelle departamento, posso segurar a V. Ex que os páos que sahem d'alli são vendidos pelo indigno admi nistrador, ou avaliados por este e seus consocios, e não remettidos pelo que justamente importarim, por ser impossivel que em tantos e tão differentes artigos de despezas não houvesse jámais um com a conta de reaes, como succedia antes da conservatoria e deste actual administrador.

Tambem lembro á V. Ex. que o meirinho da conservatoria, e assim os dous homens coiteiros, são inteiramente desnezessarios, porque observei que esses logares eram preenchidos pela justiça das villas, pois o meirinho geral era mais um criado do administrador, para tratar dos seus negocios, do que para o serviço daquella repartição para que foi destinado, especial. mente quando o Juiz conservador é tambem corregedor da comarca, e que tem todas as justiças á sua ordem sem opposição de outro magistrado.

Occorre-me mais lembrar a V. Ex. que se deve cortar e applicar, para os forros dos costados das embarcações reaes, os taboados de curanhen, a que os indios chamam femea, e que tem a casca muito lisa e adocicada, o da madeira marfim, até mesmo para o esqueleto, bem como páos de peranduba para mastros de corvetas, bergantins e escunas, por ser de grande duração e desempeno, e terão preferencia os de Capiá ou Paratigi-assú até Belmonte. Nas madeiras especificadas no $\S 21$ se devem comprehender o páo roxo, arco, amoreira e oiticica, por serem não só madeiras de lei, como de muita duração, a excepção das peças esqueletaes, servindo tambem as pinhães para os logares humidos das embarcações. Lembro tambem a V. Ex. que as madeiras das Alagoas e rio de S. Francisco devem pagar meio por cento na sua respectiva conservatoria em attenção as despezas que fazem as embarcações, e ao r'isco das barras. 
Para bem fe facturarem as madeiras, deverão ser remet. tidas copias dos planos que se hão de construir, para que por elles o mestre alministrador faça executar todos os páos destinados a execuçĩo dos ditos planos, numerando-se de sorte que não renhan sen conhecimento de preços e seus destinos, e sobrecarregados de madeiras, nem com voltas contrafeitas, fendidas as suas fibras lignosas, e expostos a uma tenue duracão, quando se degotam afim de os approximar ao estado das configurações que se exige.

Tão necessario é fara us córtes um mestre, com as condiç̃es referidas. corno para o arsenal um inspector, que seja um constructor habil e intelligente nas construcções, como pratico nos cunhecinientos das madeiras, seus prestimos e valores; cujo inspector deve examinar com cuidado todos os píos qae forem remottidos para o arsenal, conhecel da sua distribuição e arrecadação, rara que se não applique mal os que forem de grande valor em pecas insignificantes, e se não vendam por menos do seu custo; e que outrosim seja encarregado do approveitamento e sobras dos páos retalhados para batentes de artilharia, escoteiras, cunhos. cadernaes e moitões.

Ainda na ultima náo que construio Antonio da Silva em 1762, se conservara o inspector Manoel da Silva Machado com o ven. cimento de 2\$400 diarios. e supposto pareça este logar ser o:neroso a real fazenda, contudo a experiencia fez ver sempre o grinde interesse que inuito lhe resulta, com tanto que o dito inspector reja habil iustructor, e nunca outro individuo, porque a hão ser desta profissĩo, jumais será possivel utilisar a real fazenla. antes servirá de complicar a indisposição com os intendentes da marinha.

E' de igual necessilade uma aula de architectura naval e desenho. applicando-se para isso muitos alumnos, e um professor habil e com os precisos conluecimentos, bem como Manoel da Costa.

Sobretudo, lemb:ro a V. Ex., que todos estes trabalhos deverão principiar depois do almoço, para o que se lhes dará meia hora, depois de nascer o sol, e largarem ao meio dia, porque a não ser assim, jámais se poderá evitar o sahirem todos, e recolher-se menus uma quarta parte, juntando-se somente a hora e meia 
em procura du ponto: isto se observa no arsenal de Lisboa, prevenindo-se assim esta e outras malversaçoes que se seguem do almoro is $81 / 2$ horas.

Testemunhou V. Ex., no tempo do seu feliz governo, como acabaram os barcos da conservatoria, e que, como por milarne, não pereceu toda a tripolaç̃o do barco Triumpho do Sul, quando no mar alto se abrio pela pôpa desperando o cadaste e painel della dos ligamentos da quilha e cintado. Quizera eu que o administ:ador da conservatoria, e os mais encarregados das embarcações reaes, me dissessem oude estí o zelo e a obrigação de acondicionarem, reveren e fabricarem os litos vasos, expondo-os por suas omissóes e mal entendidos caprichos com as vidas a um precipicio inevitarel?

Do modo que tenho ponderado, evtou persuadido se augmentarão os vasos leaes, e que será respeitada a marinha portugueza, creando-se homens habeis, uteis a Nação e ao Estado, para que não aconteca o que succedeu a escuna Satellite, que sj regria com vento a pópa, até que fez o seu naufragio na enseada de Santa Isabel, o que ha de succeler sempre quando se deva a execucão de qualquer vaso a habilidade, e não a scirricia e arte de quem o construir.

T'enlo por agora exposto a V. Ex. as duvidas de que acho sobrecarregada a boa administraç̃o dos córtes, e o que se deve cimentar para permanecer n'ella a boa ordem, assim como os meios que, sem oppressão dos povos, poide grandemente concorrer para fazer um fundu sufficiente e interessantissimo áquelle departamento, e vantagem los navios renes, e ao bom acerto e execução de suas jeças, felicidade daquellas villas e seus liabitantes.

Digne-se V. Ex., quaudo istu lhe pareça ser de um ajustado deve:, illuminar todos os artigos que ditou a minha rudez, e fazel-os contirmar por Sua Magestade, serviulo-se da boa mente com qua o faço, pois i nascida ds zelo e honra com que me proponho sempre ao serviço de Sua Magestade, e do muito que desejo agradar a V. Ex. em retribuição dos grandes e distinctos favores de que sou devedor a sua bondade e generoso animo.

Bahia. 3 de Outubro de 1818.

Manoer. Johquim José di Crl\%. 



\section{PHYTOGRAPHIA}

\section{oc \\ BOTANICA BRASILEIRA}

APPLICADA

A MEDICINA, Ás ARTES E Á INDUSTRIA

Abacatoiro. (Laurus Persia) - Arvore maior que uma laranjeira, natural do Brasil. Tegeta espontaneamente no Pará.

Daquella provincia foi transplantada para todo o Brasil, por causa do seu excellente fructo, que é muito nutritivo, e gosa de propriedades aphrodisiacas. O caroço que está no fructo, dizem os naturaes, que possue em maior gráo aquella propriedade, tomado em pó, e infundido em agua quente.

\section{USOS MEDICINAES}

As folhas e grêlos, reduzidos a pó, ou infundidos em agua quente, tomados em fórma de chá, por nove dias, curam as obstrucç̃os do figado, e do baço, a dysenteria, a syphilis, o vicio boubatico, e faz vir o menstruo supprimido; bem como é excellente remedio, para as molestias da bexiga ourinaria.

\section{USOS ALIMENTICIOS}

A fructa come-se, estando madura, com assucar, mel, com sal, embebida em vinho, e com o sumo de limão.

\section{USOS .NAS ARTES}

Do caroço da fructa contundido, exprimido o succo, se extrahe tinta, de um amarello escuro, e indelevel, propria para marcar roupa; e gosa da propriedade de não estragar o panno. 
Abacaxi. (Bromelia pyramidalis alba.) - Variedade de ananaz, oriundo do Pará, e hoje vegeta em quasi todo o Brasil. É excellente no gosto, e mais macio, que o Ananaz. Do fructo fazem os indios, optimo vinho, muito nutritivo e saboroso.

USOS MEDICINAES

É desobstruente do figado, e favorece a digestão.

USOS NAS ARTES

As folhas do abacaxieiro dão linho, com que se fazem cor-. das, para usos domesticos.

Com este nome, se conhece um rio, que desagua no grande rio Madeira ou Mamoré, proximo de uma Missão, fundada pelos Jesuitas.

Abai-pururuca.-Milho proprio, para estalar ao fogo, ou fazer pipóca.

Abajerú ou abjerú ou abojerár ou guajixú. (Multicaulis icaca.) -- Planta silvestre, que vegeta nas praias, similhante ao carrasco; e tem a folha aspera e redonda, flòr branca, o fructo carnoso, á maneira de azeitona grande, ou damasco, de côr roxa, mais ou menos clara.

Os hespanhóes chamam-no Guajerú Icaca, e estimam a fructa, por ser comestivel.

USOS MEDICINAES

o cozimento das folhas, serve para o rheumatismo. Este arbusto, abunda nas praias da Bahia, Sergipe, Alagôas e Pernambuco.

Abaremo ou abaremotemo. (Vid. Ingá.)

Abati ou abaxi autá.-(Tupy : sea, mais) grão duro, milho. (Vid. milho.)-Esta planta, assás conhecida, é originaria da America. Tem sua variedade distincta, pelos seguintes nomes dos indigenas do Brasil.

Abati-catètê.--Milho miudo : dura tres mezes na terra: a sua planta é baixa, e o grão miudo. Cultivam nas terras de beira-mar.

Abati-catuguassú-etè.-Milho de conta, e cuja es- 
piga, tem mais de palmo; gosta de terrenos de massa pé, ou barrentos, ou dos logares de arribadas, para a sua producção.

Abati mapira ynhacurie.-Milho, cujo grão é do tamanho de chumbo de munição. Esta variedade de milho, é mui productiva.

Abati mapira inhamuái.-A sua espiga é aberta, e o grão muito redondo.

Abati michuè machauere.-A sua espiga é fechada, como a do painço, porém maior, e o grão mais reduzido, que este.

Abaxi ou abatiapé ou abatimerim.-(Arroz silvestre. Vid. arroz.)-Esta especie de arroz, nasce espontaneamente, e com muita abundancia nos alagadiços dos grandes rios do Brasil, como o Paraná; e nos que desaguam no Amazonas. Esta especie de arroz, tem differença do arroz commum, tanto na grandeza dos grãos, como em ter paragranos, que o defendem dos passaros. Com elle cosido, e com o milho, fazem os indios uma bebida, a que chamam Abaxi yy. Os escravos, em vez do arroz, ou milho cozido, fazem o aloá, com o arroz crú, por meio da fermentação.

Abiu. Caimito. (Labatia reticulata.)-Arvore do Pará, que se tem transplantado, para outras provincias do Brasil; o seu fructo é comestivel, e agradavel.

\section{USOS MEDICINAES}

0 caroço ralado, e misturado em agua morna, empregam-n'o como emetico, nas febres intermittentes.

Aboboreira. (Cucurbita.)-E' planta muito conhecida, que nasce cultivada, e espontaneamente; e alastra, estendendo-se pela terra, ou trepa por sobre as arvores.

\section{USOS MEDICINAES}

As flores passadas pelo ar do lume, e esprimido o sumo no ouvido dorido, faz passar a dôr deste orgam. As folhas pisadas, e postas sobre as queimaduras, fazem mitigar as dôres, e acceleram a cicatrização. A polpa cozida da abobora, dizem os sertanejos, ser excellente remedio, contra o cancro ulcerado, posta sobre a ferida. 
As sementes torradas são excellentes, para expellir as lombrigas e a tenia, e despedir as ourinas, nos ataques de retenção.

\section{USOS DOMESTICOS}

0 fructo da aboboreira é mui estimado, como alimento sadio, e. nutritivo. Come-se cosido, assado; e de qualquer fórma, é mui saboroso. Das folhas tenras, e dos grelos, faz-se excellente guizado, que se póde dar aos convalescentes.

Aboboreira jerimum ou jerimú. (Cucurbita major.)-0 fructo é mui doce, e saboroso, e a massa mais enchuta e macia, e por isso, preferivel entre os cultivadores do interior.

Aboboreira d'agua. (Laguaria.)-E' muito conhecida, e differe o seu fructo, do da aboboreira commum, em ser comprida, e a casca esbranquiçada. Como alímento sadio, é muito procurado o seu fructo, para diversos guizados.

USOS MEDICINAES

o sumo dos pimpolhos da aboboreira d'agua, só, ou com oleo rosado, e lançado ao ouvido do doente, faz passar a dôr; as folhas pisadas, e misturadas com sal, resolvem as aposthemas de detraz da orelha.

As pevides da abobora, feitas em emulsão, abrandam os incommodos do figado, e do baço.

Com o sumo das tripas da abobora, untado o corpo dos febricitantes, é de muito proveito, porque dá allivio aos enfermos.

Aboboreira do matto ou abobora do matto-tayuiá itaca. (T)ianosperma ficifolia.) - Esta planta silvestre, nasce nas mattas, e catingas do interior do Brasil, e mesmo nas terras cultivadas, que foram abandonadas. Suas virtudes medicinaes são muitas, e representa as propriedades de varios medicamentos. A ábobora do matto, chama-se no interior o azougue dos sertøes.

\section{usos medicinaes (No SERTÃo)}

Tome-se um plano de sipó ou rama, que será colhido em lua nova, e rachado á maneira da salsa, e depois de secco, põe-se em infusão, com quatro garrafas d'agua, por 12 horas, e posta ao fogo, até gastar a metade, e depois de frio se côe, 
e o bagaço, lave-se em uma quarta parte de agua morna, e se ajuntará ao cozimento, e então em vasilha vidrada, se vai mechendo, deitando-se dentro meia libra de assucar fino, e com fogo "lento, se vai mechendo, a tornar o liquido em fôrma de lambedor grosso, e delle se tirará uma, ou meia onça, que dissolvida em agua, se dará ao enfermo em clister.

0 taiuiá aproveita em todas as molestias syphiliticas, e tem tambem emprego na homcopathia.

Aboboreira carneiza. (Cucurbita.)

USOS MEDICINAES

A raiz pisada, e cozida em vinagre, e posta em fórma de emplastro sobre o baço, o desobstrue.

O sumo da raiz, esprimido no ouvido, faz passar a dôr.

o cozimento das folhas e raizes, serve para lavar, e curar as chagas de máu caracter; e principalmente as syphiliticas, das partes pudendas do homem, e da mulher. Tambem aproveita nas inflammações dos olhos.

o cozimento da raiz com assucar, dado a beber, em pequenas porções, cura as febres rebeldes.

Abricoteiro. (Mammea americana.)-E' arvore originaria do Brasil, que vejeta nos brejos, e logares humidos, e deita fructo carnudo, comestivel, porém, pouco apreciado.

\section{USOS MEDICINAES}

A seiva leitosa da arvore, simples, ou misturada com cal, ou com agua e sal, empregam os sertanejos no curativo de feridas de máu caracter, e nas mordeduras de marimbondos. O caroço tem a propriedade de matar as lombrigas.

Absintho. (Losna. Artimisa. Absinthum.)-Arbusto muito conhecido, vindo da Europa, para o Brasil.

\section{USOS MEDICINAES}

O seu uso em medicina vulgar, é de um tonico agradavel, por gosar de propriedades fortificantes, quando se padece fraqueza de estomago, em consequencia das digestóes tardonhas. Tambem o empregam, contra os vermes intestinaes.

Administram-n’o em fórma de chá, na quantidade de 1 até 6 
oitavas das folhas, em 12 onças de agua. Tambem 0 infundem em vinho, para se tomar de manhan, 1 onça, até 2 , confórme a idade da pessôa.

Abutua ou butua, ou parreira frava. (Cesalpina parreira.)-Esta planta mui conhecida, nasce nas mattas, e nos chapadões ou taboleiros. Tem o fructo em fórma de bago, e com uma unica semente.

\section{USOS MEDICINAES}

Desta planta, só se tem empregado em medicina a raiz, contra as molestias da bexiga ourinaria, contra os calculos, ou pedras vesicaes, contra a hydropisia, e febres intermittentes. Por seu amargo, é mui tonica, e apropriada aos que padecem debilidade de estomago, e côres pallidas. Empregam-n'a tambem internamente, para regular us menstruos.

Os sertanejos empregam a raiz da abutua, para promover a transpiração aos enfermos, que conservam nas febres, a pelle secca; bem como em cosimento, para combater as sezões, ou febres intermittentes, dando de 2 a 4 oitavas, infundidas em 1 libra de agua fervendo, ou em cozimento. Tambem empregam a abutua, nas dòres do estomago; na hepatisação pulmonar, como desobstruente, expectorante, e diurectica.

o pó da raiz da abutua, com oleo de copahyba, e aguardente, é excellente remedio para combater a colica.

Ralada a abutua, e bebida em agua morna, untando-se a parte com o mesmo pó, é de muito proveito, aos que padecem de tumores, e mesmo pontadas internas.

E' empregada em gargarejos, nas anginas ou esquinencias.

A abutua misturada com o sumo do limão, os sertanejos empregam-n'a contra a morphéa, e tomada em vinho, é proveitosa na inchação do ventre. A abutua misturada com o sumo do limão, é prompto remedio contra a mordedura de cobra.

Abutua merim ou miuda. (Cocculos filipendula.) -E' planta muito conhecida no interior do Brasil.

USOS MEDICINAES

Tem esta planta os mesmos prestimos, que a abutua commum. 
Acá.-E' arvore corpulenta de 50 palmos de altura, e de 2 de diametro. Floresce em Novembro: a sua madeira é macia, e propria para a construcção. (Silva Lisboa.)

\section{USOS MEDICINAES}

Não são conhecidos.

Acacia. (Acacia.)-Arvore de 30 palmos de altura, e de 2 de diametro. Floresce em Setembro. A sua madeira é macia, e pouco porosa. (Silva Lisboa.)

\section{USOS MEDICINAES}

o povo serve-se do entrecasco, e das folhas, em infusão nas febres continuas.

Acacia asiatica.-Temol-a em varios logares do Brasil.

Acaciroba, acaricaba ou acaricoba. (Hydrocotyle umbellata.)-Esta planta deve o seu nome, á fórma concava das folhas.

\section{USOS MEDICINAES}

Os Srs. Merat e De Lens dizem, servindo-se da auctoridade do nosso amigo Dr. Martius, que o succo fresco extrahido da planta, é empregado em grandes porções, pelos naturaes, como emetico; quando em menor quantidade, obra com proveito, nas doenças do figado, e combate a hydropisia. A raiz desta planta, tomada em cosimento, é conveniente aos enfartos dos orgãos abdominaes, nas affecções do figado, dos rins, como remedio especifico, dessas enfermidades. A planta distillada, serve para tirar as sardas, lavando o rosto com a agua assim preparada.

Agafrôa. (Quarea specaefera.)-Planta conhecida, e cultivada nas hortas.

\section{USOS MEDICINAES}

A casca, e a raiz são usadas em cozimento, nas febres intermittentes e continuas, com muito proveito; é tonica, e estomachica. As sementes em pó, bebidas em agua morna, combate a somnolencia, e a tosse; misturadas no caldo de gallinha, purgam o ventre.

\section{usos CULINARIOS}

Os calices e as flores da açafrôa, usam nas cosinhas, para tingir o arroz, e outros cosinhados, para as mesas. 
Acafroeixo do Brasil. (Vid. urucui.)

A gafrooiro oriental ou agafrāo oriental. (Crocus sativus.)-E' planta da Asia, que foi transportada para a Europa, e depois para a America.

\section{USOS MEDICINAES}

As flores são aperitivas, isto é, desobstruentes, e convenientes aos males do estomago, e do utero. Servem-se das flores em infusão na quantidade de 18 a 32 grãos, em uma libra de agua, para se ir tomando de espaço em espaço.

A cafram.-Planta conhecida, de folhas delgadas, compridas, estreitas, o talo cheio de flores, e a raiz como cebolas.

\section{USOS MEDICINAES}

Misturado com vinho, perde toda a virtude que possue. Machucado, e posto na apostema ou tumor inflammatorio, o faz arrebentar em pouco tempo; e possue tanta força e vigor, que applicado na palma da mão, vai obrar no coração. As suas principaes virtudes são coser, mollificar, e adstringir. Misturado o açafram com leite, cura as inflammaçoes dos olhos, e a erysipela. Cura as dores uterinas applicando-o sobre o baixo ventre.

Acajá ou cajá. (Spondias myrobolanus.)-E' arvore mui conhecida, que folga em todo o Brasil. O seu lenho é branco, e as folhas pequenas. O fructo é acido agradavel, e cheiroso.

\section{USOS MEDICINAES}

o cozimento feito da casca, e folhas novas, cura as feridas da garganta, por suas adstringencias; cura as diarrhéas, e as gonorrhéas. Os caroços dos fructos pisados, feito cozimento, é proveitoso no fluxo branco das mulheres.

Acajá.-Fructo da arvore acajaiba ou acajazeira.

Acajaiba ou acajá. (Ibametara Spondias mirabolanus.) - Acajaibeira é a arvore, que dá o fructo. E' silvestre, e copada, com casca grossa, aspera, e com o lenho molle; se o ferem ou incisam, exhala um oleo branco, que corre em fio. Das suas folhas se sustenta o bicho da seda.

USOS MEDICINAES

A sua flor é branca, e o seu fructo amarello, saudavel, e 
proprio para dar aos doentes. Os indios fazem com elle, um saboroso vinho. Os indios, quando atacados de enfermidades, fazem um buraco na terra, no qual lançam brazas vivas, e sobre ellas, os caroços dos acajás, chamados Abranhos de Momblim, e por cima põem os joelhos, ou partes enfermas, todo o tempo que podem aturar'o seu calor ; e desta maneira curam-se. Os homens o chamam Uvi, e as mulheres Mombim.

A caja-i.-E' acajá pequeno.

USOS DOMESTICOS

E' comestivel.

A cajá ou cajá. (Spondias venulosas.)-Ameixa da America. E' planta do Pará, e de Cayenna, cujos fructos acidulos, se parecem muito com as ameixas, sendo a còr dos fructos, de um amarello alaranjado.

\section{USOS MEDICINAES}

Os fructos são comestiveis, e se faz com elles, uma tisana refrigerante. Os caroços pisados, na quantidade de uma oitava, em cosimento, aproveitam nas leucorrhéas. 0 cosimento da casca, é mui usado nas feridas da garganta, contra as diarrhéas, e nas gonorrhéas.

Acajayg.-Bebida usada pelos indios, na qual poem em infusão o acajá, para lhe communicar certo sabor acido, e egualmente o seu suave cheiro.

Acajú. (Anacardium occidentalis.)-Fructo do Acajuiba, a que os portuguezes chamam cajueiro. São uns vermelhos, outros amarellos, e todos mui formosos, saborosos, e de um cheiro mui suave.

\section{USOS MEDICINAES}

E' medicinal, porque dissipa as febres, extingue o fastio, e corrobora o estomago; com este fim, muita gęnte, toma alguma porção de seu sumo de manhan em jejum.

\section{USOS DOMESTICOS}

Delle se fazem muitas iguarias, e doces deliciosos. Compũe-se o fructo de certos filamentos esponjosos, ensopados em um succo, que reune em si, as duas qualidades de agro e doce, que re- 
frigera muito, e se julga ser mui proveitoso, aos que padecem do peito, e desmaios, juntando-se-lhe assucar. Em qualquer panno, que caia o succo do cajú, imprime-lhe nodoa, que só depois de muitas lavagens desapparece.

Acajucala.-A amendoa ou castanha do acajú, ou cajú vulgar. Nasce por fóra da fructa, e pegada a uma extremidade, do feitio de um rim de cabrito.

\section{USOS DIVERSOS}

A casca é dura, e muito esponjosa, e contém um succo oleoso, tão fortemente acre, que queima, lançado em qualquer parte do corpo. A amendoa da castanha assada, é deliciusa, e com ella se fazem differentes acepipes. Os indios queimam a castanha, e fazem pingar o oleo que contém, «sobre as verrugas e sobre os callos », para os amolleccr e extrahir.

Acajucai peracoba.-Os indios empregam estas duas palavras, para dizerem, que as ichuvas dos mezes de Agosto, e Setembro destroem as flores dos cajueiros, e os privam dos fructos.

A cajucatinga (dos Indios.)-Gabriel Soares affirma, que a madeira desta grande arvore, não se corrompe nunca. Encontra-se nas mattas dos Ilheos, na provincia da Bahia.

USO NAS ARTES

E' a sua madcira apropriada para construcção de navios, para assoalho de casas, e mesmo apropriada á marcenaria.

Acajú-cica.-E' a resina do cajueiro.

\section{USOS MEDICINAES}

E' ligeiramente adstringente, e se a emprega nas hemoptyses.

USOS NAS ARTES

Os encadernadores empregam a resina do acajú-cica, como preservativo dos insectos, que estragam o papel.

A cajuem-om (expressão indigena.)-Doce do cajú.

Acajuiba. (Anacardium occidentalis.)-Arvore de um mediano crescimento, da qual os ramos se inclinam tanto, que tocam na terra. 
Acajupé-mixim oé cajuy.-Certa especie de cajú, rasteiro, que nasce, sómente nas provincias meridionaes do interior do Brasil. Floresce em Setembro. Seus fructos são menos succosos, porém mais doces e saborosos, que os do cajueiro commum. Os fructos desta planta colhe-se em Dezembro e Janeiro. Gostam das campinas descobertas do sertão. Nascem em Minas, S. Paulo, Goyaz, Cuyabá, Bahia, Alagôas, etc.

A cajú-potyra.-Flor do cajueiro. São brancas, quando novas, e encarnadas quando velhas. Crescem em ramalhetes, e são tão cheirosas, e seu cheiro tão suave, que admira. Floresce em Setembro e Outubro, e os fructos colhem-se em Dezembro, e Janeiro.

A cajurama.-Planta conhecida no Pará.

\section{USOS MEDICINAES}

O cosimento da casca, que é amarga, empregam para laval as feridas velhas.

A caju royg (anno.)-Como esta planta dá fructo, uma vez no anno, os indios aproveitaram esta circumstancia, para contar a sua edade, pelas castanhas de cajú, a que chamam acajii royg.

Acajuys. (Vinho de cajú.)

\section{USOS MEDICINAES}

O vinho feito de cajú, é excellente para confortar o estomago, e muito conveniente, para depurar os humores do corpo. Quando bem preparado, confunde-se com c vinho de uva.

Acambuy ou cambuy. (Mirtus brasiliana.)-E' arvore mediana, e nasce nos logares humidos. As fructas são pequenas, amarelladas ou avermelhadas. São muito abundantes nas Alagôas.

\section{USOS NAS ARTES}

$\mathrm{Na}$ provincia das Alagòas, fazem das fructas excellentes vinhos, a que chamam de cambuy.

Acapú. (Andira aublitii.)-E' uma arvore do Pará, mui rija, e de lenho preto, e algumas vezes com veios brancos. 


\section{USOS MEDICINAES}

O cozimento feito com a casca, por sua adstringencia, serve para lavar as ulceras chronicas.

\section{USOS NAS ARTES}

E' empregada na marcenaria, para a fabricação de moveis, e na carpintaria para vigas, esteios e outros empregos.

Acapu preto. (Aupedira aublitii.-Lacerda.)-E' arvore conhecida no Pará, e Maranhão.

\section{USOS MEDICINAES}

No Maranhão, e no Pará empregam o cozimento do lenho deste vegetal, para curar chagas antigas.

Acapurana. (Acapurana pulcra.-Lacerda)-Esta arvore do Pará, cuja casca de sabor amargo, com cheiro desagradavel, é narcotica.

\section{USOS MEDICINAES}

o cozimento da casca, serve para curar feridas; e reduzida a pó, depois de lavada a ferida, pulverisam-n'a com elle.

Acaricoba. (Hydrocotyle Bonariensis.)-Planta medicinal brasileira.

\section{USOS MEDICINAES}

O succo da planta, em dóse elevada provoca vomitos, em pequena quantidade é tonico, e provoca as urinas. 0 cozimento da raiz, é desobstruente; e a agua distillada, serve para tirar as sardas do rosto.

Acataya. (Veja-se herva de bicho.)

A cayáca. (Cidrilla odorata.)-Cedro do Brasil, similhante por sua madeira, ou no tôdo, ou por suas propriedades e utilidade, ao cedro do Libano. Diz o autor do Diccionario da Lingua Brasilica, inedito, que se acha na Bibliotheca Publica do Rio de Janeiro, tratando desta arvore, que os francezes nas Antilhas, a appellidam de Acaju.

Accajuca.-Resina ou gomma da Acajuiba. 
A coita cavalios. (Luhea Grandiflora.)-Arvore do interior do Brasil.

\section{USOS MEDICINAES}

o cozimento da casca, dado em clyster, cura a diarrhéa, e em banhos, combate os tumores articulares. Cura as hemorrhagias de sangue.

\section{USOS NAS ARTES}

o lenho desta arvore, serve para o fabrico das coronhas de espingardas.

Aderno verdadciro.-E' arvore de 60 palmos, conforme o Dr. Silva Lisboa, e de ,3 de diametro. Floresce em Outubro e Novembro.

\section{USO NAS ARTES}

O seu lenho é pouco poroso, e muito procurado, para construcção. E' tão duravel na terra, que resiste por mais de cem annos. Não tem-se feito uso da casca, folhas e flores em medicina, que me conste.

Aderno marcanaiba. (Silva Lisboa.)-Arvore das florestas do Brasil, conhecida dos derrubadores.

\section{USOS MEDICINAES}

Não tem emprego conhecido em medicina.

$$
\text { USO NAS ARTES }
$$

E' uma variedade do aderno verdadeiro, e procurada a sua madeira, para os mesmos usos.

Agnaes ou cascaveis dosindios. (Lacerda.)Planta do Pará.

\section{USOS MEDICINAES}

Diz o Dr. Lacerda, que a fructa da agnaes, ralada, e posta sobre o eancro ulcerado, por muito tempo o cura.

Agoniada. (Plumeria lancifolia.)-Arvore das nossas florestas.

\section{USOS MEDICINAES}

A casca da arvore Agoniada, é empregada em fórma de chá, para combater as febres continuas, e para provocar os menstruos. 
A sua madeira é empregada na construcção civil.

Agrrião. (Sisymbrium.) - O agrião é planta hortense. Foi transplantado da Europa para o Brasil. E' mui conhecido, e vegeta nos terrenos encharcados, e vallados.

\section{USOS MEDICINAES}

Comestivel crú em salada, e cozido com a carne. o agrião é mui procurado por sua virtude purificadora do sangue, e como desobstruente do figado.

Agriāo do Pará ou do Brasil. (Spilanthes Dleacea.)-Diz o Dr. Arruda dz Camara, que, o agrião do Pará, é muito cultivado na Europa.

\section{USOS MEDICINAES}

No Pará comem o agrião cozido, como alimento sadio. E' elle estimulante, e anti-escorbutico.

Aguapé. (Nymphoea).-E' uma planta vulgar, especie de golpho. (Anaphrodisiaca.)

\section{USOS MEDICINAES}

E' muito usada em cozimento, para banhos, nas affecções hemorrhoidaes.

A raiz pisada e bebida em vinho, ou aguardente, empregam os sertanejos, para curar a obstrucção do baço, a dysenteria e a colica.

Os Drs. Merat e De Lens, com a auctoridade de Pison, dizem, que as folhas desta planta applicadas sobre as erysipelas as curam.

Que as raizes cozidas, e comidas em salada, podem servir de alimento medicamentoso, contra os tumores das gengivas.

Tambem dizem os naturaes, que as sementes pisadas, e postas em agua, e bebidas, embotam o appetite venereo, (anaphrodisiaca) no homem e na mulher, e retém o fluxo mensal nas mulheres.

Dizem que a raiz, possue a mesma virtude.

Aguaraciunha acú ou jacuacanga. (Tiaridium medicum.)-E' uma especie de fedegoso das Alagoas, e Pernambuco. 
USOS MEdicinaes

Empregam-no como um poderoso consolidante, nas feridas e ulceras. Convém nas inflammações do anus. Usam da raiz, como desobstruente. 0 Dr. Martius affirma o que dizemos, por ter visto, os bons effeitos desta planta.

Aguariana. (Lacerda.)-Arvore do Pará, e Maranhão, e tambem das outras provincias do Brasil.

\section{USOS MEDICINAES}

Usada em medicina vulgar, para curar obstrucções do figado, e do baço.

Machuca-se bem o páu, e deita-se uma porção em um pote d'agua, para o enfermo ir bebendo della, em logar d'agua commum, e em pouco tempo se restabelecerâ.

Agutiguepo obi. (Thalia geniculata.)-Arbusto pequeno, conhecido nas Alagoas e Pernambuco.

USOS MEDICINAES

E' modificante das ulceras, posta em fórma de emplastro sobre ellas.

\section{USOS DOMESTICOS}

A raiz come-se assada.

Anouai. (Cerbera ahouai.)-E' arvore do Brasil, de folhas lertosas. Os Indios servem-se das nozes desta arvore, para enfeitarem os cinturões.

\section{USOS MEDICINAES}

O succo desta arvore, é mui venenoso. Em pequena dóse laz vomitar, e lançado no rio, mata os peixes.

Aipim. (Jatropha Maniot.)-E' uma variedade da mandioca (vid. mandioca.)

o aipim, era o alimento vulgar dos indios, e, como variedade da mandioca, é mais macia e menos perigosa. 0 padre Fr. José de Santa Rita Durão, no seu poema Caramurû (canto $7^{\circ}$ est. 29), fallando do aipim, se exprime assim: 
Chama o agricultor raiz gostosa,

Aipi por nome: e em gosto se parece

Com a molle castanha sáborosa,

De que tira o paiz vario interesse.

Gabriel Soares, fallando do A ipim, affirma, que os indios distinguem o Aipim, da mandioca, propriamente dita, porque as raizes são alvissimas, e, comidas estas cruas, sabem a castanhas assadas, e são muito mais doces que as de Hespanha, etc., e que de cinco mezes, já se pódem comer assados, e que logo que passam seis mezes, fazem-se duros, e não se assam bem, e servem então para beijús, e para farinha secca, que é mais doce e preferivel, que a da mandioca. Que as raizes ficando oito mezes debaixo da terra, apodrecem muito. Que ha sete ou oito castas de aipins, mas os que são mais estimados, por serem mais saborosos, são os que chamam jurumus.

\section{USOS MEDICINAES}

A farinha ou tapioca, do aipim, com agua e assucar, além de ser um bom regalo, é um grande refrigerante, no curativo das gonorrhéas; liquefaz o sangue, e modera os ardores delle. Misturada a farinha com vinagre, e posta sobre as feridas de máu caracter as limpa, e promove a sua cicatrização.

\section{USOS DOMESTICOS}

Fazem os indios vinho com as raizes cozidas, para as suas festas. Cozido ou assado, é de sadia alimentação, sendo sua farinha preferivel á da mandioca. A farinha do Aipim, é mais sadia e proveitosa que a do trigo, por ser de melhor digestão. Os governadores Thomé de Souza, D. Duarte da Costa, e Mem de Sá, não comiam no Brasil pão de trigo, por se não darem bem com elle, e assim, o faziam muitas outras pessoas, preferindo a farinha, e os bolos de Aipim.

Aipo. (Apium.)-E' planta vulgar, que vegeta nas 'praias do mar.

\section{USOS MEDICINAES}

o cozimento deste arbusto, é muito usado internamente nas molestias das vias urinarias. 
o Dr. Langaard diz, que tambem se applica a raiz, ou as sementes do Apium graveolans, nas liydropesias.

Airratenbira dos indios.-Planta brasileira, mui conhecida dos indios.

\section{USOS NEUICINAES}

Nảo são conhecidos.

\section{USOS SOMIAES}

E' um arbusto muito estimado dos indios, porque produz ructos vermelhos, dos quaes extrahem um oleo encarnado, com que se ungem, afim de terem a pelle mais lustrosa e bonita. Nos apontamentos que achei em um manuscripto dos jesuitas, relativos a esta planta, não indicam as virtudes medicinaes della, e nem outro prestimo, que o que mencionei.

Albara, ou nerva dos Coridos. (Canna angustifolia.)-Planta de 2 metros de altura, e de folhas largas, como as da bananeira.

USOS MEDICINAES

As folhas são vulnerarias, e a raiz é maturativa dos tumores.

Mcagrz. (Dulcis radix.)-E' uma planta da altura de tres á quatro palmos, de flor e fructo, em forma de cachos. Vegeta em bons terrenos, e é muito vulgar nas Alagòas. Ha outra especie de alcaçus, que não prodiz fructo, sendo-lhe similhante em tudo mais.

\section{rSOS MEDICIALS}

Emprega-se a raiz do alcaşuz, nias bronchites, nos catarrhos, e nos incommodos de peito. Mitiga a sède, e se o emprega em infusão. O extracto do alcaçuz, serve para trazerem-n'o na boca, nas tosses rebeldes.

Acamphoreira ou pé de perdiz. Froton perdicipes.)-Arvole que produz em Minas Gerass, e no interior do Brasi!.

rSOS MEDICLNAES

E' planta diuretica, e anti-syphilitica, tomada em cozimento.

0 Dr. Peckolt affirma, que as tolhas frescas piladas, ou seccas, 
pulverisadas, applicadas topicamente, favorecem a cicatrisação das feridas. As cataplasmas feitas com as follhas frescas, applicadas sobre os bubũes e tumores brancos, os resolvem promptamente. Partes iguaes da raiz desta planta, e raiz de velame branco, em cozimento, é um especifico contra as gonorrhéas.

Alcor-noco. (Bowdichia major.)-Arvore de folhas miudas. flores azuladas, e fructo em fórma de vagem.

USOS MEDICINAES

A casca é adstringente, e usada no rheumatismo syphilitico, e nas hydropesias,

Alecr-iza. (Rosmurinus officinalis.)-E' um arbusto mui conhecido de todos.

\section{LSOS MEDICINAES}

A flor e folhas distilladas, e deste liquido bebido uma e meia, e mesmo duas oitaras, conforta o cerebro, os nervos, e alegra o coraç̃o.

E' contra as dores de cabeça: desfaz os máus humores,' . purifica o sangue, dissolve as arèas dos rins e da bexiga, tonifica o utero, e dá fecundidade ís mulheres. O alecrim, é um preservativo da apoplexia, tomado em chá pela manhã. Applicado o cozimento aos olhos, clarêa a rista, tendo a cautela de lhe ajuntar assucar candi em pó, ou mel de Uruçú.

Piladas as folhas, com um, ou mais dentes de alho, e infundido tudo, em azeite doce, em um vaso de louça vidrada. passado pelo fogo, é excellente remedio, paracurar a paralysia. friccionando as partes lesadas.

Alecrim do canpo ou do sorito. (Lantana microphylla,)-Esta variedade do alecrim verbaceo, é differente, por ser planta maior, e nũo ter o mesmo aroma forte, que 0 alecrim da Europa.

Vegeta nos taboleiros, e por todas as partes; as suas folhas são mais miudas, e de um verde mais claro.

\section{USOS MEDICINAES}

Pisada a planta com as folhas, extrahe-se-lhe o succo, o qual misturado com agua, applica-se em clysteres, aos enfer- 
mas de febres malignas. As flores dentro de um frasco, com um pouso de assucar candi, e posto ao sol, por algumas horas, o liquido, que apparecer, applicado aos olhos, dá o mesmo resultado, curando tambem as belides. Tem excellente propriedade, de fortalecer as partes esquecidas pelo estupor; curiz as defluxões do peito, fraqueza da cabeça, dos.ouvidos, e olhos; tambem applicam nos flatos e rentosidades. O seu emprego é em förma de chá, tomando se com assucar, pela manhã em jejum.

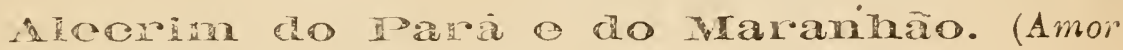
crescido.)-Esta rariedade de alecrim tem o sabor amargo.

\section{USOS MEDICINAES}

E' utilissimo nas diarrhéas e dysenterias, por debilidade da mucosa intestinal.

No Pará, e no Maranhão, conforme o testemunho do Dr. Lacerda, usa-se desta planta, coin 'muito proveito, nessas enfermidades.

Ha outras especies de alecrim, com quasi os mesmos prestimos na medicina popular, conhecidas no Brasil.

Alacoa. (Lactuca virosa.)-E' planta mui conhecida, e foi transportada de Portugal, para o Brasil.

USOS MEDICINAES

o extracto é um porleroso calmante, e preferivel ao opio.

USOS DONESTICOS

E' precioso alimento.

Alfavaca brarca ou mansa. (Occimum incandecens.)-Vegeta nos logares pantanosos, e é pouco differente da alfavaca de cobra.

\section{USOS MEDICINAES}

Os moradores dos nossos sertões, empregarn a alfavaca branca, externamente em banhos quentes, nos que padecem de rheumatismo em todo o corpo.

Internamente, fazem cozimento e dĩo, com assucar bom, its mulheres, que tèm falta das regras. 
No Pará e Maranhão, diz o Dr. Lacerda, (1) tambem applicão a alfavaca branca, em banhos, para provocar os menstruos; e internamente fazem muito uso della. nos enfermos de dysenteria, e nos hydropicos.

AlPavaca de cobra. (Monnieria trifolia.)-E' tambem a alfavaca de cobra mui conhecida e vulgar. Nasce nos logares humidos, e á beil'a das casas.

\section{LSOS MEDICINAES}

o cosimento adoçado com assucar, é escolhido refrigerante, a quem se quer preparar, para o curativo de molestias chronicas. E' mui diuretico.

No Maranhão e Pari, affirma o Dr. Lacerda, emprega-se com vantagem á moda de chá, para provocar as regras, sem nenhum iiconveniente.

A cataplasina feita das folhas fervidas, com vinagre, é prompto resolutivo dos tumores.

O xarope feito com o cozimento das folhas, não só é poderoso medicamento, para extinguir a tosse convulsa, como a tosse por mais chronica que seja.

o sumo bebido, faz estancar o sangue pela boca áquelles, que o lançam, por effeitus de pancadas, ou queda. O sumo com oleo rosado, posto no ouvid', fuz passar a dor. As folhas socadas, com vinagre, e applicadas quentes sobre a virilha, recolhe a hernia, sendo renovadas de duas em duas horas.

o chá feito com as folhas é muito proveitoso naș dòres de ourinas, e mesmo nas ourinas de sangue.

Tambem empregam o sumo da alfavaca, nas colicas agudas. o cozimento misturado com gemma de ovo é utilissimo nos defluxos do peito; bem como é bom remedio para curar a diabetis.

\section{USOS DOMESTTICOS}

Os sertanejos fazem uso desta planta, nas comidas de carne.

(1) Manuscripto inedito, existente na Bibliotheca publica do Rio de Janeiro. 
Alfaraca cheirosa. (Occimum fuminense.)-E' planta vulgar, muito conhecida, e apreciada nos sertões do Brasil.

\section{USOS MEDICINAES}

o xarope ou calda, feito com o cozimento da alfavaca cheirosa, é approvado remedio, nas tosses convulsas; e o cozimento, é utilissimo no rheumati-mo. O Dr. Arruda da Camara affirira, que applicadas as sementes ass olhos que têm argueiros, os attrahe e sahe com ellas.

\section{USOS DOMESTICOS}

Os sertanejos usam da alfavaca de cheiro, para tempero, na comida de carne.

Alfazema de caboclo ou sambait. (Hyssopus cryspapilla.)-Planta que vegeta na provincia das Alagòas, de dous metros de altura.

\section{USOS MEDICINAES}

Empregam o succo das folhas, e tambem a raiz, para destruir as belides da cornea; e com o cozimento em bochechos, combatem as dores de dentes.

Alpazema da Europa. (Lavandula spicata.) - Esta planta, transportada da Europa, è cultivada no Brasil.

\section{USOS MEIICINAES}

Como planta aromatica, é excitante, e mui proveitosa em banhos, para facilitar o parto tardio. Precedem ao bauho de alfazema, um clister emoliente, para desembaraçar o recto da parturiente, e com isso, o resultado não se deixa esperar muito.

Aliza. (Alga Chenemkegio.)-Planta do Maranhão descripta pelo Dr. Lacerda e Linneu, classificada na familia das criptogomas. Todas as algas contém iodo e soda.

\section{USOS MEDICINAES}

Pelas experiencias feitas pelo Dr. Lacerda, reconheceu-se ter esta planta a propriedade diuretica, e sob laxativa, com accão especial, sobre differentes apparelhos organicos. Os sertanejos servem-se della, pára o curativo das inflammações de olhos. 
Ha duas especies variadas de algas; uma que vegeta na agua salgada, a que chamam sargaso, e servem para adubar as terras; e dizem, ser proveitosas contra os vermes intestinaes, e contra as escrophulas.

As outras especies, que nascem na agua doce, tèm elementos nutritivos, ou alimenticios

Algodăo ou alogodooilo. (Gossipium vitifolium.)Gabriel Soares, diz que os indios, chamam manym ao algoàoeiro.

Planta muito conhecida. cultivada em abundancia, em todo o Brasil, e principalmente nas Alagôas e Pernambuco, sendo a cultura desta planta, um dos ramos de commercio do paiz. Vegeta por toda a parte, sendo o melhor, o que produz nas Alagóas e Pernambuco, pela maciez do seu vélo.

\section{LSOS MEDICINAES}

As flores do algodoeiro, de um amarello agradavel, passadas ao ar do lume, e espremido o succo morno no ouvido, faz passar a dôr deste orgam. O Dr. Nicolau Moreira, diz que, « as folhas são emolientes, e as raizes diureticas. 》 O cozimento das folhas, é applicado contra as picadas dos insectos, e das viboras. Tambem com as sementes, se preparam emulsões peitoraes, e febrifugas. Fazem-se fumigações, injecções e tisanas, com esta planta, para as doenças do systema lymphatico.

As folhas, maceradas em vinagre, e postas sobre a fonte, são ante-hemicranicas (enchaquecas.) Frescas, e applicadas sobre os olhos, são ante ophtalmicas. 0 succo das flores, e das folhasé vulnerario. O felpo do fructo, (algodão), applicado sobre as queimaduras, diminue o ardor, e contribue para o curativo. Em Pernambuco, nos casos de menstruações difficeis, favorece o corrimento sanguineo, fazendo-se a mulher tomar por seis dias, antes do dia usual do apparecimento da menstruação, uma chicara da infusão dos caroços do algodoeiro.

Os sertanejos empregam o cozimento das folhas do algodoeiro, para combater a dysenteria; e pisadas, postas sobre as feridas sordidas, as limpam e curam.

USOS NAS ARTES E NA INDUSTRIA

o vélo do algodão, é empregado em tecidos, para os usos 
dos homens. O oleo extrahido das sementes, é empregado para a luz, e para outros mistres. A casca serve; para a fabricação de papel.

Ha diversas especies de algodoeiros, possuindo os mesmos prestimos, e empregados nos mesmos usos.

Algoctio bravo. (Hibiscus bifurcatus.)-E' planta brasileira, e vegeta no interior.

\section{TSOS MEDICINAES ।}

O Dr. Lacerda, diz serem as folhas emolientes em banhos, applicados is partes inflammadas.

\section{USOS DOMESTICOS}

As folhas, são comestiveis, preparadas convenientemente.

Ax:20. (Allium sativum. Alho hortense.) - E' planta conhecida e usual. Cultiva-se nas hortas. e nasce em qualquer parte, que o plantam. Ha o alho silrestre, o alho parvo.

A raiz do alho parvo é romitiva.

\section{USOS MEDICINAES}

E' poderoso contra-reneno, contra a peste, ante-helmintico, contra a suffocaçĩo uterina, ou spasmos hystericos, contra o tetano e febres intermitenttes. O Dr. Langaard diz, que a applicação externa do alho, produz uma inflammação na pelle, seguida de empolas e ulcerações.

\section{ESOS DOMESTICOS}

E' o alho precioso adubo, para as comidas: mas convém não usar delle as pessoas, que sentem fraqueza de cabeça. E' mui proveitośo ás pessoas de trabalho grosseiro, e para os que bebem muita agua.

0 alho tem antipathia á pedra de cevar, ou iman.

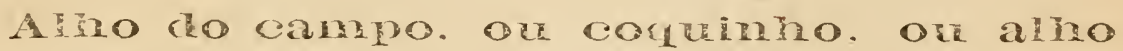
da campinis. (Marica paludosa.)-Planta pequena, conhecida nas Alagòas e Pernambuco.

\section{USOS MEDICINAES}

Empregam esta planta, contra as escrophulas, internamente; e em banhos, contra as gonorrheas. 
Alisma ou tansagom aquatica. (Plantago.)Planta aquatica, que vegeta nos logares humidos, e mesmo nos brejos.

\section{USOS MEDICINAES}

Dizem os camponezes, que este arbusto, é um podeross medicamento, para curar a hydrophobia. Servem-se da raiz em cozimento. Este arbusto, vem descripto por João Vigier, na sua historia das plantas mais usadas na Europa, Asia, Africa e America.

Alloluia. (Mikania dastrica.)-Chama-se esta planta em Pernambuco alleluia, e nas Alagôas e Bahia chamam-n’a camará.

\section{USOS MEDICINAES}

E' purgativa, e com acção mui violenta sobre o utero.

Almecega-assú ou igtaizcyca dos inclios. (Incenso branco dos portuguezes.)-E' arvore corpulenta. similhante ao almecegueiro igcica, mas os indios a denominam igtaigcyca, porque distilla a resina mais compacta e lustrosa.

\section{Usos Medicinaes}

o cosimento da casca e folhas, serve para lavar e curar as feridas velhas, bem como as partes atacadas de rheumatismo. Tambem serve, para a composiçâo do balsamo de Arceu, e outros.

\section{USOS NAS ARIES}

Os carpinteiros e canoeiros, empregam a resina no calafeto das embarcações e canôas; e os indios servem-se della, para vidrar a louça de barro. e para fumıgações nas partes enfermas, devido ao resfriamento.

Almecoga on igeyca dos indios ou almecegueir.o. (Hedwigea balsamifera.)-Arvore vivaz, que abunda nos sertões, e nas praias do mar, a qual cresce de 20 a 30 palmos: floresce em Outubro, e distilla uma resina branca. muito aromatica, a que chamam almacega ou almacegão. O lenho desta arvore, é reverso no serrar e lavrar.

\section{USOS MEDICINAES}

A resina é empregada nas pharmacias, para a composição lo balsámo de Arceu, e outras composições officinaes. 
E' no Brasil, este balsamo, o mais primoroso medicamento, para curar as feridas, porque as preserva da podridão. Internamente tomada a resina, em fórma de pilulas, ou em cosimento, facilita as urinas.

o emplastro feito com a almecega, oleo de copahyba, therebentina, azeite doce, ou oleo de côco, é muito efficaz nas fracturas dos ossos. E' excellente remedio, para as feridas frescas, produzidas por armas de fogo, misturada a resina da almecega com o oleo de copahyba.

o cosimento da casca e folhas, é empregado para lavar as feridas velhas, de máo caracter. Usam com muito proveito o emplastro da almecega. posto ras fontes (temporas), para combater as enchaquecas.

USOS NAS ARTES

Além de outros usos, servem-se da resina, jara o calafêto das canôas e barcos.

Almeirão ou chicorea do campo. (Cicho. rium silvestre).-Desta planta se conhece o almeirão da horta, o do campo, o almeirão dente de leão, o almeirão verrugoso, e mais outra valiedade.

\section{USOS MEDICINAES}

As folhas crúas do almeirão, comidas, são uteis ào estomago, e ao figado. O seu cosimento em vinho, purga os humores viscosos. A agua distillada, é mui conveniente ao estomago, porque o fortifica, e favorece as digestões tardias.

o cosimento, bebido tres vezes ao dia, é excellente remedio, para curar o rheumatismo gottoso; e para os que escarram sangue, e para suspender o fluxo involuntario do licor prolifico (espermatorrhea.)

o sumo do almeirão, misturado com vinăgre, e oleo rosado, mitiga as dôres de cabeça. Dado em infusão, purifica o sangue, e cura as inflammações do figado, e do estomago; sendo efficaz nas febres adynamicas, e continuas.

Aimiscar ou Horva almiscancina. (Gratiola centaurides.)-Esta planta tem o cheiro do almiscar, do qual tirou o nome. 


\section{USOS MEDICINAES}

E' empregada no sertão, com bom resultado, para amadu. recer as apostemas, e combater o panaricio. Internamente empregram-na, para suspender a diarrhéa, e vomitos. 0 modo de usar, é raspar a jaiz, pilal-a mui bem, e em forma de cataplasma applicar á parte enferma.

Internamente a administram en forma de chí. As sementes desta planta, provocam vomitos.

Áocs. (Herva bobosa-Herva do Azebre.)-E' planta mui conhecida, por suas folhas succulentas e cheiro forte.

LSOS MEDICINAES

E' purgativo, rarefaz o sangue, provoca.os menstruos, e as hemorrhoidas, purga o estomago, confortando-o, mata os vermes intestinaes, consolida as chagas, dissolve os humores crassos, resiste á corrupção. Sendo applicado exteriormente, tira as dôres do anus, provocadas pelas hemorrhoidas, introduzida a polpa da folha nessa parte.

Althéa do Burasil ori malvaisco. (Vide Mal. vaisco.)

Ammanciosana ou amandureana ou algodào brogvo.-Esta planta brasileira, cujo vélo é mui insignificante, não tem tido emprego nas artes. talvez por não ter sido cultivada.

\section{USOS MEDICINAES}

Os sertanejos servem-se das follhas passadas pelo fogo. para applical-as sobre as pontadas da caixa do peito.

Amansa bestar. (Eucalyptus femuginosa.)-Esta planta rem descrita no diccionarin le J. Almeida Pinto, extrahida a descripção dos trabalhos do Dr. Arruda da Camara. Näo indica os usos em medicina pratica.

Amapá-Arvore do Pará, mui conhecida naquella provincia, a qual dá leite quando se incisa.

USOS MEDICINAES

O leite ou seiva desta arvore, serve para curar feridas internas, tomado em pequenas porções. 
Curam as boubas com elle. misturando um pouco de pedralipes (sulphato de cobre). Applicam este mesmo leite, sobre os tumores frios, como resolutivo.

Amarello ou Vintatico. (Vide Vinhatico.)

Ambaigha ou ejababa or undoaba. (Cicropia.)-Arvore mui conhecida, cujas folhas sĩo similhantes is do mamoeiro, asperas; vegeta nas capoeiras, e principalmente, onde houve plantação. O tronco da arvore é ôco, e direito.

USOS MEDICINAES

ó succo da casca, serve para curar feridas frescas, causadas por golpes, e velhas; e dos pmpollhos se faz xarope, com que no interior do Brasil, curam a tysica pulmonar. O succo misturado com leite de vacca, é empregado para curar flores brancas, e as gonorrheas. A massa que existe no tronco, dizem ser bom remedio nos cancros ulcerados.

No Pará, diz o Dr. Lacerda, costuma-se tirar a agua da raiz da umbauba, aparando-se em cuia, para se beber; e fazem cozimento dos grelos contra as flôres brancas, bebendo-se uma chicara, pela manhan, e outra á noite.

LSO NAS ARTES

As folhas seccas, servem para lixảr as obras de madeira, de chifre, e outros artefactos.

Ambalinga dos inchios. Figueira do infexmo ou stramonio-Esta planta, mui conhecida, de 3 a 4 palmos de altura, vegeta nos logares sombreados e na beira das estradas; tem as folhas similhantes ás da figueira, e de um cheiro nauseante.

\section{USOS MEDICINAES}

As folhas da ambaitinga applicadas ao ventre, cura as colicas ventosas, e obstruccões. Os serıanejos fazem cozımento das tolhas, e tomam em pequenas porções, para suspender os vomitos rebeldes.

USO DOMESTICO

O fructo desta planta contém sementes, das quaes se extrahe oleo, que se emprega na luz dos candieiros. 
Ambuares.-E' planta conhecida, que regeta nas provincias do norte.

USOS MEDICINAES

Esta planta é empregada no curativo da asthma, nas dores. de cabeça, e em resolver as apostemas. Depois de soccada infundem-n'a em vinho, por 12 horas, depois de coado, dão ao enfermo á beber. Frita a planta em azeite, e posta sobre a ferida que tem estrepe, ou espinho, o arranca por si. Pisada e misturada com o mel de abelhas, produz o mesmo effeito.

Ambé ou imbé.--E' um sipó. (Vid, Imbé.)

Ambira, embira ou pindalnytua. (Vid. estas palavras).

Ambuia-ombó, (Aristolochia labiosa.)-Planta brasileira classificada pelo Dr. Martius.

\section{USOS MEDICINAES}

O Dr. Martius, apresenta na sua Materia medica, brasileira ( ${ }^{1}$, algumas variedades desta planta, e servindo-se da autoridade popular diz, que a raiz e haste do Ambuia-embó, com um cheiro fortissimo de alho e de camphora, e com um sabor amargonauseoso, é considerada como um dos mais f mosos elixir pharmaco. E' anteputrido-diuretico, promove a transpiração: é contra veneno das cobras, mui proveitosa nas febres nervosas, acompanhadas de torpor, nas febres putridas, e nas ulceras malignas dos pés.

\section{MODO DE USAR}

A dóse do pó, é de 10 á 20 grãos. varias vezes ao dia; a da infusão é meia onça. A acção desta planta, é mais efficaz, que a da valeriana, e da serpentaria da Virginia.

Ambuarembó ou Amboiarumbó (Pará). E' um sipó, mui conhecido no Pará.

(1) Traduzida pelo illustrado desembargador Henrique Velloso de Oliveira, de saudosa memoria. 
USOS MEDICINAES

o cozimento da raiz deste sipó, é muito empregado para combater as flores brancas ou leucorrheas, bebendo as mulheres, pela manhã e á noite, meia chicara do cosimento simples, ou com um pouco de assucar bom.

Amendoim, mendobi on mandobi. (Arachis hypogea.)-Fallando desta planta, diz Gabriel Soares:

Dos amendois temos de dar conta particular, porque é cousa que se não sabe haver senão no Brasil, os quaes nascem debaixo da terra, onde se plantain á mão, um palmo do outro; as suas folhas são como as dos feijões de Hespanha, e tèm os ramos ao longo do chĩo. Cada pé, dá um grande prato destes amendois, que nascem nas pontas das raizes. *

USOS MEDICINAES

As amendoas são aphrodisiacas, comidas assadas ou cozidas. o oleo, é empregado nas pharmacias, em preparações emolientes

usos CULINARIOS

Gabriel Soares, além de outras coúsas, refere que as mulheres portuguezas, fazem com as amendoas, todas as castas de doces, e as cobrem com assucar, de mistura com os confeitos.

Amexieira da terra. (Ximerica americana.)-E' arbusto espinhoso, de folbas pequenas e quasi redondas, tendo - fructo cheiro agradavel, e é comestivel.

USOS MEDICINAAS

Não são conhecidos.

Amoreira amarella ou tatagiba ou tatajuba. - E' arvore de 40 palmos, e de dous at tres de diametro. (S. Lisboa.)

\section{LSOS MEDICINAES}

A seiva desta arvore, é um soberano supurativo dos bobões venereos, posta em fórma de emplastro.

o xarope feito da fructa, s excellente medicamento, para curar as feridas da garganta, porque adelgaça os humores, e resolvo a corrupção. 


\section{USOS NAS ARTES E NA INDUSTRIA}

A sua madeira é empregada na carpintaria, para diversos nsos. Della se extralie uma bella tinta amarella, que serve para a pintura.

Anzorelire do amaso branco.-E' arvore de 40 palmos de altura, e de 2 de diametro, muito macia ao serrar. Floresce em Setembro, sendo o seu fruito agradavel ao gosto (S. Lisboa.)

\section{USOS MEDICINAES}

Não é conhecido o seu prestimo em medicina vulgar.

\section{USOS NAS ARTES}

Serve para construcção, e para madeiramento de casas.

Anioreina de amago preto. - E' arvore de 25 palmos de altura, e 2 de diametro. Floresce em Setembro, sendo a sua madeira macia ao serrar e lavrar. (S. Lisboa.)

\section{USOS NAS ARTES}

Como o lenho desta arvore é mui compacto, empregam-n'o na marchetaria.

\section{USOS NA IYDUSTRIA}

A arvore reduzida a cinzas, produz excellente soda.

Amor isereito. (Viola tricolor.)-Foi esta planta, transportada, da Europa, para o Brasil. E' muito conhecida, e cultivada nos jardins.

\section{USOS MEDICINAES}

A raiz é vomitiva, e o cosimento das folhas, é empregado como depurativo do sangue.

Amuicy.-Arvore ș̆

USOS MEDICINAES

O entrecasco desta arvore, diz o Dr. Lacerda, pisado, e posto sobre a mordedura da cobra, neutralisa-lhe o veneno, ao mesmo tempo, bebendo-se-lhe o cosimento.

Anajamirim.-Conta Gabriel Soares, que o Anajamirim, é uma casta de palmeira brava, que dá muitos e formosos palmitos, e o fructo como as palmeiras, mas são os côcos, mais 
pequenos, e as palmas que se lhe tiram de junto dos olhos, tẻm as folhas mais miudas, com que tambom cobrem as casas, onde nũo acham as outras palmeiras.

\section{USOS MEUICINAES E NAS ARTES}

Gabriel Soares, nada revela em relaçĩo ans prestimos desta planta ; apenas diz, que os cachos nascem en uma maçaroca parda, de 2 a 3 palmos 'ie comprido, e quando este cacho quer lançar a flór, arrebenta esta maçaroca ao comprido, e sai o cacho para fóra, e a maçaroca fica muito lisa por dentro, e dura como pío, da qual se servem os indios como de gamella.

Ansangaryiabo. (Pente do diabo.) - Gabriel Soares diz que esta arvore é de bom tamanho, e dá fructo em fúrma de bainha grande, que contém um corpo duro, branco, da feíção de um pente, de que o gentio se aproveitava, para alisar os cabellos.

\section{USOS MEICINAES}

Não são conhecidos.

USOS NAS ARTES

O historiador Gabriel Soares nada mais lembra sobro esta arvore.

Manaz (fructo.) Anamazoiro (a planta.) Bromelia. No cheiro o ananaz tem mil perïmes. Silveira (côro das muesas.)

E' o ananazeiro planta pequsna, mui conhecida, de follhas longas, de dentes ou espinhos, de cada lado, á similhança de serra. A fructr que dá, chamada ananaz, é deliciosa, tanto no aroma. como no gosto. Frei José de Santa Rita Durĩo, no seu famoso poema epico Caramuri, chama o ananaz - o rei dos fructos.

USOS DIVERSOS

o ananaz é um alimento sadio, e refrigerante, que niio enfastia, por mais que se coma. Os indios, e os sertanejos fazem com elle, saboroso vinho, sendo mais forte e generoso, que o manufacturado com a uva. Dizem, que, se o vinho i labricado 
com a fructa inchada, ainda mais generoso se apresenta. O succo do ananaz maduro, póde se dar aos enfermos de febre continua, ou mesmo aguda, como salutar refrigerante. E' recommendado aos doentes do figado, e estomago ; e mesmo, aos que padecem de pedras no figado, e na bexiga urinaria.

O sumo do ananaz verde, provoca o aborto. Posto sobre a ferida de estrepe, ficando dentro, o arranca sem custo. O Dr. Nicoláu Moreira, servindo-se da auctoridade de Labat, diz que o succo do ananaz, reunido ao oleo de amendoas doces, é um excellente carminativo.

o Dr. Arruda, refere que o ananaz maduro é diuretico, e emenagogo; e verde, tem a propriedade desobstruente. A raiz da planta do ananaz, tem as oresmas propriedades medicinaes da fructa.

C Dr. Nicoláu Moreira affirma, ¡ue só na provincia do Cearáa, se conhecem sete variedades de ananaz. As folhas da planta, dão linho, para a confecçĩo de cordas.

O padre Simão de Vasconcellos, na Chronica da Companhia, accrescenta, ser o succo do ananaz efficaz remedio para a suppressĩo de urina e dôr de rins, e juntamente contra veneno, especiaimente contra o sumo da mandioca (manipoeira), ou raiz della.

Anany. (Arvore que di breu.)-E' una bella arvore do Pará, e dos nossos limites sptentrionaes, que distilla uma gomma-resina, que tem o mesmo nome. Por ser muito alta, flexivel e direita, è propria para mastros de navios.

A seiva desta arvore, quando se extrahe, é amarella, e em contacto com o oxygeneo do ar, fica preta.

\section{USOS MEDICINAES}

A seira emquanto se concerva amarella, serve para resolver tumores, contra o rheumatismo, e dôres nos ossos, nos enfartes das glandulas, e nas obstruccōes do figado e baço.

Aralá. (Andá brasiliensis.) - E' arrore de 25 palmos de altura e 2 de grossura, e de madeira esponjosa. Floresce em Outubro.

O desembargador Silva Lisboa, juiz conservador das mattas 
da Bahia, diz que esta arvore dá um fructo, em cuja amendoa existe oleo mui acre.

\section{USOS MEDICINAES}

A casca e a amendoa são purgativas. .E' cicatrizante, applicada ás féridas de máu caracter. Pisadas a casca e as folhas, e postas nas lagôas e rios, mata os peixes.

\section{USOS NAS ARTES}

Dos páos do andá, formam jangadas, para navegação dos rios e lagôas; e da madeira, fazem tamancos. Os indios, com o oleo da amendoa desta arvore, fazem galanterias pelo corpo, e as indias o empregam, para amaciar, e lustrar os cabellos.

Anda-assú. (Joannesia Princeps.)-Esta arvore, de 16 a 20 palmos de altura e de dous de grossura, descripta pelos nossos frei J. Mariano da Conceição Velloso e Dr. Bernardino Antonio Gomes, é mui conheciḍa, de copa frondosa, e cresce depressa, nos logares humidos.

\section{USOS MEDICINAES}

0 povo serve-se do fructo em purgantes, para curar a hydropisia, e inchações do corpo.

o Dr. Nicolau Moreira diz que a dóse é de uma á tres amendoas, ou na de seis á oito gottas de oleo, em agua morna assucarada.

\section{USOS DOMESTICOS}

Torrada a fructa, se extrahe oleo para luz, e para a composição da tinta azul.

Andayá-assú. (Attaloa compacta.)-E' uma palmeira do Amazonas, pequena, e dá cachos similhantes ao do dendè.

\section{USCS ALIMENTICIOS}

Os indios se alimentam com a amendoa do caroço.

Andiroba, angiroba, nandiroba. (Carapa gruanensis.-Arvore corpolenta, frondosa e muito graciosa, que folga em quasi todo o Brasil, e produz um fructo, do qual se extrahe oleo, de gosto acerbo. O Dr. Martius a descreve, bem como Almeida Pinto. 
USOS MEDICINAES

o Dr. Martius recommenda o cozimento da casca, que é muito amargosa, e mesmo das folhas, para combater as febres intermittentes, e verminosas, e contra as ascarides; externamente, contra as empigens e exanthemas, provenientes das picadas dos insectos. O oleo da andiroba é amargo, e muito usado nas fazendas do interior, para curar (em fricções) as erysipelas, inchações. e as feridas provenientes das mordedüras dos borrachudos.

\section{USOS DOMESTICOS E NA INDUSTRIA}

o oleo serve para o consumo das luzes, e para fabricação de sabão.

Andorinha ou tonga tonga.-E planta vulgar. e nasce em todos os terrenos

\section{USOS MEDICINAES}

Os sertanejos fazem uso da Andorinha, applicada em clister. para combater as diarrhéas e dysenterias. Internamente empregam-na em chá, para curar o pleuriz, e as dores que ficam, em consequencia desta affecção.

Andréquicé ou malmiquor-grande. (Adiante fallarei desta planta).

Andú ou gruandú. (Cajanus flavus.) - Arbusto mui vulgar, e por toda a parte cultivado, e produz vagens mui apreciadas, como alimento vulgar.

\section{USOS MEDICLNAES E CULINARIOS}

o cozimento das folhas com assucar, é mui proveitoso na inflammação chronica do figado.

Com as vagens, fazem as familias brasileiras, diversos guisados, apreciados nas mesas communs:

Angelica cheirosa ou catinga de cheiro. (Gentiana rubra.) - Arbusto do sertão, conhecido pelo nome de catinga de cheiro, cujo arbusto vegeta em terrenos seccos, e arenosos, e particularmente nos taboleiros e agrestes. E' aromatico, anteseptico, anti-spasmodico, e tem a propriedade de purificar os logares onde vegeta. 
USOS MEDICINAES

O seu entre-casco, serve para banhos nos rheumaticos; eito em chá, e adoçà̃o com mel de abelhas, ou assucar bom, é mui proveitoso nos defluxos do peito. As fulhas, como possuem bastante aroma, teem mais prestimos que a casca. Torradas as fulhas, e reduzidas a pó, em fórma de tabaco, servem-se assim dellas os sertanejos, no entupimento defluxionario do nariz, para descarregar a pituita.

Com o cozimento, lavam as feridas de máu caracter.

A raiz desta planta, que é amargosa, é excellente contra o veneno das cobras.

Ultimamente se reconhecen que a angelica cheirosa, é um poderoso medicamento contra as febres continuas, e de caracter pernicioso.

Angelica do campo.-Esta planta, e bastante conhecida pelos moradores do interior, mui prestimosa, por suas virtudes.

\section{USOS MEDICINAES}

E' resolutiva, e sudorifica. A flor distilada e dado o liquido a leber, na quantidade de meia onça, é singular medicamento, para curar as suffocações, e falta de respiração, fazendo que os nervos adquiram novos alentos.

A raiz em pó subtil, é remedio efficaz, para os que sentem pontadas no estomago, provenientes de encarceração de ar.

Combate as febres continuas, por meio dos suores copiosos, que provoca, cobrindo-se convenientemente o enfermo.

o extracto da raiz, misturado com assucar, na quantidade de duas oitavas, dissolvido em agua, ou em aguardente, cura radicalmente a enchaqueca. Dizem os sertanejos, que a raiz e folhas da angelica do campo, é remedio provado contra a mordedura das cobras.

Angelica do jar.dim (Angelíca archangelicu.) - E planta europea, que passou para o Brasil.

USOS MEDICINAES

A raiz è amarga, estomachica e sudorifica. Empregam-n'a tambem para curar as escrophulas e o escorbuto. 
Angelicó. (Aristolochia glandulosa.)-E' uma planta trepadeira.

\section{USOS MEDICINAES}

A raiz é contra veneno das cobras, e contra as febres intermittentes:

Angelim aracuxy. (Andira.)-Nasce esse vegetal, em terrenos seccos, E' planta mediocre, e produz flòres brancas, e de aroma summamente agradavel. A raiz, bem como a casca, que a envolve, são amarelladas. E' mui vulgar nas provincias da Bahia, Sergipe, Alagoas, e Pernambuco.

\section{USOS MEDICINAES}

Este vegetal se póde, com justos motivos, chamar o salva vida dos sertões. Infelizmente os habitantes das cidades, não lhe conhecem os prestimos, por que tirariam o mesmo proveito. que delle gosam os moradores do interior.

E' excellente medicamento, contra as febres malignas, de caracter perniciosissimo; cura as intermittentes e as febres defluxionarias, causadas por resfriamentos. A tintura feita com a casca e raiz, é de grande proveito, para curar as le:idas penetrantes, causadas por ferro, e mesmo feitas por outros instrumentos. O modo como usam os sertanejos, é o cozimento das flores, da casca e raiz com assucar, ou sem elle, dado ao enfermo.

Angolim canafistula. (Andira.)-Arvore conhecida no paiz. Floresce em Setembro, e as flores, de um roxo claro, apparecem em cachos pelos galhos e ramos.

\section{USOS MEDICINAES}

Tem os mesmos atimos do angelim verdadeiro.

\section{USOS NAS ARTES}

Particularmente empregam o lenho do angelim canafistula, para a fabricação das dentaduras das moendas, raios das rodas, e bolandeiras dos engenhos.

Angielim-còco ou urarema.-Esta arvore é uma variedade do angelim verdadeiro, e tem as mesmas dimensões; e a sua madeira presta-se, para os mesmos usos. O pharmaceutico, Almeida Pinto, servindo-se dos trabalhos do Dr. Arruda 
Camara, descreve scientificamente as diversas especies do angelim, memorando-lhe os prestimos.

Angelin graveto.-E' arvore de 60 á 70 palmos de altura, e 2 á 3 de diametro. Floresce em Setembro. (S. Lisboa.)

\section{USOS MEDICINAES}

E' provavel, que tenha os mesmos prestimos, que o verdadeiro angelim.

USOS NAS ARTES

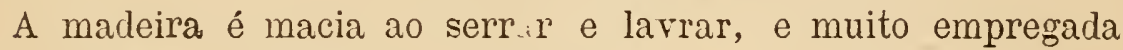
na fabricação das caixas de assucar.

Angelim tento.-E' arvore de 80 e mais palmos de alto, e de 2 á 3 de diametro. Floresce em Setembro e fructifica, sendo as sementes encarnadas, com um ponto preto, e como são mui rijas e formosas, empregam-n'as em tentos, nas mesas de jogo. E' por causa das sementes, que deram-lhe o nome de Angelim tento.

\section{USOS MEDICINAES}

Não me consta, que empregassem a casca, folhas e as sementes no curativo das enfermidades.

USOS NAS ARTES

Serre a sua madeira, para fazer caixðes, e para construcção de casas.

Angelim verdadeiro, ou andirá ou andura ou bajari dos indios.-Arvore de 100 e mais palmos de altura, e de 3 á 5 de diarnetro, conforme o testemunho do desembargador Balthasar da Silva Lisboa, juiz conservador das mattas da Bahia. Floresce em Setembro, apparecendo as flores entre os galhos e ramos, em lindos cachos, donde nasce uma fructa, de fórma oval, e de um gosto amargo, ingrato e adstringente. 0 illustre Dr. Langaard, fallando desta arvore, diz que as especies mais usadas são o angelim-côco ou urarema, andirá stipulacea, Benth; o amargoso ou aracuy, o andirá authematico, Benth; vermifugo Martius; 0 andirá ibaiariba ou andurd-abaia miri, de Pison; o andirá-roseo, de Martius. 


\section{USOS MEDICINAES}

A fruta, reduzida a pó, e dada a beber, é vermifuga. 0 succo do entrecasco, dado em quantidade de l oitava, produz o mesmo effeito. O succo do entrecasco, dado internamente, e applicado á mordedura da cobra chamada Jararácuçú, é approvado contra o veneno desta serpente.

o Dr. Nicolau Moreira, diz que o angelim, dado internamente em dóse elevada, obra como drastico energico.

o Lr. Martius recommenda muita cautela, :o uso do Angelim, porque é venenoso, e perturba o ventre, produzindo vomitos,

o Dr. Peckolt, fazendo a analyse do Angelim de pedra. diz que, as arvores velhas, fornecem muitas vezes uma resina particular, que occupa quasi todo o alburno, e ás vezes se púde apanhar de uma arvore uma arroba.

Os pedacos sem côr, e puros, semelham-se pedaços de barro branco, não dando a idéa de que é uma resina, mas expondo-se ao calor, são completamente volateis; ella consiste quasi uricamente de uma base organica, que forma com os acidos, saes crystalisaveis. Chamei esta base Angelina. Os saes são soluveis em agua, mas a Angelina não. Esta resina, é muito procurada; na provincia de Minas, é chamada sulphato, e julga-se, que suppre o quinina, como especifico contra as febres intermittentes. applicada na dóse de 3 á 6 grãos.

Serir um beneficio immenso, se se fizesse ensaios therapenticos com est alcaloide anti-febril, preparado pelo laboratorio da natureza, porque a libra desta resina, poderia ser vendida por 83 até 10 , e póde-se extrahir tambem da madeira, como alcancei ultimamente. De boa vontade fornecerei gratuitamente a substancia, para experiencias therapeuticas. Segue-se a analyse chimica, feita pelo illustre Dr. Peckolt.

Os derrubadores dizem, que quando cortam a arvore do angelim, corre um licor amargo e espirituoso, cujo uso desconhecem em medicina vulgar.

ADVERTENCIA

Antes do emprego do angelim, para destruir as lombrigas, convém dar an individuo, alguma cousa doce, afim de chamar 
os vermes ao estomago; e o tempo mais conveniente, é durante o minguante da lua.

\section{VSO NAS ARTES}

A madeira ou o lenhoso da arvore do angelim, serve para a fabricação de lemes, váus, cadastros dos navios, e torneado; serve para o fabrico de bilros, e de contas, etc.

Ingico. (Acacia angico.)-Arvore, puramente brasileira, e folga nas immediações das catingas ou agrestes. Suas folhas sĩo caducas.

\section{USOS MEDICINAES}

No sertão empregam o Angico. em banhos, no curativo das leucorrhéas, nas inchações das pernas, e para cicatrizar, as ulceras.

Com a tintura feita com as folhas, curam as contusões, os talhos feitos com o ferro, e mesmo as commocões cerebraes.

A resina do angico serve, para curar a tisica pulmonar feita xarope e trazendo a na boca.

\section{USO NAS ARTES}

Servem-se da casca e folhas, para curtir o pellame.

Angico monjolo. (Acacia virginalis.) - E' arvore corpulenta das nossas mattas, e vegeta em terrenos seccos, onde fructifica.

USOS MEDICINAES

o seu entre-casco è adstringente, e tem muitos prestimos, como sejam de soldar as quebraduras, ou rendiduras das veriIhas, desvanecer ò sangue das contusões (echimoses) 0 cozimento feito do entre-casco, ou das follas, bebido, serve para quem deita sangue pela bocca, fazendo-o estancar, como por encanto; serve tambem para lavar as feridas frescas ou velhas, promovendo-lhe a cicatrização; e serve igualmente para as flores brancas.

A rezina do angico é excellente medicamento, para favorecer a cicatrização das cavernas dos pulmões dos tysicos.

Quando os nossos medicos, pre erirem o estudo da esplendida flora medica brasileira, á estranha, conhecerão a profusa riqueza que temos, em proveito da humanidade que soffre. 


\section{USO NAS ARTES}

As folhas e a casca, servem, pela grande quantidade de tanino que possue, para curtir o pellame, e a madeira é estimada, para as obras de carpintaria.

Angustura ou laranjeira do matto.-Desta planta fallarei adiante.

Anhahyba.-Arvore assim chamada pelos indios, mui corpulenta, com folhas similhantes ás do aderno, porém maiores, e com a mesma configuração.

\section{USOS MEDICINAES}

São desconhecidos.

\section{USOS NAS ARTES}

Serve para construcção de casas.

Anil. (Indigofera anil.)-E' planta vulgar, ramosa, e vegeta em qualquer terreno. Foi muito cultivada no Rio de Janeiro; e para o fabrico do anil, se levantaram engenhos no Andarahy, e mesmo houve um engenho no perimetro das ruas do Lavradio, e Invalidos, entre os annos de 1780 a 1800.

\section{USOS MEDICINAES}

o cozimento feito com a raiz, é poderoso andidoto contra o veneno das cobras. Os sertanejos raspam a casca da raiz do anil, e applicam sobre a picada feita pelo dente da serpente. Tambem servem-se do cozimento, tomando em bochechos, para combater as dores de dentes.

USOS NAS ARTES

Foi o anil um bom ramo de industria do Brasil, nos tempos coloniaes, mas hoje, que até importamos paus para cabos de vassouras, cocos de beber agua, ovos de gallinha, até mesmo a nossa tapioca, chrismada com o vocabulo francez-tapioca Louisnão é para admirar, que o anil, que foi um ramo importante de exportação da industria brasileira, entre com os ovos de gallinha, e os cabos de vassouras de varrer a casa, pimenta malagueta, importado do estrangeiro. 
Aninga. (Anum linifera.) -E' uma planta conhecida, que folga nos brejos e logares humidos. O Dr. Arruda da Camara, a descreve scientificamente. Pison, que tambem fallou nella, a menciona com o nome indigena de aningaiba. Os Drs. Merat e De Lens, em presença dos trabalhos de Pison e Macgrave, lembram varias especies de aningas, cujas descripções omitto.

\section{USOS MEDICINAES}

As folhas da aninga, pisadas e postas sobre os tumores frios, os resolve.

\section{Aninga do pará ou de espinhos.}

\section{USOS MEDICINAES}

E' contra a mordedura de cobras, e promove a cicatrização das feridas e ulceras. Rala-se a raiz, e põe-se em cima da mordedura da cobra, depois de sarjada a ferida.

o Dr. Nicoláu Moreira assevera, que o succo desta planta é acre, e empregado comó modificativo das ulceras atonicas: usa-se em cataplasmas, machucando-se as folhas. Recommenda o cozimento, em banhos, para o rheumatismo, bem como a raiz da aninga secca, na quantidade de cinco á vinte e cinco grãos, tendo dado bons resultados no hydro-thorax ou hydropisia do peito.

Apehy ou oapoiny.-E' planta do Pará, de muito prestimo em medicina vulgar.

\section{USOS MEDICINAES}

Empregam-n'a nas tosses catarrhaes, e nas febres continuas. E' expectorante, dada em cozimento, feito das folhas, e da raiz, pela manhan, e á noite.

Aperta-ruão. (Piper ademeum.)-Arbusto mui conhecido, de 3 a 4 palmos de alto. As folhas são ovaes, e nascem dos ramos que partem das junturas dos troneos, que são tambem articulados. Dá fructo e sementes em fórma de espiga.

\section{USOS MEDICINAES}

Internamente tomado o cozimento, feito com a raiz, é excellente desobstruente do figado; externamente é proveitoso nas erysipelas. 
Api. (Nimphia. Pará e Maranhão.)-Esta planta vegeta nos lagos, e aguas estagnadas.

USOS MEDICINAES

E' ligeiramente laxativa. Empregam-se as flores, em fórma de chá, nas diabetes, mas o Dr. Lacerda nega-lhe esta virtude.

Apostomeira. (Furnera fotida.) Maranhão.

\section{USOS MEDICINAES}

Empregam -na no Maranhão, em cataplasmas, para amadurecer os tumores.

Apotiacoravi. Herva medicinal do Parí.

LSOS MEDICINAES

Serve o cozimento da raiz, para curar a tosse defluxionria, adoçado com mel de abelhas, ou com assucar.

Apry..(Frius.)-E' uma planta, que vegeta no Pará.

\section{USOS MFDICINAES}

A seiva leitosa, e as folhas, sã usadas como calmante, nas molestias nervosas.

Araçá. (Psidium aruça.)-E' o fructo do araçazeiro, o qual é conhecido na sciencia sob o nome Psidium aíaśá.

Ha varios especies de araçazeiros, conhecidos por diversos nomes.

Gabriel Soares fallando dos araçazeiros, diz que são arvores que, pela maior parte se dão em terra fraca, na visinhança do mar, as quaes são como maçan na grandeza, na côr da casca, no cheiro, na folha, na côr e na feição della. A flôr é branca e da feição da da murta, e cheira muito bem.

Ao fructo chamam araçazes, que são da feição das nesperas, mas alguns são muito maiores. Quando são verdes, teem a côr verde, e quando são maduros teem a côr das pêras, e por dentro caroço, como ellas, mas muito mais pequeno. Esta fructa se come toda, e tem a ponta do azedo mui saboroso, do qual se faz marmellada, que é muito boa e melhor, para doenças de camaras. Perto do salgado, ha outra casta de ara- 
çazeiros, cujas arvores são grandes, e o fructo, como laranjas, mas mui saboroso, ao qual aparam a casca, por ser muito grossa.

Arapixacaé. Axapabaca. (Vid. Lombrigueira.)E' uma arvore, cujo lenho é indestructivel.

USOS MEDICINAES

Não são conhecidos.

USOS NAS ARTES

Serve para construcção civil e naval.

Axaga bravo. (Angofora pseudocarpo.)

USOS MEDICINAES

E' ligeiramente adstringente, e serve para lavar as feridas velhas.

USOS NAS ARTES

O lenho deste vegetal, é procurado para o encaibramento das casas, e para estacas de cercas, pela sua grande duração.

Aracáiguassú ou aragainhuna. (Psidium.)E' arvore de mediana grandeza, e produz fructos similhantes aos da jaboticabeira, os quaes apparecem nas pontas dos ramos.

Não são conhecidos.

USOS MEDICINAES

USOS NAS ARTES

Serve para cercas.

Axaçá mixim ou ver-dadeir--E' arbusto vulgar, que vegeta em qualquer terreno, á excepção do acatingado. E' ramoso, de folhas ovaes, flores brancas, e um pouco aromaticas; produz um fructo ligeiramente acido, e mui precioso.

\section{USOS MEUICINAES}

0 cozimento das folhas, serve para lavar as feridas, e chagas, bem como para gargarejo, para os que padecem feridas na garganta (angina). Serve tambem, para banhar os logares doidos, pelo rheumatismo. 
USOS NAS ARTES

Com o fructo do araçazeiro, faz-se excellente doce, para a mesa, e já li, que se póde dar sem o menor inconveniente aos febricitantes.

Aracá piroca.-E' arvore corpulenta, das nossas mattas, e floresce em Outubro.

USOS NAS ARTES

0 seu lenho é empregado na construcção de casas.

Aracá pocca.-Arvore de 30 palmos de altura, e 2 de diametro. Floresce em Outubro. (Silva Lisboa.)

USOS NAS ARTES

Serve para frechaes e para varios objectos de carpintaria.

Aracangri. (Psidium pomiferum.) -E' uma arvore do Pará.

USOS MEDICINAES

A casca deste vegetal é amarga. Socada e desfeita em agua, e dada a beber, em quantidade que faça vomitar, cura o veneno da cobra; pondo-se ao mesmo tempo, sobre a mordedura, uma cataplasma feita com a mesma casca.

A infusão é mui proveitosa, para combater a debilidade do estomago.

Aracaroba.-E' uma arvore corpulenta das nossass florestas. que produz fructo similhante ao da sapucaia, a qual tem dentro uma amendoa medicinal.

USOS MFDICINAES

O oleo da amendoa empregam-n'o, para curar a erysipela.

USOS NAS ARTES

A madeira serve para a construcção de casas.

Aragá de umbigo. (Psidium.)-E' arvore grande, que esgalha muito, e vegeta nos logares arenosos. As suas folhas, sã mais lisas, que as do araçá commum; e o seu fructo é rnaior.

USOS MEDICINAES

A fructa é refrigeranto, e muito agradavel no sabor. 
USOS DOMESTICOS

o doce feito com a fructa é excellente, e muito estimado nas mesas, principalmente o fabricado em Pernambuco.

Aragá do matto.-E' arvore de quarenta palmos de altura e dous de diametro: floresce em Setembro. (S. Lisboa).

USOS MEDICINAES

Não são conhecidos.

USOS NAS ARTES

A sua madeira, é macia no serrar e lavrar : serve para vigas e para diversas obras de carpintaria.

Axacá do veaclo.-Arbusto, que vegeta em logares seccos. E' muito conhecido. O seu fructo é agradavel ao gošto.

Axacui ou ar·ari.-E' o nome que em varios logares do Brasil, se dá ao angelim.

Arapixoca.-Arvore das mattas das Alagòas, que cresce muito.

\section{USOS MEDICINAES}

Não são conhecidos.

USOS NAS ARTES

Do seu lenho serrado, tiram excellente taboado, para diversas obras.

Arapoca amarella ou gurataipoca. (Galipea dictoma.)-Arvore brasileira dos mattos do sul.

\section{USO NAS ARTES}

E' pouco empregado o lenho desta arvore, por ser a madeira um pouco fraca. Servem-se della para algumas obas internas.

Arára-sipó.-E' planta trepadeira, que abunda no Amazonas, nasce no cimo do castanheiro.

\section{USOS MEDICINAES}

Cortado um gommo do sipó, corre com abundadcia uma seiva limpida e crystalina, a qual bebida, extingue a sêde, e promo we a secreção e sahida das urinas. 
Arara-ubá da varzea. - Arvore que vegeta ein grande quaritidade nas margens do Amazonas.

LSOS MEDICINAES

Não são conhecidos.

\section{USOS NAS ARTES}

Fervida a casca, e ao liquido se addicionando um pouco de pedra hume, obtem-se uma delicada cor de carmim, propria para a tincturaria.

Araribí. (femca.)-E' arvore corpulenta, que vegeta em ter'renos fortes. A sua madeira resiste muito, e por isso é muito estimada.

\section{USOS MEDICINAES}

Não são conhecidos.

USO NAS ARTES

Da madeira fazem couçoeiras, qne mandam para o mercado, as quaes depois de serradas fabricam portas, e mobilias. Da raiz se extrahe uma bella tinta encarnada, e da casca tiram a mesma tinta, mas de còr menos viva.

Araribá roxo. (macho.)-E' arvore de 60 palmos de alto, com 2 a 3 de diametro. Floresce em Outubro. E' macia ao serrar, e cortar, apezar de ser o seu lenho pouco poroso. (Silva Lishoa.)

\section{USOS MEDICINAES}

Năo são conhecidos.

\section{USOS NAS ARTES}

Serve para a fabricação de portas, e para ornatos.

Da sua raiz se extrahe uma bella tinta cor de rosa, e é com ella, que os indios pintam as esteiras, e pannos, as cuias, pennas, e outros objectos de uso.

Araribá da serra.-Esta arvore é uma variedade do araribá. Floresce em Outubro, e tem 40 palmos de altura, e 2 de diametro.

\section{USOS MEDICINAES}

Não são conhecidos. 
USOS NAS ARTES E NA INDUSTRIA

E' muito usada na marcenaria.

Do cozimento da casca, e do lenho, e emprego de reagentes chimicos, se extrahe una materia còr de rosa, conveniente á tinturaria.

A -ar.o Da.-Arvore das nossas mattas, conhecida dos derlubadores, principalmente nas Alagoas. Não encontrei o nome scientifico: apenas dizem pertencer esta arvore ás leguminosas.

E' arvore de 30 palmos e de dous á tres de diametro.

Floresce em Agosto.

LSOS MEDICINAES

No amago desta arvore existe um pó, da côr do enxofre, que é empregado no sertão, com muito proveito no curativo das empingens.

LSOS NAS ARTES

A madeira da araroba serve na carpintaria, e para construcção de casas.

Araruna.-Aprore corpulenta, que vegeta em terrenos fortes. Floresce em Setembro (Silva Lisboa.)

USOS MEDICINAES

พัลัo s̃̃o conhecidos.

USOS NAS ARTES

O seu lenho é muito estimado, e com proveito empregado na architectura.

Arar'uta.-(Maranta arundinacia.)-E' planta brasileira, geralmente conhecida; e o padre Antonio Caetano da Fonseca, no seu Manual do Agricultor, ensina o modo de cultivar a araruta, por ser esta planta de grande proveito á humanidade.

\section{USOS MEDICINAES}

A'fecula, ou a araruta do commercio, é alimento apropriado aos enfermos, e convalescentes, feita em mingau, no caldo de frangão, ou em papa. 
Aratagrui.-E' arvore robusta das nossas florestas, de 70 palmos de altura, e dous de diametro. Floresce em Outubro.

\section{USOS MEDICINAES}

Não são conhecidos.

\section{USOS NAS ARTES}

O seu lenho é mui compacto, e apropriado para os artefactos. de marcenaria.

Axataia.-Arvore de 40 palmos de altura, e 1 de grossura. Floresce em Outubro. (Silva Lisboa.)

\section{USOS MEDICINAES}

Não são conhecidos.

USOS NAS ARTES

E' excellente madeira, para marcenaria.

Arati-seu. - Planta do Pará, descripta pelo Dr. Lacerda.

USOS MEDICINAES

E' anti-febril, e mui proveitosa nas febres intermittentes. Usam do succo da raiz, misturado em vinho branco, para combater as febres intermittentes, e ao mesmo tempo fervida a raiz em vinagre, passam o liquido nos pulsos, testa e fontes do enfermo.

Araticuin apé, ou araticum da matta. (Anona silvaticu.)-Arvore das nossas florestas, de 40 a 45 palmos, e de 2 á 3 de grossura ; floresce em Setembro ; mui conheAda no interior, a qual produz uma fructa, similhante á do conde, mui saborosa, e sadia.

\section{USOS MEDICINAES}

A fructa póde dar-se aos convalescentes.

As folhas, bem quentes, e postas sobre os tumores inflammatorios, promovem a suppuração com brevidade. O suador feito com o cozimento das folhas, faz desapparecer as febres intermittentes, e isto antes de principiar o accesso.

As folhas soccadas, e applicadas sobre os boböes syphiliticos, os faz suppurar com rapidez. 
O chá feito com os grelos do Araticum, é precioso medicamento, para combater a dor de colica.

Araticumpaná ou caca. ou araticum da praia. (Anona palustris.) - E' arvore descripta por Gabriel Soares, do tamanho e feicão do marmelleiro, a qual vegeta em logares humidus, alagoados de agua salobra. cuja madeira é molle, lisa, ese esfola toda em the puxando pela casca. Dí esta arvore, um fructo, como o marmello, lavrado pela casca, como pinhas, e muito liso o qual, arregôa quando maduro, e cheira muito bern. Gabriel Soares diz, que o fructo é de natureza frio.

\section{USOS MEDICINAES}

o cozimento feito com a casca, e a raiz desta arvore, serve para baulıos no rheumatismo, e é coıtra o veıeno de cobra.

USOS DOMESTICOS

Os indios comem o fructo de-ta arvore, com medo, porque têm pal'a si, que os caranguejos da terla, fazem mal, porque comem o fructo do Araticumpaná.

USOS N.AS ARTES

A raiz serve para afiadores de navalhas, e para a fabricação de rollhas de garrafa.

Araticum de arêa. (Anona arenaria.)

USOS NAS ARTES

Do píu fazem arco de barril, e da casca fabricam cordas.

Aratioum ponhé. (Anona maregrans.)

Araticum do rio. (Anona spinescens.)

\section{USOS MEDICINAES}

As sementes, reduzidas a pó, e postas sobre as ulceras comichosas das crianças, matam o bicho das sarnas, e curam-u'as em pouco tempo.

Araticum embira. - E' arvore de triata palmos. USOS NAS ARTES

A casca deste vegetal serve, para o fabrico de cordas das embarcaços de cabotagem. 
Araucaria brasiloira. (Pinus Araucana).- Esta varierlade da araucaria da Australıa, dos Estados-Unidos, da A merica, do Chile e do Perú, é conlecida dus guaranys, pelo -nome de Curi-y, e dos tupis pelo de Cury-ûva.

\section{USOS MEDICINAES}

Este vegetal produz uma resila de cheiro suavissimo, que póde mui bem sibstituir a therebeitiı européa.

Serve em fricçōes, para curar o rheumatismo, e as dôres produzidas por accumulo de ar. Póde servir pura a confecção de ungue.ıtos medicinaes.

Arco do pipa.- E' arvore de 30 palmos e de $11 / 2$ de diametro. Floresce em Setembro.

\section{USOS MEDICINAES}

Não são conhecidos.

\section{USOS NAS AR'TES}

Por sua rigidez e flexibilidade, serve para se fazer arcos de pipa.

Arco verde ou ipé, ou guirapariba.-Está arvore é mui conhecida, porque na estacão prupria, se reveste de flòres amarellas, o felpudas; e tem diversos nomes na zona onde veg, t): chamam-1'i ipé guirapx o'sx, urupari, txlspipoca. Em Santa Citharina, chimam-n'i upiuna ou arco de pipa, mariquita; no Maranhĩo chamam-n'a pimba, e arapari.

USOS MEDICINAES

o cozimento das fulhas e flôres, é, proveitoso nas inchações. dos pés, e no rheumatismo.

\section{USOS NAS ARTES}

A sua madeira, mui rija, é procurada com preferencia, para obras de segurança e duração.

Arcunan. (Bigonia eskinata.)-Arbusto indigena, e conhe'cido nas Alagôas, pelo nome de arraia dn matto E' planta trepalteira, com flóres côr do rosa escarlate, sendo esta planta uma das bellezas do campo. 


\section{USOS MRDICINARS}

Não são conhecidos.

Argomonia. (Argemone mexicrna.)-E' planta do Mexica, e do Brasil, similhante ao Carlu Sa.ıtu,

\section{USOS MEDICINAES}

Os indios curam as ulceras syphiliticas. pulverisando-as com o ṕs, féto com as fulhas. O oleo é purrativu, e o, succo desta pli.ita, cura as molestias da pelie.

Argueiro.-Arvore espiahosi, de mediana grandeza, e proluz vagens, dentro dis quaes, etio u.ıs fuijoes escallates, ou pi tados, que não têm silu experime.ıtiulus e.n medivi.ıa domestica.

\section{USOS ENTRE OS INDIOS}

Os indios empregam os caroıos du argueiro em braçaletes, com que se enfeitam.

Ar'iri. (V. Aricuri ou Aracuri ou Alicuri.)--E' uma palmeira de grandeza mediata, muito vulgarr.

\section{USOS MEDICINAES}

o succo do coco do Ariri. ainda ve:d, exprimido, serve para cur.ır a inflarnmaciio lifeiıa de olhus, bashando-os com elle.

Arooira. (Schinus Terebinthifolius) - Arvore brasileira, que vegeta em qualquer terreno, e por mais calur que faça, couserva-se sempre verde. E' aromatica.

\section{LSOS MEDICINAES}

As cascas desta arvore, diz o Dr. Langgaard, contém tanino, materia g.urdurosa e resiıa: o seu cozi neito, é usado em fome.1taç̃es, nas affecções rheumaticas, tumores lymphaticos e debilidaje dos membros

o extrato feito dos olhos da aroeira serve, para curar a dyarrhía, na dóse de uma á duas oitavas, em caldo de gallinha, duas vezes por dia. Nas hemoptyses, tambem applicim-1a os sertanejos com vil.ti gem. O le.lho dos ramos é muito ernjregado para limpar, e alvejar os dentess. 
As exhalacres resinosas, produzem, nos que ficam por muito tempo deitadus debaixo desta arvore, erupção da pelle semelhante ao sarampão, e a escarlatina.

A resi.ıa tomada inter.ame.ıte, é optimo remedio contra a morp!liá

A agua distillada das flores, fructos e pimpolhos, é excellente cordial uas febres continuas, dada na yua.ıtidade de una onça. Tambem servem-.e do emplastro, feito com a casca da aroeira, para curar as reıdeduras dis verilhas.

Aroeira do sortao. - E' arvore de extraordinaria grandeza, e o seu leaho é de taita duracào, que, enterrado no chão, resiste atj 300 annos. Eu vi no arraial do Bum Despacho, freguezia de S. José dos Itapororocas, irr.ncar-se o esteio de uma casa velha, que diziam ter para mais de 100 annus, em perfeito estado.

\section{USOS MEDICINAES}

A casca é adstringente, applicada nas diarrhéas.

USOS NAS ARTES

A madeira é ompregada na co.ıstruccão de casas, e serve para a marcenaria. La sui fructa se extrahe, ti.ıta cỏr de rosa.

Arrebenta cavallo. E' a melancia da praia. (Vid. adeante os usos desta planta.)

A $x^{\circ} \mathbf{x}^{\circ}$ ogada.-E' um arbusto pequeno, que vegeta nas provincias do norte do Brasil.

USOS MEDICINAES

As folhas pizadas, e postas subre a pelle, produzem o effeito do caustico. Dissolvidas em agua, matam os piolhos dus cavallos.

Arropondido.-E' uma planta agreste, mui conhecida dos matutos das Alagoas. E' mui similhante ao sipó de rego. E' provavel, que esta planta teıha virtudes medicinaes, se for estudada.

Ar'1-inga-iba. (Caladium arborescens.)-E' um arbusto de natureza picaute.

UEAS MEDICINAES

E' resolutivo; a o cozimento das folhas, e raizes feito em 
ourina, é muito usado pelo povo do interior, para curar o rheumatismo articular.

Arroz. (Oryza sativa)-Gabriel Soares diz, que o arroz que se cultiva no Brasil, fui levado de Cabo Verde, paral a Bahia, e dali espalhado por todo o BrasiI.

o padre Antonio Caetano da Fonseca, no seu Manual do Agricultor, ensina o modo de cultival-o.

\section{USOS MEDICINAES}

E' empregado em cozimento, como emoliente, nas inflammações i.ıtestinaes; e externamente fazem cataplasmas co..t'a as inflammações da pelle, e contra os abcessos.

\section{USOS CULINARIOS}

o arroz fórma um proto indispensavel nas mesas, e se affeiçôa a todas as preparações culinarias.

\section{USOS NAS ARTES}

Com a palha do arroz, tecem esteiras, e fazem chaṕ̧us. A palha dada como alimento aos animaes, produz a estermidide chamada môrmo.

Arooz do matto. (Oryza subulata.) - Esta especie de arroz, nasce espontaneameate nas Alagòas, e no Pari: os grĩos são maiores que o do arroz asiatico. Come-se, e é agradavel o gosto. Tem os mesmos usos do arr z commum.

Arreuda vulgax. (Ruta graveolens.) - Esta planta dos jardials. foi transportada da Europa, para o Blasil. E' muito conhecida, e pega de galho.

\section{USOS MEDICINAES}

E' antipasmodico poderoso; e fortificante do cerebro.

O sumo da arruda, embebido em algorlão, e posto em cima das feridas, as cura. Misturado com leite de peito de mulher, e posto 1 o ouvido doente, passa a dòr deste organ.

E' mui proveitosa a arruda, para os flatus, e paralysia, tomada em chá, e frícionando as partes cum o sumo das folhas.

Arruda do matto. (Pilocarpus officinalis) Maranhão. 


\section{USOS MEDICINAES}

Esta variedade de arruda. que vegeta no Brasil, é usada no Maranhão. em banhos. no rheumatismo articular; internamente, em fórma de chá, nas molestiss do figado, na anemia, e na falta de. mentruos. Tambem aproveita do mesmo modo, para curar as escrophulas, a tisica pulmour, e o catharro leringu-plıaringeo, tomado pela mauhan, e á noite. E' emenagogo, e abortivo.

Arthimiria do campo. (Arthemisin campestris.)Arbusto mui vulgar, e mui prrecilo com a macella ou camomilla. Abunda estir plinti, was margens do ri., S. Francisco. O seu aroma é agradivel, eos uaturaes das provincias das Alagòas e Sergipe de El-rei, fazem delle os mesinus usos, que o da macella.

\section{USOS MEDICINAES}

Empreçrm. $\mathrm{em}$ infusão. nas febres adynami as e continuas nas dirrhéas sorosas, provenieutes de debilidade iatestinal; Applicam com muito 1 roveito ás crianças, nas diarrlı́as causa das da deniticão.

As folhas fritas em azeite doce, são louvado remedio, para resolver os tumores ve.ıereos das articulaços, e timbem para resolver as glandulas eufartadas do pescoco, ou cachumbas, Os clysteres feitos com a infũãu da arthimizia são proveitosos. nas liemorrhoidas.

Arthimizia. (Arthemisia vulgaris.)-A arthimizia vuI rar, foi trazida da Europa para o Brasil. Esta planta rem descripta por Joâo Vivier, na sua Historia das Plantas, e diz, que na Europa, ella fluresce em Julho e Agosto.

\section{USOS MEDICINAES}

E' planta de natureza quente, e desecca mediocremente os vapores do sangue. As mulheres, recebendo a fumigacão nas partes pudendas, lhes provoca os menstruos, e faz expellir as secundinas, e mesmo o feto.

E' singular medicamento, para as mo'ectias uterinas, e para as molestias provenientes de resfriamentos. E' empregarla, como dissulvente da pedra da bexiga, e aproveita na reteiçĩo das 
ourinas. O sumo desta planta, misturado com mirrha, e applicado em fórma de pessario, e mettido pela vagina, faz purgar o utero, de todas as suas immundicies.

Arvore do alho. (Valgarmente píu d'alho) Cerdana aliorlora.-E' arvore alta e natural do Bra il, do Chile, e do Perú. As suas, folhas alter ıas, sĩo caducas. Di flores em cachos.

Aqui mesno no Rio de Jineiro, se e.tc stra a arvore do alho.

Defrunte do portão lateral do cemiterio de S. Francisco de Paula, e á beira mesmo da rua de Itapi ú, antiga de Catumby, existe uma àrvore, do alho, que póde ser estudada em proveito da materia medica brasi'eira.

\section{USOS MEDICINAES}

Ecta arvor nunciado. E' usada em bauhis. entre os sertanejos. como estimulante, nas dores rheumaticas, devidas a resfriamento. Convém ser estudada.

\section{USOS CULINARIOS}

No sertão usam das folhas da arvore do alho, para adubar a comida em falta do alho.

Arvoro da camphora.-Na provıncia das Alagòas, existe uma arvore, que distilla um succo recinoso, esbranquiçado, trasparente e volatil, e de cheiro similhante ao da curmphora, cuja resina pusta nas brazas produz flamma.

\section{USOS MEDICINAES}

Os sertanejos servem-se da casca dest tr arvore, para banhos, nas molestias prove.ile.ites de resiriane tos.

Arvore da cera. (Myrica cerifera.)-E' arvore de mediana grandeza, florifica, e dít fructos.

\section{USOS MEDICINAES}

Não são conhecidos.

\section{USOS NAS ARTES}

Do fracto fervicio se extrahe boa cera de cor esverdeada, a qual depois, toma a cor amarella, e com ella se fabricam velas, que exhalam um suave, e agrudavel cheiro, durante a combustão. 
Quantas fontes de riqueza existem neste nosso abencoado paiz, se elle fusse admini-trado, não pela chicana politica e judiciaria, como infelizmelite trm sido, mas por homens patriotas, e puramente brasileiros, que, esquecilos de si, se empenhassem pelo uturo engrandecimeuto do Brasil!

Desde a fundacão do imperio, nominal do Equador, como o chamou o conselheiro Jusé Bunifacio de Andrada e Silva, os seus estadistas, o nòo couheciam, como aiıda os que o admini-tram tambem o. não conhecem, por que o não estudam; e, por isso o vemos sem industria, sem commercio nacional, porque o que temos só tem de nacional o nome, sem navegação, quasi sem agricultura, e em vespera de algum desastre.

Do que cuidam os norsos advogallus politıcos, é das eleiç̃es, para trazerem o malfudido paiz envo'to no e.ıredo, e na chicana politica. Fiquem certos, que a historia contemporanea, está escripta com calma, imparcialidade e documentada. Todos são julgados, sem excepcão de ninguem, em vi:ta das desgraças publicas. Os homeas po'iticos não perteucem á familia, e nem aos amigos: são do dominio da historia.

Arvoredo jasmim. (Carlota odorata.)-(') E-ta arvore é de grandeza regular, direita, con casca fila, um pouco eshranquiçada, e em cina escalha em muitos ramos, e ramusculos. onde nascem as fo'lhas, de configuração oblongali, tendo o dorso esbranquicado, e a nervura bra ica. A outra face da fulha. é de um verde carregado, e os bor'os cahidus de espaco em espaço. As flores sĩo alvissimas, e similhantes ao jasmim da Italia; porém, mais engracadıs, e de um aroma suavisimo. Os borlos das flores são similhantes aos bordos das folhas.

Dá fructo com picos, similha ites aos da jaca, e aberto ó encarnado, tendo as sementes pegadas-aotrophosperma.

\section{USOS MEDICINAES}

São desconhecidos: convem ser estudada, em proveito da the-

(1) A arvore é uma planta lenhosa e vivíz, cuja haste se eleva. e engrosia, esgalliando em cim ', e se ornando de fullias, seado imposivel determiar-lhe o tamanho. 
rapeutica, porque a planta dá um succo leitoso, que deve ser medicisal.

\section{UEO NA INDUSTRIA}

A planta picada deixa escapar abundante leite, de quo a inlustria poderia tirar muito proveito; bem como pela distillação. extrahir das flores, fragrantissinı cheiro, para a perfumaria.

Arvore do pào.-Vide Fructa pão.

Arvore do papel.-Vide adeante Páu papel.

Arvore pomisa.- Nasce em qualquer terreno, principalmente nos arenosos, e fracos. Eucontra-se esta arvore em ahıudancia nas proviıcias da Bahia, Sergipe, Alagòas, e Pernambuco.

\section{USOS MEDICINAES}

A infusão, ou cozimento feito da entre-casca, serve para lavar, e curar as feridas chronicas.

Do amago distilla um balsamo ou oleo, que é empregado para o mesmo fim.

A infusão em repouso, deixa um sedimento ou gomma, que sendo applicada ás ferłilas, promove a cicatrização dellas.

A'vore da pare a. (Yucca gloriosa.)-E' um arbusto, pareci lo com o gravatii. Serve de ornarmento aos jardiıs. Dá flores de cor branca, e furmusas.

USOS MEDICINAES

Não são conhecidos.

Arvore santa.- Esta planta nasce nos terrenos aridos, e mórmente nos sertões.

E' de altura mediana, floresce e fructifica.

\section{USOS MEDICINAES}

A casca da raiz, pisada, e mistuiada com sufficiente quantidarle de agua, é optimo vomitivo, para os enfermos de opilações; e prara os que padecen de cansaço.

Dí-se em pequena dóse, para provocar o vomito, e não ha perigo, pela morosidade da acção medicamentosa. 
A rvore do viajor. - E' uma planta formara, que vegeta nos agrestes, e sertões dı Brasil, e mórmente nos logares onde inteiramente falta agua. No passeio nublico do Rio de Janeiro, existe esta planta, devilla ao cuidado do nosso amigo o illustrado Sr. Dr. Glasion, onde póde ser vista, e estudada.

A arvore do viajor è de aitura regular, com folhas largas, similhantes ás da bananeira, tendo os peciolos ócos, contendo agua potavel, que servem de foutes, podendo conter, cada um peciolo, uma garrafa de bua agua.

Dizem os sertanejos, que em uma arvore, podem beber agua, 100 pessoas á fartar.

E' mais uma maravilha, que a munificencia do Altissimo Creador, espalhou sobre este nosso abeıcoado paiz, olhado com indifferenç, pelos que dirigem seus destiıos.

A falta de estudos sobre a fiora brasileira, tem feito, que algumas pessoas julguem, que esta arvole, fosse vinda da ilha Madagascar, para o Biasil.

Assacú. (Hura brasiliensis.) - Esta planta, nasce espontaneamente em Cayenna, no Pará, no Mexico, e nas Antilhas; e é de uma grandeza extraordiıaria. O Dr. Lacerda, diz, que o leite do tro.ıco desta arvore, que escurre pur incisăo, é reputado mui venenoso, e que vindo em 1847, a noticia do Alto Amazonas, que o leite do assacú era util, na cura da nıorjó̉a, fazendo-se repetidas experie.ıcias, não deram resultados satisfactorios.

\section{USOS MEDICINAES}

Faz-se com a casca, cozimeit to para banhos, e o leite empregam-n'o i،tername.ıte, em pequena quantidade. No Pari, o assacú, é tido por um veneno activo, e muitus pessoas alli, sĩo victimas desse porleru: o toxico.

No periodico Tres de Maio, de 11 de Agosto de 1847 n. 725, se roticiou ter apparecillo um i.ıdividuo de nome Josśs Joaquim de Souza Gomes, semi-curado da morphéa. A camara da villa de Santarim, tomando esse facto em consideração, passou a examinar a marcha de:te successo, e conheceu que Autunio Vieira dus Passos, accúsado do crime de morte, era aquelle, que 
tinha tratado a José Joaquim de Souzá Gomes, e que para este curativo, usava do leite do arsacu; $\theta$ que este remedio, lhe tiaha ensinado um caboclo, de Juruty, do Pard, chamado Manoel José Joaquim.

A camara de Santarém, entregou por sua conta ao pharmaceutico Raymundo Jusé Rabello, um e.ıfermo, para ser tratado com assacú, e com effeito melhorou, do mal que soffia.

\section{EXPERIENCIAS HOMGOPPATHICAS}

Feitas com uma gotta da tintura, em $5^{\mathrm{a}}$ dynamisacão :

o assacú, foi perfeitamente estudalo pela humcupathia; e - Dr. Beito Mure, no seu livro Doutrina da eschola do Rio de Janeiro e Pathogenesia Brasiliense, desde a pagina 163. até a pagina 200, consigna as varias experie.ıilis, diı por dia, fitas com o assacú. no homem são, l'ecullieceu-se que o assacú é precioso medicamento, para curar as diversis lưrmas de mye.ite, as excita.ões nervosas, estremecimentıs, e excitaçào mural.

o Dr. Martius, affirma que os i.dius, dío o leite du assacú, ás criallças, como anthelmintico; beın como se servem delle, para embebedar o peixe, deitando-o no rio, ou na lugôa.

Assahy. (Euterpe edulis )-E' uma palmeira, que nas Alagôas, e no Maranhão chamam Iussara. Leita cachos, e us cocos são do tamanlıo de uma azeitona. O cỏcu é comestivel.

USOS MEDICINAES E NA INDUSTRIA

Não são conhecidos os prestimos em medicina domestica. Os indi. $\mathrm{s}$ fazem delicioso vinho da Iructa, e gostam muito delle.

Assa peixe. (Bohemeria caudata.)-E' planta vulgar, e mui conhecida nas Alagôas, e Peruambuco.

\section{USOS MEDICINAES}

o cozimento da raiz, é remedio presentaneo, para estancar - sangue pela boza, e para desfazer as aposthemas iuternas. Tambem é approvado medicamento, para desfazer o sanguo coallıado, resultunte das co.tusões e pisaduras; para lavar quaes. quer firidas vel las incuraveis, lava.ıdo-ıs com o cozimentu da planta toda, e pulverizando-as com o pú das folhas.

Einpregam o as 
As folhas fritas em azeite, ou mesmo socadas, e applicadas ao utero, o corrobora e fortifica. Em banbos, mitiga as hernorrhoidas.

Assauy. -E' planta conhecida no Pará, que não está classificada.

\section{USOS MEDICINAES}

o emplastro feito com o leite desta planta, e applicadó ao peito, suspeude o sangue posto pela boca.

Assupa.-E' um pequeno arbusto, do Alto Amazonas, que tem a propriedade de produzir febre, em quem o lespira durante meia hura; e por isso os indios, têm um mêdo extraordinario delle, e por cousa alguma se lhe atrevem a tocar. Presentiudo-o, fogem delle.

\section{USOS MEDICINAES}

Não são conhecidos, porque não tem sido estudado, nem experimeutado.

A tc há. (Begonia.) - Esta planta produz uma raiz comestivel, tendo o mesmo gusto do aipim.

Aturii.-E' uma planta do Pará, e Maranhão.

\section{USOS MEDICINAES}

As fulhas e a casca da raiz, seccas e cozidas, dadas pela manhan e á nuite, urna chicara com ou sem assucar, é buin remedio para a tosse, e para os flatos.

Auhy-axá-cahy.-E' planta do Pará e Maranhão.

\section{USOS MEDICINAES}

o sumo desta planta empregam-n'o na inflammaçĩo dos olhos.

Avaramo. (Mimosa unguiscati.)-E' planta coilhecida nas proviucias do Brasil,

\section{USOS MEDICINAES}

Por suas qualidades, amarga e dissecativa, empregam-n'a internamente em c simento, para curar as febres; externime te para curar as feridas velhas, e o cancro. 
Avenca brasileira. (Adianthum risophorum)-E' planta rasteira, especie de fet, mai vulgar no Rio de Janeiro. Abunda nos morrus de Catumby Ha varias especies no Brasil. USOS MEDICINAES

E' e ripregada com proveito, nos que deitam sangue pela boca (hemo ${ }^{\prime}$ tysis), e para os que têm dôres de peito.

A yayana. (Eupatorium ayajana.)

\section{USOS MEDICINAES}

E' p!anía amora, aromatica e diaphoretica. A sua raiz é contra veneno de culsa, bsbendo-se o susco, e pondo-se as folhas pisadas subre a ferida.

A t a de morcego, do rolna grande. (Bossiaca unijugata.)-E' um áribusto das Alagôas.

USOS MEDICINAES

Não são conhecidos.

Aza do morcerso do folha miuda.-E' um eipó, que vegeta nas Alagóas, e Purnambuco.

$$
\text { USOS MED.CINAES }
$$

Não são conhecidos.

Azoda. (Rumex acetsa.)-E' planta conhecida.

USOS MEdiC:NAES

Serve para ne atralisar a ac jão dis substancias purgativas, acres.

Azedinha do brejo. (Biyznia acila.)

\section{USOS MEDICINAB3}

E' o seu succo refrigerante, e anti-scorbutico, e empregado nos eatarrhos da bexiga, e nas dysen erias.

\section{USOS CULIXIRIOS}

E' comestivel, estando a planta verde.

Azoitona da torra. (C inhea niti la.)-E' planta brasileira, de duas e moia bracas de altura, e conhecida nas Alagoas e Pernambuco, por esse nome. Di flores e fructos pare- 
cidos com a azitıra, e sào comestiveis, e tinge os labios de roxo. O seu sabor é asidalo, e pouco doce.

USUS MEDICINAES

Não são conhecidos.

A zougue dos pobres. (Vid. velame.)

\section{B}

Babi, banbão, cannapú, arrobenta cavallo, melancia da praia. Solanun agrarium)E' um arbusto ra teiro e espinhoso, que proluz em qualquer lozar frescs. Floresce e fructifica, se.ldo o fiuctu iınocente e comestivel. As criducas gostam delle.

\section{USOS MEDICINAES}

o cozimento desta planta, é optimo remedio para as gonorrhéas.

A especie de babi, a que chamam arrebenta carallo, tem a mesma coafiłuração, só com a differença de que os fructos são vernielhos.

Arra.scrila a planta, e feito cozimento com ella toda, serve para resolver a inchação do escroto.

Baba de boi, (vide Ourzcury, cocus coronata)

Baboza ou alóos.-Planta couhecida, e hortense.

USOS MEDICINAES

Do miolo da follha desta planta, depois de assada no rescald., se fazem boliıhas cobertas de algodão, que se i.ıtıodızem no a.ıus, de 2 em 2 horas, para tirar as dures dessa parte. Algumas pessoas empregam-na mesmo crua, para o mesmo fim.

USOS DOMESTICOS

Fazem com o miolo da folha da bxbrza, excellente e sadio doce para mesa, e se póde dar aos convalescentes.

Bubunha. (Gurlielma insignis.) - E' uma palmeira da Bahia, cujos fructos são comestiveis, e muito estimadus.

USOS MEDICIDAES

o oleo do coco, serve para o rheumatismo. 
Bacaba. (Oenocurpus brcx'r.)-Palmeira do Pará.

\section{USOS MEDICINAES}

Não são conhecidos.

USOS NAS ARTES

A sua madeira e fulhas, servem para diversos misteres.

\section{- usos alimenticios}

0 fructo è comestivel.

Bacamarte. - E' planta co.hecida nas provincias do norto do Brasil.

\section{UEOS MEDICINAES}

Empregam-n'a como aperitivo, nas d'bilidades do estorugo; e externameate, como resulutivo de tumores.

Bacazy.-E' arvore de 40 palmos e de 2 de diametro; floresce em Setembru (Silva Lisbua).

USUS MEDICINAES

Não são conhecidos.

\section{USOS NAS ARTES}

Serve para as obras de architectura.

Baccharica ou baceha: ta (Baccharis brasiliana.) -E' planta amarǵsa. arunatica, resinosa, e póde mail bem substituir a losıa, por suas propriedades medicamentosas.

\section{USOS MEDICINAFS}

o seu uso é contra a debilidade do estomago, e intestinos, a dyspepsia, bem pronu.iciada, cumplicada com anemia, provoniente de perdas sangui.ıeas.

Bacopari. (Calypso bacopari.)-E' uma arrore conhecida nas Alagòas, Peruambuco, Bahia, Rio de Juneiro, S. Palilo, Minas, etc., etc.

\section{USOS MEDICINAES}

Não são ronhecidos; mas o fructo é comastivel, e o succo queima os labiss, se não ha cuilado quando se come.

Bacopari da matta.-Aivore de 30 a 50 palmos. Florasce em Outubro (S.liva Li.stou). 


\section{USOS MEDICINAES}

Não são conhecidos; mas a fructa é comestivel.

\section{USOS NAS ARTES}

Serve o lenho para esteius e obras de casas.

Bacumixa.-Arvore de 60 palmos de altura, e dus de grossura.

\section{USOS MEDICINAES}

Não são conhecidos.

USOS NAS ARTES

E' empregado o lenho na architectura.

Bacumixa-assú.-Arvore, que só se differenca da preeedente, nas folhas, e nas flores, que apparecem em Novembro. USOS NAS ARIES

Serve para obras de archite tura.

Bacury. (Moronobia coccocinea.)-Alagôas, Maranhão e Pará. E' arvore lactecente e alta, que vegeta nus logares liumidos, similhante ao pequiı́ na contiguração.

USOS MEDICINAES

Não são conhecidos.

USOS NAS ARTES

O fructo, que é comestivel, presta-se á confeccão de excellente doce. 0 seu lenho serve para construccão naval.

Baza a inarolla. -E' arvore de 60 palmos de altura, e de dous á tres de diametro.

\section{U8O3 MEDICINAES}

o fructo desta arvore, é empregado contra as colicas do ventre, e nas dòres de estomago, causadas por debilidade.

\section{USOS NAS ARTES}

O lenho desta arvore serve, para taboados e frechaes.

Baza de louro.-E' arvore de igual dimensão, que a baga amarella.

Floresce em Agosto. (Silva Lisboa.) 
USOS NAS ARTES

O seu lenho scrve para os mesmos prestimos.

Baza da praia. (Coccoloba vifern.)-Arvore das mattas do Brasil.

\section{LSOS MEDICINAES}

A casca é adstringente poderoso, empregado nas dyarrhéas "lencorrhéas.

Bagopari.-E' arvore corpulenta, que dá uma rezina medicinal.

\section{LSOS MEDICINAES}

Dizern os derrubadores das mattas, que a resina d'esta arvore, tem emprego na medicina domestica, mas não indicam as enfer. midades em que aproveita a rezina.

Balaio de velha.-E' um arbusto, que folga em terrenos trabalhados, e resiste á intensidade do calor do sol, sem esmorecer.

\section{USOS MEDICINAES}

o banho do cozimento, feito com as folhas d'esta planta, faz jarar o frouxo de sangue das mulheres.

Balsamo. (Mirospermum crytoxiluin.)-Apvore pertencente a familia das leguminosas, e das catingas das Alagôas, alta, tendo de dous a tres palmos de diametro.

\section{rSOS MEDICLNAES}

A casca do balsamo é vulneraria.

\section{USOS NAS ARTES}

O lenho d'esta arvore. é empregado na construcção de casas, c na marcenaria.

Bapsano do Per.'s. (Myroxylum peruiferum.)-Arvore le 80 a 109 palmos de altura. e de dous a oito de grossura, coberta com uma casca grossa, ci.rzenta, a qual ferida na lua chena de Fevereiro, e Mirco, distilla um oleo, coshecilo por halsamo do Perí.

A madeira d'esta grande arvole, é macia no serrar e lavrar. o) oleo que verte, è muto cheiroso. 


\section{USOS MEDICINAES}

o oleo é empregado em rarias preparações óflicinaes.

\section{LSOS NAS ARTES E NA INDLSTRIA}

O oleo presta-se para a confecção de pastilhas aromaticas. A madeira serve para as obras de ornatos, e assemelha-se au Inogno.

Balsamo hor.tense.-E' um arbusto mui conhecido, cultivado nos jardins, e estimado por suas virtudes medicinaes.

\section{I'SOS MEDICINAES}

Empregam esta planta, como um dos melhores vulnerarios: para curar as feridas causadas por ferro ou estrepe, para as contusões e outros accidentes mecanicos.

'A folha, que é de fórma cylindrica, aberta ou machucada, usam-n'a com proveito, para curar os callos dos pés.

Bamoú. (Bambusa grada.)-Esta planta muito abundante na Asia, tambem é producto do grande valle do Amazonas, das mattas das Alagôas, Bahia, e n'ellas tem o nome de taquarassú. Ha bambús ou taquarassis tão grandes, e grossos, que os indios selvem-se dos gommos, para depositos de agua.

\section{USOS MEDICINAES}

E' empregado como emoliente.

O illustre C. A. Taunay, no seu interessante Manual do Agricultor, fallando das plantas gramineas, que « de baixas, humildes e reptantas, ellas se elevam á altura arborescente onde o sólo, o calor e a humidade favorecem seu desenvolvimento. Só as terras tropicaes produzem as gigantescas taquaras.

« Ninguem duvidará que nma familia espalhada com profusão, no mundo inteiro, tenha usos economicos e virtudes medicinaes, e, com effeito, quem ignora as qualidades nutritivas dos cereaes que alimentam quasi todo o genern humano? Quão numerosas as gramineas, que nutrem os anımaes selvagens e domesticos, que servem para a nossa laroura, e nos alimentam, ninguem desconhece as grandes vantagens que nos tiramos das taquaras. São ainda as gramineas, com que o pobre abriga-se na sua casa; e quão grandes resultados não se poderiam tirar d'el- 
las, se nós tivessemos o genio de investigação, e escrutassemos, tanto estes, como outros tantos vegetaes de transcendente utilidade. 》

As ubcis tomam posse das ilhotas arenozas de nova formação, apenas sahidas da superficie da agua, fixam e fertilisam o sólo, sendo depois expulsas, por arbustos e arvoredos, os quaes cedem a sua vez ao homem investigador, que toma posse, para a sua lavoura.

o capim gordura é o flagello do agricultor brasileiro.

A barba de bode, esterilisa vastissimos campos, nas provincias do sul.

A gramma da praia é optima, para fixar a arêa movediça. As raizes do capim peba, do sapé, da gramma, sĩo mucilaginosas, sudorificas, etc.

As exoticas, porém, já naturalisadas, sĩo o capim da Angola, - da Colonia, o massambará, o painço e o bambú da india. o bambri ou taquarassî, tem diversos usos nas artes.

Banana.-Fructo da bananeira.

USOS MEDICINAES

Assada, e feita cataplasma, é emohente e maturativa.

USOS DOMESTICOS

E' sem a menor contestação o melhor, e o mais bem preparado podim, que a natureza creadora offereceu ao homem, para sua alimentaçio. Se tivessemos industrias, o que se não faria da banana, em relação aos regalos das mesas!

Bananeira, pacoba, figueira de Acáa. (Musa paradisiaca.)-Planta formosa, pelo seu aspecto, succulenta, composto o tronco de laminas longitudinaes.

Suas folhas sũo larguissimas: as flores (vulgo cñupa-mel), se desenvolvem do engaço.

o cacho sahe por cima, quasi de repente, dobrando-se logo, vindo cada penca, cuberta com sua capa, que vai cahindo, it medida que a fructa se desenvolve.

\section{USOS MEDICINAES}

As flores da bananeira infundidas em agua, e postas ao sereno da noite, é banho salutar, para as molestias dos olhos. 
o engaco pisado, e desfeito em agua, e dado em clyster, é approvado remedio, para curar as dysenterias rebeldes.

0 xar.jpe feito com as flores da bananeira, é utilissimo, para as tysicas pulmonares; e no sertão já se tem curado a tysica pulmonar, unicamente com xarope das flores da bananeira. A fructa é emoliente, e maturativa dos tumores.

USOS DOMESTICOS

E' a banana, ordinariamente a sobremesa das familias, em quasi todo o Brasil.

USO NAS ARTES

As folhas da bananeira servem para diver'sos usos domesticas. As fibras do tronco dão linho, para tecidos de panno, e para fabricar excellente papel.

Na Bahia em 1843, pouco mais ou menos, se montou uma grande fabrica de papel, cuja materia prima, na maior parte, eram troncos de bananeiras. Os jornaes diarios, e o commercio, se utilizavam, com geral satisfação d'essa nascente industria brasileila, que morreu pela baix extraordinaria do papel estrangeiro, em concurrencia, que por fim a fabrica nacional, não podendo competir, pelos desfavores do governo, d'esta desgorernadi fazenda chamada Imperio do Brazil, teve de fechar suas portas, com gravissimos prejuizos de seus patrioticos introductores.

N'esse papel, fabricado na Bahia, imprimi a minha memoria, a Ing'aterra $e$ os seus tratados ou o greino inglez perante o mundo, e eram impressos o Mercantil do Bahia, e o Correio IVercantil, dos quaes eu era o redactor em chefe, e outros periodicos daquella provincia.

Bananeira. - Na familia das Muzacias, a especie bananeira se apresenta com alguma variação e conta:

Bananeira anan.

Bananeira do bico verde.

Bananeira brava.

Bananeira curta ow de S. Thomé.

Bananeira maçan.

Bananeira de Madagascar ou Arrore do Viajor. 
USOS NA INDUSTRIA

O envolucro da semente dá um excellente sebo vegetal, que póde ser aproveitado.

Bananeira do matto.

USOS MEDICINAES

A raiz é diuretica, e cura as gonorrhéas. As folhas pisadas, cozidas, e feitas cataplasmas, são emulientes.

USO NA INDUSTRIA.

Dá tinta vermelha. Das sementes fazem rosarios.

Bananeira meia pataca - O cacho é de mais de metro de comprido, e a fructa muito grande.

Bananeira de morcego.-Assim chamada, porque esses vampiros, gostam muito dos fructos.

Bananeira samburá.-Similhante á anan.

Bananeira de ouro.

Bananeira de papagaio.

Bananeira de prata.-E' conveniente plantal-a, separada das outras especies, para não degenerar.

Bananeira do Taiti.

O illustre C. A. Taunay, fallando das Muzacias, diz serem ellas e igualmenete annexas ás scitamineas, porém, os estames são em numero de cinco e seis, Pentandria, e Hexandria. As bananeiras do Matto, a Urania, as Heliconeas, fazem pelas folhas, flores, e ainda mais, pelos bractios o oruamento dos mattos e bosques do Brasil.

As varias especies, ou variedades de bananeiras, formam uma abundancia de alimeutos nutritivos, emquanto que das folhas, e do tronco, fabricam-se tecidos e cordas; a seiva é adstringente, e diaphoretica. Fallando do fructo da bananeira, o nosso epico Santa Rita Duıão disse:

As bananas famosas na doçura, Fructa, que em cachos pende; cuida a gente Que fora o figo da cruel serpente. 
Gabriel Soares, que investigou as cousas do Brasil, para darnos noticias d'ellas, fallando da Pacoba, a descreve, e diz ser fructa natural d'esta terra, a qual se dá em uma arvore muito molle, e facil de cortar, cujas folhas são de 12 á $\$ 20$ palmos de comprido, e de 3 á 4 de largo, as de junto ao olho são menores e muito verdes, e umas e outras, e a arvore da mesma còr, mas, mais escura; na India chamam a estas Pacobeiras-figueiras -e o fructo figos.

Cada arvore d'estas, não dá mais que um só cacho, e que pelo menos tem passante de 200 pacobas, e como este cacho está de vez, cortam a arvore pelo pé, e de um só golpe, que the dão com uma fouce, e cortam cerce, do qual corte, corre logo agua em fio, e dentro em 24 horas, torna a lançar do mesmo córte um olho mui gresso, de onde se gera outra arvore, e ao redor desta, arrebentam muitos filhos, que aos 6 mezes dão fructo; e como se corta esta Pacobeira, tirando-lhe o cacho, que tem o fructo verde, e penduram em parte onde amadureca, e se façam amarellas as pacobas, e em casa onde se fizer fogo, amadurece mais depressa com a quentura; e a fructa madura cheira bem.

Bananeira da terra ou comprida. (Musa sapientium.)-Ha d'ellas outras castas, refere Gabriel Soares, que os indios chamam pacoba mirim, que quer dizer pacoba pequena, que são do comprimento de um dedo. As bananeiras têm a figura, folhas e creação, como as pacobeiras, e não ha entre cllas difierenç, as quaes foram ao Brasil de S. Thomé, aonde ao seu fructo chamam bananas, e na India chamam figos da horta, as quaes sĩo mais curtas, que as pacobas.

\section{USOS MEDICINAES}

O succo do grelo da banana de $\mathrm{S}$. Thomé, posto sobre a parte inflammada da erysipela, ou sobre o cobrelo, é proveitoso remedio, para combatel-os.

A banana assada, puiverizada com canella, embebida em vinho, e posta sobre o estomago, cura a diarrhéa sorosa ou asthenica.

o cozimento das folhas em banhos, cura a erysipela, e faz 
lesinçhar as partes. A banana de papagaio, é bom medicamento, para combater as gonorrhéas, e flores brancas.

Bapiva.-Arvore de 50 ou mais palmos de altura, e de 2 a 3 de diametro. Floresce em Setembro.

USOS NAS ARTES

E' de por'os fechados, e macia ao serrar: serve para obras de utensilios, como mão de pilão, para soccar arroz, ou milho, e para obras de edificios.

Barabra, -E' arvore corpulenta das nossas mattas, que vegeta em terrenos fortes. A sua madeira é muito macia ao serrar.

\section{USOS NAS ARTES}

E' muito apreciado o lenho d'esta arvore, para construcçăo, e para a marceneria.

Paraura ol guarahuma ou Maria picta da matta. (Melanoxilon barauna,)-Floresce em Setembro, com flores amarellas em cachos.

E' uma arvore gigantesca, muito copada, de folha miuda, disposta em palmas. A sua. fructa é uma vagem comprida, como a do feijão. O lenho ou cerne, é de um roxo carregado, e mui duro. Nas Alagoas chamam a esta arvore Maria Pretc ta Matta, em consequencia da còr escura do lenho, ou cerne.

\section{USOS NAS ARTES E NA INDUSTRIA}

Serve para a marceneria e para a construcção, e é de tanta luraciáo, que mettida na terra se conserva perfeita cem e mais annos. Além d'estes prestimos, a industria póde tirar vantagens da tinta rubra fusca, que ella fornece.

Barba de baxata ove chagas. - Planta vulgar, e prestimosa.

\section{USOS MEDICINAES}

O cozimento das folhas d'esta planta, é precioso medicamento, para combater as anginas tonsillares, e dòres de dentes. As tlores em infusão, sĩo purgativas, e a raiz serve, para curar as febres terçans. 
Barba de bode. (Cactaria pallens.)-E' uma especie de capim, mui conhecido em Pernambuco e nas Alagôas.

\section{USOS MEDICINAES}

o povo serve-se da barba def bode, para curar a inflammação do figado, tomada em cozimento, e mesmo feita em cataplasma, posta sobre a região hepatica. Tambem servem-Se d'ella, como aperitiva e diluente. Nas Alagòas a barba de bode. serve de pasto para animaes.

Barba de boi. (Remirea maritima)-E' outra especie de capim, de caule rasteiro e nodoso, que vegeta nas praias.

\section{USOS MEDICINAES}

Tomada em cozimento é sudorifico, e promove as ourinas.

Bax-ba de macaco.--Especie de sipó finissimo, e macio, que nasce, e cresce perpendicularmente nas folhas das grandes arvores.

\section{USOS NA INDUSTRIA}

A barba de macaco, secca ao sol, é empregada, na fabricação de colchões.

Barba de velho. (Tillandia usneoides.)-E' uma parasita, que cresce sobre os troncos das arvores.

\section{USOS MEDICINAES}

o succo d'esta planta misturado com banha, ou azeite de mamona, é precentaneo remedio, para curar as hemorihoidas. Como é adstringente, os matutos servern-se d'ella, para curar as hernias das virilhas, applicando-o sobre a ruptura.

Barbasco ou vorbasco. (Buddeja brasiliensis).E' arbusto medicinal, e nasce espontaneamente em varios legares do Brasil.

\section{USOS MEDICINAES}

Serve para combater os catarrhos pulmonares, tomado em infusão ; e feito banho, é proveitoso nas hemorrhoidas.

Barbatimão. (Mimosa virginalis)-Arvore, que vegeta em terrenos secros. A que dá fructo não é boa, e sim a que tem a casca vermelha. Ha grande abundancia em Minas Ge- 
raes, e nas provincias do norte do Brasíl. Nas suas folhas criam-se cantharidas em quantidade, que póde ser um grande ramo de commercio, quando entre nós se desenvolver o espirito da industria.

\section{USOS MEDICINAES}

o cozimento da casca do barbatimão, é poderoso medicamento, para curar feridas; e é tal a força adstringente d'este vegetal, que o banho feito com o cozimento do entrecasco, traz ás mulheres a doce illusão, tendo mesmo procreado, de tornarem an estado de viruindade.

A medicina tem n'esta arvore, promptos recursos para is asthma, to:ses antigas, as hemorrhagias, febres, e curar as queimaduras; serve para curar as hernias, as dyarrhéas, leucorrhéas, e o escorbuto.

CSO NAS ARTES E NA INDUSTRIA

A casca do barbatimão, serve para curtir o pellame.

As cinzas servem para a fabricação do sabão.

Entre esta familia, ha plantas venenosas, que matam os peixes; e uma, cuja casca é tão amargosa, que suppre a verdadeira quina.

Barberina.-Planta vulgar, conhecida dos hervanarios.

\section{USOS MEDICINAES}

E' amarga, e a casca da raiz empregam-n'a nas febres intermittentes terçans.

Barboleta.-E' arrore de 40 palmos de alto, e dous de diametro.

\section{USOS NAS ARTES}

Tem os mesmos prestimos, que o bacury.

Barexy. (Laceida.)--Planta vulgar do Maranhão e Parú.

\section{USOS MEDICINAES}

F'. empregada como adstringente, para curar ulceras velhas.

$$
\text { USOS NAS ARTES E NA INDUSTRIA }
$$

No Pará empregam-na, para tingir pannos de algodão.

Barimbé.-Arbusto que vegeta no Parí de 3 á 4 palmok de altura. 


\section{USOS MEDICINAES}

Os indios preparam uma bebida com o succo das folhas, e raizes d'esta planta, e fazem uso d'ella, porque os excita, provocando grande agitação nervosa, e actividade no corpo, e no espirito. Provoca vomitos, quando uzam d'ella. Convém ser estudarla esta planta, em proveito da humanidade.

Barriguda ou paineirea. (no Rio de Janeiro). Borrbax ventriçosa.)-E' arvore esquisita no aspecto, que vegeta nos sertões, pela enorme barriga que tem, a qual ás vezes mede de 3 a 4 varas de circumferencia. A paineira do Rio de Janeiro, não tem a mesma configurução. Floresce e fructifica no verão, c dentro do fructo existe a lã mais fina, macia, e delicada, que se conhece. Esta arvore distilla uma resina medicinal, mui apreciada pelos selvagens.

\section{USOS MEDICINAES}

A resina é empregada, para curar as hernias das virilhas. o mesmo prestimo tem o extracto, feito com a casca, e o lenho da barriguda.

\section{USO NAS ARTES}

A lã da barrigucia é empregada na colchoaria, e é de preço subido, pela sua maciez. N'este opulento Brasil, onde tudo di em abundancia, e tudo possue, menos juiro e patriotismo nos homens, chamados de Estado, que só olham para as rendas das alfandegas, indirectas e fallives, porque nũo cream as directas e infalliveis, que sĩo as fontes de riquezas, que a industria do paiz produziria, se fosse animada pelo patriotismo, não se perderiam milhares de arrobas, señ̃o milhũes d'esse producto precioso, que a Mão munificente do Creador, plantou no solo brasileiro, e que o vento carrega diariamente, para enfeitar de branco, a vegetação dos nossos sertões, no tempo em que este precioso vegetal, se adorna com seus fructos.

Baré. (Dipterix pleropus de Martius.)-E' arvore do interior do Brasil, notavel pelo cheiro suavissimo de suas sementes. Diz o Dr. Martius, que as sementes são apreciaveis, por communicar o seu cheiro agradavel ao tabaco. 
USOS MEIICINAES

As sementes são nervinas, analepticas (restaurativas), cordiaes. diaphoreticas, e lazem vir os menstruos.

Bassoura ou vassoura. (Buddleja connata.)-E' um arbusto conhecido e muito vulgar: ha diversas qualidades de bassoura.

\section{USOS MEDICINAES}

Serve para curar as defluxões do peito, e para banhos, nas affecções hemorrhoidaes. A raiz soccada, e infundida em aguardente boa, é contra veneno de cobra, dada a beber ao mordido.

Bassourinha ou vassourinha. (Buddleju australis.)-Planta vulgar e semelhante á bassoura.

\section{USOS MEDICINAES}

E' famoso medicamento, para curar as dores hemorrhoidaes, tomado o cozimento da planta em clyster, e tambem em banhos. Tomada em fórma de chá, é efficassissimo nas molestias do peito, como tosse e sangue pela bocca.

Satata. (Convolvus batata.)-A batata, planta brasileira, é uma raiz farinacea de agradavel alimentacĩo pertencente it familia das convolvulacias; e de tal maneira produzem, que, onde se plantam uma vez, nunca mais desinça, as quaes tornam a nascer das pontas, das raizes, que ficaram naterra, diz Soares Gabriel, quando se colheu a novidade d'ellas.

As batatas não se plantam de rama, como nas ilhas, mas, de talhada, das mesmas raizes. e em cada enchadada, que dão na terra, sem ser mais cavada, mettem uma talhada de batata, as quaes se plantam em Abril, e começam a colher a noridade em Agosto, d'onde tem que tirar até todo Março, porque colhem umas batatas grandes, e ficam outras pequenas, que se vão criando Ha umas batatas grandes, brancas e compridas, ha outras pequenas, redondas e mui saborosas; ha outras, que são roxas, ao longo da casca, e brancas por dentro; ha outras que são todas encarnadas e mui gostosas; ha outras, que são de cor azul anilada muito fina, as quaes tingem as mãos; ha outras, verdoengas muito doces e saborosas; outras todas de cor almecegadas muito saborosas; outras torlas amarellas, e de cor muito tostada, as quaes são tordas humidas e ventosas, de que 
se não faz muita conta, entre gente de primor, senão entre as lavradures. (Gabriel Soares)

\section{- USOS MEDICINAES}

o cozimento das folhas, serve para banhos emolientes, .e para gargarejos nas inflammações e tumores da boca, e da garganta.

\section{USOS CULINARIOS}

Come-se as batatas cozidas, assadas. e são tão gostosas pelo assucarado e perfume que teni, que não enfastiam: é uma alimentacão sadia e dehciosa, e com ellas fazem doces para as mesas, apreciados, pela delicadeza da massa.

\section{USOS, AGRICOLAS}

Os fazendeiros servem-se das folhas, para sustento dos porcos. e cabras, e mesmo as dão aos animaes muares, sem o menor incoilveliente.

Batata do ax.-E' planta trepadeira que, sem dar flor, dá um fructo de fưrma irregular, sem caroço nem pevide, coberto de uma pelle verde, como a da batata, da qual, tem o sabor.

Batata doee. (Convulus dulcis.)

Batata ingieza ou amoricana. (Solanum tuberosum.) - O Dr. Merart, no longo artigo, a respeito da extensa familia das solaneas, tratundo da batata, impropriamente chamada batata ingleza, deixa ver ter sido a sua descoberta a mais util conquistu, que o homem fez no reino regetal, porque ella se reproduz em todos os climas, e em todas as latitudes. Flla é i.xco.testavelmente natural da America, porque Pavo., diz tel-a encoitrado selvagem nas vizinhanças de Lima, (Реı ú), e no Mexico.

Não se sabo precisamente a data, e nem o anno em que foi levada á Europa, e sò o que é certo é, que a batata american , foi levado por Walter Raleigh, em 1586, da Carolina (America Septentrional), para a Inglaterra.

José da Costa, ern 1590, disse, que os peruanos empregam, em logar do pão, as batatas seccas ao sol, a que os naturaes chamam chunno ou chug.ıa. Os hesparıhóes levaram-n'a do Perú, para a Italia, Belgica, Borgonna e para a Allemanha, sem que 
se saiba quem a levou, e nem a epocha em que este notavel acontecimento se deu. 0 que é certo. e incontestavel é, que a batata americana ou ingleza, é um alimento universal, sadio e mui reparador. E' bem para se crer, que ella exista no i.ıterior do Brasil, no estado de selvagem, mas como a preguica, o deleixo e a indifferença, por tudo o que é brasileiro, têm feito que ella ainda se não tenha encontrado.

\section{USOS MEDICINAES}

Servem-se das folhas, flores e das bagas em cozimento, para curar o rheumatismo gottoso, e dôres nervosas; e o chá serve, para combater os catarrhos chronicus. A cataplasma feita com as batatas, cura as feridas causa las por queimaduras. Cortada em talhadas e posta nas fontes, cura as dôres de cabeça. Dizem que o uso da batata americana, é mui salutar aos que padecem de escorbuto.

Batata do mar ou salsa da praia. (Ipomcea maritima.) -E' planta da costa do mar, conhecida dos hervanarios.

USOS MEDICINAES

E' empregada esta planta nas nerralgias, catarrhos chronicos, e para combater o escorbuto.

Batata de pur.sa. (Convolvutlus gomesii.) - E' planta herbacea, mui vulgar nas Alagôas, e na Bahia.

\section{USOS MEDICINAES}

A raiz d'esta planta, ralada, dá uma fecula branca, conhesida por gomma de batata, que é purgativa, e purificante dos humores. E' um infallivel medicamento, para curar as leucorrhéas ou fluxo branco das mulheres.

Na Bahia fazen um cozimento com is agua da la ranja da terra, assucar, aguardente e a gomma da batata, e com este licor dado um calix, pela manhan, e outro, á noite, por nove dias, curam perieitamente as flores brancas.

Com a mesma raiz, formam a resiua da batata, que é pursativa. 
Batata de teiŕ.-E' planta rasteira, e conhecida nas Alagôas e provincias do norte. A batata é esverdeada por fóra, e por dentro é excessivamente amargosa.

\section{USOS MEDICINAES}

Nenhum medicamento é mais efficaz e infallivel, do que esta batata, para curar as mordeduras das cobras, inclusive a cascavel. Ralam-n'a, tiram-lhe o succo, e vão dando ao paciente em pequenas dóses, e cobre-se com o bagaço a dentada da cobra.

Batatinha. (Vid. contra herra.)

Batauá ou coqueiro batauá. (Pará.)-E' planta do Alto Amazonas.

\section{USOS NA INDUSTRIA}

Os indios fazem com os fructos deste coqueiro vinho, de que usam.

Batim.-E' uma planta trepadeira, do genero do maracujá, muito conhecida no Ceará.

\section{USOS MEDICINAES}

Sabe-se por muitas experiencias, que esta trepadeira é um dos melhores antidotos contra o veneno da cobra cascavel. Servem-se da raiz soccada, e infundida em aguardente, para darem ao mordido, e externamente applicam o bagaço ensopado no mesmo liquido, sobre a ferida produzida pelos dentes da cobra.

Batinga branca. (Eugenia durissima.) -E' arvore de 25 a 30 palmos, com dous á dous, e meio de grossura. Florece e fructifica em Agosto. O seu fructo é comestivel, e saboroso. USOS MEDICINAES

Não são conhecidos.

USOS NAS ARTES

o seu lenho é mui rijo no serrar e lavrar, e é empregado em frechaes, vigas, portaes, caixilhos, etc.

Batinga tucano. (Silva Lisboa.)-E' arvore de 40 e mais palmos, com dous de diametro. Floresce em Setembro.

USOS MEDICINAES

Não se tem empregado em medicina vulgar. 
USOS NAS ARTES

Serve para vigas e frechaes.

Batinga vermelha. (Silva Lisboa) -E' arvore de 60 palmos de altura, e de dous á ties de grossura. Floresce em Setembro.

\section{USOS MEDICINAES}

Não são conhecidos.

\section{USOS NAS ARTES}

Serve para cumieiras de casas, e outras obras de architectura, e bem assim, para a fabricação de remos de voga.

Batinguassú. (Silva Lisboa.)-E' arvore de 40 palmos, c de um á dous de diametro. Floresce em Setembro.

\section{USOS NAS ARTES}

A sua madeira é macia no serrar e lavrar, e tem os mesmos prestimos, que a batinga tucano.

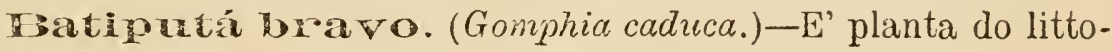
ral, muito formosa quando se acha florida, com os seus cachos amarellos. Produz sementes oleosas.

\section{LSOS MEDICINAES}

O oleo que se extrahe do fiucto do batiputá braro, é empre. sudo no rheumatismo, e na erysipela.

Batiputi nanso. (Gomphia jabotaputá.) - E' plantit semelhante á brava, e tem sementes oleosas.

\section{USOS MEDICINAES}

O oleo é empregado para curar o rheumatismo, as erysipelas, e para curar as feridas do utero, e as demais feridas, ainda que sejam chronicas.

Batonica ou , Datonica. (Betonica trusiliensis.)(Alagoas, Pernambuco, Sergipe e Bahia.)-E' arbusto mui vulgar, e aromatico. Folga nos telrenos seccos, como os dos sertōes, e particularmente ao pé das pederneiras.

USOS MEDICINAES

Dizem os sertanejos, que a batonica, é optimo diaphoretico, 
para os rheumaticos, e singular remedio, para desfazer tumores quentes, on inflammatorios, leito cozimento da raiz, e tomado em forma, de chá, e em banhos. Cura a hydropesia, e faz vir as regras ás mulheres, tomado em cozimanto, ou em fórma de chá.

Baunihha. (Vanitha aromatica.) - E' uma planta trepadeira bem conhecida, que produz em todo o terreno, e mesmo dentro das mattas. Suas folhas são carnudas e compridas, podendo esta planta ser cultivada entre iós, e dar grandes interesses. Os sertanejos ignoram os prestimos da baunilha, e por isso deixam perder tão excellente producto natural.

USOS MEDICINAES

E' excellente, aphrodiziaco, faz vir os menstruos ás mulheres, e promove as ourinas.

USO NAS ARTES

Por seu aroma agrádavel, entra na confecção do chocolate.

Bauniha de lioorizoiro. (Baunitha palmarum.) -Esta parasita nasce sobre os licorizeiros, e vive á custa de sua seiva. Dí fructo, e tem pouco aroma.

USOS MEDICINAES

As folhas do cipó, pisadas, é especial remedio, para curar as pannos do rosto, e do corpo, empigeas e brotoejas.

Baxiuba ou conueiro do matto. (Sriartea ven(ricosa.) - Esta planta é da familia de palmaceas. O fructo que dá, é comestivel.

\section{USOS MEDICINAES}

Não s̃̃o conhecidos.

LSOS NAS ARTES

Serve para ripas de casas.

Baiucurír.-Esta planta vegeta no Rio Grande do Sul. vsos MEDICINAES

O seu bolbo passa entre us campoaios do Rio Grande do Sul, como remedio especifico, para curar as hydrupezias.

Beijo do matto. (Phaseolus rubrus. Alagòas)-E' planta 
trepadeira e fructifera, sendo as flores mui rubras, e as fructas semelhantes ao feijão, porém finissimas.

\section{USOS MEDICINAES}

Não tenho noticia das suas virtudes, em medicina domestica.

Beijo de moẹa. (Cosmos bipinatus.) - E' planta de jardim, natural do Mexico. As flores são formosas.

\section{USOS MEDICINAES}

Tomada em chá, é proveitosa na ictericia e desobstruente do figado.

Beijoim. (Laums Bensoin.)-Arvore, que se encontra nos sertões do Brasil, pertencente á familia das Styracaceas.

\section{USOS MEDICINAES}

o Beijoim serve, para curativo da bronchite, asthma, e na iraqueza dos orgãos digestivos. Entra na composição do balsamo catholico, do leite virginal, que serve para tirar as sardas, e manchas da pelle.

Beldroega. (Portulacca olerccea.)-E' uma planta conhecida de todos, floresce, fructifica e nasce espontaneamente $\mathrm{em}$ logares humidos.

\section{USOS MEIICINAES}

As folhas d'esta planta, postas sobre feridas de mau caracter as limpam, e as dispoem para a facil cicatrização. 0 cozimento da planta toda, é diuretico, e favorece a secreção do leite ás amas, que criam. O succo da beldroega serve, para curar a inflammação dos olhos, e as sementes s̃̃o contra os vermes intestinaes.

\section{USOS DOMESTICOS}

Com a beldroega fazem salada, e differentes guizados, mui apreciarlos nas familias.

Belota da follua docoiada. (Liatris inciza.) Planta ronhecirla nas Alagòas, por suas lindas flores.

\section{USOS MEDICINAES}

Não são conhecidos. 
Bem-me-quer. (Calendula officinalis.)-E' planta rasteira, e conhecida.

\section{USOS MEDICINAES}

o seu uso domestico, é em chá, nas enfermidades nervosas, e hystericas das mulheres.

Bengão de Deus. (Abutilon esculentum.) - Este sub arbusto, conhecido nas provincias do sul do Brasil, foi descripto pelo nosso celebre botanico, frei José Mariano da Conceição Velloso, e por Mr. St. Hilaire,

\section{USOS MEDICINAES}

Não são conhecidos.

Bengala. (Silva Lisboa.)-Arvore de 50 palmos de altura, e de dous de diametro.

Floresce em Setembro.

\section{USOS MEDICINAES}

Não são conhecidos.

\section{USOS NAS ARTES}

Serve para molduras, e obras de marchetaria, porque o seu lenho é de côres variadas.

Benjoim. (Styrix benjoim.)-E' arvore asiatica, e que tambem vegeta nos sertões do Brasil; floresce e fructifica. As flores são amarellas, e o fructo é uma baga. O balsamo que corre por incisão da arvore é branco, e posto em contacto com o ar se congela, e se solidifica, com a có $\hat{L}^{\circ}$ escura. O benjoim que os derrubadores extrahem, como é mal preparado, não tem o mesmo preço no mercado, que o importado do estrangeiro, e isto devido á nenhuma industria, que ha no Brasil.

\section{USOS MEDICINAES}

Emprega-se o benjoim no curativo das bronchites, na asthma, .na fraqueza do estomago, e intestinos Entra na composição do balsamo catholico, muito procurado do povo, para curar as contusões, os golpes. etc.

\section{USOS NAS ARTES}

o benjoim entra na composição do leite virginal, com a 
qual as senhoras lavam o rosto, para aformosear a pelle, desvanecer as sardas, e manchas do rosto.

Boque cheiroso. (Piper aromatico.)-E' planta indigena, e conhecida em Pernambuco, e Alagòas, por seu aroma suave.

\section{USOS MEDICINAES}

E" empregado, em cozimento, para combater o rheumatismo, dado em banhos.

Bergamota. (Citrus limetta.)-Arvore espinhosa, e de tolhas grandes, sustentadas por longos pecciolos. A casca do fructo tem um oleo essencial e suave, proprio para a perfumaria.

Bergamota de jardim. (Limetta vulgaris.)-Planta conhecida, e serve de ornamento de jardim.

Bertalha. (Baselta rubra.)-E' planta trepadeira, exotica, trazida do Malabar, para o Brasil, com folhas succulentas, e fructo roxo.

\section{USOS MEDICINAES}

O cozimẹıto da raiz, é emoliente e refrigerante.

usos CULINARIOS

As folhas são comestiveis, e com ellas se fazem diversos guizados.

Bote. (Bitte vulgaris.) - Arbusto aromatico, que folga em qualquer terreno. As folhas machucadas, exhalam um cheiro semelhante ao da noz moscada.

\section{LSOS MEDICINAES}

Os sertanejos encarecem os prestimos d'esta planta, no curativo do rheumatismo, feito em banhos.

o cozimento, misturado com clara de ovo, é excellente remedio, para as hemorrhoidas, dado em clyster. o cozimento, adocado com a calda de assucar, é poderoso medicamento, para curar as gonorrhéas, tomando tres vezes ao dia.

Betys. (Pipei encalyptifolium.)-E' planta do Pará. 
USOS MEDICINAES

o cozimento d'este arbusto, é contra as colicas flatulentas.

Bicolbossú. (Silva Lisboa.)-Arvore de 30 e mais palmos de altura, e de dous á quatro de diametro; floresce em Setembro.

\section{usos Medicinaes}

Não são conhecidos.

\section{USOS NAS ARTES}

0 seu lenho serve para a carpintaria.

Bicuiba branca. (Silva Lisboa.)- Arvore de 80 palmos de altura, com dous á tres de diametro. Floresce em Setembro.

\section{USOS MEDICINAES}

Não são conhecidos.

USOS NAS ARTES

A madeira é molle, e macia no lavrar e serrar, e serve para o fabrico de caixões.

Bicuiba vermelha. (Miristica officinalis.)-E' arvore das mesmas dimensões, e só diversifica no fructo, de cuja amendoa se extrahe a manteiga, ou balsamo conhecido, por oleo de bicuiba.

USOS MEDICINAES

A manteiga ou oleo de bicuiba, é empregado em fricções, nas molestias da pelle, nas erysipelas, nas houbas, nas feridas frescas, nas feridas causadas por bichos dos pés, no cancro, nas dóres uterinas, obstrucção do baço, nas dores nervosas.

Internamente, o cozimento feito com as amendoas, tomado ligeiramente adoçado com assucar bom, é excellente remedio, para confortar o estomago debilitado, nas ventosidades, cansaço ou fadiga de caminho; cura o mau halito da boca, dores no ventre, procedidas de resfriamento; conforta o cerebro, e ajuda a memoria; uma ou mesmo duas fructas comidas, tira o mau halito da bocca, e aclara a vista. A fructa comida. na quantidade de duas onças, é venenosa. 
USOS NAS ARTES

A madeira é branca, e empregada em vigamento e assoalho. 0 oleo serve tambem, para a fabricação de velas, e para a luz da candeia.

Bilimai ou carambola. (Averrhoa bilimbi)-E' planta oriunda da Asia, e aclimatada no Brasil.

\section{USOS MEDICINAES}

A fruta é refrigerante, usada em limonadas, nas febres ardentes.

\section{USOS NAS ARTES}

Serve para tirar as nodoas da roupa, na arte de tinturaria.

Bilros. (Cartoleta speciota.) - Diz o pharmaceutico Almeida Pinto, que esta planta dos nossos sertões, foi classificada pelo distincto naturalista. Dr. Arruda da Camara, e que o bolbo que produz, se come no sertão. Eu não conheço este vegetal, por isso o não descrevo.

Biriba.-E' arvore de 50 a 100 palmos de altura, e de amago preto, durissimo; é a pederneira dos indios, com a qual por meío do atrito, obtêm fogo.

Floresce ern Outubro, em ramos de flores cheirosas.

\section{USOS MEDICINAES}

Não são conhecidos.

\section{USOS NAS ARTES E NA INDUSTRIA}

Serve para mastros de navios, e para taboado de forro das embarcações. O taboado de biriba, é o menos atacado pelos guzanos, e por isso é a madeira mais estimada, para forrar os navios. Serve para esteios de casas, pela rijeza do seu lenho.

Da casca da biriba, se extrahe boa estopa, para o calafeto dos navios, e tem o nome de estopa da terra.

Boas noites. (Vinca rosea.)-Esta planta dos jardins, é oriunda de Malabar e de Madagascar, trazida para o Brasil, pelos navegantes: nasce por toda a parte.

\section{USOS MEDICINAES}

o cozimento serve para dóres de dentes. 
Bocaiuva. (Palma bocaiuva.)-E' uma palmeira de S. Paulo, semelhante á macaúba da Bahia.

\section{USOS MEDICINAES}

As amendoas são emulsivas, a polpa é comestivel.

USUS NAS ARTES E NA INDUSTRIA

Se extrahe oleo, que serve para luz, e mesmo para diversos usos culinarios. O palmito da bocainva, sendo guizado, fórma um prato apreciado nas mesas de familia.

Bogaxi. (Jasminium 'sambax.) - E' planta muito vulgar, oriunda da India, e aclimatada no Brasil. A sua flor é branca. e de cheiro suavissimo e mimoso.

E' o ornamento dos jardins.

\section{USOS MEDICINAES}

o cozimento da raiz do bogari, é empregado para curar a ictericia.

Boi gordo. (Cassia rugosa.)-Esta planta, é conhecida em Minas Geraes.

USOS MEDICINAES

o cozimento é empregado no curativo das tosses, defluxoes, e nas erysipelas.

Bom nome verdadeiro. (Elceodendron cauliflorum.)-Arvore conhecida por este nome nas Alagôas, e Pernambuco.

\section{USOS MEDICINAES}

Não são conhecidas.

USO NAS ARTES

o seu lenho serve, para differentes usos de construcção civil.

Bonina, (Nyctago hortensis.) - E' planta americana, oriunda do Perú, do Mexico e da India. Em Pernambuco, Alagóas e Bahia chama-se Bonina, no Maranhão e Pará, chamam-na de Boas noites; no Rio de Janeiro, S. Paulo e Minas, chamam-na de Maravilha.

Ha tres qualidades de bonina: branca, vermelha e amarella. 


\section{USOS MEDICINAES}

As folhas infundidas em vinho, é presentaneo remedio, para vir a menstruação ás mulheres.

o sumo das folhas, aplaca as dores de dentes; e faz deitar as secundinas, tomando clyster, sendo feito das follıas da bonina branca.

O sumo das folhas, posto no rosto, desfaz as sardas; e as sementes pisadas, misturadas em oleo de ricino, servem para tirar as nodoas da pelle do rosto.

A raiz da bonina é purgativa.

Borboleta.-E' a flor de uma planta. que vegeta nas Alagòas e Pernambuco, sendo uma de corr amarella, e a outra branca.

USOS MEDICINAES

Não são conhecidos.

Bordão de vellio. (Mimosa vaga.)-E' arvore de mediana grandeza, e mui conhecida nas Alagòas, e Pernambuco, porque o seu tronco é cascudo, em fórma de grandes escamas esponjosas, que com o tempo abrem, e reapparecem outras, sendo o seu- fructo uma vagem chata, contendo sementes, como as do feijão. A madeira d'esta arvore é branca, e mui fraca.

\section{USOS MEDICINAES}

Não são conhecidos.

\section{USOS NA INDUSTRIA}

A planta queimada dá boa lexivia, para o fabrico do sabão.

Bordāosinho (em Sergipe d'El-rei), sumauma (nas Alagòas e Pernambuco*) - E' o bordãosinho, uma planta trepadeira, e leitosa.

\section{USOS MEDICINAES}

Não são conhecidos.

USOS NA INDUSTRIA

Dá fructo, e dentro contém um felpo branco, muito macio, com que se enchem travesseiros, colchı̃es e outros objectos de uso domestico. 
Bororé.-E' o succo, ou massa venenosa, que se suppõe, extrahida de um strichnos com que os indios envenenam as suas armas de guerra. Dizem outros, que o bororé tambem é extrahido das raizes de certas plantas, dos lagos e pantanos.

A preparação do bororé é mui perigosa, e por isso, só a confiam aos cuidados de uma velha india, muito experimentada na sua fabricação.

\section{USOS MEDICINAES}

Merart e De Lens, que fallam d'elle, com muita autoridade dizem que em pequena dóse é estomatico, em consequencia do amargo que contem. Dizem mais, que o bororé obra na organisação como veneno narcotico acre.

Borracha ou gomma elastica ou soringa. (Siphonia elastica.)-No Brasil a gomma elastica, podia-se extrahir de um grande numero de vegetaes, se n'elle houvesse industria, e patriotismo. No Pará, a gomma elastica se extrahe do vegetal, a que chamam siringueira.

USOS MEDICINAES

E' um excellente medicamento, para consolidar as hernias. (Veja-se a obra Commissão do Madeira pelo Conego Bernardino de Souza).

USOS NAS ARTES E NA INDUSTRIA

A industria americana e européa, tem se servido da gomma elastica, para differentes objectos, porque ella se presta, para o que se deseja.

Borragen. (Echium plantaginum.)-Esta planta hortense, é mui conhecida. A sua constituição physiologica, é de natureza quente.

USOS MEDICINAES

Adoça a acrimonia do sangue, e dos outros humòres do corpo, corrigindo os saes; laxa o ventre, e suas flores são cordiaes e sudorificas.

Box'y. - E' uma especie de palmeira, de 25 palmos de altura, pouco mais ou menos. 
USOS NAS ARTES

Serve para ripas de casas.

Botanica.-E' a sciencia, que tem por objecto, o conhecimento dos vegetaes, suas funcções, seus caracteres, suas differenças, e sua classificação methodica. (Vid. Phytographia.)

A Botanica estuda:

1. Anatomia vegetal, ou sciencia da structura intima dos vegetaes.

$2 .^{\circ}$ A Organographia vegetal, ou a descripção dos orgãos exteriores dos vegetaes.

3. A Physiologia vegetal, ou o conhecimento das leis, que regem a vida dos vegetaes.

4. A Toxonomia vegetal, ou a classificação dos vegetaes.

5. A Botanica descriptiva, ou a descripção dos vegetaes, que nascem, crescem e vivem, sobre a face da terra.

6. A Geographia Botanica, ou as leis da distribuição dos vegetaes, na superficie do globo.

7. A Botanica applicada, quer a agricultura, a medicina, e quer a industria, ou Botanica agricola, medica, e industrial.

o vegetal é um ser organico, dotado de vida e crescimento, fixo ao solo, que se nutre e desenvolve de elementos inorganicos, extrahidos da terra, e do ar atmospherico, por meio das raizes, e das folhas. O vegetal nutre-se, e respira. A nutrição se effectua com a seiva, que experimenta modificações nas nervuras das folhas, analogas ás que experimenta o sangue nos pulmões, pela influencia do ar atmospherico, que lhe communica as propriedades nutritivas.

A planta inspira pelas partes coloradas, durante a noite, o oxygenio do ar; e expira ou exhala o acido carbonico.

Pelas partes verdes durante a noite, absorve o oxygenio do ar, e exhala o acido carbonico.

Durante o dia decompõe o acido carbonico, e exhala o oxygenio, conservando em si o carbono. Este acido carbonico, o extrahe do ar atmospherico, das raizes e da combinação do oxygenio absorvido durante a noite, e a electricidade com o carbono da planta.

A agua, e a luz produzem as cores e as propriedades dos vegetaes. 
Braco do proguiga. (Solanum cernum.)-E' planta trepadeira, que nasce nas provincias do sul do Brasil.

\section{USOS MEDICINAES}

E' sudorifica e diuretica, empregada em cozimento. As molestias em que empregam esta planta, são a sarna, a syphilis, e a gonorrhéa. Externamente servem-se d'ella, para lavar as ulceras de mau caracter.

Brasilête. (Silva Lisboa.)-E' arvore de 60 palmos, com 1 á 2 de diametro. Floresce em Outubro.

USOS MEDICINAES

Não são conhecidos.

USO NAS ARTES

Serve para obras de marchetaria, e de ornatos.

Brauna.-Arvore corpulenta das nossas florestas, e mui conhecida dos derrubadores. O seu lenho è precioso, para as obras de construcção.

\section{LSOS MEDICINAES}

Não são conhecidos.

\section{USOS NAS ARTES E NA INDUSTRIA}

Serve para as obras de carpintaria, e para as construcçôes navaes.

Possue este vegetal internamente um liquido, que é a mais lina, negra, e lustrosa tinta de escrever, que se possa desejar.

Brèdo. (Amaranthus virudis.)-E' planta vulgar. e se conhece varias qualidades de brêdos.

\section{USOS MEDICINAES}

0 cozimento da raiz do brêdo, adoçado com o mel de abeIha Jitahy, empregam os curiosos, no curativo das hydropesias, e principalmente na anazarca, e nas inflammações do figado.

USOS CULINARIOS

Com o brêdo, fazem diversos guizados, mui apreciados entre as familias brasileiras. 
Brijauba. (Astrocarium Ayri.)-E' uma palmeira conhecida por coqueiro ayri, que vegeta na Bahia, cujos fructos não são aproveitados, pela incuria, ou pela ignorancia.

\section{USOS MEDICINAES}

Não são conhecidos.

\section{USOS NAS ARTES E NA INDUSTRIA}

Se tivessemos industria, se obteria d'esta prestimosa e excellente palmeira sebo vegetal, que se empregaria em diversos usos.

Brincos de sahoim. (Pitheculobium avaremotemo.)Arvore das nossas fiorestas. E' conhecida dos derrubadores.

\section{USOS MEDICINAES}

Tem os mesmos prestimos, que o angico.

Bringella. (Solanum melongena.)-Esta planta è natural do America meridional, mui conhecida, e cultivada nas hortas.

USOS MEDICINAES

F' diuretica, e faz expellir as areias da bexiga.

\section{USOS CULINARIOS}

Com o fructo fazem-se diversos guizados

Brio de estudante ou barba de barata. -Planta vulgar brasileira.

\section{USOS MEDICINAES}

o cozimento d'esta planta, é empregado no curativo da inflanmação da garganta, e nas dôres de dentes.

Broma branca ou matta canna. (Verbascum) -Esta planta rasteira, nas Alagôas, é conhecida pelo nome de broma, e em Pernambuco, pela denominação de matta canna; é mui delicada, e as suas flores são brancas. Ha outra especie, que é roxa.

\section{USOS MEDICIN AES}

o pharmaceutico Almeida Pinto, assevera, ser este vegetal poderoso emetico e drastico, e tambem emenagoga.

Bucha. (Luffa purgans.)-Esta planta, é uma especie de 
cabacinha, e o seu extracto, diz Almeida Pinto, póds substituir - da coloquintida.

\section{USOS MEDICINAES}

O seu uso é nas hydropesias, e inflammações de olhos: é purgativa e vomitiva.

Bucha dos paulistas, bucha do cagador ou cabacinha. (Momardica operculata.) - 0 tecido do fructo - celluloso, e tem sementes.

Os camponezes servem-se d'este fructo, em medicina domestica, regulando as forças do enfermo, e para o que, partem o fructo em duas, ou quatro partes, e pondo-o em infusão em agua fria, ou quente, por 12 horas, depois de tirada a banha do liquido, agita-se ou bate-se-o com uma coller, até formar espuma, e depois côa-se, e se vai dando gradualmente ás colheres ao enfermo, até apparecerem vumitos, ou evacuar.

0 extracto usa-se na dóse de 15 centigrammmas.

\section{USOS MEDICINAES}

E' a bucha de paulista, um poderoso medicamento, para curar as hydropesias, a cachexia, as febres perniciosas.

Ella move as ourinas.

Bucho de veado. (Amaioua cryptocarpa.)-E' arvore das mattas das Alagôas, pertencente á familia das Rubiaceas.

\section{USOS NAS ARTES}

Serve para a carpinteria.

Bugio ou rabo de bugio. (Combrettum bugio.)E' planta trepadeira, muito conhecida nas Alagōas.

Floresce, e dá fructo. As flores em cacho, são mui cheirosas. 0 fructo é semelhante a uma azeitona pequena.

\section{USOS MEDICINAES}

E' um poderoso anti-syphilitico, e particularmente empregada para curar a sarna, e as molestias chronicas da pelle.

Burarema.-Arvore trondosa das nossas florestas.

\section{USOS MEDICINARS}

Não são conhecidos. 


\section{USOS NAS ARTES}

o seu lenho serve, para construcção civil e naval.

Buranhem ou guranhem. (Chrysophyllum buranhem.)-E' arvore, que folga em qualquer terreno. 0 seu entrecasco é doce, e produz os effeitos do alcaçuz.

\section{USOS MEDICINAES.}

E' muito proveitoso o seu extracto, nas molestias do peito, na asthma, nas hemoptyses. nas diarrhèas, nas blenorrhagias, e externamente serve, para curar as ulceras.

USOS NAS ARTES

Serve seu lenho, para carpintaria.

Buranhem macho. (Silva Lisboa.)-Arvore de 60 palmos de altura, com 2 á 3 de diametro. Floresce em Outubro. A sua madeira é macia no serrar e lavrar.

USOS MEDICINAES

Não são conhecidos.

\section{USOS NAS ARTES}

Serve, para varaes de sege, pela sua elasticidade, e para a carpintaria.

Bu uy. (Mauritia vinifera.)-E' uma palmeira brasileira muito alta, conhecida nas Alagôas e Pernambuco, pelo nome de burity, e na Buhia pelo de bury. O fructo é comestivel, e abunda em todas as provincias do norte. o burity tem muitos prestimos.

\section{USOS NA INDUSTRIA}

A industria pule extrahir d'esta palmeira, precioso vinho.

Burra loiteira.-E' um vegetal da familia das euphorbiaceas, que nasce na ilha de Fernando de Noronha.

Conta o pharmaceatico Almeida Pinto, que esta planta é de tal natureza, que quem s? aproxima d'ella, queima-se a tal ponto, que as partes offendidas, nunca mais criam cabello. Uma gotta da seiva basta, para fazer uma ferida semclhante á de fogo. Que, nem a madeira serve para o fogo, porque a fumaça ataca a vista.

Se se estudasse esta planta convenientemente, é bem pro- 
vavel, que a medicina, acharia n'ella proveitoso recurso, para algumas enfermidades.

Butua. (Coculus cineracens.)-E' planta conhecida em todo - Brasil. Ha outras variedades, e com applicações medicas.

USOS MEDICINAES

A sua raiz é desobstruente, diuretica, e faz vir o menstruo ás mulheres. O cozimento feito com raiz, o dão aos hydropicos, ás mulheres, que têm os lochios supprimidos, e ás que padecem de dores uterinas depois do parto.

\section{C}

Caa-assúr. (Malpighia rosea.)-Panta indigena do paiz.

USOS NAS ARTES

Esta planta brasileira, não tem emprego em medicina vulgar, mas no norte do Brasil, os pescadores servem-se d'ella, para tingir as redes de pescar.

Caa-átava. (Vandellia diffusa.)-E' planta da familia das scrophularias

\section{USOS MEDICINAES}

Usam os camponezes d'esta planta, para combater as inflammações do figado, e febres intermittentes. Ella é amarga, purgativa e diuretica.

Caa-cica. (Euphorbia pilulifera.) - E' planta herbacea, e conhecida nas provincias do norte.

Usos Medicinaes

Dizem, que esta planta, é um. poderoso neutralisante do veneno das cobras, e particularmente do da vibora, pisada e applicada sobre a ferida.

Caa-chira. (Oldenlandia coryinbosa.)-Planta da familia das rubiaceas.

\section{USOS MEDICINAES}

Não são conhecidos. 
USOS NA INDUSTRIA

Usam d'esta planta em tinturaria.

Caá-enguia (nome indigena,) Pará.-Essta planta, conhecida pelo Dr. Lacerda, vive nas lagôas e alagadiços. O nome de Caa-enguia the deram, porque as enguias, ou estão sobre ella, ou junto d'ella.

\section{USOS MEDICINAES}

Servem-se das folhas d'esta planta, para curar as feridas e chagas, provenientes de queimaduras, empregando-se o sumo da folha, estendido sobre a parte, ou mesmo a folha reduzida a pó.

Caa-membeca. (Polygata paraensis.)-Este arbusto, regeta no Pará, e é conhecido por todos.

LSOS MEDICINAES

o seu emprego medico, é para combater as hemorrhoidas, tomando-se em infusão.

Caapeba ou pariparoba. (Cissampelos caapeba)Esta planta mui conhecida, vegeta em logares humidos, e sombriados.

\section{USOS MEDICINAES}

E' um grande desobstruente do tigado. Usam externamente em cataplasma, sobre a região do figado; e internamente, empregam a raiz em cozimento, adoçado com assucar bom, ou mel de abelhas, tomando-se uma chicara pela manhan, e à noite. E' diuretica, e promove a transpiração insensivel. O sumo da caapeba com vinagre e sal, dizem ser admiravel remedio, para curar as contusões; e bebido o sumo, com algumas gottas de vinagre, estanca o sangue pela boca. O cozimento feito com as folhas e raizes, e feito lambedor, cura as tosses rebeldes. (Vide pariparoba.)

Caaropmogoxandigba. (Dos indios.)-Suppõe-se ser esta arvore, a propria Cnina, (Quina,) porque os indios servem-se della, para curar as febres, e o virus syphilitico.

Cabaeo amargoso ou cabayo de cuia. cabago marimba.-E' este vegetal, originario do Brasil, e mui conhecido. 


\section{USOS MEDICINAES}

Os indios usam das folhas d'esta planta, applicando-as sobre o ventre, e cadeiras das mulheres, para provocar o parto, e expulsar as secundinas. Em consequencia do miolo da fructa ser muito acre, irritante, e mesmo corrusivo, fazem d'elle cozımento, e dão-no en clysteres purgativos, para curar as obstrusçoes, e as chloroses.

Disse-me o meu collega, conego M. J. de Siqueira Mendes, em conversa na camara dos deputados, que curou um seu escravo, no Pará, de uma hydropesia escrôtal (hydrucele,) com a fructa do cabaceiro, do modo seguinte:

* Mandou pòr uma fructa verde, ao rescaldo, e quando ella muito quente, abriu-a, e tirou parte do miolo, em quantidade de ser preenchida pelo volume do testiculo hydropico, e, ainda a fructa quente, em estado do enfermo poder supportar o calor, metteu o escrôto dentro, atou-o, e assim ficou, até que a fructa esfriou de todo. Depois tirou a fructa da parte, e nos dias seguintes, fazendo a mesma applicação, conseguiu curar perfeitamente, sem operaçio, o hydrocele do seu escravo. "

Disse-me mais, que durante este processo, mandava dar um banho de assento as doente, com o cozimento das folhas do cabaceiro.

LSOS NA INDUSTRIA

Serrada a fructa madura, fazem cuias, e outras cousas, para os usos domesticos.

Cabaro raston.o. ou yambí. oll cabaci-

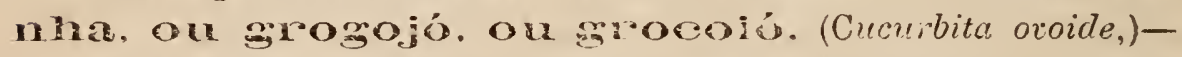
E' planta muito conhecida nas Alagòas e Pernambuco, sendo a tructa bonita, e í semelhança de um ovo de gallinha.

\section{USOS MEDICINAES}

E' desobstruente, e a medicina vulgar, emprega o miolo da fructa, e mesmo as follhas em clysteres, para curar as hydropesias. E' um purgante mui drastico, e violento.

USOS NA INDUSTRIA

Propriedade singular do cabacinho, para cmpietar os cabellos biancos

o cabacinho tem a propriedade de empretecer os cabellos 
brancos, sem causar damno algum, ao casco da cabeça. Corta-se a extremidade da fructa, por onde estava pegada a planta, e tira-se uma parte da massa, e se enche com azeite doce; põe-se a assar ao borralho, por quasi uma hora, e depois de esfriar, se untará os cabellos, que os empretece logo.

\section{USOS MEDICINAES DO OLEO DO CABACINHO}

- Embebido em algodão o oleo do Cabacinho ou Grogojo, se cura a dor de ouvidos e a surdez; untado pelo carpo, cura a lepra. A massa ou miolo do cabacinho mal assada, posta sobre a hernia, e comprimida pela funda, cura este mal.

Cabega de fradie. (Villaria Nymphooides.)-Planta trepadeira, que não tem folhas, mas o seu fruto é dividido em talhadas, e sobre ellas, rosas de espinhos, como alfinetes grandes, semelhando uma coròa, como de velludo purpurino.

USOS MEDICINAES

Descascada a fructa, apparece um miolo, de que se faz doce mui saboroso, que se póde dar aos doentes.

o miolo bem ralado, ou bem moido, dá uma gomma, ou polvilho, de que se faz escolhido refrigerante.

Cabega de negro ou de moleque.-E' planta trepadeira, e mui abundante no interior do Brasil, e n'elle geralmente conhecida.

\section{USOS MEDICINAES}

Da raiz se extrahe uma fecula amargosa, de que se servem os sertanejos, para purgar os humores. E' um drastico forte, na lóse de uma colher de sopa, pela manhã. Usam d'esta preciosa planta, cumo anti-syphilitica, anti-scorbutica, para combater as diarrhéas chronicas, e mesmo, para curar as febres continuas. E' facto averiguado, que durante a invasão do cholera, ninzuem, que usou no sertĩo da Cabeça de negro, morreu d'esse mal.

Cabello de negro. (Eritroxylon campestre.)-E' um arbusto de Minas Geraes, empregado em medicina domestica.

\section{USOS MEDICINAES}

Empregam esta planta, como purgativa. 
Cajo de, facto on lo macinaclo. (Myricaria brasilicnsis.)-E' arvore conhecida nas Alagòas, de lenho mui rijo.

\section{USOS MEDICINAES}

Não são conhecidos.

USOS NAS ARTES

A madeira é de muita duração, e por isso empregada na marceneria. E' com o Jenho d'esta arvore, que os trabalhadorés fazem os cabos de machado, fouces, etc.

Caboatan. (Cupania vienalis.) - E' um vegetal das capoeiras das Alagoas.

USOS MEDICINAES

E' um poderoso medicamento, para combater a tosse convulsa, e a asthma, tomando-se o cozimento da casca ou mesmo da raiz, com, ou sem assucar.

Caboatan do Ieito, (Mauria lactifera.)-E' um vegetal leitoso, e conhecido nas Alagôas.,

\section{USOS MEDICINAES}

o cosimento das folhas, serve para banhos contra o rheuma tismo.

Cabureigba on Balsamo do Espirito Santo. (Myrocarpus fastigiatus.)-E' arvore balsamica, e da qual se extrahe, por meio de incisão um balsamo, aromatico, descripto pelo nosso douto naturalista Freire Allemão.

USOS MEDICINAES

Este balsamo serve, para cicatrizar as feridas recentes, e mesmo as ulceras chronicas, possuindo a singular particularidade, de não deixar o signal da cicatriz.

USOS NAS ARTES

A madeira é rija, e serve para construcção.

Cagará ou biodozinho das calgadas. (Sanguinaria.)-Planta rasteira de folhas miudas, e quasi redondas, que nasce nos intersticios das calçadas das ruas, e por isso é conhecida pelo nome de herva das calçadas. Abunda nas calçadas da cidade do Rio de Janeiro. 


\section{USOS MEDICINAES}

Em medicina vulgar, é empregada esta planta em cozimento, para combater as tosses rebeldes, e para curar as enfermidades da pelle. O succo da planta, desfeito em agua assucarada, é um polleroso remedio, para estancar as hemorrhagias de sangue, pela bocca.

Cacio. (Theobroma cacio.)-E' arvore indigena do Brasil, de grandeza regular, e vegeta facilmente nas provincias do norte. E' uma planta de grande prestimo.

\section{USOS MEDICINAES}

o cozimento da casca do cacrio, cura a dysenteria, e a semente torrada ao rescaldo, e comida, cura a azia. o oleo serve para mitigar as dores hemorrhoidaes.

\section{USOS CULINARIOS}

Com as sementes torradas, bem moidas, com baunilha, canella, e assucar, prepara-se excellente massa, com que se confecciona o chocolate. Faz-se com as sementes, saborosa geléa.

\section{USOS NAS ARTES E NA INDUSTRIA}

Faz-se vinagre, depois de fermentado, e posto em alambique dá boa aguardente.

As cinzas do cacaozeiro dá lexivia, para confecção do melbor sabão, para a lavagem da roupa.

Cachine, (Sapizm ilicifolizm.) - Arvore leitosa, brasileira da familia das Euphorbiareas, que floresce e fructifica.

$$
\text { USOS MEDICINAES }
$$

As amendoas são purgativas; e bastam sómente tres, para se obter um purgante sufficiente.

USOS NAS ARTES

O lenho da arvore serve para diversos misteres.

Cachinguba. - E' uma planta do Pará, usada pelo Dr. Lacerda,

\section{USOS MEDICINAES}

Empregam o leite d'esta planta, para matar as lombrigas da 
erianças, e combater as diarrhéas, dando-se uma colher de chá, - mesmo duas, podendo-se augmentar a quantidade, conforme o -ffeito. E' conveniente não se abusar, porque, em vez do bem, trará a morte ao enfermo.

Cactus. (Iramacurú on Iamaxacorú, (Pará.)-Esta planta, cortada verde, tem aroma brando, e proprio dos cactus, e aloes. A parte verde tem sabor agradavel.

USOS MEDICINAES

E' empregada contra a mordedura das cobras, nos catarrhos pulmonares, e nos tumores internos.

Caculucagse ou Quitòco. (Vid. Quitôco.)-E' planta mui conhecida nas provincias do norte do Brasil, e principalmente nas Alagôas e em Pernambuco.

USOS MEDICINAES

E' empregada com vantagem, como resolutiva dos tumores, earminativa, e anti-hysterica.

Caetano. (Silva Lisboa.)-E' arvore de 40 palmos de altura, e I de grossura. Floresce em Setembro.

USOS MEDICINAES

Não são conhecidos.

USOS NAS ARTES

E' empregado o lenho, na construcção das casas.

Cafezeiro. (Coffea arabica.)-o café é uma planta mui conhecida; e por isso a não descrevo.

Pelos annos de 1760, o chanceller João Alberto Castello Branco, vindo de Góa para o Rio de Janeiro, trouxe umas poucas de plantas de café, de que só chegaram quatro, capazes de vegetar: uma d'ellas conservou-se no quintal das casas, onde foi residir ; ${ }^{1}$ 2 outra deu para a cerca das freiras de Santa Thereza;

1 A casa, onde o chanceller Castello Branco residio, foi no sobrado, que existio, no principio da rua da Guarda Velha, e ficava no comeco da ladeira do convento de Santo Antonio, a qual foi demolida para se construir a typographia nacional.

Esse sobrado pertencia ás religiosas de Santa Thereza. 
outra, para a cerca dos frades barbadinhos italianos, estabelecidos na rua dos Barbonos, e a quarta, offereceu de presente a Mr. Hoppman, que residia no predio oitavado da chacara da rua de S. Christovão, e proxima á rua do Aterrado, hoje de Miguel de Frias.

Conforme um manuscripto que possuo, de lettra do chaneeller, depois ministro de estado Thomaz Antonio de Villanova Portugal, ce todos os pés de café offerecidos aos particulares, o unico que pegou, floresceu e fructificou, foi o plantado na cerca das freiras de Santa Thereza, que foi o progenitor de todo o café, da provincia do Rio de Janeiro, S. Paulo e Minas, etc.; não ha muitos annos. que ainda vivia esta planta preciosa, alli abandonada, como são abandonadas, entre nós, as cousas de merecimento real. Em outra parte, onde se estuda, e se aprecia as antiguidades nacionaes, que apreço se não daria ao cidadão das selvas, que produzio um dos principaes ramos da riqueza publica!

Alli viveu ignorado, e alli morreu, sem que ningnem fosse assistir, por gratidão, dos seus ultimos dias de vida!!!

Não se admire o leitor d'isto... O desembargador, depois capitão-mór, Dr. Antonio de Moraes e Silva, autor do melhor diccionario da lingua portugueza que temos, que nasceu no sobrado de dous andares, da rua do Ouvidor, do lado opposto e mais acima do Jornal do Commercio; o padre Dr. Antonio de Souz Caldas, famoso preta lyrico, e granùe orador sagrado, que nasceu na rua dos Pescadores, e falleceu'na rua do Sabão, na casa onde estere a secretaria da policia, e outros, ainda não tiveram seus nomes escriptos nas esquinas das ruas, onde vieram ao mundo, que, com os seus trabalhos, ennobreceram o seu paiz, emquanto que se tem apagado nomes historicos, e tradicionaes, para se iuscrever a perpetuidade de criminosos, e nomes irrisorios. Em tempo lá chegarei, na chrouica geral, e minuciosa do Imperio do Brasil, desde a descoberta do novo mundo até o anno de 1880, que estou imprimindo.

Não ha muito tempo, que se descobrio a planta do café, na provincia do Paraná, tendo a amendoa u mesmo gosto e aroma, que o café arahico. N'este nosso abençoado paiz, ha tudo; menos bom senso e patriotismo. 
Eu espero pelos homens do futuro; confio n'elles.

\section{USOS MEDICINAES}

o cozimento das folhas do café, dado em banhos, provoca os menstruos, e cura os resfriamentos, e misturado com folhas aromaticas, cura o rheumatismo; interuamente, a infusão do café torrado, é util nas debilidades do estomago, e farorece a digestão, accelerando a circulaçũo sanguinea. Alegra o espirito.

E' util nas colicas flautulentas, nas fraquezas produzidas pelo trabalho, e mesmo nos excessos dos prazeres venereos. E' um proveitoso remedio, dado aos bebados: allivia as dôres de ca* beça, e mitiga os accessos da asthma, e da tosse convulsa. E' proveitoso remedio para os catharros chronicos.

E' um poderoso antidoto, no envenenamento pelo opio.

Caforana. (Qunsia do Parci.)-E' um arbusto, nuito semelhante ao café, e abunda no Parú.

\section{LSOS MEDICINAES}

A raiz d'esta planta é empregada como especifico medicamento das febres intermittentes.

Cagaitoira. (Mystus dysinterica.)-Este arbusto é mui vulgar em Minas Geraes.

\section{USOS MEIICINAES}

Por sua propriedade adstringente, empregam-n'o, para combater as diarrhéas.

Cahapiciá. (Dr. Lacerda.)-Planta do Pará, muito amargosa, e de cheiro desagradavel.

\section{USOS MEDICINAES}

o seu cozimento, em banhos, serve para curar o rheumatismo.

Cảa-ivucá. (Lr. Lacerda.)-Planta que vegeta, na grande ilha de Narajó.

\section{USOS MENICLNAES}

Servem-se do cozimento da raiz, como diuretico e emenagogo.

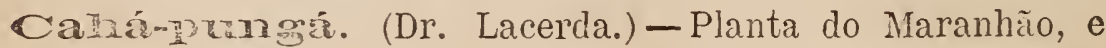
Pará. 
USOS MEDICINAES

As follas passadas ao fogo, e applicadas sobre as escrophulas, as resolve.

Cairca. (Chiococca angufuga.)-Planta indigena, mui parecida com a raiz preta.

\section{LSOS MEDICINAES}

Empregam a raiz, para curar a hydropesia, a apoplexia, a demencia, o rheumatismo, e a syphilis, e isto, em doses pequenas, porque provoca vomitos.

CaIté. (Canna aurantica.) -D'esta planta do Brasil, ha. varias especies.

\section{USOS MEDICINAES}

O seu cozimento, é empregado como calmante, e diuretico nas gonorrhéas.

Oaissara.-- Arbusto conhecido nas provincias do norte. USOS MEDICINAES

O succo das folhas e raizes, é empregado, como efficaz remedio, contra as mordeduras de cobra.

Caixeta. (Silva Lisboa.)-Arrore de 25 palmos de altura, e uin de grossura. Floresce em Agosto,

\section{USOS MEDICINAES}

Não são conhecidos.

\section{USOS NAS ARTES}

O seu lenho serve, para a fabricação de portas, e para forros de casas.

Cajaota.-Gabriel Soares diz, que ao longo do mar se criam umas folhas largas, que dão um fructo á que chamam Cajcota, que é da feição de maçaroca, e amarello por fóra; tem bom cheiro, a casca grossa e teza, a qual.se lança fóra, para se comer o miolo, que é muito doce, mas embola-se a bocca, a quem come muita fructa d'esta.

\section{USOS MEDICINAES}

Gabriel Soares nada memora a respeito de seus usos na medicina dos Indios. 
Cajapia.-Planta das nossas florestas.

\section{USOS MEDICINAES}

Dizem os sertanejos, ser esta planta o melhor antidoto do veneno das cobras. Servem-se da raiz moida, posta em agua, - dada a beber ao mordido. Os indios servem-se d'ella, para. curar as feridas de flexas embora envenenadas, e estão tĩo seguros de suas virtudes, que, bebendo a infusão da raiz do sajapiá, nenhum mal thes fará o veneno. Os sertanejos tambem empregam a raiz d'esta planta, para combater as febres de máo caracter.

Cajaty.-Arbusto de casca mui grossa, e regoada. 0 seu fructo, um pouco semelhante ao do jambo, é aromatico, e agradavel.

\section{LSOS MEDICINAES}

Não sĩo conhecidos.

Cajazeiro. (Sponaias lutéa.)-Arvore conhecida, pertencente á familia das anacardeaceas. Vegeta em qualquer terreno.

\section{USOS MEDICINAES}

o cozimento das folhas, aproveita em banhos, aos que têm frouxidão nos membros inferiores. A fructa é acida, e de um cheiro e sabor deliciosos, e por isso servem, para limonadas refrigerantes.

\section{USOS NAS ARTES E NA INDUSTRIA}

Os indios fabricam da fructa do cajazeiro delicioso vinho.

Como a casca do tronco d'esta arvore, é dividida em grandes e asperas crostas, os imaginarios servem-se d'ella, para differertes artefactos.

Na cidade de Santo Amaro, (provincia da Bahia), vi uma capellinha de inestimavel valor, cujo ornato interior, e imagens, feitos a canivete, era trabalho paciente de um curioso, e do qual me não recorda a memoria o nome, exclusivamente feito da casca do cajazeiro.

$\mathrm{Na}$ villa da Palmeira dos Indios, (Alagôas), Manoel Antonio de Oliveira MeIlo, fez uma typographia, que chegou a imprimir, pela perfeição das lettras, com a casca do cajazeiro. 
Cajueixo ou acajú. (Anacardium occidentalis.)-E' o cajueiro arvore de 20 a 25 palmos, com dous á tres de diametro, floresce em Julho e Agosto. Vegeta nos terrenos seccos, arenosos, pelas praias do littoral, e pelos taboleiros dos sertões ${ }^{\circ}$

As flores, em cachos, mui cheirosas, d'onde nascem os cajús, fructo delicioso e medicinal, que è apreciado geralmente por todos.

Na extremidade livre do fructo, existe a castanha, composta de uma casca grossa, embebida de um succo resinoso, caustico, e da amendoa, que, assada, é deliciosa, e serve para a confecção de varios bocados.

Ha cajueiros em tanta abundancia, nos longos taboleiros da Bahia, Sergipe, Alagòas, Pernambuco, e outras provincias, que poucas arvores existem, que não sejam cajueiros. Ha cajús de mais de palmo de comprido, e e lindissima cousa ver-se, um cajueiro ornado de seus fructos amarellos, ou todos avermelhados purpurinos.

\section{USOS MEDICINAES}

o sumo do cajú é diuretico, anti-syphilitico, e refrigerante. o uso continuo do sumo do cajú, cura as entermidades da pelle. o oleo da castanha, é um poderoso caustico.

\section{USOS NAS ARTES}

A madeira do cajueiro, serve para a marceneria, e para a construcção. O cajueiro distilla uma gomma-resina, que substitue a gomma arabica.

\section{USOS DOMESTICOS E NA INDUSTRIA}

Os indios fazem do sumo do cajú, excellente vinho, e nos sertôes fazem da amendoa da castanha verde (matury), saborosas frigideiras, para regalo das mesas. o doce do cajú, é mui apreciado, bem como o xarope feito coin o sumo, para limonadas refrigerantes.

Cajueiro bravo. (T'richospenum lichen.)-E' arvore de 40 palmos, e de 2 á 3 de grossura. Floresce em Outubro.

Não são conhecidos. 
USOS NAS AR'TES

O seu lenho serve, para frechaes, e vigotas.

Cajueiro vermelino.

USOS MEDIĆ́NAES

E' proveitoso medicamento externamente, para curar feridas frescas, e mesmo golpes profundos, que interessam os nervos.

Calumba beasiloira. (Simaba calumba.)-Planta da familia dos rutaceas, que vegeta nos sertões, e por outros logares.

USOS MEDICINAES

E' por seu amargo tonica e anti febril.

Calumbj or malicia do iponzona. (Mimosa.) -E' planta pequena, de folha miudissima, que fecha ao sol posto, e abre pela manhã. Ha duas qualidades de calumby; macho, e femea, ambos armados de espinhos.

LSOS MEDICINAES

O cozimento das folhas, dado em banho, serve para desinchar os membros inferiores.

Oalumga. (Sinaba fernginosa.)-E' arvore da familia das leguminosas.

\section{USOS MEDICINAES}

A casca d'esta arvore, é empregada internamente, contra a hydropesia, e fraqueza do estomago; e em clysteres, aproveita no prolapso do recto.

Camasari. (Caraipa pyramidata.) - E' uma bella arvore das nossas florestas, e mui conhecida dos derrubadores.

LSOS MEDICINAES

Não são conhecidos.

USOS NAS ARTES

A sua madeira, é empregada para diversos usos de construcção civil, e naval.

USOS NA INDLSTRIA

A resina que distilla é combustivel, e dá boa luz. Esfregada nos pés, os preserva dos bichos. 
Camapú ou bato-tosta. (Phisallis edulis.)-E' planta conhecida, que vegeta em todas as provincias do Brasil.

USOS MEDICINAES

O seu cozimento serve, para combater a ictericia, tomando-se uma chicara pela manhã, e outra á noite, e ao mesmo tempo tomando-se banho, com o cozimento da mencionada planta. Tambem empregam o camapu, para curar a inflammação chronica do figado, e a anazarca,

O Dr. Lacerda, fazendo varias experiencias, diz ter colhido admiraveis resultados, nos padecimentos da bexiga ourinaria, nos ataques de asthma, e na tysica pulmonar. Preconisa esta planta, como um calmante poderoso, empregando-a como meio curativo da tristeza, e abatimento moral.

Campér-mairima.-Planta silvestrc conhecida dos hervanarios.

USOS MEDICINAES

Os sertanejos servem-se d'esta planta, nas molestias da bexiga, nas do utern, dos rins, e mesmo para combater as urethrites agudas, e chronicas.

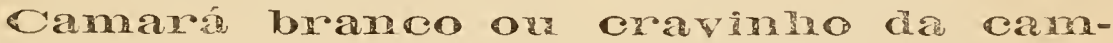
pina. (Bemanthum alternum).-E' planta conhecida nas provincias do norte, principalmente nas Alagòas, e mesmo nas do sul do Imperio.

LSOS MEDICINAES

O cozimento d'esta planta, é muito preconisado para curar sarnas, boubas, coceiras e empigens.

Camari de cheiro ote do nog popmeina. -E' planta mui conhecida nas Alagôas, Bahia e Pernambuco e ǹo Rio de Janeiro.

\section{USOS MEDICINAES}

O sumo das folhas, diluido em agua, serve para curar as fe. ridas dos olhos; pisadas e postas sobre os tumores é um poderoso maturativo.

Camará do capocira. (Verbena quadrilata.)-Nas Alagôas tambem chamam a esta planta mucamba. 
IISOS MEDICINAES

0 cozimento feito com esta planta dado a bəber, e em clyster, em pequena quantidade, cura os achaques do peito, com tendencia ao defluxo asthmatico.

Camará da matta.-Arvore de 20 palmos de altura, com um de diametro. Floresce em Setembro.

USOS MEDICINAES

Não são conhecidos.

\section{USOS NAS ARTES}

o lenho do camará é mui rijo, e por isso empregam-n'o em obras de torno, poliame miudo, e cavernas de embarcaçzes pequenas.

$$
\text { USO NA INDUSTRIA }
$$

Com a madeira fazem fachos para luz.

Camarana de Colna rolpuda.-E' planta, que vegeta no interior do Brasil.

\section{LSOS MEDICINAES}

Os sertanejos servem-se,do cozimento da raiz d'esta planta, nas retenções de ourinas, provenientes de gonorrhéa.

Camarátinga. (Lartana involucrata.)-E' um arbusto conhecido, da familia das verbenaceas.

\section{USOS MEDICINAES}

Dizem os indios, que o sumo das folhas d'esta planta, bebido com assucar branco, ou mel de abelhas, faz romper as vomicas, ou aposthemas internas. Cura as molostias dos pulmões.

Camassú.-Arrore que produz oleo, sem applicação na industria.

\section{USOS NAS ARTES}

O seu lenho serve para obras de construcção civil.

Camarambaia. (Iussia scabrósa.)

\section{USOS NA INDUSTRIA}

E' esta planta empregada na tinturaria.

Camassari.-Arvore de 80 palmos, e de dous á tres de grossura. Floresce em Setembro. (S. Lisboa.) 


\section{USOS MEDICINAES}

Não são conhecidos.

\section{USOS NAS ARTES E NA INUUSTRIA}

o tecido do seu lenho, é revesso no lavrar e serrar. Serve, para taboados de andaimes, soalhos de embarcações, para vigas, Prechaes e vergas de navios.

Esta arvore dá uma resina, que se não tem aproveitado, por falta de industria.

Cambota.-Arvore de mediana grandeza.

\section{USOS MEDICINAES}

O succo da raiz é amargo, e um poderoso antidoto do veneno das cobras, dado á beber, e ao mesmo tempo pondu-se a casca da raiz pisada sobre a ferida.

Cambuy. (Myrtus tinella.)-E' arvore mui conhecida nas Alagoas, Pernambuco e Sergipe, de 30 e mais palmos de altura. Floresce em Setembro. Ha tres diversidades, que dão fructos agradaveis, e de diversas cores, branco, negro e encarnado.

\section{USOS MEDICINAES}

Não são conhecidos.

\section{USOS NAS ARTES E NA INDUSTRIA}

A madeira serve para a fabricação de tamancos, e com os fructos fabricam excellente aguardente chamada de cambui.

Cambuca. (Eugenia edulis.)-E' o fructo de uma arvore dos sertres de Pernambuco, Rio de Janeiro e Minas Geraes, conhecida por cambucazeiro. 0 fructo nasce da propria casca da arvore, é redondo, amarello e mui agradavel á vista.

A polpa, que contém o fructo, é uma verdadeira geléa natural, assáz apreciada de todos.

\section{USOS MEDICINAES}

A polpa do cambucá, póde-se dar aos enfermos, sem o menor inconveniente, por ser um refrigerante innocente.

Campecino. (Hematoxylum campevhianum.)-Arvore dos sertzes mui conhecida, pertencente á familia das leguminosas. 
Creio que o campeche se confunde com a arvore conhecida pelo nome de Catinga de porco, ou, Tinta de sapateiro.

USOS MEDICINAES

Não tem sido empregado em medicina vulgar.

\section{USOS NA INDUSTRIA}

Do seu lenho se extrahe tinta vermelha ou roxa, conforme - reagente chimico que se emprega. Vid. Catinga de Porco.

Quando tivermos industria, a arvore campeche, será um ramo importante de riqueza publica.

Canuracani dos indios.-E' planta conhecida no interior do Brasil.

\section{USOS MEDICINAES}

E' empregada em fórma de chá, para curar as hydropesias.

Candeia. (Lychonophora.) - E' arvore dos agrestes, cujo lenho é de muita duração.

\section{USOS MEDICINAES}

Não são conhecidos.

USOS NAS ARTES E NA INDUSTRIA

Serve para a construcção de casas, para cercas, e para a fabricação de excellentes palitos. Os sertanejos servem-se d'ella para fachos.

Canella ou canelleira. (Laurus sinamomum.)Arvore transplantada da Asia para o Brasil, sendo as melhores, as que se cultivam em terrenos seccos.

\section{USOS MEDICINAES}

E' tonica, estimulante, empregada nas digestões tardias, nos vomitos nervosos, e para combater o resfriamento do estomago.

\section{USOS NA INDUSTRIA}

O oleo que se extrahe da canelleira, serve para a perfumaria. USOS DOMESTICOS

A canella serve para aromatisar os doces, e outras preparações alimenticias. 
Canoj1a. (Silva Lisboa.)-Arvore de 30 palmos de altura, e dous de grossura; floresce em Setembro. A madeira é macia no serrar e lavrar, apezar de pouco porosa.

\section{USOS MEDICINAES}

Como o lenho é aromatico, fazem cozimento d'elle, para curar o rheumatismo.

\section{USO NAS ARTES}

A canella é empregarla para obras de ornatos, e para assoatho de casas.

Canella do biejo.-Arvore 25 palmos de altura, e de um de diametro; floresce em Setembro.

\section{USOS MEDICINAES}

Não são conhecidos.

\section{USO NAS ARTES}

Serve para chumaceiras de carros, e para taboados.

Canolia-capitio.-Arvore de 40 palmos de altura, e de um á dous de grossura; floresce em Setembro.

\section{USOS NAS ARTES}

Serve para esteios, vigas e cabos de machado.

Ha outras arrores com a denominação de

Canella jacui, canella limão, canella silvestre, canella velha, canella batalha, canella branca, canella de cheiro, e canella de ema.Esta arvore, tem a madeira mui rija; floresce em Outubro, e tem prestimos medicinaes.

\section{USOS MEDICINAES}

As folhas cozidas, e dadas em banhos, servem para os que padecem de diarrhéa sanguinea. As folhas rèduzidas á pó, e tomadas internamente, curam as boubas, tendo-se o cuidado de pulverizal-as com o mesmo pó.

Cangabixa.-Arvore de 40 palmos de altura, e dous de diametro. Floresce em Setembro. 


\section{USOS MEDICINAES}

Não são conhecidos.

USOS NAS ARTES

Serve para esteios e frechaes de casas.

Cangorana. (Cangerano.) - Arvore de 50 palmos de altura, com dous de grossura; floresce em Setembro. E' o seu lenho pouco poroso, e macio ao serrar.

\section{USOS MEDICINAES}

Não são conhecidos.

LiSOS NAS ARTES

0 seu lenho serve para bolandeiras de engenhos, frechaes, e para as obras de embarcações.

Caninana. (Chicocca densifolia.)-Planta trepadeira, e mui conhecida.

\section{USOS MEDICINAES}

A raiz, de sabor amargo, acre, e de cheiro nauseoso, é estimulante, mui diuretica, e purgativo drastico.

E' empregada com vantagem, para curar a hydropesia, tanto ascite, como anasarca. Os sertanejos dão a raiz em cozimento, e em quantidade de meia onça, até seis oitavas, em seis onças le agua; e em pó, até meia oitava diluido $\mathrm{cm}$ vinho.

o extracto aquoso, obra com mais efficacia na dóse de um escropulo, até dous; porém irrita mais à mucosa intestinal.

Canivete.-Planta conhecida nas provincias do norte.

\section{¿SOS MEDICINAES}

Os curandeiros empregam-n'a, para curar a morphéa.

Canna de assucax. (Arundo saccharifera.)-A canna le assucar affirmam, que viera da Asia, para a Sicilia, e da Sicilia para a ilha da Madeira; e d'ahi para o Brasil.

Gabriel Soares affirma, que na India não se dão as cannas, se ñ̃o regam os cannaviaes, como as hortas, e se lhes não estercam as terras; e na Bahia plantam-se pelos altos, e pelos baixos, sem se estercar a terra uma vez.... Na Bahia ha muitos cannaviaes que ha 30 annos, que dão cannas, e ordi- 
nariamente as terras baixas nunca cansam, e as altas dão 4 e 5 novidades, e mais....

Consta que a canna-mirim ou crîoula foi achada em S. Vicente, pelos primeiros colonos, levados por Martim Affonso de Souza, e d'ali transplatada para todo o Brasil.

A cultura da canna de assucar, nos tempos coloniaes, e o processo da fabricação do assucar, foram magistralmente descriptos pelo jesuita padre Prudencio do Amaral, brasileiro, no seu poema -De Sacchari opificio-, excellentemente traduzido pelo professor de latinidade João Gualberto Ferreira dos Santos Reis (traductor de Virgilio.)

D'este poema, e do de Cultura Radicis Brasilicoe (mandioca) do professor Jose Rodrigues de Mello, portuense, extrahi um compendio de agricultura brasileira, para transcrevel-o na minha Corographia Historica etc. Mas, como não pude concluir essa minha obra, ahi ficará inedita.

Muito se tem escripto, sobre a canna de assucar: no Diccionario de botanica brasileira do Sr. Almeida Pinto, vem uma luminosa memoria do Dr. Arruda da Camara, que deve ser consultada com proveito.

O douto Bispo de Pernambuco D. José Joaquim da Cunha de Azevedo Coutinho, no seu Ensaio Economico, mandado imprimir em 1774, pela Academia Real das sciencias de Lisboa, diz, que os portuguezes e hespanhóes, que primeiro descobriram a India, foram tambem os primeiros, que aprenderam dos Indios o modo de cultivar, e fabricar o assucar, e o vieram ensinar á Europa, e estabeleceram fabricas nas ilhas da Madeira e das Canarias.

Depois passando á America, onde acharam cannas de assucar, nascidas naturalmente, $\left.{ }^{1}\right)$ estabeleceram novas fabricas, pelos annos

(1) No Rio de Janeiro ainda antes de lá entrarem os portuguezes, ou alguns outros europeus, haviam já cannas de assucar, como attesta Lery, um dos companheilos de Villegaignon, que primeiro entrou na bahia em 5 de Novembro de 1555. 0 brigadeiro Antonio de Almeida Lara, o primeiro que cultivou as cannas de assucar em Cuyabá, não achando cannas algumas de assucar, nem sendo conhecidas em todas aquellas terras, já então habitadas pelos portuguezes, foi tırar as primeiras plantas das terras então luabitadas pelo gentio Parecis. 
de 1557, (1) e aperfeiçoaram tanto os seus assucares, que excederam intinitamente em beleza, e em bondade, aos das Indias Orientaes.

\section{USOS MEDICINAES}

A canna assada, é empregada paria o curativo da ictericia, e dores dos rins.

O assucar tem muito emprego nas pharmacias para a confecçĩo dos xaropes, geleas, limonadas, etc.

\section{USOS CULINARIOS}

Com o assucar fazem doces de todas as qualidades para os regalos das mesas.

Canna brava. (Anthoxanthiun gigans.)-A canna brava, parece-se com a de assucar, mas não fórma touceira, como a canna de assucar. Deita em cima a flexa cabelluda, composta de florinhas esbranquecidas, que servem para encher colchões e travesseiros.

\section{USOS MEDICINAES}

o cozimento da raiz da canna brava, é diuretico.

\section{USOS NAS ARTES E NA INDUSTRIA}

A canna brava é empregalla, para a confecção de balaios e cestos, e mesmo para ripas de casas de páu a pique. As flexas são empregadas pelos fogueteiros, nos foguetes do ar.

Camma do br·ejo. (Alpina spicata.)-Especie de junco, deitando varas flexiveis, e só semelhante á canna-mirim na configuração.

\section{LSOS MEDICINAES}

o cozimento é muito recommendado para curar as molestias da bexiga, e inflammaçĩo da uretra.

Canna fistula. (Cassia brasiliana.)-E' arvore alta, e

(1) Lery esteve no Rio de Janeiro pelos annos de 1557, como elle diz no fim do cap. $5^{\circ}$ da sua historia. Já por aquelle tempo fazia menção dos engenhos de assucar, que os portuguezes tinham em algumas partes do Brasil. 
produz uma enorme vagem, contendo dentro uma polpa medicinal, e purgativa.

\section{USOS MEDICINAES}

o sumo das folhas misturado com a clara de ovo e sal. posto sobre a empigem a mata.

A polpa é purgativa, e efficaz remedio, para combater os ardores dos rins, e impedir a formação de areias n'esse orgão.

\section{USOS NAS ARTES}

Como o lenho d'esta arvore é mui poroso, tem pouco emprego nas artes.

Cannarana felpuda. (Lacerda.) - E' planta, que vegeta no Pará, e Maranhão.

\section{USOS HEDICINAES}

Piza-se o tronco, e com elle faz-se cozimento, e dá-se uma chicara pela manhã e á noite, adoçada com assucar, ao que padece de gonorrhea, com dores de ourinas, e inflammação da uretra. O Dr. Lacerda, que descreve esta planta diz, que a

- medula, é usada com admiravel proveito nas gonorrheas sanguineas, bebendo-se o sumo do colmo assado, ro rescaldo, na quantidade de uma onça, de cada vez, pela manhã, ao meio dia e a noite. Tira as dores, desinflamma o canal, e restabelece a saude, promovendo as ourinas.

Canssansão. (Urtica furibunda.)-Arbusto em förma de mamoneira pequena, que vegeta em qualquer terreno. Tanto as folhas, como o tronco, são ornados de espinhoso pello, que tocado apenas, causa tiio estimulante prurido que, além do paciente raspar, coçando a pelle, vê levantada em vergões, toda a parte onde tocaram os espinhos, ou pellos do cansansão.

\section{USOS MEDICINAES}

A agua que se extrahe da medulla da planta, utilisa aos enfermos dos ollos, que os desinflamma e refresca. Destroe as belidas.

USO NAS ARTES

As amendoas do cansansão, dão azeite, que póde servir para luz. 
Capadelxa, -E' planta conhecida na provincia do Rio de Janeiro.

\section{USOS MEDICINAES}

Pisada e frita em azeite, e posta em pamo de modo, que cubra o testiculo carnoso (sarcocele), sendo a applicação continuada resolve o mal,

Caparosa. (Jussievia caparosa.)-Arvore de 60 palmos de altura, 2 de grossura; floresce em Setembro. A sua madeira é macia ao serrar e lavrar.

\section{USOS MEDICINAES}

Não são conhecidos.

USOS NAS ARTES

Serve para a fabricação de remos, para frechaes, e ripas de casas.

Capiama.-Arvore das nossas florestas, de pouco prestimo. Da casca transuda uma resina, que posta sobre a empigem, a. mata.

Capéba ou pariparoba. (Piper macrophyllım.)Esta planta indigena, è conhecida na Bahia, Alagòas e Pernambuco pelo nome de Capeba, e no Rio de Janeiro pelo de Pariparoba.

\section{USOS MEDICINAES}

E' empregada como desobstruente do figado.

Capianga de folha miuda. (Silva Lisba.)-E' arvore de 50 palmos, com dous de diametro: floresce em Outubro.

\section{USOS MEDICINAES}

Não são conhecidos.

\section{USOS NAS ARTES}

Serve o seu lenho para frechaes, e para taboado.

Capiangussú. (Silva Lisboa.)-Arvore de 50 palmos de altura, com dous de grossura; floresce em Outubro.

\section{USOS NAS ARTES}

Serve para frechaes, e para taboado. 
Capy-pomonga.-Arbusto silvestre. Ha duas variedades: uma vermelha, de folha mui pequena, de côr um tanto verde e lança ramos de còr roxa, e flor vermelha nas pontas; a outra, a que chamam carrapicho, tem as folhas compridas, e umas sementes, que pegam na roupa.

\section{USOS MEDICINAES}

0 chá feito com a raiz d'esta planta, é presentaneo remedio para curar a leucorrhéa, e a dysenteria sanguinea.

Capim-assû. (Chrytopogon alperrinum)-0 capim-assû é planta mui conhecida em Pernambuco, e Alagôas.

\section{USOS MEDICINAES}

o cozimento da raiz serve, para combater os fluxos do peito, provenientes de resfriamento.

Capim mellado, ou gordura, ou de cheiro.-Esta variedade de capim, abunda em todo o Brasil.

\section{USOS MEDICINAES}

o cozimento do capim mellado, é um poderoso medicamento contra a diarrhéa sanguinea.

Ha grande variedade de gramineas no Brasil, e algumas empregadas em medicina vulgar, como o capim pé de gallinhu, e outras variedades, para combater a inflammação do rosto, proveniente de dôres de dentes. O capim milhan ou capitinga é de muita nutrição para os animaes, e podia substituir a alfafa, se no Brasil houvesse industria.

Capitão. (Hydrocotyle umbellata.) - Planta rasteira, mui conhecida em Pernamuco e Alagôas.

\section{USOS MEDICINAES}

Esta planta é tida como excellente remedio, contra a elephantyasis dos arabes, contra a morphéa e erysipelas, escrophulas, affecç̃es tuberculosas, e contra a syphilis, e o rheumatismo.

Capitãosinho. (Ximenia pentandra.)- Arbusto rulgar nas Alagôas e Pernambuco. 


\section{USOS MEDICINAES}

Em Pernambuco e Alagôas, durante a invasão do cholera em 1856, foi empregada esta planta com muito proveito, no curativo dos cholericos.

Capruxoba. (Maranhão.) Dr. Lacerda. - E' planta vulgar, tendo a folha do feitio de serrilha.

\section{USOS MEDICINAES}

No Maranhão empregam esta planta, para curar os cravos dos pés, a bouba secca, e o calor de tigado dos pés, e das mãos.

Cara. (Dioscorea brosiliensis.)-E' planta brasileira, mui vulgar, que produz uma tubera alimenticia pertencente á familia das dioscoraceas.

\section{USOS MEDICINAES}

Affirmam os curandeiroś, que o uso da alimentação do cará, é proveitoso aos morpheticos.

A homœopathia se serve d'esta planta para curar a asthma, a suffocação, e os padecimentos nervosos.

\section{USCS ALIMENTICIOS}

o cará é alimento sadio, e póde substituir o pão, porque se presta para o almoço, comido com manteiga, e com a carne ou peixe, e para sobremesa comido com mel.

\section{caxá roxo.}

\section{USOS MEDICINAES}

Ralado o card, e misturado em agua quente, e dado ao enfermo de febre intermittente, a combate.

Cará de pedra. (Dioscorea silvestris.)-Esta especie de cará silvestre, nasce sobre as pedras, e terrenos mui seccos; possue muitas virtudes medicinaes; e a homœpathia tem tirado excellentes resultados, nas enfermidades nervosas do peito.

\section{USOS MEDICINAES}

E' poderoso medicamento para curar a asthma nervosa ou humida; a falta de respiração, com rincheira bronchica; as 
tosses nervosas, como a coqueluche, e outras enfermidade subordinadas á acção nervosa.

Caxana. (Anyris carana.)-Arvore corpulenta do extenso valle do Amazonas, que distilla uma resina negra, e lustrosa, com virtudes medicinaes.

\section{LSOS MEDICINAES}

Os naturaes do paiz, servem-se da resina, para combater as molestias do pulmão.

Caraná. (Mauntia acubata.) Pará.-E’ uma palmeira do Amazonas.

\section{USOS MEDICINAES}

Nĩo são conhecidos.

LSOS NA IX̃DLSTRIA

As folhas novas servem, para o fabrico de cordas e de redes.

Carapani-uba or anacauica. - Arvore abundante no valle do Amazonas, e principalmente nas margens do rio das Trombetas.

\section{USOS MEDICINAES}

São os seus prestimos conhecidos, nas preparações officinaes dos Americanos do Norte, com a denominação de anacahuita.

Cará-obumirim.-E' outra arvore, de que falla Gabriel Soares, da mesma qualidade, porém mais pequena, e de folhas mais miudas.

\section{LSOS MEDICINAES}

E' mais prestimosa, que o carapanci-ıbba.

Carauba. - Planta indigena brasileira, conhecida dos hervanarios.

\section{csos MEDICINAES}

O seu cozimento serve, para curar as boubas, e dado em clyster, é proveitoso nas hemorrhoidas.

Cardo. (Cactus triangularis.)-E' planta dos sertões, e por' todos conhecida. 


\section{USOS MEDICINAES}

Serve o cozimento em banhos, no rheumatismo; e internamente emprega-se nas affecções do coração.

Cardo santo. (Argemone mexicana).

\section{USOS MEDICINAES}

O cozimento serve para combater as dores de dentes, e as defluxões do rosto, e a pleuresia.

As sementes, oleosas, dadas internamente provocam o vomito, e curam a asthma.

Applicado o succo do cardo santo, sobre os bobões syphiliticos, ou mesmo sobre as ulceras, calma as dores.

O cardo santo, é narcotico e sedativo: as flores, e as sementes curam a asthma.

Carnaubeira. (Arredaria cerifera.)-Foi o Dr. Arruda da Camara, quem estudou, e descreveu a palmeira carnauba, que prodnz a cêra, conhecida pelo mesmo nome da planta.

\section{USOS MEDICINAES}

A raiz da carnaubeira serve, para curar as molestias syphiliticas, e as da pelle, e cura às febres continuas.

\section{USOS NAS ARTES E NAA INDUSTRIA}

Da cêra, depois de bem curtida, fazem velas para luz. 0 lenho serve, para o fabrico de casas, e para a marcenaria. Com as folhas fazem tranças, com que fabricam chapeus. A fructa torrada, e reduzida a pó, póde substituir o café.

\section{USOS CULINARIOS}

Com o palmito, fazem diversos guisados para a mesa.

Carahyba.-Arvore das nossas florestas, cuja flor amarella, grande, é delicioso alimento dos veados, que a procuram debaixo da arvore, onde os caçadores os esperam e matam.

Esta arvore distilla um balsamo, á que chamam balsamo ou oleo de carahyba.

\section{USOS MEDICINAES}

O oleo serve para curar feridas, e feito com elle emplastro, cura as dores do estomago, applicado no epigastrio. 
Este mesmo emplastro, applicado sobre o umbigo e cadeiras, faz desapparecer os tumores hemorrhoidaes.

o pó do lenho, misturado com o olev, desmancha os tumores venereos, gommas (exostosis), e a papeira (bocio).

Caroá ou caroatá. (Bromelia variegata.)-Planta conhecida, e que nasce ordinariamente sobre arvores antigas, e de folhas enciformes, e mui compridas.

\section{USOS MEDICINAES}

Não são conhecidos.

USO NAS ARTES E NA INDUSTRIA

Dá linho para a fabricação de cordas, e se fôr bem preparado, presta-se para tecidos.

Caroba. (Bigonia krasiliana,)-E' planta vulgar, e mui conhecida dos hervanarios.

\section{USOS MEDICINAES}

A caroba serve, para o curativo das boubas, da syphilis, e contra as affecções da pelle, usada em banhos, e mesmo internamente. Ha diversas especies d'esta planta, com as mesmas propriedades.

Caxobussú. (Silva Lisboa.)-Arvore de 40 á 50 palmos, com dous de diametro; floresce em setembro.

USOS MEDICINAES

o cozimento das folhas serve, para as molestias da pelle.

USOS NAS ARTES

o seu lenho é empregado, para taboados, e frechaes.

Carqueja ou vassoura de botão. (Cacalio amara.)-Planta pequena, semelhante á vassoura, e conhecida. dos jardineiros e hervanarios.

\section{USOS MEDICINAES}

E' ante-febril, e tonica. Serve para restabelecer as força do estomago, e suspende a diarrhéa.

Usam tambem da carqueja, para desobstruir o figado, e o baço, e para curar a hydropesia geral e parcial. 
Carrapicho ox carapomonga ou capymonga. (Urena sinuata.)-D'esta planta, ha o carrapichinho, o carrapicho de agulha, o carrapicho beiço de boi, e o de calcada.

\section{USOS MEDICINAES}

o carrapicho de agulha é infallivel remedio, para curar a ictericia, e para curar as gonorrhéas.

Carrasco. (Cambessederia umbelicala)-Planta que vegeta nos logares seccos, e agrestes do Brasil. A casca é verde, e quando machucada, tem um cheiro desagradavel, e de gosto nauseante.

\section{USOS MEDICINAES}

0 Dr. Lacerda, fazendo experiencias em si, com a casca d'esta planta, reconheceu ser ella mui proveitosa, para curar a inflammação do estomago, e conveniente na tisica pulmonar.

USOS NAS ARTES

0 seu lenho, serve para frechaes e vigotas.

Carvoeiro. - E' planta natural do Brasil. Vegeta nos logares seccos, agrestes, e fructifica.

\section{USOS MEDICINAES}

Não são conhecidos.

\section{USOS NA INDLSTRIA}

A fructa pilada, e misturada com caparosa, e postá em infusão, produz boa tinta de escrever.

Casadinha.-Arbusto conhecido nas provincias do norte do Brasil, e muito medicinal.

\section{LSOS MEICINAES}

O succo crú, ou cozida a planta, dado a beber, ou tomado em clysteres, é presentaneo remedio contra as febres malignas, inflammatorias e intermittentes.

Cascomilho. - Arbusto aromatico do Perú, Paraguay e do Brasil.

\section{USOS MEDICINAES}

E' tonico, e obra como estimulante energico. 


\section{USO NAS ARTES E NA INDUSTRIA}

D'ella se extrahe um oleo volatil, de cheiro suare, que póde ser àproveitado na perfumaria.

Casca de anta. (Drymis Winteri.)-Arvore das nossas florestas, de folhas grandes, ovaes, succulentas, e aromaticas.

\section{USOS MIEDICINAES}

A casca é de sabor acre, aromatica. Usa-se de infusão, como estimulante, para excitar as forcas musculares enfraquecidas, contra a colica originada por resfriamentos.

\section{USOS NAS ARTES}

o lenho serve, para obras de construcção civil.

Casca de caubi. (Silva Lisboa.)-Arvore corpulenta das mattas do Brasil, com 60 palmos de altura, e dous a dous e meio de diametro; floresce em Agosto.

\section{USOS MEDICINAES}

Não são conhecidos.

USOS NAS ARTES

Serve para frechaes,

Casca de onuri.-Planta aromatica, e conhecida nas provineias do norte.

\section{USOS MEDICINAES}

Feita em fórma de chá, é muito usada esta planta, para os que padecem dores de cabeça, e dores intestinaes.

Casca para-tudo. (Cinamodendron axillare.)-A casca para tudo, é amarga.

\section{USOS MEDICINAES}

Tomada em fórma de chá, serve para combater o fastio, para fortificar a organização debilitada, e para curar as febres inter mittentes. Dizem ser um contra-veneno das cobras.

Reduzida a pó, e pulverisadas as feridas, as faz cicatrisar.

Casca paracauba.

USOS MEDICINAES

Esta planta é um vulnerario excellente. 
Casca preciosa. (Cryptocarea preciosa.) (Pará e Rio Negro.) - E' planta aromatica.

\section{USOS MEDICINAES}

Serve a sua infusão, para combater a asthma nervosa, provocada pelo abuso do conjuncto sexual. Cura o rheumatismo syphilitico, e o catarrho chronico.

Casca de taperoba. Planta conhecida dos hervanarios.

USOS MEDICINAES

o cozimento d'esta planta serve, para desinchar os pés, fazendo-se uso prolongado.

Cascudo. (Silva Lisboa.)-E' arvore de 45 palmos do altura, e de 2 á 3 de diametro; floresce em Setembro.

\section{USOS NAS ARTES}

O lenho serve para taboado, e para frechaes.

Casquinha vermelha. (Silva Lisboa.)-Arvore do 30 palmos de altura, com 2 de diametro; floresce em Setembro.

\section{USOS MEDICINAES}

Não são conhecidos.

USOS NAS ARTES

A madeira serve para as obras de architectura.

Cassatinga. (Solanum anilatum.)--E' arbusto das Ala_ goas, que não foi estudado, em relação á medicina vulgar.

Castanha do Pará ou Maranhão. (Bertholletia excelsa.)-E' arvore gigantesca, oriunda do Pará e do Mara. nhão, pertencente á familia das myrtaceas, e mui conhecida por seus fructos, que são comestiveis.

\section{USOS MEDICINAES}

o oleo serve para unguento.

$$
\text { USOS NAS ARTES E NA INDUSTRIA }
$$

O oleo serve para illuminação, e para impedir a oxydação do ferro; a madeira é empregada na construcção naval. 
Cataia-Herva de bicho ou persicaria.E' planta acre, estimulante, e aperiente.

\section{USOS MEDICINAES}

Os indios empregam-n'a em chá, nas suppr'essões/ das ourinas, e contra a podridão gangrenosa. E' um poderoso medicamento contra a erysipela, fazendo-se uso continuo d'ella. Foi o unico medicamento, que combateu a grande e medonha peste, que appareceu no Rio de Janeiro, em tempo do marquez do Lavradio, sob a denominação de Zamparini, cujo mal os que, sendo atacados, não pereceram, ficaram aleijados. Esta planta deve ser estudada, em nossas faculdades medicas.

Cathaxina conga. (Silva Lisboa.)-E' arvore de 40 paimos de altura, e dous de diametro; floresce em Outubro.

USOS MEDICINAES

Não são conhecilos.

\section{USOS NAS ARTES}

Serve para frechaes.

Catinga do mulata. (Leucus martinicensis.)-Herva vivaz, de sabor amargo, e aromatica, pertencente á familia das labiadas.

USOS MEDICINAES

E' muito resolutiva, alexipharmaca e nervina. Suas flores em infusão são sudorificas, e carminativas. O cozimento de toda a planta, usado em banhos, allivia e desvanece as dores das articulações.

Catinga do porco ou pau de rato ou'pau de tinta do sapateiro. - Arvore mui conhecida no sertão, e principalmente na provincia da Bahia. Vegeta em agrestes.

\section{USOS MEDICINAES}

Não sào conhecidos.

\section{USOS NAS ARTES E NA INDUSTRIA}

O amago, e a casca d'esta arvore, como o pau de campeche, dão escolhida tinta de escrever, lançando limalha de ferro dentro do cozimento; a escripta fica negra e brilhante, mas avermelha 
depois, o que acontece pela impericia da composição. O lenho serve, para a construcção de casas.

Catingueiraa. (Cosalpina.)-E' planta leguminosa. USOS NA INDUSTRIA

E' planta brasileira da qual se extrahe uma bella tinta amarella conveniente na tinturaria.

Catingueira brava.(Croton) --E' planta euphorbiacea. usos Na iñustria

D'esta planta se extrahe a mesma tinta amarella, que póde aproveitar-se para o mesmo fim.

Catolé.-(Rhapis paramidata.)

E' uma bonita palmeira do Brasil de 35 à 40 metros de altura, que regeta em grande abundancia na provincia das Alagôas. Dá cachos grandes, compostos de côcos, do tamanho de um ovo de gallinha, contendo uma polpa espessa, amarella, muito agradavel ao paladar. Dentro do caroco, que é mui rijo, está a amendoa branca, mui oleosa, tambem comestrvel.

\section{USOS MEDICINAES}

o azeite que se extrahe da polpa espessa, serve, para matar os bichos dos pés, e para curar erysipelas

\section{USOS NAS ARTES E NA INDUSTRIA}

0 azeite da polpa exterior serve, para a confecç̃̃o do sabão e para luz, e seria um utilissimo ramo de commercio, se entre nós houvesse industria.

A casca do fructo serve, para a cordoaria. O caroço que contém a amendoa, póde ser aproveitado para o fabrico de botões, e outros objectos de luxo.

Com a palha d'esta palmeira, cobrem-se as casas campestres, etc.

\section{LSOS ClLINARIOS}

o palmito do catolé, fornece saboroso prato, para a mesa. o oleo da amendoa, é empregado para frigir o peixe, e para outros misteres da cozinha, bem como para a luz, sendo pre ferivel ao azeite doce, por ser mais fino, e não incommoda a fumaça, quando se apaga o pavio. 
Catuaba.-E' planta do Maranhão e do Pará.

\section{USOS MEDICINAES}

o Dr. Lacerda affirma, ter esta planta a propriedarle aphrodisiaca.

Cauby. (Silva Lisboa.)-Arrore de 60 palmos de altura, com dous ou tres de diametro; floresce em Outubro.

\section{USOS MEDICINAES}

Não são conhecidos.

\section{USOS NAS ARTES}

Serve o seu lenho para o fabrico de canôas, e para taboado.

Canstico vegotal ou 10 uco.-Arbusto conhecido nas Alagôas, e no Rio de Janeiro: vegeta principalmente nas praias do mar.

\section{USOS MEDICINAES}

Socadas as folhas e postas sobre a pelle, em pouco tempo produz os effeitos de um caustico.

Dizem convir esta planta no curativo do cancro ulcerado. Convinha que os medicos praticos fizessem tentativas com esta planta contra essa cruel enfermidade.

Lembro-me ter lido, que em Java, e em Ceylão, o cancro é curado em oito dias, c quem sabe se lá não é o louco, o agente therapeutico de que se servem!

E' conveniente a experiencia com esta planta, com a qual muito ganhará a humanidade soffredora.

Caxapóra do gentio. (Terminalia argentea.)-Arvore das nossas florestas, e conhecida em Minas-Geraes. Esta arvore produz uma gomma resina, semelhante á gomma gutta.

\section{USOS MEDICINAES}

E' purgativa dada em emulsão, vu em 'pilulas.

Cobola drava. albaran. (Allium cepa.)-A cebola brava, vegeta em qualquer terreno, e tem particulas venenosas. Havendo chuva, ella produz; mas com a permanencia do sol, murcha, secca e se reduz á terra. 
USOS MEDICINAES

o povo a emprega, nas queixas defluxionarias; mas em dóses mui diminutas. Ella tem acção sobre o cerebro, e faz mal á vista, e póde causar lethargo. Dizem, que provoca as ourinas, e excita 0 apetite venereo.

Cebola cemcem. (Amaryllis belladona.) - E' planta agreste, e conhecida na provincia das Alagóas, pelo nome de cebola do matto.

Dá flores e fructifica.

USOS MEDICINAES

E' vomitiva, e expectorante. Faz-se com a cebola xarope, para curar as affeccões pulmonares, e a asthma.

Cebola vermelna. - E' planta das hortas, e mui conhecida.

\section{USOS MEDICINAES}

Soccada com sal, e posta sobre o pente, provoca as ourinas, e por isso os sertanejos se servem d'ella assim, nas retenções das ourinas.

\section{USOS CULINARIOS}

E' um dos melhores adubos, que os cozinheiros empregam, para o rega'o das mesas.

Cebolinha. (Allium schoenoprasum.) - A cebolinha foi transportada da Asia, para o Brasil, e se cultiva nas hortas.

\section{USOS MEDICINAES}

E' desobstruente.

\section{USOS CULINARIOS}

Servem-se d'ella, para tempero de comida.

Cedro bravo.-E' arvore de 40 palmos de altura, com dous de grossura. Floresce em Agosto.

\section{USOS MEDICINAES}

Parece-me ser esta especie de cedro, a que chamam pequeno, de que falla José Monteiro de Carvalho, o qual tem ramos nodosos, madeira vermelha, e produz umas bagas amarellas, umas mais pequenas, e outras mais grossas: a madeira de qualquer 
dellas, Iança suave cheiro, e tem grande uso em medicina, principalmente nas queixas dos olhos: quebra os dentes, e tira as dores delles; não deixa apodrecer a carne, que junto a ella estiver, e a faz seccar sem tomar corrupção.

\section{USOS NAS ARTES}

Tem os mesmos prestimos que as outras especies.

Cedro da costa do mar. - E' arvore de 60, e mais palmos de altura, e de dous á seis de grossura. Floresce em Setembro e Outubro.

\section{USOS MEDICINAES}

Tem os mesmos prestimos, das outras especies.

USOS NA $\dot{S}$ ARTES

Serve igualmente para os mesmos usos, e principalmente para o cintado grosso dos navios, em razão das suas fibras, não se partirem; embaçam as balas soltas, e não rompem a sua natureza estoupenta.

Cedro vermelho. (Cedrela brasiliensis.)-Arvore das nossas florestas, de 100 e mais palmos de altura, e de tres até 24 de grossura; floresce em Setembro, em pequenos ramalhetes de 6 á 7 flores verde-gaios. A madeira é aromatica.

USOS NEDICINAES

Da entre casca, se faz salutar cozimento, para os que padecem de boubas, gommas (exostosis), e corrimentos.

o seu cozimento é muito util em banhos, aos que padecem de sarcocele, promovendo-lhe a resolução. A casca é adstringente, e provoca o vomito, tomada internamente.

USO NAS ARTES

A madeira do cedro serve para costados dos navios, figuras de pròa, caixilhos de portas, taboado de forro, obras de entalhador, e canôas.

Gabriel Soares diz, que o cheiro do cedro, faz mal aos vestidos, que se guardam nas gavetas feitas com elle.

Cega-olho. (Asclepics umbellata.)-Planta leitosa, conhe- 
cida nas Alagôas. Em Pernambuco chamam-n’a camará bravo. E' planta venenosa.

\section{USOS MEDICINAES}

o leite cura as dôres de dentes.

Celidonia. Bahirania. (Pä́á)-E' planta que vegeta no Pará, e tem emprego na medicina vulgar.

\section{USOS MEDICINAES}

A infusão feita com a raiz d'este vegetal, é empregada como diuretica, sudorifica, e desobstruente.

Celidonia ou planta Andorin ha ou her va de passarinho. (Euphorbia coecorum.) - As follas d'esta planta postas inteiras sobre feridas apostemadas, lhes tira toda a inflammação: a sua raiz posta de infusão em vinho, e auxiliando-a uma pitada de herva doce, e bebida pela manhã e á noite cura a ictericia.

Centaurea maior, e centaurea menor ou iol da ter ra.-Estas duas plantas, não são semelhantes quanto afigurão, mas são de natureza quentes e seccas.

\section{USOS MEIICINAES}

Centaurea mainr: a raiz tomada em pó, é empregada nas convulsões, pleurizes, difficuldade de respirar, tosse chronica, e sangue pela bocca. E' recommendada para curar as hemorrhoides.

Centaurea menor ou fel da terra, é detersiva, aperitiva, vulneraria, sudorifica, emenagoga, antiscorbutica, e favorece o parto; é anthelmintica; contra a mordedura do cão damnado; contra a paralysia, e serve para desobstruir o figado. As folhas curam as chagas antigas.

Centeio. (Secale cereale.) -0 centeio passou da Asia, para a Europa, e dalli para o Brasil. E' empregado na fabricaçĩo do pão.

USOS MEDICINAES

A cataplasma da farinha do centeio é emolliente, e resolve a inflammação. 
centeio ospigado ou esporado. (Secale cornutum).

\section{USOS MIEDICINAES}

Promove as contracções uterinas, e suspende a hemorrhagia de sangue pela bocca.

Cerilba.-E' uma variedade do mangue, com 30 palmos de altura, e 2 de grossura. Floresce em Setembro.

\section{USOS MEDICINAES}

Não são conhecidos.

\section{USO NAS ARTES}

Serve para caibros de casas.

Cortado o páo, e enterrado por espaço de 60 dias no mangue, toma a madeira a còr do ebano.

Chá de café.-0 Dr. Peckolt, fazendo a analyse chimica d'esta planta diz, que as folhas do chá de café, devem ser levemente torradas; é esta a fórma, como o commercio quer introduzil-o na Allemanha; sendo a empreza promovida ultimamente pelo Dr. van Tochuor. Poderia embalar-se do mesmo modo que o matte; fornece um chá agradavel, que por suas qualidades poderia substituir o chá da India, não tendo effeitos tĩo estimulantes.

"As folhas, ainda depois de cahidas, conservam por muito tempo a cafeina; o acido tanico se decompõe em parte, n'uma substancia selurica. »

«A cultura d'este chá seria recommendavel em logares onde o fructo do café, não se desenvolve, ou não chega a amadurecer, emquanto o arbusto desenvolve viçosa folhagem, como por exemplo na Serra dos Orgãos, e outros logares semelhantes. »

\section{USOS MEDICINAES}

Não são conhecidos.

\section{USOS NA INDESTRIA}

A cultura d'esta planta, poderá dar seguros resultados ao agricultor, e ao Estado. 
Oni de frade ou lingua de tiú. (Caseara lingua.)-Arbusto vulgar em quasi todas as provincias do Brasil.

USOS MEDICINAES

o povo emprega o cozimento d'esta plantid, contra as febres inflammatorias, e de caracter pernicioso.

Chá da India. (Thea sinensis.)-E' planta asiatica, e particularmente do Japão: foi transportada para o Brasil, onde produz, e prospera admiravelmente no Rio de Janeiro e em S. Paulo. Floresce e fructifica.

\section{USOS MEDICINAES}

A infusão branda do chá, é mui proveitosa, para as inflammações dos olhos. E' excitante, estomachico, diuretico, e excita as faculdades da alma.

USOS DOMESTICOS

E' empregado nas mesas a infusão do chá, para almoço e ceia.

Chá da terra ou chá do matto. (Buddlija quinquenaria.)-E' planta mui vulgar nas Alagòas, e em Pernambuco, e crê o povio, ser esta p!anta, o verdadeiro chá da India, e fazem o mesmo uso que o chá, com as folhas, e acham mui agradavel ao paladar.

\section{USOS MEDICINAES}

o povo usa da infusão do chá da terra, como calmante, no máo estar nervoso.

Chamburú. (Carica digitata.) Pará.-E' muito parecida esta arvore, com o mamoeiro, e vive nas margens do Amazonas.

Diz o Dr. Arruda da Camara, que esta arvore é tão malfazeja, que as emanações que desprende de si são mortaes, como acontece com a celebre mancenilha javaneza.

Merart e De Lens não fallam n'ella, e nem me recorda, se - Dr. Lacerda, tambem fez d'esta arvore especial menção.

Cnanana ou nove horas. (Drosera tuberosa.) Herva, mui conhecida nas provincias do norte. 
USOS MEDICIANES

As pequenas batatas, que nascem pelas raizes, são mui empregadas, para curar as dysenterias.

Chicoria maritima.-E' planta vulgar.

USOS MEDICINAES

0 povo emprega esta planta em cozimento, para combater as bronchites, e as inflammações do figado.

Chicoria. (Sonchus oleraceus.) - Ha duas especies de chicoria; uma cultivada nas hortas, e a outra brava ou do campo. A chicoria cultivada nos veio da Europa.

\section{USOS MEDICINAES}

o cozimento em vinho purga a bilis, e os humores viscosos. A agua distillada é conveniente para os ardores do estomago, e do figado. Comida crûa, é util ao estomago e ao figado; mas comendo-se cozida, perde a virtude aperitiva. As folhas, passadas ao calor do fogo, e untadas com leite de peito, e postas nas fontes, é util á quem tem dôres de cabeça. Em förma de chá, estanca o sangue pela bocca. Cura o pleuriz.

A chicoria é um purificador do sangue.

Chirimbá.-Arvore das nossas florestas, que ainda não teve emprego na medicina.

\section{USOS NAS ARTES}

A sua madeira sendo reduzida a cinza, arde como isca, e é a melhor que se conhece para a fabricação do sabão.

Chique-chique. (Cactus peruvianus.)-Planta espinhosa que vegeta nos sertões.

\section{USOS MEDICINAES}

E' diuretica. O succo bebido faz enrouquecer.

Cidreira.-Arvore mediana, e semelhante ao limoeiro. Floresce e fructifica, sendo a casca da fructa mui grossa.

USOS MEDICINAES

o chá feito com as folhas é estomachico, e carminativo. 


\section{USOS NA INDUSTRIA}

Os confeiteiros servem-se da casca, para a confecção de varios doces.

Cidreira. Herva cidreira. (Milissa hortenses.)-E' planta conhecida, e se cultiva nos jardins, e nas hortas; floresce em os mezes de Julho, e Agosto.

\section{USOS MEDICINAES}

A infusão feita com esta planta, conforta e alegra o coração, o cerebro, o estomago, provoca os menstruos, e dissipa os flatos uterinos; serve na apoplexia, epilepsia, vertigem, na melancholia, nas febres malignas e na peste.

USOS NA INDUSTRIA

Fazem na industria diversos licores com a herva cidreira.

Cidrilla. (Verbena triphylla.)-E' planta conhecida de todos.

\section{USOS MEDICINAES}

E' estomachica, e em fỏrma de chá, é usada para combater a indigestão.

Cinco folnas ou turuman. - E' planta mui vulgar no Rio de Janeiro, e mui empregada em medicina popular.

\section{USOS MEDICINAES}

O cozimento das folhas, serve para o curativo do rheumatismo, principalmente o que ataca os ossos.

Cyadi capeto. (Vallesta tinctorial.)-E' planta do Ceará. USOS MEDICINAES

Não são conhecidos.

USOS NA INDUSTRIA

D'esta planta se extrahe uma tinta cor de rosa mui bella; e das sementes se obtem sabão.

Cinamomo.-Muitos botanicos, confundem o cinamomo, com a canella; mas não é a mesma planta.

Cipó d'alho. (Bigonea alliacea.)-Este cipó, se encontra nas mattas virgens; e trepa, abraçando-se com os troncos das 
ar'vores, e com elles se enreda. Lascado apparece dentro uma especie de embira, cujo aroma é ainda mais activo, que o do proprio alho: extrahida a essencia, fica vigorosissima, por pequena quantidade que seja, serve para tempero da comida, produzindo, em tudo, os prestimos do mesmo alho.

USOS MEDICINAES

E' proveitoso medicamento, para os dẹfluxões do peito.

\section{USOS NA INDLSTRIA}

A industria humana, póde tirar d'este cipó, excellente proveito; porque o gado, que the come as folhas, ninguem the come as carnes, nem usa do leite, pela vehemencia, e insupportavel sabor que adquire do proprio alho. O caititú, que é caça escolhida dos sertanejos, se lhe come a batata, fica com a carne incapaz de se comer, pelo excssivo sabor de alho, que adquire.

Cipó de caboc1o. (Tetracera volubilis.)-E' uma trepadeira conhecida em Minas, e no Rio de Janeiro.

\section{USOS MEDICINAES}

As folhas d'este cipó, feita infusão, são purgativas; tomarlas em banho resolvem os tumores.

Cipó carneiro. (Echistes suberrosa.)-E' uma trepadeira, de flores grandes, e brilhantes.

\section{USOS MEDICINAES}

E' um poderoso hemostatico, para suspender o sangue pela bocca, e principalmente as hemorrhagias uterinas.

Cipó catinga. - É mui conhecido nas Alagôas.

\section{USOS MEDICINAES}

Pisa-se o cipó, e misturado com agua, lava-se a testa, e com este processo, desapparecem as dòres de cabeça.

Curam os sertanejos as febres malignas, banhando o enfermo com o cozimento quente d'esta planta.

A infusão, tomada em banhos, cura as dòres do corpo, provenientes de rheumatismo. 


\section{Cipó cavallo.}

USOS MEDICINAES

o cozimento d'este cipó, serve para curar feridas e chagas chronicas.

Cipó de cesto. (Paterium sarmentosum.)-Vegeta nas Alagôas em abundancia.

\section{USOS MEDICINAES}

Não sã்o conhecidos.

USOS NA INDUSTRIA

Fazem com elle cestos de todos os tamanhos, e qualidades, - cassuás, para carregar mandioca, e outros objectos.

Cipó de chrumbo. (Cuscuta americana.)-E' este cipó bastante conhecido, não só pelo seu aspecto, como por suas virtudes vulnerarias e consolidantes.

\section{USOS MEDICINAES}

E' approvado remedio, para as camaras ou diarrheas de sangue, defluxões, quédas, pancadas, e inflammações das glandulas submaxillares. hydropesia, e para quem bota sangue pela bocca, dando-se a beber o cozimento.

Sabe-se, que os animaes, que se nutrem com o cipó de chumbo, offerecem a carne sadia, para a alimentação do homem.

Cipó de caxijó, de coxijó ou sambaibinha. (Davilla brasiliana.)-Este cipó sarmentoso, é conhecido em todo o Brasil.

\section{USOS MEnicinaes}

E' muito adstringente, e empregado para curar as ulceras chronicas e atonicas.

Cipó cravo.- Este cipó, conhecirlo pelos derrubadores das mattas, e pelos plantadores, tem as folhas com o mesmo aroma do cravo da India.

Não são conhecidos.

\section{USOS MEDICINAES}

USOS NA INDUSTRIA

Póde ser aproveitado, para a perfumaria. 
Cipó cruapé vermelho. (Paulinea pinata.)Este cypó é mui vulgar nas Alagôas, e em Pernambuco.

\section{USOS MEDICINAES}

Não são conhecidos.

USOS NA INDUSTRIA

E' empregado para amarrar cercas, lenha e outros objectos do campo.

Cipó cururú. (Echistes elexicaca.)-Produz nas mattas. E' venenoso.

\section{USOS MEDICINAES}

Não são conhecidos.

Em consequencia da sua actividade toxica, servem-se d'este cipó machucado, para tingir as aguas, e matar o peixe, sendo mais violento, e com effeitos toxicos que o cipó Tingui.

$\mathrm{E}$ ' de consistencia fortissimo.

A medicina póde tirar d'elle, excellentes resultados em proveito da humanidade.

Cipó cruz. (Chiococa anguicida.)-E' planta trepadeira, e mui conhecida em S. Paulo.

\section{USOS MEDICINAES}

E' contra veneno das cobras, dado a beber infundido em aguardente.

Cipó dos taboleiros. - Esta planta que nasce e alastra nos taboleiros, e logares seccos e fracos, tem as folhas compridas.

\section{USOS MEDICINAES}

Da sua raiz pizada e còda por panno, se extrahe gomma ou tapioca, que, bebida com assucar, é optimo remedio para curar gonorrheas, e flores brancas.

Os camponezes servem-se tambem da tapioca, para refrescos.

Cipó de cunamam. (Euphorbia phosphorea.) - E' planta mui conhecida na Bahia.

\section{USOS MEDICINAHS}

Conta Almeida Pinto, que o succo d'esta planta posto sobre 
a pelle, causa grande prurido; e a picada dos espinhos, produz botres resiculosos na pelle dos animaes.

USOS NA INDUSTRIA

A industria poderá tirar d'este interessante arbusto muito proveito, porque cortando-se um galho deita de si um liquido branco, que no escuro resplandece como fogo, e sacudindo-se com elle, faz rastilho luminosos.

Os lavradores servem-se d'este vegetal, para por nas cercas, afim de evitar que os animaes entrem nas roças, e destruam as plantações.

Cipó guiraa. (Bigonia guira.) (Pará)-E’ planta do Alto Amazonas.

\section{USOS MEDICINAES}

A sua raiz, é empregada em cozimento, como purgante violento.

Cipó de impigenr. (Stadinania depressa.) - Esta planta vegeta nas Alagòas.

\section{USOS MEDICINAES}

A fructa, pisada, e posta sobre as impigens as cura; bem como o banho produz o mesmo effeito dado em cozimento.

Cipó de Imbé, (Philodendron Imbé).

\section{USOS MEDICINAES}

As folhas verdes, curam as ulceras; o cozimento d'ellas em banhos, serve ao curativo do rheumatismo e da orchitis.

Cipó lustroso. - Este cipó abunda nas margens do Rio de S. Francisco, mórmente de Propiá para baixo. E' fino, roliço, e muito flexivel; e possue tal verniz, sobre a côr parda natural, que mette gosto vêl-o.

\section{LSOS MEDICINAES}

Não são conhecidos.

USOS NA INDUSTRIA

E' um rano de commercio alli, que fazem, com o cipó lustroso, para o fabrico de balaios, e outros artefactos.

cipó muricudua ou muruquitua. (Pará) 
-Este cipó quando se corta, deita grande quantidade de agua insipida, que se kebe, sem causar damno algum, e mitiga a sêde.

\section{USOS MEDICIXAES}

o cozimento bebido, serve para curar a obstrucção do figado, e do baço; e tem a propriedade de fazer sahir o cabello, molhando-se a cabeça, ou qualquer parte cabelluda, com o cozimento d'elle.

Cipó páo.-Mui conhecido nas provincias do norte.

USOS MEDICINAES

Não são conhecidos.

\section{USOS NA INDUSTRIA}

Fazem com elle bastões de differentes gostos.

Cipó do purga ou purza de cipó,-Este cipó, mui conhecido nas provincias da Bahia, Sergipe, Alagòas e Pernambuco, vegeta nas mattas; é um dos melhores purgantes, para os que padecem molestias venereas; é tão forte, que é necessario regular a dóse com a força do paciente, porque a sua violencia provoca o fluxo de sangue.

\section{USOS MEDICINAES}

Emprega-se para curar a syphilis.

\section{MODO DE LSAR O MEDICAMENTO}

A maneira de preparar o purgante é a seguinte:

o cipó tem articulações ou gommos, e cada gommo é um purgante: tira-se-lhe a casca, deixa-se seccar, e depois esmiuça-se, e se cozinha em bastante agua, ató ficar a porção de um clyster, e applica-se ao enfermo.

Recommendam os camponezes, que antes de se usar este medicamento, deve-se refrescar o enfermo; e durante o uso do remedio, deve haver muito resguardo, tanto na alimentação, como dos ventos, chuvas, sereno e sol. .

Cipó de seda ou seda vegetal.-Este cipó abunda nas provincias do Rio de Janeiro, e capitania do Espirito-Santo.

Dá seda vegetal alvissima, e còr de ganga, e os fios podem se subdividir ao infinito. 
Em 1871, foi um individuo á camara dos deputados, com uns poucos de saccos, com a seda já prompta, com o cipó quebrado, com a seda pendente, e grande porção de cipó enrolado, fazendo ver a grande utilidade que a industria póde tirar d'esta interessantissima planta.

Ao mesmo tempo apresentou panno tecido e prompto, obtido de uma palmeira, dizendo que para se obter o panno, para com elle se fazer qualquer obra de uso, não precisava mais que metter a palmeira entre dous cylindros, espremel-a e expôr o panno tecido ao sol e secal-o.

$\mathrm{Eu}$ era deputado, e obtendo de tudo as amostras mandei apresental-as na praça do commercio, e nada pude obter !!!

Nem a camara dos deputados, e nem os ministros de Estado, em vista dos prodigiosos productos naturaes do Brasil, se digna: ram mover-se ! ! !

Cipó sumia. (Anchieta salutaris.) - Planta conhecida em S. Paulo, e Minas Geraes.

\section{USOS MEDICINAES}

Emprega-se a raiz da planta em pó, ou em infusão, como emeto-purgativa nas tosses convulsas das crianças.

Cipó de tres quinas ou cipó de rego. (Bigania rego.)-Esta especie de cipó, abunda em qualquer sertão, das provincias da Bahia, Sergipe, Alagôas e Pernambuco, onde è mui conhecido de todos.

\section{USOS MEDICINAES}

o seu cozimento ou infusão, é mui proveitoso para curar gonorrhéas.

Ha outras variedades de cipós, que näo menciono por serem conhecidos os seus usos na industria.

Claraiba.-E' arvore de 60 palmos de altura, com 3 á 4 de grossura; floresce em Setembro. A sua madeira é macia no serrar e lavrar, e tem os póros abertos.

\section{USOS MEDICINAES}

Não são conhecidos. 
USO NAS ARTES

Serve para couçoeiras e para o fabrico de canôas.

Coapinjuva. (Ficus anthelmintica) Pará.- Esta arvore que se cria no Amazonas e no Rio Negro, é uma especie de gamelleira, e tem emprego na medicina vulgar.

\section{USOS MEDICINAES}

o leite que dá, por incisão, e tomado de l á 2 grammas, por alguns dias, expelle a solitaria. A amendoa come-se assada, por ser doce e agradavel, e goza a propriedade de excitar o apettite venereo, e activa a memoria tardia.

Coca. (Erythroxilon-coca.)-Planta do Perú e do Brasil, e cultivada no Chile, cujas folhas mastigadas e conservadas na boca, mitiga a fome e a sede.

O modesto e illustrado botanico Dr. Glasiou, transplantou para - Passeio Publico do Rio de Janeiro este utilissimo vegetal, onde póde ser visto e estudado.

\section{USOS MEDICINAES}

E' refrigerante.

Coea-coga. (Solanum urens.) - Planta das Alagoas, Pernambuco.

\section{USOS MEDICINAES}

Não são conhecidos; mas se sə esfrega esta planta na pelle produz grande coceira.

Cocão. (Silva Lisboa.)-E' arvore de 60 palmos de altura, com 3 a 4 de grossura: floresce em Setembro. 0 seu lenho é macio no serrar e lavrar.

\section{USOS MEDICINAES}

Não são conhecidos.

USOS NAS ARTES

Serve para couçoeiras.

Cochonilha vegetal.-E' certo musgo, que se encontra em alguns vegetaes, nos logares avarjados e campestres. 
Usos NA INDESTRIA

D'este musgo se extrahe, uma tinta roxa-viva e delicadissima, propria para a tinturaria.

Coité, (Cresentia cujete.)-E' arvore conhecida nas Alagoas e Pernambuco, que floresce e fructifica.

\section{USOS MEDICINAES}

o succo do fructo do coité é usado nos tetanos, e nas convulsões em pequenas dóses.

\section{USOS NA INDUSTRIA}

Faz-se com a casca do fructo cuias, para os usos domesticos.

Comicha.-E' uma arvore semelhante á laranjeira, de que falla Gabriel Soares, e produz fructo muito saboroso.

\section{USOS MEDICINAES}

Não são conhecidos.

Commaty. Pará. (Lacerda.)-Planta do Maranhão e do Pará.

\section{USOS MEDICINAES}

E' muito empregada para curar as dores de ouvidos, toman. do-se suadouros com o cozimento, na região do ouvido enfermo. Recommenda-se ter muita cautella, em se não expor ao ar durante 4 ou 5 dias.

Commendi assú.--Planta leguminosa, conhecida dos hervanarios.

\section{USOS MEDICINAES}

A fava ralada e infundida durante 12 horas, e na infusão pondo-se-lhe sal, e alguns pingos de vinagre, e se applicando sobre a empigem a cura perfeitamente, sem deixar signal na pelle.

Comnomubá femea.-E' arvore corpolenta, que só differe na côr do commumbá vermelho, por ser esbranquiçada a sua structura. Floresce em Setembro.

USOS MEDICINAES

Não são conhecidos. 
USOS NAS ARTES

o seu lenho é empregado na architectura, e cintas de navios.

Comumbá vermelho.-Arrore de 60 palinos de altura e 3 de grossura, semelhante ao jequitibá. Floresce em Setembro. A sua madeira é macia no serrar e lavrar, e mesmo no trabalho, apızar de ser pouco porosa.

USOS MEDICINAES

Não são conhecidos.

USOS IAS ARTES

Serve para architectura, para vigotas, frechaes, e para construcções navaes, para cintas e váos das embarcações miudas.

Condurú. ou gandurú. ou cundurél. (Brossinium condumi.) Silva Lisboa.-E' arvore das nossas mattas, de 60 palmos de altura, e de 1 á 2 de diametro: floresce em Agosto.

\section{USOS MEDICINAES}

Não são conhecidos.

USOS NAS ARTES

A sua madeira é encarnada tirando a roxo, serve para a marcenaria. O candurú que vegeta nas ilhas, differe do das mattas, por ter o cerne mais encarnado.

Congonha do matto ou matte do campo. (Luxemburgia polyandria.)-Esta planta, com folhas semelhantes, ás da laranjeira, e gosto de malvas, cresce em Minas Geraes, e no Paraná, e dizem que o melhor é, o que nasce na serra Maracajú. Não se espera que as folhas caiam: são tiradas, e depois de torradas convenientemente, para uso alimenticio.

\section{USOS MEDICINAES}

E' estomachico, e promove a transpiração insensivel.

\section{USOS DOMESTICOS}

Toma-se o chá do matte, como alimento ordinario.

Contra herva. (Drakena radix.)-E' arbusto pequeno. - mui conhecido nas provincias do norte do Brasil. 


\section{USOS MEDICINAES}

E' sudorifica, e contra veneno de cobras, lacráos, etc. Em. pregam-n'a contra as febres, e contra as defluxões do peito.

Coentro. (Coriandrum majus.) - E' arbusto mui conhecido. A sua natureza é fria e secca. E' hortense, e tambem nasce pelos campos.

\section{USOS MEDICINAES}

A semente conforta o estomago, ajuda a digestão, corrige o máo halito da boca, e desfaz os flatos do estomago, e ventre.

\section{USOS CULINARIOS}

Usa-se muito do coentro nas Alagôas e Pernambuco, nas comidas diarias.

Coentro de Tajuro (Maranhão) ou cosicoria da terra no Pará.-E' planta conhecida no Maranhão e no Pará.

\section{USOS MEDICINAES}

Sua acção é diuretica, sudorifica e emenagoza.

o Dr. Laeerda diz que no Maranhão faz-se uso d'esta planta para provocar a menstruação, tomando-se em fórma de chá, feito da raiz, mas que duvida d'esta propriedade, por ter applicado com o mesmo fim, sem o resultado preconisado pelo povo.

Coerana ou coeraneira, (Cestrum nocturnun.)-

Planta que nasce e vegeta nos logares habitados. Seu tronco e folhas cheiram mal; suas flores brancas apenas se abrem á noite, exhalam delicioso aroma.

\section{USOS MEDICINAES}

As folhas sĩo regulares e macias: applicadas sobre qualquer chaga suja, a limpa e purifica, e lhe promove em breve a cicatrisação.

O cozimento das folhas é recommendado, para o curativo da sarna, em banhos; bem como para mitigar as hemorrhoides. Espalhadas as folhas pela casa, afugentam as pulgas; porém se o gado as come murchas ou seccas, tonteia e morre. 


\section{USOS NA INDUSTRIA}

Das flores póde-se obter uma essencia, de aroma delicioso para a perfumaria.

Capambuca. - E' arvore mui alta, cuja madeira é inole, e sú serve, para a fabricação de cinzas, para decoada. Esta arvore tem as raizes fóra da terra, em fórma de taboas, as quaes se cortam a machado, de que fazem gamellas de 5, e 6 palmos de largo.

\section{USOS MEDICINAES}

Gabriel Soares, que faz menção desta arvore, nada refere l'ella em relação a medicina dos indios.

Copinha.-Gabriel Soares diz que a copinha é uma arvore da feição do loureiro, assim na cỏr, como na casca do tronco e folhas, a qual carrega muito, de uma fructa preta. Esta arvore cresce nas costas do mar, e ao longo dos rios. A fructa come-se, e tem o sabor da uva.

\section{USOS MEDICINAES}

Não são conhecidos.

Coponyba.-Arvore de 25 palmos de altura, e de 2 de diametro. Floresce em Agosto. A sua madeira é mui direita, e muito macia, e facil á manipulação.

\section{USOS MEDICINAES}

Não são conhecidos na medicina vulgar.

USOS NAS ARTES

Até agora só se tem applicado o lenho d'esta arvore, para o fabrico do taboado, e vigotas.

Coqueiro on coco da Bania ou da Enda. (Cocos nucifera,) $\rightarrow 0$ coqueiro pertence á Asia, á Australia, a Africa e a America. E' arvore de 20 á 30 metros de altura; é assás conhecido.

\section{USOS MEDICINAES}

A agua do coco é reírigerante. e o leite se emprega contra a solitaria. 
USOS NAS ARTES E NA INDUSTRIA

Aproveita-se tudo d'este utilissimo vegetal, para a fabricação de divursos artefactos; e mesmo, para a fabricação de vinhos.

\section{- usos CUlinarios}

O oleo, e o leite do coco, além de serem medicinaes, servem nas cozinhas, para se misturar com a comida. Nas Alagôas faz-se muito uso d'elles.

Ooqueiros ou palmoiras.-Ha no Brasil 65 generos de coqueiros ou palmeiras, e 273 especies, que não as nomeio, por ser longa a nomenclatura; e todas ellas, com seus prestimos em proveito da humanidade.

Coquinho. (Phyilanthus pendulus.) - Planta indigena herbacea, conhecida nas Alagoas.

\section{USOS MEDICINAES}

E' um poderoso hemostatico, porque promptamente suspende as hemorragias de qualquer orgĩo do corpo.

Carobussú. - E' arvore como o pecegueiro, inas tem a madeira mais secca, e as folhas miudas.

\section{USOS MEDICINAES}

Gabriel soares conta, que os indios servem-se das 'iolhas pisadas desta arvore, para o curativo das bobas, pondo o sumo em cima das bostellas e chagas; e quando isto assim não basta, reduzem as folhas a carvĩo, e pulverisam as feridas, que as faz seccar logo. Tem esta planta, outros usos na medicina dos indios.

Coragão de resus. (Mihania officinalis.)-E' planta vulgar em S. Paulo, e Minas.

\section{USOS MEDICINAES}

Tem as mesmas virtudes da quina, e é empregada na dyspepsia, e nas febres intermittentes.

Coracão de negreo.-E' arvore bastante alta, com 60 palmos, e com 2 de diametro. Floresce em Outubro.

\section{USOS MEDICINAES}

Não são conhecidos. 
USOS NAS ARTES

Seu amago é negro, e serve para as obras de architectura, e marcenaria.

Coragão de trade ou do s. Hancisco: (Phlomis nepetifolia.)-E' planta conhecida em todo o Brasil. USOS MEDICINAES

Serve esta planta em binhos, para curar a dysenteria, e o rheumatismo. Tambem serve, para fortificar as criancas debeis, dando-se-lhes banhos, com o cozimento do mesmo vegetal.

Coré.-Arvore de construcção, com 60 palmos de altura, e 2 de diametro. Floresce em Outubro. Sua madeira é macia, e facil no serrar e lavrar.

USOS HEDICINAES

Nĩo são conhecidos.

USOS NAS ARTES

Sendo o seu amago pouco poroso, recebe excellente polımento, quando é empregado nas obras de architectura, e marcineria.

Coronachris. (Himosa Farnesinna) - Esta planta é mui conhecida, já pelo nome de coronachris, e já pelo de Esponjeira. E' uma leguminosa.

\section{USOS MEDICINAES}

O cozimento das folhas desta planta cura, as dores de dentes, e é antipasmodica. O cozinento da casca serve, para as dores articulares.

Cornuba.-Arvore, semelhante a aroeira de Hespanha, com as mesmas virtudes para os doentes, segundo atirma Gabriel Soares, e dá nas raizes muita resina aromatica.

\section{USOS. MEDICINAES}

A resina é empregada para a confecçĩo de balsamos. Os indios servem-se da resina em fumigações contra as dôres do corpo.

USOS NAS AR'TES

Gabriel Soares diz, que a arrore dá boa cinza, para decoada dos engenhos. 
Corroio da carde. (Ipomaca.)-E' planta trepadeira, que nasce nas margens do rio Camaragibe, nas Alagoas, e abre a flor, das 4 ás 5 horas da tarde, e feixa das 8 , ás 9 horas da manhã.

USOS MEDICINAES

Não são conhecidos.

Cotó cotó. (Palicurea densifolia.)-Arbusto semelhante a herva de rato, que produz no Rio de Janeiro, S, Paulo e Minas.

\section{USOS MEDICINAES}

o cozimento das folhas, cura o rheumatismo. A infusão em pequenas dóses, cura a dyspepsia, e a asthenia geral.

Tomada em dóse elevada, é vomitiva, e cathartica.

USOS NA INDUSTRIA

Serve para a tinturaria.

Couco.-E' arvore de construcç̃o, com 60 palmos de altura, e com dous de diametro. Floresce em Ontubro.

USOS MEDICINAES

Nĩo são conhecidos.

USOS NAS ARTES

A sua madeira, serve para portas, e outros usos.

Cozrve. (Brassica crispa.)--E' planta vulgar e alimenticia.

USOS MEDICIN.AES

A couve verde, é boa para os tremores dos membros, e fraqueza da vista, e contra a embriaguez; o seu primeiro cozimento laxa o ventre; a semente da couve, serve para curar a colíca; as folhas passadas ao lume, aproveitam na gotta dos pés.

\section{USOS CULINARIOS}

E' a principal verdura, no cozido das mesas.

Còvinha do matto.-Planta mui conhecida, no Rio de Janeiro, que nasce sem cultura, principalmente nos logares sombreados. 


\section{USOS MEDICINAES}

O cozimento feito com esta planta, é de grande proveito para as inflamımações testiculares, e para as molestias do utero.

Orajux'ú.-Panta sarmentosa.

\section{USOS NA INUUSTRIA}

Os indios do Rio Negro, extrahem uma fecula, servindo-se do mesmo processo, do da extração do anil. Esta fecula é de côr carmezim, muito procurada na pintura, por se dar bem com os oleos.

\section{USOS MEDICINAES}

Não são conhecidos.

Craveiro. (Caryophillus hortensis.)-E' planta mui conhecida nos jardins.

\section{USOS MEDICINAES}

A flor dos mais pequenos, encarnados, cheirosos, e dos maiores, feita em chá é cordeal, cepholica, contra a epilepsia, antiparalytica, contra a vertigem, contra o veneno das cobras, e promove os suores.

Cravo.-E' arvore corpulenta, de 40 palmos de altura, e dous de diametro. Floresce em Outubro. O seu nome provém de que, cortada de fresco a arvore exhala, um aroma semelhante ao do cravo da India. Machucadas as folhas, recendem o mesmo aroma.

\section{USOS MEDICINAES}

A infusão das folhas são empregadas nas flatulencias.

\section{USOS NAS ARTES}

Emprega-se a madeira, para frechaes de casas.

\section{USOS NA INDUSTRIA}

Os industriaes podem tirar d'este vegetal muito proveito, quando se servirem d'elle na perfumaria.

Cravo de dofunto. (Cariophyllus major.) - Cresce na Barbaria, na Italia, pelos campos; no Brasil vegeta nos jardins. E' mui vulgar. 


\section{USOS MEDICINAES}

A semente é de natureza quente, e secca; e a sua virtude é deterciva, purgativa e aperitiva; tem emprego nas affeccõos uterinas.

o cravo de defunto dobrado, emprega-se com proveito em banhos, no rheumatismo.

Cravo da Trdia. (Caryophillus aromaticus.)-Arvore semelhante ao louro, com as folhas mais estreitas. As flores mudam de côr, endurecendo-se e formam os cravos. Nascem nas Molucas, e se dão mui bem no Brasil, e particularmente no Maranhão e Pará, e na Bahia.

I:SOS MEDICINAES

A agua distillada dos cravos recentes, cheira maravilhosamente, e bebida, conforta o coracão. Serve para combater o humor syphilitico e bobatico, provocando suores.

E' tanibem proveitosa para o estomago, e para confortar o figado; ajuda a digestĩo, mas convém não abusar, porque adstringe o ventre. 0 oleo do cravo, cura a dôr de dentes.

\section{LSOS NA INDUSTRIA}

O oleo de cravo serve para a perfumaria.

Cravo do Maraminäo. (Laurus borbonic.)-O vegetal que nos fornece esta especiaria, habita as margens dos rios Capim, Nauhé e outros; a extraccão da sua casca, tem o mesmo methodo, da extraccĩo das canelleiras, com que tem identidade, e em ter oləo volatil, desce as suas primeiras ramificações, até as suas raizes capillares; ha com abundancia, e se obteria com profú ão. se no modo de o extrahir, rão louvesse tanta barbaridade, de maneirn que, mais parece que querem extinguil-a, do que tirar vantagem, com que as florestas mimoseam generosa e expontaneamente ; muito maior é o escandalo, desde que a ignorancia se persuadio, que a raiz d'esta mimosa producção natural, era mais aromatica do que os seus troncos.

Com dôr o dizemos : em poucos annos, não haverá uma só arvore de cravo do Maranhão, se o governo não lançar um beuigno olhar sobre esta, ccmo sobre outras arvores de utilidade real. 
Cista de gallo ou Pedegoso de lerinambuco, (Heliotropum utilissimuin )-Arbusto conhecido, que folga nos logares humidos. Suas folhas sũo asperas, e as flores em fôrma de espigas tortnosas, simulando a crista do gallo. Por sobre estas cristas, so observa uma serie de campanulas brancas, ou roxas, que dĩo um aspecto engraçalo a inflorescencia.

\section{USOS MEDICINAES}

Os seus usos medicinaes são mui conhecidos do povo, e particularmente no curativo das chagas chronicas.

Cubobas.-E' uma trepadeira, que pruduz fruçto semeIhante a pimenta da India.

\section{tSOS ME?CINAES}

Emprega-se o fructo secco. em melicina. Conforta o cerebro, provoca o appetite, e é medicamento conhecido, para as gonorrheas.

Curzeri.-E' arrore que abunda no Malanhĩo, e pronuz o cravo chamado do Maranhão.

\section{USOS VEDCHANS}

São os mesmos que os do cravo da India,

Cucira, centé. caldaceira, cria volde, cabaco de cuia. (Mycarpora pubecens.)-E' arvore de 20 a 30 palmos, com um e meio de grossura, um pouco esgalhada. Floresce em Outubro. Ordinariamente os fructos sĩo espheroides, e esverdinhados, de que o poro se serve para o fabrico de cuias.

\section{USOS MEDICINAES}

O miolo da fructa é empregado, como poderoso resolutivo dos tumores, applicado sobre elles. O miolo é de um amargo extraordinario. Resolve as carnosidades testiculares, usando-se do modo seguinte: faz-se um biraco. pelo qual possa entrar o testiculo, inchado, ou quando mui volumoso, assa-se a fructa ao rescardo, e ainda quente, parte-se a fructa, tira-se parte do miolo, e mete-se o testiculo dentro. Esta operaça se repete algumas vezes.

E' tambem efficaz nas contusões, mettendo-se uma porção de 
assucar dentro, e pondo-se a cuia no rescaldo, e depois de cozidu assim o miolo, espreme-se, côa-se, deste liquido bebe-se pequena porçäo, pela manhã e á noite. Tambem serve o Iiquido do miolo quente para curar a erysipela, e o cabrelo applicando-se ans logares inflammados.

Misturado o miolo em azeite de mamona, e untandc-se ao redor. do anus, aproveita ás hemorrhoides.

Cubataia. (Parí.)-O Dr. Lacerda falla d'esta planta. dizendo, ser ella caustica. Não sei se ella é, a que nas Alagòas chamam Louco, que igualmente é caustica.

\section{USOS MEDICINAES}

E' empresada em cozimento, para curar os corrimentos venereos. Faz-se fricções com as folhas, sobre as dores rheumaticas: mas as folhas derem ir entre dous pannos, sem o que produz o effeito do caustico.

Cuipana. (Myrcia Tingens.)-Arvore brasileira, e conhecida no norte do Brasil.

\section{LSOS MEDICINAES}

O succo da casca d'esta arrore, misturado com agua, é empregado para o curativo de feridas.

\section{USOS NA INDUSTRLA}

Da casca desta arrore se extrahe tinta, que póde ser empregada na tinturaria.

Cuiprora.--E' uma planta semelhante a murta, que regeta pelos campos da Bahia, e dá flores aromaticas, como as da murta.

\section{USOS MEDICINAES}

Gabriel Soares diz, que no seu tempo, na Santa Casa da Misericordia da Bahia se fazia uso da planta cuipuera, para cura dos penitentes, e para todos os lavatorios de ulceras, porque ella tem virtude dissecativa, ou vulneraria.

Cuipuna. (Leptos permuntinctorum.)-E' arvore de grandeza mediana, cujas flores amarellas, apparecem em Setembro, 


\section{USOS MEDICINAES}

o sumo das flores fervido em agua da fonte, serve para curar. as chagas chronicas, e purulentas.

USOS NA INDUSTRIA

Do entrecasco, os indios, extrahem um succo glutinoso, com que envernisam as cuias, e outras obras de seus uzos. Pizada a casca com agua, dí excellente tinta preta, para a escripta, e para a tinturaria.

Cuinc-cannia. (Pará.)-Planta que vegeta nas mattas do Rio Mojú, e dá leite adocicado

\section{USOS MEDICINAES}

Os naturaes empregam o cozimento d'esta planta em banhos, nas dores do ventre, e para limpar as feridas chronicas.

Cunuacahy.-Planta do Pará.

USOS MEDICINAES

A gomma, que se extrahe da raiz d'esta planta, dada a beber, ao enfermo de paralysia, é efficaz o seu effeito.

Cumaxia, - Arvore corpulenta, que produz a preciosa semente, a que os francezes de Cayenna chamam Guayac, pelo muito oleo que em si contém; e pelo seu emaranhado tecido fibroso, possue uma madeira boa de construcção.

\section{USOS MEDICINAES}

A semente é nervina, estomachica, e tortificante do cerebro.

USO NAS ARTES

A madeira é empregada em cylindros dos engenlos de moel canna.

\section{LSO NA INDUSTRIA}

A fava que produz esta arvore, é empregada para aromatisar o rapé, sendo ella vendida no mercado, com o nome de fà

Cumaty.-E' arvore do Pará, de ruuita estimação pelos seus prestimos, em medicina, e na pintura. 


\section{LSOS MEDICINAES}

Póde-se empregar externamente, no curativo das ulceras chronicas.

\section{USOS NA INDUSTRIA}

E' igualmente o melhor mordente vegetal que se conhece.

Cumbarér ou cumarí. (Dipterrx odorata.) Pará.() cumbarú é arvore colossal, mui conhecida no alto Amazonas. Floresce e fructifica, sendo o seu fructo um legume ovoide, contendo uma unica semente, branca por dentro, tendo a pelicula de fóra escura.

USOS MEDICINAES

A tintura feita com a fava é cordial, nervina, emenagoga, e diuretica: aproveita o cozimento da casca na syphilis. Dizeri, que a casca d'esta arrore, fóde substituir o guaiaco.

\section{USOS SOCIAES E NA INDUSTRIA}

A semente é aromatica, e serve para aromatisar a roupa, e preserval-a dos insectos. Como é mui suave o aroma, servem-se da fava para deitar no rapé.

Cominsoos. (Cuminum satiutm.) - E' planta cultivada nas hnrtas, e mui conhecida.

\section{LSOS MEDICINAES}

A sua natureza, é quente e secca: carminativo, mui estomacal. E' dissecativo, diuretico, e provoca os menstruos. Faz desinchar os testiculos, misturados com passas, ou postos pisados em banha de porco, com um pouquinho de antimonio em pú.

Gunamby on conabi.-(Phyllanthus conambi.)-E' planta que vegeta no Pará, de um cheiro vigoroso, muito usada dos indios.

ISOS MEDICINAES

Os indios usam d'ella, como diuretica, nas molestias das vias ourinarias, na diabetes, e retencão de ourinas.

Convém ter cautela na administraçĩo medicamentosa d'esta planta, pela propriedade narcotica que possue. As folhas pisadas, e postas no rio, embebedam os peixes. 


\section{Cunuarú ou kesina de sapo. (Lacerda.)}

\section{USOS MEDICINAES}

As fumiqgaçoes d'esta resina, curam as dôres de cabeça.

Cupahuxama. (Pará.)-Esta planta, que vegeta no Pará. è empregada em medicina vulgar.

\section{LSOS MEDICINAES}

Os naturaes do Pará empregam o cozimento d'esta planta em meios banhos, no resfriamento uterino, e nas ulceras dos olhos. Tambem servem-se do succo da planta, misturado com clara de ovo, para as feridas dos olhos.

Cupayba. (Tupy.) Coparnya, cupauba. oleo preto. (Copaifera officinalis.)-E' arvore de grande altura, direita, com 150 palmos, e 24 e mais de grossura. Tem casca cinzenta ou esbranquiçada. Floresce em Outubro, e produz o oleo conhecido por todos. que se extrahe, ferindo-se a arvore na conjuncção da lua cheia, e principalmente na lua cheia de Janeiro, em que a arvore dá extraordinaria abundancia. de oleo.

O máo processo de extrahir o oleo, tem causado grande destruiçĩo d'esta admirarel, e util arvore.

\section{USOS MEDICINAES}

o oleo de cupahyba, usa-se de tres modos em mediciıa: o $1^{\circ}$, pela bocca; o 2, em fricçoes : e o $3^{\circ}$ é especial, misturando-se com outras substancias.

1. Toma-se pela bocea em jejum, em uma gemma de ovo, ou em uma colher de caldo, ou em vinho, quatro ou cinco pingos de oleo de cupahyba, cura a asthma, as dòres da bexiga; tira as dôres inveteradas do estomago; aproveita aos tysicos; combate as inflammaçoes chronicas do figado; facilita a transpiração insensivel; cura as oplações, fortifica nervos; faz tor. nar a côr perfeita do rosto; conforta e purifica o bafo da bocca ; combate as febres continuas, e as intermittentes, tomando - oleo antes do apparecimento do accesso; cura as gonorrheas; i) contra as epidemias, causadas por miasmas deleterios; conserva as forcas viris, e cura as roturas; cura as dysenterias chronicas mui rebeldes. 
2 - modo, em unturas e fricçoes, para curar as feridas frescas, especialmente as da cabeça, applicado o oleo quente, cura as contusões, e faz desinchar; limpa as chagas velhas, os cancros, e mina as cicatrizes mal formadas; desembaraca a circulação nervosa; cura todas as dôres causadas de frialdades, ou ventosidade, untando a parte dorida; conforta e preserva o cerebro, e tira todos os humores do mesmo, os vapores que comprimem o mesmo cerebro, esfregando-se com o oleo as fontes, a nuca, a espinha, e a parte enferma; fortifica o estomago, fazendo-se fomentações, desvanece os flatos; desobstrue o baço, pondo-se o oleo quente sobre o logar; tira as dôres provocadas pelas pedras e areias da bexiga e rins; mitiga as dôres do ventre, e dos dentes, esfregando a nuca, da parte da dôr : faz desapparecer as dôres de colicas do ventre, por acumulo de ar, esfregando-se o umbigo com oleo; tira e cura as empingens, e fogo selvagem; restabelece a saude do utero, e sempre que se empregar o oleo de cupahyba seja quente. Cura a erysipela, e a elephantiasis.

3. ${ }^{\circ}$ modo, mistura-se o oleo com clara de oro, e unta-se o rosto, para tirar a vermelhidão d'esta parte, e as nodoas, e mesmo as sardas.

\section{ISOS NAS ARTES}

o seu lenho, serve para mastros, mastaréos, e vergas. o taboado é mui precioso, para varias obras de marcenaria.

\section{LSOS NA INDUSTRIA}

O oleo serve aos pintores, para dar consistencia á côr rerde, e com preferencia, para polimento de encarnar.

\section{VARIEDADES}

Ha grande variedade d'esta arvore, a que chamam cupahyba de oleo vermelho, branco, pardo, macho, femea, servindo todas para os mesmos usos.

Diz o Dr. Lacerda, que é poderoso remedio para curar as bicheiras dos animaes, porque as preserva das moscas.

Curaree. - o curare é um veneno vegetal agudissimo, preparado pelos indios, extrahido de uma planta, ou nós, do genero strychnos, com o qual envenenam as flexas. 
USOS E ACÇÃo DO CURARE

Introduzido no corpo, ou mata em pouco tempo, ou entorpece o individuo.

Nào se tem tirado resultado algum na therapentica.

Curnatí.-Este vegetal é mui commum no Maranhão, e no Pará.

\section{USOS MEDICINAES}

o Dr. Lacerda affirma, ser especial medicamento, para curar a diabetis.

Curupicanyghba.-E' arvore corpolenta, das nossas norestas, a qual pela incisão dá um leite viscoso, e medicinal.

\section{USOS MEDICINAES}

Os indios servem-se do leite d'esta arvore, para curar as feridas Prescas e velhas, e para o curativo das bôbas em particular. Dizem, que nas feridas onde é applicado o laite, não deixa signal algum de cicatriz. 0 succo da planta misturado com agua, e hebido, estanca o sangue pela bocca:

Cururé ou planta do sait. (Rio Negro.) - Nas rochas, que constituem as cachoeiras do Rio Negro, cresce uma planta de folhas carnudas e mui salitrosas, a que os naturaes dão o nome de Cururé. Desenvolvem-se em grande abundancia, e fórmam assim sobre as pedras, um como colchão macio, por onde facilmente escorregam as canóas, sem que soffram a menor avaria. Os moradores vizinhos, principalmente os indios, aproveitam-se d'ella, para extrahirem o sal, de que fazem uso; de modo que o cururé, é um recurso indispensavel, para o poro do Alto Rio Negro.

Cutir.ibá. Pará. (Dr. Lacerda.)-E' planta conhecida no Pará.

\section{USOS MEDICINAES}

E* empregada na dor dos ouvidos. Rala-se a semente, e mistura-se com leite de peito. e embebendo-se em algodão, espreme-se no ouvido. Se a dor não passa logo, repete-se, e do mesmo modo. 
Outucaom. - Arvore de 40 palmos de elevaçĩo, com dous de diametro. Floresce em Setembro, e Outubro.

\section{USOS MEDICINATS}

Não são conhecidos.

\section{USOS NAS ARTES}

Serve a sua madeira para taboados, vigas, frechaes e para obras do mar.

Cututurilba. (Maranhão.)-Planta conhecida no Maranhão, e que tem emprego na medicina popular.

\section{USOS MEDICINAES}

A semente desta planta pisada, e misturada com leite de peito, posta em algodão no ouvido, cura a dor deste orgão.

Cypreste. (Cupressus.)-E' arvore conhecida como symholo da tristeza e da morte. A sua natureza é quente e secca.

\section{USOS MIEDICINAES}

0 fructo do cypreste cura a dysenteria, herneas, e gonorrheas, por sua adestringencia, bebida em cozimento, e em banhos. 0 cozimento feito em vinagre, faz passar a dor de dentes, tomado em bochechos. O cozimento em vinho branco, tomado 3 oncas carla dia, cura as herneas, e fumentando os testiculos, com as folhas pisadas. Garante-se a efficacia.

\section{USOS PARTICULARES E NA INDUSTRIA}

o fumo das folhas e do lenho afuqenta os mosquitos, e os ramos metidos entre os vestidos, preserva-os da traça.

Dadocommenda. (Lacerda.) -Esta planta é uma parasita, de folhas semelhantes a da Taioba, muito conhecida em quasi todas as proviacias do Brasil, porque regeta pegada is arvores, das quaes se sustenta. 


\section{USOS MEDICINAES}

- Dr. Lacerda, que fez experiencias com esta parasita, aftirma, ser ella conveniente, para curar feridas, quer em cozimento, e quer em pó. Tambem as folhas passadas pelo ar do fogo. e postas sobre as feridas ou chagas vellas, as faz purgar muito, e promove a cicatrisação em pouco tempo.

Dandá.-Planta que produz nas mattas da provincia de Sergipe : é uma especie de Licoriseiro, donde se extrahe suave, e proveitoso purgante.

\section{USOS MEDICINAES}

o purgante, do Dandá é empregado nas feores, provenientes te ervsipelas, nas obstrucç̃os do baço, e nas affecções hemorrhoidaes.

Damasqueiro. (Prunus Armeniaca majora.)-Arrore, que produz o Damasco, especie de Pecegueiro, que foi aclimatado na America do Sul. Seu fructo é de natureza frio, e humido. os damascos comendo-se em demasia, causam indigestão. Ha varias especies.

\section{USOS MEDICINAES}

() oleo extrahido da amendoa, é proveitoso, para curar as hemorrhoidas inflammadas, untando-se o anus; e bebido, convem nas dores de colicas.

USOS DONESTICOS

Não se abusando é mui agradavel, para se comer, e não produz mal algum.

Dendezeiro. (Elais guinecensis.) - Geralmente é conhecida esta palmeira, por todos; e abunda em qualquer parte do Brasil. Dá precioso fructo, com que enriquece o cacho, e de que se extrahe azeite saborosissimo.

USOS MEDICINAES

O oleo amarello é empregado na erysipella, no rheumatismo, no panaricio, para amadurecer as apostemas, e untado nos pás. preserva-os dos bichos. 


\section{USOS NA INDUSTRIA}

No logar em que a palma está presa ao estipo, dá um pello, como de velludo, que tirado e misturado com a cinza das folhas maduras da bananeira, em termos que uma libra de pello, se ajunte uma quarta parte de cinza, trabalhado as mãos, e cora lo ao sol, é optima isca, para o fogo, extrahido por meio do fusil. Do fructo, quando maduro. se extrahe dous oleos differentes, um amarello, que estí entre a casca da fructa, e o caroço, e outro branco, contido na amendoa. O processo da extrac ão de ambos, é muito vulgar.

Com o oleo amarello. se fabrica excellente sabão; e com o oleo branco, mimosos sabonetes para lavar o rosto, e para as mãos.

\section{LSOS NAS ARTES}

O tronco de arvore serve para alguns misteres, no fabrico das casas. Com a palha sa fazem balaios, e paracuns, muito apreciados nas Alagoas e Pernambuco.

USOS CULINARIOS

Tanto o oleo amarello, como o branco, é muito usado, para adubo das comidas, principalmente o oleo ou azeite de cheiro, que è muito procurado, para a confecção do cararú e vatapá. O oleo branco, empregam-no na fritagem do peixe, nas luzes, etc.

Debata cascucko.-Arvore das mattas das Alagóas, e Pernambuco.

USOS MEDICINAES

Não s̃̃o conhecidos.

USOS NAS ARTES

o seu lenho é tão consistente, que cóga os mashados na derlubada. Serve para construcção naval.

Diconrozue ou feijão dos caboclos. (T'rophis.)-Arvore, das mattas virge.ıs do Brasil : produz fructos, que encerram feijões, que, cozidos, têm o sahor do feijão preto, e de que se servem os indios, para alimentação.

O Dr. Peckolt, fez analyse chimica dos grãos da fructa do diconroque, e reconheceu, serem os grãos apropriados á alimentação. 
USOS MEDICINAES

Não são conhecidos.

tSOS CULINARIOS

Cozidos são comestiveis.

Dormideiras ou papoulas. (Papaver hortensis.)Ha duas qualidades de durmileiras: brasca, e verıeelha. E' assáz co.llecida.

\section{USOS MEDICINAES}

As sementes misturadas com pão, e comidas, conciliam o somno; serve aos que padecen de vertigens; o sumo tem mais força; mas é periguso. O opio é extrahilu do sumo, que se extrahe das cabeças: mitiga as dôres, priıcipalmente da cabeça, fir dormir, mitiga a tusse, fucilita o esuarro. E' convesieute na asthma, nos cutarlios iaveteruos, e nos pleurizes.

Dorstonia. (Caapiá ou crntra herva)-Esta herva brasileira, foi estadada pur varius butanicos, como Pison e Maregrave, Ber.ıardiıo A.tonio Gomes e pelo Dr. Manuel Joaquim Henrique de Paiva, que a estudou no Rlo de Janeiro, no estądo de viva, e flurescente; e o.ıde reconheceu duas especies, tendo ambas raizes arumaticas e um tanto amargosas.

o nome de dorstenia, que lhe deram, foi em honra do botanico allemão Dorsten.

\section{USOS MBDICINAES}

E' corroborante e estimulante.

Empregam-u’a em tudas as enfermidades, em que convém a contra herva, e principalmeite nas febres podres.

Douradinha do campo. (Palicourea rigida.)-E' arbusts conhecido.

\section{USOS MEDICINAES}

E' diuretica, e muito proveitosa no rheumatismo, tomada em infusão.

Douradinha, papa terra, matacana. (Waiteria douradinha.)-Esta planta vegeta em quasi todo o Brasil. Tem'o aroma desagradarel, sabor amargo, e nauzeoso. 


\section{USOS MEDICINAES}

E' emetica, anti-dysentherica, sudorifica, irritante da membrana mucosa das vias ourinarias. E' bom medicamento, para as molestias do peito, e contra a tosse.

Drag̃o fedorento. (Monstera.)-E' planta trepadeira da ordem do cipó imbé.

\section{USOS MEDICINAES}

Pisada à planta, e applicada á face, cura a inflammação do ouvido. A raiz, é um poderoso cauterio, nas feridas produzidas por mordedura de cobras.

\section{E}

Ebano ou tecoma. (Leucoxilon.)-Arvore do Brasil, da Goyana, e das Antilhas, de textura finissima.

\section{USOS MEDICINAES}

Não são conhecidos.

USOS NAS ARTES

Serve para a marcenaria, e é incorruptivel ao tempo.

Egrio. (Narturtium pumilum.)-E' um arbusto vulgal. USOS MEDICINAES

E' anti-espasmodico, e empregado contra o catharro pulmonar. USOS ORDINARIOS

Usam d'esta planta em salada, em algumas mesas de lamilia, nas provincias do norte.

Elemi ou almecogueira. (Amirys hecteophilla on amirys elemifera.) -E' arvore do Brasil, conhecida pelo nome de almecegueira, e que distilla uma resina aromatica, molle. que depois endurece, mas fica quebradiça.

\section{USOS MEDICINAES}

Com a resina elemi ou almecega, se prepara o balsamo de 
arcêo, que é o melhor digestivo, para curar as feridas de qualquer natureza, no Brasil.

\section{USOS NA INDUSTRIA}

Nas Alagòas servem-se da almecega, para brêar as cancas.

Fmbauba ou umbauba. - E' um regetal semethante ao manoeiro, tendo o tronco ôco.

E' urna planta mui conhecida no Brasil.

\section{USOS MEDICINAES}

Os olhos, e fructos da embauba, feito xarope, ou mesmo cozimento, é muito recoımendado, para curar a tysica.

Os olhos d'esta planta pisados com sal, e postos sobre os tumores, os reso!ve.

Fimbira araticum.-Arvore de 40 palmos de altura. com dous de diametro. Floresce em Outubro.

USOS MEDICINAES

Não sũo conhecidos.

USOS NAS ARTES

Serve o seu lenho para a carpintaria, e para taboado.

Embira prota ou vermelha. (Couratoria ardentis.)-Arvore do Brasil, mui conhrecida nas A'agôas, e Pernambuco. Floresce e fructifica em Setembro, e Outubro.

\section{USOS MEDICINAES}

A casca interna, de sabor doce, pilada, e posta em maceração, e dado o liquido, com bebida ordinaria, cura as enfermidades das vias ourinarias. Serve tambem, para curar feridas velhas, para as cortaduras on golpes.

\section{USOS NAS ARTES}

o seu lenho, è o melhor combustivel que se conhece; e ganhando fogo não se apaga.

Serve para esteio de casas, é indestructivel, e tem a propriedade de solidificar os terrenos, onde os esteios são fincados.

Embira vordadeira ou semento de embira.-E' arvore de 40 palmos de altura, e de um e meio de grossura. Floresce e fructifica em setembro. 


\section{USOS MEDICINAES}

o fructo é de sabor pian ite. e serve, infundido em aguaardeate, para carur as flut lleacias, e as colicas ventosas.

\section{USOS N.IS ARTES}

A madeira serve para diversas obras.

Embiratan a o u brerizuda do sortão.Arvore mui co.ıhecila, que fl resee em Setembro. De.stro do

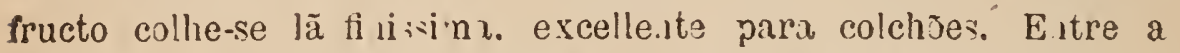
lã se eacostra uma ameıloa, que dí bom azeite para luz.

\section{USOS MEDICINAES}

o oleo d'esta arvore, serve para a desa'struccĩo do firado; e o entrecasco, feito cataplisma, prodiz o mestno effeito.

o cizimento da casca serve, para curar as feridas causadas pelo fogo.

Embirussí.-Arvore corpolenta das nossas mattas, de 60 a 70 palmos de altura, e 4 de diametro, que prodiz muita resiala. Floresie em Sutembro. e folga em terie.ıs furtes. Di fructo.

USOS MEDICINAES

Não são conhecidos.

\section{USO NAS ARTES E NA INDUSTRIA}

A resina, serve para soldar qualquer objecto quebrado, e dá luz; e póde substituir o breu, para os usos dos navios. 'Do eatrecasco tira-se excelle.ite embira, prupria para fabricar chaṕos e cordas. Póde dar materia prima, para a fabricação do papel.

o seu lenho é reverso, e serve, para a fabricação de canôas, para frechaes, ripas e vigas Do fructo se colhe la fina, de cor pardace.ıta, excellente para colchres e travesseiros.

Embirussú da costa.-E' arvore de 60 jalmos de alto, com 4 de grossura. A sua madeira é reversa no serrar e lavrar.

\section{USOS MEDICINAES}

Serve a sua casca, para curar a obstrncção do figado.

$$
\text { USOS NAS ARTES }
$$

o sen lenho é empregado em diversas obras de carpintaria. 
Fmburana ou Umburana.-E' arrore que vegeta em terrenos seccos, dos nossos sertões, e dá fructos saburoros, com os quaes se fazem deliciosas limonadas, e mesmo excellente doce e gelea.

\section{USOS MEDICINAES}

o seu extracto é contra o veneno das cobras, e as suas folhas são empregadas pelus sertancjos, para curar feridas.

Fmburoma ou Tamanqueira. (Pará.) - E' arvore do Amazonas

\section{USOS MEDICINAES}

No Pará serrem-se da casca desta arvore, em banhos, para curar as dores uterinas, e se diz que é aburtiva.

Encacia.-Arvore de casca grossa, amarga e adstringente.

\section{USOS MEDICINAES}

O cozimento, serve para curar feridas velhas, e é empregado como cuntra-veneuo das cobras.

\section{USOS NAS ARTES}

o seu lenho, serve para a construcção de casas.

Enxerto do passarinho. (Lorunthus brusiliensis.) Planta parasita, que vive solre olitras. Este vegetal, é o emblema dos radios, que virem á custa dos que traballiam, como os homens politicos, que fazem, por via do enredo, da intiga, e do palar vrorio, dos re dimentos do Estado, o seu patrimouio, para viverem.

\section{USOS MEDICINAES}

A que rasce, e se sustenta da seiva do cajueiro, serve para curar as feridas uterinas, feita cczimento, e dala em seringatorios. No lugar em que nasce, na arvore, fórma uma especie de batata, que soccada ou machucada. cura as f'eridas, pulverisadas com elle. Usam tambem d'ella em cuzimeuto, has molestias do peito.

Isconde fozo. (Chaenophera cryrtofrcus.)-Arvore po quena, conhecida nas Alagòas pur este uome. 


\section{USOS MIEDICINAES}

Não ธão conhecidos.

PROIRIEDADE SINGULAR PARA A INDUSTRIA

o páo d'esta arvore, esconde o fogo de tal modo, que parece estar apagado, quando se o tira da fornalha, ou debaixo da trempe; mas soprando-se, apparece repentiıamente fogo acceso.

A industria, poderia tirar proveito d'esta arvore singular.

Eisparso. (Spargo sativa.)-E' planta conhecida, e muito apreciada nas mesas, e mesmo em medicina pratica. Ha espar. gos silvestres, e hortenses. Cultivam-se no Rio de Janeiro.

\section{USOS MEDICINAES}

Provocam as ourinas, e desobstruem o figado, e o baço; limpam os rins e a bexiga, mas se se comer em demasia, e amiudalas vezes, fazem chaga na lexị̣a. São aperitivos, prorocam a menstruac̃a, e fazem estereis as mulheres, que abusam d'elle. Empregam-se os talos e as raizes, para o uso da medicira.

Espolina. (Perianthopodus tomba)-Planta conhecida em S. Paulo, e em Santa Catharina.

USOS METICINAES

E' purgativa, e antidoto de qualquer veneno. Em S. Paulo, é esta plauta conhecida e apreciada.

Espiga de sangue. (Helnisis brasiliensis.)-E' una parasyta, que sustenta-se das raizes da ortiga branca.

USOS MEDICINAES

As flores e a batata que produz, é remedio presentaneo con tra as hemorrhagias, e contra a diarrhéa.

Espinheiro. (Mimosa.)-Arvore de 70 e mais palmos, com tres de diamietrn. Floresce em Setembro. o leıho é ama.rello. Ha duas qualidades: macho, e femea.

USOS MEDICINAES

'o Dr. Lacerda diz que no Maranhão, curam o carbunculo com a cinza do espinheiro. 
USOS NA INDUSTRIA

Do lenho se extrahe bonita tinta amarella.

Espinha de carneiro. (Yanthium macrocarpum.) -Planta que vegeta no Rio Grande do Sul.

\section{USOS MEDICINAES}

Dada em banhos, resolve os tumores frios.

Espirradeira. (Nerium oleander.)-E' esta planta conhecida nos jardins.

\section{USOS MEDICINAES}

Não são conhecidos os seus prestimos; convém ser estudada em proveito da therapeutica.

Esponja ou tabaco da Mndia.-Pequeno arbusto, de cor atabacada, conhecido no norte do Brasil.

\section{LSOS MEDICINAES}

o cozimento d'esta planta, serve para estancar o fluxo de sangue da cava dos dentes, quando são extralidos.

Tambem servem-se d'ella, mettendo na cava do dente, e cobrindo com cêra.

Estoranue ou Baisamo. (Storax officinarum.)Vegetal que produz nas Alagoas, Bahia e Minas Geraes, e alli mui conhecido, pela gomma resina, muito aromatica que produz.

\section{USOS MEDICINAES}

E' estimulante, e o balsamo emprega-se no curativo das ulceras chronicas, na leucorrhéa, e goriorrháas, em fórma de pillulas. Servem-se do estoraque em fórma de emplastro, como fortificante: usam d'elle para tosse, rouquidão, na difficuldade de respirar; alegra o curacão, e provoca o somno, tomando muitas vezcs, e em dóse elevada.

\section{USOS NA INDUSTRIA.}

Entra na composição das pastilhas aromaticas, pela fragrancia do seu aroma.

Estramonio. (Datura stramonium.)-0 povo conhece esta planta, pelo nome de figueira do iuferno. 


\section{USOS MEDICINAES}

E' empregada contra a asthma, e rheumatismo tomada em pequena dóse; mas, em maior quantidade, produz vertigem, somnolencia, vomitos, delirios, agitação, ardor na garganta, e mesmo a morte.

Estaca cavallo. (Gratiola.)-Planta conhecida nas Alagoas, e Pernambuco.

\section{USOS MEDICINAES}

E' purgativa, e deleteria.

Fstanca sangrue. (Chrysocoma sanguinea.)-E' um cipó conhecida nas Alagoas, por este nome.

\section{USOS MEDICINAES}

o cozimento é empregado, para suspender as hemorrhagias intermittentes; é externanente applicado para curar os golpes e ferimentos.

Estoupa de boi.-Arvore de 50 palmos de altura, e 2 de diametro.

\section{USOS MEDICINAES}

Não săo conhecidos.

\section{USOS NAS ARTES}

Serve para frechaes, e vigotas.

Euphorbia. Aputy ou Rastoirinua.-E' planta conbecida e leitosa.

\section{USOS MEDICINAES}

o cozimento feito com esta planta, e bebido. cura as hydropesias; e o leite posto nos olhos, cura a inflammação.

\section{F}

Faia.-Arvore de 30 palmos de altura, e cum um de grossura. As flures despontam em Setembio. 


\section{USOS MEDICINAES}

Não são conhecidos.

USOS NAS ARTES

o seu lenho serve, para a fabricação de instrumentos de musica.

Fava. (Vicia sativa.)-E' uma leguminosa, mui conhecida, 'a que os Indios chamam omenda. D'esta leguminr sa, ha uma grande variedade, que as não meńciono por serem vulgares.

\section{USOS MEDICINAES}

As folhas são emolientes e resolutivas.

\section{USCS ALIMENTICIOS}

As favas são alimento sadio e nutriente.

Fava.-Arrore de 60 palmos, com dous de diametro; floresse em Outubro, produzindo uma fava redouda, côr de rosa luzente, muits dura.

\section{USOS MEDICINAES}

Não são conhecidos.

\section{USOS NAS ARTES}

o seu lenho, por ser muito compacto, é empregado em obras de duracão, e na architectura civil.

Fava do cobra. (Bignonia opnidiana.)-E' planta tre padeira, senielliante ao cipo de cesto, e conhecida nas Alagôas.

\section{USOS MEDICINEES}

E' contra o veneno das cobras.

Fava do matco. - E' planta conhecida no norte do Brasil.

\section{USOS MEDICINAES .}

o miolo da fara ralado, e misturado com um pouco de pedra hume, cura a empigem, esfregando-se a parte enferma.

Fava do santo Imancio ou Guapora. (FGvillea trilobata.)-E' planta trepadeira. 


\section{USOS MEIICINAES}

O ol ?:0 extrahido das sementes é amargoso, e serve para curar a ictericia, as molestias nervosas.

Faya iguassí. (Dr. Lucerda.)-Herva que deixa sahir da sua raiz quaıtidade de folhas grandes, com talos como da hananeira; sendo a raiz comprida, e alva.

\section{USOS MEDICINAES}

Internamente serve, para os que padecem de aposthemas internas. A raiz pisada e feita cataplasma, e posta sobre os tumores os resolve.

Fedogoso ou Mangirloba ou Pío Mangirioba. (Tiaridium utilissimum.)-Arbusto conhecido, a que os inlios chamam Tararaçi.

\section{USOS MEDICINAES}

Gabriel Soares diz, que as folhas d'esta planta deitam muito sumo, se as pisam, o qual de natureza é muitu frio, e serve para desafogar as chagas; com este sumo, curam o anus dos indios e das gallinhas, porque criam n'elle muitas vezes bichos, de que morrem, se the não acodem em tempo Os olhos comem os indios doentes de boubas, e outras pessoas, e dizem acharem-se bem com elles, e affirma-se, que esta é a salsaparrilha "das Antilhas.

A raiz cozida, é especial remedio contra as erysipelas, febres malignas, e defluxão do peito. O chí feito com as fulhes, serve para quem padece calores no ventro, e dureza n'elle, com accunnulo de veatosidades. As flores e ollos d'esta planta, é remedio presentaneo, para quem pa lece prisão de ventre. As sementes turradas, dão excellente café medicinal.

Empre ̧am o fede ̧oso, como calmante do systema-nervoso, e para curar a paralysia, a asthma, a tosse convulsa, os catarrhos pulmonares, as suffocações, e a tisica tuberculosa.

Federal, amor dos vehros, espinino gua. bireú. (Silphium anti-dysenterica.) Planta conhecida nas Ala. góas, pelo nome de amor dos velhos; no Cearáa pelo de Federal; na Bahia pelo de Federação; e em Pernambuco pelo de espinho guaburu. 
USOS MEDICINAES

o cozimento d'esta planta em bochechos, cura as dôres de dentes; tomado en fórma de chá, cura as dyarrhéas chroni. cas; e em fórma de banhos, cura a inflammação do rosto, e o rheumatirmo articular agudo ou chronico.

Fel da torra. (Lophophytum mirabile.)-E' uma parasyta conhecida, fungosa e phanerogänica.

USOS MEDICINAES

Serve para combater as febres continuas.

o Dr. Peckolt fez a analyse chimica d'esta parasyta, e diz que se emprega a batata fresca, para banhos contra a rachitis: secca e pulverisada, contra a ictericia; as flures, cumo aphrodisiaco.

Féto macho do Brasil. (Polypódium incomem.)E' planta conhecida nas Alagôas, que vegeta nos terrencs seccos.

USOS MEDICINAES

A raiz é vermifuga, e principalmente contra a tenia; provoca o ahorto, matando o feto, e faz a mulher esteril; cura a obstrucção do baço, provoca as ourinas, e cura a hydropesia.

\section{USOS NA INDUSTRIA}

A raiz do feto mettida deatro de uma pipa de vinho, impede que azede. Esta planta possue um oleo acre.

Fiandoiro. (Stalugmites officinale.)-Arvore das mattas das Alagoas, e dá fructo, que se não come.

\section{USOS MEDICINAES}

Não são conhecidos.

\section{USO NAS ARTES}

A sua madeira, serve para a carpintaria, e para a construc ção de casas.

Figueira. (Ficus seminarosa.)-E' planta mui conhecida, e estimada por seus fructos.

\section{CSOS MIEDICINAES}

Os figos maduros, são quentes e humidos, e mui convenientes aos que padecem de pedras, ou arêas na bexiga. Comidos 
moderadamente não fazem mal, e laxam o ventre: os figcs seccos, são indigestos, mas cozidcs e com assucar, aproveitam nas tosses, e catarrhaes.

\section{Figueira do incerno. (Vide Estramonio.)}

Flor d'argua ou Lentilha d'agua. (Pistio occidentalis.)-E' planta que fluctua nagua, e conhecida dos hervanarios.

\section{USOS MEDICINAES}

Serve para curar aposthemas, applicada á parte; internamente serve, para combater as ourinas sanguinoleutas, a erysipela, as molestias de pelle, e l:emoptyses.

Flôr de babado. (Echistes longiflora.)-Arbusto vulgar cujas raizes, depois de seccas, prcduzem uma resina mui drastica.

USOS MEDICINAES

Não tem sido empregada na therapeutica domestica; mas os tropeiros fazem cozimento da raiz para curar as molestias dos animaes de carga, quando adoecem.

Folna da fonte. (Arum.)-E' 'planta mui conhecida nas Alagoas, e Pernambuco.

\section{USOS MENICINAES}

E' um poderoso desobstruente; e os fazendeiros curam com ellas, as molestias de relle dus ailimaes.

As ganhadeiras furram com as tulhas d'esta planta os taboleiros, e cestos, em que ve.ulem as maugabas.

Folha da fortuna. Herva. (Verea involucrato.)-E" planta vulgar e geralmeite conliecida.

\section{USUS MEDICINAES}

A cataplasma feita com as fu.has d'esta planta, borriada com vinagre, cura o sarcocellé.

Folna laxga. (Elocceea macrephyl'a)-Arvore das mattas das Alagôas, e conhecida dos clerrubador'es.

\section{USOS MBDICIYAES}

Não são conhecidos. 
USOS NAS ARTES

o sen lenho é incorruptivel, que nem os insectos o destrỏem; empregam-no em carpintaris, e em molduris.

Flor da noite ou flor cheirosa. (Castus yrandiflora)-E' a plaista flur da noite, uma especie de cardo, mui conhecida por suas flores mui aromaticas, que se abrem de noite. De suas hastes nasce n espi،hos mui agudos.

USOS MEDICINAES

E' a homøeoyathia, que tem tirado resultarlos efficazes, com o emprego d'este vegét,l brarileiı, em muitas enfermidades nervosas e congestivas, e pri.ucipalmente nas do coraçio.

Feijào. (Phaseolus vulgaris.) - Planta alime.sticia mui conhecida, e da qual ha varias qualidales.

10 feijão preto, é o mais co.ıve vie.tte al alimeatrcĩo do homem, por ser de mais facil digestão, e o mais azotado.

\section{USOS MEDICINAES}

o emplastro feito com a massa de feijão fradi.ıh), depois de bem cozido, e posto sobre a heraia, a faz recolher, sem o esforço da arte.

Ha grande variedade de feijões, e são conhecidos:

\section{Рeijão aาão.}

$\gg$ bacamarte.

$\gg$ boi lle capoeira.

"de boi.

bravo.

$\gg$ caliucio.

" carriapato.

» castanho.

\ cỏso

\# de corda.

》) eitxifi'e.

" tigadu de gallinha.

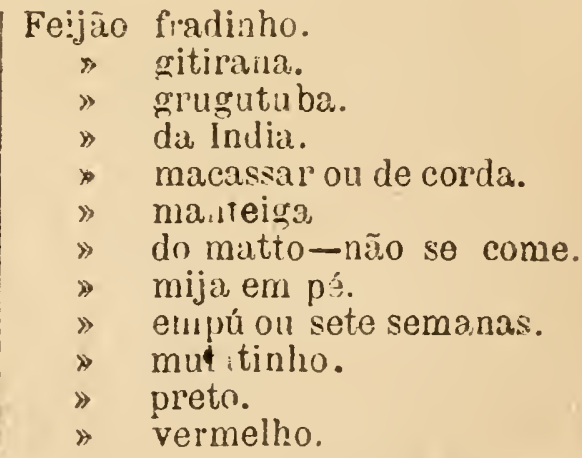

Furmo bravo ou silvestre. (Cormilla Alagoensis.) -Esta planta brasileira, folga em toda a parte, e tem muita semelhança com o fumo cultivado.

USOS MEDICINAES

Os camponezes empregam-n'o em cozimento, em clyster, nas febres milignas, porque limpa o sangue, e o corrige. Empre- 
gam-n'o em förma de chá nos pleurizes, nos catarrhaes. E' remedi) presentaneo coatra o veileno das cobras, do baiacú, e contra a embriagaez da maxipoeira (seiva da mandisca), tomado em clyster, e bebido em cozine.lto, ox em in usĩs. Alguns ajuntam ao cozimnnto, a raiz da a.rgelica, e um nunco de vinagre.

Fumo, tabaco, nicosiana. (Petum pytimn). Tabaco herva. (Tapy.) - Esta planta, que constitie um ramo da riqueza publica do Brasil, tem virtudes medicas especiaes.

\section{USOS MEDICINAES}

E' um poderoso narcotico. Cura a frieira, a gangrena, a dôr de cabeça, a enchaqueca, a colica, a dòr de estomago, e o resfriamento dos membros.

o povo serve-se do sarro do cachimbo, misturado com sebo de vacca, sal e vinagre, tudo misturado, e fervids ao fogo, para curar as frieiras. As folhas do fumo fervidas na ourina da criança e sal, servem para lavar a parte gangrenada.

As folhas machucadas e postas que.ites na cabeca, cura a enchaqueca, e dôres n'essa parte; posta no pescoço, cura as dôres do estomago: postas no ventre, cura as ventuosidades e flautulencias.

Wucho. (Faeniculum vulgaris.)-E' uma variedade da herva doce, e mui conhecido.

\section{USOS MEDICINAES}

o chá ou infusão das sementes do funcho, serve para curar as dôres de cabeça, e fraqueza do estomago. Fiz fecuudas as mulheres estereis; fortifica a vista, e desembaraça a respiração. E' um bom medicamento, para desobstruir o baço; promove as ourinas, e destróe as pedras dos rins e da bexiga.

Alım d'estas virtudes, serve para desvanecer os espasmos, e tonteiras de cabeça, porque colforta o cerebro; tira o máo cheiro da bocca; facilita as ventosidades. Lavando-se com o cozimento a cabeça, destróe as caspas.

O lambedor da raiz do funcho, feito em mel de abelhas, corrobora o peito, e cura a tosse.

As sementes postas na comida das amas, faz augmentar-lhes o leite. O mesmo effeito produz, postas as sementes no vinho. 


\section{G}

Gabiraba ou Grabiraba. (Camomanesia guabiiaba.) Planta vulgar nas Alagoas, e Pernambuco. Dá fructo comestivel.

\section{LSOS MEDICINAES}

o cozimento das folhas, serve para o curativo do rheumatismo. O cozimento da raiz, é desobstruente do figado.

Gabiraba ou Guabiraba vernella.-Arvore de 69 e mais palmos de altura, com 2 de 'grossura; floresce era Setembro.

\section{USOS MEDICLNAES}

Nĩo sãก conhecidos.

\section{USOS NAS ARTES}

A sua madeira, serve para obras de architectura, e para cabos de machados.

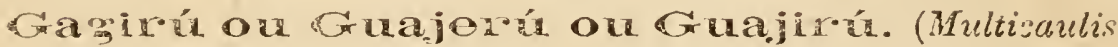
icaco.)-Planta do litoral do Brasil, e mui conhecida nas Alagos, e Pernambuco: floresce e fructifica, sendo o fructo maduro de cor roxa.

\section{USOS MEDICINAES}

O cozimento da raiz e das folhas, é bom medicamento, para curar a diarrhea chronica, caimbras de sangue, fluxos brancos da uretra, e a leucorrhea das mulheres.

Gameloira bianca. (Ficus coliaria.)-Arvore bem conbecida, que vegeta na margem dos rios, e nos log res pantanosos. Tem de 60 á 100 palmos de elevação, e 4 e mais de diametro. A arrore dá leite em abundaneia.

\section{USOS MEDICINAES}

- leite da gameleira é um poderoso remedio, para as que padecem de cansaço (anemia) ou opilaç̃a, e se administra ao 
enfermo, dando-se uma colher de sopa a beber pela manhã. Alguns enfermos tomam o leite da gameleira, metidos dentro d'agua, porque d'este modo, não é necessario reşuarlar-se do sol, e da chuva.

o leite da gameleira, cura tambem os cravos dos pús dos boubaticos.

\section{USOS NAS ARTES}

o lenho, serve para a fabricação de canoas, e gamelas.

Gameleira vermoina. (Ficus glabra)-Esta arvore, tem as mesmas limen oes, que a gameleir b:a $b$ ca, e fluresce em Setembro, e Ostubro.

\section{USOS MEDICINAES}

Não 'são conhecidos.

UEOS NAS ARTES

O seu lenho serve, para o fabrico de canoas e gamelas.

Ganaeloira tropadoira. (Syphonia volubilis.) - E' vegetal particularmente das Alagoas. Tem a particularidade de se enrolar sobre as outras arvores, e as vai apertando de tal modo, que por fin as mita. Esta variedil le da gameleira, é o emblema do amigo traidur, que tira a vids do outro, com fingidos abraços.

\section{USOS MEDICINAES}

Não são conhecidos.

Ganha saia ou christa do Nerí. (Lubelia edulis.)-E planta conhecida nas Alagoas, e Pernambuco.

USOS MEDICINAES

O cozimento d'esta planta, é proveitoso nos dores de dentes. USOS CULINARIOS

As folhas bem escaldidas, e depois cosidas, e adubadas, dão bom prato para a mesa.

Gapoy,-Planta do Pará e Maranhão.

USOS MEDICINAES

o cozimento da raiz é mui proveitoso, para curar a inflammação dos olhos. 
Garahuna.-Arvore de 60 palmos, c 2 de grossura; floresce em Setembro.

\section{USOS MEDICINAES}

Não são conhecidos.

USO NAS ARTES

Serve para a carpintaria.

Garapiapunha.-Arvore de 50 á 60 palmos de altura com 3 de diametro. Floresce em Outubro.

$$
\text { USOS MEDIUINAES }
$$

Não são conhecidos.

$$
\text { USOS NAS ARTES }
$$

Serve para vigas e frechaes, e obras de architectura.

Garapiroca.-Arvore das nossas mattas, conhecida dos derrubadores.

\section{uSOS MEDICINAES}

Não são conhecidos.

USOS NAS ARTES

A sua madeira, é empregada na carpintaria.

Gararoba, (A ibor umara)-Arvore conhecida dos derrubadores.

USOS MEDICINAES

Não são conhecidos.

LSOS NAS ARTES

o seu taboado serve, para assoalho de casas, e para outros usos.

Gionciana brasileira. (Lesianthus pendulus.)Planta herbacea brasileira; a raiz é amarga. D'esta planta ha varias especies. e com as mesmas propriedades.

\section{USOS MEDICINAES}

- $E^{\$}$ estomachica e tonica, e é empregada na debilidade do estomago.

Grendiroba ou Nhandiroba. (Fenilea nhandiroba.) - E' uma trepadeiraque dá fructos e oleo, medicinal conhecido nas Alagoas, e outras provincias do Norte, pelo nome Oleo Gendiroba, ou de Nhandiroba. 


\section{USOS MEDICINAES}

Usa-se d'este oleo, para curar a erysipela, empigens, e tambema a mordedura da cobra, untando-se as partes com elle.

Gengibre. (Zinciber officinale.) - Pison affirma, que o gengibre é tambem natural do Brasil, e era conhecido dos indios pelo nome de Mangaratiá. Gabriel Soares, diz que o gengibre veio da Ilha de S. Thomé, para a Bahia, onde a cultura chegou a dar, para mais de quatro mil arrobas, durante cada anno, e pelo que foi prohibida a sua cultura no Brasil, em proveito do mesmo genero cultivado na India. A raiz da planta tem a configuração de dedos reunidos, de casca amarella pardacenta, de gosto picante, e contém muito oleo volatil.

\section{USOS MEDICINAES}

E' empregado para curar a dyspepsia, para fraquesa de estomago, nas colicas flatulentas, e no cholera morbus. As pessoas flatulentas o trazem na bocca, para dissipar os flatos, e clarear a vista.

\section{USOS CULINARIOS}

E' empregado em certos guizados, para aromatisar, e estimular o paladar.

Genipapeiro. (Genipa americana.)-E' arvore robusta de 30 a 40 palmos de altura, com 2 de diametro. Floresce em Agosto, e folga em quasi todo o Brasil.

$\mathrm{E}^{\prime}$ de um verde alegres, e tem a particularidade de mudar de folhas todos os mezes. A madeira é muito rija, e macia para o trabalho. A fructa é do tamanho de uma laranja, de côr amarella pardacenta, e acida, e de um cheiro activo e agradavel ; é comestivel.

\section{USOS MEDICINAES}

O succo da fructa é refrigerante, e conveniente aos que padecem de dysenterias, e obstrucções de figado e baço.

E' singular remedio para asthma, ou defluxo asmathico, tomado em fórma de lambedol. A massa feita do genipapo verde e mel de gitahy, ou de urussî, posta sobre as hernias curam-nas. O genipapo verde posto sobre os cravos dos pés os destroe. Cortada a casca verde, applicada sobre qualquer ruptura, principalmente do umbigo das crianças, e atando com uma ata- 
dura e compressa, e se revesando de tres em tres dias, cura a ruptura.

\section{USOS NAS ARTES}

Extrae-se do genipapo verde, uma tinta preta, difficil de largar. Quando se expreme a fructa, o succo é branco, e não tinge logo ; mas d'ahi a algumas horas, ficam as partes onde cahio o succo do genipapo tão preta, como azeviche. Com este sumo os indios se pintam, deitando-o nos golpes que dão na pelle, para se tornarem tão extravagantes em feições, como se apresentam. Os indios assim pintados acham-se tão elegantes, que á excepção das pennas, contas, e buzios com que se enfeitam, não se adornam de mais nada.

Com a fructa fazem os indios soboroso vinho, com que se embebedam.

A madeira do genipapeiro, serve para as junças das bombas.

Genipapoino do matto.-Arvore de 50 e mais palmos, com 2 de diametro. Floresce em Setembro.

\section{USOS MIEDICINAES}

Não são conhecidos.

USOS NAS ARTES

Serve o seu lenho para frechaes, e cabos de machado.

Gemipapinho, (Genipa verticulantis) (Maranhão.) - E arvore pequena; a sua folha é semelhante á do genipapeiro, e o fructo pouco maior, que um ovo de pomba, do feitio e fórma do genipapo. Arites de maduro tem a côr pardacenta, e maduro é amarello desmaiado, A casca do páo, é verde esbranquiçada: o seu entrecasco é aromatico, e um tanto amargoso. A raiz é preta, e de casca rugosa.

\section{USOS MEDICINAES}

A raiz d'esta planta, é contraveneno das cobras. 0 pó da raiz tomado em pequenas dóses, pela manhã, é singular remedio, para supprimir os ardores da carne e desejos venereos. A sua acção sobre o apparelho genital é tão poderosa, que é preferivel ao agnus castus. 
Gergelim ou gixgifim. (Sesamum indicum.)-Planta conhecida, e cultivada em quasi todo o Brasil.

\section{USOS MEDICINAES}

o oleo é nervino, e proveitoso no rheumatismo; e a fécula é dada contra as hydropesias. Torradas as sementes, e piladas com farinha e assucar são mui gostosas.

o oleo abranda os tumores schirrosos; e tomado em clysteres, é mui proveitoso nas colicas. As sementes piladas, e feitas emplastro curam os tumores frios. Cura as dores de ouvidos, e as queimaduras de fogo.

Gericó.-Almeida Pinto diz, que esta planta, vive sobre as pedras, proximas aos rios.

\section{USOS MEDICINAES}

A infusão feita com a planta gericó, combate a asthma, e as tosses.

Giervão. (Lantana Pseudo Thea.) - E' um arbusto mui conhecido e vulgar, que vegeta por toda a parte. Ha branco, e roxo. o mais empregado é o roxo.

\section{USOS MEDICINAES}

E' o melhor desobstruente conhecido. Favorece a digestão, e promove o parto, e a sahida das secundinas. Conheço um africano de nome José Leite, que actualmente tem 130 annos, o qual ainda percorre esta cidade do Rio de Janeiro, sem difficuldade, segundo me disse elle, muito tem concorrido para a prolongação da sua existencia o uso exclusivo, que tem feito do chá do gervão.

Gequitibá roxo ou vermelho. (Courataria legalis.)-Arvore corpulenta, e copada, das nossas florestas.

USOS MEDICIANES

o cozimento da casca é mụito usado nas anginas, por sua adstringencia.

\section{USOS NAS ARTES}

o seu lenho serve, para a carpintaria, e principalmente para assoalho, e forro das casas. 
Giboia do brejo.-Arvore de 30 á 40 palmos de altura, e 2 de diametro. Floresce em Setembro,

USOS MEDICINAES

Não são conhecidos.

USOS NAS ARTES

O seu lenho serve, para o fabrico de caixões.

Gicāo. (Serpoea cearensis.)-E' planta do Ceará, e Pará, semelhante a coentro.

\section{USOS MEDICINAES}

A sua tintura é aromatica, e mui. proveitosa nas enfermidades do peito, e catarrhaes.

Giló ou .Jiló (Solanum Gilo,-E' planta vulgar transplantada das Antilhas e cultivada no Brasil.

USOS MEDICINAES

E' estomachico o seu fructo, e muito usado ria comida, pelo seu amargo suave.

Gingeira brava ou ceregeira do Brasil. (Prunus sphaerocarpa.)-Arvore brasileira, conhecida dos indios pelo nome de Juci-açi Juci-uva. Tem as mesmas propriedades do louro cerêjo da Europa. O Dr. Peckolt, fez a analyse d'esta planta, e diz que a agua distillada da casca fresca, póde rivalisar com a agua do louro cerejo.

USOS MEDICINAES

E' um poderoso calmante.

Giquix-ili. (Abrus precatorius.)-Planta das Alagoas, e Pernambuco.

\section{USOS MEDICINAES.}

As sementes reduzidas a pó, e infundidas em agua fria, aproveitam nas inflammações dos olhos.

Giricó ou Gericó.-E' planta amarga, que se enrasca em outras. E' conhecida nas Alagoas e Pernambuco, por seu prestimo medicinal. 


\section{USOS MEDICINAES}

A raiz é empregada para curar a paralysia, proveniente de golpe de ar.

Girasol, (Helianthus annus.)-E' planta da America meridional, muito elegante, principalmente quando está circulada de seus sóes.

\section{USOS MEDICINAES}

As suas flores e folhas são vulnerarias, e podem substituir perfeitamente a arnica; resolve as alporcas, tira as verrugas, - provoca as ourinas, A raiz feita em pó, e bebida em vinho, faz boas cores no rosto. As sementes dão oleo emoliente, e no sertão engordam as gallinhas com ellas.

\section{USOS CULINARIOS}

Com as folhas preparam appetitoso prato, para a mesa.

$$
\text { USOS NAS ARTES }
$$

As cinzas dão excellente potassa, para a fabricação de finissimos sabonetes.

Girasol de batata ou Topinambor. (Helianthus tuberosus.) - Esta especie de girasol, mui semelhante ao girasol do Perú, é planta brasileira, e produz uma batata, propria para alimento do homem.

\section{USOS MEDICINAES}

As folhas em cozimento, servem para curar feridas.

Girimú on abobora. (Cucurbita major rotunda.)E' planta trepadeira, e produz fructo de tamanho variado.

\section{USOS MEDICINAES}

As flores passadas pelo lume, e postas sobre a erysipela por alguns dias, dissipa a inchação. Cozida a fructa, e posta sobre a ferida cancerosa, dizem que a cura.

USOS CULINARIOS

E' bom alimento, de qualquer fórma preparado. D'esta planta ha diversas qualidades que são:

Gerimú caboclo; Girimú cor de rosa; Girimú de Fernando; 
Girimú gomo; Girimú jacaré; Girimú de Lisboa; Girimú de Pernambuco; Girimú de pescoço; Girimú do sertão.

Gitany anarello falso.-Gitany verdacleiro. (Thomazia pseudo lutea.)-São arvores das mattas das Alagoas e Pernambuco.

\section{USOS MEDICINAES}

Não são conhecidos.

USOS NAS ARTES

A sua madeira serve para a construcção de casas, e para a marcineria.

Gitirama. (Argyrea alagoana.)--A gitirana é uma trepadeira, tendo as flores como campainhas brancas, e sem cheiro.

USOS MEDICINAES

Näo são conhecidos.

Gicó ou Bilreix.o. (Guarca purgans)-Arvore conhecida nas Alagòas, que dá fructos em cachos.

\section{USOS MEDICINAES}

A casca e a raiz, são drasticas, e mui energicas. Emprega-se a casca em banhos, contra os tumores das juntas.

o extracto em pequena quantidade, em clysteres, é contra as ascarides, e tem acção mui pronunciada sobre o utero, e provoca - aborto. A raiz en cozimento, internamente, ou em clysteres cura a hydropesia.

E' um purgante violento, e cura as molestias syphiliticas.

Ginsão, (Panax quinquefolium.)-Arbusto, cujos iructos são bagos redondos, e vermelhos.

\section{USOS MEDICINAES}

Passa por ser aphrodisiaco.

Goembeguassúu. - E' planta silvestre, cujas raizes são mui compridas.

A sua casca é mui rija, e de que se fazem cordas, e amarras, para os navios, e tem a propriedade de reverdecer dentro d'agua. 


\section{usos MEDICINAES}

o cozimento serve, para suspender o fluxo de sangue das mulheres.

Goiabeira. (Pisidium pommiferum.)-E' arvore de tama nho regular, de folhas asperas e aromaticas. Floresce e fructifica, sendo os seus fructos mui saborosos. As folhas são adstringentes.

\section{USOS MEDICINAES}

o cozimento dos grelos da goiabeira, dado a beber ou em clysteres, é o melhor medicamento para curar as leucorrheas, e as diarrheas, agudas ou chronicas, e o rheumatismo. Reduzidas as folhas a pó e pulverisadas com elle as feridas chronicas as cura.

\section{USOS CULINARIOS}

Com as fructas fabricam o precioso doce, conhecido pelo nome de goiabada.

Golpho ou golfo. (Nimphcea Alagoensis.) - Planta aquatica, que nasce nos riós e lagos. No Pará chamam Mururé: em Sergipe Orelha de burro., nas Alagoa's Golfo, e nas provincias do sul, Gigoga.

\section{USOS MEDICINAES}

Serve para tirar as nodoas da pelle do rosto, e do corpo. o cozimento da raiz serve, para curar a dysenteria, a leucorrhea, e é muito recommendado para curar a spermatorrhea, tomando-se o cozimento pela manhã e á noite, durante nove dias.

E' contra a elephantiasis dos gregos, e contra as feridas fungosas.

Gomma Lacre-Lacre ou Caaopiá. (Vesmia lacrifera) (Tupy.) -E' um arbusto das Alagoas, Pernambuco e Pará, de 6 á 8 palmos de altura, de folhas ovaes oblongas, e de flores compostas. Incisada a planta, transuda uma seiva vermelha gommo-resinosa, que se coagula, a que o povo chama gomma lacre, e os botanicos gomma gutta da America. Desta gomma resina, ha branca, e vermelha, e dizem a branca, que póde substituir a gomma gutta, nas preparações officinaes. 
,USOS MEDICINAES

E' purgativo energico, e resolvente; e emprega-se no curativo das molestias das vias ourinarias, dada internamente, e externamente em banhos.

Gongaio Alves. (Astronium fraxinifolium.)-Arvore de 25 a 30 palmos de altura, com 1 a 2 de grossura. Floresce em Agosto.

USOS MEDICINAES

Não são conhecidos.

USOS NAS ARTES

O seu lenho pela dureza e brilhantismo de suas ondulações, e polimento é muito estimavel para o fabrico de trastes, molduras e obras de marchetaria.

Gramma.-E' planta vulgar, que produz em toda a parte.

USOS MEDICINAES

E' diuretica e modificante, applicada em cozimento serve para curar as irritações intestinaes.

Gravatá ou crasuatá. (Bromelia muricatá E' planta semelhante ao ananaz. Fructifica de Jàneiro á Março. O seu fructo é aromatico, e tem bom gosto para se comer, depois de sazonado; estando verde, tem um acido tão picante, que córta a lingua, e n'este estado, é bom remedio para os vermes intestinaes.

\section{USOS MEDICINAES}

Os fazendeiros costumam dar o gravatá cozido, e depois de férmentado, aos enfermos de opilação ou cansaço, sendo uma chicara pela inanhã, e outra á noite, guardando o enfermo as condições dieteticas.

USOS NAS ARTES -

Dá excellente linho, para o fabrico de pammo.

Gravatá crarasuatá de enrolar.-E' planta geralmente conhecida nos sertões, onde abunda e fructifica de Março a Outubro. 
o seu fructo se come, e bebendo-se logo agua em cima, é o purgante mais violento, que se póde desejar.

\section{USOS MEDICINAES}

Dizem que o fructo é muito estomacal, e retrigerante. USOS NAS ARTES

Dá linho para o fabrico de cordas, e para o tecirlo do panno.

Graveco. - Arvore de 30 a 40 palmos de altura, com dous a tres de diametro: floresce em Setembro.

USOS MEDICINAES

Não são conhecidos.

USOS NAS ARTES

o seu lenho, serve para taboado de caixöes.

Graveto vermelino. - Arvore de 60 palmos, com dous á tres de grossura. Serve para o mesmo fim.

Gravitaia.-Arbusto dos sertões ; é mui conhecido, porque dá uma batata, que serve de alimento ao povo, nas grandes seccas, quando ha falta de farinha de mandioca.

\section{USOS MEDICINAES}

Não tem emprego em medicina vulgar.

Grogahy-azeite, - Arvore de 40 palmos de altura, com 1 a 2 de diametro. Floresce em Outubro.

USOS MEDICINAES

Não são conhecidos.

\section{USOS NAS ARTES}

Serve para a carpintaria, e para frechaes.

Gróggojó ou grrocoió. (Cucurbita ovoides.)-E' um cabacinho, mu: galante, e alvo, conhecido nas Alagôas e Pernambuco, ponco maior que um ovo de gallinha.

USOS MEDICINAES

A polpa da fructa é drastica, e os sertanejos a esapregam com proveito, no curativo da hydropesia. 
USOS NA INDUSTRIA

Este formozo fructo tem a propriedade de fazer os cabellos pretos, sem causar damno á cabeça. - Córta-se pelo gargalo, tira-se um pouco do miolo, e enche-se de azrite doce: põe-se a assar ao borralho por cinco quartos de hora, e depois de frio se espreme, o oleo que apparece serve para empretecer os cabellos.

Grosolna ou pitanga do matto. (Ribes grossularia.)-Vid. Pitanga do matto.

Gruge.-E' um cipó, que se estende pelas arvores, vegeta em qualquer terreno, que não seja taboleiro, ou agreste.

\section{USOS MEDICINAES}

E' poderoso medicamento, para suspender hemorrhagias, ou Huxos de sangue immoderado das mulheres, ralado e desfeito em agua, mas administrado em pequenas dóses.

Grumary.-E' uma arvore, cuja madeira amarella, é tão pouco porosa, que substitue perfeitamente o buxo.

USOS MEDICINAES

Não são conhecidos.

\section{USOS NAS ARTES}

Serve para mastros, bengalas, para caixas de rapé, e obras de gravadores.

Grumichama ou grumbehama. (Engenia brasiliensis.)-Arbusto brasileiro, cultivado nos jardins e chacaras. O fructo é redondo e de cỏr roxa, quando maduro; e a massa polposa, de um agro doce.

\section{USOS MEDICINAES}

E' refrigerante, e agradavel aos enfermos de febres, e aos convalescentes.

\section{USOS NAS ARTES}

o fructo da grumichama, póde dar vinho.

Guabirába. (Cordia rotundofolia.)-Arburto das Alagôas, Pernambuco, e de outras provincias, que floresce, e dá fructo saborosos. 
USOS MEDICINAES

As folhas são aromaticas, e servem para banhos, no curativo do rheumatismo. Queimada a planta, o pó do carvão, se applica contra as belides.

Guabiraba femea.-Arvore de 50 palmos de altura, com dous de grossura. Floresce em Setembro.

USOS MEDICINAES

Não são conhecidos.

\section{USOS NAS ARTES}

Serve a sua madeira, para cabos de machado.

Guabiroba do Rio Grande. (Myrtus macronatus.)-E' um arbusto, conhecido no Rio Grande, empregado na medicina popular.

USOS MEDICINAES

o seu emprego é conveniente para banhos, e em clysteres, para combater a diarrhéa mucosa, o catarrho da bexiga, e a leucorrhéa.

Guaco. (Mikanıa guaco.)-E' planta trepadeira, e que alastra, tem sabor amargo, e cheiro desagradavel.

USOS MEDICINAES

E' sudorifico energico, e antisyphilitico. Cura o rheumatismo, e é antidoto do veneno das cobras. Dá-se em infusão, interramente; $e^{s}$ externamente em banhos.

Guaimbé. (Caladium acerum.)-Planta, que se assemelha ao cipó imbé.

\section{USOS MEDICINAES}

E' emprégada a raiz em dóses pequenas, para curar a hydropesia. O banho feito com o cozimento das folhas, serve para o rheumatismo.

Guando ou guandú. (Cajanus flavus.) - Arbusto l eguminoso, e mui conhecido dos agricultores.

USOS MEDICINAES

As folhas são ligeiramente adstringentes, e o seu cozimento 
em zargarejos é empregado, para curar as anginas, frouxidão das gengivas, e dores de dentes.

\section{USOS CULINARIOS}

As sementes são comestiveis, e de facil digestão.

Guapera de S. Paulo. (Hypanthera guapera.)-E' planta trepadeira, conhecida em S. Paulo por Guapeva, e em Minas Geraes, por Fava de Santo Ignacio : dá sementes oloosas e amargas.

\section{USOS MEDICINAES}

As sementes, em peqnena quantidade, curam a ictericia tomando-se em dóses repetidas; e em maior porção, obra como purgante drastico.

Guapuy. (Longisiculo.)-Planta trepadeira, do Alto Amazonas.

\section{USOS MEDICINAES}

O succo da raiz crua, qu assada é empregado com muito proveito nas inflammazões chronicas dos olhos, e nas molestias syphiliticas.

Guarabú. (Astronium.) - Arvore muito conhecida em todo o Brasil, da qual transuda excellente balsamo de cheiro therebentaceo.

\section{LISOS MEDICINAES}

o balsamo é fortificante, e serve para a confecção de unguentos.

$$
\text { USOS NAS ARTES }
$$

A sua preciosa madeira, serve para construcção civil e naval.

Guaracica. - E' arvore de 30 palmos de altura, com 1 a 2 de diametro. Floresce em Agosto.

\section{LSOS MEDICINAES}

Não s⿱̃o conhecidos.

$$
\text { USOS NAS ARTES • }
$$

Serve para a fabricação de ripas.

Guaraná. (Paullinia sorbilis.)-E' o producto indigena extrahido de um arbusto, que tem o nome de guaraná, que nasce no Pará e Amazonas. 
USOS MEDICINAES

Serve para curar a diarrhea e dysenteria, as febres, as colicas fiatulentas, a enchaqueca. E' aphrodisiaca. (Vide commissão do Madeira, Pará e Amazonas pelo conego F. Bernardino de Souza, o artigo Guaraná).

Gruaraiuba.-Arvore das florestas do sul do Brasil. USOS MEDICINAES

Não são conhecidos.

USOS NAS ARTES

O seu lenho é de muito prestimo, para os bicames de conduzir agua, e para a carpintaria.

Guaraquimia.-E' um arbusto brasileiro, semelhante ao myrto.

\section{USOS MEIICINAES}

0 poro emprega esta planta, contra os vermes intestinaes.

Guararema.-Arvore de 50 palmos, com tres de grossura. Floresce em Setembro.

LSOS MEDICINAES

Não são conhecidos.

USOS NAS ARTES

A sua madeira, serve para o fabrico de caixões.

Guarassahy-ver-melho.-Arvore de 40 palmos de altura, com dous de diametro. Floresce em Outubro.

USOS MEDICINAES

Nầo são conhecidos.

\section{USOS NAS ARTES}

O seu lenho, serve para a carpintaria, e obras dos edificios.

Guardião. (Melothria officinalis.)-Planta conhecida nas Alagôas, e Pernambnco, que vegeta nos mattos, e sóbe pelas arvores.

\section{USOS MEDICINAES}

O povo do interior, serve-se muito d'esta planta usando-a em clysteres, para curar diversas enfermidades. 
Guanó. (Guarea trichilioides.)-E: ma arvore semelhante ao gitó.

\section{USOS MEUICINAES}

O suceo ou seiva leitosa que possue, é emetico, e purgativo forte. A infusão das folhas, e mesmo da casca, é menos forte.

Conqubig ou boxinho. (Peltoginea guarubi.)-E' arvore das nossas florestas, de 40 palmos de altura, e de um a dous de diametro. Floresce em Setembro.

\section{USOS MEDICINAES}

Não são conhecidos.

\section{USOS NAS ARTES E NA INDUSTRIA.}

O lenho é roxo, e póde dar tinta para a tinturaria. A madeira é empregada com vantagem, para raios de carros, nas construcções, e para a marcenaria.

Gruaromá (Maranhão.) Arunia (Pará.)-Planta do Maranhão, e do Pará.

\section{USOS MEDICINAES}

Os vapores do cozimento d'esta planta, sĩo efficazes para cural o sarcocelle.

Guaxinguba or lombrigueira (Pará.) - E' planta leitosa. e mui util em medicina popular.

\section{Usos MedicinaEs}

O leite ou a gomma-resina liquida é caustica, e um poderoso anthelmintico, tomado na dóse de um escropulo em café, ou em agua morna. pela manhã em jejum, por alguns dias seguidos.

Convém toda cautella, na administração d'este remedio, por ser mui caustico, e produzir a morte, em virtude de ulcerações gastro intestinai que produz.

Guaxima ou carrapichinho. (Triumfetta villosa.)-0 Dr. Manuel Joaquim Henrique de Paira diz, que a guaxima, foi estudada por Brown, na historia da Jamaica, publicada em 1702; por Jacquin, na Historia natural da Ainerica, e por Linneo; mas que achando entre os muitos manuscriptos de 
seu irmão José Henrique Ferreira, uma memoria sobre o uso e utilidade da guaxima, que lêra na real academia, depois da descripção, trata dos prestimos da planta.

USOS MEDICINAES

A raiz, folhas e sementes, são de sabor ensôso, e abundante de monco; e a sua virtude, é ser emoliente.

Emprega-se em todas as molestias, cuja indicação é relaxar e amollecer. Tambem cura as molestias da pelle

USOS NA INDUSTRIA

Com a casca fazem cordas, mui procuradas, para diversos usos.

Guaxuma do mangue. (Hibiscus pernambucensis.) - O Dr. Manuel Arruda da Camara, na dissertação sobre as plantas do Brasil, extrahida da sua Centuria das plantas de Pernambuco, descreve com muita proficiencia esta planta, e para ella envio o leitor.

Guarubá.-F' arvore do Pará, que dá boa tinta amarella.

\section{USOS MEDICINAES}

Não s̃̃o conhecidos.

LSOS NAS ARTES E NA INDUSTRIA

A madeira é boa para a construeção civil, e a tinta deve ser de grande uso na tinturaria:

Gutta percha. (Isonandra percheira.) - E' arvore do Amazonas, que dá um succo leitoso, como a Maçaranduba, que se solidifica, e adquire maior dureza, que a gomma elastica.

\section{USOS MEDICINAES}

E' cicatrisante das feridas, cobrindo-as com uma solução feita com o chloroformio.

\section{USOS NAS ARTES}

Com a gutta percha, fabricam-se algalias, pessarios, e muitos outros objectos de cirurgia; e como se electrisa com muita facilidade, fazem com ella o tecido contra as dores nervosas. 
Guilandin. (Moronobia coccinea.)-Arvore das nossas florestas, e conhecida dos derrubadores. Floresce e fructifica em Setembro.

USOS MEDICINAFS

Não são conhecidos.

USOS NAS ARTES

Serve a madeira para estivas de estribarias, por ser um tanto molle.

Guiné.-Arvore pequena, mui conhecida, miąas raizes têra cheiro activo, um pouco nauseante.

\section{USOS MEDICINAES}

O cozimento das folhas de Guiné, cura o rheumatismo.

Os africanos servem-se das raizes, para fazer figas, com que se enfeitam.

Guinna. (Portlandia luxandra.)-E' uma arvore do Ama onas, sendo a casca de gosto amargo.

\section{USOS MEDICIN LES}

E' adstringente, e serve para curar feridas velhas.

Guitycoroba. (Lucuma rivicoa.)-Arvore mui parecida com o sapoti, e com fructos semelhantes aos d'este vegetal.

\section{USOS MEDICINAES}

Os fructos são empregados contra a diarrhéa, e catarphos pulmonares.

\section{$\mathrm{H}$}

Herva andorinha. (Euphorbia cocomum.) - Esta planta é mui conhecida dos hervanarios, e mesmo, de muitas pessoas do povo, para curar as molestias dos olhos.

\section{USOS MEDICINAES}

Pilarla, e applicada ás ulceras syphilıticas, ainda sendo mui chronicas, as limpa e cura. Em clysteres cura a diarrhea, e as 
hemorrhoides. Internamente, em fớrma de chá fraco, é emplegada a herva andorinha, para combater o pleuriz.

I Tex'va babosa. (Alóes.)-E' planta mui conhecida.

\section{USOS MEDICINAES}

E' o melhor medicamento para mitigar as dóres do anus, proveniente das hemorrhoides.

A folla, passada em manteiga crua, posta sobre os callos, amollece-os, e permitte extrahil-os perfeitamente.

\section{USOS CULINARIOS}

Com as folhas da herva babosa, faz-se excellente doce para as mesas.

Herva de bicìo. (Polygonum anti-hemorrhoidale.)-E' planta, que folga nos terrenos lumidos. Ha duas qualidades, uma branca, e outra de talo roxo. A mais medicinal, é a de talo roxo.

\section{USOS MEDICINAES}

O sumo da planta bebido com assucar, cura a retenção de our'inas; o sumo batido com clara de ovo, e dado em clyster, cura as lebres malignas, e as dysenterias sanguineas.

o cozimento da herva de bicho, tomado pela manhã, e a noite, é o mais poderoso remedio contra as erysipelas.

Foi o unico medicamento que fez milagres na epidemia que appareceu em ternpo do governo do vice-rei Luiz de Vasconcellos, no Rio de Janeiro, denominada Zamparini, cujo mal foi tão fatal, que, aos que não matou, sendo d'elle accommettido, deixou aleijado. (Vide Pimenta d'agua.)

I repra de canudo ou alfavaca silvestre. (Hytis faciculata)-E' planta aromatica, que vegeta pelos campos.

\section{USOS MEDICINAES}

0 povo emprega o cozimento d'esta planta, para fortificar o estomago, melhorar as digestões tardias, e contra a flatulencia intestinal.

Em banhos, é empregada contra as llôres do corpo.

Herva capitāo. (Hydrocntyle bmariensis.)-Plauta vul- 
gar', que folga em toda a parte, principalmente nas proximidudes das lagòas, e rios.

\section{USOS MEDICINAES}

() cozimento serve, para limpar as feridas purulentas.

Inter'namente é diuretica, desobstruente do tiggado e baço Tumada em dóse eleviada provoca vomitos.

Ler.va cidreira. (Melissa officinalis)-Planta exotica transplantada no Brasil.

\section{USOS MEDICINAES}

E' anti-espasmodica, amenagoga e mui conveniente nas digestões tardias, e nos espasmos nervosos. O seu modo de usar, é infundindo as folhas em agua fervendo, e dando a beber a enfermo.

Ierva le cobra ou Santa Luzia. (Euphorbia unicoloi:)-Planta pequena, de flor amarella, e dá uma vagemzinhá. Seu nome vem da grande virtude que tem para curar as doenças dos olhos dos animaes, e mesmc as alteraçooes dos tecidos d'estes orgãos; cura-se, com ella, a mordedura de cobra, machucando-se as folhas, pondo-se em cima das feridas e dando-se o sumo a beber ao mordido.

\section{USOS MEDICINAES}

Além da virtude especial que tem, dando-se a raiz pisada em aguardente com assucar, ou em cozimento, ‘́ mulher de parto, promove-lhe os loquios, e combate a febre.

Cura a asthma, os espasmos nervosos, a paralysia, a hydro. pesia, as febres intermittentes, a opilação, a tympanite. a diabetes, e expelle os vermes intestinaes.

Meíva dóce ou anizo. (Anisum vulgaris.)-E' planta conhecida, trazida da Europa, e cultivada nos jardins da Ame rica meridional.

USOS MEDICINAES

Dá bom cheiro á bocca, e provoca as ourinas. Augmenta o leite dos peitos das mulheres que criam, tira as dôres de cabeça e dissipa as flatulencias. 
Forva ducra. (Mikaní martiusianc.)-Planta mui conhecida em S. Paulo, e mesmo no Rio de Jalleiro.

USOS MEDICINAES

Serve com proveito nas diarrheas chronicas, dada em clyste res por alguns dias.

I I r va ferro.-Planta que folga nos sertões do Brasil. e com preferencia nos logares trabalhados; assemelha-se á planta chamada crysta de gallo.

\section{USOS MEDICINAES}

Os sertanejos servem-se do pó d'esta planta, como poderoso vomitivo.

Herva de fogo. (Pará)-Planta do Pará lembrada pelo Dr. Lacerda.

\section{USOS MEDICINAES}

E' especifico remedio, applicando-se as folhas sobre as empingens escamosas, para as fazer desapparecer.

Ierva do gentio ou sravatí. (Vid. Gravatá.)

\section{USOS MEDICINAES}

o cozimento da casca dado a beber, serve aos hydropicos, applicando-se-lhe ao mesmo tempo banhos do cozimento da mesma casca, e clysteres.

Ferva japona. (Dr. Lacerda.) - Plata do Maranhão e Pará.

\section{USOS MEDICINAES}

() chá feito com esta planta, serve para combater o envenenamento do arsenico, e para mordedura de cobra, pondo-se ao mesmo tempo as folhas pisadas sobre a ferida.

Terva mi.jona ou espia caminho. (Clitoria urinaria.) -E' planta, que alastra; encontra-se nas beiras das estradas, conhecida na Parahyba do Norte, por espia caminho.

USOS MEDICINAES

E' mui diuretica, e se emprega na hydropesia.

Herva inoura. (Solanum bacciferum officinalis.) -E' uma p lanta conhecida nas Alagôas, empregada em medicina domestica. 


\section{USOS MEDICINAES}

o sumo das folhas, misturado com vinagre, cura as dores de cabeça, e as enchaquecas. Tambem a empregam no curativo da erysipela, das empigens, coceira, e mesmo nas dores do corpo, em fricções e em banhos.

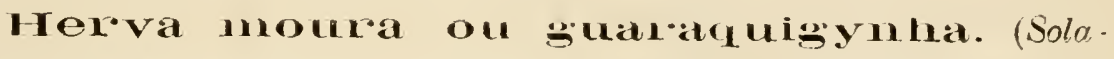
num niginu.) -E' planta conhecida nas Alagóas, e Pernambuco.

USOS MEDICINAES

As folhas pisadas, e feitas cataplasma, e applicada sobre a região da bexiga, promovem a emissão das ourinas; as sementes. dadas em pequena dóse, são vermifugas.

Trerva do pantano. (Sagittaria brasiliensis.) - E" planta conhecida dos hervanarios.

\section{USOS MEDICINAES}

A cataplasma da raiz, misturada com plantas aromaticas e adstringentes, cura às-hernias.

Irerva pombimha. (Phyllanthus nimuri.)-Planta rasteira e conhecida.

\section{USOS MEDICINAES}

Cura as empigens, os darthros, as gonorrheas, e os fluxos brancos, tomando-a em cozimento, e banhando as partes. Toda a planta é diuretica.

Irerva préiá. (Chrysocoma repanda.)-E' planta trepadeira. e conhecida no Rio de Janeiro.

\section{USOS MEDICINAES}

Com o cozimento d'esta planta, cura-se a erysipela branci, e o rheumatismo.

I Iexva de r.ato. (Palicuria.)-Planta brasileira, e mui conhecida nas Alagóas, e Pernambuco.

E' venenosa, mata os ratos, bem como aos outros animaes.

\section{LSOS MEDICINAES}

Não são conhecidos, porque? se não tem feito experiencias na therapeutica vulgar. 
Ha outras especies de herva de rato.

Irerva de SantAnna. (Kuhnice argutr.) - Esta planta é conhecida pelos hervanarios, e empregada na medicina vulgar. .

\section{(SSOS MEDICINAES}

o cozimento, é usado no rheumatismo; e o succo da plantit, è contra o veneulo das cobras.

Ierva le tianta I.uzia, (Luzia virosa.)-Chamam em Minas-Geraes, herva de Santa Luzir, a uma arvore, que tem as folhas, como a jaqueira, a qual distilla um succo leitoso. que cahindo nos olhos de qualquer animal cega.

USOS MEDICIÑAES

Não são conhecídos. Convinha que fosse estudada esta al'vor'e em proveito da therapeutica.

Herva de Santa Maria (no Rio de Janeiro,) ou mastruço (na Bahia, Alagôas e Pernambuco.) Chenopodium ambiosioides.-Planta geralmente conhecida, e muito medicinal.

\section{USOS MEDICINAES}

As follhas passadas pelo fogo, e borrifaclas de leite de peito. curam as dòres de cabeça, postas nas foittes. Bebido o sumo, e postas as folhas pisadas sobre as fracturas dos ossos, os consolida. E' excellente remedio para a tysica pulmonar.

As sementes são o melhor e mais innocente remedio, contra os vernes intestinaes das criancas.

Para se apreciar a forca vulneraria dil herva de Saita Maria. ou mastruço, é fracturando-se o osso da coxa de uma gillinha, dar-se a beber o succo da planta, applicando-se sobre a parte fracturada $u$ m emplastro das folhas da Santa Maria. depois de encanado o osso, e depois fde consolidado o osso, matando-se a mesma ave para se comer depois mesmo de cozida, se encontra no calo do osso ar cór verde do succo herbaceo, que a gallinha bebeu.

5e:-ra do soño, (Glacomu kederacea)-Planta vulgar, aromatica e mui prestimosa, conhecida nas Alagôas, pelo n ome de mentrasto. 


\section{USOS MEDICINAES}

Bebida a infusão cura a anasarca, as obstrucçoes do tigado. a diabetes, as ourinas turvas e mucosas; cura a inflammação do figado, mata as lombrigas das pessoas adultas; e dizem, que, comidas as flores, refrescam a memoria.

Postas as follhas entre a roupa, embebem-lle um aroma agralavel, e afugentam as traças das caixas e commodas.

I Ierva de $\rightarrow$. Pedro (Pará.) (Hiptis melepofolia.)Planta de cheiro agradavel, mui semelhante i hervat cidreira, com a qual se confunde pela figura e aroma.

USOS MEDICINAES

Isa-se com proveito em fórma de chá, nas dôres de cabeça. estomago, molestias nerrosas e hysterismo. Externamente enprega-se em banhos, no rheumatismo, e dores syphiliticas.

leiva dó sapo ou azenimha do biejo. Herva saracura. (Begonia acida.)-Planta conhecida dos hervanarios.

\section{USOS MEDICINAES}

F' empregarla esta plarta, para curar os catarrhos da bexiga. USOS DOMESTICOS

No interior das familias servem-se do sumo d'esta planta para tirar das roupas as norloas de tinta de escrever.

I Ierva -iereno. (Conysa laniginea.) Alagòas. - Esta planta pequenina e mimosa. vegeta nas Alagôas, onde the dĩo o nome de herw sereno.

\section{ISOS MEDICINAES}

o cozimento, serve para curar as feridas da bocca das criancas; e mesmo mettida a planta em um saquinho, penduram-n'a ao pescoço da creança, com o mesmo prestimo.

Herva solidouia. - Planta que nasce, e vegeta nas paredes velhas.

LSOS MEDICINAES

O cozimentu serve para as molestias dos olhos.

Ierva tostão ou bxedo de porco. (Bophatia 
hirsuta.)- Planta pequena, muito esgalhada, que produz pelos quintaes, e por qualquer parte, tendo uns frutinhos que se assemelham a herva doce. Esta planta é mui conhecida de todos.

\section{USOS MEDICINAES}

o cozimento da raiz, tomado pela manhã e á noite, com oil sem assncar, é diuretico e desobstruente do figado.

Tambem é empregada nos catarrhos do peito, nas defluxzes"; bebido o sumo da raiz ou batata, é contra o veneno das cobras.

Herva trombeta. (Datura fastuosa.) Roxa.-E" plauta esgalhada, com flores grandes como trombeta.

Ha duas especies de hervatrombeta, sendo uma branca e a outra roxa.

\section{USOS MEDICINAES}

Não são conhecidos; mas, sabe-se que é venenosa.

FIerva vonenosa. (Echites venenosa.)-Planta venenosa, conhecida dos sertanejos; porque mata o gado que a come.

I:SOS MFDICINAES

Não são conhecidos.

Frerva de vintén. - Esta planta conhecida no Maranhão pelo nome de herva do vintém. é de sabor amargo, e empregada na medicina domestica.

\section{USOS MEDICINAES}

o cozimento é estomachico, e tambem empregado para curar a defluxão do peito.

Herva-hai.-Arvore corpulenta que cresce nas margens do rio Paraná.

\section{LSOS MEDICINAES}

Não ลão conhecidos.

ISOS NAS ARTES

Serve para obras de construcção civil.

Tumisi. (Humirium forihundum.) - Arvore das mattas to Brasil, floresce em Setembro. 


\section{USOS MEDICINAES}

A casca d'esta arvore, por sua adstringencia, serve para curar as feridas chronicas.

\section{USOS NAS ARTES}

O seu lenho é empregado na construcção civil.

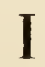

Tarivá.-Palmeira de S. Paulo.

USOS MEDICINAES

o palmito d'esta palmeira, é especial remedio, para curar 0 diabetes.

Ibabiraba. (Nyitus aiborecens.) - Arvore de grandeza regular, oriunda do Parí.

\section{USOS MEDICINAES}

As folhas e as flores, misturada's com o camará, fervidas, e com o cozimento dando-se escalda-pśs a um enfermo, é bom revulsivo.

Ibaiariba. (Andiru rosea.) - E' arvore corpulenta, dạs mattas do Amazonas.

\section{USOS MEDICINAES}

Crê-se ser uma variedade do angelim, possuindo:llie,as.mesmas propriellades.

Ibirapitanga. (Vid. pio Brasil.)

Ibirarema. (Seguieia americana.) - Arbusto medicinal.

USOS MEDICIXAES

o seu cozimento serve para curar o rheumatismo, eas empigens.

Internamente tomado, serve para combater a liydopesia. 
USOS NAS AR'TES

As cinzas servem, para clarificar o assucar, e para o fabrico do sabão.

Ibira. (Xylopia frutescens.)-Planta brasileira, cujos fructos são estomachicos e aperitivos.

\section{USOS MEDICINAES}

A raiz d'esta planta, é contra o veneno das cohras.

Iacamiau-caá. (Dr. Lacerda.)-Planta do Pará, conhecida e experimentara pelo Dr. Lacerda, no Maranhão.

\section{USOS MEDICINAES}

A casca pisada, e infundida em agua morna, cura as febres intermittentes.

Icicariba. ((Icica icicariba.)-Arvore, que distilla a resina Icica, chamada elemi occidental, que é preferivel ás outras resinas.

\section{USOS MFDICINAES}

Os mesmos prestimos da almecega.

Icó. (Colicodendron Icó.)-Planta das catingas, e agrestes de todo o Brasil, $\theta$ mui conhecida dos tropeiros, e sertanejos.

\section{USOS MEDICINAES}

Não são conhecidos, mas as folhas comidas pelos cavallos, e mullas, produzem colicas, inflammação dos intestinos e rins, causando-lhes a morte, se lhes não acodem, com sal de cozinha e oleo, dado pela bocca; ou grande quantidade de milho, a omer, para lhe neutralisar a acção venenosa.

As sementes do Icó, são venenosas.

Igbacamuci. - Planta, que folga na provincia de S. Paulo.

\section{USOS MEDICINAES}

Os camponezes empregam esta planta, no curativo das dysenterias sanguinolentas.

Imbé. (A rum usum.)-Especie de cipó, de que se servem os camponezes para curar as feridas velhas; e as raizes usam em purgante, nas hydropesias. 
Imbé de comor. (A rum edule.)--Planta mui conhecida nas Alagôas e Pernambuco, e parecida com a sua con genere.

\section{USOS MEDICINAES}

As raizes são usadas, como diureticas, na cura das hydropesias. USOS NAS ARTES

As vergonteas servem para a fabricação de cestos, e balaios, e para amarrar as cercas.

Imbiri. (Canna angustifolia.)-Planta do Amazonas, usada na medicina domestica.

\section{USOS MEDICINAES}

E' diaphoretica, contra o rheumatismo, e antidoto do mer curio.

Imbirussú. (Bombax hexaphyllum.) - E' uma arvore semelhante á barriguda de Pernambuco e Alagôas, que vegeta no Rio de Janeiro, vulgarmente chamada Paineira.

\section{USOS MEDICINAES}

o cozimento da casca serve para curar as feridas velhas

Imbuinseiro. - Arvore dos agrestes do Rio de Ja neiro, conhecida dos lenhadeiros.

TSOS MEDICINAES

Não são conhecidos. A fructa d'esta arvore, serve de alimento aos passaros.

Imburana. (Bussera leplophlocos.) - Arvore muito vulgar em todo o Brasil. Por incisão fornece um balsamo verde alourado, semelhante a therebentina, que faz o mesmo effeito.

USOS MEDICINAES

Este balsamo c digestivo das feridas velhas.

USOS NA INDUSTRIA

A industria poderá tirar vantajosos resultados d'esta arvore, quando ella fôr convenientemente estudada.

Imbuzeixo. umbuzeixo. (Spondias tuberosa.)-E' 
nma arvore dos sertões do Brasil, mui estimada de todos por seus fructos, e mesmo por suas raizes.

\section{USOS MEDICINAES}

- o succo da fructa è um refrigerante nas febres inflammatorias.

\section{USOS ORDINARIOS}

o succo da fructa misturado com leite e assucar, fórmá a umbuzada, que serve de sobremesa nos sertões da Bahia. Com a massa da fructa, fabrica-se delicioso doce. As batatas que dĩo nas raizes, são comestiveis.

Inajaxana.-Planta vulgar do Pará.

USOS MEDICINAFS

o cozimento da casca d'esta planta, conforme o testemunho do Dr. Lacerda, serve para curar as dòres rheumaticas syphiliticas.

Indá-assín. - Arvore de 30 í 40 palmos de altura com 1 de grossura. Floresce em Agosto.

USOS MEDICINAES

O seu fructo é purgativo.

\section{- USO NAS ARTES}

O lenho d'esta arvore, serve para o fabrico de formas.

Ingá. (Miniosa.)-Arvore de 40 palmos, com 2 de diametro. Floresce em Agosto.

\section{USOS MEDICINAES}

- cozimento da casca, serve para curar as feridas velhas, e em clysteres cura a diarrhéa

\section{USOS NAS ARTES}

A madeira, serve para frechaes.

Ingá racão.-Arvole de 30 palmos, com 1 á 2 de diametro. Floresce em Agosto.

\section{USOS MEDICINAES}

Tem os mesmos prestimos medicinaes, que a precedente. 
USOS NAS ARTES

Serve o seu lenho para taboados.

Ingia bravo.-Arvore esgalhada das Alagoas e Pernambuco, e folga nas margens dos rios.

\section{ESOS MEDICINAES}

A casca d'esta arvore em infusão ou cozimento, serve para a diarrhéa, a blennorrhéa, e hemoptises. o pó da casca, ou mesno das follias é antiseptico.

Ingá cipó. (Mimosa)-Arvore de 30 palmos, com um de diametro. Floresce em Setembro.

USOS MEDICINAES

Não são conhecillos.

USOE NAS ARTES

Serve o seu lenho para verwas e ripas.

Ingahi. (Mimosa.) - Arvore de 60 palmos, com 2 a 3 de grossura. Floresce em Setembro. A sua madeira é amarella e macia ao trabathar, e de poros fechados.

\section{USOS MEDICINAES}

Não são conhecidos.

LSOS NAS ARTES

Serve para o fubrico de canóas, e de taboados.

Inga-assí. - Arvore de 40 a 50 palmos de altura, com 2 de diametro. Floresce em Setembro. A madeira é macia, e de poros abertos.

\section{USOS MEDICINAES}

Não são conluecidos.

USOS NAS ARTES

Tem os mesmos usos que o ingá-facão.

Inhabatan.-Arvore de 50 à 60 palmos de altura, com 2 á 6 de diametro. Floresce em Setembro, e assemelha á sapucaia no tronco e raizes. Ha diversas qualidarles. 


\section{USOS MEDICINAES}

Não são conhecidos.

\section{USOS NAS ARTES}

Serve para mastros de sumacas e galeras, e para diversos usos na carpintaria.

Inhahiba amarella.-Arvore de 60 á 70 palmos de comprido, com 2 á 3 de diametro. Floresce em Setembro.

\section{USOS MEDICINAES}

Não são conhecidos,

USOS NAS ARTES

Serve a sua madeira, para taboado, frechas e vigas.

Inhame. (Dioscorea sativa.)-E' uma tubera oriunda da Africa, transplantada no Brasil, cujas hastes são trepadeiras. E' excellente alimento. D'esta planta ha differentes qualidades.

Ipadú._Planta do Pará.

USOS MEDICINAES

A infusão das folhas do Ipadú, bebida de 2 , em 2 horas, meia chicara, cura as febres nervosas.

Ipana. (Pará.)

\section{USOS MEDICINAES}

A infusão feita com esta planta, cura as mordeduras das cobras.

Ipé, ou páo d'arco. (Tecoma ipé.)-Ha uma grande variedade d'esta arvore, conhecidas dos derrubadores.

\section{USOS MEDICINAES}

o cozimento da casca tomado em gargarejos, cura as ulceras syphiliticas da garganta; e em fomentações, cura as empigens.

o succo das folhas applicado nas palpebras, cura a inflammação dos oḷhos.

Ipé branco. (Patagonula vulneraria.)

USOS MEDICINAES

As folhas curam com efficacia os bobões syphiliticos. 
Ipé contra a sarna. (Tecoma impetiginosa.)

\section{USOS MEDICINAES}

Esta planta, originaria do Piauhy, é usada em banhos, para curar as empigens, as leucorrheas e catarrhos da bexiga.

Ipé-merim ou páo santo. - Arvore de 50 å 70 palmos de altura, com 2 a 4 de diametro. Floresce em Ontubro.

\section{USOS MEDICINAES}

o cozimento das folhas, serve para o rheumatismo.

\section{USOS NAS ARTES}

A sua madeira serve para a architectura.

Ipé roxo. (Tecoma curialis.) - Arvore de 60 e mais palmos de altura, e grossura proporcional.

USOS MEDICINAES

Não são conhecidos.

USOS NAS ARTES

A madeira serve para construcção civil e naval, por ser de muita duração.

Ipé tabaco. (Tecoma.)-Arvore de grandeza regular.

\section{USOS MEDICINAES}

o cozimento da casca, serve para curar a inflammaçĩo de gar. ganta, dartros, e inflammação dos olhos; e dizem, que o succo expresso, serve para curar a paralysia das palpebras, fomentando-se as partes com elle.

Ipé ipeuva. (Tecoma speciosa.)

\section{USOS MEDICINAES}

A infusão ou cozimento da casca é dituretico, e contra o catarrho da bexiga.

Ipé-una.-Arvore de 50 á 70 palmos de altura, e com 2 a 4 de diametro. Floresce em Outubro.

\section{USOS MEDICINAES}

Não รão conhecidos. 
USOS NAS ARTES

Serve para as obras de architectura.

Ipeuva ou cinco follhas. - Arvore de mediana grandeza, e muito conhecida.

\section{USOS MEDICINAES}

As folhas são diureticas e depurativas, e contém um amargo agradavel Usa-se em infusão ou cozimento. 0 cozimento é muito proveitoso em banhos no rheumatismo articular syphilitico.

Ipecacuanha, ou poaya, ou raiz preta. (Cephcelis ipecacuanha.) - Esta planta vegeta nas mattas, e nos taboleiros. A raiz é fina, nodosa e aspera. Em Matto Grosso, fórma un ramo do commercio, muito lucrativo.

USOS MEDICINAES

A raiz é vomitiva e purgativa, e se emprega nas pharma. cias, para muitas composiçres officinaes.

A ipecacuanha serve para combater as febres, a diarrhéa, as camaras de sangue, a suppressĩo da transpiração, e os padecimentos do estomago.

Tambem emprega-se a ipecacuanha, com muito proveito nas febres inflammatorias.

Tpocacuanha branca ou do campo. (Solea campestres.)-Pison e Marcgrave foram os primeiros que deram noticia na Europa da Ipecacucuha, em 1648, na sua obra Historia naturalis Brasilice, impressa em Amsterdam. N'essa obra fallam da ipecacuanha branca e preta, reconhecendo ser a ipecacuanha branca mais fraca, que a preta, e preconisam os effeitos medicamentosos d'esta planta, contra as molestias occasionadas por antigas obstrucçũes.

\section{USOS MEDICINAES}

E' purgativa. Os moradores do campo empregam a raiz da ipecacuanha branca, para todas as molestias, e principalmente para curar as febres inflammatorias, as obstrucções do figado e baço; provoca os menstruos tardios.

Ipecacuanha branca da praia. "(Viola litto- 
rali s.) - E' esta planta a ipecacuanha branca de Pinson e Marcgrave. Vegeta nas costas do mar, e nos logares arenosos.

\section{USOS MEDICINAES}

o povo serve-se d'ella, para curar a dysenteria, a epílepsia, os catarrhos da bexiga, e a diabetes ou ourinas doces.

Issicariba. - Arvore, que produz a resina chamada gomma elemi, suppre a falta da almecega, e é de muita estimação, e preço.

\section{.}

Jabiziandi. (Piper Jabigrande.)-Esta arvore é o Be- tele da india, cresce pelas proximidades dos rios.

\section{USOS MEDICINAES}

E' efficaz para as molestias do figado. 0 betele menor, serve para curar a dôr de dente, mettendo o succo da raiz, no buraco do dente.

A raiz d'esta planta é ardente. e ingorgita a mucosa da bocca.

raborandi bravo. (Piper Joborandi.) - Planta pequena, que nasce nos mattos. Floresce e dá fructo. A sua acção picante, é trio energica, que tocada na lingua, a faz tremer.

\section{USOS MEDICINAES}

E' o mais poderoso aphrodisiaco, que se conhece, e sudorifico energico. Como estimulante empregam a tintura em fricções nos membros paralysados.

Cura a dor de dente, mettendo-se a tintura embebida em algodão no buraco do dente doído.

Taborandi :hamso. - A diflerenca que tem esta planta, da sua congenere, é, que as suas flores exhalam um. aroma, como o do aniz. 
USOS MEDICINAES

A tintura é empregada para curar o rheumatismo, e a paralysia dos membros, friccionando-se as partes paralysadas.

Jaborandy ou jambuacú. - Arvore das nossas mattas, que tem muita camphora.

\section{USOS MEDICINAES}

Empregam as folhas, para curar o cansaço; e a sua raiz, que é venenosa, servem-se d'ella, para matar o peixe nos rios. E' picante, e queima como pimenta, e posta no buraco do dente faz passar a dôr, provocando a salivação.

Tambem servem-se d'ella em cozimento, para curar a colica, dado em clyster.

Jabotá. (Fevillea passiflora.)-Planta, que dá uma fructa, que se parece com a de Santo Ignacio. (Ignatia amara.)

\section{USOS MEDICINAES}

E' purgativa em dóse maior. Em pequena porção, serve para curar as flatulencias, a constipação do ventre, e os espasmos intestinaes.

Jabotapitá de Minas. (Gomphia hexasperma.)

\section{USOS MEDICINAES}

o cozimento da casca, é empregado no curativo das picadas dos insectos

Jaboty-racuanna ou jambuassú. (Pará.)

\section{USOS MEDICINAES}

o cozimento da casca, é empregado no curativo das boubas.

Jaboticaboixa. (Myrtus jaboticaba.) - Ha differentes variedades; a vulgar é a arvore, que produz a fruta agro-doce, conhecida pelo nome de Jaboticata, agradavel ao paladar, e da qual os indios fabricam vinho. As fructas nascem desde a raiz, até aos ramusculos da arrore. Tem a arvore de 25 á 30 palmos de altura, com 2 á 3 de diametro. Floresce em Agosto. Desde que priaci liam as trovoadas no sertão, cobre-se de folhagem, e a fructificação pouco dura. 


\section{USOS MEDICINAES}

E' mui conveniente aos que deitam sangue pela boca, e para as ruturas internas. O cozimento da entrecasca, é bom remedio para a asthma.

USOS NAS ARTES

A sua madeira, serve para otras de casas.

Jabotimata. (Dellilea grandeflora.)-E' planta conhecida no norte do Brasil.

\section{USOS MEDICINAES}

o cozimento das folhas, é muito medicinal para curar as queimaduras.

Jaca. (Artocarpus integrifolia.)-Arvore mui conhecida. 0 seu fructo é delicioso, e de saudavel alimentação.

Na provincia das Alagôas, ha jaqueiras em tanta abundancia, que até se deitam fructas aos animaes.

\section{USOS MEDICLNAES}

0 xarope feito com jaca molle, cura as defluxões do peito, e atè mesmo a tisica pulmonar no $2^{\circ}$ gráo.

o caroço, diz o autor da Pharmacopéa tubalense, é aphrodisiaco.

\section{USOS ARTES}

A madeira é empregada em differentes artefactos, sendo as raizes procuradas para a fabricação de mobilias. Os esculptores servem-se da madeira, para esculpirem imagens.

Jacamicaá. (Anthelmentica.)-Planta do alto Amazonas. USOS MEDICINAES

A infusão das folhas, é poderoso remedio contra os vermes intestinaes; mas é necessario muito cuidado nas dóses, porque é venenosa a planta.

Tacamincaa. (Commelina serrata.) - Arbusto paraense, e conhecido do Dr. Lacerda.

\section{USOS MEDICLNAES}

o cozimento d'esta planta, empregam-n'o contra os vermes intestinaes. 
Jacarámaxúr. (Dr. Lacerda.)-l'lanta do Pará, usada em medicina vulgar.

\section{USOS MEDICINAES}

o sumo d'esta planta, bebido na quantidade de 3 á 4 onças, e a casca pisada, posta sobre a ferida da mordedura da cobra, cura o mordido, neutralizando o veneno.

Jacarandá. (Bigonia jacaranda.)-Arvore, cuja madeira é preta, e lusidia, com 60 e mais palmos de altura, e de $]$ á 6 de diametro. Floresce em Setembro.

\section{USOS MEDICINAES}

E' empregado como anti-syphilitico. 0 cozimento da raiz servo para expellir os vermes intestinaes.

\section{USOS NAS ARTES}

o seu lenho, serve para todas as obras de ornatos das salas, e para diversas obras de carpintaria e marcenaria.

Ha outra especie de jacarandá, chamado branco, que tem emprego na carpintaria.

Jacarandi pardo. (Nissolia.) - Esta qualidade de jacarandá, só differe do jacarandá preto pelas ondulações, e mesclas do preto, sobre um fundo pardo.

\section{USOS MEDICINAES}

E' anti-syphilitico.

\section{USOS NAS ARTES}

Serve o seu lenho, para as obras de carpintaria, e marcenaria.

. Tacarandá paulistano. (Jacarandá oxyphilla.)

USOS MEDICINAES

o cozimento dado em fórma de chá, cura os syphiliticos. 0 extracto dá-se em fórma de pi lulas. 0 pó do jacarandá serve para curar as feridas syphiliticas, pulverisando-as com elle.

Jacarandá pitanga.-Arvore do mesmo tamanho, e igual grossura, que as suas congeneres. 


\section{USOS MEDICINAES}

Goza dos mesmos prestimos.

USOS NAS ARTES

o jacarandá pitanga, é preferido para as obras de marcenaria, pelo atartarugado de seus veias, que dão graça $\theta$ brilhantismo ás obras de luxo.

Jacarandarama. - Arvore de 100, e mais palmos de altura, com 6 á 8 de diametro. Floresce em Novembro, sendo as suas flôres brancas.

\section{USOS MEDICINAES}

Não são conhecidos.

USOS NAS ARTES

A sua rijissima madeira, é empregada em esteios, por se não corromper na terra, em dentes de moendas, e rodas de machinas.

Jacaré-y-tauá. (Gonania apendiculata.) - Planta, tre• padeira, abundante no Pará.

\section{USOS MEDICINAES}

o cozimento d'esta planta é proveitoso, para limpar a caspa da cabeça.

Jacatupé. (Pachyrrhizos angulata.)-E' planta tuberosa, e d'ella tira-se farinha muito saudavel.

\section{USOS MEDICINAES}

A farinha é empregada nas molestias das vias ourinarias.

.racua-acanga. (Tiaridium indicum.) - Planta vulgar brasileira, conhecida dos hervanarios.

\section{USOE MEDICINAES}

E' desobstruente, e serve para curår a inflammação do anus, tomada em banhos.

Talapa. (Convolvus officinalis.)-E' uma trepadeira natural do Mexico, e vegeta na America, em quualquer terreno.

A batata que produz, soccada e espremendo-se-lhe o succo, e usaudo-se do sodimento que deixa, a que se chama gomma 
ou tapioca de Jalapa, ou extrahindo-se-lhe, chimicamente a resina, é por si só excellente purgante, e entra nas differentes preparações purgativas, usadas nas pharmacias ordinarias.

\section{USOS MEUICINAES}

0 uso mais frequente que dá o povo a esta utilissima planta, é para curar o estupor ou paralysia; e tanto que logo que se sentem affectados do estupor tomam um, dous ou tres purgantes de resina de jalapa, com o que se restabelecem.

A jalapa é mui vulgar nas provincias da Bahia, Sergipe, Alagôas e Pernambuco. Alguns dizem, que a jalapa só differe da planta vulgarmente chamada purga da batata, em ser a raiz ou batata da jalapa comprida, e a de purga de batata, redonda. Esta pequena differença, supponho ser dependente da indole do terreno, porque no mais são em tudo iguaes, na configuração geral, como nas folhas, cipó, flòr e semente que as propagam.-(Vid. a historia da jalapa, e seu descobrimento no Brasil, pelo Dr. M. J. Henrique de Paiva.)

Jamacarú. (Cereus geometricans)-Arbusto indigena.

\section{USOS MEDICINAES}

E' planta empregada contra o scorbuto; externamente $\dot{e}$ resolutiva dos tumores glandulares.

Jambeiro. (Eugenia jambosa.)-Arvore de 25 palmos de altura, de 1 á 2 de diametro. Floresce em Dezembro. 0 fructo é mui cheiroso, e enchertada a arvore, torna-se o fructo mais delicioso.

B

\section{usos MEdicinaes}

A casca do jambeiro cosida, serve para curar a dysenteria. USOS NAS ARTES

A madeira è empregada na fabricação de tamancos, e ou. tras obras ligeiras.

Jambuassú. - Planta conhecida dos hervanarios, do norte do Brasil.

\section{USOS MEDICINAES}

A raiz infundida em aguardente, é proveitoso remedio, em fricçðes, nas dôres rheumaticas. Cura o spasmo, untando-se a lingua do enfermo com esse licór. 
A infusão da raiz em agua quente, e dada ao enfermo de tosse rebelde, o cura.

Janauba.-Arvore que vegeta nas terras fracas, e seccas, com 40 palmos de altura, e 1 de diametro. Floresce em Maio. Este vegetal é utılissimo, por suas virtudes medicinaes.

\section{USOS MEDICINAES}

A sua raiz é purgativa, e póde ser applicada em todas as enfermidades, e principalmente as venereas. E' um poderoso emenagogo, para as mulheres, que não são menstruadas, ou que soffrem irregularidade da menstruação E' excellente remedio, para o cansaço, a hydropesia, e enchaqueca.

Esta planta dá por fructa uma banana, que sendo pisada, e em fórma de emplastro, posta sobre a rutura, ou quebradura, a cura.

USOS NAS AR'TES

A sua madeira, serve para a fabricação de remos.

Jandiroba.-E' um arbusto rasteiro. Floresce em Agosto. Dá uma fructa redonda, de que se extrahe o mals excellente azeite para luz.

\section{USOS MEDICINAES}

o oleo ou azeite da jandiroba, é muito util para curar o rheumatismo.

Jangada jangadeira ou ombira branca. (Apeiba cimbalanea)-Arvore de 60 palmos, com 2 á 4 de diametro. Floresce em Outubro.

\section{USOS MEDICINAES}

O cozimento da entre-casca, dizem ser poderoso remedio contra os vermes intestinaes. Convém ser usado em proveito das crianças.

\section{USOS NAS ARTES}

Serve a madeira para a fabricação de jangadas, com que nas Alagòas e em Pernambuco, pescam no alto mar, e fazem viagens costeiras.

Tapacamim. (Dr. Lacerda.)-Planta do Pará, descripta 
pelo Dr. Lacerda, que tem o cheiro e sabor semelhante, ao das amendoas amargas.

\section{USOS MEDICINAES}

o cozimento é empregađio como diuretico, nas hydropesias.

Japaranduba. (Gustavia brasiliensis.)-Arbusto conhecido, que vegeta em fórma de touceira, o qual floresce e fructifica.

\section{USOS MEDICINAES}

As sementes, não têm sido empregadas em medicina vulgar; mas sabe-se que ellas matam os cães. Convém que se façam experiencias em proveito da humanidade.

\section{USOS NAS ARTES}

O lenho serve para a fabricação de cestos, e balaios.

As folhas mergulhadas nos tanques e rios, desenvolvem ura cheiro nauseante e insupportavel.

Japary-pondá. (Pará.) - Plarita indigena, que quer dizer na linguagem dos indios, Diabo azul, empregada no Pará, para curar as diarrhéas, bebendo-se a infusão da casca.

.Tapecanga. (Similax japecanga.)-E' uma trepadeira ou cipó das mattas e capoeiras, espinhoso, mui vulgar nas Alagôas, Pernambuco. e outras provincias.

\section{USOS MEDICINAES}

Quer o cipó, e quer a raiz são mais efficazes, que a salsaparrilha, e raiz da China, para curar a syphilis. O tempo mais conveniente, para se colher o cipó, e a raiz, para o uso da medicina, é em Novembro e Dezembro, dous dias antes da lua nova; devendo se rachar em duas metades. 0 amago do cipó é mais efficaz ainda, para o curativo da syphilis.

. aracamacú. (Lacerda.)-Planta do Maranhão e Pará.

\section{USOŚ MEDICINAES}

A raiz d'esta planta, é empregada com proveito, nas mordeduras das cobras. 
Jaracatiá ou mamão matto. (Carica spiciosa.) -Planta conhecida e vulgar.

\section{USOS MEDICINAES}

o leite da fructa é optimo medicamento, para curar as hydropesias. Tira-se o leite, e logo depois coagula, porém deite-se ao sereno, no dia seguinte está dissolvido, e então bebe-se ás colheres com graduacĩo, conforme a idade do enfermo. Tambem embebem o leite com polvilho e formam pilulas para administrar aos enfermos.

Jaxaraca. (Silva Lisboa.)-Arvore de 30 a 40 palmos, com 1 de diametro. Floresce em Setembro.

\section{USOS MEDICINAES}

Não são conhecidos.

\section{USOS NAS ARTES}

Serve para as obras de carpintaria.

Jararaca.-Herva, cuja haste é pintada, como a cobra jararaca. e a sua raiz, é uma batata muito alva por dentro.

\section{USOS MEDICINAES}

Ralada a batata, e bebida em agua morna, é remedio effi. caz, contra a mordedura de qualquer cobra.

Jararaca. (Dracontium poliphyltum.) -E' plauta conhecida no Pará. e no Maranhão.

USOS MEDICINAES

o cozimento das raizes, serve para limpar as feridas veIhas. Internamente empregam-n'a para a mordedura das cobras.

Jararaca. (Maranhão e Pará.)-E' planta do Pará, deseripta pelo Dr. Lacerda.

\section{USOS MEDICINAES}

O cozimento das raizes é proveitoso na asthma, na chlorose, e provoca os menstruos supprimidos, a mesmo serve contra 0 veneno das cobras.

Tacaraca-tajo.-Planta do Parí. 


\section{USOS MEDICINAES}

A raiz d'esta planta, ralada, e com o pó, feita emplastro, resolve os tumores endurecidos.

Jaratacaca ou mercurio vegetal. - Planta vulgar brasileira. (Vide Manacć.)

USOS MEDICINAES

E' excitante energico do systema lymphatico, e expelle o virus venereo pelo suor, e pela ourina. E' preciso não tomar esta planta em dóse elevada, porque é um veneno acre.

Jarrinha ou cahau-pena. (Aristolochia cymbifira.)-Herva que produz em qualquer terreno, e muito conhecida dos hervanarios nas provincias do norte, e principalmente nas Alagòas.

\section{USOS MEDICINAES}

E' empregada para banhos no rheumatismo. Bebido o sumo, é contra o venono das cobras.

Ha outra especie chamada jarro-grande, que nasce nos brejos, e dá flôr grande e rajada de branco e roxo. o cozimento da raiz e follhas d'esta planta, sərve para curar a inflammação dos testiculos, e para curar as hernias. E' medicina presentanea, para a retenção das ourinas, e para os que deitam sangue pela bocca. Cura as pontadas, em qualquer parte do corpo, adelgaça os humores, e combate a obstrucção do baço.

A raiz em chá, provoca os menstruos ás mulheres.

As raizes verdes pisadas e borrifadas com vinagre, é excellente remedio para as contusões, e pisaduras. Desfaz as alporcas, e os favos (amygdalas) intumecidos da garganta.

o sumo da raiz, misturado com duas oitavas de cominhos, é singular remedio para desfazer, e consumir as hemorrhoidas. Cura as sardas do rosto, untando o sumo com mel de abelhas em partes iguaes.

o lambedor da jarrinha, faz passar a tosse, e a falta de l'espiração, com sangue pela bocca.

Faz purgar brandamente, tomando-se duas oitavas do pó da raiz, com duas oncas de assucar.

Cura as chagas, a queimadura, fazendo-se linimento, com o sumo das folhas. 
o sumo da raiz, applicado com o dedo, por 8 dias, ao orificio do utero, antes do parto, o facilita.

.Tasmim. (Jasminum.) - Ha muitas variedades d'esta planta, que não tem emprego na medicina, e sim na perfumaria.

.Tasmim do matto. (Jasminum fuminense.) (Vide Carlota Odorata.)

\section{USOS MEDICINAES}

A raiz e folhas d'esta planta, fervidas em quatro chicaras d'agua, até que fiquem em tres, e bebida meia chicara de manhã, e á noite, cura as gonorrhéas, e as dôres venereas.

\section{USOS NA INDUSTRIA}

As flôres pela distillação, podem fornecer uma essencia de cheiro mui agradavel.

Jatahypeba-mirim. - E' "arvore de 50 e mais palmos de altura, com 4 e mais de diametro, de folhas miudas. Floresce em Outubro.

\section{USOS MEDICINAES}

Não são conhecidos.

USOS NAS ARTES

Serve para construcções miudas, e esteios de casas.

Jataicica. - Arvore das mattas, que dá uma resina, conhecida pelo mesmo nome da arvore.

USOS MEDICINAES

A casca e a resina servem. para soldar as feridas frescas, externamente, e para os que botam sangue pela boca, tomando internamente um cozimento.

Jatobá. (Hymencea surbaril.)-Arvore de maravilhosa grandeza, de 100 a 140 palmos de altura. com 10 a 12 de diametro. Floresce em Outubro, com flóres paniculadas brancas. 0 fructo é cheiroso, doce, e agradavel ao paladar. Pelo tronco e raizes, rebentam massas de uma resina transparente, que se dissolve no alcool, ficando lambreada, e espirituosa, com cheiro baisamico, no gosto acre, e ligeiramerte amargoso, com - qua! se prepara um lindo verniz, contendo sua resina, substancias oleosas, e espirituosas, que se separam pela digestão. 


\section{USOS MEDICINAES}

A resina de jatobá, é remedio popular, para fazer estancar - sangue pela boca (hemoptisis), tomada uma pitada da resina pulverisada, misturada em uma gemma de ovo, tres vezes 20 dia.

As sementes, são usadas contra a asthma, infundidas em agua, dando ao enfermo, tres vezes ao dia.

A resina serve para massas cheirosas, unguentos balsamicos, e emplastros, pela virtude fortificante, nervina, cephalica, anti-catarrhal, e vulmenaria que possue.

\section{USOS NAS ARTES}

o seu lenho serve para cintados dos navios, para moendas de engenhos, e rodas de carros, para portas, e obras de igreja. Extrahe-se da sua entre-casca finissima tinta de escrever, misturada com sulphato de ferro (caparosa).

Jatuahuba.-Planta conhecida dos hervanarios.

\section{USOS MEDICINAES}

A raiz d'este vegetal é purgativa, dada em clysteres; serve para curar a dyarrhéa, as dôres de madre, e falta das regras.

Jatuatuba. - Arvore do Amazonas, conhecida por seus fructos em cachos, semelhantes aos da parreira.

\section{USOS MEDICINAES}

A infusão da raiz, é poderoso cathartico; e affirmam, que este remedio, tem a virtude de fazer da mulher esteril, focunda, e prolifica.

.Taunaa. (Solanum jaura.)-Planta do Pará.

\section{USOS MEDICINAES}

E' empregada para curar o scorbuto.

Jequigty-goaé ou saboeiro. - E' arvore de grandeza regular, que vegeta i beira dos rios, e nos logares humidos. Nas Alagôas ha abundancia d'este vegetal. Floresce e fructifica, sendo o seu fructo do tamanho de uma uva muscatel, e dentro tem uma semente muito negra, e rija, que não tem gosto. 


\section{USOS MEDICINAES}

Não são conhecidos.

USOS NAS ARTES E NA INDUSTRIA.

Com as sementes fazem contas para enfeites, e a casca que as cobre, que é amarga, desenvolve tanta espuma, como o melhor sabão.

As lavadeiras servem-se dos fructos, para ensaboar a roupa.

Jequetibá. (Pyxidaria macrocarpa.) - Arvore de prodigiosa altura, com 100 e mais palmos, com 4 a 6 de diametro. Floresce em Novembro.

\section{USOS MEDICINAES}

Dizem, os sertanejos, que a casca do jequitibá, serve para suspender as hemorrhagias uterinas, e curar as leucorrhéas.

USOS NAS ARTES

Sendo a sua madeira leve, e elastica, a empregam para mastros dos navios, mas tem o defeito de apodrecer em pouco tempo na carlinga, (assento do pé do mastro).

Em geral, usam do lenho de jequitibá, para o tabrico de canôas, e para caixas de assucar.

Texicó.-Nasce esta planta debaixo das arvores, e folga nos terrenos sèccos, sem que o sol a consuma, e tem uma particularidade, digna de reparo, e vem a ser, que depois de sêcca, deitando-se n'agua, reverdece dentro em seis horas, como se estivesse na mais viçosa vegetaç̃o.

USOS MEDICINAES

Nãu sĩo conhecidos.

Te ruirioba. (Solanum jequirioba.) - Especie de cammi. Planta vulgar, e medicinal.

\section{USOS MEDICINAES}

o cozimento da planta, é proveitoso nas anginas, e serve para curar a escarlatina, e fazer apparecer o leite ás mutheres, tomando 12 gottas da tintura, em uma libra d'agua.

Jequiry da matta.-E' planta das nossas mattas, a qual sendo incizada, dá seiva leitosa. 


\section{USOS MEDICINAES}

o leite é muito proveitoso na hemoptisis, e na pneumatorrhéa.

Jetahy amarello. (Silva Lisboa.)-Arvore de 80 a 120 palmos de altura, com 4 a 12 de diametro. Floresce em amarello, no mez de Setembro. A sua madeira é amarella, compacta, durissima, e lusidia.

\section{USOS MEDICINAES}

A casica e anti-syphilitica.

\section{USOS NAS ARTES}

Serve para taboado, para rodas de machinas, poliame, e obras de architectura.

\section{USOS NA INDUSTRIA}

Da casca, e rasuras da madeira, se obtém tinta amarella.

Jetahy-juba. (Silva Lisboa.)-Arvore de 60 a 100 palmos de altura, com 2 a 8 de diametro. Floresce á imitação da angelica, em Setembro.

A madeira tem os poros fechados, e é macia ao serrar, e lavrar.

\section{USOS MEDICINAES}

Não são conhecidos.

USOS NAS ARTES

Serve para curvas dos navios, couçoeiras, e cavilhas de portas.

Jetahy-pébussú. - Arvore que tem as mesmas dimensões, e serve para os mesmos usos. Só se differença nas folhas, e flôres.

Jetahy preto ou paxdo. - Arrore de igual altura, e mesmo diametro, que o jequitibá amarello. Floresce de côr carmezim, em Setembro.

A madeira é rijissima, e revessa ao serrar, e lavrar. USOS MEDICINAES

A entre-casca é purgativa e anti-syphilitica. Dos fructos faz-se extracto ou conserva, para se dar aos enfermos. 
USOS NAS ARTES E NA INDUSTRIA

A industria póde d'esta arvore extrahir boa tinta, para a tinturaria. o lenho serve para obras de carpintaria.

- Jetirana ou batata brava. - E' planta trepadeira, e mui conhecida nas Alagôas.

\section{USOS MEDICINAES}

o pó da raiz, bebido em aguardente, vinho, ou agua quente. pela manhã, cura a gonorrhéa.

As folhas pisadas, e feitas cataplasma, e applicadas aos testiculos endurecidos, os restabelece ao seu estado natural.

. Tiquiry. (Dr. Lacerda.)-Planta de Pará, empregada em medicina vulgar.

\section{USOS MEDICINAES}

A raiz d'esta planta, cozida em agua pura, durante 6 ou $\tau$ dias, até que mude a côr em amarello, dada a beber ao que padece de pedras nos rins, ou na bexiga, as desfaz sem o emprego de instrumento cirurgico.

Joá ou joaseiro. (Ziziphus jouseiro.) - Arrore espinhosa dos sertões, e cutingas. Floresce, e fructifica, sendo os fructos comestiveis.

\section{USOS MEDICINAES}

o fructo, é estomachico; a infusão da casca, é proveitosa em limpar a cabeça das caspas.

o succo da casca é vulnerario, e com elle se faz no sertão um lambedor, com que curam os tysicos, até o segundo gráo.

João Gomes ou Brêdo . Toão Gromes.E' brèdo de folhas largas, mui apreciado, para os guizados das mesas.

Joanninha.-Planta aromatica do campo, que folga em qualquer terreno. E' mui conhecida dos hervanarios do sertão.

USOS MEDICINAES

Os sertanejos, servem-se d'esta planta em fórma de chá, para combater as ventosidades hemorrhoidaes. 
o gado que a come, engorda muito, e torna a carne saborosa.

Joápitanga. (Alagoense.) - Arbusto pequeno, e rasteiro, que se estende em vergonteas, e conhecido nas provincias do norte do Brasil.

USOS MEDICINAES

E' sudorifica, tomando-se em cozimento e anti-syphilitica.

Joeira prego. (Silva Lisboa.)-Arvore corpolenta, das nossas mattas. A sua madeira é de boa qualidade.

\section{USOS MEDICINAES}

Não são conhecidos.

USO NAS ARTES

Serve para canoas, e mesmo para o fabrico de casas.

.ooilana amarella. (Silva Lisboa.)-Arvore de 30 a 60 palmos de altura, com 4 e mais de diametro. Floresce em Setembro.

USOS MEDICINAES

Não «ão conhecidos.

\section{USOS NAS ARTES}

o seu lenho serve para o fabrico de caixões.

.5oeirana br'anca. (Silva Lishoa)-Arvore de 60 a 80 palmos de altura, com 3 it 10 de diametro. A sua qualidade 6. inferior a joeirana amarella. porque é malleira fraca.

ISOS MEDICINAES

Não ลล̃o conhecidos.

USOS NAS ARTES

Serve para o tabrico de canôas e caixões.

rocirana vermolha. (Silva Lisboa.) - Arvore corpolenta, e mui alta. Floresce em Novembro, O sen lenho é macio, de poros abertos, e avermelhado.

USOS MEDICINAES

Não são conhecidos. 
USOS NAS ARTES

Serve para taboados, para o fabrico de canôas, e de caixões.

Ioào. (S. João.) -Arbusto pequeno, que vegeta em terrenos aridos. E' conhecido dos hervanarios.

USOS VEDICINAES

Serve o seu cozimento em banhos, para curar o rheumatismo. USOS NA INDUSTRIA

A casca e o fructo, dão uma bella tinta amarella, e se se expõe esta tinta ao sol, torna-se coxa. A raiz, é ainda mais rica em tinta, por ser mais fina, e agradavel.

Joíba. (Silva Lisboa.)-Arvore conhecida dos derrubadores, de 50 palmos de altura, com 3 de diametro. Floresce em Setembro. A sua madeira é macia, e de poros fechados.

rSOS MEDICINAES

Não são conhecidos.

USOS NAS ARTES

Serve para pranchões, taboados e vigas.

Iuaityuma. (Dr. Lacerda.)-Arbusto do Pará, muito conhecido do povo.

USOS MEDICLNAES

Pisada a planta, e posta na picada fresca da alraia, a cura promptamente.

-Iucá. - Arvole das provincias do norte, principalmente das Alagoas, Pernambuco e Ceará.

USOS MEDICINAES

A sua raiz é purgativa, desobstruente, e empregada para curar a hydropesia. Servem-se da casca, em infusĩo, no curativo da tysica pulmoilar, e para curar a asthma. Nos sertうes servem-se d'esta planta, como remelio ef̣icaz nas co.tisões.

Jumbeba. (Cactus oprntia.) - Planta conhecida, e muito vulgar no Rio de Janeiro.

USOS MEDICINAES

o cozimento d'esta planta modifica as dôres sciaticas, e 
mesmo fazendo se della całaplasma. Misturado o cozimento com agua vegeto-mineral, é proveitoso na elephantiasis dos arabes.

o xarope dos fructos e folhas, é empregado com proverto na tysica pulmonar, bem como aos que padecem de lepra.

o succo, misturado com leite, é mui proveitoso na inflammação simples dos olhos.

Jinea. (Cyporus esculentus.)-Planta que nasce nos brejos, e na beira das praias. Abunda nas Alagoas.

\section{USOS MEDICINAES}

E' de reconhecido prestimo, para as dôres de ventosidades, e particularmente para mordeduras de cobras. Emprega-se a. raiz ralada, ou contundida, e da qual se extrahe o succo. e se bele; e ao mesmo tempo, applicam-se os residuos sobre a parte offendida. E' carminativa energica, e anodyna.

\section{USOS NA INDUSTRIA}

En consequencia de possuir cheiro mui agradavel, é empregada em perfumaria.

Junco. (Lepidosperma officinalis.) - Planta que nasce nos lagos, e logares paludosos, cujas follhas, em fôrma de canudos, são roliças, verdes e estaladiças. Dí uma batata muito amarga. Esta planta abund.r nas Alagoas e Pernambuco.

USOS MEDICINAES

Conforme a opinião vulgar, a batata do junco, é efficaz medicamento, contra a inordedura das cobras.

USOS NA INDUSTRIA

Além d'esta especie, ha outra mais fina, que serve para o fabrico de esteiras, para soadores das salas, cangalhas, chapéos, e outros objectos de uso.

Jundiba.-Arvore de 60 e mais palmos de altura, com 2 á 6 de diametro. Floresce em Setembro. Tem a madeira de poros fechados, e macia ao serrar.

\section{USOS MEDICINAES}

Não são conhecidus. 


\section{USOS NAS ARTES}

Serve para vigas, frechaes, e caixões.

Inondinida. (Silva Lisboa.) - Arvore de 60 palmos de altura, com 2 e mais de diametro. Floresce em Agosto. A sua madeira é de poros fechados, macia ao lavrar e serrar.

\section{USOS MEDICINAES}

Não são conhecidos.

USOS NAS ARTES

Tem os mesmos prestimos que a Jundiba.

Junamoir.a. (Cressa anti-syphilitica.) - Planta rasteira. conhecida em Pernambuco e Alagoas.

\section{USOS MEDICINAES}

o cozimento feito com esta planta, cura as gonorrhéas, e as dores rheumaticas, provenientes do vicio venereo.

Iunqueira-assí. (Adenanthera thyrsosa.) - Arvore do Pari, e alli empregada em medicina vulgar.

\section{USOS MEDICINAES}

As folhas pisadas, e feitas cataplasma, são empregadas nos corrimentos articulares.

Tunquilho. (Narcisus junquilla.)-E' planta de jardim, muito conhecida, cuja flôr é assás aromatica.

\section{USOS MEDICINAES}

A natureza do junquilho é quente, e a raiz é deseccante, e glutinosa; se se come, faz vomitar. E' consolidante, e dizem que serve para consolidar as hernias. As flôres tidas muito tempo na bocca, são narcoticas.

Tuquiri, (Mimosa brasiliensis.)-Arbusto, que folga junto dos rios, e alagadiços, semelhante á esponjeira.

USOS MEDICINAES

As tolhas pisadas, e applicadas sobre as hernias, as faz recolher. 
Iuroma. (Mimosa jurema.) - Arvore de mediana grandeza, que vegeta em terrenos fracos e seccos.

\section{USOS MEDICINAES}

A entre-casca da jurema serve em cozimento, para lavar feri. das. A casca da raiz, serve para curar as diarrhéas, tomado o cozimento em clyster.

Os sertanejos, curam o cansaço, e a cachexia, com a casca d'esta arvore.

Os indios extrahem da jurema, certa especie de vinho, que embriaga, com transporte delicioso; e para este fim, tiram a casca, poem-n’a em infusão, por 24 horas, coam depois a infusão, ajuntam-lhe mel de abelhas, para corrigir o gosto adstringente d'essa embriagante bebida, e guardam-n'a para o uso.

Os sertanejos empregam a entre-casca da jurema, como fortificante do apparelho uterino.

Juruboba. (Solanum paniculatum.)-Planta, de grandeza mediana, tendo as folhas largas, e todas ellas semeadas de espinhos. E' mui conhesida na Bahia, Sergipe, Alagoas e Pernambuco, onde vegeta em abunda cia. Esta planta é mui estimada por suas virtudes medicinaes.

\section{USOS MEDICINAES}

A raiz cozida, e dada a beber, cura as gonorrhéas, combatendo ao mesmo tempo o virus syphilitico. A fructa, que é amarga, é grande remedio para as apusthemas internas; bem como servem-se do sumo bebido, e posto externamente nas contusões, pela manhã, e á noite, misturado com agua. E', além d'isso, estomacal, e um precioso desobstruente do figado.

o padre-mestre José Bonifacio Bezerra de Mello (meu professor de latim), constantemente comia, còmo regalo, a fructa da jurubeba.

Jussara ou assahy. (Alagoas.)-Especie de coqueiro, mui abundante nas Alagoas.

USOS NA INDUSTRIA

A industria póde obter d'esta planta, optimo vinho.

Iussara. - Especie de capim, cuja folha imita ao capim Sapé, e deita flor amarella. 
USOS MEDICINAES

A batata, que produz, é remedio valente, contra a mordedura das cobras.

Jutuayba.-Arvore das nossas florestas, de casca amarellada.

\section{USOS MEDICINAES}

A casca da raiz é muito amarga, e feita cozimento, e dado em clyster, é de muito proveito, para curar a hydropesia, ou barriga d'agua.

.Tutuauba. (Guarea pendula.)-E' arvore brasileira, cuja casca é purgativa.

\section{USOS MEDICINAES}

E' empregada ema clysteres, tendo os mesmos usos medicinaes do Gitó.

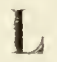

Labaga. (Lapathum.)-Planta vulgar, que vegeta em logares baixos, e ferteis.

\section{USOS MEDICINAES}

E' empregada em banhos nas erysipellas chronicas, e nas molestias da pelle.

Cacre branco. (Depotiton odorata.)-E' uma arvore das Alagoas, esgalhada, de fulhas grandes, coberta de um pello acinzentado, e flôres brancas.

\section{USOS NAS ARTES}

o seu lenho é empregado na marcinaria.

Lacro vermeiho. (Vismia antiscrophylla.) -Arbusto conhecido nas Alagôas, e medicinal; e dá toores amarelladas.

\section{USOS MEDICINAES}

E' poderoso remedio contra as escrophulas, e ophthalmias. 


\section{USOS NAS ARTES}

o fructo e a casca produzem uma gomma amarella averme lhada, que pole ser empregada em diversos usos, não só na pintura, como na tinturaria.

0 povo serve-se do fructo para tingir o arroz, e a cornida.

Lagimas do tossa sienhora. (Cois lacrima.) -E' planta silvestre, de acção excitante.

\section{USOS MEDICINAES}

Usa-se em banhos, nas fraquezas dos membros.

Lamimas de Vonus. (Lacrime veneris.) - Planta de jardim, geralmente conhecida.

Até agora não se lhe cornece as virtudes medicinaes, porque não se tem feito experiencias, com a cebola.

Iuancisa. (Solidago vulneraria.)-E' um arbusto conhecido no sul do Brasil, e empregado em medicina popular.

USOS MEDICINAES

o cozimento feito com a planta, é empregado para curar as feridas.

Candinn. (Silva Lisboa.)-Arvole que abunda em Santa Catharina e nas Alagoas, de 40 palmos de altura, com 2 de diametro.

\section{USOS MEDICINAES}

Nĩo s⿱̃⿻ conhecidos.

USOS NAS ARTES

Serve para mastros de navios, e para taboado.

Eandirana. (Silva Lisboa.)-Arvore de 30 palmos de altura, com 1 1/2 de diametro. Floresce em Agosto. A sua madeira é macia ao lavrar.

\section{USOS MEDICINAES}

Não รão conhecidos.

\section{USOS NAS ARTES}

0 ceu lenho serve para remos, e canôas pequenas. Do tronco d'esta arvore rebenta uma resina amarella, e elastica, applicavel a diversos usos. Convém ser estudala. 
Isantink. (Collophyllum bickiliensis.) - Arvore corpolenta das mattas da capitania ou provincia do Espirito-Santo. Floresce, e fructifica em Setembro.

\section{USOS MEDICINAES}

I resina que distilla esta arvore, empregada em emplas- tro, para resolver os tumores.

USOS TAS ARTLS

O seu lenho serve para taboados.

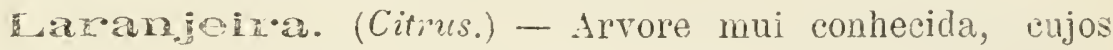
ructos são deliciosos. Ha diversas qualidades de laranjeiras, como sejam, do matto, secca, selectu, tungeina, da teria, turanja, de nmbigo, e da Ćhine, ete.

\section{UEOS MEDICINAES}

En geral as fulhas, e a casca das laraujeiras, são estimulantes, antispasmodicas, tonicas, e empregadas nas wolstias nervoas, nas digestões tardias, nas convulsões, nos spasmos, e palpitações do coracão.

A casca da raiz da laranjeira da terra, é muito proveitosa na asth na, nas erysipellas e na epilepsia.

As sementes pisadas, e bebidas em agua, nuta os vermes intestinaes.

As follas servem para banhos, e suadores.

$$
\text { USOS NAS ARTES }
$$

A madeira selve para molduras, e obras de adorno.

\section{USOS NA INDUSTRIA}

Quando tivermos inrustria no Brasil, será a flòr da laranjeira, o sumo da laranja, e o oleo que contém a casca, uma fonte pereune de riqueza publica, porq̣ue, pela distillacão las flôres, teremos a agua de flôr; pela fermentação, teremos optimo vimho; e pela maceracão, obteremos oleo para luzes.

Actualmente, não sú importamos a agua de tlôr de laianja da Europa, como até a casca sêcea da fructa, para os usos officinaes das boticas.

Tava piato. (Cassic medica.) - Planta vuigar em ser. sipe, Alagoas, e Pernambuco. 


\section{USOS MEDICINAES}

E' calmante, empregada em cozimento; provoca us menstruos supprimidos. Cura a mordedura das cobras.

Lecythis. (Grandifora ou L. Ollaria.) - Arrore das nossas mattas, especie de sapucaia, com fructos semelhantes, dos quaes se obtém um oleo aphrodisiaco, usado nas debilidades nervosas do apparelho genital.

\section{USOS MEDICINAES}

Emprega-se a fructa em emulsão, para curar os catarrhos da bexiga.

Os Srs. Merat e De Lens, fallam d'esta planta, pertencente á familia dos Myrtos memorando-lhe os mesmos prestimos.

Leiteirimha. (Lacerda.)-Planta da provincia do Pará. USOS MEDICINAES

o Dr. Lacerda, fazendo com esta planta experiencia em si, reconheceu que ella augmenta a circulação, e tem a propriedade sudorifica, e laxativa.

Lentiha d'azua ou Flor d'agua. (Lemna minor.)-E' uma planta da familia das Nayades, que vive sobre as aguas

USOS MEDICINAES

Pisada a planta, e posta sobre os tumores, os faz amadurecer em pouco tempo; resolve as hernias das crianças.

Internamente, tomado o cozimento, serve para combater as ourinas sanguinolentas, e as molestias da pelle.

Liga-liga. (Dorstenia aculeata.)-Planta rasteira, vulgar, conhecida nas Alagoas e Pernambuco.

USOS MEDICINAES

E' empregada com vantagem nas fracturas dos ossos, porque tem a especial virtude de accelerar a consolidação dos ossos.

Serve tambem para curar a ty.sica pulmonar, até o segundo gráo

Diz Almeida Pinto, que na villa do Cabo, en Pernambuco, ha abundancia d'esta preciosissima herva. 
Limoira ou Iima da Persia. (Citms limetta auraria.)-Linoira ou lima de unbiso. (Citrus limetta vulgares.)-Ambas estas arvores são mui conhecıdas.

Da Asia foram transplantadas para os logares maritimos do Mediterraneo, e para Portugal, e d'alli para o Brasil.

\section{USOS ORDINARIOS}

Os fructos são alimenticios e refrigerantes, podendo-se dar sem o menor inconveniente aos enfermos.

Linno do rio. (Fucus communis.) - E' uma helva que se encontra nas bordas dos rios, riachos, e tanques.

\section{USOS MEDICINAES}

Não são conhecidos.

\section{USOS NAS ARTES}

Serve para encher colxões, e é estimado poì ser macio, e fresco.

Limoeiro ons linaro azedo. (Citus limonum vulgaris.)-Arrore mui conhecida, espinhosa, que vegeta em qualquer terreno.

\section{USOS MEDICINAES}

As folhas sêccas do limociro são sudorificas. As mesmas, queimadas, afugentam os mosquitos A raiz do limoeiro, junta com a planta pé de gallinha, é muito recommendada para dôres de dentes, tomado o cozimento em bochechos. A raiz, é antidoto das mordeduras das cubras, bem como o sumo do limão, misturado com aqua

O sumo do limão, dado em limonada, é refrigerante nas febres inflammatorias, e corta a maldade do sangue.

A agua distillada do limão, é empregada com proveito nas ourinas, e colculos dos rius e bexiga. Os caroços são mui convenientes para desenvolver as ourinas. Cura o carbunculo, misturado com o sarro do cachimbo, e sal. .

\section{USOS NAS ARTES}

A madeira. serve para a marchetaria, e obras de ornatos.

Limoeiro ou limato doce. (Citrus bergamina vulgaris. 
Thmooixo ou rimna fiancez. (Citmus limoum.)

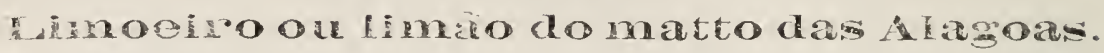
(Citrus viscosum.) - Esta especie de limão silvestre é conhecido particularmente na provincia das Alagoas, e não tem tido emprego em medicina domestica, e vulgar.

tinmpa de extia on sacea ostropo. (Sida linguis cutia.)-E' uma planta muito vulgar em Sergipe, Alagoas e Pernambuco. Floresce, e dí firucto.

\section{USOS MEDICINAES}

Hachucarla a planta, e posta em fórma de emplastro sobre os tumoles, os faz suppurar com presteza.

Lingua do tareario. (Emynguium lingua tucani.)Pianta agreste mucilaginosa, e um tanto amarga.

\section{ISOS MEDICINAES}

E' Ciuretica, e empregada para curar as feridas da garganta, ern gargarejos.

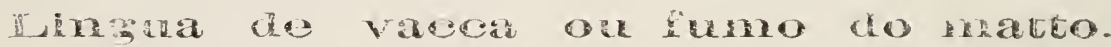
(Fussilago nutans.)-Arbusto yue produz em qualquer terreno.

USOS MEDICINAES

Serve para curar qualquer lerila, e o sumo tem virtudes balsanicas, de modo que a folha applicada em qualquer golpe, consolida em pouco tempo.

o cozimento usa-se com vantagem, nas febres continuas; e rura as gonorrhéas.

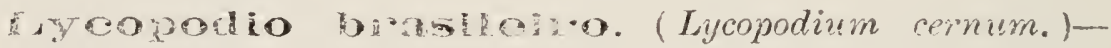
¿ planta indigena.

\section{VOS MEDICINAES}

Sua virtude é aiuretica, e contra os tumores las jumtas, applicada em banhos.

Lö́o ou queinateinar. (Plumbago scandens.). Os indios dão a esta planta o nome de Cuapomanga, ou planta que queima Ella é mui conhecida nas Alagoas e em outras provincias do Brazil pela sua propriedade caustica. 
USOS MEDICINAES

Machucada, e posta sobre a pelle, produz os effeitos do caustico; e serve para matar o cancro ulcerado, applicando-se na ferida.

Supponho ser a planta de que usam os Japonezes para curar o cancro, em pouco tempo.

Locuxy. (Silva Lisboa.)-Arvore de 50 palmos de altura, com 2 de diametro. Floresce em Setembro.

USOS MEDICINAES

Não sĩo conhecidos.

USOS NAS ARTES

o seu lenho, serve para frechaes, e vigotas.

Lombrimueira. (Spigelia anthelmintica.)-E' planta indigena; e chamam-n'a tambem Herva de Santa IIaria.

USOS MEDICINAES

o succo da planta, dado á beber, aos que têm vermes intestinaes, os expelle com facilidade.

Iongana. (Euphoria longana.)--Arvore que produz um fructo comestivel, e que nâo tem emprego conhecido na medicina.

No Jardim Botanico, do Rio de Janeiro, existe esta arvore, que póde ser estudada.

Losma ou absinthio. (Artemisia absinthio.) - E' planta de jardim. As sementes são mui amargosas.

USOS MEDICINAES

E' tonica, e excitante, vermifuga, e emenagoga.

Tem accão sobre o figado, porque purga a bilis pelas ourinas, faz passar os vapores do vinho, a contra as polluções nocturas, porque obra sobre a medulla espinhai. Combate as febres intermittentes.

Yosna do Mraranhāo. (Artemisia ambrosiaca.)

\section{USOS MEDICINAES}

Tem as mesmas propriedades da Losna da Europa.

Loureeiro. (Laurus vulgaris) - Esta arvore, é a que produz o cravo das Mollucas, sendo esta especie uma droga de 
aroma, e sabor tão particular, que nada pode supprir a sua falta, nem substituil-a, até que se descobrio o Loureiro do $M a-$ ranhão.

\section{USOS MEDICINAES}

As folhas, e as bagas do louro, affirma João Vigier, são incisivas, attenuantes, detersivas, resolutivas, e contra os flatos intestinaes; conforta o cerebro, e os nervos, provocam as ouririnas, e o menstruo.

As bagas do louro, pisadas, e misturadas com mel, é excellente remedio para curar a tysica pulmonar, as tosses chronicas, a difficuldade de respirar, e os defluxos do peito.

Louro amarella. (Cryptocurya luteola.)-E' arvore de 60 e mais palmos de altura, com $21 / 2$ de diametro. Floresce em Outubro, e folga nas mattas do Brazil, principalmente nas da Bahia, Alagoas, Pernambuco, e Pará.

\section{USOS MEDICINAES}

Não ¡ão conhecidos.

\section{USOS NAS ARTES}

Serve a sua madeira, para vergas, e taboados.

Ha diversas qualidades de louro, que são:

Louro annuiba.

Louro annuiba-oleo.

Louro annuiba do brejo.

Louro baga ou commum.--As folhas servem para condimento, como o Louro europeu. A fructa tem o mesmo prestimo que o Pechelim do Pará.

Louro cagão.-A madeira d'esta arrore cheira a excremento humano.

Louro canella.

Louro boraia.

Louro batata.

Louro casca pretu.

Louro giboia .

Louro labruge.

Louro marfim.

Louro pimenta.

Louro sabão. 
Louko sassafraz.-Arvore de 80 e mais paimos de altura, com 2 ‘ 4 de diametro. E' muito abundante nas Alagoas. Floresce em Outubro.

USOS MEDICINAES

E' anti-syphilitico, e fortificante. Infundido o lenho, que é muito aromatico, póde se tomar pelo mais delicioso chá.

USOS NAS ARTES

Serve para taboados, e para obras de adorno.

Touno ver.dadoiro.-Arrore de 60, e mais palmos de altura, com 2 a 4 de diametro. Floresce em Setembro.

USOS VIEDICINAES

Não são conhecidos.

USOS NAS ARTES

Serve para taboados de duração.

Eon virote. (Silva Lisboa.)-Arvore de 60 palinos de altura, com 2 á 3 de grossura. Floresce em Outubro.

USOS NAS ARTES

Serve para taboados.

Lupaclo. (Humulus lupulus.) - Planta enropśa, a cultivada no Brazil.

USOS MEDICIYAES

As fiôres são tinicas, e cephalicas.

USOS NA INDUSTRIA

E' de grande consumo para o fabrico da cerveja.

\section{M}

Madouia. (Maisonia horibilis.) - Irvore do Alto Amazonas, que produz seiva leitosa, semelhante í da Seringueira. 
LSOS MEDICINAES

Não são conhecidos.

USOS NAS ARTES

Póle ser aproveitada, como a Gomma elastica, para os mesmos usos.

Macaco. (Silva Lisbon.)-Arvore de 60 palmos de altura, com? de diametro. Floresce em Outubro.

\section{USOS MEDICINAES}

Não são couhecidos.

USOS NAS ARTES

O seu lenho é empregado na construcção de casas, em vigas e frechaes.

Macaianbrín. (Parí e Alto Amazonas.)-Arvore das grandes florestas do Parí e Rio Negro.

Seu lunho é vermelho carrezado, e todo marchetado, semelhante a Tartaruga.

USOS MEDICLNAES

Não são conhecidos.

USOS NAS ARTES

E' apreciado o lenho para a fabricação de mobilia, e outros moveis; e para a construcçĩo naval.

Macambi:a.-Planta semelhante ao Ananas. Floresce de Outubro á Janeiro, havendo chuva.

\section{USOS MEDICLNAES}

Não são conhecidos.

USOS NA INDUSTRIA

Suas folhas dĩo linho, e as flòres, saboroso mel.

Maganoira ou magan eira.-Arvore que se encontra nas margens dos rios dos sertões, a qual dá um fructo semelhante a Maçã ; come-se, tem um acido, e é aromatica.

Esta planta onde mais abunda, é nas margens do Rio de S. Francisco, da villa de Propiá, para cima. Fructifica no verão. 
Nắ sào conhecidos.

USOS NAS ARTE

Com a fructa, preparam os sertanejos delicioso doce; e dá por meiu da infusão, com assucar, deliciosa bebida.

Maga do smatio. (Sorbus bictsiliensis.) - Arrore brazileira, estudarla pelo Dr. Peckolt.

\section{LSOS MEDICINAES}

O Dr. Peckolt, affirma quetola a arvore, á excepcão das sementes, abunda em acido prussico; e que a casca, por sua acção tonica é anti-febril.

\section{USOS NA IADUSTRIA}

A industria pód: obter, para o consumo. d'esta arrore, o acido prussico.

Hacola ou axtrennisia do sertio. - Esta planta abunda nos campos e margens do rio de S. Francisco.

\section{USOS MEDICINAES}

O poro emprega a arthemisia do sertão, em todos os casos eun que emprega a macella gallega, ou camomilla romana.

Taceila los taboloinos das Alagoas. (Corysa arida.) -E' uma planta que abunda nos extensus taholeiros da provincia das Alagoas, e geralmente conhecida.

\section{USOS IIEDICINAES}

Năo são couhecidos.

\section{USOS NA INDUSTRIA}

Com as flòres da macella dos taboleiros, enchem-se colchões e travesseiros, mas dizem que convím deixar as fiôres perder o cheiro, que é suave, para então se usar d'ellas, por ser nocivo o aroma, continuamente respirado fóra do ar livre.

Macirixe. ( Cucumis anguria.)-E' planta que alastra, dá flores e fructos, geralmente conhecidos.

\section{USOS MEDICINAES}

O fructo cortado em pequenos pedaços, e introduzidos no no anus, é mui proveitoso nos ataques hemorrhoidaes. 
USOS CULINARIOS

O fructo é precioso alımento, cozido com a carne, e em frigideiras.

Macucú. (Ilex maconcona.)-Arvore do Pará e Amazonas, cujo succo côr de viıho, é doce e adstrin̊rente.

USOS MEDICINAES

Póde-se aproveitar o succo, applicando-o no curativo das ulceras chronicas.

\section{USOS NAS ARTES E NA INDUSTRIA}

O fructo dí uma bella côr preta, com que os indios pintam os tecidos de algodào.

A sua maleira serve para o fabrico de archotes.

Macueú-ino $1 \cdot i m$. (Mordente vegetal.)-Arvore do Amazonas, mui util á manufactura dos indios.

\section{USOS MEUICINAES}

Não são conhecidos.

\section{USOS NA INDUSTRIA}

Os indios pjem de inlusïo a entre-casca d'esta arvore, e passam com o liquido ás cuias, o depois de sècco, assentam as côres com que as querem pintadas. E' este liquido o Mordente vegetal, de que dispjem os indios, para pi.tar os objectos de que usam.

Madrocravo. (Sphiranthus anodinus.)-E' planta aromatica, que nasce nas Alagôas e Pernambuco. Os indios chamam a esta planta Quitoco.

\section{USOS MEDICINAES}

O cozimento serve para banhos nas dores rheumaticas.

USOS NOMESTICOS

As lavadeiras servem-se d'esta planta para alvejar a roupa.

Madresilva. (Alstrmeria pelegrina.)- A madresilva é planta de jardim e muito conhecida.

\section{USOS MEDICINAES}

T João Vigier diz, que as sementes seccas na sombra, bebidas em vinho, em pequena quantidade, restabelecem o bafo agradavel da 
bocca, tira o cançasso, faz passar o soluço, a asthma, e faz adiantar o parto.

A agua distillada das flores, serve para curar a inflammação dos ollos. A planta pisada, e posta nas chogas das pernas, as limpa e cura.

Mái do sapatono. (Palicourea argentea.)-Arvore conhecida nas Alagóas, que floresce e fructifica.

VSOS MEDICINAES

Não ะ⿱艹o conhecidos.

Maimb i.-Planta rasteira en fórma de sipó, que nasce nas praias.

\section{USOS MEDICINAES}

C povo serve-se d'esta plantia em cozimento, para curar as bouhas e a syphilis.

Maleiteira. (Euphorbia papillosu.) - Esta planta éconhecida no Rio de Janeiro, pelos hervanarius.

\section{USOS MEDICINAES}

E' resolutiva epurgativa, e procnida para sombater os enfarte: intestinaes.

Mattado. (Pittosporum dispersum.) - Arbusto de flores brancas como a angelica, conhecido nas Alagôas.

\section{USOS MEDICINAES}

Não são conhecidos .

rsos Na moustria

A casca serve para a Pabricaçĩo de corlas.

Malicia do me: Do $1^{\circ}$. (Mimosa sensitiva).-Esta planta, ¿ que charaam tambem Juquiry, ó mui conhecirl e vulgar.

\section{USOS MEDICINAES}

Serve para desfazer a inchacio testicular, causala pelo vir'us syphilitico, cura a elephantiasis dos arabes. .

A planta toda soccada. e lita em azeite doce, cura as alporeas resolvendo-as, e as aposthemas. E' tambem empregada no curativo das inflammações chronicas do tiggado. O chí da planta restabelece 
as forças viris ou prolificas, sem cansar damno algum ao individuo enfraquecido.

Malmoquer. (Wedelic trilobata.) -E' planta da familia das compostas, e muito conhecida nas fazendas de engenhos das Ala ̣̂âs.

Vegeta nos logares humilos, e em terrenos proprios para a plantação de cannas.

\section{USOS MEDICINAES}

o cosimento da raiz de malmequer, serve para curar a bronchite defluxionaria.

LSOS NA INDLSTRIA

As folhas servem para tirar as nodoas da roupa, esfregando-se com ellas, e em seguida lavando os logares com agua e sabão.

Malva branca das Alagòas. (Sida velluta.)--Planta vulgar, e muito conhecida pelos camponezes.

\section{USOS MEDICINAES}

O seu cozimento serve para lavar feridas; e a cataplasma feita com as folhas, abranda os tumnres e inchações.

Maiva Euzopea. Malva rotumdifolia.)-Esta malva é descripta por João Vigier e pelos Drs. Merat e De Lens com minudencia.

\section{USOS MEDICINAES}

As folhas são emollientes, adoçantes, e aperitivas. As flores são peitoraes.

Malva preta.-Arbusto aromatico que vegeta nos logares reccos.

\section{USOS MEDICINAES}

o cozimento d'este arbusto serve, para o rheumatismo. Contão os sertanejos, que esta planta é passigo grato aos armentios; mas causa-lhes grandissimo damno, por mirrar-lhes as carnes, inchãolhes as juntas em modo a entorpecer-lhes os passos.

Malva da terra ou do campo. (Sida susitivandio.) - Por todos os logares do Brazil vegeta esta planta, conhecida do poro por malva do campo. 


\section{USOS MEDICINAES}

Os habitantes do campo servem-se d'esta planta como emolliente, para calmar as dores, e lavar as feridas; em clysteres empregão como emolliente e calmante nas irritações intestinaes.

Ma!vaisco. (Uren" lobata.)--As folhas d'esta planta, conhecida nas Alagôas, e em Pernambuco, são aromaticas. Os ramos são articulados No Rio de Janeirn chamão ao Malvaisco das Alagôas, Aperta-rũ̃o.

\section{LSOS MEDICINAES}

0 povo serve-se das folhas em banhos comocalmante e emolliente, e da raiz em fórma de chá, como diuretica.

Mamào macleo. (Carica microcarpa).

USOS MEDICINAES

Com as flores fazem os camponezes cozimento e xarope, com que curão os catharraes e cerrações do peito.

Mamooiro de Cayemna ou da rudia.

Mamoeiro do matto ou Iaracatín.

Manocino principe.

USOS MEDICINAES

Têm os mesmos prestimos do mamão macho com pequenas modificacões.

Mamoeiro (arvore do mamão.) Carica papaya.-Arrore mui conhecida em todo o Brazil, que vegeta em qualquer terreno, e cresce com rapidez; floresce e fructifica sem cultura, e dá fructos deliciosos a que chamão mamão. A arvore é cylindrica e occa. e as folhas largas e palmadas.

\section{USOS MEDICINAES}

o leite dia arrore e da fructa, bem como as sementes são contra os vermes intestinaes.

O leite da arrore e da fíucta envolvido" em polvilho, e tomado pela bocca, favorece com promptidão a cocçĩo da digestão dos ali. mentos, reanimando as forças do estom ago enfraquecido : é o leite de mamũo a pepsina vegetal, que sem trabalho se póde obter em proveito dos enfermos. 
o leite do mamneiro applicado á pelle, a amacia e a limpa das nodoas ou pannos, bem como cura sem perigo as empi rens.

o leite misturado com verdete, e applicado ao unheiro, o cura : o xarope feito com as flores cura a tosse e defluxão do peito.

A fructi madura, comida pela manhan, e sobre clla bebendo-se am ropo d’agua, é um laxativo brando; comendo a fructa, e bebendo-se aguardente em cima, cura a febre intermittente.

\section{USOS DOMESTICOS}

Com a fructa faz $\cdot$ se doce sadio, proprio para a mesa, e convenieite ao: convalescentes.

As folhas são empregarlos pelas lavadeiras, para alvejar a roupa.

As folhas do mamoeiro possuem a sincular virtude de fazer a cåne tenra e macia, que è envolvida n'ellas.

Mamona ou carrapato-E' o fructo da Mamoneira, mui parecido ao insecto chamado carrapato. Ixodes, achurros da familia dos apteros.

Mamoneira ou carrapateiro. (Ricinus communis.)-Arrore esgalhada de mediana grandeza, e geralmente conhecida, que floresce e fructifica. Vegeta em qualquer terreno,

\section{USOS MEDICINAES}

0 cozimento das folhas, serve para bainos, aos que padecem de hemorrhoidas. Da fructa se extrahe o oleo de ricino, mui empregalo como purgativo. 0 oleo posto sobre as queimaduras, miga as dores, e promove a cicatrisacão. Em Cururipe (provincia das Alagôas, fazem grande commarcio com o olêo feito da mamona, a que chama azeite de carrapato, que empregão nas luzes.

Mamona. (Silva Lisboa.) -Arvore das mattas da Bahia, de 40 palmos de altura, 2 e mais palmos de diametro. Floresce em Setembro. o lenho è de poros fechados e mui rijo.

\section{USOS MEDICINAES}

Não ลล̃o conhecidos.

$$
\text { USOS NAS ARTES }
$$

o len ho serve para molduras e obras de ornatos.

Manaci ou nor de quarosma. (Duranta bicolor.)-E' um arbusto indigena do Brazil, pertencente á familia 
natural das verbenaceas. As flores brancas e roxas exhalào um perfume suavissimo.

\section{USOS MEDICINAES}

E' este vegetal um energico excitante dos vasos lymphaticos, e poderoso modificador da physioncrasia escrophulosa : é o mercurio vegetal, e neutralisante do virus syphilitico. Empregão-no como fortificante dos membros toraxicos e abdominaes Em pequena dóse, é resnlutivo; e em dóse maior é purgativo e diuretico: proyoca o aborto. O seu uso desenvolve salivação copiosa, e grande movimento convulsivo dos nervos da lingua, dos beiços, e da garganta. Em dóse elevada obra como veneno acre. E' antidoto do veneno das cobras.

Com o succo da planta os indios envenenão as pontas das flechas. Crê-se que as contorsões que os feiticeiros ou pagés, praticão,-para illudir os indios credulos, são devidas á acçâo do manací; e acreditão alguns, que se embriagando com o succo d'esta planta, conversando depois com alguma mulher gravida, the passa a bebedeira.

USOS NA INDUSTRIA

Pela distillaç̃o a industria póde tirar o mais suave e delicioso aroma das flores do manacil, para perfumaria.

Ninaci Manacin ou Camganbi. (Francisca unifhra.)-E' arbusto pequenino que floresce nos campos de Minas Geraes, de flores vermelhas no primeiro envoltorio, e laminas amarelladas.

\section{USOS MEDICINAES}

Toda a planta, e particularmente a raiz, é sudorifica, e diuretira e anti-syphilitica. Em pequena dóse é purgativa, antidoto do veneno das cobras, e um veneno acre, tomada a planta em dóse elevada.

Manací do natio das Ilagòas. (Admosna superflua.)-Esta planta, que dá flores da conflguração de trombetag roxas, nasce nas mattas das Alagôas.

USOS MEDICINAF.S

A sua raiz é usada pelos camponezes, como poderoso diuretico.

Iasconidite. (Hyppoinane mancinilla) - A mancinilla è 
arvore americana, que vegeta nas Antilhas, e nas mattas do Amazonas, Rio Negro e Rio Branco, pertencente á familia das Euphorbiaceas. Floresce e fructifica. E' arvore venenosa: as sementes dão um leite ve.renoso, contendo um oleo volatil.

\section{USOS MEDICINAES}

Os indios curão o cancro ulcerado, com a seiva leitosa d'esta arvore; e para o que lavão a ulcera com agua fria, e depois de a

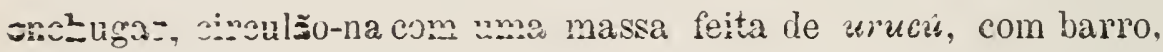
e ssbre a ulcera cancroca, pingão o leite, e logo depois, ennegrecendo os tecidos mortificados, os destaca das partes sãs. Limpa a ferida, curão-na com o olèo de copahiba e plantas emollientes.

\section{USOS DIVERSOS}

Com o leite da'mancinilla, os indios envenenão as pontas das flechas, quando vão para a guerra.

Mandacar-úr. - Planta mui conhecida, que vegeta em terrenos seccos, e principalmente nos sertões, ou em algumas praias maritimas, ou costas aridas: não tem folhas, mas sómente galhos quinosos, e por cima das quinas nascem rosetas de espinhos, e alguns de pal no. Cortando-se esta planta, assemelha-seá babosa. Tem lenho ôcco, e n'esse concavo tem um miolo, de que se faz delicioso doce. 0 ; animaes comem o mandacaru, mormente no tempo da secca. Floresce e fructifica e muitas pessoas comem o fructo. Ha outra especie mais miuda e em tudo semelhante.

\section{ISOS MEDICINAES}

O succo da raiz é contra o veneno das cobras, e dizem os sertanejos, que a raiz deve ser tirada da parte d'onde nasce o sól. Tambem empregão o cozimento da raiz, nas irritaçoes intestinaes. Os matutos nas Alagôas, empregarão a raiz do mandacarú com proveito, nos enfermos accommettidos de cholerina.

Mandaque ou Mandak (Achirantes campestris.)-E' uma herva muito conhecida nas Alagôas. que dá sementes pretas.

\section{CSOS MEDICINAES}

Não são conhecidos.

USOS ALIMENTICIOS

Esta planta serve de hom alimento para o gado. 
Mandibi. (A'um sum.) -E' planta trepadeira e parasita; conhecida nas Alagôas.

\section{USOS MEDICINAES}

Não tem sido experimentada em medicina vulgar.

\section{USOS NA INDUSTRIA}

Com estas planta fazem balaios, para usos domesticos.

Mandioca. (Iatropha maniot) - Esta planta, assim chamada de luas palavras da lingua Tupi: mandi, pão, e oca, casa, isto é, pão de casa, é tão conhecida que poupa o trabalho de a descrever. O tronco chama-se manive, e a raiz mandioca. A raiz se torna ao estado de comer-se de 6 á 9 mezes, conforme o terreno em que é plantada a maniva. O methodo da sua cultura está descripto, no famoso poema Cur a Boum, do professor José Rodrigues de Mello, Portuense, mui bem traduzido pelo professor João Gualber'to Ferreira dos Santos Reis; e nas obras, chronica da companhia de Vasconcellos, Fazendeiro do Brasil do douto Fr. José Mariano da Conceição Velloso; no Manual do Agricultor Brasileiro de Carlos Augusto Taunay; no Manual do Agricultor dos Generos Alimenticios do padre Antonio Caetano da Fonseca.

\section{USOS MEDICINAES}

Os indios fazem com a raiz di mandioca bom vinho, fresco e medicinal, que serve para curar a obstruccão do tigado. As folhas soccadas com cachaça, servem para curar o cobrelo, e empigens applicando-se sobre a parte affectada. A mandioca puba, ou cariman cura as feridas de máo caracter, applicada sobre ellas em fórma de emplastro.

o professor José Rodrigues de Mello, Portuense, vindo da cidade do Porto, enfermo de tysica pulmonar, para o Rio de Janeiro, recommendado aos jesuitas, foi recolhido á casa de recreio e noviciado los padres da companhia, hoje hospital dos Lazaros, em S. Christovĩo, e o en'ermo sem outros meios medicinaes que os bons ares, e mingaus de carimans com leite e otos, se restabeleceu da tysica, que the ameaçava a existencia.

Por gratidão, o professor Rodrigues de Mello, Portuense, foi percorrer o interior da capitania do Rio de Janeiro, e estudar a cultura da mandioca, e escreveu, em quatro cantos, o seu poema de Cultura 
Radicis Brasilicae, que o professor João Gualberto Ferreira dos Santos Reis, traduzio, que começa :

A raiz canto, que os propicios Numes

Em mimo ao povo brasileiro derão,

E onde a terra, mãi sua, o pão the ofi"rece ;

E dos nescios colonos apiedados, Que cultivos primeiros à planta cumprão, Depois á que usos mostrarei adulto Aproveite a raiz; e os peregrinos Pierides gentis do Aonio cume Trarei commigo is brasilas florestas. $\mathrm{E}$ aos horridos covis, que alojão monstros etc.

\section{USOS ALIMENTICIOS}

E' a farinha da mandioca, o alimento geral do povo brasileiro; e se fosse bem preparada, deixando o polvilho, seria preferivel, em todos os sentidos ao pão de trigo.

A tapioca ou polvilho tem varios empregos culinarios; e serve para engommar a roupa, e fazer grude para collar papelão e outros ob,ectos.

Ha varias qualidades de mandioca, que são:

Mandioca aipim.

Mandioca amarella.

Mandioca Atan do Callado (Alagôas).

Mandioca Barroso (Alagoas).

Mandioca branquinha. (Alagoas e Pernambuco.)

Mandioca caboclinha.

Mandioca canella de urubut.

Mandioca caniri de fogo.

Mandioca cruvella, ou caravella ou mamão. (Alagóas e Pernambuco).

Mandioca cruvellinha. (Alagóas).

Mandioca engana ladrão. (Alagôas e Pernambuco).

Mandioca freira.

Mandioca fria, da matta. (Alasgoas e Pernambuco).

Mandioca humana.

Mandioca humana branca 
Mandioca humana fria.

$M$ andioca humana vermelha.

Mundioca Isabel de Souza. (Sergipe).

Mandioca Landim. (Alagoas e Pelnambuco).

Mantioca manipeba. (Alagoas e Pernambuco).

Mandioca manivinha.

Mandioca milagrosa. (Alagoas).

Mundioca mulatinha (Alagôas e Pernumbuco).

$M$ andioca gommo branco. (Alagoas e Pernambuco).

Mandioca gommo roxo. (Alagoasi.

Mandioca Pacoré. (Pernambuco)

Mandioca Parahyba.

Mandioca periquito (Alagoas).

Mandioca pipoca. (Alagôas).

Mandioca retroz. (Alagòas).

Mandioca Rio Grande.

Mandioca tapicima. (Alagoas e Pernambuco).

Mandioca tio Pedro. (Alagoas e Pernambuco).

Mandiuca vermelha. (Pernambuco).

Mandioca brava.-E' planta mui venenosa, que produz em qualquer terreno.

A sua raiz e folhas são venenosas e matão o animal quo as come

\section{l OOS MEDICINAES}

A raiz ralada e posta sobre o cancio ulcerado o cura.

Mandupuss:-Arrore agreste. que floresce e fructifica, sendo os fructos amarellos, e nascem á roda do ramo, como a jaboticabeira.

\section{USOS MEDICINAES}

Não sấo conhecidos.

\section{USO NAS ARTES}

A madeira serve para obras de casas.

Mangabeira. (Apoicynum hancornia.)-Arvore graciosa, de 20 o mais palmos, com 1 it 2 de diametro. floresce de branco en Agosto, de folhas ovaes, e naste nos extensos taboleiros da Bahia, Sergipe, Alagoas e P.rnambuco etc. O seu iructo aromatico, cha- 
ma-se mangaba, i redondo, amarellado, com algumas manchas escuras, sendo mui delicioso e refrigerante. EIle desfaz-se na bocca, tendo alguns caroços, que, mastigados, se podem engulir.

\section{USOS MEDICINAES}

Os indios fazem vinho d'esta deliciosa fructa. O leite da mangabeira cura a tysica pulmonar. as rupturas ou hernias. Ha além d'esta especie outra, conhecida por mangabeira brava, que nasce nos logares cultivados, e a sua propriedade medicinal é de servir de vomitorio em todas as enfermidades que necessita de emetico, e para o que dão os camponezes uma e meia oitava do leite diluido em agua. 0 extracto da entrecasca, tem a mesma virtude. 0 leite na quantidade de meia chicara, resolve ou faz deitar as aposthemas internas. A firucta verde applicada ás ropturas as consolida.

\section{USOS NA INDUSTRIA}

o leite da mangabeira serve, para o fabrico do verniz, e púde ser empregado para os mesmos usos da gomma elastica.

Mangabeira agreste.-Esta especie de mangabeira, vegeta nos fertilissimos terrenos das Alagoas, Seroipe e Bahia. O fructo se não póde comer, por ser muito azedo.

\section{USOS MEDICINAES}

A casca serve para curar as obstrucções do tigado, a ictericia. e as molestias chronicas da pelle.

Mangabeixa das catingas, ou brava. (Hanconnia pudescens. - E' uma planta silvestre, frondosa e copada, dos sertoes da Bahia, Alagous e Pernambuco, cujos fructos amarellos, quando madurns, são mui procurados pelos veados e outros animacs, que percorrem as catingas.

\section{USOS MEDICINALS}

A casca da raiz épurgativa, e empregada pelos sertanejos, como conveniente ás mulheres que padecem do utero, e mesmo empregam-na para desafiar o fluxo mensal tardio ou supprimido.

Mangaló. (Sitra Lisboa.)-Arvore de 40 e mais palmos de altura, com dous de liametro: floresce em Setembro. 


\section{USOS MEDICINIAES}

Năo saio conhecidos.

USOS NAS ARTES

O seu lenho serve para obras de architectura civı!.

STangaraz.-Vide Taibu.

Iangar-ito. (Assarm.)-E' planta herbacea, natural do Brasil, couhecida nas Alagoas, Bahia, Sergipe, Maranhão, e no Rio de Janeiro. A raiz é uma tubera farinacea, apreciada como alimento sadio.

\section{USOS MEDICIYAES}

Não são conhecidos.

USOS DOMESTICOS

Come-se a batata cosida com carne; e com me!, na sobremesa. As folhas picadas e bem cosidas, com ovos, lazem un saboros, prato para a mesa.

Mangueira. (Manguifera indica.)-Arvoremi frondosa, de 50 e mais palmos de altura, e de tres a quatro de diametro, pertencente á famılia das terebintaceas. Floresce em Setembro e Outu. hro, e fructifica desde o mez de Novembro até Marco. A fructa chama-se mangc, de delicioso aroma, e sabor, mui estimada, e procurada por todos. A casca da fructa tem resina, e por isso convém descascar a fructa, e laval-a, para então ser comida.

\section{USOS MEDICINAES}

o xarope feito com a polpa da manga, é peitoral, e applicado nas tosses e bronchites.

\section{USOS NAS IRTES}

A madeira serve para a fabricação de ubras ligeiras.

A mangueira tem sido cantada por varios poetas, e entre clles pelo illustrado pro"essor de latinidades na Bahia, Guilherme Balduino Embirussú Camacan, de saudosa memoria.

Mangericão. (O cymum.)-O mangericão \& um arbusto aromatico. e mui conhecido nos jardins. Ha duas especies; o de folha larga ( O cymum basilicum), que serve para tempero de comida, a que chamão catinga de mulata, que é muito cheiroso; e outro de folhas miudas (O cymum minimum) muito medicinal. 
USOS MEUICINAES

Emprega-se o cozimento de mangericão em banhos, para curar as dores do corpo: é anti-febril. Cura a tosse catarrhal, e suspende o sancrue pela bocea; é proveitoso na lyspnéa, bebendo-se-lhe o sumo. Furtifica o ute. 0 , esuspende-Ihe a hemorrhagia; promove e favorece o parto, é efficaz, na expulsão do feto morto, no ventre materno. Resolve o leite coarulado dos peitos da mulher, untando-s e mama com o sumo. Fervido em vinho, ou em azeite doce, mitiga e cura as hemorrhoidas applicando-se ao redor do anus.

Cura o cobrelo untando-se o sumo. As sementes infundidas em aqua, e tomada em bochexos, cura as feridas da boca As sementes, reduzidas a pó, e se pondo sobre as verrugas as faz cahir.

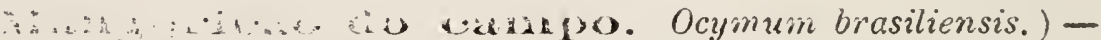
Planta silvestre, conhecida tamben pelo nome de remedio de Vaqueiro, é aromatica, e folga nos logares cultirados.

\section{USOS MEDICINAES}

O sumo bebido é ur poderoso remedio contra as quedas e pancadas, em modo á dizerem os sertanejos, que depois de uma grande pancada o'l queda, bebendo-se o Mairgericãs do campo, não se padece de aposthemas, porque elie tem a virtude de restabelecer - curso normal dos liquidos do corpo, que te:tdem a estagnar-se. As sementes, bebidas em vinho são muito uteis ás molestias dos olhos, e tiram as afflicções e ancias do coração.

Mangerioba ou Fedegoso. (Cassia occidentalis.)-A mangerioba nas Alagôas e Pernambuco, e fedegoso no Rio de Janeiro, é uma plonta vulgar e prestimosa.

\section{USOS MEDICINAES}

0 cozimento das iolhas, feito com cevada, cura as tosses agudas va chronicas, a erysipela e a colica. O cozimento, ou a infusão do tronco e hastes da mangerioba ou fedegoso, em agua commum, tomado diariamente cura as inchacões das pernas. O cafó preparado com as sementes, é contria as flatulencias.

A raiz é um heroico medicame ito contra o dyarrhea, ainda que seja epidemica, ou seja dada em cozimento, ou infundida era aguardente. 
Ianmerona. (Origanum manjorann.) - A mangerona é pianta herbacia, aromatica, pertencente a familia das Labiadas, e cultivada nos jardins.

\section{USOS MEDICINAES}

E' estimulante e tonica ; e o seu cozimento é medicamento approvado, pira curar a hydropesia, em cumeco; desenvolve as ourinas, e cura as dures do ventre.

\section{USOS CULINARIOS}

A mangerona é empregada como tempero na comida de carne.

inngrona to canpo. (Glechon spatulatus.)

\section{USOS MEUICINAES}

A infusão da mangerona do campo, promove os suores, e cura os catarihas.

Ianjuo. (Menzahiba brasiliensibus.)-Arvore de 25 palmos de altura, e de 1 á 2 de diametro, que folga nos rios de agua salobra, que se communicão com o mar: ou mesmo nas enseiadas maritimas.

\section{USOS MEDICINAES}

O cozimento da rasca, do mangue serve para lavar as feridas velhas.

\section{USOS NAS ARTES}

A madeira serve para caibros de casas e para cercas.

USOS NA INDUSTRIA

A casca. pela sua adstringencia. empregada nos cortumes para tanar o pellame. Deitada a casca n'agua, mata o marisco, que se cria nos mangues.

Manguo amaxello.-Avicencia nitida.

Hangze bianco ou Cereiba. - Lagunculana racemosa.

Tangac do Brejo.-Eugenia nitens.

Mangue vermelho.- Rhirophora mangle. 
LSOS NA INDUSTRIA

Lista variedare de mangue dá tint t para tingir a roupa, porén convém ter cautella nos olhos, que, cahindo n'elles, os cega.

Hi outras rarierlades de mangues, que omitto, por não ter emprego na medicina popular.

Manicá. (Rutilia fertilis ou Manicá.-E' planta rasteira per'ere 1t? a fa mila das Acanthaceas, que vegeta nos campos das Alagoas e Pernambuco.

\section{USOS MEDICINAES}

Os matutos empregão o cozimento d'esta planta, para curar as tosses e deflusos originados de resfriamentos.

Mantimento de Araponga. (Eugenia adstringens.) -E' planta adstringente. O fructo comem-nos as arapongas, e não tem emprego na medicina domestica.

Miu risinho. (Mimosa malvasinha.)-E' um espinheiro das Alagôas, pertencente á familia das Ləguminosas, que não tem emprego na medicina domestica.

Majichi. (Myica lanceolata.) -E' um arbusto com cheiro therebintaceo, que ñ̃o tem sido experimentado em medicina do. mestica.

Mapirunga Drara. (Eugenia tinctoria.) E' uma planta que vegeta ras Alagôas, cujo fructo roxo e adstringente, póde fornecer materia corante para a tinturaria.

Mappa 10. (Hippomane brasiliensis.)-E' arrore do alto Amazonas, pertencente a familia das Euphorbiaceas, e uma variedade da mancenilla, que já mencionei.

\section{USOS MEDICINAES}

Os indios curão com o leite d'este vegetal os cancros ulcerados, pingando o leite na ferida, e quando a escara que se fórma com o tecido esponjoso, cahe, a ferilla está cicatrisada: cura tambem as boubas ulceradas. O enfermo transpira, e ourina com abundancia.

$\mathrm{Na}$ ilha de Java curão os naturaes o cancro em 8 dias, e é provavel, que seja com o leite de Mappam, ou de Mancenilla.

Maracují assú ou Maracujá de Cayenna. 
(Possiflora alata.)-E' planta brasileira, que nasce nas mattas. Cultiva-se com proveito em latadas nas hortas. O fructo é delicioso.

\section{USOS MEDICINAES}

Dizem que uma só folha do maracujá cosinhada e bebida, cura efficazmente a tosse convulsa,

Ha diversas especies de maracujas que são:

Maracrija de cobra. (Alagôas).

Maracujá de corra.ja. (Alaggôas.)

Maracujá do estallo. (Em todo o Brasil.)

Maracujá mirim ou perlquaho. (Alagôas.) E bom para a confecção de doce.

Mracaín peroba. (Alagôas.)

USOS MEDICINAES

En geral o cozimento feito com as folhas do maracnjá, é mui proveitoso aos que padecem de hemorrhoidas, tomado em clysteres.

Maracuja. (Possiflora maliformia.) -n maracujá é planta trepadeira mui conhecida e vulgar.

\section{USOS MEDICINAES}

0 fructo feito em limonada póde-se dar aos tebrıcitantes.

o cozimento do pericarpo do fructo, serve para curar a inflammação dos olhos : as folhas postas sobre as empigens as mata.

As folhas, o sipó e a raiz s̃̃o antisyphiliticos: dizem que têm as mesmas virtudes da salsaparrilha.

A raiz do maracujá, serve para adelgaçar os humores, bebendo-se em cozimento.

O sumo das folhas em pequena quantidade, tomado com mel de Jitahy, ou sem elle, que é melhor, ficilita abundantemente as . ourinas.

O sumo das folhas, ou da planta, engrossalo ao logo, e applicado topicamente aos cancros venereos e ulceras syphilicas, cura efficazmente.

o cozimento do maracujá não se deve dar ás mulheres gravidas, porque póde provocar o aborto.

Maraji ou Tucum do Pen'mambuco. (Pactris marajá,)-F' uma especie de Palmeira fina e baixa, de que tambem 
falla 0 Dr. Arruda Camera, na sua dissertação das plantas do Brasil, que dão li.tho, impressa em I810, no Rio da Ja"eiro. Esta. palmeira vegeta nas Alagjoss, e nas provincias do norte.

USOS MEDICINAES

Não são conhecidos.

USOS NA INDUSTRIA

A industria extrahe linho das folhas, por meio da maceração.

Marapi mirim ( Dr. Lacerda.) -E' planta do Pará, experimentada pelo Dr. Lacerda, do Maranhão.

\section{USOS MEDICINAES}

A raiz é empregada para curar a diarrhéa sanguinea, e mesmo a diarrhea chronica tomada em clyster.

Maraponima. - E' uma arrore gigantesca, das ricas mattas do Alto Amazonas.

\section{USOS MEDICINAES}

Năo são conhecidos.

\section{USOS NAS ARTES}

o lenho d'esta arvore, que ó mui compacto, e de um amarello marchetado de veias parlacentes, é empregado na marcenaria, para diversos moveis.

Marapuama, or hasiantan ou pák ho. mem.-E' arbusto conhecido dos hervanarios do Pará, e procurado como poderoso aphrodisiaco.

USOS VEDICINAES

Como excitante do systema norvoso debilitado, se emprega em banhos externamente. o uso interno é preparado em vinho, para se tomar um calix pela manhan e outro á noite. E' proveitoso na paralysia, na dyspepsia, e na impotencia Se nåo produz - resultado que se espera, não ataca a organisação.

Maravilha. (Impatiens balsamina.) -A maravilha a que tambem chamão beijo de frade, é uma planta re jardim, e de differentes côres.

USOS MEDICINAES

A raiz ou tubera secca dada em pó na dóse de uma oitava 
purga e cura a leucorrhéa ou flores brancas. O succo da planta, dizem ser especial remedio para dores de dentes.

Marcina or malmequer de Cayena.-E' um arbusto que serve para ornamento de jardim. Não se lhe conhece prestimo algum em medicina domestica.

Marrim. (Melochia rimbelata.) -Arvore pequena que vegeta nas Alagóas, de casca grossa e escura, folhas grandes, espatuladas e duras.

USOS MEDICINAES

Não sĩo conhecidos.

USOS rA IYDUSTRIA

Serve o páo para cabos de enchadas, machados, foices e outros instrumentos agricolas.

Mar.fin vesgotal.-(Phytelephas maciosarpa.) - Arvore dos limites io Brasil, com o Perú.

\section{LSOS MEDICINAES}

Não são conhecidos.

\section{USOS DLVERSOS}

Produz grandes iructos, que contem agua, com que se fartão as viandantes, tirada immediatamente do fructo.

Se o liquido é posto em algum vaso, fica còr lo leite, e pouco á pouco se vai coagulando, e toma a consistencia dura, assemelhando-se ao marfim.

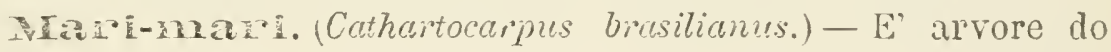
Brasil, um pouco parecida com a cassia-fistula.

\section{TSOS YEDICINAES}

O fructo, que é uma ragem semelhante a do tamarineiro contém uma polpa ligeiramente purgativa.

STapia Gonem.-E' a lingua de vacea da Bahia.

Naria Ycite.-E' a herva de cobrả ou a herva de Santa Luzia.

Fanianina ord Frapoeinaba. (Commelina deficiens)._E' uma planta conhecida, que regeta nos logares humidos.

Ni Bahia, em Serogipe, chamam-na Marianinh ; no Maranhão, 18 
chamão-na Trapoeiraborana; no Rio de Janeiro Trapoeiraba; nas Alagoas chamão-na Olho de Santa Luzia.

USOS MEDICINAES

o cozimento feito com a marianinha ou trapoeiraba é precioso refrigerante, e optimo remedio para curar as gonorrhéas, flores brancas, empigens, e pannos da pelle.

Maria preta.-Vid. Barahuna.

Maria preta. (Conoclinium.)-E' um arbusto pequeno, cuja folha é quasi redonda elixosa.

\section{USOS MEDICINAES}

Pisada a planta e tirado o succo, com algumas gottas de vinagre, faz estancar o sangue pela boca áquelles que o lanção devido á pancada ou quéda, tomado internamente. Faz resolver as posthemas, que principião a formar-se.

Marinheiro. (Guarea spicceflora)-Arvore de 40 palmos pouco mais ou menos, e 2 de diametro. Floresce em Agosto.

\section{USOS MEDICINAES}

A casca do tronco e da raiz é amarga, serve para curar, a hydropesia e as obstrucções do figado e baço.

\section{USOS NAS ARTES}

o seu lenho é empregado em talabordões das lanchas, e para frechaes de carros.

Marinhoiro.-Planta vulgar, que vegeta em qualquer terreno. E' conhecida especialmente pelos hervanarios.

USOS MEDICINAES

o extracto feito d'esta planta é remedio muito approvado para curar o cansaço e opilação. Provoca as menstruações, e as regularisa. E' anti-syphilitico.

Marinheiro carapeta.-(Moschoxilon catharticum.) -Arrore de 40 palmos e dous de diametro: floresce em Setembro. o fructo desta arvore tem a configuração de uma carrapeta. 


\section{USOS MEDICINAES}

o cozimento da casca dado em clyster, combate as febres terçans.

USOS NAS ARTES

O lenho serve para talałardão das lanchas, e para frechacs de casas.

Maririêo. (Sisuinchium galaxioides.)-0 maririçô, é uma planta da familia das Irideaceas, semelhante a um capim, cuja raiz é um bolbo.

\section{USOS MEDICINAES}

o bolbo desta planta é sem cheiro, um pouco adocicado, e depois de secco, e reduzido o pó, é um laxante brando, empregado nos que padecem molestias de pelle.

Em clyster é proveitoso ás creanças, e aos que soffrem de hemorrhoidas.

Mariseiro.-Esta planta produz nas margens dos rios dos sertões do Brasil, e dá fructo comestivel.

\section{USOS MEDICINAES}

No sertão servem-se do entre-casco cozido, ou cru, para curar as enfermidades internas causadas por quedas ou pancadas, que tenha offendido as entranhas. Recommenda-se que o cozimento seja mui deluido.

Marmajuda brava. (Bisa alagôana.)-E' arvore corpulenta que regeta nas mattas das Alagòas.

$$
\text { USOS MEDICINAES }
$$

Não são conhecidos.

\section{USOS NNAS ARTES}

O seu lenho serve para taboados.

Marmajuda mansa. (Bixa.)- Arvore das mattas das Alagôas.

\section{USOS MEDICINAES}

Não são conhecidos.

$$
\text { USOS NAS ARTES }
$$

Serve para taboado, e para obras de pouca duraçăo. 
Maxmeneino. (Cydoina sinensis.)-E' arvore da China, que se aclimatuu no Brasil, onde floresce e fructifica.

\section{USOS MEDICINAES}

Os carocos da fructa são mucilaginosos, e empregados nas tosses e defluxões do peito.

\section{USOS NA INDUSTRIA}

Com o fructo fazem doces e geléas mui apreciados nas mesas. o fructo come-se assado, com assucar, e cozido em fórma de sopa, com assucar e manteiga.

Marmelleiro do nato. (Casearea ulmifoliu.)-E' um vegetal brasileiro, que floresce em Janeiro.

\section{USOS MEDICINAES}

O succo das folhas deste vegetal é o mais poderoso remedio contra veneno das cobras, dando-se á beber ao mordido, e pondo-se as folhas pisadas sobre as feridas.

Marnolleiro do sereão. (Elacococa aromatica.)-E' um arbusto aromatico, pertencente a familia das Euphorbiaceas.

\section{LSOS MEDICINAES}

Não são conhecidos.

\section{USOS PARTICULARES}

Os sertanejos, envolvem as carne das rezes que matão, corn os ramos desta planta, para lhes communicar o aroma que é agradavel.

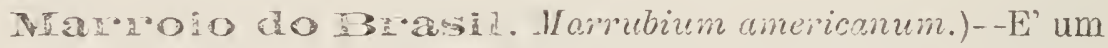
arbusto aromatico, parecido coin o mangericão.

\section{USOS MEDICINAES}

Empregão-no en cozimento como confortante, e desobstruente do figado e baço.

Marcun. (Simanuba officinalis.)-Planta natural do Pará e Amazonas, pertencente a familia das Rutaceas.

\section{USOS MEDICINAES}

O cozimento é empregado na dysenteria, e leuchorrhéa. Tambem servem-se desta planta, como tonica e anti-febril. 
Mar upá-assú.-Planta do Pará, de um amargo particu. lar e nauseoso.

\section{USOS MEDICINAES}

O seu cozimento é empregado para combater a diarrhéa chronica, e a que é causada p tla presença dos vermes.

Marupi miri.-Arbusto conhecido no Alto Amazonas, e empregado na medicina domestica.

USOS MEDICINAES

A infusão da raiz é poderoso remedio para combater as diarrhéas.

Max- (Geoffroya.)-E' uma arvore das Alagoas e Pornam. buco, que floresce e dá fructos, e em tempo de secca são aproveitados pela pobresa para alimento.

\section{USOS MEDICINAES}

o caroço é adstringente, e tem virtudes medicinaes. particularidade Desta planta

Póde-se considerar esta arvore, como o hygrometro do sertão. Em tempo de secca, quando esta arvore comeca a transpirar pela casca, e verter gottas de liquido, é signal certo de apparecerem as chuvas.

Massambari. (Trachypaysn avenaceus.)-E planta pertencente a familia das gramineas, especie de capim conhecido por esse nome.

USOS MEDICINAES

o cozimento da raiz do massambará é empregado como tonico e diuretico.

\section{USOS ALIMENTICIOS}

O Dr. Peckolt que analisou esta gramminea diz, que a semente nutriente d'este joio, quasi geralmente despresada, poderia utilisar-se com vantagem, para alimento dos animaes, etc.

Massarandiba. (Eugenia Pison):-E' arvore brasileira, que floresce e fructifica, sendo os seus fructos comestiveis.

\section{USOS MEDICINAES}

o succo da casca é proveitoso nas molestias da garganta e do peito. 
Massaranduba. (Arvore leiteira.) (Mimusops excelsa.) - Arvore elevadissima de 100 e mais palmos, com 5 á 12 e mais de diametro. (Silva Lisboa). Floresce em Outubro e Novembro, com flores brancas. O fructo quasi encarnado, tornando para roxo, quando maduro, contem um licor lacteo dulcissimo, de virtude nutriente, peitoral e emoliente.

Esta preciosa arvore abunda na Bahia, Alagôas, Pernambuco, Pará, Minas Geraes e Matto Grosso. D'ella ha mais duas variedades, com os mesmos prestimos.

o Dr. Freire Allemão, descreveu a arvore; e o Dr. Peckolt analysou o leite da Massaranduba apellidada yelo Dr. Martius Lucuna procera, e reconhecem ser succedanea da Gutta-Percha.

\section{USOS MEDICINAES}

O leite da Massaranduba é peitoral analeptico, usado internamente; e resolvente usado topicamente. Dizem que resecca o ventre abusando-se do seu uso.

Os indios servem-se do leite da Massaranduba, misturado com mel de abelhas, para curar os tisicos, e aos que padecem de tosse.

\section{USOS ALINENTICIOS}

Algumas pessoas servem-se do leite da Massaranduba, para fazerem mingáos ; outros usão mistura-lo com chá, ou café, no que substitue perfeitamente o leite de vacca. Outros bebem-no puro; mas tem acontecido acidentes fataes, em virtude da coagulação do leite assim puro no estomago, não ser facil digeril-o.

USOS NAS ARTES E NA INDUSTRIA

o leite da Massaranduba é a melhor solda conhecida, para grudar a louça de porcellana, vidros e madeira, ficando a peça mais solida que dantes. Os marcineiros devem com preferencia usar delle na união das peças de mobilıa, por que senão desgruda, como acontece com a colla animal, que resecca e despega. E' a melhor materı, para o calafeto das obras do mar, e para pintar os pannos dos toldos, porque fica perfeitamente impermeavel. E' preferivel a Gutta percha, porque é mais elastica. A industria póde tirar grandes resultados desta preciosa arvore brasileira. 0 leite se coagula lentamente, e em contacto coin o ár, adqire a côr branca um pouco acinzentada, muito solida, compacta, e perfeitamente 
identica a Gutta percha. A massa solida posta em agua quente, torna-se elastica e toma as förmas que se lhe quer dar.

o lenho da arvore serve para sobre-quilhas das náos, fragatas e outros vasos maritimos.

Matta-pasto. (Cassia dormicus.)-O Matta-pasto é umarbusto de de 3 a 5 palmos pertencente a familia das Leguminosas, de cheiro particular e activo, sabor amargo doce, e mui conhecido nas Alagôas e Pernambuco. No Ris de Janeiro, tambem tenho visto esta planta. E' o emblema do homem do trabalho, que ao cahir da noite se acha abatido, e ao sahir do sol se apresenta com vigor. As folhas do Matta-pasto abatem-se ao por do sol, e no dia seguinte achäo-se no seu vigor.

\section{USOS MEDICINAES}

Usa-se das folhas pisadas com vinagre externamente para curar a erysipela, a sarna e as affecções schabiosas.

o succo, ou o cozimento das folhas, é empregado para curar a febre maligna e o pleuriz. o cozimento da raiz é usado contra as dores do corpo, e serve para aplacar as dores de dentes

Tambem usão do succo desta planta, com alguns pingos de vinagre, em clysteres, para curar as febres malignas ou perniciosas.

As folhas passadas pelo ar do fogo e postas sobre as regiões do figado e do baço, por 9 dias desobstruem estas duas entranhas.

Mastruco ou herva de Santa Maria. (Lepidium sativum )-E' planta muito corhecida por seus varios prestimos medicinaes.

LSOS MEDICINAES

E' um consolidante nas fracturas dos osssos tomado o sumo pela boca, e as folhas pisadas postos sobre a parte fracturada e para as contusões. O cozımento concentrado tomado em fórma do chá, é proveitoso na tisica pulmonar.

o chá feito com as folhas do mastruço e da hortelan é remedio salutar contra os vermes intestinaes. As sementes do mastruço soccadas, e mettidas em banana assada e dadas a crianças expellem os vermes intestinaes.

Matta Mratta. (Lecythis idatimon.)-E' uma planta trepadeira medicinal do Pará. 
USOS MEDICINAES

A casca desta rlanta é empregada no Pará, como remedio proreitoso, para curar a tisica pulmonar e a asthma, tomando-se em fórma de chá tres vezes ao dia.

Matarana ou matatar'ana. (Kompferea longifolia.) --Nas Alagôas conhece-se, uma planta herbacea que floresce em Maio e Junho da familia das Amomaceas, pela denominação, de Matatarana. Sua raizé doce, succulenta, de tubereulos roliços alongados, formando anneis superpostos.

\section{USOS MEDICINAES}

Não são conhecidos.

\section{USOS ORDINARIOS}

A matarana, ou matatarana come-se crua, assada, ou cozida sem o menor inconveniente.

Matataúba ou sambacuim. (Cecropia palmata).-E' arvore conhecida de 25 á 30 palmos de altura e de 2 de diametro. Floresce em Setembro. O troneo desta arvore é nodoso e liso, de folhas pecialadas palmadas semelhantes as do mamoeiro.

\section{USOS MEDICINAES}

Não ลão conhecidos.

USOS NAS ARTES

Os peciolos servem para ponteiros de gaiolas; e a arrore para fabricar bom carvão: das cinzas se extrahe excellente soda.

Mate-me ensor'a.-E' uma graminia que vegeta em abundancia por toda parte, sendo o flagello das hortas e jardins, por que embora seja arrancada ou capinada, logo depois reapparece.

\section{USOS MEDICINAES}

O seu cozimento é emoliente.

Mathias. (Tacalia optica.)-Esta planta natural do Brasil, pertencente a familia das compostas, é conhecida nas Alagôas pelo nome de cipo Mathias, Estanca sanque, em Sergipe pelo de Assa peixe e em outros logares pela denominaçào de Mangericão das moças. Os indios chamam a esta planta Tramanhen (estanca sangue). 


\section{LSOS MEDICINAES}

O succo das folhas e flores posto nos olhos, desfuz as belides. o cozimento é proveitoso nas tosses e tisica pulmonar, e nos grandes defluxios do peito.

o cozimento da raiz, faz estancar as hemorrhagias pela bocca.

Mateo do Parasuat ou do parami. (Ilex paraguayensis.) - 0 padre Hanoel Ayres do Coral, na Corograhic brasilica. falando do herva matte do Paraná, diz que é um arbusto grande, com folha semelhante á da larangeira, e gosto de malva. esta é a que se aproveita. Dizem que a melhor é a da serra Haracaji. Não se espera que as follhas caiam: depois de colhidas são torradas por algum dos methodos approvados, commumente sobre couros entre duas ígueiras.

Matte on Consonlua do Campo. Luxemburgia polyandia.) - E herva de Minas Geraes, conhecida pela denominação de Congonha de campo.

\section{LEOS MEDICINAES}

Dizem que o uso abusivo do matte, produz flatulencia uterina. Não garanto esta acersão E' usado como chá, e tem a propriedade de amassiar a pelle, e favorecer a transpiraçõo insencivel. Em todas as provincias do sul da America meridional, é o matte a bebida mais commum e apreciada.

Maxixindn 0.-Arrore das capoeiras das Alagòas. Floresce e fructifica, sendo os seus fructos parecidos com o maxixe.

\section{USOS MEDICINAES}

Não s̃̃u conhecidos.

Mãy Izabel. - Planta vulgar nas Alagôas, e anthelmintica.

\section{USOS MEDICINAES -}

O cozimento das folhas, bebido pela manhã e a noite è contra os vermes intestinaes.

Maya-cá. (Xiris americuna.)-Plantabrasileira, que tambem vegeta em Cayenna. 


\section{LSOS MEDICINAES}

Pisada a planta, infundida em vinagre e posta sobre as empigens as cura.

Iechoacana (Hechuacanica diuretica.) - E' uma herva conhecida nas provincias do norte, empregada em medicina domestica.

\section{USOS MEDICINAES}

A raiz é purgativa, e conveniente nos enfartes intestinaes.

Mechoagão. (Convolvulus mechoacana.) - Planta trepadeira, de folhas cordiformes, flores brancas, e as vezes roxas.

\section{USOS MEDICINAES}

A sua raiz tuberosa, é purqativa. O Dr. Bernardino Antonio Gomes descreve esta planta, e falla dos seus usos therapenticos.

Nedicineiro. (Jatrorha officinalis.)-0 medicineiro é uma planta leitosa, pertencente a lamilia das Euphorbiaceas, mui pare. cida ao pinhão.

\section{USOS MEDICINAES}

Os matutos servem-se da raiz desta planta, para curar as molestias syphiliticas.

Meirú de proto. (Guatteria scariosa.)-Planta das Alagôas, que não tem sido empregada em medicina domestica.

Boimondro nogro. (Hyosciamus niger.) - 0 meimendro é planta européa, transplantada no Brasil, de talo grosso, guarnecido de muitas folhas largas, compridas, fendidas lanuginosas, e flores semelhantes ás da romeira. Ha tres especies: a $1^{a}$ tem a semente negra; a $2^{a}$ tem-na vermilhinha com flores amarellas; a $3^{\text {a }}$ produz flores brancas, e sementes da mesma côr.

\section{USOS MEDICINAES}

A raiz do meimendro cozida em vinagre, cura as dores de dente.

A homœpathia serve-se do meimendro negro, para curar a alienação ineital, a apoplexia, a chorea, o delirio tremulo, a encephalite etc. (Vide a minha pathogenesia homœpathica).

Meladin ha redadeira. (Stemodia viscosa.)-Arbusto de flores roxas, mui conhecidos nas Alagôas, e Pernambueo, onde 
vegeta pelos pastcs, campos, e tem prestimôs mui salutares. Os indios chamão-na Boia-cad. No Maranhão e Parí conhecem-na pelo nome de Paracary. As folhas deste arbusto possue certa viscosidade, com que prende as pulgas e pequeninos insectos, quando com elle se varre as casas.

\section{USOS MIEDICINAES}

Serve para curar a asthma, os defluxos asthmaticos, as tosses nervosas rebeldes. Tambem serve para neutralisar o veneno das cobras, tanto interna como externamente applicado. Usão da tintura, e mesmo do succo da planta.

Meladinha falsa. (Ruellia verticifolia.)-Esta planta vegeta nas Alagôas, e Pernambuco, e nasce pelas beiras dos caminhos, e nos quintaes, indistinctamente.

USOS MEDICINAES

o cozimento deste arbusto, com follhas de café, e alfavaca do campo serve, em banhos, para as dores rheumatic $ı$.

Melambo. (Drynus Winteri.)-E' uma formosa arvore pertencente a familia das magnoliaceas.

\section{USOS MEDICINAES}

A casca desta arvore, é precentaneo remedio contra a febre amarella e a disenteria.

Mrelancia. (Cucurbita citrulus dicta.)-A melancia é o fructo de uma planta herbacea, rasteira, e que alastra pela terra. Gosta dos lugares arenosos e tambem do massapê Nas Alagôas, em Itamaracá. no Pará, e nos sertões do Brazil, são as melancias de um tamanho extraordinario e mui boas.

\section{USOS MEDICINAES}

A semente da melancia é de natureza fria, e diuretica. Pisada e misturada com sôro de leite, serve para curar a ulceração da bexiga.

\section{USOS DA FRUCTA CONO ALIMENTO}

Comida a fructa 2 ou 3 horas antes do jantar, refresca aos que tem muito sede; porém os que tem estomago frio, em lugar de beneficio lhe faz mal.

João Morteiro de Carvalho diz que a melancia é mui nociva, 
porque não deixa fazer o cozimento natural no estomago, e causa indigestão .

Melancia da praia. (Solaum arrebenta.) - E' uma planta da familia das Solanaceas, conhecida na Bahia pelo nome de Babá; no Rio de Janeiro pelo nome de Arrebenta cavallo; e nas Alagôas pelo de Melancia da praia ou Mingolla.

\section{USOS MEDICINAES}

O cozimento bem concentrado de toda a planta, serve para curar os pannos e manchas da pelle.

Meláo. (Melo vulgaris.) - O melão o fructo de uma planta rasteira, que alastra, pe:tencente a familia das cucurbitaceas. E' excellente no gosto e no aroma.

\section{USOS MEDICLNAES}

João Vigier falando das virtudes do Melão diz, ser o fructo de qualidade fria, e muito humida: os que tem a polpa amarella ou avermelhada não estando muito maduro, humedece e tempera o ardor do sangue, é cordial comerdo-se moderadamente; os brancos

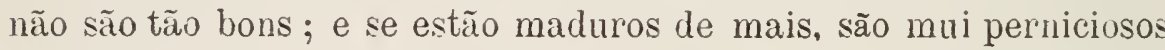
a saude, porque gerão maus humores. As sementes são adoçantes, aperitivas, tomadas em amendoadas.

\section{USOS ALIMENTICIOS}

As pessoas de estomago fraco e humidos, não devem comer o melão, porque é indigesto, promove colicas fortissimas e compromettem a vida.

Meiño ou sabão de soldado. (Bazella saponaria.) -Nas Alagôas e Pernambuco chamão melão de soldado ou sabão de soldado a ura planta saponacea de que usavão os soldados, para lavar com ella a roupa.

USOS MEDICINAES

Não s̃̃ conhecidos.

Molão de - Caetano. (Momordica charantia.)-Plantá trepadeira, mui conhecida, que vegeta por toda a parte, e em qualquer terreno, floresce e fructifica. 


\section{USOS MEDICINAES}

As folhas preparadas em forma de chí remedio aprovado para a iudigestão e constipacão E' contra a colica rerminova, a leucurrhea, e contra a hydropesia.

As folhas mui quentes, e applicados aos pes, dos que padecem de cravos, em modo que o suceo das folhas penetrem as rachaduras da pelle, os cura.

Apolpa di fructa misturada com sabũo, é un poderoso maturativo dos tumores, e mesmo proveitosa contra o carbunculo. Comida a polpa, exacerba as humorrhoidas.

o succo das folhas misturado (om aguardente e behilo, cura as febres intermittentes.

\section{LSOS DOMESTICOS}

As lavadeiras servem-se das folnas e ramas do llelão de S. Caetano, para alveijar a roupa.

yrendoea.-Planta do Parí, experimentada pelo Dr. Lacerila.

\section{HSOS MEDICINAES}

o seu emprego é contra as gonourheas. Faz se cozinento de toda a planta, e se toma meia chicara pela manhr̃. o outra noite.

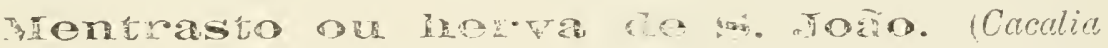
mentrasto.) - o mentrasto é um arbrsto pertencente a familia das compostas, mui conhecido an tolo o Brasil, classificarlo na Flora Fluminense, por Fr. Jośs Mariano da Conceicĩo Vellozo. com ad.ıminacĩo da Cacalic mentiasto. Nus Alagoas, Pernam. buco chamão a este arbusto Mentristo; no Rio de Janeiro, S. Paulo, e Miass Graes, conhecem-no nor Herva do S. Joũo.

\section{IISCIS MEDICIXAES}

o cozimento deste arbusto, é empregado internanente para curar as felres malignas, o pleuriz, nrovocar o fluxo mensal supprimi lo. Externamento em banhos, aproveita muito nas dores rheumaticas. As folhas applicarlas no ventre da mulher gravida, accelera 0 parto. 
USOS DOMESTICOS

Postas as follhas na roupa lavada, deixa-lhe um aroma agradavel; e afugenta as traças nas commodas e arcas.

Merapinima. - Arvore brasileira conhecida dos derru badores das mattas, cujo lenho, é compacto, pezado, e manchado, parecendo tartaruga depois de polido é muito estimado para os artefactos.

\section{USOS MEDICINAES}

Não ธão conhecidos.

USOS NAS ARTES

O lenho é mui apreciado na marcenaria.

Meruré-meri. (Pará.)-Planta do Pará, empregada em medicina vulgar.

\section{USOS MEDICINAES}

o seu emprego é contra as dores rheumaticas, tomada em infusão internamente, e em banhos externamente dados nas partes doridas.

Merru-caá ou merucá. (Pará.)-E'planta vulgar no Pará.

\section{USOS MEDICINAES}

Serverm-se do cozimento d'esta planta em clysteres, e banhos, para curar as hemorrhoidas.

Merú. (Canna utilis.) - Nas Alagoas chamão Periquito, ao arbusto conhecido em Pernambuco, pelo nome de Merú. Floresce em vermelho, e fructifica, sendo os fructos semelhantes as contas de rozario.

\section{USOS MEDICINAES}

E' emenagogo, e contra o hysterismo tomado internamente em cozimento; e externamente em banhos, serve para curar a paralysia, e as dores rheumaticas.

Milho. (Zea mais.)-O milho, é uma graminea conhecida de todos, por ser un dos mais uteis alimento que o Supremo Creador deu á humanidade. E' o milho indigena da America, e o seu modo de cultura, está descripto no Fazendeiro do Brasil 
do naturalista Fr. José Mariano da Conceição Vellozo; no A gricultor Brazileiro do illustre Carlos Augusto Taunay; e no Manual do Agricultor do illustrado Padre Antonio Caetano da Fonseca.

\section{USOS MEDICINAES}

O suador dado com cozimento do milho vermelho, cura a paralysia, e a fraqueza nervosa. O milho vermelho torrado e reduzido a pó, e feito mingáo e dado á comer cura a diarrhea sanguinea.

João Vigier, na sua historia das plantas, falando das virtudes do milho diz, que o pão do milho grosso é pesado ao estomago, dos que padecem obstruccões; a farinha do milho è excellente para cataplasmas maturativas. As folhas verdes do milho são boas para curar as inflamaçães e as erysipelas. 0 milho torrado cura a asia (pyrose.)

Pão do milho miudo, nutre menos que o feito com o graudo e sendo feito com leite aperta o ventre e provoca as urinas. Torrado com sal, e posto sobre o ventre, expele os flatos intes tinaes. Os medicamentos e as carnes, conservão se perfeitos e por mais tempo, mettidos dentro do milho, que em outra qualquer parte. Virgier diz que Santo Ambrozio, curava as febres terçans misturando ao cozimento do milho, vinho branco, dando a beber ao enfermo, provocando the as ourinas e suores.

0 cozimento feito com os cabellos do milho, cura as dores de dentes.

\section{USOS NA INDUSTRIA}

0 milho pode substituir a cevada, na confecção da cerveja.

Milhome. (Aristolochic milhome.)-Planta trepadeira, amarga, um pouco alcamphorarla, mui conhecida nas Alagoas e Pernambuco; vegeta em qualquer terreno.

\section{USOS MEDICINAES}

A raiz ralada e dada a beber, em agua morna, é excellente remedio contra as colicas e ventosidades. As vezes obra como emetico: provoca as regras nas mulheres, que as tem suprimidas. Empregão-na tambem para combatter as febres malignas. E' contra o veneno das cobras, e de animaes venenosos. O pó da raiz, é util nas gangrenas pulverisando as partes com elle. 
o millome que nasce na beira do mar, é aromatico: e embora pareça diffirir na especie, comtudo os prestimos são os mesmos.

Miloló ou coração de Boí. (Anona reticulata.) - E' uma planta indigina, pertencente a familia das Anonaceas: floresce e fructifica, e o fructo é comestivel.

\section{ISOS MEDICINAES}

As sementes são emulsivas, e com agua e assucar forma-se emulsão, que se applica ans febricitantes, e aos que tem diarrhéa.

Ming '́n-5ardo. (Silva Lisboa.)-E' arvore de 30 palmos de altura e I the diametro, das matas da Bahia Floresce em Novembro.

\section{USOS MEDICINAES}

Não são conhecidos.

\section{USOS NAS ARTES}

o lenho serve para as obras de molduras e marchetaria.

Mingre proto.-Arvore de 30 palmos de altura e I de diametro: Floresce em Novembro.

\section{USOS MEDICINAES}

Não são conheridas.

LSOS NAS ARTES

O seu lenho, em consequencia da cor ondeada de preto e amarello assetinado, serve para as obras de moldura e marchetaria.

Mingú hono.- Arvore de 30 palmos de altura e 1 de diametro.

$$
\text { LSOS MEDICINAES }
$$

Nĩo são conhecir!as.

\section{USOS TIS ARTES}

o lenho é ondeado de roxo, e serve para as obras de marchetaria e de moldura.

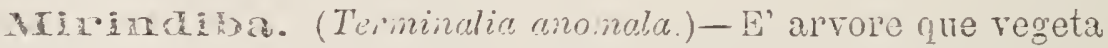
em quasi todo o Brasil, e mui conhecida dos derrubarores.

\section{LSOS MEDICINAES}

Não sĩo conhecidos. 
USO YAS ARTES

o lenho d'esta arvore, é d'um amarello claro, e serve para a marceneria, e obras de casas.

USOS NA INDUSTRIA

Do lenho se extrahe excellente tinta de côr vermelha violacea. propria para a tinturaria.

Mrocerengrue. - Arvore de 40 á 50 palmos de altura, com 2 á 3 de diametro: floresce em Setembro.

USOS MEDICINAES

Não são conhecidos.

LSOS NAS ARTES

Serve para varaes, estacas, e vigas.

Mocerengussú. - Arvore das mattas da Bahia de 40 a 60 palmos, com 2 á 3 de diametro. Floresce em Setembro. USOS MEDICINAES

Não são conhecidas.

$$
\text { USOS NAS ARTES }
$$

Serve para varaes, estacas e vigas.

Mocoģè ou mucogrè.- Arvore particularmente originaria da provincia da Bahia, de 30 á 40 palmos de altura, com 2 á 3 de diametro: floresce em setembro.

USOS MEDICINAES

o fructo é saborosissimo e mui delicado, e se pode dar aos eniermos.

USOS NAS ARTES

0 seu lenho serve para vigotas.

$$
\text { USOS NA INDUSTRIA }
$$

E' arrore leitosa, como a mangabeira, e r'ella se pode obter a borracha. O estrago que fazem em derrubal-as, quando querem tirar-lhes os fructos, tem feito que já vá escasseando, onde vegetavam em abundancia.

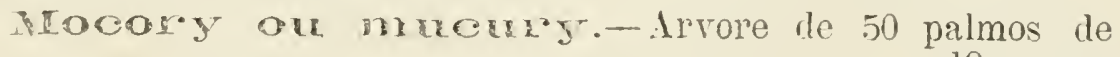


altura, e 2 de diametro: floresce em Setembro, e fructifica. o fructo é do tamanho de cajá, amarello, aromatico e mui saboroso.

\section{USOS MEDICINAES}

Nâo são conhecidos.

\section{USOS NAS ARTES}

O lenho do Mocory, serve para couçoeiras, e forro das embarcações.

Mocotó. (Etytroria alogoana.)-E' uma planta que vegeta nas Alagoas, floresce e fructifica, e alli conhecida pelo nome de Mocotú.

USOS MEDICINAES

o mais commum emprego que the dão, em medicina domesticá, é em cozimento para cural as opilações.

Mocuba.-Arvore de 60 e mais palmos, com 2 á 3 de diametro: floresce em Setembro.

\section{USOS MEDICINAES}

Não são conhecidos.

USOS NAS ARTES

Serve para taboados.

Macobussú. - Arvore das nossas mattas, de 40 palnos de altura, e 2 de diametro: horesce em Agosto.

USOS MEDICINAES

Não são conhecidos.

USOS NAS ARTES

Serve o seu lenho para vigotas e frechaes.

Moensa. - Arvore das mattas da Bahia, de 60 palmos de aitura, com dous de diametro: floresce em Outubro.

\section{USOS MEDICINAES}

Não são conhecidos.

USOS NAS ARTES

O seu lenho é empregado na fabricação de canôas, gamellas, e tamancos. 
Moloix.ona.-Planta do Maranhão e Pará.

\section{USOS MEDICINAES}

o Dr. Lacerda fez experiencias em si, para conhecer as propriedades medicinaes d'esta planta, e reconheceu ser diuretica e sudorifica.

Mondax.ú.-Arvore de 20 á 30 palmos, com l de diametro: floresce em Setembro.

\section{USOS MEDICINAES}

Não são conhecidos.

$$
\text { USOS NAS ARTES }
$$

Serve para varaes de cerca.

Mondurur ú. - Arvore das mattas da provincia da Bahia. de 20 á 40 palmos de altura, e 1 de diametro: floresce em Outubro,

\section{USOS MEDICINAES}

Não são conhecidos.

\section{USOS NAS ARTES}

Serve para varaes de cerca.

Mondururú fidalgo.-Arrore das mattas da provincia da Bahia, de 20 á 40 palmos de altura, e 1 de diametro: floresce em Outubro.

\section{USOS MEDICINAES}

Não são conhecidos.

USOS NAS ARTES

Serve para varaes de cerca.

Mondur.ulinga.-Arvore de 20 á 30 palmos de altura, com 1 de diametro: floresce em Setembro.

$$
\text { USOS MEDICINAES }
$$

Não são conhecidos.

$$
\text { USOS NAS ARTES }
$$

Serve para varaes de cerca.

Mongubúra ou mungubeira. (Bombax simigut. 
tiferc.)-Arvore mui alta das mattas das Alagôas, de flores brancas em cachos, de casca grossa e resinosa.

\section{USOS MEDICINAES}

Não são conhecidos.

\section{USOS NAS ARTES E NA INDUSTRIA}

A sua madeira serve para taboados, e caibros de casas.

o velo que envolve as sementes, é mui procurado para encher colchõ s e travesseiros. As sementes dão oleo excellente para a luz.

Monduany.-Arvore das mattas da Bahia de 40 palmos ue altura, com 2 de diametro: floresce em Agosto.

\section{USOS MEDICINAES}

Não são conhecidos.

USOS NAS ARTES

O seu lenho é empregado em esteios, vigotas e frechaes.

Mondurit-Arvore de 40 palmos, com 2 de diametro: floresce em Outubro.

\section{USOS MEDICINAES}

Não são conhecidos.

USOS NAS ARTES

A sua madeira é macia no serrar e larrar, e a empregam em frechaes e vigotas.

Mrorotó ou pro bastarcho. (Panas chrysophyllum.) -Arvore vistosa do Brasil.

\section{USOS MEDICINAES}

Não sũo conhecidos em medicina vulgar.

\section{USOS NAS ARTES}

Serve a madeira, para obras de construccão civil.

Mostarda. (Sinapis nigra.)-Pla ta que foi trazida da Europa para o Brasil João Vigier trata da mostarda hortense, da do campo, e da mostarda domestica.

USOS MEDICINAES E DOMESTICOS

As sementes são efficazes nas febres intermittentes e quartans, e 
na asthma; provoca as ourinas e os menstruos. Deluida em agua tira as nudoas da pelle: é contra o escorbuto: Dizem que reduzida a pó, e misturada em ourina de crianças, de 6 á 9 annos, cura a hydropesia Misturada com vinagre, cura as empigens e a lepra; misturada com mel. cura a tinha; misturada com vinagre, cura as mordeduras dos animaes venenosos. Misturada a mostarla com 0 alimento, desperta o appetite, e é boa para fortificar o estomago. E' muito usada nas mezas, para a confecção do molho.

\section{USOS NA INDUSTRIA}

Pisada a mostarda, e misturada no vinho impede que ferva, e assim se conserva por muito tempo em estado de pureza.

Motête.-E' uma planta da famılia das cucurbitaceas, conhecida nas Alagôas, e apreciada por seus fructos.

USOS MEDICINAES

Empregam o cozimento da raiz d'esta planta em clysteres, para mitigar as hemorrhoidas.

USOS DOMESTICOS

Com a massa da fructa, fazem doce para regalo da meza.

Moxerocuighba.-E' planta agreste, que ve geta nos sertões do Brasil, e dá fructo do tamanho de uma laranja, onde se encontra pevides que dão oleo, com que os indios se ungem.

USOS MEDICINAES

Não se conhecem os seus prestimos em medicina domestica.

USOS NA INDUSTRIA

A casca desfeita na agua, mata os peixes, e qualquer outro animal que d'ella beber.

Mracara-cá.-E' uma planta do Maranhão e Pará, experimentada pelo Dr. Lacerda,

\section{USOS MEDICINAES}

E' contra o veneno das cobras, tomando-se o chá da raiz, e applicando-se a mesma, pisada sobre a ferida.

O suador tomado com esta planta, faz desapparecer as dores do corrimento, produzidas pelo resfriamento. 
Mucunan ou mucuná, ou fava purgativa. (Lavradio.) - (') A mucunan é uma planta trepadeira, que se enrola nas arvores, conhecida na Balia, Alagoas e Pernambuco pelo nome de Coroa de Frade, pertencente á familia das leguminosas, e de flôres papilonaceas, que vegeta em qualquer terreno, principalmente no humido e sombrio. As fructas são vagens, cobertas de um pello duro e louro, que se despega facilmente, e produz terrivel coceira n'aquelle que lhe tocar No Kio de janeire, onde tambem abunda este cıpó, chamam ao pello da vagem do mucunan pó de mico.

\section{USOS MEDICINAES}

As sementes em pó, affirma o Dr. Paiva, ou postas de molho em vinho e agua, purgam por cima e por baixo, e d'ellas usam os caboclos, e os negros, em muitas enfermidades, quando intentam vomitar e purgar.

A penugem on catão, que cobre a vagem, e a que vulgarmente cliamam pos da India, misturada com qualquer xarope, em forma de electuarin, é approvado e effica r remedio para destruir e matar as lombrigas, de qualquer casta que ellas sejão, e, consequentemente, as infinitas desordens que causam. Não é este um remedio recommendado e uzado somente pelos barbaros do Brasil, e da Guyanna, mas tambem pelos medicos e cirurgiões estabelecidos n'este paiz, que o têm feito conhecer á Europa.

(') O Dr. M. I. Henrique de Paiva deu á planta Mucunan, o nome de Lavradio, em memoria do Marquez do Lavradio, então Vice-rei do Rio de Janeiro; creador de uma Academia de Sciencias, que Horesceu debaixo do seu patrocinio, e fez dar, em pouco tempo, passos agigantalos, frequentrudo os socios, em cujo numero entra elle $\mathrm{Dl}^{\circ}$ Paiva, para n'ella trakalharem em um Jardim Botunico, gente e instrumentos; hourando-os, e animando muito os ectudos dos Academicos etc. (Dr. Henrique de Paiva. Memoria 4 a)

O Jardim ou Horlo Botanico, foi no Morro do Castello, dentro da cerca do collegio dos Jesuitas Em 4 de Novembro de 1793, foi nomeado pejo conde de $R$ ezende, o primeiro tenente do regimentu de artilheria Jusé Constantino Lubo l'utell o. para administrador do Horto Butunico, na cerca dos Jesuitas. Em 1801, se mandou pro eder a vistoria na cerca chamara do cullegio, pelo Dezembariarlur Juiz dus Feitos da Fazenda, Fl'ancisco Lopes de Souza de Faria Lemos. 
Assim o doutissimo Bergio, na sua materia medica, impressa em 1782, diz por testemunho de Bancroft, que d'elle usou na Guyanna, com bom succerso, mais de mil vezes, e que é o unico, e mais poderoso antidoto, que se tem inventado contra as lombrigas, especialmente nos negros, que ahi são vexados por ellas.

o cozimento da raiz, tomado em gargarejos, cura as feridas da garganta.

\section{USOS NA INDUSTRIA}

Os indios servem-se da fructa, para alisarem a louça de barro, de que usam, do succo das folhas e mesmo de toda a planta, para pintarem as cuias. No tempo de fome, no interior do Brasil, o povo serve-se da fructa do mucunan para alimento, depois de cozida em nove aguas, para the tirar o principio medicamentoso.

Mucura-cáa. (Dr. Lacerda.) - Planta do Pará, descripta pelo Dr. Lacerda, e por elle experimentada em medicina vulgar.

\section{USOS MEDICINAES}

A raiz infundida em 2 chicaras d'agua, e dada a infusũo á beber. faz expellir as molas do utero. Se á infusão the addicionar algumas gottas de vinagre, mais efficaz é o resultado.

As folhas e a raiz passadas pelo ar do lume, e postas na testa, curam as dores de cabeca o cozimento da raiz é empregado contra o rheumatismo syphilitico.

Mucuybeira.- Arvore silvestre, cuja copa assemetha-se a chapéo de sol, a qual fluresce e fructifica em forma de azeitona, contendo uma amendoa.

\section{USOS MEDICINAES}

A amendoa ralada e infundida em agua, e dada a beber, facilita o parto tardio. O oleo ou manteiga, que se extrahe em abundancia da fructa, os indios empregam em diversas enfermidades,

Muboboca. (Dr. Lacerda.) - E' uma arvore espinhosa do Pará. 


\section{USOS MEDICINAES}

As folhas d'esta arrore queimadas, e pulverisadas com o pó as feridas provenientes de queimaduras, as cura com rapidez.

Mumaxoco.- Arvole de Minas Geraes, mui conhecida, por sens prestimos medicinaes E' mui copada, de folhas caducas, e em Setembro reverdece, e florifica com flôres vermelhas.

\section{USOS MEDICINAES}

A casca é empregada para combater as febres intermittentes.

\section{USOS CULINARIOS}

Os grellos d'esta arvore, que são mucilaginosos, são comestiveis.

Mungubeira. (Bombas semiguttiferr.)-E' uma arvore das Alagoas, e muito abundante em todo o Amazonas, de casca srossa e resinosa, flôres brancas em cachos, e o fructo contem um pello pardo, muito estimado na colchoaria.

\section{USOS MEDICINAES}

Não são conhecidos os seus prestimos em medicina domestica.

$$
\text { USOS NAS ARTES }
$$

O lenho d'esta arvore. serve para caibros das casas, e para vigotas.

\section{USOS NA INDUSTRIA}

As sementes da mungubeira dão oleo para luz, e para a fabricação do sabão. O pello que as cobre é mui procurado. para o enchimento de colchões e travesseiros, pela sua maciez.

Munupie. (Sapium exphorbium.) - E' uma planta da familia das euphorbiaceas, mui leitosa e venenosa.

\section{USOS AIEDICINAES}

O leite d'esta planta, misturado com verdete (sulphato de cobre) destroe os cravos dos pés, e cura as boubas.

Muquibeira. - Arvore que produz nas mattas, principalmente nas do reconcavo da Bahia: floresce e fructifica. 


\section{USOS MEDICLNAES}

O fructo, que parece com a noz moscada. tem muitos prestimos ma medicina popular, sendo o principal facilitar o parto as mulheres, dando-se á beber ralado edesfeito em agua.

\section{USOS NAS ARTES}

o seu lenho selve para diversas obras civis.

USOS NA INDUSTRIA

O fructo é tão olcoso, que dá manteiga em abundancia, e púde ter diversas applicações em medicna e na industria.

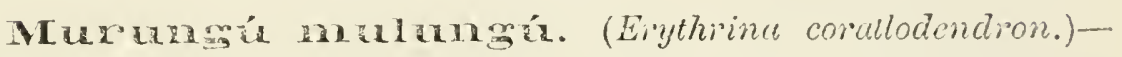
Arvore elegante, mui conhecida nas Alagoas. Pcrnambuco, e Bahia, pertencente a familia das leguminosas, a qual floresce em vermelho e fructifica em vagem, contendo uma ou duas sementes vermellas. A casca d'esta arvore $\dot{e}$ um tanto herbacea, e semeada de espinhos conicos, e grandes, que se desprendem facilmente.

\section{USOS MEDICINAES}

O murungú é o melhor calmante, que se conhece, do systema nervoso, preferivel ao opio e á thridacea, porque, provoca o somno reparador, sem provocar congestĩo de sangue aos centros nervosos cerebraes. E' mui proveitoso na tosse convilsa, na asthma, nas brorchites. E' um poderoso desobstruente do figado, tendo reputação firmada na therapentica popular 0 uso interno, é feito com extracto da entrecasca, ou com o xarope simples ou diluido em agua morna, ou em qualquer cozimento emoliente, na dose de uma coiher de sopa, de 3 em 3 horas, para os adultos, e uma coller de chá, para as criancas. Tamben servem-se do cozimento, externamente, em banhos, como calmante e desobstruente. O poro serve-se da entrecasca picada com as folhas da coneba, ou pariparoba, misturada em azeite de carrapato ou mamono, pora curar as obstrucções chronicas do figado.

Aluriassat-- Arvore de 40 palmos de altura, com 2 de diametro foresce em Agosto.

USOS HEDICINAK

Nẽo sฉ̃o conhecidos em medicina vulgar. 


\section{USOS NAS ARTES}

O lenho d'esta arvore serve para vigas e frechaes.

Nuricy. (Bysonima.)-E' arvore de 35 is 40 palmos de altura, com dous e meio de diametro: floresce em Agosto.

USOS MEDICINAES

Não ลão conhecidos.

USOS NAS ARTES

O seu lenho, que é macio, e de poros fechados, serve para vigas e coucoeiras.

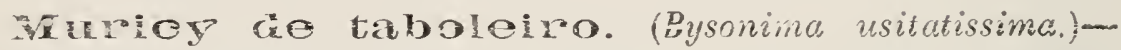
Fista planta vive nos extensos taboleiros das Alagoas, e mesmo nos de Pernambuco. Floresce e dá fructo mui aromatico, e apreciado pelo sabor agro-doce. Não the conheço os prestimos em medicina vulgar.

Mururé.-E' arvore do Pará, leitosa, de regular grandeza.

LSOS MEDICINAES

o cozimento da casca, dado em banhos, faz desapparecer as dôres do rheumatismo syphilitico.

Huró. (Canna aurantiaca.) - O murú é uma planta pertencente á Pamilia das Amomaceas. Creio ser a canna conhecida no Rio de Janeiro, por canna do brejo.

\section{USOS MEDICINAES}

Tomarla em cozimento, quando verde, é diuretica; e em banhos, serve para mitiqar as dôres rheumaticas. 0 pó da raiz secca, cura as dôres de dentes. O succo da planta neutralisa a acção do mercurio. o fructo quasi maduro, é recommendado contra as dôres de ouvidos, appiicado ao orgão doido.

Mlururé vermelho.-O mururé é uma arvore do Maranhão, estudada pelo Dr. Lacerda. Picada dá leite côr de ganga amarella.

\section{LSOS MEDICINAES}

O leite, e mesmo a casca d'esta arrore, tem acção sobre as pupillas dos olhos.

Há outra variedade d'esta arvore, cujo leite é branco. 
Mururue. (Bichetia officinalis.)-E' planta do Pará pertencente a familia das urticeas.

USOS MEDICINAES

No Pará empregão esta planta em cozimento contra os males syphiliticos.

Murussuca.-Arrole das mattas da Bahia, que floresce em Novembro.

$$
\text { - } 30 \text { MEDICINAES }
$$

Não são conhecidos.

USOS NAS ARTES

0 seu lenho é empregado em varames.

Nurta. (Silva Lisboa).-Arvore de 25 a 40 paimos de altara. com um á dous de diametro: florese em Agosto.

\section{USOS MEDICINAES}

Não são conhecidos.

USOS NAS ARTED

O seu lenho serve para vigotas e frechaes.

Murea eulivada. (Myrthus communis.)-- Esta planta foi transplantada no Brazil, e se:ve do ornato aos jardins. As flores sĩo brancas, e mui aromaticas. Os gregos e romanos, a consagravam ao culto deVenus, e do amor. Era o symbolo da pureza.

\section{USOS MENICINAES}

As folhas, reduzidas a pó, são empregadas para curar o umbigo dos recém-nascidos.

Nertha de facho. (Silva Lisbon.)-E' arvore de $40 \mathrm{pal}$ mos, com um á duus de diametro: floresce em Setembro.

USOS MEDICINAES

- Não são conhecidos.

\section{USOS NAS ARTES}

O seu lenho serve para vigas e frechaes.

Mrecin Do.-E' arvore das mattas da Bahia, de 30 a 40 palmos de altura, e de um de diametro: floresce em setembro, dá fructos comestiveis. 
USOS MEDICINAES

Não são conhecidos.

\section{USOS YAS ARTES}

O seu lenho serve para varames.

Mur tim nos.-Há diversos arbustos no Brazil, com este nome, que não tem sido empregados em medicina vulgar.

Murgo. (Lichen.) - O musgo nasce sobre as pedras, ou em terrenos tão seccos e duros, como se fossem pedra. A sua natureza é de tal forma arida, que parece não gozar de vida vegetativa : em consequencia da sua sequidão, não produz seiva alguına, e por isso. moendo-se, torna-se em pó, mas apenas molhado, incha e cresce: não tem folhas, e nem sabor algum; tem o feitio de uma macã de algorlão, e ató $\dot{a}$ alro na côr. Encontra-se commummente, onde ha candèaes.

\section{USOS MEDICINAES}

o pó, serve para cicatrizar as feridas chronicas.

Musgono.- Hit outra especie de musgo, que vegeta nos mesmos terrenos, que tem 3 e ás vezes 4 folhas, e quanto mais sol apanha, mais produz. E-te musgo, abunda nos campos da comarca do Rio Real, na provincia de Sergipe.

Iussanoé. (Cleome heptaphylla.)-E' um arbusto muito vulgar, e conhecido nas Alagôas, Pernambuco e nos sertões, que vegeta com preferencia nos logares frescos. Suas flôres são brancas, e de aloma suare, e produz vagens cheias de sementes, que attrahem bandos de pintasilgos, e outros passaros. Na cidade velha das Alagôas, o mussambé nasce até pelas ruas e quintaes.

\section{USOS MEDICINAES}

O cozirnento das folhas, dado em banhos, cura as molestias dos testiculos; e machucadas, e feita emplasto, e posto sobre as hernias chronicas as reduz, e mesmo as hernias das crianças, ainda mesmo as que trazem, desde o nascimento. 0 banho feito com o cozimento das folhas, é mui proveitoso nas hemorrhoidas, mas não deve ser frequente, por poder desenvolver a hydropesia.

o cozimento da raiz, adocado com assucař, é approvado remedio, contra as gonorphéas e flores brancas. 
Fressetaniba.-Arrore semelhante ao carvalho, de 60 á 100 palmos de altura, de 2 í $f$ de diametro: floresce em Outubro.

DSOS MEDICINAES

Não tem emprego conhecido em medicina vulgar. I:SOS NAS AR'TES

o seu lenho serve para esteios, eixos de machinas, poleames. ornatos, e marchetaria.

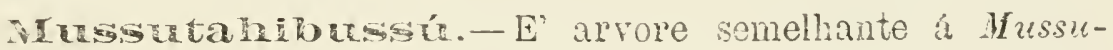
tahiba, de igual tamanho e grossura, a so difierente nas folhas e flôres.

ISOS MEDICINAES

Nĩo sĩo couhecidos.

USOS NAS ARTES

Tem a mesma serventia, que a mussutuhiba.

Mutamioa mabombo. (Thebroms gucuma.) - E. anvore de grancieza regular, conhecida nas Alagoas, e em quasi todo o Brasil, que vegeta em qualquer terreno. Floresce e fructifica, sendo o seu fructo uma baga espliorica, coberta de picos molles, contendo dentro sementes, e uma mucilagem branca, e doce, com o sabor de figo secco.

\section{LQOS MEDICINAES}

A entrecasca picada. e misturada com azeite de mamono ou carrapato, applicada á região do figgado, eura as obstrucções d'este orgão. O cozimento serve para la rar as feridas velhas. O cozimento feito xarope, é empregado contra a tosse, a pneumonia, o catarrho e a asthma, na dóse de uma colher de sopa, de espaco em espaço.

Murugcicica. (Dr. Lacerda.)-A miruquitica é planta do Pará, conhecida pelo Dr. Lacerda.

\section{tSOS MEDICINAES}

o cozimento feito com esta planta, addicionando-Ihe un grĩo de pedra lipes, cura a inflammação dos ollios. 


\section{N}

Tabo. (Brossica napus) - o nabo é uma planta hortense, e mui conhecida, e de que se faz muito uso na comida de carne. Ha duas qualidades d'este vegetal, uma domestica, que a a cultivada nas hortis, e outra brava, que nasce pelos campos. o nabo hortense, é o de que trato

\section{USOS MEDICINAES}

O cozimento do nabo, serve para amadurecer a defluxão do peito; as sementes, sĩo contra as bexigas. O nabo tenro, assado, e ainda quente, e applicado ás frieiras, que apparecem no cal:anhar, dizem ser remedio eficaz.

USOS CULINARIOS

o nabo cozido com a carne, é alimento sadio, e nutriente, IIas provoca ventosidades intestinaes. João Vigier diz, que o uso mui continuado da alimentação do raiz do nabo faz as rarnes molles.

\section{USOS NA INDUSTRIA}

As sementes du nabo, dĩo oleo, que póde ser aproveitado.

Noneibéa. (Manettia cordifolia.)-E' uma planta trepadeira, da familia dos Rubiaceas, de folhas em fórma de coração, e flores vermelhas.

\section{USOS MEDICINAES}

o pó da raiz, em pequena quantidade, é mui proveitoso para (-nrar a hydropesia, e a dysenteria, causadas pelos resiriamentos.

Nar.Ciso. (Nurcissus pratensis.) - Planta, de jardim, proveniente de uma cebola lisa, d'onde nasce um talo, com flores brancas e amarellas no centro, mui aromaticas. Ha varias especies.

\section{LSOS MEDICINAES}

A cebola cozida, é vomitiva; e picada com mel, cura as queimaduras, e solda os nervos cortados. 
Nax-do. (Nardus.)-Planta aromatica, que produz en grande quantidade na serra do Caraça, em Minas Geraes.

\section{USOS MEDICINAES}

A raiz é excitante, provoca o suor, as ourinas, e fortifica os orgũos internos.

\section{USOS IA INDUSTRIA}

A industria póde extrahir o aroma do nardo, para as diversas preparações de perfumaria.

Negra mina.-E' arvore conhecida nas Alagôas, e Pernambuco, pertencerte a familia das Laureaceas.

\section{USOS MEDICINAES}

Não são conhecidos.

\section{USOS NA INDUSTRIA}

Possuindo esta planta um aroma forte, e roui agradavel, it ind!rstria póde tirar a essencia, para a perfunaria.

Neve.- Arbusto aromatico, que nasce em terrenos seccos.

\section{LSOS MEDICINAES}

O coziruento das follas, dado em banhos, alliviam as dores rheumaticas. O sumo é conveniente, para curar feridas.

Nhambi. (Anthemis.)-Planta annual, indigena, aroma. tica, empregada pelos indios em suas enfermidades.

\section{USOS MEDICINAES}

Os indios brasileiros servem-se d'esta planta, para curar as obstrucções do figado, e expellir os calculos biliarios, as obstrucçóes do baço, a hydropesia, e os flatos intestinaes.

\section{LSOS CULINARIOS}

As folhas do nhambi servem, para aromatisar as saladas.

Nhánói. (Piper caudatum.)-Esta planta brasileira, é descripta por Pison.

\section{USOS MEDICINAES}

A infusc̃o da raiz provoca o suor, e as ourinas. As folbas reduzidas a pó, s̃̃o sternutatorias. 
Nomuoira da Fndia. (Nux juglans.)-A nogueira é originaria da India, transplantada e aclimatada no Brasil.

\section{USOS MEDICINAES}

João Vigier, na sua historia das plantas, diz, que a casca das nozes ver'des é sudorifica, e resiste ao veneno. As nozes de conserva em assicar ou em mel, confortão o estomago, são aphrodisiacas, e coirigem o bafo da bocca. O oleo das nozes, serve nas colicas, adoça e mitiga as dores uterinas das mulheres paridas: resolve e conforta os nervos. A seguinda casca da noz secca, lia quantidade de uma oitara em pó, suspende os vomitos. O cozimento da raiz da nogueira, dado em banho, é bom remedio para curar o rheumatismo.

\section{USOS NAS ARTES E NA INDUSTRIA}

O lenho da nogueira serve, para varias obras de construcção civil. Os tintureiros, tiram da casca da nóz verde, uma tinta mui forte.

Noz inoscada do Brasil. (Cryptocaria moschata.)E' uma arvore da familia das Lanreaceas, de flôres pequenas e cheirosas, tendo o seu fructo um aroma activo.

\section{USOS MEDICINAES}

E' carminativa. A casca, depois de secca, tem aroma, e sabor mui agradaveis. Empreqa-se nas digestões laboriosas, e nos vomitos espasmodicos. O Dr. Peckolt, affirma, que em cataplasma, tem bom efieito contra a debilidade do estomago, e colica das criancas; para este effeito julga preferivel o oleo graxo, que se obtem do fructo, e que se applica contra o rhenmatismo.

A magnifica arvore desapparece cada rez mais, em consequencia da mania frenetica de destruir todas as arvores, sem distincção; ella mereceria a mesma consideração, como na Europa o loureiro, em virtude não só dos seus fructos, como tambem das folhas, e da casca, ambas aromaticas.»

Nucurry.- Palmeira de grandeza mediana, que dá cocos mui saborosos. 
USOS NA INDUSTRIA

No cacho que produz, fornece uma resina de côr verde, da qual se pode usar, em logar de lacre, pois, sendo derretida ao fogo, gruda perfeitamente o papel, ou objecto que se quizer lacrar.

Nux vomica. (Strichnos guyanensis.)-E' uma arvore do Brasil, cuja fructa é venenosa.

\section{USOS MEDICINAES}

Com muita reserva, e em pequena quantidade, é proveitosa na paralysia. A homeœpathia tira grandes resultados da nux vomica nas molestias da cabeça, nas do ventre, e nas febres. E' um poderoso medicamento, para os padecimentos da bexiga ourinaria, e para as hemorrhoidas.

USOS NA INDUSTRIA

Com o succo de nux vomica, os indios envenenam as pontas das settas, para matar com mais rapidez os seus inimigos.

\section{()}

Drani. (Moronobia coecina.)-Arvore gigantesca do Pará, Amazonas, e das Missões do Orenoque, que produz abundante leite, e distilla uma resina medicinal, amarellada, que empretece quando secca, chamada mani.

\section{USOS MEDICINAES}

Com a resina se faz emplastro contra as dores rheumaticas. o leite não tam sido empregado, nem em medicina domestica, nem na industria.

USOS NAS ARTES

() lenho d'esta arvore, serve para taboados.

Oanassú. (Attalea spectabilis.)-E' uma palmeira natural do Brasil, cujos fructos são estimados dos indios. 


\section{USOS MEDICINAES}

As amendoas dos cocos são comestiveis, e sendo pisadas e misturadas com agua, e assucar, se fórma uma emulsão refrigerante.

\section{USOS NAS ARTES}

o lenho da arvore, serve para fabrico das casas de campo.

Ocotea aromatica. (Ocotea opifera.)-Planta aromatica, do interior do,Brasil, que floresce e fructifica.

\section{USOS MEDICINAES}

Não são conhecidos.

\section{USOS NA INDUSTRIA}

Das sementes se extrahe um oleo essencial, que se assemelha ao oleo do limão vulgar.

Ocotea amargosa. (Ocotea amara.)-Arvore do interior do Brasil, e particularmente das margens do grande rio Japurá, que desagua no Amazonas.

\section{USOS MEDICINAES}

A casca d'esta arvore, que é amargosa e aromatica, empre. gão-na em infusão, para combater a fraqueza do estomago, e a dispepsia.

Ocuba. (Pará e Amazonas.) - E' uma planta que vegeta em muita abundancia, na vasta zona do Amızonas, e produz fructos de côr vermelha purpurina, envolvendo uma nóz preta, mui proveitosa á industria. (Vide uсuиba.)

\section{USOS MEDICINAES}

Não são conhecidos.

\section{USOS NA INDUSTRIA}

Pisadas as nozes, e fervendo-se-as em agua, se extrahe cêra branca e brilhante, para a fabricação de vellas, que dão bonita luz, e mais resplendente que a luz da cêra commum.

Ogervāo ou gervāo. (Elytraria usitatissima.)-E' planta mui conhecida e popular no Rio de Janeiro, Bahia, Sergipe, Alagôas, e Pernambuco. Ha duas qualidades: uma de 
flores roxas, e a outra de flores esbranquiçadas. O povo serve-se do gervão roxo, que tem as propriedades medicinaes mais activas.

\section{USOS MEDICINAES}

o povo serve-se das f.lhas do gervão em chá, para as molestias do estomago e do figado. A raiz tem os mesmos pres ${ }^{-}$ timos.

Oiti-oitizeiro da Mata ou oiticoró. (Arbor pomisfera.) (Pison e Marcgrave.) - 0 oiti ou oitizeiro é arvore de 50 e mais palmos de altura, e de 2 á 4 de diametro; floresce em Setembro, com flores brancas, e dá fructo do tamanho de um limão doce, e mesmo maior, de côr verde escura, tendo uma massa doce e agradavel.

\section{USOS MEDICINAES}

o cozimento da entrecasca, serve para combater a dysentiria de sangue; bem como o caroço da fructa; deve-se ter cuidado na administração, porque póde haver suspensão repentina da diarrhéa, e causar a morte do enfermo,

\section{USOS NAS ARTES}

C lenho d'esta arvore serve para taboado de forro, e fundo de embarcações, por se conservar perfeitamente dentro d'agua.

Oiti da Praia. (Pleragia adorata.)-Esta arvore foi classificada pelo Dr. Arruda da Camara: tem diversos nomes na Bahia, Alagôas e no Pará. E' mui conhecida por seus fructos, que são amarellos, aromaticos, e gostosos.

\section{USOS MEDICINAES}

E' adstringente, e serve para curar as feridas chronicas.

Oiticia. (Pleragina um brosissima.) - E' arvore de 80 e mais palmos de altura, e de 1 á 10 ou 12 de diametro, que vegeta no interior das nossas florestas. Em Setembro se orna de flóres amarellas, e em seguida fructifica. Foi estudada pelo Dr. Arruda da Camara.

\section{USOS MEDICINAES}

Não são conhecidos. 
USOS NAS ARTES

A madeira que é amarella, um pouco resinosa, côr de flôr de algodoeiro, serve para taboado; mas lasca facilmente. Serve para cintas de navios, curvas, polenmes e para obras de casas.

\section{USOS NA INDUSTRIA}

Da entrecasca e ramos, extrahe-se tinta amarella.

Olandim. (Moronobia cocinea.) - E' arvore lactifera conhecida dos derrubadores, cuja madeira é estimada, para todo o genero de construcção.

\section{USOS MEDICINAES}

o leite que distilla; por meio de incisão, é um optimo resolvente de qualquer tumor.

USOS NAS ARTES

o lenho é estimado para as obras de construcção civil, e naval.

Olandim Carvalho.-Arvore de 60 palmos de altura com 2 á 4 de diametro: floresce em Outubro.

\section{USOS MEDICINAES}

Nào são conhecidas as suas virtudes em medicina vulgar USOS NAS ARTES

O lenho d'esta arvore serve para váos descobertos etaipores das embarcações, por ser madeira leve.

Oleos.-Oleos que se extrahem das plantas para a exportação:

Oleo de Dendê, empregado nos usos culinarıs, e para o fabrico do sabão amarello.

Oleo Umiry.-Extrahido da casca da arvore umirium balsamiferum. Quando bem purificado é muito aromatico, e empregado na perfumaria, e na medicina. Quando a arvore está muito impregnala de oleo, que por si mesma o exsuda, embalsama o ár que a circumda.

Oleo de Amendoim. - E' empregado nas comidas, e em fricções contra o rheumatismo. 
Oleo de Jacaré-cupahyba.-E' extrahido da arvore calaphilum brasiliense. O seu uso é para o calafeto das embarcações, preferivel ao breu.

Oleo de Jupati. E' extrahido da amendoa da palmeira Sagus tcedigera. Serve para o fabrico do sabão.

oleo de mucaja.-E' extrahido da amendoa da palmeira mucajá.

Oleo de patauá.-E' extrahido da fructa da palmeira cenocarpus distinctus. Serve nas cozinhas para substituir o azeite doce, ou oleo de oliveira, que perfeitamente 0 substitue.

Oleo de cacaio._São mui] conhecidos os seus prestimos.

Oleo de copahyba. - São mui conhecidos os seus usos.

Oleo commumba.- Arvore das nossas florestas, de 60 palmos de altura, com 3 de diametro. Floresce em Outubro. USOS MEDICINAES

Não são conhecidos.

USOS NAS ARTES

O seu lenho é pesado, macio ao serrar e lavrar, e serve para coronha de espingardas, mastaréos de navios, e obras de marcenaria.

oleo pardo ou caburé-iba. (Myrocarpus fastigiatus.)-E' arvore de 60 palmos, que distilla uma resina de aroma agradavel, semelhante ao balsamo de Tolú, que tem emprego em medecina.

\section{USOS MEDICINAES}

o balsamo ou oleo caburé-iba, é fortificante, nervino, e se presta á confecções de unguentos, para curar feridas.

\section{USOS NAS ARTES}

o lenho da arvore, serve para obras de construcção civil e naval.

Oleo vermelho. (Myrospermum erythroxilum.)-E' uma bella arvore balsamica, da nossa esplendida flora, prestimosa e util, que vegeta em nossas magnificas florestas, sem a impor- 
tancia que merece; se fosse cultivada, seria um interessante, ramo de exportação industrial. Desde a raiz até as folhas, dá esta arvore um porfume delicioso. D'esta interessante arvore se extrahe um oleo essencial, superior ao balsamo do Perú.

\section{USOS MEDICINAES}

Tem os mesmos usos, que o balsamo do Perú.

$$
\text { USOS NAS ARTES }
$$

o seu lenho, de bella côr vermelha, é empregado em marcenaria, e em obras de construcção naval.

Olhos páos.- Arvore de 50 palmos de altura, com 2 de diametro. Floresce em setembro.

\section{USOS MEDICINAES}

Não são conhecidos.

\section{USOS NIAS ARTES}

o lenho d'esta arvore, serve para as obras de carpintaria; porém affirma o Dezembargador Balthazar da Silva Lisboa, que a fumaşa da madeira faz cegar.

Oliveira brasileira.-A oliveira, chamada brasileira ou cambi, é uma arvore semelhante á pitombeira, que dá fructo igual a azeitona, em configuração e cheiro, e só differente no sabôr, e no caroço, que é brancacento.

\section{USOS MEDICINAES}

Năo são conhecidos.

\section{USOS NA INDUSTRIA}

Do fructo agri-doce, da oliveira brasilica, se póde fazer excellente vinagre.

Omer'y.-E' arvore brasileira, que distilla o Estoraque.

Ombér.- Arvore indigena, não classificada, que dá fructo semelhante a ameixa.

\section{USOS MEDICINAES}

A raiz é refrigerante, e empregada nas febres inflammatorias.

Orecella ou Urzella. (Rocella Tinctoria.)-E' planta do interior, que vegeta principalmente nas margens do lago de 
S. José, perto de Obidos, e outros logares do grande rio Amazonas.

\section{USOS MEDICINAES}

o seu cozimento é emoliente e peitoral.

USOS NA INDUSTRIA

D'esta planta se extrahe uma tinta côr de azinhavre, propria para a tinturaria.

Quanta riqueza se perde n'este abençoado Brasil, por falta de industria!

Orelha de Gato. (Hypericum connatum.)-E' planta que vegeta em terrenos humidos, e floresce em Dezembro e Fevereiro

\section{USOS MEDICINAES}

o cozimento feito com esta planta, tomado em gargarejos, serve para curar as dôres de garganta, e anginas.

Orelha do Onça. (Cissampelos ovatifolia.)-E' a orelha de onça, um pequeno arbusto, que nasce no interior de Brasil. Em Minas Geraes, e na Provincia de Goyaz é este arbusto muito conhecido.

\section{USOS MEDICINAES}

o povo serve-se do cozimento d'esta planta, para combater os defluxos do peito, dôres pelo ventre, as febres intermittentes e as malignas; e servem-sa com preferencia da raiz, e lhe dão muita estimação, por sua efficacia medicinal.

Orelha de páu alaranjada ou Urupé pironga. - E' um cogumello circular, de côr alaranjada, que se encontra nos campos.

\section{USOS MEDICINAES}

0 Dr. Lacerda fez com este cogumello experiencias em si, e o recommenda tomado em infusão, na quantidade de meia á uma onça, para combater as febres inflammatorias, as molestias do figado, as perturbacões da caleca, as gastrites, e as constipações.

O sumo applicado sobre as escrophulas as cura.

Ortelã cheirosa ou da horta. (Mentha crispa.) -E' planta geralmente conhecida, e usada nas cozinhas. 


\section{USOS MEDICINAES}

A infusão da ortelã conforta o cerebro, o coração, o estomago, expelle os flatos, e desperta o appetite. O sumo desfeito em agua, provoca os menstruos e o parto. Mata os vermes intestinaes, e para isto usa-se interna em cozimento, e externamente em fórma de emplastro, sobre o umbigo.

Orucurana.-Arvore de 60 á 100 palmos de altura, com 2 e mais de diametro: floresce em Novembro.

USOS MEDICINAES

Não são conhecidos.

USOS NAS ARTES

o lenho d'esta arvore, é empregado em construcção, rodas d'agua, e para a carpintaria.

Orvaeza.-Arvore das mattas da Bahia de 40 palmos de altura, e 2 de diametro, conhecida dos derrubadores : floresce em setembro.

USOS MEDICINAES

Não são conhecidos.

USOS NAS ARTES

O lenho d'esta arvore, é macio no serrar e lavrar, e serve para as obras de carpintaria.

Ouricuri, ou licori, ou baba de boi.-E' um coqueiro mui conhecido e vulgar.

\section{USOS MEDICINAES}

o palmito da baba de boi, é excellente contra o veneno das cobras.

\section{USOS NA INDUSTRIA}

A amendoa do coco, dá azeite mui claro, e preferivel ao azeite doce, para os usos culinarios. Usado nas luzes, não desenvolve fumaça.

Ouyrarema. (Acacia oyraremas.)-E' arvore do Amazonas, pertencente á familia das leguminosas. 


\section{USOS MEDICINAES}

Não tenho noticia dos prestimos medicinaes d'esta leguminosa. e por isso não lembro-lhe as virtudes.

\section{P}

Pacar-i.-E' planta do Pará, cuja raiz é amarga, e medicinal.

\section{USOS MEDICINAES}

A raiz d'esta planta, é reputada um medicamento infallivel para combater as febres. E' tonica, e util na colica flatulenta. Tem-se experimentado ser um poderoso remedio, para deter os progressos da morphea, uzando-se em cozimento, por bebida ordinaria, na dóse de meia onça, para cada libra de agua, e ao mesmo tempo, tomando-se banho do cozimento da planta. A raiz da pacari é contra o veneno da cobra cascavel.

Pacavira.- Planta mui conhecida nas Alagôas, Bahia, e Pernambuco, que regeta nos logares humidos.

\section{USOS MEDICINAES}

Não são conhecidos.

USOS NA IXIDUSTRIA

Com as folhas da pacavira, embrulhão os camponezes os differentes objectos, que conduzem ao mercado.

Pajorá ou Paiorá. (Pará.)-E' planta do Pará, e Maranhão.

\section{USOS MEDICINAES}

o Dr. Lacerda affirma, que as sementes d'esta planta, pisadas, postas em agua, e bebidas, curam a diarrhéa de sangue.

Palnatoria. (Castus oprentia.)-E' uma planta dos agrestes e sertões do Brasil, mui conhecida mesmo no Rio de Janeiro, pela sua configuração. Floresce e fructifica. 


\section{USOS MEDICINAES}

o fructo de um vermelho purpurino come-se; e é refrigerante, e diuretico.

Palmeira. (Palmo.)-E' uma elegante arvore mui conhecida em todo o Brasil, da qual ha cerca de duzentas esperies, e todas tão prestimosas, que d'ellas nada se perde. Ha uma observação á fazer e é, que todas as palmeiras sangradas, deitam um licor, que fermenta, e de que os indios usam por bebida espirituosa, e de que a industria póde fazer vinho e licores. De algumas palmeiras, mencionarei os nomes e os prestimos que têm.

Palmeira côco de Airiri-Serve para carapeta, bilros' fuzos, botões, bodoques. o fructo come-se.

Palmeira côco cabelludo.-E' o fructo comestivel.

Palmeira còco de catarrho, ou Macahuba.-E' comestivel o fructo.

Palmeira coco da India ou da Bahia.-Tem de 40 á 100 palmos de altura, com 2 de diametro.

D'esta palmeira tudo se aproveita para diversos usos.

As fibras da casca servem para cordoaria, e para escovas; a palma e o tronco servem para diversos usos; o fructo contém agua clara e refrigerante; a amendoa come-se, e se emprega em differentes guisados, para as mesas, confeitarias, e dá azeite, para luzes, e para comida. O casco da fructa serve para diversos usos, sendo a principal o de tirar agua nas talhas e potes.

Palmeira côco de Dendé. - Serve o azeite para luzes, para o preparo do sabão, e para tempero de diversos guisados.

Palmeira còco de Giraha.-Tem o mesmo uso, que o côco de catarrho ou macahuba.

Palmeira coco de Goriri._Esta palmeira, vegeta pelas restingas das praias; come-se os fructos, que são cheirosos.

Palmeira coco de Indaid.- Tem 20 a 25 palmos de altura: servem as suas hastes, para ponteiros de gaiolas, e as folhas ou palmas são procuradas para as festas do Domingo de Ramos, em memoria do martyrio de Christo 
Palmeira coco de Indaiassi._Esta palmeira, é maior que a precedente. Servem os palmitos, ou grêlos, para comer-se; e do côco se extrahe azeite para luzes.

Palmeira coco Isára.-O seu lenho, serve para ripas; o fructo comem os passaros, e o grêlo fornece os melhores palmitos, para os diversos guisados das mezas.

Palmeira coco de Patigabiraba. - A haste serve para fazer-se bicas de agua, e comem os porcos do matto os fructos que dá.

Palmeira Jussaia.-Esta palmeira tem de 25 á 30 palmos de altura, com meio de diametro. Do tronco batido, se formam cabos para arrastar as madeiras nas mattas, sendo esses cabos mais fortes que os preparados com o linho canhamo. o grêlo, que é amargo, fornece excellente palmito para as comidas.

Palmeira Oricury.-Esta palmeira vulgar, fornece palha, para crenas das embarcações, confecção de esteiras, e chapéos, e o tronco para estiva das estribarias de ani maes.

Palmeira Paty.-Esta palmeira serve para ripas, e se é cortada em tempo, tem grande duração.

Palmeira Piassaba-Esta palmeira, floresce em Julho; e fornece a materia prima, para o fabrico de amarras e cabos; a palha sorve para a crena das embircações. Os talos servem para cercados ou armadilhas em que o peixe entra (gambôas), e não póde sahir. O coquilho serve para butões e outros objectos de uso, e da noz se extrahe azeite para luzes.

Palmeira Tapity.- Tem esta palmeira 40 palmos de altura. A piassaba, que fornece, serve para cabos; e a amendoa do fructo, dá azeite para luzes.

Palmeira Ticum ou Tucum. - o tronco d'esta palmeira, é delgado e espinhoso. Das fibras das folhas, extrahe-se linho lustroso, como seda, sem signaes de arestas, rijo, o qual todo se co.ısome no trafico das rèdes de pescaria. Do côco se extrahe azeite para luzes. 
Palmeira coco Carnauba.-Vide adiante a mesma Palmeira.

Palmeira coco Cotolé.-E' uma palmeira preciosa, por seus prestimos nas artes e na industria. E oriunda das Alagôas.

Palmeira Purunam.-Esta grande palmeira, é particular das Alizgôas.

Dá côcos com pôlpa saborosa. A amendoa fornece azeite finissimo, que póde-se empregar na relojoaria.

Paimeira carmauba. (Arrudaria cerifera.) - Esta palmeira é muito commum na provincia do Ceará, Parahyba e Rio Grande do Norte, muitissimo util, podendo-se com ella fazer uma casa, sem empregar nenhum outro material, mais que o barro. o seu typo é rijissimo, e serve para tirantes e ripas. A copa da arvore é pequena, folhas em forma de leque fechado, servem para cobrir as casas; como tambem para o tecido de esteiras, chapéos, etc. As folhas são sadio sustento do gado vaccum, em tempo da maior secca. Emquanto é nova, o amargo é tenso, e dá-se aos animaes, em falta de outro alimento. Ainda se extrahe, da palmeira carnauba, uma especie de farinha, que é um recurso alimenticio que tem o povo, em tempo de fome. Nas folhas do olho, cria-se um pó glutinoso, em pequena quantidade, que por meio do calor do fogo, põem-se na consistencia de cera, da qual tem o cheiro.

o fructo, em cacho, de cor negra, é bom alimento. Com o caroço, que contém a amendoa, fazem-se botões; e da madeira, se fazem lindas bengalas, que, depois de polidas e envernizadas, parecem salpicadas de marchetaria. Esta palmeira foi bem estudada pelo Dr. Arruda da Camara.

Pango. on Diandba, ou Iiamba ou Fumo da Ingola. ou atchi dos Indios. (Cannambis sativa indica.)-Esta planta Asiatica foi transplantada para 0 Brasil. Os africanos a cultivam.

\section{USOS MEDICINAES}

A homœopathia serve-se do Pango ou Cannabis sativa para curar a catarata, a amaurose, a asthma, o catarrho da bexiga, a gonorrhéa, a impotencia, as dores dos rins, a retenção das ourinas e os espasmos. 


\section{USOS SOCIAES}

Os indios preparam com o succo l'esta p'anta, uma bebida embriagante, para terem sonhos agradaveis; e o mesmo fazem os africanos, pitando as folhas seccas no cachimbo.

Páo d'Alno. (catraeva tapia.)-E' uma grande arvore, cuja casca e folhas tèm o mesmo cheiro e sabor do alho, e em gráo mais forte, sendo a sua essencia melhor que o alho, e até a preferem para tempero da comida.

Para conseguir-se extrahir boa essencia, deve ser no mesmo dia, que se tira a casca da arvore, pisada e mettida no alambique para distillal-a; porque fermentzndo, fica com o cheiro do alho tão forte, que se não póde supportar.

USOS MEDICINAES

Serve para matar os vermes intestinaes, e para curar as henorrhoidas, que atacam a cabeça.

USOS CULINARIOS

Os matutos servem-se das folhas do páo d'alho, para tempero das comidas, e para afugentar as cobras.

USOS NA INUUSTR IA

As cinzas d'esta arvore dá boa decoada, para a preparação do sahão, e alvejar o assucar.

Páo Amapá. (Parí). - E' arvore do grande valle do Amazonas, que, incisada a casca, deixa correr leite medicinal.

USOS MEDICINAES

o leite d'esta arvore, misturado com pedra lips, embebido em algodão, e posto sobre as boubas, as. cura.

Páo d’arco on Ipé, (Bigonia chrisantha.) - 0 páo d'arco, é uma bonita arvore das nossas florestas. Ha duas qualidades; uma de flores roxas, e outra de flores amarellas. Seu lenho é mui rijo, e se presta ao polimento.

\section{USOS MEDICINAES}

0 cozimento da casca é anti-syphilitico, e serve para combater as inchações geraes, e dores rheumaticas. Tomado em chá serve 
para destruir o vicio syphilitico. Tem as mesmas virtudes do páo santo ou guayaco. O cozimento serve para curar as ulceras velhas.

USOS NAS ARTES

o lenho d'esta arvore é empregado em obras de duração, como eixos de carro, moendas de engenho e obras de casas. Os marcineiros empregam-no tambem em mobilias, e obras de ornatos.

Páo d'arco mijão. - Arvore de grande altura das mattas do Brasil : floresce em Outubro.

USOS MEDICINAES

Não são conhecidos.

USOS NAS ARTES

o seu lenho serve para a architectura civil.

Páo d'arco da moda.-E' uma grande arvore, das nossas florestas; varia na côr esbranquiçada. E' menos procurada, que as outras arvores do mesmo nome.

USOS MEDICINAES

Não são conhecidos.

USOS NAS ARTES

O seu lenho serve para construcção civil e naval.

Páo d'arco preto.-E' arvore de mais de 100 palmos de altura, com 6 á 24 de diametro: floresce em Dezembro, com flores carmezim claro.

USOS MEDICINAES

o seu lenho serve para moendas de engenho, cavilhas, varaes de carros, vigotas, obras de casas e outras construcções.

Páo balla. (Trichilia guara.)-E' uma planta leitosa, cujo succo é um violento purgante, e vomitivo. 0 cozimento feito com ella, não tem a mesma força.

USOS MEDICINAES

o poro serve-se d'esta planta, para purgar os enfermos de obstrucções do figado e baço.

Páo balsamo. (Toluifera balsamum.)-Esta arvore da mesma familia das leguminosas, que vegeta nas nossas mattas, e 
no Amazonas, distilla uma resina liquida, de aroma suave, que se apara em vasilhas, e que depois se congela, tomando a côr loura: é o verdadeiro balsamo conhecido na Europa por Balsamo de Tolú, Balsamo de S. Thomaz, e Balsamo de Carthagena.

\section{USOS MEDICINAES}

o seu emprego, é para combater os catarrhos pulmonares, em xarope, ou reduzido a pastilhas. Consolida as feridas, e internamente serve para a asthma.

Páo balsamo. (Myroxilum peruiferum.)-E' esta bella arvore brasileira, de 80 á 100 e mais palmos de altura, de 2 á 8 de diametro, de casca lisa, grossa e pertencente a familia das leguminosas, a mesma que distilla o Balsamo Peruviano, de flores brancas, sendo o seu fructo uma vagem fusiforme, contendo uma ou duas sementes. Da sua casca, ferida na lua cheia de Fevereiro e Março, distilla o Balsamo chamado Peruviano, de cheiro agradavel.

\section{USOS MEDICINAES}

Serve para unguentos, e tambem é empregado ás vezes nas molestias do peito. Consolida as feridas; conforta os nervos; serve para o rheumatismo. Internamente aproveita na asthma; fortifica o cerebro, e desobstrue o mesenterio.

\section{USOS NAS ARTES}

o seu lenho serve para obras de ornatos. Assemelha-se ao mogno.

Páo Brasil, ou Ibirapitanga dos Indios. (Coesalpina brasiliensis.)-Arvore de 60 e mais palmos, de 2 á 4 de diametro, ornada de curtos espinhos. Floresce em Dezembro, com flores arramalhetadas de côr de carmim. Ha tres qualidades d'esta arvore; mirim, assí e brasilete.

\section{USOS MEDICINAES}

E' especifico remedio, contra a asthma. 'E' anti-syphilitico, e promove a transpiraçĩo.

\section{USOS NAS ARTES}

o seu lenho na carpintaria serve para diversas obras, e para a marchetaria. 
USOS NA INDUSTRIA

Săo mui conhecidos os seus prestimos na tinturaria.

Páo campeche. (Hematoxylum.)-E' uma bonita arvore, da familia das leguminosas, que folga nas mattas do Pará, de flores amarellas, e aromaticas.

USOS MEDICINAES

A casca da raiz, que é adstringente, emprega se em clyster contra as diarrhèas.

USOS NAS ARTES

O cerne ou amago, serve para obras de marcenaria.

USOS NA INDUSTRIA

Do lenho d'esta arvore se extrahe tinta roxa, que se torna preta, mui estimada em tinturaria.

Páo cardozo. (Polypodium pungens.)-E' planta conhecida nas Alagôas e Pernamkuco, semelhante a uma palmeira pequena.

\section{USOS MEDICINAES}

A medulla d'esta planta, serve para curar a asthma, a tosse convulsa, os catarrhos pulmonares, e as bronchites agudas ou chronicas.

Páo de canne. (Casearea usucaris.)-E' um arbusto, ou antes é uma arvore pequena mui conhecida e vulgar nas, Alagôas, em Pernambuco, e em Sergipe.

\section{USOS MEDICINAES}

A casca d'esta planta, é purgativa, e contra o mal venereo. 0 cozimento das folhas, cura as febres intermittentes.

A raiz é purgativa, e.um porleroso medicamento contra a syphilis.

Pacova catinga. (Parí.)-E' uma palmeira pequena, que floresce e fructifica.

USOS MEDICINAES

Não são conhecidos. 
USOS NA INDUSTRIA

Do fructo d'esta planta, se extrahe uma excellente tinta violeta, propria para a tinturaria.

I cio cavalio ou Maria pieta da campina. (Vitex nigrum.)-E' arvore do paiz, pertencente á familia das verbenaceas, que floresce, e dá fructo como ameixa.

\section{USOS MEDICIYAES}

Năo săo conhecidos.

USOS NAS ARTES

O seu lezho serve para as obras de carpintaria, e para portadas de casas.

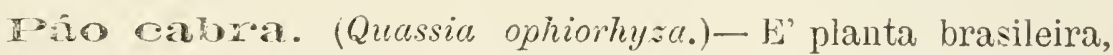
amargosa, e mucillaginosa, pertentente i familia das rutaceas.

\section{LSOS MEDICINIES}

A raiz d'esta plinta, que é amaroa, serve para combater as febres, diarrheas chronicas, e a asthma, tomada em cozimento ou infusão.

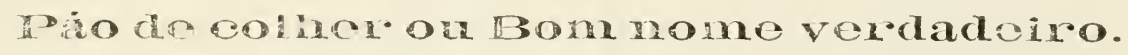
(Elcuedendron cauliflorum) - Arvore que folga nos terrenos seccos, e dá fructo. Conta um viajante dos nossos sertões, em un seu manuscripto, que tenho á vista, que quando esta arvore está verde, apresenta manchas de varias, còres e agradaveis; depois de secca, en tempo de chuva, de noite, desenvolve uma luz phospliorecente, que illumina í grande distancia: o mesmo acontece em casa escura. A luz, que desenrolve, é semelhante á do vagalume ou pyrilampo. Diz, que separou uma porç̃̃o d'esta luz, e apertando em um papel, ficou este, como um facho. A luz procele de certa cinza, de que é coberto o lenho. De dia lesapparece a claridade, e tambem de noite, havendo outra luz, que a ofusque. Exposta a cinza ao ar, e sem resguardo illumina; e lepois de tirarla do tronco; perde a phosphorescencia.

\section{USOS MEDICINAES}

o cozimento da entrecasca, que é adstringente, serve para curar feridas velhas. 


\section{USOS NAS ARTES}

A industria póde tirar proveito, se estudar e experimentar as propriedades d'esta arvore.

Páo do collher. (Tabernomontana e chinata.)-Planta leitosa, de folhas aromaticas. pertencente á familia das apocineas.

\section{USOS MEDICINAES}

O Dr. Lacerda recommenda o leite d'esta planta, para curar as rupturas ou hernias, posto sobre a hernía, e sobre elle, sangue de Drago em pó, e sobre este, cupim em pó, e por cima de tudo, uma pasta de algodão.

Dizem que o chá d'esta planta, é proveitoso para curar as febres; porém convém ter muita cautella com a planta, que é venenosa.

Páo cruz.-E’ um vegetal conhecido pelos hervanarios. USOS MEDICINAES

o seu cozimento dado em banhos, cura as hemorrhoidas.

Pá ferpo on Itú ou Quiripininga. (Arana Brasilieneis.)-E' uma grande e robusta arvore, de forma pyramidal, pertencente á familia das leguminosas, que folga em qualquer terreno, e se cobre de fructos, de Setembro á Outubro. D'ella se tira bôa tinta de escrever, podendo sem a menor' differença substituir a noz de gallha.

\section{USOS MEDICINAES}

A casca é anti-syphilitica, cura a gôtta, o rheumatismo, e as escrophulas, chagas velhas, purifica o sangue, promove a transpiração, e suspende o curso do ventre.

\section{USOS NAS ARTES}

O seu lenho roxo, é mui rijo, e serve para obras de edificios, para pontes, e é de tanta duração, que cada esteio, equivale a um pilar.

Páo goeremú. (Spinacia Geremii).-- Arvore das mattas das Alagôas, de casca avermelhada, cujo fructo é dotamanho de uma mangaba. 


\section{USOS MEDICINAES}

Não são conhecidos.

USOS NAS ARTES

O seu lenho é forte, e por isso é empregado em architectura civil.

I'io mangelioba ou pajamangiroba ou fedegoso.-E' planta conhecida em todo o Norte do Brasil, e particularmente nas Alagoas.

\section{USOS MEDICINAES}

O cozimento d'esta planta, é empregado para curar as febres malignas; a retenção de ourinas ; a dysenteria; as vomicas do peito; contra a embriaguez da manipoeira (çumo da mandioca); contra as empigens, e bexigas.

O sumo da planta com leite, cura a inflammação dos olhos. A raiz d'esta planta, é a parte mais prestimosa.

As sementes torradas, e feito café, são mui convenientes aos que padecem do estomago, e do figado.

14o de moquin. - Este vegetal de folhas verdes, tem um cheiro particular, que augmenta esfregando-se, é de sabor amargo.

\section{USOS MEDICINAES}

E' o melhor consolidante que se conhece, para cicatrizar de prompto os golpes, e estocadas. Dão a beber o sumo das folhas verdes, se emjejum melhor, ao ferido; e externamente applicam o mesmo sumo, na parte offendida.

Páo ou ar.voro do papol. (Lasiandra popyrifera.)-

Este vegetal nasce nas provincias de Minas, Goyaz e Matto Grosso, e se crê ser o verdadeiro Papyrus dos antigos, porque d'elle tiram folhas tão delgadas e alvas, quie parecem folhas de papel de escrever. O engenheiro Franco de Almeida, na sua memoria sobre a provincia de Matto Grosso, faz menção desta preciosa e util planta.

Páo parahyba. ( Simaruba parahyba).-E' arvore de 50 palmos de altura, com 2 de diametro, que vegeta em quas 
todo o Brasil. E' arvore mui conhecida dos derrubadores. Sua madeira é mui leve.

\section{USOS MEDICINAES}

E' eficaz contra as mordeduras das cobras. A raiz é vomitiva e applicam-na contra a epylepsia e a paralysia. A casca, dizem ser um poderoso anthelmintico.

\section{USOS NAS ARTES}

o seu lenho serve para forro de salla, pela sua alvura.

USOS NA INDUSTRIA

A madeira por ser mui leve, é empregada no fabrico de tamancos.

Páo pereira ou páo de pente, ou páo forquilha ou camaré de bilro, ou camará do matro, ou canudo amargoso, ou pinguaciba. (Gessospermum.)-E' arvore descripta pelo nosso famoso botanico o conselheiro Freire Allemão Sisneiro, que cresce além de 340 metros, a produz em qualquer terreno. Floresce e fructifica, mas nenhum animal come-lhe as folhas, pelo terrivel amargo que tem.

\section{USOS MEDICINAES}

E' empregada como febrifuga. Com o seu cozimento, os sertanejos lavam os animaes atacados de piolhos, e carrapatos; e se suppõe que é o vegetal mais amargo, que se conhece.

O cozimento da casca, é contra veneno da cobra cascavel, e disse Joaquim da Rocha Guedes, morador na Palmeira dos Indios (Provincia das Alagôas), que sendo mordido de uma cascavel, e fica:ıdo cego, logo que bebeu o cozimento da entrecasca do Páo Pereira, recobrou a vista.

Os a:imaes que comem, por acaso, as folhas d'esta arvore ficam doentes, ou empereirados, e se lhes dĩo milho á comerer, como antidoto do mal, ficam bons.

Páo pòdro:-E' uma planta da familia das euphorbiaceas, conhecida em Minas Geraes, cujos fructos se parecem com o do carrapateiro ou mamoneira. 
USOS MEDICINAES

As amendoas são purgativas.

USOS NA INDUSTRIA

As amendoas do fruto, dão bom oleo para luzes, e para a fabricação do sabão.

Páo pormbo. (Odina Francoana.)-Arvore de 40 palmos de altura, e de 1 á 2 de diametro. Floresce e fructifica. E' abundante em todo o Brasil.

USOS MEDICINAES

Não são conhecidos.

\section{USOS NAS ARTES}

Serve o seu lenho, para obras de casas, e para cabos de machados.

Páo preto ou Maria preta.-Arvore das mattas das Alagôas, e dos sertões. Pelo verão se conserva sempre coberta de folhas e fructos, embora não hajam chuvas. seu lenho é mui riju, e proprio para construcções de obras de grande duração.

\section{USOS MEDICINAES}

Da sua entrecasca se faz extracto com que curam as que braduras, applicando-o sobre as rupturas.

o coziouento serve para lavar as feridas chronicas, e promover-lhes a cicatrisaç̃o.

Páo sanzue.- Arvore corpulenta das mattas do Brasil. Apenas é ferida a casca, por qualquer instrumento cortante, deita um liquido ou seiva de côr tão purpurina, que parece sarıue de animal.

\section{USOS MEDICINAES}

o extracto da sua entrecasca, é remedio conhecido, para curar as rupturas internas e externas.

Páo do Santa Luzia. (Dalbergia.)-Esta planta pertencente á familia das leguminosas, produz uma noz de côr purpurina, embebida de uma substancia resinosa.

\section{USOS MEDICINAES}

Não são conhecidos. 


\section{USOS NA INDUSTRIA}

A massa da noz arde com luz brilante, e a industria póde tirar d'essa massa muito proveito, para a illuminação particular.

Táo Santo. (Mahurea spicioca.)-E' arvore de 50 á 60 palmos de altura, com 2 de diametro. Floresce em cachos amarellos.

\section{USOS MEDICINAES}

Não são conhecidos.

\section{USOS NAS ARTES}

O lenho d'esta arrore, que é vermelho e duro, serve para as obras de marcenaria.

Páo Sassarraz, ou Louro Sassarraz. (Laurus sassafraz)-E' arvore muito vulgar nas Alagôas, pertencente á familia das laurinaceas. Em Naceió, eu vi, algumas arvores do louro sassafraz, e d'ellas me utilisei, no uso medico.

\section{USOS MEDICINAES}

Toda a arvore tem prestimos medicinaes. E' sudorifica, antivenerea, e contra o rheumatismo.

Páo serrote ox páo pedra. (Offmanuseggia preta.)-E' arvore frondosa, de folhas lustrosas, e flores de um branco amarellado escuro. A fumaça da madeira d'esta arvore, cega em pouco tempo,

\section{USOS MEDICINAES}

Não são conhecidos.

Páo sotim.- E' arvore do Pará, cujo lenho é mui precioso, pela sua côr, e bonita distribuição de seu tecido. O piquía maifim, parece ser uma variedade de páo setim, por confundir-se com elle.

\section{USOS MEDICINAES}

Não ล̃o conhecidos.

USOS NAS ARTES

Serve para as obras de marcenaria, e para a marchetaria. 
Páo terras grandes. (Gualea grandiflora.)-E' arvore brasileira, de flores grandes, resinosas.

usos MEDICINAES

Não são conhecidos.

ISOS DA INDUSTRIA

D'esta arvore se extrahe bella tinta amarella, propria para a tinturaria.

Páo terras poruenas. (Gualea grandiflora.)- E' arvore menor, é d'ella se extrahe tinta preciosa para a tinturaria.

Páo de 'Tinsini. (Mogonia pubescense.)-E' arbusto silvestre, que floresce em Agosto e Setembro.

$$
\text { LSOS MEDICINAES }
$$

Não são conhecidas.

USOS NA IXDUSTRIA

Serve para embebedar o peixe. D'esta planta se extrahe tinta propria para a tinturaria.

Páo unar'y.-E' arvore leitosa, com propriedades medicinaes.

\section{USOS MEDICINAES}

O leite que se extrahe d'esta arvore, dissolvido em tres colheres de agua morna, proṽoca o vomito, e faz purgar. .

O succo da entrecasca diluido em agua morna, cura a inflammação dos olhos.

Papo de perí. (Aristolochia cumbifera.)-E' uma planta trepadeira, pertencente á familia dos aristolochias, mu conhecida nas Alagôas, cujas flores são semelhantes a um papo de perú, todo salpicado de pequenas manchas pardacentas.

\section{USOS MEDICINAES}

As flores d'esta planta, é resolutiva em alto gráo. Affirma-se que as fumigações, dadas com elias, no sarcocele, o resolve perfeitamente. Convém experimentar o mesmo processo no hydrocele, á ver se se obtem o mesmo resultado.

o cozımento d'esta planta, previne a putrefaccão. 
A raiz é empregada para provocar os menstruos, facilitar as ourinas, e promover a transpiração. Cura as molestias uterinas, combate as febres malignas e perniciosas. O cozimento concen trado feito com toda a planta, cura as ulceras cancerosas dos pés.

Papoula. (Papaver somnifera.)-E' uma planta conhecida, por suas virtudes medicinaes. Há tres especies de papoulas, que se distinguem pela cor das flores, brancas outras encarnadas, e outras carmezim.

\section{USOS MEDICINAES}

E' adoçante, peitoral, facilita o escarro chronico, e o suor; modifica ou faz passar os accessos da asthma; concilía o somno. Cinco ou seis cabeças de papoulas fervidas em vinho, até se gastar a metade, fazem dormir quem as beber. A fomentação com as folhas da papoula, faz dormir. O cozimento da raiz, aproveita na schiat:ca, na inflammação do figado, e limpa as impuridades das ourinas.

Paracal-3. (Peltodons mudicans.)-Esta planta de flores aroxeadas, pertencente á familia das labiadas, é conhecida no Pará pelo nome de Paracairy, ou Hortelan brava; em Pernambuco pela denominação de Melladinha, nas Alagóas pelo de Mentrasto; e no Rio de Janeiro pelo nome de Herva de S. Joũo. Quando secca tem um aroma agradavel.

\section{USOS MEDICINAES}

o cozimento adoçado com assucar, é empregado para curar os catarrhos pulmonares, a tosse convulsa, e a asthma.

Externamente cura as molestias da pelle, como empigens. sarnas, e a tinha syphilitica. E' um poderosc medicamento contra - veneno das cobras, applicado interna e externamente; porque além de neutralisar a peçonha da serpente, tira as dores, e favorece a cicatrisação .

\section{USOS DOMESTICOS}

As follhas postas entre os vestidos, embebem-lhes um aroma agradavel, e os preservadas traças.

Pazatudo.--Arvore que folga nos terrenos fracos dos agrestes, e se encontra nos sertões do Orobó, provincia da Bahia. 


\section{USOS MEDICINAES}

A casca d'este vegetal, cozida, dá proveitoso licor, con que nos sertões curam as febres. E' de um amargo agradavel.

Paratudo ou eravo das Minas. (Canella alba.)E' uma arvore do interior do Brasil, pertencente á familia das Guttifteras.

\section{USOS MEDICINAES}

A raiz d'este vegetal está acreditada em todo o sertão, por um grande especifico, para curar as febres pôdres, e malignas ; usam não so nas febres, mas tambem para dissipar as colicas flatulentas. Servem se do pó, na dóse de um escropolo, até uma oitava, em agua morna. Usam igualmente da casca em infusão, para curar as febres; bem como em gargarêjos, para curar as ulceras velhas da garganta, e amygdalas (favos).

o Dr. Peckolt, fazendo a analyse d'esta planta, reconheceu que a casca aromatica do paratudo, tem effeito tonico, e estomachico; e em banhos, aproveita como fortificante

Paraturá. (Remirea maritima)-E' uma variedade do capim, que nasce nas beiradas dos terrenos paludosos, e visinhanças dos rios, ou d'agua salgada.

\section{USOS MEOICINAES}

A raiz, que é ligeiramente aronatica, e sudorifica, cura perfeitamente as gonorrhéas, tomada em cozimento.

Parica. (Pará.)-E' uma planta do Maranhão e Pará, cujas folhas são avermelhadas, e as flores esbranquiçadas.

\section{USOS MEDICINAES}

o cozimento feito com esta planta, serve para curar as dôres rheumaticas, tomado em banhos.

Parietaria. (Parietaria officinalis.)-Esta planta, que vive nas paredes velhas, é geralmente conhecida por seus prestimos em medicina domestica.

\section{USOS MEDICINAES}

o cozimento feito com esta planta ê diuretico, cura as irritaç̃es da membrana mucosa da bexiga, e em consequencia do 
principio nitrozo que possue, empregam-na, para combater as febres inflammatorias, e as ourinas leitosas.

Pariparoba oz caapeba ou Malvaisco. (Piper umbellatum.) - Esta jreciosa planta, é conhecida por esses no nes nas provincias do Brasil.

USOS MEDICINAES

E' estomachica, e desobstruente do figado.

Parity. (Lacerda.)-E' planta do Maranhão e do Pará. USOS MEDICINAES

o Dr. Lacerda, diz que a casca d'esta planta, dada em forma de chá, é preferivel á raiz da althea.

Parratucá. (Vide Arvore de Jasmim.) (Carlota adorata.)

USOS MEDICINAES

O cozimento da raiz é diuretico, e serve para combater as blenorrhagias. O leite, posto sobre os tumores brancos, os resolve.

Parreira brava ou abutua ou butua. (Cissampelas parreira.) (Vid. Abutua.) - Este vegetal conhecido no Brasi], por suas virtudes medicinaes, é uma trepadeira, de que o povo se serve, tanto da raiz que é amarga, como das folhas em medicina popular.

USOS MEDICINAES

Empregam a raiz para curar a hydropesia, a falta do menstruo, a suspensão dos lochios, com dores uterinas. O cozimento fortifica o estomago; promove a transpiração, facilita as ourinas, e combate as febres.

O succo das folhas, posto sobre a mordedura da cobra, e ao mesmo tempo dando ao mordido á beber o cozimento da raiz, cura, neutralisando o veneno.

Parreira do matto. (Securidaca florida.)-E' uma planta trepadeira conhecida nas Alagôas e Pernambuco, muito semelhante ao cipó caninana. 
USOS MEDICINAES

A raiz é emenagoga, e o povo usa mui frequentemente d'ella para regular a menstruação da mulher que padece.

Pataquira.-Planta do Pará.

\section{USOS MEDICINAES}

E' adstringente, e se a emprega em banhos no rheumatismo, nas inchações articulares, e nos enfartes das glandulas lymphaticas.

Patumujér ou putumujú.-Arvore das mattas das Bahia e Alagoas, de outras provincias, que floresce e fructifica. A madeira é amarella.

\section{USOS MEDICINAES}

Não sĩo conhecidos.

\section{LSOS NAS ARTES}

o lenho d'esta arvore serve para a marcenaria, e para a tanoaria, pelo compacto do seu tecido lenhoso.

Paupeira. (Vellosia.)-E' arvore do Pará e Amazonas; cujas flores são brancas.

\section{USOS NEDICINAES}

o cozimento da casca d'esta arvore, cura o scorbuto Ella foi experimentada pelo illustrado e muito conhecido medico mineiro Dr. Ildefonso Gomes, de saudosa memoria.

\section{USOS NAS ARTES}

O seu lenho é empregado na construcção naval.

Pé de gallinha. (Panicum dactylon.)-Chama-se assim a um capim mui conhecido, que nasce por toda a parte.

\section{USOS MEDICINAES}

o cozimento da raiz, é muito empregado, para os que soffrem de defluxo do peito; dores de dentes; e tambem mui resolutivo nas intumecencias inflammatorias. 0 povo serve-se igualmente do cozimento da raiz do capim $P \dot{e}$ de Gallinha, para prevenir o aborto, 
Pé de pato.-Esta arvore das Alagôas, produz uma noz, que ainda não foi estudada.

\section{USOS NAS ARTES}

O seu lenho é empregado na construcção civil.

Pocego ou pecegueiro. (Amygdalus persica.)Arvore pequena, de pouca duração, que produz fructos saborosos. $\mathrm{Ha}$ varias especies d'elles. O pecegueiro é planta Aziatica, e oriunda da Persia, que se aclimatou na Bahia, em Minas, Rio do Janeiro, S. Paulo, e no Rio Grande do Sul.

\section{USOS MEDICINAES}

As folhas e flores são purgativas. Com as flores se prepara um xarope purgativo, que se dá ás crianças.

USOS NA INDUSTRIA

Da amendoa do caroço se extrahe o acido prussico. Com a fructa faz-se doce.

Pecharim. (Laurus Pechurim.) - E' uma arvore de mediana grandeza, natural da America Meridional, e particularmente do Pará, Paraguay, Goyanna, e Venezuella, que dá um fructo conhecido pelo nome de Pechurim, ou Noz do Pará, do tamanho de um ôvo de pomba, mui aromatico. Foi analysado o fructo, pelo chimico francez $\mathrm{Mr}$. Bonastre.

\section{USOS MEDICINAES}

o pechurim é carminativo, cortra a colica flatulenta, a dyarrhéa, e dysenteria. E' febrifugo; e muito efficaz para curar as flores brancas, na dóse de uma oitava por dia. E' adstringente e tonico.

\section{LSOS NA INDUSTRIA}

E' empregado para aromatisar o rapé, e o chocolate.

Pega pinto.- E' planta conhecida do povo, e principalmente dos hervanarios.

\section{USOS MEDICINAES}

Pisada a planta, e posta sobre os tumores os amadurece em pouco tempo. 
Pepino de s. Gremorio. ou popino silvestre.-E' uma especie de pepino das hortas, que só se differença, em ser o fructo menor, e muito amargoso.

\section{USOS MEDICINAES}

O succo distillado, tira as dores dos ouvido A raiz pisada e posta sobre os tumores, os faz arrebentar; e misturado com terebenthina, os resolve. O cozimento da raiz, tira as dores de dentes. Ás folhas pisadas, são empregadas para curar a hydrophobia.

Pepino. (Cucumis sativa.)-E' o fructo mui conhecido de uma planta herbacea, que alastra como a melancia.

\section{USOS HEDICINAES}

E' refrigerante, e util aos incommodos da bexiga; tira o máo halito da kocca, e cura a inflammação dos olhos. O cheiro cura o desmaio: as folhas pisadas com vinho, curam a mordedura dos cães; e pisadas com sal, curam as sarnas. A raiz secca, e tomada na quantidade de uma oitava, faz vomitar.

O sumo, misturado com as sementes e farinha, posta a massa a seccar ao sol, e depois desfeita em agua, lavando-se o rosto, tira-lhe as nodoas. Com o sumo da fructa, se faz pomada muito procurada, para mitigar as dores hemorrhoidaes.

\section{USOS ALIMENTICIOS}

A salada de pepinos, é usada nas mesas, e procurada por' muitos, mas é indigesta aos estomagos fracos, e tem causado grandes males aos que têm feito uso da salada.

Pepiroca.-E' planta das provincias do Maranhão, e Pará.

O Dr. Lacerda a recommenda em medicina vulgar.

USOS MEDICINAES

O cozimento da raiz é febrifugo. O pove socea a raiz com vinagre, e esfrega o corpo do enfermo, e o abafa; ou quando não serve-se do cozimento em banhos, para curar as febres.

Poqui ou piqui. (Carjocar brasiliensis.)-E' uma al'vore gigantesca, das nossas florestas. Ha varias qualidades d'esta arvore:-amarella, vermelha, preta e carmim. 


\section{USOS MEDICINAES}

Não são conhecidas.

LSO NAS ARTES

O lenho d'estas arrores, serve para construcção naval.

Poquim.- Esta grande arrore, das florestas do Amazonas e de outros logares do Brasil, floresce e fructifica, sendo o seu fructo cozido comestivel.

\section{USOS MEDICINAES}

Não são conhecidos.

\section{USOS NAS ARTES}

O lenho serṿe para construcção naval.

USOS NA NDLSTRIA

A semente d'esta arrore dá sêbo alvo, e duro, proprio para a fabricação de relas.

Pexa ou peroina. (Pyrus sativa.)-E' arrore Europea, acclimatada no Brasit. Ha diversas qualidades.

\section{USOS NEDICINAES}

Não tem uso em medicina vulgar. O que a experiencia tem mostrado é, que a pera comida em jejum é nociva ao estomago, e produz colicas flatulentas, e arêas na bexiga. Cozida não faz mal algum.

USOS NA INDUSTRIA

Cum a fructa fazem doces.

Pexcoliana amnarella.-Esta arvore tem a mesma altura e diametro da pereirana branca, e só differe na côr, tendo os mesmos prestimos.

Pereir.ana branca.-Arvore brasileira de 30 á 40 palmos de altura, com 1 á 2 de diametro. Floresce em Agosto.

\section{USOS MEDICINAES}

Não são conhecidos.

\section{USOS NA INDUSTRIA}

A sua madeira serve para taboado de forro, para ripas e frechaes. 
1'oreis·ina.-E' planta do Maranhão e Parí.

\section{USOS MEDICINAES}

O Dr. Lacerda experientou o cozimento da casca d'esta planta em si, e reconheceu ser ella proveitosa nas febres, irritação intestinal, e nos padecimentos do figado.

Per-iaca.- Arvore das mattas do Brasil, de 40 palmos de altura, com 1 á 2 de diametro. Floresce em Setembro.

\section{USOS MEDICINAES}

Não săo conhecidos.

\section{LSOS NA IXDESTRIA}

O seu lenho serve para obras de construcçĩo civil.

Poripir.i. (Rhynchospor'c storea.) - O peripiri, é uma planta muito conhecida e vulgar nas Alagóas, e Pernambuco, pertencente a familia das cyperaceas, que regeta nos alagadiços, pantanos, e terrenos humidos.

USOS MEDICINAES

A planta secca e queimada, reduzida a pó, e misturada em agua assucarada, ou aguardente e agua estanca as hemorrhagias de sangue pela bocca. Posto o pó sobre uma arteria ofiendida, suspende a hemorrhagia. Dado o pó em aguardente, faz desapparecer a dysenteria.

LSOS NA INDESTRIA

Com o peripiri fabricam nas Alagòas, e Pernambuco esteiras para as camas, e mesmo suadores para sellas, e cangalhas.

Peroba.-Arrore de 60 e mais palmos de altura, com 2 e mais de diametro. Floresce em Setembro.

\section{USOS MEDICINAES}

Não são conhecidos.

USOS NidS ARTES

A sua madeira, serve para taboado de fundo das embarcações; - para o fabrico de camas de dormir, por ter esta madeira, a especial virtude de não receber percevejos. 
Ha outra varierlade de Peroba avermelhada, que serve para os mesmos usos.

Perperua ou Suspiros. (Gomphrena globulosa.)Arbusto muito vulgar nos jardins.

\section{USOS MEDICINAES}

o cozimento d'esta planta é muito uzado nos que padecen serração de peito, defluxão e tosse.

Pexuri amarello.-E' arvore de 80 palmos, com 2 á 6 de diametro; floresce em Outubro.

\section{USOS MEDICINAES}

Não s⿱艹\zh2o conhecidos.

\section{USOS NAS ARTES}

O seu lenho que é macio no trabalho, e pouco poroso, serve para obras de ornatos, marchetaria, e carpintaria.

\section{USOS NA INDUSTRIA}

A madeira fornece tinta amarella, propria para a tinturaria.

Ponuia doce. (Yasearia dulcis.)-Arvore das mattas da Bahia, de 50 palmos de altura, e de 2 á 4 de diametro. Floresce em Setembro e fructifica.

\section{USOS MEDICINAES}

O fructo d'esta arvore silvestre, é redondo e do tamanho de uma laranja, cheio de delicioso mel, contendo muitas sementes pretas. O mel da fructa, serve para as molestias do peito; e se póde conservar por um anno engarrafado, dando-se-lhe certo gráo de fervura.

\section{USOS NAS ARTES}

O lenho d'esta arvore, serve para obras de edificios.

'seâo. (Bidens bullatus.)-E' planta herbacea, muito conhecida do povo.

\section{USOS MEDICINAES}

O succo do picĩo, cura a ictericia, não havendo febre, e neminflammação aguda do figado. o cozimento da raiz, é preferivel, porque combate a febre. 
Picão da piaia. (Acanthospermim litoralis.)-0 picão da praia, é um arbusto muito vulgar no Rio de Janeiro.

USOS MEDICINAES

O cozimento d'esta planta, cura a erysipella, e as febres.

Pichuá ou picuí. (Euphorbia portulacoides.)-E' uma planta da familia das Euphorbiaceas, de uma actividade purgativa extraordinaria.

\section{USOS MEDICINAES}

Cinco ou seis pingos do succo d'esta planta, dentro de um pouco de caldo de gallinha bastão, para promover frequentes dijecções. (Vide Merart e De Lens. T. 3, pag. 188.)

Pigericum ou pimenta do sertão. (Xylopia sericea.)-Arvore dos agrestes, que dá fructos acres e aromaticos, proprios para especiaria, preferivel á rimenta da Jamaica. Esta pimenta, tambem é conhecida nas Alagôas, por Pimenta de Embira.

\section{USOS MEDICINAES}

Serve para as debilidades do estomago, e para as flatulencias intestinaes.

\section{LSOS CULINARIOS}

Como substancia estimulante e aromatica, pode servir para tempero de comidas. Convém que se cultive este vegetal, porque póde servir de um vantajoso ramo lucrativo de exportação.

Pimenta dagua ou Frerva de Bicho. (Polygonum antihemor'shoidale.) - A Pimenta d'ag'ua ou Herva de Bicho, é uma planta muito conhecida e vulgar, que nasce dentro d'agua doce, pelos brejos e logares humidos, de folhas compridas, delgadas, e que ardem como pimenta.

\section{USOS MEDICINAES}

Pisada a planta, e extrahido o succo, empregĩo-no em clysteres, aos enformos de febres malignas ou perniciosas, e mesmo para curar as febres intermittentes, causadas por emanações paludosas. O cozimento d'esta planta, tomado em forma de chá é um poderoso remedio contra a erysipella. Dado em clyster, 
é utilissimo para as hemorroidas. Foi esta planta que salrou os enfermos accommettidos da tremenda epidemia chamada $\mathrm{Zam}^{-}$ parini, que assolou o Rio de Janeiro, no governo do Vice-rei Luiz de Vasconcellos e Souza.

Pimenta da America. (Schinus mollis.)-Esta planta da America meridional, pertencente á familia das therebinthaceas, é descripta pelo Dr. Monard, memorando-lhe as virtudes medicinaes.

\section{USOS MEDICINAES}

A resina aromatica que d'ella se extrahe, é purgativa, e corroborante das gengivas.

A decocção das folhas e da casca, serve para curar as dôres rheumaticas. A resina dissolvida em leite, dessipa as nuvens e perturbação da vista.

Pimenta de cheiro. (Capsicum adoriferum.)-E' ai pimenteira de cheiro, um arbusto indigena do Brasil mui conhecido. Ha varias especies.

\section{USOS MEDICINAES}

o cozimento das folhas e da raiz, dado em.clyster, aproveita nas febres.

\section{USOS CULINARIOS}

A pimenta é empregada na cornida, principalmente nas de peixe.

\section{USOS NA INDUSTRIA}

Fazem d'ella conserva, de mistura com outras fructas, para uso das mesas.

Pimenta cumary ou cumarim. (Capsicum cumarim.)-A pimenta cumary, muito usada no Rio de Janeiro, é preferida as outras, por ser menos estimulante. A pimenta cumary vegeta em todo o Brasil.

USOS MEDICLNAES

0 cozimento das folhas, com algumas pimentas, dado em clyster, é mui proveitoso nas hemorroidas. Empregam-no tambem em gargarejos, para combater as anginas. 


\section{USOS CULINARIOS}

A pimenta serve a preparação do molho, para as mesas das familias fluminenses.

Pimonta da India ou pimenta nogra. (Piper nigrum.)-E' um arbusto trepador e mui conhecido por seus fructos, negros, denominados pimenta da India, ou do reino.

USOS MEDICINAES

E' a pimenta da India um poderoso estimulante, tonico e sudorifico. O cozimento tomado em bochechos, é mui proveitoso por combater a inflammação da bocca, e accelerar a supuração dos tumores, que apparecem na cavidade boccal.

USOS CULINARIOS

A pimenta da India tem muito emprego, na preparação alimenticia das familias brasileiras.

Pinonta dos Indios ou Aperta-ruão. (Piper unguiculatum.)-E' um arbusto, de hastes articuladas, de folhas semicordiformes, e flores em espigas roliças.

\section{USOS MEDICINAES}

o cozimento da raiz, é diuretico, mui usado contra as hydropesias, e para calmar as dores de dentes.

Pimonta Malagueta. (Capsicum baccatum.)-E' arbusto mui conhecido e vulgar, principalmente nas provincias do Norte do Brasil.

\section{USOS MEDICINAES}

o sumo das folhas bebido, cura a dôr de cabeça; e os olhos da pimenteira cozidos, e feito clyster, é bom remedio para curar as hemorrhoidas. E' anti-febril.

Uma pimenta esprimida dentro do canal fistuloso, do boubão, o consolida. Esprimida uma pimenta no olho, cuja inflammação é chronica, a desvanece. A tintura da pimenta malagueta, fo usada para curar o colera morbus.

USOS CULINARIOS

E' a pimenta malagueta, de grande estimação em todas as provincias do norte, para molho das comidas, e ha pessoas que 
nada comem, sem que haja o molho de pimenta malagueta. E, de todas as pimentas a mais sadia, apezar da grande ardencia que possue. O Dr Diniz, medico bahiano muito illustrado, dizia que o uso da pimenta malagueta, é mui conveniente para a promptiılão da digestão alimenticia.

Entra na confecção das conservas.

Pimentão. (Capsicum anuuum.)-o pimentão é mui conhecido no Brasil, e empregado em conservas para a mesa, e mesmo para adubar-se as comidas. Ha outras variedades de pimentões que as não menciono por thes não conhecer os prestimos.

Pindahyba ou acoita cavallo ou semente de embira.-Arvore de 40 á 60 palmos de altura, com 2 á 4 de diametro. Floresce em Junho, dando fructo aromatico e picante, de que se faz uso nas cozinhas. O fructo substitue perfertamente a pimenta do Malabar.

\section{LSOS DOMESTICOS}

Os fructos são empregados em forma de chá, para desvanecer as flatulencias intestinaes. Para o mesmo fim, trazem o fructo na bocca. 0 doce do fructo tira o fastio. 0 banho das folhas tomado pelos lombos das costas, produz o mesmo effeito.

\section{USOS NAS ARTES}

o lenho d'esta arvore, serve para mastros de lanchas, e balieiras, e outros usos semelhantes.

Pindoba. (Cocos australis.) - A pindoba é uma palmeira mui vulgar nas Alagôas, que floresce e fructifica. 0 fructo come-se, e o caroco contém uma amendoa oleosa, que dá azeite proprio para comer-se, e para a luz.

\section{USOS MEDICINAES}

o azeite que é emoliente, serve para abrandar as dores rheumaticas. O povo serve-se da amendoa em forma de orchata, contra a leucorrhéa, gonorrhéa, diarrhéa, e hemorrhagias.

\section{USOS CULINARIOS}

A palmeira pindoba, fornece bom palmito, para preparação de empadas, e para a sopa. 
USOS NA INDUSTRIA

As folhas servem nas Alagoas, ao fabrico das pitinbaias, com que pescam os camarões; e para tranças de esteiras e chapéos de palha.

Pinguim. (Bromelia pinguim.)-E' planta mui rasteira, pertencente á familia das bromeliaceas.

\section{USOS MEDICINAES}

Emprega-se o cozimento d'esta planta brasileira, contra os vermes intestinaes, e para desenvolver as ourinas.

Pinha ou queimadeira. (Cuidosculus.)-E' planta herbaceá, pertencente á familia das euphorbiaceas. Floresce e fructifica.

\section{USOS MEDICINAES}

As sementes são mui drasticas, e basta uma pimenta, para um purgante de um homem robusto.

Pinha ou ata. (Anonu squamosa.)-E' vegetal tão conhecido, que me dispensa descrevel-o. Floresce e fructifica, sendo os seus fructos mui apreciados. Dá em abundancia nos sertões da Bahia, e no Ceará.

\section{USOS MEDICINAES}

As folhas passadas pelo lume, curam as dores de cabeça. As sementes dizem ser venenosas.

Pinhão bravo ou pinhão de cerca. (Jatropha curcas.)-0 pinhão bravo, é uma planta indigena, que vegeta nos agrestcs sertões do Rrazil, pertencente á familia das euphorbiaceas; floresce e fructifica, tendo em toda a planta um succo leitoso medicinal.

USOS MEDICINAES

O succo leitoso do pinhão, posto sobre os golpes os cicatrisa logo. O oleo da fructa, é um poderoso medicamento purgativn, para curar a hydropesia, na quantidade de 6 até 18 gottas, posto em bebida emoliente.

A raiz deste Pinhão bravo, é poderoso remed o contra o veneno da cobra cascavel. Na Barra do Traipú (confluente do Rio de S Francisco, na provincia das Alagoas) atirando-se uma cascavel sobre um 
homem, este para se defender, jogou sobre a serpente uma vara de pinhão bravo, e a cobra mordendo-a, em poucos instantes morreu.

Pinhão de purga. (Iatropha curcas.) - Este vegetal è semelhante ao pinhão de cerca, mui conhecido, e vegeta em qualquer terreno.

\section{USOS MEDICINAES}

A seiva leitosa que distilla este vegetal, é o melhor vulnerario, e consolidante que se conhece, para curar os golpes, em qualquer parte do corpo, e tambem o panaricio.

A sua amendoa é um excellente vomitivo, de que usam as pessoas do campo, com preferencia ao tartaro emetico. Conforme a pessoa serve-se, de uma, duas e tres amendoas, para um vomitorio; e o seu effeito além de ser prompto, é suave.

Os sertanejos empregam com vantagem o pinhão, como emetico nas inflammações dos olhos; e dizem que se com este medicamento não fica logo bom o enfermo, a moletia se prolonga. Dão o primeiro vomitolio, e o repetem, no intervallo de 48 horas, de um á outro. Tainhem empregam o vomitorio do pinhão, para curar as febres intermittentes, e a apoplexia. O oleo é purgativo na dosé de 36 á 72 gottas.

\section{USOS NA INDUSTRIA}

Da ilha de S. Thomé ou dos Açores, se exporta grande quantidade de pinhão de purga para Marselha, para a fabricação de excellentes sabonetes, e oleos finos. O pinhĩo, que nasce espontaneamente, sendo cultivado, como merece, seria um ramo de commercio de exportação, para o lavrador brasileiro.

Pinho. - Arvore d 60 palmos de altura, com 6 á 12 de diametro. Cresce em grande copia, na comarca do Paranaguá.

\section{USOS MEDICINAES}

Não tem emprego em medicina vulgar.

$$
\text { USO NAS ARTES }
$$

O lenho é de excellente prestimo, e preferivel ás demais madeiras, para mastros das embarcaç̃es. Foi com o pinho de Paranaguá, que no governo do conde da Cunha, se mastreou a náo $D$. Sebastião, que se construio no Rio de Janeiro, e foi para Lisboa. 
Pinhohá.-Arvore de 60 á 100 palmos de altura, com $3 a ́$ 8 de diametro. Floresce em setembro, com lindas flores.

\section{USOS MEDICINAES}

Nãợ̆são conhecidos.

USOS NAS ARTES

O seu lenho serve para curvas dos navios, couçoeiras e vigas. Piolho. (Casearia parcifolia.)-E' arvore da provincia de Minas Geraes, que floresce em Abril e Maio.

\section{USOS MEDICINAES}

Não são conhecidos.

\section{USOS NAS ARTES}

O seu lenho, serve para construcção ciril.

Pinneiro ou pinhão do Brasil. (Araucaria brasiliana.)-Arrore que vegeta em S. Paulo, Minas Geraes, Paraná e Paraguay, floresce e fructifica, sendo o seu fructo comestivel.

\section{USOS MEDICINAES}

Não são conhecidos.

\section{USOS NAS ARTES}

A sua madeira que é branca e resinosa, semelhante ao pinho da Europa, serve para a mar'cenaria, e para construcção de casas.

$$
\text { USOS NA INDLSTRIA }
$$

Da resina misturada com cera, fabricam vellas para uso das familias.

Pipirioba.-Planta do Pará, rasteira, como o gengibre, e muito aromatica.

\section{USOS MEDICINAES}

Os indios servem-se d'esta planta, para fomentar o corpo, nas dores que lhe apparecem.

\section{USOS NA INDUSTRIA}

As mulheres se perfumam com esta rlanta, botando o pó nos cabellos. A perfumaria pode tirar d'ella excelllente aroma, para as suas confecções. 
Pequiã amare11o.-E' arvore do 80 palmos de altura, com 2 á 6 de diametro; floresce em Outubro. Seu lenho é macio ao lavrar, e serrar.

\section{USOS MEDICINAES}

Não são conhecidos.

USOS NAS ARTES

O lenho d'esta arvore serve para obras de ornatos de salla, marchetaria, e para a carpintaria.

Pequiá marfim.-E' arvore das mattas do Brazil, de uma rijeza admiravel.

USOS MEDICINAES

Não são conhecidos.

\section{USOS NAS ARTES}

O seu lenho emprega-se em todas as obras de construcção civid e maritima, e mesmo para obras de torno.

Piquiy.-Arvore das mattas da Bahia, que floresce e fructifica, sendo o seu fructo do tamanho de uma amendoa.

\section{USOS MEDICINAES}

Não são conhecidos.

\section{USOS NAS ARTES}

O seu lenho, serve para construcção civil.

\section{USOS NA INDUSTRIA}

Do caroço se extrahe sebo duro e alvissimo, com o qual se póde fazer vellas, para o uso domestico.

Piquy.-Arvore de grande elevação, de 150 palmos, com 20 de diametro. Floresce em Outubro e Novembro, com flores brancas amarelladas. Sangrando-se esta arvore, banha-se de um licor branco, e espirituoso, amargo, com que se mata o peixe nos rios. O fructo espinhoso contém uma doce amendoa, coberta de uma massa verde, de substancia da cera. A amendoa, e a capsula são reniformes. A seiva, a casca e o fructo d'esta arvore, não têm sido estudados. 
USOS NAS ARTES

O lenho serve para grandes peças de construcções de navios, e outras cousas.

Piranduba.- Arvore de 50 palmos de altura, com 2 de diametro. Floresce em Setembro.

USOS MEDICINAES

Não sâo conhecidos.

USOS NAS ARTES

O lenho d'esta arvore, serve para mastros de lanchas, e para obras de carpintaria.

Piranga ou chica dos Indios. (Bigonia chica.)

- Vegetal conhecido no Alto Amazonas, e kio Negro.

USOS MEDICINAES

Não são conhecidos.

USOS NA INDUSTRIA

Os indios extrahem d'esta planta, por meio da maceração, tinta vermelha, com que pintam o rosto.

Pixiqueti, ou chiqui xique, ou bananeira do matco our sororoca. (Canna glanca.)-E' planta do brejo, e logares humidos, semelhante a uma bananeira pequena, produzindo uma haste, que termina em flores vermelhas, e um casúlo cheio de sementes redondas; quando maduras ficam pretas. Nas Alagôas, é que chamam ao fructo d'esta planta Piriquity.

\section{USOS MEDICINAES}

o cozimento feito com a planta é mur util, em banhos, no rheumatismo agudo, ou chronico.

\section{USOS ALIMENTICIOS}

A batata ou raiz, come-se assada; e na grande secca de 1825, em Pernambuco e Alagôas, foi d'um grande soccorro, para os povos famintus dos sertões.

\section{USOS NA INDUSTRIA}

Com as sementes pretas e vermelhas, fabricam diversos enfeitos para adorno das mulheres. 
Pita ou gravati-assíx. (Agave Pitte.)-E' planta mui conhecida em todo o Brasil, por suas folhas largas, compridas e muito carnudas. Dí uma haste, que floresce e fructifica, e qua.ıdo cahe no chão se reproduz sem se plantar, sahindo o pendão do meio da planta.

\section{USOS FA INDUSTRIA}

o pendão da pita serve para afiadores de navalhas; e as folhas dão linho, para boas cordas, e para esfregadores de lavagem de casas.

Pitanga ou pitangreoira. (Myrtus brasiliana.)E' planta brasileira, que floresce em Março e Abril, de folhas agradavelmente aromaticas e balsamicas.

\section{USOS MEDICINAES}

O cozimento das folhas, em banhos, é utilissimo nas dores quer rheumaticas, gottosas, e quer venereas. O fructo é acido, refrigerante e calmante do sangue, tomado em limonadas.

\section{USOS NA INDUSTRIA}

Com a fructa (pitanga) faz-se doce de calda, e apreciada gelea, limonadas, e excellentes sorvetes gelados.

Pitambo. (Silva Lisboa.)-Arvore das mattas, de 20 palmos de altura, com 2 de diametro: floresce em Setembro. Dá um fructo de figura elyptica, de polpa branca gelatinosa, acida, adstringente e agradavel.

\section{USOS MEDICINAES}

Não são conhecidos.

USOS NAS ARTES

O lenho serve para construccão civil.

Pitombo do matto.-Arvore de 40 palmos de altura, com 1 á 3 de diametro: floresce em Setembro.

USOS MEDICINAES

Nũo são conhecidos.

USOS NAS ARTES

o seu lenho serve para frechaes. 
Pitombeira. (Sapindus esculentus.)-E' uma bonita ar. vore das Alagôas, que floresce de Fevereiro á Abril, e dá fructos contendo uma gelea doce e saborosa.

\section{USOS MEDICINAES}

0 caroço do fructo por sua grande adstringencia, é empregado para cura a diarrhéa chronica.

\section{USOS NAS ARTES}

A madeira serve para diversas obras de carpintaria, e marcenaria.

Poòjo. (Mentha pulegium.)-E' uma plinta mui conhecida, e cultivada nos jardins.

\section{USOS MEDICINAES}

o chá feito com o poejo, faz vir os menstros, e tira as dores uterinas.

Pójo da praia. (Centrospermum xantioides.)-E' este arbusto natural do Rio de Janeiro, vegeta pelas praias, e mesmo por outros logares.

\section{USOS MEDICINAES}

0 chá feito com as folhas da planta, é um corroborante do estomago.

Polipodio. (Polypodium vulyare.)-Esta planta nasce nos troncos das outras arvores. E' uma especie de feto.

\section{USOS MEDICINAES}

Cura a melancolia. Cozida a planta com gallinha, e bebido o caldo purga o ventre, Pisada e posta em forma de emplastro, sobre o membro deslocado o cura. o cozimento adoçado com assucar e bebido, cura a febre.

Popocé. (Dr. Lacerda.) - E' planta do Maranhão, descripta pelo Dr. Lacerda, no $2^{\circ}$ tomo do seu manuscripto, existente na Bibliotheca Publica do Rio de Janeiro.

\section{USOS MEDICINAES}

A infusĩo d'esta planta, é vigoroso remedio contra a syphilis Popunna. - E' arvore do Maranhão e Pará, que floresce e fructifica, sendo o seu fructo oleoso, demulcente e comestivel, 
estando maduro. Com a polpa do fructo e arroz em pó, faz-se um excellente mingáo, mui nutritivo, proprio para as pessoas sadias.

Praturá.-E' uma especie de gramma, que nasce nas praias

\section{USOS MEDICINAES}

o povo emprega o cozimento d'esta planta, para curar a inflammação do estomago, do figado e a dyarrhèa.

Na margem oriental das Alagôas, ha um logar com a denominação de Praturás, e creio que o nome lhe veio da presença d'esta graminea.

Primavera. (Ipomoea quamoclit.)-E' uma planta trepadeira da familia das convalvulaceas, e serve de ornamento dos jardins.

\section{USOS MEDICINAES}

As foihas seccas, fervidas em vinho, dizem que enxugam as humidades do cerebro.

Ha outra especie, a que chanam primavera de Cayenna (Ipomea coccinea) que serve para carramanchão de jardim.

Proacahi.-E' um vegetal brasileiro, conhecido dos hervanarios.

\section{USOS MEDICINAES}

O sumo da casca, é empregado contra o veneno da cobra.

Proacaxis de folha miuda.-E' um vegetal do Maranhão e Pará, estudado pelo Dr. Lacerda.

\section{USOS MEDICINAES}

A casca d'esta planta, é purgativa, e contra o veneno das cobras. Raspa-se ou piza-se a entrecasca, e desfeito o succo em agua, dá-se a beber ao mordido.

Puga. (Cissus antiparaliticus.)-E' uma planta trepadeira do Maranhão, e Pará, de raiz tuberosa, de que falla o Dr. Lacerda.

\section{USOS MEDICINAES}

As folhas de um sabor acre, pisadas, serve para o curativo da paralysia, e tetanos friccionando as partes com o sumo d'el'as. 
Puchiry ou pochurim. (Nectandra Puchury.)-E' arvore do Alto Amazonas, que produz uma grande noz, com duas amendoas. Ha duas especies d'esta arvore.

\section{USOS MEDICINAES}

A semente é um poderoso remedio contra a diarrhéa, a dysenteria, a leucorrhea, a colica e o cholera, tomado em pó, na dose de um escropulo, á uma oitava, dando-se á pessoa, em meia chicara d'agua tepida.

Puraqui.-E' uma planta do Pará.

\section{USOS MEDICINAES}

Os indios servem-se do chá d'esta planta, e mesmo em banhos, para suadores, no curativo das dores rheumaticas.

Purga do campo. (Echittes alexicaca.)-E' uma planta mui conhecida dos hervanarios, cuja raiz é purgativa.

USOS MEDICINAES

o povo nas provincias do norte, emprega a raiz d'esta Apocinea, como purgante, nos enfermos de ictericia, e nos engorgitamentos ou obstrucções das viceras abdominaes.

Purunan.-E' uma palmeira oriunda das Alagôas, muito menor que a cotoló; e dá grandes cachos, sendo os seus fructos maiores que o da palmeira cotolé. A maça polposa da fructa, é muito saborosa, e por isso muito apreciada pelo povo.

E' uma interessante palmeira, da qual a medicina, as artes, a industria, e o commercio pódem tirar muito proveito.

Putumujú. - E' uma das mais bellas e lindas arvores das nossas mattas, com 100 e mais palmos de altura, e 16 á 24 de diametro. Floresce em Agosto, com flores amarellas côr de ouro.

\section{USOS MEDICINAES}

Não são conhecidos.

\section{USOS NAS ARTES}

O lenho d'esta arvore, serve para cintado grosso de grandes navios, e outras obras de construcçào naval. o taboado é indestructivel, mesmo exposto á acção do tempo; elle iguala ao 
Tecke da Asia, e se une ao prego, não permittindo que se enferruge. Serve tambem para obras de ornatos, e para a architectura.

\section{Q}

Quassia de Cayonna. (Quassia amara.)-E' um arbusto vergonteado, que se entouceira, natural de Cayenna, de folhas em palmas, e de um verde roxeado, que se cultiva no Pará, e na Bahia, por ser medicinal.

USOS MEDICINAES

o cozimento da raiz d'esta'planta, é tonico energico, anti-febril e empregado contra a dispepsia, e contra os vomitos spasmodicos.

Quassia Paraense. (Vide Caferana).

Quassi simaruba.'(Simaruba officinalis.)-Arvore brasileira, que floresce e fructifica.

\section{USOS MEDICINAES}

E' tonica, aphrodisiaca, e anti-febril. Todas as partes d'esta utilissima arvore, são medicinaes.

Quaxinduba ou gameleira.-(Vide Gamelleira.)

Queimadeira ou louco ou Capomonga dos indios. (Plumbago scandens.) E' um arbusto conhecido em todas as provincias do Brasil, por suas propriedades causticas.

\section{USOS MEDICINAES}

Sobre esta planta já memorei as virtudes, e creio ser ella, que cura o cancro em Ceylão, por ser um forte cauterio. Pisada, e posta a massa, ou o succo do louco, sobre as manchas pretas da pelle, as destroe.

Quetim ou Tequim.-E' uma planta, semelhante na configuração a uma pequena bananeira, que dá fructo comestivel, em pequenos cachos. O caroço do fructo é redondo, negro, e mui rijo. Vegeta esta planta em abundancia, nos terrenos seccos, e roçados abandonados. 


\section{USOS MEDICINAES}

Arrancado o tronco com as folhas, pisado, e espremido o succo e dado a beber á quem levou pancadas, quedas, ou quaesquer contusões, e mesmo applicando-se em pannos ás partes offendidas, ou mesmo feridas, descoagula o sangue, quasi instantaneamente, podendo contar-se com a promptidão da cura.

\section{USOS NA INDUSTRIA}

Com o caroço fazem-se contas, e enfeites para adorno.

Quiabo ou Quingुombó. (Hibiscus esculentus.)-E' planta mui conhecida, e o seu fructo é um legume mui commum nas mesas das familias brasileiras.

\section{USOS MEDICINAES}

E' resolutivo, dos tumores, á que o povo chama alporcas. Misturado com o azeite de dendê, é emoliente e maturativo dos abcessos, applicado em fórma de emplastro.

Ha algumas variedades d'esta planta, com os mesmos usos e prestimos.

Quina. (Silva Lisboa).-Arvore das nossas mattas de 50 palmos de altura, com 2 a 3 de diametro. Floresce em Setembro.

\section{USOS MEDICINAES}

A casca d'esta arvore, que sėcca se enrola, como a canella, serve para curar as febres intermittentes palıdosas, e para as remittentes.

\section{USOS NAS ARTES}

O lenho é mui compacto, e serve para as obras de adorno.

Quina ou quina puina. (Chinchana officinalis.)Arvore de mediana grandeza, que floresce e fructifica, preferindo para vegetar os terrenos seccos, pertencendo á familia das labiaceas. Encontra-se nus sertões de Minas, Bahia, Alagoas, Sergipe, Pernambuco, e outras provincias do Brasil. A virtude tonica e febrifuga da quina, já era conhecida dos indios, antes da vinda dos europeos á America, sendo usada na Hespanha e Roma ha mais de 200 annos.

Ha tres especies de quina cinzenta, amarella, e vermelha; e recebe o nome dos logares onde é encontrada. 


\section{USOS MEDICINAES}

A casca da arvore é o que se emprega em medicina, como tonico energico, antifebril, e contra as nevralgias.

Quirs ou froi Jorge.-Arvore de 80 á 100 palmos de altura, com 3 á 12 de diamerto. Floresce em Setembro.

\section{USOS MEDICINAES}

Não são conhecidos.

\section{USOS NAS ARTES}

O seu lenho serve para váos de embarcações, couçoeiras, vigas, e obras de casas. Tambem serve para o fabrico de bengallas, pelo marchetado que offerece, depois de envernizado.

Quitòco. (Pulchea quitòco.) - E' planta aromatica de flores purpurinas, mui conhecida nas Alagôas, que nasce por toda a parte onde ha paús, e logares frescos.

\section{USOS MEDICINAES}

o cozimento d'esta planta tomado em forma de chá, é carminativo, anti-hysterico, digestivo, e emprega-se para combater os flatos, a metrite, e para apparecerem os lochios supprimidos: em banhos serve para tirar as dores do corpo. Em chlyster, allivia a cabeça perturbada.

Quixaba ou quixabeira.-E' arvore mui conhecida nos sertões du Brasil, e vegeta em grande abundanzia nos logares seccos e acatingados: floresce e fructifica, sendo o seu fructo quasi semelhante á uva bastarla: come-se, porque são mui doces; e os animaes nutrem-se com ellas.

\section{USOS MEDICINAES}

O cozimento da entrecasca, é empregado com vantagem, no curativo das boubas.

\section{USOS NAS ARTES}

O lenho serve para diversas obras de carpintaria, e para a marcenaria.

\section{USOS NA INDUSTRIA}

A industria, póde tirar dos fructos assucar ; bom vinho; vi- 
nagre e aguardente. O caroço do fructo dá excellente azeite para a confecção de sabonetes, e para luzes.

\section{$\mathrm{R}$}

Eabaga. (Liatiis etulis.)-Planta agreste das Alagôas, e Pernambuco.

\section{USOS MEDICINAES}

Não são conhecidos.

USOS CULINARIOS

Com as folhas fayem guizados para as mesas.

Rabaga ariatica.- Planta de folhas compridas, e talos grossos, angulosos, e ocos. As flores são brancas, em forma de rosas pequenas.

\section{USOS DOMESTICOS}

A raizes fibrosas, são aperitivas; adelgaçn os humores; dissolve a pedra dos rins e da bexiga ; tira o máo cheiro da bocca, proveniente do estomago, e comidas as follhas em salada, é muito peitoral e proveitosis.

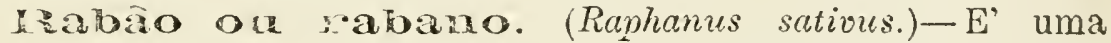
planta herbacea. cultivada nas hortas, de raiz fusiforme. e de gosto agradavel: é legume para a mesa.

\section{ISOS MEDICIXAES}

E' anti-scorbutico, diuretico, expectorante, e desobstruente do figado. O sumo das folnas misturado com oleo de amendoa doce, é muito louvado para curar a surdez.

As sementes limpam a cutis, e é vermifuga. A raiz é indigesta, não sendo bera cozida; é flatulenta, e laz criar muito semen. José Martins de Carvalho diz, que a raiz do rabano é aperitiva, digestiva, incisiva, aphrodisiaca, contra a peste. turba o cerebro, e causa outros efieitos. 
Rabão silvestre.-Esta planta tem as folhas retalhadas, a raiz avermelhada, e muito dura.

\section{USOS MEDICINAES}

E' muito indigesta a raiz, causa arrotos, vomitos, e cura a mordedura das viboras; tira as nodoas do rosto, e é purgativa.

Rabo de bogsio. (Vide Bugio.)-E' planta das Alagôas, mui conhecida.

\section{usos MEDicinaes}

E' contra as tosses chronicas, catarrhos, e hemopthises, tomada a raiz em cozimento.

Rabo de tatú. ou sumaré.- - E' uma planta parasita do Brasil, e do Mexico, tendo o caule ou talo dividido em gommos, como canna, embebidos de um succo albuminoso, ou glutinoso de muitos prestimos.

\section{USOS MEDICINAES}

o succo mucilaginoso do sumaré ou rabo de tatú, feito xarope, e mui proveitoso, para curar a tosse convulsa, as tosses agudas e chronicas, os catarrhos, a tysica pulmonar, a suffocação, e a hemoptises.

\section{USOS NA INDUSTRIA}

Misturado o succo, com o carvão animal, ou vegetal, forma excellente graxa para o calçado. Os marceneiros servem-se do succo, com preferencia á colla animal, para grudar a madeira. Gruda a porcellana, o vidro, e é preferivel para encadernação de livros.

Rabugem. (Cordia officinalis.)-E' arvore mui conhecida das mattas das Alagôas, que tem muitas especies, cuja madeira, sendo muito difficil de lavrar, confunde-se com o Jacarandatan, que tem muita serventia nos arsenaes, para construcção naval.

\section{USOS MEDICINAES}

Não são conhecidos.

Rabugem de cachorro. (Cordia vulneraria.)-E' 
uma herva, conhecida tambem pelo nome de herva cavalleira, e camphora do campo, nas Alagỏas, Pernambuco, S. Paulo, Minas Geraes e outras provincias, que vegeta em todo o tempo do anno, e se a encontia nos terrenos fracos, não the embaraçando os ardores do sol.

\section{USOS MEDICINAES}

E' esta planta de uma virtude singular, e quasi miraculosa, para curar as feridas e golpes, especialmente se os golpes são recentes. Pisadas as folhas, com o mesmo tope de flores da herva, extrahido o succo, e posto na parte golpeada, e applicando depois o bagaço, une e consolida as bordas das feridas sem deixar ver as costuras.

o extracto que se obtem da herva rabuqein de cachorro, é de agradavel aroma, que tanto mais requinta, quanto bem guardado se conservar.

Raizes aromaticas. (Parí.)-O conego Francisco Bernardino de Souza, na exposição que apresentou, dos trabalhos fertos pela commissão do Madeira, Pará e Amazonas, mencionando a riqueza vegetal do grande valle do Amazonas, memora as raizes dos vegetaes de que a industria humana, e a medicina, pódem tirar grandes vantagens que são: Raizes de

Iratassihoba:- Raiz bastante aromatica, com que costumam perfumar a roupa, e lavar a cabeça.

Hucuracá:-Raiz tambem aromatica, com que perfumam a roupa. Dizem que é empregada com bom resultado, no tratamento de certas febres.

Cipópocá:-Raiz aromatica, que empregam com bom resultado nas paralysias.

Puiaqué-caa:-Batata aromatica, com que perfumam a roupa.

Cipó inira:- Raiz cheirosa, e medicinal: serve para banhos no rheumatismo, e nas molestias nervosas.

Corimbó:- Cipó muito aromatico, que serve para banhos, nas enfermidades nervosas e rheumaticas.

Raizes diversas; Raiz amargosa.-E' a genciana.

Raiz de Anvers.-E' a caferana. 
Raiz de Barbeiro.-E' a chites longiflora.

Raiz de Brandão.-E' purgativa e anti-syphilitica.

Raiz do Brasil.-E' a Ipecacuanha.

Raiz da China.-E' a Japecanga.

Rai de Cabra.-E' a raiz de Tiú.

Raiz de Frade.-E' o cipó de cruz, em S. Paulo.

Rais de Guiné.-E' uma variedade de Tipi ou Pipi.

Raiz de Jacaré-aru. -E' a raiz da cafferana.

Raiz de mil homens.-E' a Aristolochía cymbifera, mui recommendada para curar a hydropesia, os incommodos do estomago, e a paralysia.

Raiz do Padre Salerma.-E' aromatica, e serve para curar a dyspepsia, a diarrhéa, as febres intestinaes, e as mordeduras das cobras.

Raiz do Sol.-E' uma aristolochia do Pará, muito recommendada pelo Dr. Lacerda, em forma de infusão para curar a amenorrhea, e as dores uterinas. As folhas e a raiz em cozimento, servem para curar as molestias dos olhos.

Ratainha da corra. (Krameria argentia.)-E' planta conhecida na Bahia, e Minas Geraes.

USOS MEDICINAES

A raiz d'esta planta, por sua adstringencia, é empregada em cozimento, para curar as diarrhéas chronicas.

Relogio. (Sida horologa.)-E' um arbusto, muito conhecido nas Alagôas, que floresce e fructifica. O nome do relogio do campo lhe veio, porque a flor se abre á hora do meio dia, e se fecha de tarde.

\section{USOS MEDICINAES}

o cozimento d'esta curiosa planta, é emoliente, e empregado nas dores de dentes. Eu tenho visto esta planta nas proximidades e beiras dos caminhos, da capital do Rio de Janeiro.

Remedio de vaqueiro. (Ocynum incanescens.)Esta planta é uma especie de mangericão do campo, muito commum nos agrestes dos sertões. 


\section{USOS MEDICINAES}

Com o cozimento d'esta planta, tomam os vaqueiros suadores, para curar as dores do corpo.

Resedá. ou Resedal. (Lawsonia inermis.)-E' una arbusto lenhoso, cultivado nos jardins por suas flores mui aromaticas e suavisssimas.

\section{USOS MEDICINAES}

Não são conhecidos.

USOS NA INDUSTRIA

As flores, pela distillação, podem fornecer uma essencia mui preciosa á perfumaria.

Rhuibarbo do campo. (Ferraria cathartica.)-E' planta de sabor amargo, e flores de aroma suave, tendo a raiz bulbifera.

\section{USOS MEDICINAES}

o succo da raizé purgativo, na quantidade de uma á duas oitavas, tomado pela manhã em jejum.

Rinchão.-E' planta do Pará, experimentada pelo Dr. Lacerda.

\section{USOS MEDICINAES}

E' purgativa, e conveniente para curar a hydropesia. O Dr. Lacerda diz, que se pisam as folhas, e se mistura o succo com quanto baste d'agua, e bem 3 pingos de limão, e um pouquinho de sal, para formar um clyster, que será applicado ao en fermo.

Fomanzeixa. (Punica granatum.)-A romanzeira é planta mui conhecida e vulgar, e se é africana, não o diz Gabriel Soares, que a descreve, florescendo e fructificando no Brasil, sem designar a procedencia. Ha duas especies : uma doce, e a outra azeda.

\section{USOS MEDICINAES}

0 succo dos bagos do fructo chamado 'roman, é refrigerante. A casca do fructo por sua adstringencia tem muitas virtudes medicinaes, conhecidas do povo, para curar as hemor hagias, a diarrhéa, a leucorrhéa; e para banhos e gargarejos adstringentes. A casca verde da raiz da romeira, é poderoso remedio para expulsar a solitaria. 
USOS NA INDUSTRIA

Da casca da roman, se extrahe, tinta preta para a tinturaria e para escripta.

Rosario de Jaubú. (Eugenia racemosa.)-Planta das Alagoas e Pernambuco, pertencente á familia das myrticeas. USOS MEDICINAES

O cozimento da raiz é diuretico, e desobstruente do figado. A casca da planta, e as sementes curam as febres.

Rozeiraa. (Rosa rubra vel Punica.)-E' arbusto espinhoso que produz rosas, de que ha varias especies: brancas, vermelhas, roxas, amarellas, e outras; sendo a Rozeira de Alexandria, a mais antiga cultivada no Brasil, por sua formosura, aroma delicado, e côr agradavel.

\section{USOS MEDICINAES}

Como as rosas são adstrigentes, servem para curar a leucorrhéa e as feridas ehronicas da bocca; e a agua distıllada das flores, servem para curar a inflammação dos olhos.

A rosa pallida é purgativa, e mui proveitosa ás mulheres.

USOS NA INDUSTRIA

Pela distillação se extrahe o oleo essencial, ou essencia de rosa, mui estimada na perfumaria.

\section{S}

Sabão. (Ricinus saponarius.)-E' planta conhecida nas Alagôas, que vegeta em qualquer terreno, preferindo as immediações dos rios.

\section{USOS MEDICINAES}

O seu extracto presta-se, para resolver qualquer tumor ou apostema.

USOS NA INDUSTRIA

Com as folhas d'este vegetal, as lavadeiras lavam a roupa, 
em falta de sabão, porque, ellas fazem espuma, e alvejam a roupa, com mais uma propriedade singular, de não desbotar as côres das tintas que tem, nem cortar o panno, como acontece com o sabão.

Sabonete. (Sapindus saponaria.)-Arvore mui vulgar nas Alagôas, que vegeta á beira dos rios, e nos logares humidos. E' de grandeza regular, floresce, e dá um fructo conhecido pelo mesmo nome.

USOS MEDICINAES

o cozimento da raiz, é empregado contra a chlorose. O succo applicado exteriormente, $\mathrm{r}$ esolve as alporcas; o pó da raiz, mata as lombrigas.

\section{USOS NA INDUSTRIA}

O fructo que é esponjoso, e embebido de um succo oleoso, esfregado na mão com agua, produz espumas mui alvas, e por isso as lavadeiras servem-se d'elle, para a lavagem da roupa. o fructo maduro, e cozido dá sabão; porém fica resinoso, duro, levando-se ao fogo, mas depois com 0 ar se desfaz. A raiz tem a mesma propriedade. A industria póde obter d'esta planta singular, sabonetes admiraveis para o toucador das senhoras.

0 Dr. Peckolt analysou, o fructo do sabonete, e reconheceu que a casca do fructo se póde empregar para curar a blenorrhagia, sarna e chlorose. Os caroços do fructo, contém um oleo graxo, de côr amarella, com propriedade anti-escrophulosa.

Sabugueiro. (Sambucus australis.)- 0 sabugueiro foi aclimatado no Brasil, onde vegeta, floresce e fructifica, convenientemente.

\section{USOS MEDICINAES}

As flores são cordiaes, carminativas, resolutivas, anti-hystericas, sudorificas e anodinas. As folhas cozidas em forma de carurú, são purgativas, tendo a mesma propriedade, a segunda casca das raizes.

Saca-estrepe da campina. (Echinops saca-estrepe.) - E' planta conhecida nas Alagôas, e Pernambuco, de 3 á 4 palmos de altura, floresce e fructifica.

usos MEDicinaES

o cozimento da raiz, serve para combater as tosses agudas, 
e chronicas. As folhas pisadas e applicadas ao logar onde se acha o estrepe enterrado, o chama para fora. Affirmam que as folhas bem applicadas ao cancro ulcerado, o cura.

Saca-estrepe da matta. (Spennera aerifera.)-E' planta das mattas das Alagôas, conhecida dos derrubadores. USOS MEDICINAES

As folhas d'este sub arbusto, passadas pelo fogo, tomam a consistencia de cera, e n'este estado applicada no logar onde está enterrado o estrepe, ou espinho, o attrahe para a superficie da pelle.

Saca rotha odi guasuma branca. (Helicteres melifua.)-Planta conhecida nas Alagôas, pelo nome de Guasuma. Não tem emprego em medicina domestica. Servem-se da casca, para o fabrico de cordas.

Sacubaré. (Cyrtopodium sacubaié.)-E' planta silvestre, conhecida dos hervanarios.

\section{USOS MEDICINAES}

O cozimento da raiz, é empregado para curar as molestias venereas.

Sacuúbarana. (Plerandrium amarum.)-E' uma planta do Pará, experimentada pelo Dr. Lacerda.

\section{USOS MEDICINAES}

o cozimento da raiz dado á beber, e o das folhas, usado em banhos, cura as sarnas.

Sagú ou saģueiro. (Raphis vinifera.)- o sagueiro é uma palmeira utilissima, aos povos das Ilhas Molucas; e deve prosperar no Maranhão e Pará, por estarem na mesma latitude; sendo para nós mais uma riqueza, no artigo Phythologico. Esta palmeira é que produz o sagú, cujo melhor fabrico é o usado pelos molucos.

Eu possuo um manuscripto interessante a respeito do sagueiro, que ensina o modo de preparar o sagú, que o não publico aqui por não ter espaço.

Saiāo. (Kalancho brasiliensis.)-Esta planta é conhecida no Rio de Janeiro, por este nome, na Bahia, pulo de Herva da 
Costa, nas Alagoas, pelo de Para tudo, e em Pernambuco pelo de Coerona; é empregada em medicina vulgar, para banhos nas inchações erysipelatosas das pernas.

Salgueiro. (Tourneforia.)-o salgueiro é uma arvore, binita, esgalhada e natural da provincia das Alagôas, que floresce e fructifica, sendo as suas flores mui aromaticas.

USOS MEDICINAES

Não são conhecidos.

\section{USOS NA INDUSTRIA}

o lenho como é fraco, não se servem d'elle para a carpintaria, e sim para o fogo, por ser bom combustivel, e dar bôa cinza para decoada.

Salsa brava. (Mikanıa abuticefolia.)-A salsa brava é uma planta, que tem as flores semelhantes ao milmequer, ou girasol.

USOS MEDICINAES

A planta toda feita cozimento, é bom remedio dado em banhos, para curar o rheumatismo syphilitico.

Salsa de cheiro ou Mortonse. (Apium petro. selinum.)-E uma planta da horta conhecida de todos, porque serve de tempero ás comidas.

\section{USOS MEDICINAES}

A raiz é aperitiva; e as folhas são resolventes.

Salsaparrilha. (Smilax Salsaparrilha.)-E' um cipó delgado, escuro por forra, e brancacento por dentro, muito commum no Pará, no Amazonas, no Alto Rio Negro e nas cordilheiras.

\section{USOS MEDICINAES}

As raizes são sudorificas, diureticas, e empregadas para curar a syphilis e o rheumatismo. Os indios servem-se da salsaparrilha, us indo a planta com folhas e raizes; pisam-na, expremem-na e depois de fervido este succo, que imita o caldo da tapioca, adoçam-no com mel de abelhas, para tomarem em suas molestias.

Salsa da praia. (Convolvulus brasiliensis) -E' uma planta rasteira, leitosa, que alastra e vegeta na beira das praias do mar, 
e mesmo um pouco afastada, d'ellas. A salsa da praia, é um vegetal mui conhecido.

\section{LSOS MEDICINAES}

A raiz, tambem leitosa, emprega-se como purgante, nas molestias chronicas do figado e do baço. As folhas são emolientes.

Salva. (Leppia citrata.)-Planta aromatica, de folhas esbranquiçadas, flores arroxadas, e hastes quadradas cobertas de lanugem branca.

\section{USOS MEDICINAES}

O chá das folhas da salva, serve para fortificar o cerebro, os nervos e para o hysterismo; cura a paralysia, o lethargo, e aproveita muito na apoplexia.

Tomada em pó, como tabaco, purga o cerebro. E' anti-abortiva, e fortifica o utero. A sua principal acção é sobre o cerebro.

Salva das Alazòas e Permanabuco. (Cacalia odorifera.)-E' planta aromatica, que vegeta na'quellas provincias com prestimos em medicina domestica.

\section{USOS MIEDICINAES}

O cozimento d'esta planta. faz vir as regras supprimidas das mulheres; e dado em banhos, cura o rheumatismo.

Salva do Pará. (Hyptis incana)-Esta planta aromatica de sabor agradavel, vegeta na ilha de Marajó, onde é vulgar e conhecida pelo nome de salva.

\section{USOS MEDICINAES}

o cozimento dado em banhos é excitante, cura o rheumatismo e a hydropesia, e tomado em collyrios aproveita nas inflammações dos olhos. O Dr. Lacerda affirma, ser esta planta superior em tudo á herva cidreira.

O chá das folhas, é muito proveitoso para os incommodos cerebraes, e para o hysterismo.

Sambanbaia, ou Barba de Velho, ou horva dos Barbonos. (Tillandia usneoide.)-Planta que vive sobre as arrores, principalmente nas margens dos rios. 


\section{USOS MEDICINAES}

Pisada, e misturada com banha de porco, serve para curar as hemorrhoidas, applicando-se ao anus.

0 povo mette a sambambaia em um saquinho, e põe o saquinho sobre a ruptura herniosa, e como a planta fortifica os musculos correspondentes, formam-se novos tecidos, e a cura se manifesta.

O cozimento da planta é tonico, diuretico e purgativo.

Sambambaia-açú. (Adiantum brasilianum.) - E' um arbusto de ramos grossos, e folhas semelhantes ás da arthemisia.

\section{USOS MEDICINAES}

Tira-se a massa branca que está dentro do tronco do arbusto, e com ellase fórma uma especie de caldo gommoso, e se dá com muita vantagem aos tysicos, e aos que soffrem catharros chronicos do peito, nas aposthemas ou vomicas, e mesmo aos enfermos cuja convalecença, é mui demorada,

Sambambaia do brejo.--Arvore grossa, espinhosa, semelhante ao mandacarú, no tronco, que vegeta nos logares humidos e encharcados.

\section{USOS MEDICINAES}

o cozimento, bem adoçado com assucar fino, é mui proveitoso nas molestias do peito. E' vulnerario, e consolidante poderoso, para os que dão quedas, e levam pancadas; e dizem as pessoas do povo, ser a sambambaia do brejo, efficaz medicamento nas quebraduras, ou rendeduras.

Sambambaia ou matatauba. (Polypodium lepidopteris.)-Arvore que vegeta nos terrenos seccos e froscos, conhecida nas Alagòas, e outras provincias.

\section{USOS MEDICINAES}

o cozimento da casca, e folhas d'esta arvore, dado em banhos, serve para desinchar os testiculos; mas convêm ter muita moderação em seu uso, porque se abuzar, corre o risco de atrophial-os. O extrato tem a mesma virtude.

Sambacuim. (Cecropia palmata.)-Este vegetal é mui conhecido nas Alagôas, tendo as folhas palmadas, e peccioladas. 


\section{USOS MEDICINAES}

Não the conheço os prestimos em medicina domestica.

\section{USOS NA INDUSTRIA}

Dos pecciolos das folhas uiam nas Alagôas, para ponteiros de gaiolas e alçapão de apanhar passarinhos.

Sambaiba. (Cecropia concolor.)-E' arvore das mattas das Alagôas, e mui conhecida dos derrubadores.

\section{USOS MEDICINAES}

o cozimento da casca, serve para o curativo das feridas velhas.

Sangue de draggo ou de dragâo. (Pterncarpus draco.)-Arvore mediana, pouco abundante. que dá uma resina concreta, sem cheiro, e fragil, mas estimada, como a que se extrahe da Rhoa, arvore do dragão que vegeta na Ilha da Madagascar.

\section{USOS MEDICINAES}

E' tonico, e adstringente.

\section{USOS NAS ARTES E NA INDUSTRIA}

Com a resina se compõe um verniz, empregado na pintura.

Santa Iuzia. - Arvore conhecida nas provincias do Rio de Janeiro, e Minas Geraes, de mediana grandeza, esgalhada; e como ha varias especies da mesma familia, são distinctas pelas folhas: tendo umas um palmo, outras maiores, com espinhos; outras menos. Dão fructos semelhantes aos do carrapateiro, ou mamoneira. Sendo incisada a casca, verte leite, semelhante ao da mangabeira. O leite cahindo nos olhos, produz perturbação da vista, e por fim o desenvolvimento da catarata, como experimentou o fazendeiro Antonio Hervia, morador na freguezia da Apparecida. Convém ser estudada esta arvore, em relação á therapeutica.

São Thomé.- Arvore de 80 á 100 palmos de altura, com 3 á 4 de diametro proporcional, das mattas da Bahia, e das Alagôas; floresce em Outubro, e distilla uma resina, que imita o beijoim. 
USOS MEDICINAES

o cozimento da casca, tomado em banhos, serve para o rheu matismo.

\section{USOS NAS ARTES}

A sua madeira, compacta e bella, serve para obras de decoração de salas.

Sapateira. (Hibiscus rosa sinensis.) - A planta conhecida pelo nome de sapateira, não tem emprego em medicina vulgar, embora seja muito adstringente.

USOS NA INDUSTRIA

As folhas são empregadas em curtir couro:; e d'ellas se póde extrahir tinta preta, para a tinturaria.

sapé. (Anatherum bicorne.) - O sapé é uma graminea que abunda nos taboleiros, ou chapadões das Alagoaas, Sergipe, Bahia. Pernambuco, e outras provincias, mui conhecida de todos.

USOS MEDICINAES

A sua raiz em cozimento é emoliente, diuretica, sudorifica, e muito empregada no curativo das inflammações do figado, e no da hydropesia. Cura a opilacão, combate a retenção das ourinas, e a gonorrhéa. E' contra veneno das cobras.

Sapota. (Achras inammosa.)-E' arvore das mattas do Brasil, e differe o fructo do sapoti, por ser redondo; come-se: é mui saboroso. Não tem emprego em medicina domestica, que me conste.

Sapoti, (Achras sapota.)--E' arvore do Pará, transplantada por todas as proviacias do Imperio, que da um fructo oval paradunto, mai doce e apreciado por todos.

\section{USOS MEDICINAES}

A casca da alvore do sapoti, é adstringente, e anti-febril tomada em cozimento. 0 fructo \&́ contra a retenção de ourinas. As sementes são recommendadas nas colicas renaes, e areas dos rins e bexiga.

Sapucasira. (Lecythis glandifhic:)-E' uma arvore frondosa, com fructos como a sapucaia, porém pequenos. Suas amendoas" embebedam a quem as come. 


\section{USOS MEDICINAES}

o oleo da amendoa, serve para o rheumatismo. 0 cozimento da casca é diuretico, e combate a ictericia, a inflammação chronica do figado. O cozimento do pilão ou casca do fructo, cura as molestias da bexiga ourinaria, as ourinas leitosas e as areas.

USOS NAS ARTES

o lenho é empregado em obras de casas, e para a carpintaria.

\section{USOS NA INDUSTRIA}

O oleo da sapucaeira serve para luzes.

Sapucaia. (Lecythis ollaria.)-Arvore corpulenta das nossas mattas. Cobre-se de flores roxas em Agosto. O seu fructo é uma capsula coberta com uma tampa, contendo 20 e mais amendoas, que se comem cruas, assadas, cozidas. A capsula serve de côco, para beber agua. Ao fructo chamam pilão da sapucaia.

USOS MEDICINAES

A capsula ou pilão da sapucaia, é medicina diurectica e anti-syphilitica. As amendoas comidas, sevem para arrancar a espinha de peixe da garganta.

o oleo da castanlıa é excellente para resolver gommas (exostosis) e tumores gottosos.

\section{USOS NAS ARTES}

O lenho da sapucaia serve para mastros, mezenas, e couçoeiras e para obras de carpintaria. O carvão feito da madeira da sapucaia é de grande força.

Sapucaia. (Lecythis Lancelata.)-Arvore da mesma grandeza, e só diversifica no fructo, por ter as sementes miudas, e a capsula ou pilão verde, semelnante o fructo do oityseiro.

\section{USOS NAS ARTES}

o seu lenho serve para construcções e obras de edificios.

Sapucairana ou sapuporna. (Lecythis illiptica.)E' arvore das mattas da Bahia, Alagòas, c Pernambuco e de algumas outras provincias do Imperio, tendo as folhas, flores e sementes maiores que a sapucaeira. 
USOS MEDICINAES

A capsula ou pilĩo reduzido a pó, e bebido, serve para neutralisar a força emetica, que possuem as amendoas.

\section{USOS NAS ARTES}

O lenho serve para esteios, e para a carpintaria.

Saracura. (Bygonia hirtella.)-Planta conhecida no Rio de Janeiro, e muito usada na medicina popular.

USOS MEDICINAES

Por sua qualidade adstringente é empregada, em cozimento para banhar os olhos inflammados; para curar feridas velhas; e em clyster påra combater a diarrhéa, tanto recente, como chronica.

Sargago do mar. (Fucus natans.)-E' um vegetal, que se cria no mar, mui conhecido, e que se encontra nas praias maritimas.

\section{USOS MEDICINAES}

O sargaço reduzido a pó e tomado, é diuretico, e tem a virtude de destruir os calculos vesicaes. Dizem que tambem tem a virtude, de combater a obesidade.

Saudade da campina, ou cera olho, ou chibante. (Asclepias umbellata.) - E' uma planta leitosa que folga nos logares humidos, conhecida nas Alagòas. Dizem que - leite cahindo nos olhos os cega. D'ahi the proveio o nome vulgar.

\section{USOS MEDICINAES}

O cozimento da raiz, aproveita no curativo da hydropesia.

sebastião Arouda. (Physocalymna florida.)-Arvore preciosa das nossas mattas, por sua madeira, de 20 á 25 palmos de altura, com 1 á 2 de diametro. Floresce em Agosto. Do nome que tem, não lhe sei a origem.

\section{USOS MEDICINAES}

Desconheço-lhe as virtudes medicamentosas.

USOS MAS ARTES

O lenho d'esta arvore é avermelhado, com veios um tanto 
escuros, algumas vezes azulalos, e outros rubros; serve para molduras, obras de decoraçio, e mar'chetaria. Ha d'esta arvore duas quali lades: macho, e femea.

sogurolha brasileica. (Occymum gratissimum.)E' uma pequena planta aromatica, conhecida lo povo, e que scrve de tempero ás comidas.

Somente do ombira. (Gulteria.)-E' arvore muito conhecida nas Alagôas, Pernambuco, Sergipe, e Bahia. Chamam-na tambem, arvore Pindaiba, Embira de caçador, e Semente de embira.

\section{USOS MEDICINAES}

As sementes, são carminativas, estomachicas, e muito empre gada contra as flatulencias intestinaes.

\section{USOS CULINARIOS}

Servem as sementes para tempero das comidas.

USOS NA INDUSTRIA

A casca dá linho para o fabrico de cordas, e materia apropriada para bucha de arma de fogo.

Sompr.e-viva.-E' planta de jardim, cujas flores sem cheiro, sempre se conservam no mesmo estado.

\section{USOS HEDICINAES}

Dizem que o cozimento da sempre-viva maior, é refrigerante, e adstringente; cura a erysipella, chagas, inflammaçoes de olhos, queimaduras, e a gotta. O succo da planta, tira as dores de cabeça; cura a mordedura da aranha carangueijeira. a cozimento da sempre-viva menor, é singular remedio, para curar as chagas velhas, e suspender a diarrhéa.

Sone do campo. (Cassia cathartica.)-E' planta muito vulgar em Mi:as, emprezarla na medicina domestica.

USOS MEDICINAES

E' purgativa, tomadas as folhas em infusĩo.

Sonsiciva ou malicia de mulhor. (Mimosa sensitiva vel predicu.) - E' planta pertencente á familia das legu. minosas, geralmente conhecirla em todo o Brasil. O melindre, 
a sensibilidade, o pudor d'esta planta espinhosa, por demais, tem sido explicado. Vegeta nos pastos dos Engenhos, e em outros logares, encarregando-se ella por si, de semear as suas sementes, e por isso sendo ella annua, á medida que umas morrem, outras as substituem logo. Esta planta, é o emblema da geração humana.

\section{USOS MEDICINAES}

Conforme as muitas experiencias dos sertanejos, é a Malicia de mulher, o melhor tonico, e o remedio mais animador e corroborante dos vasos seminaes, quando por frouxos, e sem o devido estimulo, deixam de prestar para a funcção de reproducção. Usam da raiz tomada em chá, ou em cozimento.

C banho das folhas, cura o rheumatismo articular, e o recommendam, como proveitoso para desinchar as pernas erysipelatosas. As folhas pisadas, e postas sobre as escrophulas as resolvem.

Os sertanejos fazem um emplastro singular com o sumo da malicia de mulher, folhas e fructos da Jurubeba, olhos de Capeba ou Pariparoba, Vassourinha mofina, banha de porco, tudo misturado, levado ao fogo, até ficar em forma de unguento, estendido em uma folha de Capeba ou Pariparoba, posto sobre o lugar onde se suppõe existir algum abcesso, milagrosamente, attrahe, pucha e faz sahir pelos poros o puz, ahi encarcerado.

Seringueira. (Simphonia elastica.)-Vid. Borracha ou Gomma elastica.

Serralha. (Sonchus lavis.)-Arbusto vulgar, que vegeta sem cultura.

\section{USOS MEDICINAES}

E' empregado o cozimento da planta em fórma de chá, internamente, e externamente em banhos, para curar a dysenteria, e estranguria. Corrobora o estomago, fortifica os nervos e a vista.

\section{USOS CULINARIOS}

E' comestivel, preparada convenientemente.

Sete cascos. (Monimia friabilis.)-E' uma arrore das mattas das Alagôas, copada, que floresce e fructifica, parecendo o seu fructo com um figo, com sementes dentro. 
USOS MEDICINAES

Não são conhecidos.

USOS NAS ARTES

O lenho d'esta arvore serve para a construcção de casas, e para as obras de carpintaria.

Sote couros.-Arvore de 60 palmos de altura, e dous de diametro, floresce em Outubro.

\section{USOS MEDICINAES}

Não são conhecidos.

USOS NAS ARTES

O lenho d'esta arvore serve para coucoeiras, e para taboado de portas e assoalho.

Sete sangrias. (Cuphea ingrata.)-E' planta vulgar conhecida dos hervanarios.

\section{USOS MEDICINAES}

O povo se serve do cozimento d'esta p'anta, para curar as febres intermittentes.

Sicupira ou sucupira, ou supipira ou sepipira. (Sebipira major.)-Arvore das mattas das Alagôas, e de outras provincias, que folga nos terrenos seccos, sendo a sua madeira a melhor que se conhece, para a construcção de navios. Despe-se de suas folhas em Julho e Agosto, e floresce em Setembro e Outubro.

\section{USOS MEDICINAES}

A casca da arvore em cozimento ou em extracto, emprega-se com muito proveito no curativo das enfermidades venereas. O succo é contra veneno da cobra Jararaca. O banho do cozimento, é recommendado aos que padecem do rheumatismo venereo, a que o povo chama corrimento. A sicupira é preferivel em seus effeitos medicinaes á salsaparrilha. Os sertanejos chamam-na o azougue dos pobres; e em consequencia de ser mui quente, antes de principiar no seu uso, refrescam o doente, e misturam no cozimento grãos de cevada, ou de arroz, para corrigir a sua calidez. 
USOS NAS ARTES

O lenho serve para construcções naval, e civil.

Sucupira acariy.-E' vegetal de igual tamanho, e diametro,

\section{USOS MEDICINAES}

Não jã̃o conhecidos.

USOS NAS ARTES

E' o seu lenho muito apreciado para liames, e cintados de embarcações.

Sicapirassú.-E' arvore de igual altura, e da mesma grossura que as precedentes.

\section{USOS MEDICINAES}

Não são conhecidos.

USOS NAS ARTES

Serve o seu lenho para construcções, e obras de casas; mas não é tão apreciada como as primeiras.

Ha ainda duas variedades de sicupiras, a que os derrubadores chamam sicupirana, e sicupiruna, que serve para os mesmos usos na arte de construcçĩo civil.

Silva. (Rubus brasiliensis.)-E' planta espinhosa, de flores brancas ou vermelhas, que dá fructos avermelhados, e doces.

\section{USOS MEDICINAES}

Dizem que esta planta, tem a propriedade de curar o scorbuto. Serve tambem para curar todas as enfermidades da cabeça.

simaruba ou marupauba.-E' um vegetal do Maranhão e Pará, empregado em medicina domestica.

\section{USOS MEDICINAES.}

o cozimento, dado em clyster, cura a dysenteria sanguinea. Em banhos cura as sarnas, e perebas. O Dr. Lacerda diz, que as raspas da raiz, infundidas em agua por 12 horas, depois de coada, póde-se tomar como bebida ordinaria, que aproveita do mesmo modo, no curativo d'essas molestias. 
Simbaiba. (Dadilixa.)-Esta planta no Maranhão, tem as folhas mui asperas, em forma de lixa, e é empregada em medieina popular.

\section{USOS MEDICINAES}

Cura a dysenteria, a retenção das ourinas, o vomito anti spasmodico, e a hemoptisis.

\section{USOS NA INDUSTRIA}

Serve as folhas para lixar as obras de tartaruga, e as de chifre.

Simira. (Psiychotria simira.)-E' planta do Amazonas, que fructifica em pequenos bagos.

USOS MEDICINAES

E' adstringente.

$$
\text { USOS NA INDUSTRIA }
$$

Os indios extrahem d'ella tinta para seus usos.

Sipahuba. (Combretum ascendens.)-E' arvore mediana das Alagòas, e Pernambuco, e muito estimada para estacas de arcas, por sua duração.

Sixgy.-Arvore das mattas das Alagôas, e Pernambuco. USOS MEDICINAES

Não são conhecidos.

$$
\text { USOS NAS ARTES }
$$

o lenho d'esta arvore, passa por ser indestructivel, e emprega-se para estêios de pontes, e travejamento das mesmas.

Sôbro.- Arvore das nossas mattas de 60 palmos de altura, com 2 de diametro, conhecida dos derrubadores. Floresce em Outubro.

\section{USOS MEDICINAES}

Não são conhecidos.

\section{USOS NAS ARTES}

O seu lenho serve para taboados, e couçoeiras.

Sombra de Boi. (Pará.) - Planta que cresce nas margens dos rios, que dá fructos, semelhantes a cachos de uras; 
de côr esbranquiçada, d'onde se extrahe um liquido perfeitamente semelhante á gomma arabica. (Conego Bernardino: Commissão do Madeira.

\section{USOS MEDICINAES}

Não são conhecidos.

USOS NA INDUSTRIA

A industria poderia experimentar, essa substancia, e tirar partido conveniente d'ella.

Sobragi. (Cyanothus speciosa.)-E' uma planta amarga, que vegeta em Minas Geraes.

\section{USOS MEDICINAES}

Usam d'esta planta, para curar a diarrhéa.

Solidonia. (Trixis divaricata.)-Esta planta é muito conhecida no Rio de Janeiro, e em outras provincias, e usada em medicına domestica.

\section{USOS MEDICINAES}

o cozimento das folhas, é muito empregado para curar a inflammação dos olhos. O cozimento da raiz, faz apparecer as regras supprimidas.

Sorveira. (Callophora utilis.)-E' planta do Pará, e Amazonas, que dá um fructo semelhante á mangaba, mais saboroso ainda, cuja planta e fructo, dão um succo leitoso, com prestimos medicinaes.

\section{USOS MEDICINAES}

o succo é applicado contra os vermes intestinaes.

$$
\text { USOS NA INDUSTRIA }
$$

O succo leitoso é empregado para a confecção de verniz.

stramonio ou figueira do inferno.- Vid. Figueira do inferno.

Suassúr ega. - E' planta do Maranhão, e Pará. que florifica, e dá sementes.

\section{USOS MEDICINAES}

As sementes reduzidas a pó, e infundidas em bôa agua, e depois de coada, applicada aos olhos, tira-lhes as nevoas. 
Subaré ou sumaré.-- E' uma especie de canna, muito musgosa, que se cria sobre as arvores, e pedras: tem muitos prestimos : encontra-se esta planta nas mattas.

\section{USOS MEDICINAES}

o musgo que se extrahe da canna, applicado sobre qualquer tumor inflammatorio, accelera a suppuração, ou o faz arrehentar em pouco tempo, puchando para fora o carnegão, tirando as dôres e a inflammação. Os sertanejos empregam o musgo da planta, para extrahir qualquer estrepe ou espinho, enterrado na carne.

\section{USOS NA INDUSTRIA}

o musgo serve para grudar qualquer objecto quebrado, e para dar lustro ás botas. E' provavel que a industria possa tirar d'esta planta excellente verniz, misturando o musgo, que ella fornece, com outras drogas apropriadas.

Sucuba ou sucuúba.-E' arvore natural do Brasil, que produz gomma, que passa por ammoniaco do Levante. Sendo incizada, distilla um licor leitoso, que tomando-se em certa quantidarle produz vomitos.

\section{USOS MEDICINAES}

A gomma applicada em forma de emplastro, cura as dôres de peito. A casca da raiz verde, de sabor amargo, cheiro desagradavel, é purgativa, e diuretica Toma-se em cozimento uma chicara, pela manhã e á tarde. A raiz toma-se do mesmo modo.

Sucussú.-Arvore de 40 palmos de altura, com 2 de diametro.

\section{USOS MEDICINAES}

Não são conhecidos.

USOS NAS ARTES

o seu lenho serve para taboado de caixões de assucar.

Sucuúba do Pará. (Plumeria phagedencia.)-E' arvore leitosa do Pará, de folhas mui grossas.

USOS MEDICINAES

o leite da arvore, é contra os vermes intestinaes; e appli- 
cado sobre as ulceras chronicas as limpa e cura. Posto sobre as verrugas as faz cahir. Affirmam ser bom medicamento, contra a gonorrhéa.

\section{Sucrzréba drastica. (Plumeria drastica.)}

\section{USOS MEDICINAES}

o succo em pequenas doses, cura as febres intermittentes, a ictericia, e a obstrucção do figado; misturado com oleo de amendoas e posto sobre a dòr pleuritica a faz passar.

Sucuribarana. (Pteradium amarum.)-E' planta do Pará, empregada pelos camponezes em cozimento, para curdir a sarna, e a lepra.

sumagre.- Arvore conhecida dos curtidores.

USOS NA INDUSTRIA

As folhas, e a casca do tronco, servem para curtir couros.

Sumauma. (Eriodendron sumauma.)-E' uma arvore gigante, e immensamente copada, tendo as folhas redundas, do alto Rio Branco, no Grão Parí. (Vid. Barrigada e Paineira.)

\section{USOS MEDICINAES}

Os espinhos ralados, e desfeitos em pouca agua, diz o Dr. Lacerda, e lançada a agua nos o!hos, cura as nevoas e belides.

Sururuca. (Bigonia hirtella.)-E' um pequeno arbusto, conhecido nas provincias do Norte pelos hervanarios.

\section{USOS MEDICINAES}

o cozimento da planta, é empregado para curar a diarrhéa chronica.

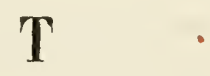

Tabibya.-E' uma arvore notavel pela levesa do seu lenho, que apenas serve para o fabrico de rolhas, e boias. 
Taboca, ou taquara, ou canna brava do matto. - E' uma graminea que regeta nos mattos, mui conhecida de todos.

\section{USOS MEDICINAES}

A raiz tomada em cozimento, é aperitiva; e tomado o cozimento em banhos aproveita na hydropesia.

USOS NA INDUSTRIA

Os fogueteiros servem-se dos gomos da taboca, para o fabrico dos foguetes e buscapís. Os camponezes fazem com as tabocas cercas mui seguras, com que preservam as plantaç̃̃es dos animaes.

Tabua. (Eschynomene.)-E' planta que produz nos logares e terras demasiadamente humidos, sahindo the as folhas do chão até duas varas de comprimento.

USOS MEDICINAES

o cozimento das folhas da tabua verde, é emoliente.

\section{USOS NA INDUSTRIA}

A là serve para encher colchões, e travesseiros, e é mais fresca que a da barriguda. Com as folhas fazem-se esteiras para cama, e suadores ou cochim das cangalhas para animaes.

Taioba. (Arum esculentum.) - Planta cultivada nas hortas, e indigena, mui conhecida de todos, cujas folhas se parecem com as do tinhorão.

\section{USOS MEDICINAES}

0 cozimento das folhas, é emoliente. A raiz quente debaixo do rescaldo, e bem pisada, faz desinchar as partes, onde a cobra mordeu. A raiz mata os bichos das bicheiras dos animaes, e destróe as carnes podres, promovendo a cicatrisação.

USOS CLLINARIOS

Com as folhas preparam nas cozinhas, excellentes pratos de hervas de alimentação sadia.

Taipoca pinho.-Arvore de 25 palmos de altura, com um e meio de diametro. Floresce em Agosto. 
USOS MEDICINAES

Não são conhecidos.

USOS NAS ARTES

o lenho serve para taboado de forro dos tectos das casas.

Taipoca assú.-Arvore de 40 palmos de altura, com 2 de diametro. Floresce em Agosto.

USCS MEDICINAES

Não são conhecidos.

\section{USOS NAS ARTES}

O lenho d'esta arvore, serve para taboado de forro.

Tajá.-E' uma tubera, conhecida no Pará, de que falla - Dr. Lacerda, cheia de succo branco e viscoso, muito usada para neutralisar o veneno das cobras, e curar as picadas da arraia.

Tamareira. (Phcenix daclylifera.)-E' uma palmeira da Asia, e da Africa, acclimatada no Brasil; onde prospera, e dá fructo do tamanho do cajá, côr escura, polpa doce, e caroço pequeno.

USOS MEDICINAES

o cozimento do fructo passado, é emoliente e peitoral, e serve nas defluxões catarrhaes.

$$
\text { USOS ALIMENTICIOS }
$$

0 fructo é comestivel, e muito apreciado.

ramarindo ou Tamarindoiro. (Tamarindus indica.)-Arvore de 40 á 50 palmos de altura, com 2 á 4 de diametro. Floresce em Novembro, pertencente á familia das leguminosas. o seu fructo é acido, e comestivel.

\section{USOS MEDICINAES}

Tem uso nas pharmacias por ser laxativo. E' anti-febril. applicado em limonadas; mas o abuso é prejudicial, porque os tamarindos atacam as hemorrhoidas.

\section{USOS NAS ARTES}

o lenho d'esta arvore, serve para as obras de construcção de casas. 
r Tambahyba,-Arvore de 60 palmos de altura, com 2 a 4 de diametro. Floresce em Setembro.

USOS MEDICINAES

o seu lenho, que é durissimo, ondeado de preto e amarello, serve para obras de moldura e marchetaria, e tambem para o fabrico de bonita mobilia.

USOS NA INDUSTRIA

Pode.se da madeira extrahir tinta azul escura, propria para a tinturaria.

Tambotojá. (Caladium.)-E' planta conhecida no Maranhão, e Pará, com prestimos em medicina domestica.

\section{USOS MEDICINAES}

o povo emprega as folhas, externamente, para curar as obstrucções do figado e baço.

Tambor. (Mimosa carunculata.)-Arvore da provincia das Alagôas, conhecida pelo nome de páo de tambor, pertencente á familia das leguminosas.

\section{USOS MEIICINAES}

Não são conhecidos.

\section{USOS NAS ARTES}

o lenho d'esta arvore, é mui leve, branco, e empregado em obras que exigem madeira leve, e por isso é procirada a madeira, para o fabrico de zabumbas e caixas de guerra.

Tamboril, tamb=im, tambers, timburi. (Mimosa.)-Arvore que vegeta nos terrenos seccos, e o seu fructo parece com uma orelha.

USOS MEDICINAES

O cozimento da entrecasca dado em clyster, é approvado remedio, para curar as hydropesias, opilações, e cachexias. Tem-se visto hydropicos radicalmente curados, com a casca d'este maravilhoso vegetal. o extracto tem o mesmo prestimo.

USOS NAS ARTES

O lenho la arvore serve para varias obras de construcção civil. 
Tamearana ou caa-jassara, ou tamiarana. (Dalecampea brasiliensis.) - E' uma urtiga, trepadeira, mui conhecida nas Alagôas, que se tocando n'ella, comicha excessivamente a pelle, levantando vergões. Não tem emprego conhecido na medicina vulgar.

rametarana ou Tamutarana,- Arbusto pequeno, que não excede de 2 palmos de altura, de folhas largas e compridas, em proporção, imitando as da bananeira. Produz nas raizes, pequenas batatas, umas redondas, e outras compridas, muito brancas, conhecidas pelo mesmo nome da planta.

\section{USOS MEDICINAES}

As batatas são mui proveitosas, para quem padece de dôres de peito, e deita sangue pela bocca.

ranchagem. (Plantago major.)-Planta vulgar, e geralmente conhecida, de fulluas largas, e floresce em espiga. Gosta dos logares humidos.

\section{USOS MEDICINAES}

O cozimento da tanchagem dado á beber, é bom remedio para quem deita sangue pela bocca. Applicada em banhos, serve para inchações das pernas, e para lavar as feridas chronicas. Serve o seringatorio feito com o cozimento, para curar as feridas uterinas. Reduzida a pó, é empregada no curativo das ulceras de máo caracter pulverisando-as.

ranģara-assú, ( Palicurea officinalis.)--E' planta vulgar nas provincias do norte do Brasil.

\section{Usos MEdicinaES}

o cozimento das folhàs, serve para curar o rheumatismo. Tambem usam em forma de chá, internamente, para o mesmo fim.

Tange tange, ou brincos de viuva ou cascavol. (Lupinus unijugata.)-E' planta muito vulgar, pertencente á familia das Jeguminosas, cujos fructos são vagens redondas, com sementes soltas dentro, em modo que, sacudindo-se a vagem, produz o ruido da cobra cascavel, quando anda, e sacode o rabo. 


\section{USOS MEDICINAES}

0 cozimento é empregado em banhos no rheumatismo.

Tapanhune.-Arvore de 60 palmos, com 2 á 3 de diametro: Floresce em Outubro.

\section{USOS MEDICINAES}

Não são conhecidos.

\section{USOS NAS ARTES}

o lenho d'esta arvore, serve para obras de architectura civil.

Taperibá.-Planta do Pará, empregada em medicina domestica.

\section{USOS MEDICINAES}

O cozimento da casca e grelos d'este vegetal, cura a inchação erysipelatosa dos pés; o sumo dos grelos passados pelo sereno durante a noite, e posto com pena de gallinha dentro dos olhos, cura a inflammação d'esses orgãos.

raporoá.-Arvore das mattas da Bahia, de 50 palmos de altura, com 2 e mais de diametro. Floresce em Outubro.

\section{USOS MEDICINAES}

Não são conhecidos.

USOS NAS ARTES

Serve para vigotas e frechaes de casas.

Taperoba.- Arvore das nossas florestas, conhecida dos derrubadores.

\section{USOS MEDICINAES}

o cozimento da casca d'este vegetal, é mui proveitoso para as inchações dos pés, rnas convém que o cozimento esteja morno, e haja demora na immersão dos pés enfermos.

Tabexiriba. - E' planta do Maranhão, e Pará recommendada pelo Dr. Lacerda, para curar as escrophulas.

\section{USOS MEDICINAES}

As folhas passadas pelo rescardo, pisadas, e ainda quentes, esfregando-se com ellas as escrophulas as resolve. 
rapiá ou 'Trapiá. (Cratceva tapic.)-E' uma arvore fructifera, silvestre, conhecida nas Alagóas, que tem emprego em medicina domestica.

\section{USOS MEDICINAES}

O cozimento das folhas d'esta arvore, dado em banhos mornos, ê muito efficaz nas dores rheumaticas e gottosas.

\section{USOS NAS ARTES}

O lenho serve para diversos usos na carpintaria.

Tapicurá.-Arvore das nossas mattas, que produz em qualquer terreno á excepção dos agrestes. Floresce e fructifica.

USOS MEDICINAES

o oleo do fructo que è aromatico, serve para fricções no rheumatismo.

USOS TAS ARTES

o lenho da arvore serve para diversas obras de construcçăo civil.

Tapinhoã.-Arvore de 60 palmos de altura, com 2 á 6 de diametro. Floresce em Setembro

USOS MEDICINAES

Não são conhecidos.

USO NAS ARTES

o lenho da arvore serve para forros dos navios, e para a fabricação de toneis de aguada.

'Tapyra-picú ou herva grrossa. (Tapiria.)-E' planta conhecida dos hervanarios, e procurada em medicina domestica.

\section{USOS MEDICINAES}

o cozimento da fructa, é empregado para curar a inflammação chronica do figado. Tambem servem-se do cozimento, para curar as ulceras das pernas e dos pés.

Taquara e Taquarassí. (Bombuza.)-A taquara é uma taboca gigantesca, de 6 á 9 metros, da Asia, e da America meridional, que produz nas mattas do Brasil. O taquarussú 
é ainda maior, e tem os gomos mais espaçosos, assım como de maior diametro, podendo conter em seu interior uma canada de liquido.

USOS NA INDUSTRIA

A madeira d'esta planta, presta-se para diversas obras de arte, e c smo são mui conhecidas as que são feitas pelos chins e indigenas do Brasil as não menciono.

'Taquary.-E' um arbusto cujo caule ou haste é ôco, e formada de nós, como a taboza, e a taquara. O taquari das Alagôas, tem o tecido da haste mais consistente, e por isso empregam o gomo, para o bico ou pipo de seringa, no uso de clysteres. Os animaes comem as folhas do taquari; mas dizem que o uso prolongado e exclusivo d'esse genero de alimento, não é conveniente por causar doença aos animaes.

Tararanga.-E' arvore de mediana grandeza, cujos fructos, semelhantes á grumixima, são pelludos, roxos e saborosos.

\section{USOS MEDICINAES}

Não são conhecidos os seus prestimos em medicína vulgar.

\section{USOS NAS ARTES}

O lenho d'esta arvore, serve para as obras de casas.

Tareroquig.-Arbusto indigena, com folhas aromaticas, semelhantes ás da alfavaca, ramos delgados, cujas flores vermelhas, tirando á roxo, apparecem nas puntinhas dos ramos. Esta planta tem a particularidade de murchar durante a noite; e em nascendo o sol, torna a abrir. E' singular este phenomeno; parece que a planta teme a escuridão da noite, porque só se conserva aberta, com a presença da luz do sol.

\section{USOS MEDICINAES}

E' carminativa. Os Indios, quando adoecem, se perfumam com esta planta, por crerem, possuir ella virtudes antiputridas. Curam com ella as camaras de sangue.

Os sertanejos servem-se do succo de toda a planta, para destruir os bichos dos bois, e dos porcos. 
Tariloiqui.-E' planta indigena, conhecida dos hervanarios das provincia do Norte do Brasil.

USOS MEDICINAES

o cozimento feito com as folhas d'esta planta, é empregado em banhos para curar a paralysia; e o cozimento da raiz, dado a beber, faz desmanchar os tumores internos.

Tatagiba ou Tatojuba ou espinheiro bravo. (Broussonetia tinctoria.) - Arrore lactifera das mattas do Brasil, de fulhas palmadas, ovaes, e de côr verde gaio, tendo a casca cinzenta.

\section{USOS MEDICINAES}

o leite que se tira da casca, passa po: especifico remedio contra as dores de dentes.

\section{USOS NAS ARTES}

A madeira é empregada na construcção civil e naval.

USOS NA INDUSTRIA

Extrahe-se do lenho d'esta arvore, uma excellente tinta amarella, propria para a tinturaria.

Tatú-Arvore de igual dimensão e prestimos que o tucahem: floresce em Setembro.

Tatú. (Eugenia axilaris.) - No Rio de Janeiro conhece-se uma planta pelo nome de Tatri, empregada em cozimento, como adstringente, para curar a diarrhéa chronica, dando-se em clysteres .

Tatuapeca.-Arvore de 50 palmos de altura, com 2 e mais de diametro: floresce em Setembro.

\section{USOS MEDICINAES}

Não são conhecidos.

\section{USOS NAS ARTES}

O lenho d'esta arvore, que é compacto, serve para vigas, e obras de construcção de casas.

Tayuyá ou abobora do matto. (Trianosperma tayuyá.) - 0 tayuyá é um cipó tortuoso, de follias cordiformes, alternas e pontagudas, o qual produz uma batata, cuja vir- 
tude é assás purgativa. No tomo $3^{\circ}$ da Revista Kedica Fluminense de 1837, a pag. 236, e seguintes vem uma memoria com a analyse chimica, feita pelo pharmaceutico João Maria Soullié, apresentada á sociedade de medicina do Rio de Janeiro em 23 de Junho de 1832, a respeito do tayuyá, e para ella envio o leitor.

\section{USOS MEDICINAES}

O povo nos sertões, empregam o tayuyá, para curar a hydropesia, o rheumatismo syphilitico, o pleuriz, quédas, erysipelas, etc.

Ha diversas qualidades d'esta planta, distinctas por seus caracteres, sendo as principaes: $1^{2}$ a que tem as folhas muito recortadas, e o fructo semelhante á pimenta cumari, amarellado com pintas verdes; a $2^{a}$ tem as folhas mais recortadas, e o fructo comprido e encarnado; $3^{\text {a }}$ tem as folhas mais asperas, e o fructo tres abobrinhas como quiabos. Esta planta é admiravel por suas virtudes medicinaes.

Teín. (Jatropha opifera.)-Planta indigena e medicinal. LSOS MEDICINAES

A raiz é purgativa, e empregada para curar a hydropesia. Tambem servem-se d'ella, contra o veneno das cobras.

Teju-kahim, ou pimenta de lagarto.Planta conhecida no Maranhão, e Pará, foi empregada pelo Dr. Lacerda em medicina domestica.

\section{USOS MEDICINAES}

o cozimento serve internamente para provocar os suores, combater a diarrhéa, e expellir os vermes intestinaes.

Temboratú. (Zanthoxylum langsdorfi.)-Planta da familia das rutaceas, aromatica, e de gosto amargo acido.

\section{USOS MEDICINAES}

O cozimento da casca serve para curar as dores de dentes, e dos ouvidos, banhando-se as partes doidas com o cozimento.

Tento.-Arvore de 50 palmas de altura, com 2 de diametro: floresce em Setembro, dando sementes encarnadas e mui Juzidas, que servem para tentos. 
LCOS MEDICINAES

Não são conhecidos.

USOS NAS ARTES

o lenho d'estai arvore serve para construcçĩo civil.

roosinte. (Keana luxurians ou Tripsacum monostachyum.) - o teosinte é uma graminea (1) oriunda da republica d• Guztemala, d'onde foi importada para o Chile, e do Chile para o Brasil em meiados de 1868, pelos cuidados do Sr. João Antonio Rodrigues Martins, consul geral do Imperio na mesma republica. E' uma graminea mui parecida com o milho; reproduz-se por meio de sementes, e, crescendo mais lentamerte do que o milho, attinge a grande altura. A touceira fórma numerosos rebentos nas raizes, que podem ser transplantados, calculando-se que cada touceira, póde alimentar diariamente um boi. No Chile, como em Guatemala, o Teosinte, passa por ser uma planta de forragem sem rival; offerece um alimeito tão nutritivo quanto o milho verde e superior á alfafa. E', além d'isso planta ornamental, pelo seu fecundo desenvolvimento e formoso porte.

Foi primeiramente notada esta rica graminea pelo Dr. Julio Rossignon, de Guatemala, que, communicando as suas observações á Sociedade de Acclimação de Pariz, foi distinguido com varias manifestações, entre ellas uma medalha honorifica. A planta acclimou-se em alguns pontos da França, dando resultados sorprenhendentes pela sua prodigiosa fecundidade.

Quanto á época da sementeira, da transplantação e dos córtes, poderá ser util aos nossos agricultores auxiliarem a sua experiencia com as seguintes indicações, que se deparam no Mercurio, de Valparaiso:

« Sementeira,-Havendo pouca semente, convém fazer sementeiras em logares abrlyados, semeando em Agosto, Setembro ou Outubro. Os grãos devem ser collocados á distancia de 5 á 10

(1) Mrs. Merat e De Lens, nĩo fallam d'esta graminea, e por isso transcrevo o que o Jomal do Commercio publicou, para utilidade dos agrricultores. 
centimetros um do outro, em terra solta e arenosa, e enterram-se de um á dous centimetros. A réga deve ser escassa, conservando-se fresca a terra, mas evitando-se que encharque. A germinação effectua-se, conforme a temperatura, em 10, 12 ou 15 dias.

"Transplantação. - Em chegando os colmos á um ou dous decimos de altura, faz-se a muda para o terreno, dispondo as filas parallelas, separadas entre si por um metro. Enterra se a planta do mesmo modo, como estava na sementeira.

«Cortes. - Quanto a planta tem colmos que attingem a dous metros de altura, effectua-se o primeiro córte, para obter da cepa outros e mais numerosos renovos. A graminea brota tão depressa que, se o primeiro córte é feito em Fevereiro, logo em Abril é necessario fazer outro. No segundo anno, e bem assim nos posteriores, pódem fazer-se tres córtes. De cada córte sahe a forragem para os animaes. As aves domesticas, alimentam-se bem com os grãos.»

Sr. A. Lietze diz ter recebido do Cairo, a 11 de Março de 1878, sementes de Teosinte, as primeiras que d'essa região chegaram ao Brasil. D'ellas obteve o Sr. Lietze em segunda geração plantas de niais de 7 metros de altura, tendo distribuidas a fazendeiros, e a outras pessoas, sementes da gigantesca graminea.

As sementes vindas do Egypto, differem pelo aspecto das importadas do Chile; são brancas, tirando a pardo, emquanto estas sĩo escuras. Entende o Sr. Lietze, que o Teosinte de Guatemala é uma variedade menos vigorosa que o do Egypto, e assegura-nos que a definitiva denominação botanica da planta é Euchlaena luxurians.

Tetipoteira. (Nitis arbustina) - Planta brasileira, descripta por Pison.

\section{USOS MEDICINAES}

o cozimento feito com esta planta, e dado a beber é fortificante, resolutivo, e empregado para curar a hydropesia.

Timbauba.-E' arvore brasileira, pertencente á familia das leguminosas, e conhecida dos derrubadores. 
USOS MEDICINAES

Não são conhecidos.

USOS NAS ARTES

O seu lenho serve para as obras de construcção civil.

Timbó ou cipó cumarúapó. (Tupy) Paulinea pinatc.) -0 timbó, è uma planta muito conhecida nas Alagôas, Pernambuco, e em outras provincias do Brazil.

O succo é um veneno acre.

\section{USOS MEDICINAES}

As propriedades medicas do timbó, são resolutivas; externamente empregado serve para combater a inflammação chronica do figado, e do baço. Internamente é anti-febril, e serve para curar a hypochondria, a alienação mental, e outras molestias do systema nervoso. Serve para curar a hydropesia, as molestias do utero, os tumores glandulares, apostemas. A tintura é preferivel a catlaplasma.

\section{USOS NA INDUSTRIA}

Machucando o timbó, e posto nos rios e lagos, embebeda o peixe. As hastes servem para o fabrico de vassouras.

D'esta planta se extrahe tinta vermelha, propria para a tinturaria.

Tiborna. (Plumeria drastica.)-Planta leitosa, e couhecida dos hervanarios, e com emprego em medicina domestica.

\section{USOS MEDICINAES}

o succo leitoso da planta, serve para curar as febres intermittentes, a ictericia, e obstrucção do figgado e baço; e contra os vermes intestinaes. A casca secca d'esta planta, é purgativa.

'Timbuhyba.-E' arvore das mattas do Brasil, cujo lenho serve para construcçĩo civil e naval.

ringoassi-uba (Zanthoxylon tingoassi.)-Arrore de construcção, cujo lenho é amarello.

\section{USOS MEDICINAES}

O cozimento das folhas dado em banhos, serve para curar o rheumatismo. 
Tingui ou 'Tinguin. (Lapinus cascavella.)--E' um cipó ramoso, muito conhecido nas Alagôas, e nas demais provincias do Norte.

\section{USOS MEDICINAES}

o Dr. Lacerda, do Maranhão, diz que este cipo, pisado, na quantidade de 5 libras, e feito cozimento, e com elle dando-se banhos aos enfermos de boubas, as cura perieitamente. Os banhos devemser tomados, antes da conjuncção da lua nova. O Dr Lacerda affirma que no Maranhão e Pará, usam do banho do tingui, como preservativo das boubas. 0 banho do cozimento serve tambem para curar as sarnas.

USOS NA INDUSTRIA

o tingui posto nos rios e lagos onde ha peixes, os embebeda e mata.

Tinhorāo. (Arum bicolor.)-Planta herbacea, vivaz, muito conhecida nas Alagôas, Pernambuco, Maranhão e Rio de Janeiro. F' uma modificação da tayoba ; e o mercurio dos sertões.

o bôlbo ou batata, é succulento, acre, e rezinoso.

\section{USOS MEDICINAES}

o cczimento das folhas tomado em gargarejos, cura as anginas, e dores de dentes.

A batata é venenosa, e mata os animaes; bem como os bichos das bicheiras, raspando-se a massa da batata, e introduzindo n'ellas.

A planta secca e reduzida a po, e pulverisada as feridas velhas, as cura perfeitamente. 0 succo das folhas è purgativo.

ripi ou pipi, Iaxatacaca ou para-acaca. (Petiverea aliacea.)-Arbusto fetido, mui vulgar nas Alagôas, e conhecido em todo o Brasil.

\section{USOS MEDICINAES}

O cozimento de toda a planta é empregado em banhos, nas febres intermittentes, na occasião dos frios. E' mui proveitoso nas dores e inchaçoes, causadas pelos resfriamentos, no rheumatismo, e na paralysia.

A raiz feita chá, toma-se, para curar a hydropesia, por ser excessivamente diuretica. Tambem empregam o chá do Tipi, para 
o curativo das molestias nervosas. As folhas pisadas e postas sobre a mordedura da cobra, neutralisa-lhe o veneno. 0 povo diz que o Tipi, tem virtude antipathica contra o maleficio.

Tiririca.-E' uma planta semelhante ao capim assú que vegeta em qualquer terreno: é conhecida dos agricultores. Quando apparece nos jardins, torna-se o flagello das plantas, e para fazel-a desapparecer convém tiral-a com a raiz.

USOS MEDICINAES

A raiz da tiririca de folha miuda, cozinhada e tomada em fórma de chá, com ou sem assucar, é proveitoso remedio para curar as gonorrhéas.

'Nitara (Euterpe sarmentosa.)-E' uma especie de palmeira, trepadeira muito abundante nas Alagôas e no Pará.

\section{USOS MEDICINAES}

O oleo do coquinho da titara, serve para o rheumatismo. USOS NA INDUSTRIA

Com as vergonteas fazem os curiosos balaios e cestos.

'Tiú. (Adenoropium opiferum.)-E' uma planta da familia das euphorbiaceas, e uma varíedade do pinhão.

\section{USOS MEDICINAES}

Em Minas, S. Paulo, e pelos sertões empregam esta planta como purgativo, para curar a hydropesia, a ictericia, e as obstrucç̃es do figado e baço.

Touca de viuva (Petroa volubilis.)-Planta trepadeira, pertencente á familia das verbenaceas, que dá flores de côr purpurea.

\section{USOS MEDICINAES}

A infusão d'esta planta provoca os suores.

Topinambor ou topinambá. (Hitianthus tuberosus.)--Planta brasileira, conhecida nas provincias do norte, de folhas asperas, sendo as raizes tuberas ou batatas roxas, ou amarellas por fora, e brancas por dentro. As batatas, comem.se cozid:us, ou assadas. Dadas ás vaccas e ovelhas augmentam-lhes o leite, As folhas seccas misturadas com o capim, engordam muito os cavallos $\theta$ as mullas. 
Tocajé. (Rupala.)-Planta trepadeira, do interior das provincias do norte do Brasil.

\section{USOS MEDICINAES}

A raiz reduzida a pó, e tomada uma colherinha desfeita n'agua, é o melhor hemostatico que se conhece, para suspender as hemorrhagias, principalmente as uterinas.

Tomate. (Solanum lycopersicum.) -0 tomate é o fructo do tomateiro, mui conhecido e apreciado por ser um excellente tempero para as comidas.

\section{USOS MEDICINAES}

o tomate applicado sobre os callos, os destroe; applicado sobre o panaricio o resolve.

\section{USOS NA INDUSTRIA}

A industria faz doce do tomate, e boa conserva, para uso das comidas.

Tucahen.-Arvore de 50 palmos de altura, com dous de diametro: floresce em Agosto.

\section{USOS MEDICINAES}

Não são conhecidos.

\section{USOS NAS ARTES}

O lenho d'esta arvore serve para as obras de architectura civil.

Tucum au tucuma. (Bactriz maroja) - E' uma palmeira brasileira conhecida nas Alagôas, pelo nome de tucum, e nas provincias do norte pela denominação de tucuna. 0 fructo come-se.

\section{USOS MEDICINAES}

Os caroços do tucum queimados, e reduzidos á pó, e misturados em agua, e depois de coado, dado a beber, é bom remedio contra a dysenteria de sangue.

\section{USOS NA INDUSTRIA}

O fructo do tucum fornece azeite, semelhante ao de dendé, proprio para a industria.

Os caroços servem para o fabrico de anneis, ponteiras e castóes 
de bengalas As folhas dão linho, e servem para o fabrico de balaios, cestos, abanos, chapéos e outros artefactos.

roucuman. (Pará.)-Planta do Pará, empregada em medicina domestica.

\section{USOS MEDICINAES}

o cozimento feito com esta planta, é emoliente e calmante, e usado em banhos nas inflammações e dôres nos olhos. O Dr. Lacerda diz, que pingando-se o sumo da planta, muitas vezes ao dia, no olho doente, cura a inflammação.

Tuxiá.-Planta do Pará, mui apreciada do Dr. Lacerda.

\section{USOS MEDICINAES}

As folhas do turiá infundidas em agua fervendo, e tomadas em forma de chá, é proveitoso medicamento para combater a asthma.

Turuman.- Arbusto indigena, de folhas pontudas, conhecido dos hervanarios da provincias do Norte.

\section{USOS MEDICINAES}

O chá feito com as folhas d'esta planta, goza da propriedade de desfazer as pedras na bexiga:

'Turury. (Arvore do panno.)-E' uma arvore brasileira magestosa, cuja tona é forte e destensivel. Extrahe-se das diversas especies d'esta arvore, um quasi panno natural. Os indios servem-se d'elle, para seus vestidos, que são de uma só peça, e sem costura. Tambem os indios empregam o panno do Turury, para fazerem ccbertores.

'Trapemonga. - E' uma herva do paiz, conhecida dos hervanarios.

\section{US OS MEDICINAES}

Os camponezes, servem-se d'esta planta secca, e reduzida a pó, para curar as feridas velhas, e de máo caracter.

Trapiá. (Cratcera trapiá.)-Arvore de mediana grandeza, das mattas das Alagóas e Pernambuco. Floresce e fructifica. 


\section{USOS MEDICINAES}

As folhas e a casca feitas cozimento, e dado em banhos, serve para curar o rheumatismo syphilitico.

Trapiá caustica.-Arvore de mediana grandeza, mas corpulenta: vegeta nos terrenos seccos e ingratos.

\section{USOS MEDICINAES}

As folhas d'esta arvore pisadas são poderoso caustico, e postas assim sobre as gommas (exostosis), as resolve em pouco tempo.

Trapo. (Evonymus aglomeratus.) - E' um cipó espinoso, trepador, que vegeta nas Alagôas, e Pernambuco.

USOS MEDICINAES

Não são conhecidos.

\section{USOS NA INDUSTRIA}

Os matutos e tropeiros servem-se das vergonteas d'esta planta, para bôas chibatas de tosar os animaes em viagem.

Trapoeiraba ou marianminha. (Tradescantia diurectica.) - Planta vulgar, e conhecida de todos, que vegeta nos lugares humidos.

\section{USOS MEDICINAES}

O cozimento dado em banhos e em clysteres, aproveita no rheumatismo. Tomado em forma de chá, é excellente remedio para. combatel a retenção espasmadia das ourinas. Usam tambem d'esta planta, para curar as hemorroidas, e a hydropesia. O succo fresco da trapoeiraba, posto sobre os dartros, applaca a cuceira; e o banho feito com o cozimento da planta, serve para curar as saruas.

'Tres ix.mäos. (Schmidelia salpicarpa.)- E' uma planta das Alagôas, conhecida do povo, e empregada em medicina domestica, para curar as dôres nervosas do rosto e da cabeça.

Tros lolinas. (Cesla aromatica.)-Arvore das mattas das provincias do Rio de Janeiro, e Minas-Geraes, descripta pelo naturalista Fr. José Mariano da Conceição Vellozo.

USOS MEDICINAES

A casca d'esta arvore, como é muito amarga e adstringente. serve para combater as febres intermittentes. 
rrồo d'agua. (Oxalis repens.)

USOS MEDICINAES

E' anti-escorbutico.

rrôvo de cheiro. (Pleurantha odorata.)

\section{USOS MEDICINAES}

Serve para neutralizar o virus das picadas dos insectos venenosos.

Trêvo de boi..- Planta conhecida no Pará, estudada pelo Dr. Lacerda.

USOS MEDICINAES

o cozimento é empregado em forma de chá na hydropesia, por ser mui diuretico. Dado em banhos, aproveita nas hemorrhoidas; e em clysteres, resolve e abranda as hemorrhoidas.

rrovo de folna minada.-E' planta conhecida e vulgar.

No Pará, diz o Dr. Lacerda, è tomado em chá contra o pleuriz. Externamente, empregam-no frito em azeite, e applicam sobre a dôr pleuritica.

Trombeta azul ou rosa paquête. (Convolvulus.)-E' planta de jardim que não tem emprego em medicina domestica.

Trombeteira branca. (Datura arborea.)

\section{USOS MEDICINAES}

As folhas seccas, feitas cigarro, e fumadas, é proveitoso remedio para a asthma.

As folhas da trombeteira roxa, têm o mesmo prestimo.

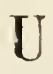

Uapé jacaná. (Victoria regia.)-E' planta aquatica dos lagos do Amazonas, sendo a maior nymphea, que se conhece. 
Suas folhas têm de 15 á 18 pés de circumferencia; e as suas flores de delicioso perfume, alvissimas quando abertas ao cahir da noite, tem de 3 á 4 pés de circumferencia; dão sementes mui feculosas, que os indios comem-nas com prazer, por serem mui saborosas.

\section{USOS MEDICINAES}

Não são conhecidos.

Uaperinguassír.-E' arvore do Amazonas.

USOS MEDICINAES

Não sĩo conhecidos.

USOS NA INDUSTRIA

Os Indios servem-se da entrecasca d'esta arvore, para fabricarem camisas e tangas.

Ubá.- Ubá canna brava, é planta indigena, e conhecida.

USOS MEDICINAES

o cozimento da raiz, é empregado interna e externamente (em banhos), como excitante, e diuretico.

USOS NA INDUSTRIA

Fazem com as hastes desta planta, cestos e balaios, e tambem servem para flexas de foguetes.

Ubaia ou canna do brejo. (Costus spicata.)-Esta planta mui conhecida, vegeta em logales humidos, e é mui estimada por suas virtudes medicinaes.

\section{USOS MEDICINAES}

0 cozimerto feito com a planta é mui proveitoso aos que padecem das ourinas, dado internamente, adoçado com assucar refinado. Tambem aproveita nas leucorrhéas, não só bebido, como usando em injecções.

Ubalan.-E' um arbusto, que se encontra por todas as mattas do Brasil.

USOS MEDICINAES

O cozimento feito com esta planta, é approvado remedio contra a diarrhéa. 
Ubatinga ou sambaubana.-E' uma arvore do Maranhão, copada, direita, abrindo em cima em ramos, com folhas largas, que servem de lixa para alisar objectos de uso, e produz fructos, como uvas de videira, um pouco compridinhos, ou semelhantes a azeitonas pretas, cobertos de pellos quasi louros.

\section{USOS MEDICINAES}

Distillado o fructo maduro d'esta arvore, e dado a beber na quantidade de duas onças, quatro vezes ao dia, por algum tempo, cura a tisica pulmonar; guardando o enfermo por cinco ou seis mezes a dieta conveniente.

\section{USOS NAS ARTES}

O lenho serve para diversas obras, e a folha secca é empregada, para lixa, pelos marcineiros.

Ucuúba ou Ucauba. (Myristica sebifera.)-Arvore brasileira, mui conhecida, que vegeta no Pará, e Amazonas, frondosa, pertencente á familia das myristicaceas, de 50 á 60 palmos de altura, e de 2 á 3 de diametro, produz fructos do tamanho de uma goiaba pequena. O Sr. Barboza Rodrigues, referindo-se ao que publicou o Diario do Grão Pard, a respeito da importancia da arvore da Ucauba, que vegeta nas margens do rio Guamá, e de cujo caroço se extrahe cèra, que, preparada em velas, dí melhor luz, e muito mais barata, que a do espermacete, dirigio ao Jornal do Commercio uma noticia circumstanciada d'esta arvore, dizendo.

"Com a epigraphe Uma riquesa do Paíd. deu o seu jornal noticia de uma fructa conhecida por ucauba, da qual extrahe-se do caroço cêra para velas, que abrio-me ensancha para d'ella dizer alguma cousa. Antes, devo dizer que o seu verdadeiro nome é ucauba, isto é, arvore de grassa ou céra-de ucu, graxa, e $y b$, arvore.

* Com este nome, no Pará se confundem duas especies distinctas que, posio que muito semelhantes no porte, que é elegante, se não confundem pelo tamanho di folha, não tratando dos caracteres botanicos. Uma é da região costeira da foz do Amazonas, crescendo nos logares alagados e humidos, é a myristica surinamensis Rol; a outra, a myristica sebifera Swartz, 
que se estende pelo Baixo Amazonas, crescendo, esta tem as folhas grandes e aquellas pequenas.

* E' uma arvore de 10 a 15 metros de altura, de casca grussa, cinzenta externamente, que, ferida, distilla um liquido transparente e avermelhado. As folhas são oblogo-lanceoladas, agudas ou acuminadas e peccioladas. A inflorescencia é em panicular terminal, e axillar menor do que as folhas.

- Os fructos são carnosos, dihiscentes, abrindo-se em duas valvulas, que na maturidade lançam ao chão as sementes cobertas por um arillodio vermelho, que, cupiliforme na base, torna-se dilacerado para cima. semente tem o albumen como que roido (rumianta), e oleoso. Em Março e Abril encontram-se os fructos maduros.

* Posto que não seja uma arvore social, comtudo é muito abundante, principalmente pela margens dos jgarapés e dos furos.

- A colheita dos fructos é difficil, porque sendo elles pequenos, dando á grande altura, sú se podem apanhar, á medida que cahem. Geralmente se espalham e se enterram na lama dos terrenos, porém como no Amazonas a natureza sempre previne as necessidades de seus filhos; as marés se encarregam de ajuntar as sementes e deposital-as pelas praias, onde o natural vai encontral-as na vasante, em grande quuntidade, já despidas do arillodio e por conseguinte, ja preparadas para a extracção da cêra. Estas sementes um pouco aromaticas, como a noz moscada, além de um oleo ethereo, o da materia cellulosa, tem quasi $50 \%$ de stearina. Em geral 45 a 50 litros de sementes, dão 15 kilos de cêra, quando bem apurada. Apezar, porém, d'essa riqueza, poucos se occupam de fabricar a cêra, a não ser para uso proprio.

* A cêra queima dando uma chamma branca-azulada, bastante forte. Os pescadores quando vão á pesca, á noite, costumam alumiar as paragens com as sementes bem seccas, espectadas em um pio, as quaes ardem por muito tempo, com linda chamma.

* O processo da extracç̃o da cêra, pelo methodo indigena, consiste em privar as sementes do arillodio, deixar secal-as bem, e depois de bem pisadas em um pillão, ferver a massa em uma 
vasilha com agua. A' medida que a fervura augmenta, o oleo vai subindo á tona d'agua, e com uma colher, é retirado para outra vasilha. Extrahida assim toda a parte oleosa, esta é apurada, e toma a consistencia de uma cêra sebacea pelo resfriamento.

* Não é só pelo lado industrial que se recommenda a ucauba, ella presta tambem grande auxilio á humanidade no allivio de seus soffrimentos.

* A medicina caseira, porque a official, essa so emprega as plantas da sua pharmacopia, tira grandes vant:xens na cura das colicas, e nas dispepsias, aproveitando-se das folhas em chá; as erysipelas são combatidas com o liquido que exuda da casca, e as feridas limpam-se e cicatrisam com lavagem do cozimento da mesma casca, que contém bastante tanino

* Por experiencia calculei a cêra extrahida, que preparei com sementes apanhadas nas praias do Carnapijo.

« Não ha muito ainda, informei a um respeitavel commerciante d'esta praça, alguma cousa sobre esta planta, e penso que breve uma fabrica se montará, para a extracção da cêra e fabrico de velas. *

\section{LSOS MEDICINAES}

A seiva leitosa que se obtem pela incisão, misturada no cozimento do camapú, serve para as hemorhoidas, embehida em algodão, e applicada a anus. o chá feito com as folhas, cura a dysenteria e a dispepsia. A seiva leitosa cura a erysipella, e limpa as feridas velhas, promovendo-lhes a cicatrisação. O cebo derrotido e applicado em fomentações, cura o rheumatismo.

USO NAS ARTES

O lenho serve para obras de pouca duração.

\section{USOS NA INDUSTRIA}

o fructo possue uma massa adipo-serosa, com a qual fabricam velas para luzes. As sementes contém oleo pingue; que se emprega em diversos misteres. Dos caroços conseguio o sr. Carlos Augusto Martins, muits bôa cêra para a fabricação de velas. Mr. Luis Leon Perreguey. estudou tambem a materia prima da ucauba, e conseguio fabricar finissimos sabonetes, dos quaes me offereceu um, para toucador de senhoras, superior ao que recebemos da Europa, iabricados com o sebo e azeite de diversas qua- 
lidades. Mr. Perreguey, obteve da casca, tratada pelo acido sulphurico excellente tinta carmesim propria para tinturaria.

A arvore dí excellente cinza, da qual se extrahe bòa potassa. A colneita annual da ucauba, póde dar 35 á 40 mil arrobas dos fructos, e convém que sc conservem as arvores existentes, e se promova a cultura a'ella, por ser um lucrativo ramo de riqueza nacional.

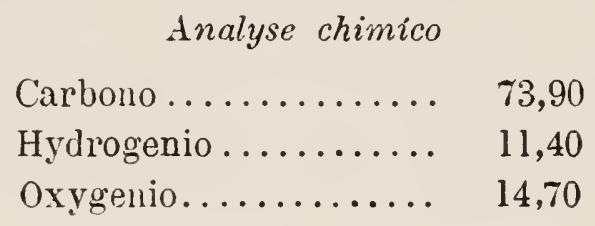

LERY.

Umari ou mari. (Groffroya umari.)-Arrore do Pará, pertencente á familia das leguminosas, a qual floresce e fructifica, sendo o seu fructo semelhante ao Oity da Praia, possuindo uma massa oleosa, doce e agradavel Ha 3 variedades d'esta arvore, distinctas pela côr da massa, sendo uma roxa, outra amarella e outra vermelha.

\section{USOS MEDICINAES}

A casca d'este vegetal, é um poderoso medicamento contra os vermes intestinaes; porém deve haver grande cuidado na dóse do medicamento, porque provoca vomitos, e largas dejecções. o melhor modo de se usar, é fazer o cozimento, empregando n'elle apenas 12 grammas de casca, para se ir tomando as colheres, com espaços, devendo-se evitar o uso da agua fria, durante a acção do medicamento.

Umbú, Imbú, Ambú. (Vid. Imbri.)-Já fallei d'esta arvore dos sertões e catingas do Brazil, e ainda accrescento que o umbuzeiro, começa a ramificar-se ao sahir da terra, sendo as suas folhas pequenas e envernisadas por ambas as faces. Floresce em Agosto, sendo o seu fructo muito estimado, por ser além de saudavel, de agradavel sabor entre doce e acido.

\section{USOS MEDICINAES}

O fructo é conveniente para tirar o fastio, por ser estomacal, e por isso dá-se aos convelescentes, e aos que padecem de i ctericia. 
Os olhos das folhas pisados com sal, e filtrado o sumo, serve para curar belides. Na raiz se encontra uma batata, que estando nova é doce, e tem a propriedade ante escorbutica. Dá excellente extracto. A raiz do umbú, é alimenticia pela sua doçura e succulencia. O succo do fructo, espremido no leite, forma um creme (umbuzada) delicioso.

USOS NAS ARTES

O seu lenho è branco, e se não faz uso d'elle.

USOS NA INDUSTRIA

O fructo do Umbú, dá vinho e licor de excellente sabor.

Umiri balsamo. (Humirium balsamifero.)-E' una arvore do Amazonas, pertencente á familia das meliaceas, que segrega uma resina aromatica, mui preciosa, para a perfumaria. obtem-se a resina, que é vermelha, incisando-se a arvore no tempo proprio.

Umir.i bastardo. (Trexandria elliptica.)-Arvore no Pará, que produz oleo, incisando-lhe a casca.

\section{USOS MEDICINAES}

o cozimento da casca, que é adstringente, tomado em gargarêjo, è excellente remedio para curar as feridas da garganta.

Unha de Anta. (Baukinea aculeata.)-Esta planta leguminusa, de folhas em palmas, e flores em cachos, é estimada por suas virtudes medicas.

\section{USOS MEDICINAES}

Os curandeiros do interior servem-se do cozimento d'esta planta, internamente em chá. e externamente em banhos, para curar a morphéa. Tambem a empregam contra a mordedura das cobras.

Unha de gato do littoral. (Solanum ruptor.)-Não são conhecidos os seus prestimos em medicina domestica.

Unha de gato do sortão. (Mimosa ungriscati.)E' planta da familia das leguminosas.

Não tem emprego em medicina domestica. 
USOS NA INDUSTRIA

O fructo dá tinta preta de escrever, e tambem propria para a tinturaria.

Urana on caruati.- Vegetal do Pará, usado pelos indios nas suas enfermidades.

\section{USOS MEDICINAES}

Os ramos da planta reduzidos a cinza, e posta em agua ferrada, e depois de mexido o liquido, bebido, desenvolve excessivamente as ourinas. Este famoso diuretico, foi descoberto em 1799, por um indio da nação carijó.

Uratacaca ou paracutaca. (Pará.)-Arvore corpulenta e frondosa, mui corıhecida no Pará.

\section{USOS MEDICINAES}

o fructo reduzido a pó, e bebido em agua morna, suspende as hemorrhagias.

U1 tiga cansassào, (Cuidoscolus pruriginosus.)-Já sobre esta planta, fallei, pertencente á familia das euphorbiaceas, e em additamento lembrarei mais algumas virtudes medicamentosas que possue.

\section{USOS MEDICINAES}

Toda a planta incizada ou quebrada extravasa leite clarissimo, cujo leite embebido em panno, e posto sobre a erysipella a cura. o cozimento feito com a urtiga cansassão, é mui proveitoso pira banhar a parte erysipellatosa, tendo-se o cuidado de enxugar a parte, e em seguida applicar o leite, e isto duas ou tres vezes ao dia; e logo que a vermelhidão desappareça, unte-se os logares com oleo de bicuiba morno, cobrindo-se a parte com papel pardo. O oleo de bicuiba, é indispensavel para evitar o retorno da erysipella.

o emplastı 0 feito com a urtiga cansassão, bem soccada, e posta nas fortes, faz dormir a pessoa em quem se applicar.

Urtiga vermelha. (Urtica urens.) - E' uma planta que vegeta no chão, nas pedras, nas paredes e por toda a parte. 
USOS MEDICINAES

o cozimento ou a infusão, bem adoçado, cura a defluxão do peito, e mesmo a asthma. E' mui proveitoso nas molestias da pelle. O cozimento é diuretico, e expelle as areias dos rins.

Urubzí-Arvore de 60 e mais palmos de altura, com 4 e mais de diametro. Floresce em Outubro, com flores amarellas, despida da sua follagem.

\section{USOS MEIICINAES}

Não são conheciđ̄os.

USOS NAS ARIES

A madeira resinosa, e macia ao trabalhar, serve para obras de canto dos navios; para frechaes, varaes de seges, raios de rodas, e reparos de artilharia.

USOS NA INDLSTRIA

Se extrahe d'esta arvore tinta roxa, propria para a tinturaria.

Ureucin'una. (Hieronina alchornioides.)-Arvore das nossas mattas, de regular grandeza.

\section{LSOS MEDICINAES}

Não sảo conhecidos.

USOS NAS ARTES

o seu lenho serve para construcção civil e naval.

Uz.ucú. (Bicha orellana.)-Arvore de grandeza mediana, natural do Brasil, e assís conhecila, a que tambem chamam Açafrão.

\section{USOS MEDICINAES}

A infusão das sementes do umuci, serve para combatter, como expectorante, o defluxo do peito, e a bronchite.

\section{tSOS CLIANARIOS}

Serve para dar côr as comidts, príıcipalmente ao arroz. USOS NA INDLSTRIA

Os tintureiros servem-se das sementes, para tingir os pannos. 
Ur.zmbeba.-E' uma especie 'de cardo espinhoso, que dá fructos tambem espinhosos.

USOS MEDICINAES

O cozimento do fructo, que é mucilaginoso serve para os que soffrem do estomago e figado.

\section{USOS NA INDUSTRIA}

As doceiras fazem com os fructos da urumbeba excellente doce para. a mesa, e proprio para os convalescente. Como os fructos são muitos espinhosos, enterram-nos por 8 dias, até que larguem os espinhos, e bem descascados, fazem com os fructos doce muito apreciado.

Uxucuba ou pio de samgue.-Arvore das Alagôas, que floresce e fructifica, contendo o ¿fructo um caroço, ao qual nas Alagốas chamam nóz-moscada da terra.

\section{USOS MEDICINAES}

O caroço da urucuba, ralado, e dado a beker em agua morna, serve para combater as flatulencias, e os incommodos gastricos e intestinaes.

Urary. (Curare.) - o urary é uma pl'eparação venenosa, feita pelos indios do Amazonas, com que envenenam as pontas das settas, com que matam os inimigos e os animaes.

0 antidotu conhecido deste veneno é o sal de cozinha, dado pela boca ao offendido.

Urabŕ-cá. (Aristolochia trilobata.)-E' planta trepadeira, mui conhecida nas Alagoas. Floresce e fructifica.

\section{USOS MEDICINAES}

O cozimento feito com esta planta, faz estancar o sangue pela boca; e em clysteres, cura as camaras de sargue.

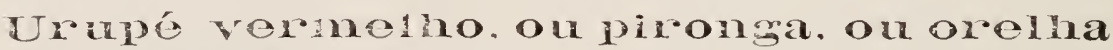
de páo verriolina.-E' um cogumello, que nasce nos troncos vellos das arvores derribadas, e mesmo sobre as madeiras dete. rioradas.

\section{USOS MEDICINAES}

o cozimento feito com este vegetal, cura as gonorrheas chronicas tomando meia chicara pela manhã, e meia á tarde. Em poucos dias fica-se restabelecido. Tambem tomado em gargarejos 
cura a angina tonsillar. Convém ter muito cuidado na quantidade do cogumello, porque é venenoso.

Utuamba ora Gitó. (Guarea mirgans.) (Vide Gitó.)Arvore natural do Brasil, da qual já dei noticia, que floresce e fructifica, com proprielides medicinaes mui activas.

\section{USOS MEDICINAES}

E' purgativa, anthelmintica. com acçĩo mui violenta sobre o utero. Usa-se em extracto, e em cozimento dado em clyster.

Uvacsias on Ubacsias. - Arvore do Brasil, que dá um fructo semelhante a jaboticaba, e de excellente sabor. O vegetal dá os fructos por todo elle, desde as raizes que ficam descobertas da terra. Não tem emprego conhecido em medicina vulgar.

Uva do matto (Cardia argentea.)-E' o producto de um arbusto que regeta nas Alagôas, comestivel, mui agradavel no gosto. Não tem a planta emprego algum em medicina domestica.

Uvalina do campo ou Pilombo. (Eugenia puriformis.)-E' uma arvore de mediana grandeza, que produz um fructo aromatico, a que na Bahia chamam pitombo.

\section{USOS MEDICINAES}

A limonada feita com os fructos é refrigerante.

USOS NA INDLSTRIA

Com os fructos que são comestiveis, fazem-se doces e geleas apreciadas para as mesas.

Uvapurama. (Hyrtus racimosa.) - Planta indigena, de folhas ovaes e pontudas, e flores em pequenos cachos; vegeta nas immediaçöes das praias do mar.

\section{USOS MEDICINAES}

O cozimento feito com a raiz da planta, e tomado pela manhã e á noite é diuretico e desobstruente do figado: o cozimento da casca, e mesmo das sementes, é proreitoso no curativo las febres.

Uxi, (Uxi umbrosissimus.)-Arvore gigantesca e frondosa, das mattas do Para: floresce e fructifica, sendo o seu fructo alimenticio.

ISOS MEDICINAES

O caroço do fructo, é empregado para suspender o sangue pela boca, e mesmo prevenir as hemorrhagias. 


\section{V}

Vack. (Silva Lisboa.)-Arvore das mattas da Bahia, de 30 palmos de altura, com 1 de diametro, conhecida dos derrubadores. Floresce em Agosto.

USOS MEDICINAES

Não são conhecidos.

USOS NAS ARTES

o seu lenho serve para o fabrico de remos.

Vai na villa. (Silva Lisboa.)-Arvore de 40 palmos, com 2 de diametro: floresce em Setembro.

\section{USOS MEDICINAES}

Não são conhecidos.

USOS NAS ARTES

O seu lenho, é empregado em todas as obras de construcção civil.

Vassourinha mofina, on to val.or casa. (Scoparia dulcıs.)-E' a vassomrinha mofina uma planta mui conhecida, e de prestimos medicinaes.

\section{USOS MEDICINAES}

o cozimento da raiz d'este arbusto é anti-febril, anti-hemorrhoidal tomado internamente, e externamente em banhos, e em clysteres. E' mui proveitoso na retenção de ourinas. O povo emprega a vassourinha, para curar as febres malignas, por mais violentas que sejam, e para suspender o sangue pela boca. o succo das folhas, serve para combater o catarrho pulmonar; e posto no ouvido, cura a dôr d'este orgão. 0 cozimento serve para regularisar os menstruos, e fortificar o utero. Desfaz as apostemas internas. Pisada a planta, e desfeita em agua, lavando-se a cabeça com ella, faz nascer os cabellos. A vassourinha de flores ruxas é mais prestimosa, que a que produz flores brancas, e de botões.

*as,son in 
- Arvore das Alagóas. de folhas miudas, pertencente á familia das leguminosas. Conheco perfeitamente esta arvore, por tê-la em abundancia nos meus terrenos do Tejuco.

\section{USOS MEDICINAES}

Não são conhecidos.

\section{USOS NAS ARTES}

Como o lenho é mui rijo, o empregam em diversos usos. E' preferivel para o fogo, porque o lenho, mesmo verde, arde como se estivesse secco.

Vellane ou velane verdadenro. (Croton campestris.)-Arbusto brasileiro aromatico, de sabor amargo, um pouco resinoso e de cheiro therebentaceo, geralmente conhecido, que nasce nos terrenos seccos, e por toda a parte.

\section{LSOS MEDICINAE:}

E' o melhor depurativo dos humores venereos. Os camponezes empregam a raiz em purgante, e é um drastico mui forte, nas molestias venereas, e rheumatismo chronico e gotoso; cura com visivel successo as empigens, e cachexia escrophulosa, os tumores syphiliticus, todas as entermidades da pelle, a elephantiasis dos arabes, as molestias dos ossos, o catarrho da bexiga, as ulceras uterinas, e mesmo é grande remedio para curar os tuberculos pulmonares. A enfermidade syphilitica que resiste á acção do mercurio, cede ao poder medicamentoso do vellame. Usa-se tambem como diuretico. Dá bom extracto. o Lr. Lacerda, no Maranhão, fez experiencias em si, com o vellame, e reconheceu que esta planta, tem acção mui pronunciada sobre os differentes apparelhos organicos. Usa-se só em infusão ou cozimento.

\section{USOS DA INDUSTRIA}

As sementes que produz o vellame, dá azeite.

USOS DIVERSOS

A vegetação do vellame è proveitosissima, porque tendo as folhas seccas, floresce de um dia para outro com uma sỏ chuva no verão. As folhas servem de alimentacão ao gado vaccum, cabrum, e ovelhum, nos agrestes e sertões do Brasil. 
Vellarinho ou barba de bode.-Arbusto aromatico, que vegeta nas charnecas dos sertões do Brasil. As folhas imitam as do vellame, mas differem por que as d'este, são mais pelludas, e as Barbas de Bode são lizas.

\section{USOS MEDICINAES}

Dizem os camponezes, que esta planta é remedio efficaz contra o rheumatismo, dada em banhos e suadores. As mulheres que acabam de dar a luz os filhos, banham-se com o seu cozimento, com muito proveito, porque facilita a sahida dos lochios, e fortifica o utero.

\section{USOS DOMESTICOS}

Serve para varrer as casas.

Verbasco.-E' uma planta sympathica, e mui proveitosa nas hemorrhoidas.

Veronica.-E' um arbusto das Alagôas, conhecido do povo.

\section{USOS MEDICINAES}

o cozimento da casca e folhas tomado com assucar, cura a blenorrhagia; e externamente cura as ulceras chronicas, lavando-as com o cozimento, e pondo-se o pó das folhas sobre ellas.

Vetiver. (Andropogon muricatum.)-E' um capim, que tem a raiz mui aromatica.

\section{USOS MEDICINAES}

Não são conhecidos.

USOS NA INDUSTRIA

Serve para a perfumaria, e preservar a roupa das traças.

Victoria régia ou milluo dagua. (Lindly.)E' planta aquatica do Amazonas, que produz sementes, como as do milho, que são comestiveis.

Videira. (Vitis vinifera.)-E' planta tão conhecida, que me abstenho de memorar-lhe os prestimos. No Brasil a videira produz muito, e em Naceió dá duas e tres vezes durante o anno, sendo as uvas muscateis excellentes. Em diversas provincias do Brasil, fabrica-se vinho. 
Vieira.-Arvore das mattas da Bahia, de 40 palrnos de altura, e 2 de diametro. Floresce em Setembro.

USOS MEDICINAES

Não são conhecidos.

\section{CSOS NAS ARTES}

0 liseu lenho serve para a carpintaria.

Vinkatico on amavollo.- Arvore robusta, pertencente á familia das leguminosas, e uma das mais elegantes e magestosas das mattas do Brasil, de tronco direito, com 150 e mais palmos de altura, com 32 e mais de diametro. Floresce em Dezembro, com flores brancas lindissimas. Sua madeira revessa, é utilissima para todos os misteres da vida social.

\section{USOS MEDICINAES}

A sua entrecasca e lenho são empregados em cozimento, em forma de banhos, para desinchar os escrotos.

\section{USOS NAS ARTES}

A sua madeira é amarella, com veios vermelhos escuros, ou carmesim, ondeados, lusentes e bellos, principalmente quando envernisada. Serve para as obras de marcenaria, e para as de construcção naval, como cintados, taboacios de cobertas e obras de salas; mas para serem duraveis, devem ser pregadas conu pregos de cobre; porque os de ferro, abrem com a ferrugem buracos nos lugares pregádos. Nas Alagôas ha vinhaticos tão gigantescos, que em 1842, vi fabricar-se uma barcassa de um só páo, que rachado, e intercallado no fundo um pranchão do mesmo vegetal, sahio pela barra da cidade velha das Alagôas, carregada com 18 caixas de assucar, para os trapiches de Pernambuco. A destruição l'este precioso vegetal tem sido espantosa, e tanto, que na minha Corographia Historica, censurei o presidente das Alagôas, ter concedıdo licença, a um potentado de Maceió, para tirar das mattas 200 duzias de pranchões de vinhatico, para exportal-os em seu proveito!! Quantas outras 200 duzias não tiraria esse devastador do Páo Brasil da provincia, que para nem as raizes deixar na terra, mandou vir da Europa uma machina de distocar e extractar - Páo Brasil, a qual quando chegou, estavam as mattas das Alagôas tão devastadas, que não achou emprego!! 
Noleca. (Viola odorata.)-E' planta de flôr roxa, e de suave aroma.

\section{USOS MEDICINAES}

o cozimento das folhas ligeiramente adoçado, serve para curar os defluxos, e a tosse.

Violete.- Arvore de 40 palmos de altura, com 2 de diametro: floresce em Outubro.

\section{USOS MEDICINAES}

Não são conhecidos.

USOS NAS ARTES

o seu lenho serve para obras de ornatos, molduras, marchetaria, e para outras obras.

Vismueiro. (Mimosa mellifua.) - O Visgueiro, é uma arvore gigantesca das mattas do Rrasil, principalmente das Alagôas, pertencente a familia das leguminosas, de casca grossa, copada; floresce e fructifica, distillando as flores um liquido viscoso, que alastra no chão, e tão consistente, que prende um passaro por maior que seja, que pisar n'elle.

\section{USOS MEDICINAES}

Não são conhecidos.

USOS NAS ARTES

O seu lenho é fraco. poroso. e só serve para taboados e obras de pouca duração.

\section{X}

Ser-izzar-E' um regetal do Pará. USOS MEDICINAES

o Dr. Lacerda recommenda a entrecasca d'este vegetal, para. curar a picada da arraya. 
Xicá-Arvore das mattas da Bahia, de 40 palmos de altura, e 2 de diametro. Floresce em Setembro.

USOS MEDICINAES

Não são conhecidos.

USOS NAS ARTES

0 seu lenho é empregado no fabrico de casas.

Xiquerique do sertão. (Cactus.)-E' este vegetal uma especie de Mandacarú espinhoso; cresce com hastes sem folhas, e nasce nos terrenos seccos. Esta planta tem servido de sustento aos habitantes dos sertões, em tempos de necessidades. Tiram o miolo, fazem fatias, seccam-nas ao sol, e reduzem a pó, e d'este usam de varios modos, para alimento. Alguns assam ao fogo o tal miolo verde, e o comem. Apezar de ter espinhos mui agudos, o gado come-o em tempo de secca, para mitigar a sede.

O fructo contém uma massa farinacea rubra, cheia de sementinhas pretas: comendo-se muito, desenvolve as ourinas. 0 tronco do xiquexiqui é excellente para o fogo, e serve para archote.

Xuxú. (Cucumis flexuosa.)-E' uma planta trepadeira, que dá um fructo com o mesmo nome, e entra como legume, nos guizados das familias. Não tem emprego em medicina domestica .

\section{Y}

Yatay.-E' uma palmeira brasileira, que produz nos logares arenosos.

USOS MEDICINAES .

Não são conhecidos.

USOS NA INDUSTRIA

Com a palha, fabricam chapéos, e com o tronco, depois de ralado. fazem farinha. 
Ypadí. (Erythroxilon coca.)-E' planta do Pará, e Amazonas.

\section{USOS MEDICINAES}

As folhas reduzidas a pó, e tomado, tem acção sobre o systema nervoso. Maszadas as folhas, mitigam a fome e a sede; o mesmo acontece tomando-se a infusão das folhas.

quetaia. (Scrophularia aquatica.)-Planta que folga nos logares encharcados.

\section{USOS HEDICINAES}

O cozimento feito com esta planta, é proveitoso na apoplexia e no pleuriz. Dizem cue cura as febres intormittentes.

\section{Z}

Zangona.- Planta do Maranhão que o Dr. Lacerda (no Tom. 2. 2 pag. 126, dos seus manuscriptos ineditos), experimentou em si os effeitos; tomando o cozimento da raiz fresca, réconheceu, ter ella acção sobre os apparelhos nervoso e sanguineo, e principalmente nas affecções da cabeça.

Rambugal. (Vid. Sapucaia.)

Lanzo ou $1 \cdot \mathbf{e l o g i o . ~ ( S i d a ~ r o m b o i f o l i a ) ~ - ~ E ' ~ u m ~ a r b u s t o ~}$ que vegeta em todo o Brasil. Floresce e fructifica.

\section{LSOS MEDICINAES}

As sementes pisadas, misturadas em agua, e dadas a beber, obra como por milagre na retenção das ourinas. As folhas pisadas com sal, e postas sobre os lobinhos e outros tumores, fal-os suppurar em poucc tempo; e depois de suppurados, applicando-se a mesma planta pisada com assucar, faz cicatrisar a ferida. 
APPENDICE 



\title{
PLANTAS MEDICINAES DA PROVINGIA DO ESPIRITO SANT0
}

\author{
PELO
}

CIRURGIÃO RAPHAEL DA ROCH 1 NEVES QUINTELLA

Oalsamo do Espirito Santo (arvore desconhecida) que, - vendem em uns pequenos cocos, é muito aromatico, desseccante, e consolidante; usa-se nas feridas, chagas, contusões, fracturas, e deslocações, e tambem aproveita em muitos outros casos.

O oleo de cupaiba, (copaifera officinalis. L.) ou cupaúba, é muito desseccante, consolidante, e nervino; tem varios usos, e applicação em muitos casos, e em differentes males.

Oleo, ou azeite de mamona, (Ricinus communis $L$.) que chamam de baga, é famoso lachante antihisterico, e nervino; nunca se faz rançoso, é util em muitos males, que pecam em aperto.

Oleo de bicuiba, (Myristica officinalis. Martius.) é um bom relaxante, nas contracturas, e convulção de qualquer membro, e tambem na rigeza dos tendões, e ligamentos, e ainda nos ankilòzes.

Aposya, ou. Ipecacuanha, (Psychotria emetica. L.) é raiz vomitiva, e purgaste, muito conhecido o seu uso na medicina: aqui ha abundancia d'ella.

A raiz de abútua, (Cissampelas parreira. L.) que é 
a parreira brava, ha duas especies d'ella, uma é mais grossa, mais solida, e nodosa, que é a melhor; outra mais delgada, mais lisa, e branda, que os naturaes do paiz chamam Ciparaba; a sua virtude é ser aperitiva, desobstruente, e resolutiva.

A raiz da pariparóba ou capéba. (Piper umbellatrm. L.) tambem é aperitiva desobstruente, e resolutiva.

A raiz de sapé macho. (uma especie do genero Arundo) tambem tem as mesmas virtudes.

A casca da raiz do fedegozo bravo (Cassia Occidentalis S. Hilaire) é um bom anti-febril, alexipharmarco, e é tambem um remedio polychrésto.

angelim (Andira Racemosa, S. Hilaire.) A sua casca, raiz, e fructo, têm a sua substancia amargosa; é ácre, e são remedios anthelminticos ou contra lombrigas, dados em cozimento, e em substancia diminuta quantidade, e com muita cautella, que do contrario os seus effeitos são muito nocivos, e quasi venenosos.

O páo de sassafrás. (Laurus Sassafrás. L.) é lenho aromatico, tem virtude sudorifica, e anti-venerea.

O paio almecoga. (Hedwigia balsamifera. Martius.) que dá bastante resina, a qual tem muitos usos na Medicina.

O arbusto chamado caróba, (Bignonia copaia. Aublet.) as suas folhas, raizes, e extracto são remedios antivenereos. e proprios para o afecto bobático.

O páo ratubá (especie do genero Hyminea) o seu amargo, é semelhante ao lenho Guaiáco, e tem as mesmas virtudes sodorifica, e antivenereas.

O cipó de Japuanga. planta sarmentosa (Smilax pseudochina. Maritus.) que tem uma grossa raiz, bem semelhante á raiz da China, e, dizem, as mesmas virtudes, e usos medicinaes; e as suas folhas curam com ellas as chagas sordidas e indigestas.

A raiz da bonina (Mirabilss Jalapa.) é a batata officinal, d'ella se extrahe a resina do mesmo nome, $\theta$ as suas irtudes é ser forte purgante drastico. 
O páo Baxbatinão, (Mimosa Cochliacarpos. Gomes.) A sua casca é um poderoso, e forte adstringente. A mesma virtude tem a casca do Mrngue, da Guaiabeira, (Psidium) e da Arueira. (Schimes Areira. L.)

O piro Guararema. (especie de genero Cerdania. Segundo o Dr. Ildeffons $\mathrm{Gomes)} \mathrm{tem} \mathrm{um} \mathrm{cheiro} \mathrm{fastidioso} \mathrm{muito} \mathrm{seme.}$ lhante ao da gomma assafetida, abunda em saes lixiviaes, aperientes, e resolutivos; a sua lexivia serve para a purificação do assucar, e para a factura do sabão: as suas folhas cozinhadas usam-se em banhos nos afecto: hemorrhoidáes, e rheumaticos.

O piro andiassí. (Jonnnesia Pinceps Veloso,) dá uns fructos, que constam de um caroço oleoso, do qual extrahem azeite, o qual é violento vomitivo, e purgante.

InInio, (Jutropha Curcas. L.) é uma arrore que dá uns carocos oleosos, quasi semelhante as azeitonas, d'elle se extrahe azeite, o qual tem rirtude de forte romitivo, e purgante.

A piteira, (Agave fotida. L.) dizem servir a sua raiz em cozimento para os males nervosos, tanto bebido como em banhos.

O mel de abelnas é aperitivo, abstersivo, e um bom saponaceo para o corpo.

O mel da dopuratão do assucar. á que chamam mel do tanjue, que se esgota das formas do assucar, tambem é detersivo, resulutivo, saponaceo, e aperiente.

Todos estes simpleces ácima narrados, e que abunda na provincia do Espirito Santo, sĩo constante as suas virtudes, e tem sido usados por muitos professores da arte de curar, e podem se descobrir outras virtudes, em diversos males, ponderadas, examinadas, bem indagarlas pela pharmacia chimica, as suas qualidades, e substancias, e extrahindo-se pela mesma arte os seus saes, gommas, resinas, oleos, etc., que muito melhor aproveitaram na praxe medica. 



\title{
VEGETAES QUE SERVEN PARA USO CASEIRO NA PROVINGIA DE PERNAMBUCO
}

\author{
POR
}

JOAQUIM JERONYMO SERPA

VEGETAES MUCILAGINosos E EMOLLIENTAS

Pio cardoso. - O seu amago é mucilaginoso, e doce; póde muito bem substituir a raiz de althéa.

Casca de matamba. -Usa-se do seu entrecasco, é muito desobstruente, e bem póde ser que se possa tirar d'ella uma especie de gomma alcatira.

Rezina do raiıba.-E' remedio bechico.

Casca do embira veimelia.

Foldioega vermelna, o branca.

saca-ost. 0 po.-A fulla da saca-estrepe posta em uma tigelinha, com uma pequena quantidade d'agua, mechendo-se continuadamente, dí uma mucilagem com que dizem algumas pessoas, ter-se curado algumas chagas no rosto com aprarencia cancrosa.

Gomma de cajueix-0.-E' soluvel em agua, assim como a gomma-arabica, e póle le certo modo substituli-a, muito principalmente em molestias chronicas do peito.

Fuboriba ve:mo: 


\section{VEGETAES EPISPASTICOS}

Leite de pinzăo.

Pimenta malagueta. e suas diversas qualidades, que tambem são indigenas.

Castanha de cajíl.

rabaco.

Gengibre branco.

Ananaz verde.

Folnas de louco (Dentelaria) ou herva dos cancros.

\section{VEGETAES ADSTRINGENTES}

Casca de barbatimão.-Usei d'esta casca em pó, e em cozimento nas febres intermittentes, combinada com Canela, em tempo, que houve n'esta provincia grande falta de quina, e obtive bons effeitos, como tonica, e anti-febril.

Futrocasco de bordão de velho.

Encherto de passarinho de laranja da terra.

Casca de cajuciso vermelno.

Casca de sapucaia.

Casca de cabuatan.

Fructo coronhacris.

Semente de páo ferro. ou . Iucá.

Pinhão omanso.- 0 seu sumo espessado póde muito bem servir de gomma-kino, e tem a mesma virtude da terra. Japonica.

Páo tocaje.-Servem-se do cozimento d'este páo, para suspender as hemorrhagias passivas.

Pío catinga de porco. 
Casca do livucto pequi.

Casca de angico.-Na dóse de duas oitavas, fervido em chicara e meia d'agua, que depois de ferver, venha a ficar em uma chicara, é remedio vulnerario, e tambem a sua gomma aproveita nas affecçõe: de tosse.

Casca de cana fistula.

Oyty coró.-Usa-se do cozimento de seu caroço, para curar as diarrhéas chronicas.

Mangaria de bananoira.

REZINAS AROMATICAS

Bojoim do Brasil.

Almecega.

Balsamo do cabacinho.

Azeite de patiputá, ou oleo que se tira das sementes de um arbusto d'este nome, e que com elle curam as chagas feitas por combustão: tambem é excellente para com elle se frigir peixe.

APERIENTES.

Carrapicho de agulha.

Raiz de capeba.

Cypó carurír.

Groama da piaia.

Raiz de corueiro vermelho.

laaiz de mulungú.

\section{PURGANTES VEGETAES}

Raiz páo de carne.-Usa-se de seu entrecasco como purgante anti-venereo, segundo a opiniz̃o dos homens do campo.

Velame.- Purgante drastico. 


\section{Gengibre do douxar, ou gensibre ama- rollo.}

\section{ANTICUTANEO}

ripi vegetal.-Tem o cheiro do hepar sulfurico; usa-se do seu cozimento para banhos nas affecções da pelle.

\section{ANTHELMINTICOS}

\section{Lerva Iumbrigueira. (Spigelia anthelmintica.)}

Tinheron.- A sua batata pizada, ainda mesmo raspada, pois que é muito tenra, applicada sobre a bicharia das chagas dos animaes, os mata immedi tamente.

Angelim. (Andira anthelmintica, Arrud. C. P.)-O fructo d'esta arvore, que é do tamanho de uma azeitona, é um poderoso anti-verminoso. A dóse para um adulto é um quarto de semente reduzida á pó subtil, e desfeita en uma chicara d'agua morna, que se adoçará com assucar: está muito em uso pelos seus bons cffeitos, e vende-se nas boticas de Pernambuco.

\section{VEGETAES SUDORIFICOS}

Dorstonia Pornambucana. (Arrud. C. P. P. Dorstenia rotundifolia.)_Estas duas especies de contra-hervas são novas, e proprias de Pernambuco. Ellas têm a mesma virtude da verdadeira contra-herva do Mexico, e Perú. (Dorstenia contra-herva.) Acha-se nas boticas de Pernambuco, e d'ellas faz-se um grande uso. Ainda que hoje em dia não se attribue á contra-herva a virtude de neutralizar os venenos, todavia pessoas veridicas affirmam que é o contra-veneno de uma especie de lagarto, á que lhe dão o nome de tijuassú, que na occasião, em que briga com a cobra, sua inimiga declarada, e é ferido por ella, corre, á comer a batatinha d'este vegetal, afim de se curar do virus da serpente, e torna, depois de tomar este antidoto, á peleja com tanto vigor, que põe a cobra fóra do combate, e ao mais das vezes lhe dá a morte pelos grandes golpes de sua cauda. Com effeito não se póde duvidar, que a contra- 
herva augmenta a secreçáo da pelle, e por isso emprega-se nos casos, que exigem o uso dos excitantes, sobretudo na atonia do canal digestivo, e nas affecções complicadas de symptomas adynamicos. Na provincia da Bahia dão-lhe o nome de tiú, em lugar de tijuassú, e a batatinha de tiú, em razão de algumas pessoas terem observado ser este o seu alexipharmaco.

\section{REMEDIO PARA PROVOCAR A EVACUACQ̃O MENSAL}

Toma-se um manipalo de caroços de algodoeiro, infude-se em agua fervente, por tempo de vinte minutos, quantidade d'agua, que dê para encher uma chicara, e se tomará de manhã em jejum. Sendo tomado seis dias antes, em que devia apparecer a evacuação mensal.

\section{CALUMBI, OU SENSITIVA}

A sensitiva. pizada e dado o sumo á beber na quantidade de meia chicara, é veneno violento: o contra-veneno é a raiz do mesmo vegetal. Costuma-se tambem á dár-se em pó, e basta uma pequena quantidade: do mesmo modo a raiz como contra-veneno.

Esta descripção foi achada em um manuscripto antigo, e ainda não tive occasião de pôr em pratica, para certificar-me dos seus effeitos. 



\title{
PLANTAS BRASILEIRAS QUE PODEM PRODUZIR EVAGUACOEES PURGATIVAS
}

POR

\author{
A. L. P. DA SILVA MANSO
}

Ifatropha lacenti. Monadelyinia decandi-ia. I. F. Triccocae in sipxens:

\section{CARACTER DIFFERENCIALE}

J. suffruticosa, foliis ovato-lacelatis glabris, margine pilis capitalis, floribus terminalibus, radice lignosetuberosa.

Flores: é Monoica: as tlores de ambos os sexos tem o calix campanulado partido em cinco partes, com as lacinias assoveladas: a coro'la tambem campanulada com o limbo patente, partido em cinco lacinias obtusas; as partes sexuaes estendidas até fora: são brancas por fóra, e por dentro ruivas, fixando para carmesim no centro de cada lacinia: estão postas em pequenos Ccrimbos nas extremidades da planta.

A flor masculina tem oito á dez estames, coadunados pela base, terminados por uma antêra sem. articulação, desiguaes entre si.

A flor feminina tem as lacinias do calix guarnecidas de pellos. com cabeça como alfinetes: sobre o germe, que é oblongo, estão tres estiletes com estigmas partidos em duas partes grossas, e abertas desigualmente. 
Fructo.-A capsila é de tres logeas, contendo cada uma, uma semente oblonga envolta em um arillo. A semente tem toda a semelhança com o ricino; porém é de um tamanho muito menor.

Habito.-Levanta-se um caule como o das hervas, quando espigam, da grossura de duas ou tres linhas de diametro, altura de dous, ou tres palnos, verde claro, em algumas partes manchado de vermelho terreo, com as folhas desigualmente alternadas, de um palmo, meio oradas compridas, e assacaladas para a extremidade, macias, verde claro com o limbo superior cheio de pontos mui miudados, e o inferior esbranquiçado, cuja substancia parece coberta de espuma muito fina: o peciolo é muito curto, com uma estipula axillar dividida em forma de alfinetes. Estes pellos com cabeça, borlam toda a margem das folhas.

Raiz.-Esta consta de um corpo de quatro pollegadas aproximadamente de diametro. de onde sahem poucos ramos fusiformes, que the dão o aspecto de um corpo humano, coberta de uma epiderme gretada de côr occracea, e todo o interior tem o rudimento de camadas ligneas; porém macio ao córte, alguma cousa amigdalaceo, e impregnado de um succo resinoso quasi purpureo como o aroma de sassafraz.

Habitação.-Observada d'esde o anno de 1822, em varias partes do Brasil na latitude de 20 graos para o Norte em campos cobertos, terreno secco ferruginoso, acima de dous mil pés sobre o nivel do mar.

Nome.-Raiz de Lagarto-Raĩ de Tein-Jalapãs-é provavelmente o Jatropha opifera, pedido por Martius.

Uso.-O uso geral das Euphorbiaceas é conhecido: esta planta contém nas sementes um oleo com as propriedades do Pinhão (Jatropha curcas) pretende-se que os Lagartos mordidos, vão comer suas folhas, com que se tornam vigorosos para novos combates contra as cobras: o certo é que em toda a planta, abunda uma seiva resinosa com qualidades sensiveis que abonam a presumpção d'este instincto. Os indigenas têm por especifico, e contraveneno de cobras. de cuja origem têm muito credito á este respeito. Os chamados Curadores, e Feiticeiros têm em muito segredo a raiz, que applicam, acompanhando de superstições, para expellir 
os maleficios, isto é, como cathartica foi esta raiz empregada no Hospital da Misericordia de Cuiabá, em casos de amenorrhéa, na dóse de dous escropulos, termo médio, e obrou sempre como cathartico suave, e com proveito: alem d'isto foi usada muitas vezes como alterante algumas vezes activada con mercurio, e aproveitou nos estrumas, escrophulas, hepatites chronica, e rheumatismos. Tem a'vantagem de não ter um sabor repugnante, e ac:ommodar-se bem no estomago, provavelmente pela natural combinação do principio aromatico com o cathartico, propriedade que talvez não se conhece em agentes d'este uso. Parece que deve ter um lugar mui distincto na materia medica Brasileira, tanto mais quanto é susceptivel de cultura.

Horva do santa Maria (chenopadium anthelminticum. L.) da qual a semente, igual á de Alexandria hia virtude, é acre, amarga, e fetida, e um bom remedio anthelmintico, ou contra vermes.

Alfaraca. (Monnieria trifolia. L.) herva aromatica, e resolutiva que dizem aproveitar em banhos nas erysipelas, e inchações inflammatorias.

Voude risgo. herva do campo, tambem dizem utilisar em banhos nas erysipellas, sarnas, e em todo o affecto scabioso.

Mata pasto. (especie de genero Cassia) herva, que tem os mesmos prestimos, do mesmo modo applicada.

Iontrusto. (Lepedium?) herva aromatica, que usam em banhos para dores, e no frio das sesões.

Caculage. on quitoco, (especie do genero Bacchairs), herva resolutiva, carminativa, e anthysterica, usada em banhos.

Bacamarte. herva aperiente, e resolutiva, applicada exteriormente, untada de qualquer oleo.

Trapomonga, herva que serve para curar as chagas. usando d'ella secca, e em pó.

Horva tustäo. (Boerhavia hirsita. L.) que usam d'ella em cozimento, bebida, e em banhos para curar gonorrhéas.

Ier-va de ma:n ta Iolena. em banhos quentes applicada para constipaços da pelle, á que custumam chamar resfriado. 
Tariíliqui. herva que dizem approveitar nas paralysias, esfregando com as suas folhas cozidas as partes padecentes; e a sua raiz em cozimento servir para desmanchar tumores de qualquer parte do corpo, e dos testiculos.

Acataya, ou herva de Bicho. (Polygonum antihemorhoidale. Martins) que è a persicaria; a sua qualidade, é acre, estimulante e aperiente; usam d'ella em cozimento como diuretica, nas supressões de ourinas, è contra as podridũes gangrenosas, e ainda tem mais virtudes.

A herva cheista de Falo serve para limpar chagas sujas, e cural-as.

A he:-va Agoapé. é usada em cozimento para banhos nos aflectos hemorrhoidaes.

Horva andorinha (Euphorbias linearis. Retz.) - o seu cozimento bebido, e applicalo em clysteres, dizem ser util nas diarrhéas, e disenterias, e ainda nos affectos pleuriticos.

A herva queimadoira, pisada e applicada em massa, dizem aproveitar nos tumores carbunculosos, e esfregando a mesma massa nas manchas da pelle, as cura.

Folna de fogo é um arbusto do qual as folhas curam as combustões.

Cabaso amargoso (cucurbitacea.)-Herva venenosa; usam das suas folhas applicadas exteriormente sobre o ventre, e cadeiras das mulheres para o parto, e expulsar as secundinas; e o seu fructo, que é muito acre, e irritante corrosivo, o applicam em cozimento formando d'elle clysteres como purgante nas obstrucções, e nas cores pallidas.

"-itanga, (Eugenia uniflria. L.) arbusto.-Usam da sua folha em cozimento para todas as dores, quer sejam rheumaticas, gottosas, ou venereas.

Cipó do chanmbo, é vulnerario, e resolutivo, usa-se em cozimento nas quedas, pancadas, e contusões, e ainda nos casos de abcessos internos, e nas vomicas do bofe.

Maimbú, é uma herva rasteira em forma de cipó que nasce nas praias, e dizem os nacionaes que em cozimento tem a mesma virtude que a caróba, no aflecto bobatico. 
Camarátinga, arbusto; dizem que o succo das suas folhas, bebido com assucar branco, aproveita para romper as vomicas, ou aposthemas internas.

Tipi, arbusto, que dizem servir as folhas, e raizes, em cozimento para banhos nas febres intermittentes, usados na occasião do frio e rigor d'elle.

- Toapitanga. ou . Tapecanga (Herreria sulsupurilha. Martius); é herva rasteira em forma de vergonteas ou braços, que dizem ser sudorifica, anti-venerea, e rue tem a mesma virtude da salsaparrilha em cozimento.

Maracuji-assí, e maxacujá min.mi, hervas rasteiras que dizem ser muito refrigerantes nas queixas cálidas, e de acrimonia, bebido o seu cozimento.

- herva pé do galinha, é uma especie de relva, ou capim; o seu cozimento é muito resolutivo, nas intumescencias inflammatorias.

Tapiá, arvore fructifera silvestre; dizem prestar as suas folhas em cozimento para as dores rheumaticas, e gottosas.

Guayambè. arbusto, que dizem servir as suas folhas para os mesmos males.

A herva de passarinho, que é visco das arvores, tem virtude consolidante.

A raiz de contra herva (Dorstenia Brasiliensis. Lam.) é sudorifica, elexipharmaca, e um remedio policrésto.

Ha aqui tambem as hervas hortenses, e domesticas, que são geraes em toda a parte, e bem conhecidas as suas virtudes e tratadas por muitos AA. Medicos.

A conservação, e beneficio das producções vegetaes, í seccando-as bem ao sol e á sombra, como são os lenhos, cascas, raizes, flores, folhas, e fructos; em quanto aos oleos, gommas, resinas, etc., não carecem de preparo algum, só sim depurando-as da terra, e bem puras se conservam em caixas, e vasos. 


\section{EUPHORBIACEAS}

Esta grande familia desde o mundo velho, ha muito tempo attrahio a attenção dos sabios da Europa, pela propriedade do individuo, que the serve de typo, isto é, a Euphorbia officinarum, o mais violento, e perigoso dos purgantes, cujos effeitos não se podem destruir por quaesquer combinações: examinada, descobrem-se todos os dias novos agentes: é n'esta familia que está na Asia o Crotom tiglium; e, na descida da cordilheira dos Andes a Euphorbia guachaca: não é muito esperar encontrar esta no Brasil, e transplantar aquella que deve, participando da doçura do paiz, perder sua aspereza, tornar-se praticavel o seu uso. No entanto temos:

Caxins. (Sapium? Arbor procera: ramis erecto, patentibus; foliis obovatis elongatis, basi atenuatis, spinose crasse dentatis, glabris.)-As sementes purgam seguramente na dose de duas ou tres, em casos de hydropesias e outros.

Pin häo-paraguay, pinhào de purga. sumuduthygraco. (Jatropha curcas. L.) E' conhecido do povo, e enunciarlo por Pison; tres até nove sementes é a dose, de que usam vulgarmente assada, o que produz dejeccões, e vomitos. Conhecemos um parocho, que conservava sempre grandes porções de sementes intimamente misturadas com assucar, e applicava a seus freguezes indistinctamente com o nome de maná. attestando seus effeitos, conservando a preparação em segredo. Quanto ao mais, os effeitos do pinhão não soffrem contradicção. Temos usado constantemente o oleo, em dose de um escropulo á uma oitava.

Coxa1. (Jatroplia multifida. L.)-Esta planta suppre a antecedente, como affirmam alguns praticos citados por Justiniano, em sua these.

Andacerí. indasugú. (fructa de arara, purga de gentio Anda Gomeziz. Juss.) - A utilidade de suas sementes como purgante, é authentica na Europa: duas ou tres sementes satisfazem toda a indicação, pisadas simplesmente, 
ou em emulsão, como indicav a o Dr. Gomes. Usa-se hoje do oleo na dose de meio escropulo, muito mais sem inconveniente.

Falapäo, raiz de laranja, raiz do teiú. (Jatropha Lacert Mans. Opifera Mart. Adenoropium elipticum Pohl.) -Usa-se la raiz em substancia, ou extracto aquoso, na dose de um a dous escropulos d'este, e dous escropulos á uma oitava d'aquella, nas hydropesias, rheunatismo, amenorrhéas, envenenamentos por picadas de cobras.

Mamona, carrapato. nhakbuguacé. figueira do in lono (Ricinus communis. L.)-E' trivial o uso do oleo d'esta planta, climatisada de tempo immemorial: dá-se de meia a quatro onças do oleo; emulsões, e orchata das sementes; e as sementes engulidas como pilulas (por este methodo purgam-se tambem as aves domesticas).

Noz da India, das Mlollucas, ox do Bancoul. (Aleurites tirloba Forst: mollucana. W.)-Oleo laxante, em muito menor gráo que o ricino.

Todas as especies não só d'este genero, como da familia, contím nas sementes oleo com mais, ou menos acrimonia, que as tornam catnarticas, ou laxantes, e algumas drasticas, e vomitivas; o que impossibilita de lançar-se mäo indistinctamente de suas seme ites, e oleos; mas os praticos nĩo devem perder occasião de observar em pequenas doses, segundo o gosto acre das semeates, visto que quando produzissem efreitos mais violentos do que se esperava, o alcool é o correctivo, com que se póde minorar alguns accidentes: e d'este modo póde-se achar para o futuro os maiores recursos. pois só clo genero Croton dever-se-ha tirar mais de cem catharticos: no entanto podemos accrescentar a materia medica para se usar como do ricino as sementes do Croton tillic-folium, conhecido pelo nome de Urucurana, e outro crnton conhecido em S. Paulo pelo nome de Capichingui: por quanto d'estes temos alguma experiencia de que não tem acrimonia, que compromeța.

(3) Vollaine (Croton fulvum, e Crotoncampestre. Hil.) duas especies: tem torca cathartica nas raizes: usa-se da infusão alcoolica de uma porção, que se póde oroçar em tres onças, secea, para um frasco, que se póde orear em seis libras de 
agoardente, macerada por alguns dias; toma-se como quatro onças por dias seguidos na siphylis, rheumatismos, gotta, etc.

Igual propriedade se deve achar em muitas raizes d'este genero. bem como em mais partes, não só do genero como da familia. que póde dar trezentos individuos uteis em muitos sentidos.

No genero Euphorbia podemos apenas affirmar por ora, o effeito ligeiramente cathartico da herva Santa Luzia, Sete sangrias. (Euphorbia linearis. Ratz.) Usa-se do cozimento das raizes nas febres inflammatorias; e, se é muito saturado, obra catharticamente.

Leitera, Luzetro, Leitariga. (Euphorbia papilosa. Hil.)-Usa-se do succo leitoso das cascas, e do sumo das folhas, duas colheres em mel nos casos (dizia uı fazendeiro do Sul) de dores de ossos, de dores siphyliticas, etc.

Concluimos este artigo com a descripção de uma planta, que existe no lado de oeste de Minas Geraes, nos campos mais limpos, desde os campos da Franca, em S. Paulo além do Rio Claro, em Goyaz, nos terrenos seccos, e altos : ella é emetica, conhecida por poucos como puaia, applicada na mesma dóse, e casos. Usam preparar préviamente a raiz logo que se arranca, fazendo-as soffrer uma pequena fervura, depois da qual se faz seccar para o uso.

\section{GENERO EUPHORBIA L.}

Mencecia androgyna L. in Spreng.

Famill. Triccocæ id.

Sp. emetica.

CARACTER DIFFERENTE,

E. suffruticosa: caule ereti, floribus terminalibus; foliis opositis subsessilibus incanis.

Caracter vatural. - Tem o envoltorio em forma de copo, em que se contém as flores de ambos os sexos. Este envoltorio tem o limbo branco, partido em cinco partes, cada uma de tres lobulos, horizontalmente dispostas, imitando corolla: na base de cada lacinia do limbo, está uma glandula verde, de 
figura oblonga, como fenda longitudinal, constituindo talvez nectarios.

Sahem do fundo do envoltorio cinco estames, que sustem antheras de duas loges, os quaes excedem o limbo.

Do centro do mesmo envoltorio levanta-se um pediculo estreito na base, da altura dos estames, sustentando um germe, que se reclina sobre o limbo, e é ovado, corado de carmezim.

Sobre este germe cstĩo tres estiletes revirados para fora, fendidos na extremidade, cujas lacinias filiforme tem as pontas separadas. O fructo é capsula de coccas, contendo carla uma, uma só semente de figura ovada. E' um Subarbusto, com a raiz do comprimento de um pé; e duas linhas, oll pouco mais de grossura, que eitra pela terra obliquamente; em fresca é ruiva; depois de secca é toda gretada marcando anneis. 0 caule, tem perto de um palmo de alto; levanta-se um, ou mais da mesma raiz, direito, fino, meio nodoso, a vermelhando por algumas partes, liso.

As folhas (que são oppostas, e quasi rentes) tem mais de compridas, são agudas, na base tirando para codiformes, cotanilhosas, erissadas, quasi brancas. As flores estão pelas pontas, uma ou raras vezes mui poucas em cada penduculo. Estara com flores em Julho.

\section{CONVOLVULACEAS}

o genero, que dá nome a esta familia é tão rico em especies utei:, com as especies, são compostas de muitos individuos; com flores, que, por sua figura, e brilhantismo de suas cores, fazem-se notar pelo homem mais distrahido. O Brasil possue a maioria das especies em commum com a zona, de que é parte; todas as outras se prestariam a fazer-lhes companhia se uma mão humana o tentasse: o Turbith, a Escamonea, a Jalapa, ha muito que nos deviam ser triviaes. Ao menos agora podemos affirmar, que o Turbith é indigena; e que as especies abaixo descriptas, ou citadas, plenamente satisfazem as indicaçũes das

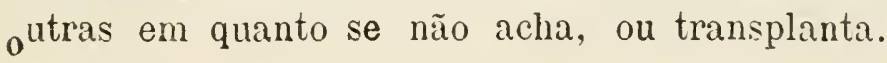


Em todas as materias Medicas, Pliarmacopéas, que nos tem chegado á mão, temos encontrado Convolutus turpetum como nome caracteristico do Turbith; nos droguistas porém, temos encontrado varias raizes cucurbitaceas, conhecidas por Tayuiá.

A planta abaixo descripta por Sprengel, di India, e nova Hollanda, a qual é a seguinte Turpetum, Convolvulus foliis cordalis subangulatis obtusiusculis mucronatis pubescentibus, pedunculis folio brevioribus, laciniis calicis exterioribus maximis tubum corallo aquantibus, caule quadrialato.

\section{DESCRIPC.AOO}

Caracter xatural. - Tres linhas abaixo da extremidade do pedunculo sahem duas bracteas oppostas, rentes e meio crespas, d'este lugar para a extremidade vai engrossando cada vez mais com quatro, ou cinco faces, ás vezes aladas: aqui se eleva 0 calix até tocar o limuo da corolla, o qual sobrevive a toda a flor, e ainda fica muito tempo depois de terem cahido as sementes: este calix é partido até a base em lacinias ovadas, membranosas, mais consistentes na base, das quaes tres exteriores quasi cobrem as duas internas: estas são côr de neve; e as exterias sĩo amarelladas meio coradas, com muitos pontos diaphanos.

A corolla é amarella, afunilada com o tubo curto, e o limbo grande pouco amarrotado, com cinco lobulos rasos.

Os estames são cinco, mais baixos que o tubo da corolla; do meio para baixo são chatos, com um rego pelo meio da banda de dentro: pelas costas meio curros, em toda esta extensão pregados ao tubo; logo ácima tem certa grossura eriçada de pellos; e d'ahi para a extremidade são meio roliços, assovelados.

As antheras são furcadas na base, por onde estão oscillantes nos estames, sĩo torcidos em espiral, de duas logeas, que se abrem revirando-se para fóra.

O estilete é da altura dos estames, mais fino para a ponta.

o estigrma é pequeno, redondo com pequeno sulco como que o divide em dous, todo gretado. 
o pollem é de particulas redondas com protuberancias.

Todas as partes genitaes são de côr branca.

o estilete parte d'um ovario de figura ovada, que está dentro de uma taça, com a margem recortada em cinco lobulos rasos.

O fructo é uma capsula cornea mui delgada, adherente dentro de uma urna, cujo operculo é amarellado, grosso, carnoso, reluzente, com quatro proeminencias rasas, e com o rudimento do estile.

Este operculo, separando-se transversalmente da parte inferior que é uma membrana delgadissima, inseparavel da capsula) murcha, revirando-se para cima, até que cahe, mostrando então a caixa transparente, de dous loculamentos, onde se contém de uma a quatro sementes envoltas em uma substancia albuminosa mui delgara, que se desfaz depois de seca.

Estas ficam sempre encerradas na sua capsula até que, depois de seis mezes, cahe todo o apparelho, quebrando-se pelo logar em que estão as bracteas abaixo do calix.

As sementes variam em figura, conforme o numero contido em uma capsula; em regra são ovadas, e de algum modo triangulares, co.itendo cotiledones foliaceas, verdes, dobradas ao lado da radicula oblonga, e perceptivel a simples vista.

As cotiledones, desenvolvidas em folhas primarias, são oppostas, divididas em dous lobulos largos, e na base mui estreitas, cordiformes.

E' uma planta duravel, que tem a raiz tuberosa de um pé proximamento de comprida, e figura oblonga apionada, dividida em baixo em dous galhos com mui poucas radiculas.

o caule é herbaceo, quadrangular, angulos terminados em membrana ondeada de côr tirando de verde para carmezim, á medida que são mais expostas à luz.

As folhas são de meio palmo, e pouco mais, ovadas, meio angulosas, com a base formando angulo reintrante, e a extremidade mais ou menos extensa, com ponta estreita, e romba, com pequeno apiculo; são inteirissimas, quintuplinerves, nervosas, venosas, estaveis, molles ao tacto, de côr verde escura por cima, - esbranquiçada na face inferior, por causa dos rudimentos cotanilhosos visiveis a microscopio: fazem angulo recto com 0 peciolo. 
Os peciolos, que terão duas polegadas, tem a face superior plana, formando canal com duas membranas estreitas, que bordam esta face.

Os pedunculos sĩo de tres a quatro pollegadas, são quadrangulares, de angulos membranosos, como o caule, axillares; e dĩo uma só flôr.

As flores, terão duas pollegadas de diametro no limbo; e uma de comprimento no tubo.

Tinha flores e fructos em Abril de 1830.

A cireumstancia de uma uria, de um opereulo, que murcha, cahindo, não solta as sementes; uma capsula, que se não abre. com a anfractuosidade das antheras, com o modo de disseminarem-se as sementes, tulo fez-nos tomar esta planta por um genero differente do Convolvulus; e, em consideração it parte que mais se faz notavel ao observador the damos o nome generico de Operculatina; conservando o da especie (turpetum).

Este precioso vegetal foi achado cultivado, em um sitio dos Batataes na provincia de S. Paulo, com o nome de Jalapa: fui depois achado na provincia de Goyaz, com o nome de purga de Amaro Leite: achou-se a que vai descripta nas margens do Rio Cuyabá, ignorada. Co seu uso é assaz conhecido.

A esta especie referimos a butata de purga (Convolvulus operculatus) de Gomes, e o Ipú, ou batata purgante, que vem em n. 6 do Patriota de Junho de 1814 descripta por Godoy, com o nome de Convolvulus. Spec Hederac varietas?

Duvidamos que seja esta especie o Mecoacanha, como entende o autor da descripção ácima, porque a descripção de Marcgrave dí as utipingitur, (diz) ducubus ad latera auriculis, e as flores com o limbo côr de rosa, o interior do tubo carmezim: por isso continlamos a enumeral o Jeticucu, como outro ente, emquanto não vemos a florescencia da que julgamos como tal, para communicar a luz, que a este respeito pudermos obter.

Salsa da piaia: batatas do man. (Convolvulus. pescaproe Spr. brasiliensis L. moritimus Desruss. Ipomoca maritima Br.) Usa-se como a Jalapa.

Talapa.- Com o nome de Jalapa há nos campos da provincia de S. Paulo uma especie, que, por não acharmos descripẹão que the corresponda, a chamamos Convolvulus paulistanus. 
A raiz é de seis pollegadas de comprido e uma de diametro, oblonga, igual por dous tercos, depois fusiforme de côr parda amarellada por fóra, e branca por dentro; a planta cresce até tres palmos com as folhas de gremio de compridas, e dous ou tres dedos de largas, todas cobertas de pellos rijos ijrancos. As flores sĩo roxas e tem toda a semelhança de flòr de batata. Usa-se como a Jalapa.

-Yaiapin Ya.-E' outra especie, a que chamamos Convolvulus, pendulus C. A raiz priıcipal terí duas pollegadas, de figura oval fusiforme, enrugada, collo comprido cheio de fibras, de que estão pendentes outras tuberas oblongas de diversos tamanhos, desde duas linhas até cluas pollegadas. A planta toda será de dous palmos, com flores grandes, como as de batatas. Usa-se como Jalapa.

Pela latitude de qui.re gráos, dous mil e quinhentos a tres mil pis sobre o mar, pala extenção de tres gráos desde o Rio Grande atś o Rio Mans.) na provincia de Mattu-Grosso, no espigão, que rerte para o Rio das Mortes, em campos um pouco cerrados, ferrilninoso-arenosos, mais abindantes pelas bacias, achou-se as tres especies catharticas, abaixo mencionadas.

Convolvulus pumiceos.-Raiz fusiforme carnosa, de um palmo; caule direito, os maiores de dez palmos, todo coberto de pello branco (bem como as follhas pedunculós até as lacinias externas do calix); duas ordens de folhas alternas fazem a figura de folhas encruzadas: as flores estĩo com abundancia do meio para a porta, e são do mais lindo carmezim.

Convolvelus polyrinizos.-Levanta se !m grupo de mais, ou menos, seis varinhas de quatro a seis palmos de altura; mui proximamente í superficie da terra, espalham-se divergindo muitas raizes, das quaes pendem para o centro muitas fibras do comprimento de um a dous palmos, em cuja extremidade estão presas muitas tuberas, quasi redondas, de duas a quatro pollegadas de diametro; as flores estão pelas pontas em abundancia; são de côr de rosa com o interior tiranlo para carmezim: as folhas são oblongas, algumas mais largas na ponta.

Convolvaius grigantous. - Na extremidade de un pendunculo commun, roliço, mais grosso para a extremidade, 
de perto de tres pollogadas de comprido, sahem duas bracteas foliaceas de duas pollegadas, e mais de comprimento, e pouco menos de largura na extremidade, estreitando para a base, concavas, aquilhadas, cobrindo perfeitamente todos os pedunculos em tres pedicelos parciaes; postos no mesmo plano, de quatro linhas de extensão, e dos quaes o do meio é sempre unifloro esteril; os dos lados tem pouco ácima do meio um par de bracteas, da figura e forma das primeiras, de tamanho sufficiente a cobrir o calix, cuja flôr é fertil. E' o ordinario cada pendunculo produzir tres flores; porém não é raro produzir mais; e então os pedicelulos dos lados dividem-se em novos pedicelulos; e estes em outros, sempre pelo mesmo progresso, cada tres pedicelos e cobertos com seu par de bracteas; todas proximamente ovadas verticalmente, tirando para espatuladas, de côr verde quasi branca as que ficam cobertas; e as de fóra cada vez mais verdes: temos visto abrir do mesmo pedunculo geral, tres, sete, quinze, e trinta e uma flores, nunca mais de duas a um tempo.

o calix é tubuloso, estreitando para a base até o nascimento das lacinias; d'ahi com pequena grossura, as lacinias espatuladas, foliaceas, duas maiores com uma pollegada, e pouco mais de extensão, cobrindo inteiramente uma, e metade de cada uma de outras duas lacinias menores.

A corolla é roxo-porpurea por dentro, e branca por fóra, com pellos crespos espalhudos: tem o limbo de tres pollegadas dé diametro com as nervuras curtas, deixando raşrado o disco até - meio, formando cinco lobulos fluctuantes truncado meio retusos, o que dá ao todo do limbo o aspecto de urn pentagono regular; o tubo é de tres pollegadas de comprimento, e uma de diametro, afunilado na base. Os estames vĩo a pouco mais de meio da corolla. nascendo quatro linhas ácima da base do tubo; são roliços, estreitando para a ponta, e na base crassus cotanilhosos. As antheras, sagittadas, oscillantes, tem duas logeas, que abrindo-se, suas margens viram para dentro: pollen redondo escabroso. O estilete, apenas mais comprido que os estames, é mais fino que estes, tambemassovelado, com o estigma pequeno, redondo, marcado em dous lobulos, todo gretado e aveludado. o ovario é piramidal dentro de um annel encrassado.

As capsulas são oblongas quadrangulares, sendo um rombo 
o plano de sua secção transversa; tem duas logeas formadas por um dissepimento pela diagonal mais comprida; póde-se abrir em duas valvulas pela diagonal menor; mas ellas cahem fechadas, deixando os calices, depois de estes terem-nas retido ao menos por tres mezes. As sementes estão uma em cada logea, e são tringulares, alongadas de modo que as duas fazem a figura da capsula.

E' planta que se alastra pela terra, enfartada desde a raiz até os ovarios de succo leitoso amarellado.

Raiz até de tres palmos de comprimento, e cinco pollegadas de diametro, dividida em duas, ou tres partes desiguaes fusiforme com algumas desigualdades longitudinaes; é de côr pardoescura por fóra, com o parenchyma branco amarellado com algumas fibras longitudinaes.

As follhas radicaes são de dous lobulos: as caulinas são de um palıno aproximadamente, pedatipartidas com nove lacinias lineares agudas, estreitando para a base, inteirissimas, meio revolutivas, levissimamente lanigeraes, com pellos ruivos pelos nervos, de côr tirando para a de verdete, mas branca por baixo; peciolos roliços, pouco menores que as folhas.

Propomos esta planta para (o extracto da raiz) supprir a Escamonéa (deve-se observar tambem o extracto das folhas); 0 uso da raiz em substancia, por causa do muito amygdalo, corresponde á dóse da Jalapa.

Purga de cavallo (Convolvulus ventricosus.) - Cresce pelos mattos em grande cipós.

Usa-se proximamente de duas oitavas da raiz, que terá dous ou tres palmos de comprimento, e perto de quatro pollegadas de diametro. Dão tambem grandes pedaços das raizes recentes na peste dos carallos. A de que fallamos estava na beira do Rio Paraná.

Taes são as especies de que temos noticia, e alguma observaç̃o; póde-se porém esperar muitas mais, servindo-se da regra de observar todas as convolvulaceas, que forem de raizes tuberosas, e parenchymatosas, que tenham a seiva visivelmente leitosa, pois que todas contém mais ou menos jalapina. D'este modo não serú muito achar cincoenta especies uteis. 
Bonina: maravilla : bollas noites. (Mirabilis jalapa.) - E' a jalapa de que se usava antes do Convolvulus jalapa, e de que se foi deixando por necessitar de maior dóse: ainda assim algum Fazendeiro tem para o seu uso; e a resina da belle de nuit ainda anda no commercio com o nome de resina de batata, tão exaltada no Erario Mineral.

\section{AROIDEAS}

A acrimonia das substancias tiradas d'esta familia faz repugnar o seu emprego; mas á vista das observações publicadas em Rosier de que a acrimonia existe na agua da vegetação, a qual se perde pela desecação, cuja observação se comprova pela pratica dos nossos lavradores de fazer exsiccar os inhames, tayuiás, mangaritos, etc, para o uso culinario, concluimos que deve ter todo o logar, com emulices, as vezes meio torradas (se forem muito recentes) e assim enriquecer a materia medica com mais:

Tararaca. (Arum dracunculum L.)

Dé de bezerio tanhoninorone: (Arum maculatum L.)-Estas duas especies tem: algum uso entre os lavradores da Europa.

Arringaiva? (Caladium arborescens Spr)

Granimbé (Caladium lacerun Spr.)

Gínimbé (Caladium pendulinum, C.) - A dóse de todos é de cinco a vinte e cinco grãos da raiz em pó em casos de hydrotorax, ascites, e quando conviesse irritar a parte opposta, e obrar por antagonismo.

\section{IRIDEAS}

A propriedade cathartica d'esta familia existe como na antecedente na agua da vegetação, e em uma mucilagem adstrin- 
gente; mas como esta propriedade benefica é branda, forçoso é que se perca pela desecação; é o que confirma a experiencia que vem no Dicc. de Agr. sobre a Flambia Iris germanica L. da qual a raiz recerte purga ponco; secca lavada não purga) por cuja parilade se tem observado successivamente todas as especies conhecidas da familia, que, sendo havida ao principio por um só genero, achou-se ao depois competirem a varios: todas mais efficazes em recentes.

Fin io roxo. (Morea nortiana? Morea spicata her.)

LRibarbo da hoxta : Barerissó. (Morea.)Esperavamos ver n'esta planta o Sisirinchium Bermudiana; mas achamos o genero, que annunciamos em uma flôr amarella hemispherica de tres linhas de diametro, folha: linearcs, caule um pouco geniculado com espathas successivas raginantes.

rylairit. ririo amanello do campo. (Morea.) Ririo roxo do camrio. (Morea.)

Estas duas especies são ordinarias nos campos de Goyaz, Minas, e Matto-Grosso. Tem folhas plicadas.

Lixio samilhado. (Morea.)-Flores de duas pollegadas de diametro: dá debaixo dos mattos frondosos.

Lixio bianco do canmpo. (Horea.)-Flores brancas de duas pollegadas de diametro. (Ha outro do matto com folhas maiores que o scapo.)

Ruibabbo do campo: Vareta: Batatinka: Barerissib do canpo. (Morea apylla.) - Não tem follhas: levanta-se o calamo de perto de cinco palmos, em cuja extremilade estĩo ordinariamente uma ou duas flores amarellas de tres linhas de diametro, e raramente mais. Dão oito raizes para um purgante.

Temos por Morea um Iridea, que se nos mostrou no Curumbá com scapo ramoso ancipite, de um palmo, geniculado, folhas ensiformes vaginantes: tinha dous pendunculos terminaes.

lenibarbo do cllareo: Piretro: (Ferrario purgans Mart.)

Neiraria catmaxticar (Mart)-Estas duas especies nascem pelus logares encharcados de Minas, e S. Paulo. A $11 \mathrm{r}^{2}$ 
não tem o caracter, que vimos em Sprengel, mas temos toda razão de suppor que aquelle Sabio descreveu á vista de algum exemplar confundido pela exsicação; e por isso tomou os estames por tres petalos, o estilete dividido em tres por stamina tria connata, e os fasciculos de pellos que estão entre os estames por Stigmata penicclata.

Mazirièò Bareressú. (Sisirynchium bermudiana. Cærtner?)

Facil será termos a Iris germanica. De todas estas especies; usam-se as raizes tuberosas pisadas, e misturadas com agua fria (em clysteres nas febres das crianças, como purgantes, todas até quatro oitavas: o extracto, e a fecula como alterantes em casos de affecções da pelle.

Lirio roxo. - Usa-se quando se carece purgar nas intermittentes, e se faz composições com quina, e limão, que obram por ambas as vias.

Da vareta podemos affirmar o effeito nas boubas, posto que sempre se faz acompanhar por algum mercurial; comtudo muito menos mercurio é preciso, e em casos, que não tem cedido a outras preparaçoes mercuriaes tem-se visto ceder á vareta só.

\section{RUBIACEAS}

Oainca; Cruzeirinha; Caninana: Raiz Preta: Puaia (Chiococca racemosa L.)-O Patriota, depois de ter descripto a Raiz preta, e afiançado (me teste) seu effeito na hydropesia, diz da caninana (que não tinla advertido ser a mesma) que é um dratico, urinario, tem curado aceites, e anasarca: dóse em cozimento de quatro a seis oitavas, em pó, até uma oitava; extracto aquoso um, a dous escropulos: porém irrita mais. E' d'esta especie que H. Langsdorff applicava quasi indistinctamente emquanto esteve no Brasil; e fazia copiosas remessas para a Europa, ultimamente em extracto.

Achamos extraordinario que se aconselhe maior dóse do extracto do que da raiz, de que se faz o mesmo extracto: pelo 
menos carecia combinar com mais praticos que não tenham feito especulações com o extracto. Algumas observacões que temos a este respeito tem correspondido á indicação do Patriota.

E' usada no interior de Minas como emmenagoga: algumas pretas vimos, que ahortaram de proposito por effeito d'esta especie, que é muito abundante pelos cerrados de S. Paulo para o Norte em todo o Brasil. E' subarbortira, de dous ou tres pés de altura.

Cipó cruz (em S. Paulo) Fedorenta: Dambro: Laiz de reade (em Minas) (Chicocca angricida Mart.)Cresce nos mattos até seis ou mais pés de altura encostando-sc ás outras plantas.

E' purgante muito seguro contra as mordeduras de cascarel, e outras cobras, e applica-se no rheumatismo, etc., macerada em agoardente: regula-se ros pugillos dous para uma medida de agoardente, e assucar, para tomar ús chicaras duas vezes por dia.

Chicocea consiíolia (Mar.)-Cresce em moitas de muitos individuos pelos campos.

Puaia (cephaelis ipecacuanha W.) (Emetica Pers.)-Cresce pelos lugares sombrios.

Tuata (spermacoce pucia? Hil.)

zuaia (spermacoce ferruginea? Hil)

Tuaia (Richaedsonia pilosa Runth.) Sperimacoce hirsuta W. Richardia pilosa R. e P.

Iraaia (Psycotria emetica Spreng.)-E' a mais ordinaria pelo mattos.

Para (Manettia cordifloria Mart.)

Puaia (Manettia auradiflora.)-Assim chamamos a uma especie, que é ordinaria pelos campos cerrados da provincia de S. Paulo. Tem o limbo breve amarello, e o tubo grosso, encarnado do comprimento de quatro linhas.

E' tido pelos hahitantes como puaia.

Cargamba: Jorataca; Manaca; Mercutio vegetal (Franciscea uniflora Hil?)--Usa-se da raiz na dóse de seis a dezoito grãos. 
Grenipapo (Genipa americana Tourn.)--Descourtilz, citado por Merat affirma ser purgante a casca da raiz. Esta casca, como toda a planta é adstringente; temos noticia de alguns indiriduos do genero Gardenia (que è mui proximo do Genipa) os quaes, tendo sabor adstringente, tem effeito purgativo; pelo que concordamos no effeito nĩo só do Jenipapo, como de outras casças adstringentes, que todas se devem tentar a exemplo do effeito, que se observa na quina quando excede a dóse

Igualmente temos de obter muitas mais especies de puaia nos generos Hamelia, e Psychotria com o nome de herva de rato, que serve para matar os cães.

\section{JONIDEAS}

wolca inecaceanha (Spreng.) Viola ipccacuchha L.Pombalia Vand.-Jonidum Vent.-E' o primeiro emetico, e unico, que se conlreceu do Reino regetal até o principio d'este seculo.

s.solea (Spr.) Brevicaules. Jonidium Mart.

soloa (Spr.) Lrticafolic. Jonidium Mart.

Sisiea (:spr.) Puaia Jonidcum Hil.

sioioa (Spr.) Parviflora Viola L.

Todas estas cinco especies tem o nome de puaia. ou puaya. Ha ainda uma Noisetia Mart. que é emetica. Purga do campo, e purga de veado são duas especies de Solea: o que tudo dá razão de contar-se com a fumilia para tentar-se o efieito cathartico, ainda que a especie nĩo seja determinada

wima: Pyragaia: Mnchiesa: (Anchieta salutaris Hil.)-Lsa-se da raiz na dóse de uma oitava em recente Parece carecer da mesma dóse em secca.

\section{CONTORTAS}

Presentimos e entrevemos que este grande grupo, que abrange mais de uma familia natural, viri um dia a primar na Materia 
Medica Brasileira pelas suas qualidades aromaticas, picantes, antivenenosas, emeticas, catharticas, drasticas, e deleterias: quasi todas tem a seiva leitosa; a maior parte de gosto acre, e desagradavel.

As Aselepias principalmente tem a curassavica conhecida com o nome de herva de rato, que mata os cães, precedendo evacuações por todas as vias. A Asclepias syrica da America boreal já foi enumerada como cathartico, e emetico em forte dóse; qualidades sensiveis analoqas conhecemos em perto de oitenta d'e:ta subdivisĩo: no entanto temos:

riborna: Raivosa em Minas (Plumeria bicolor R. e P. Plumeria drastica,)-O leite é cathartico, reccute na dóse de uma colher; o extracto da casca purga na dóse de oito grãos; a casca secca : em pó purga na dóse de dous escropulos.

reipoca é tambem Pulmeria, que tem proximamente o mesmo efleito.

Fonites grandinora (Nart.)-E' emetica no Pará.

Fchites cuauru (Mart.)-Emetica como a antecedente.

Varias plantas d'este genero, que se applicam, como contraveneno, todas obram cathartica, e algumas tambem emeticamente.

Quina do campo: Para trucho: (Strichnos pseudnquina Hil.)-Dóse de duas a quatro oitavas em cozimento, seģu : clo dizem os Sertanejos.

\section{CUCURBITACEAS}

N'esta familia, e suas affins estr̃o agentes do maior merecimento, não só pelos seus effeitos, que sáo nosso objecto, como pela particular applicação. que é proplria á sua maioria em casos de maleficio (que sĩo envenenamentos lentos, e continuados, que hoje estão em grande auge pelos aricanos, e outıos de suas circunstancias) hydrotorax, ascites, qualcuer molestia que tenha por causa virus escorbutico, e venereo até certo ponto, 
amenorrhéa, esterilidade, epilepsia, e envenenamentos por picadas de cobras. Le alguns d'estes casos temos sido testemunha. Da maioria das cucurbitaceas servem as sementes, e raizes como vomitivos, e purgantes: de muitas tambem as folhas em bebida como alterantes, e em banhos resolutivos. Suas virtudes são do conhecimento do poro, em algumas partes a mesma especie com diverso nome; em outras, outro genero, ou especie da mesma familia; e o nome mais trivial é o de Tayuiá, de que rimos annunciado haverem sete especies diversas conhecidas por valios sertanejos, e fazendeiros; mas pouco adiantam i sciencia annuncios, que não trazem algum caracter distinctivo.

A florescencia de todos os generos d'esta familia é tão delicada, e carnosa, que se confunde quasi sempre pela deseccação; - que faz com que algumas plantas das que temos examinado, não concordem com as descripções, e porque, para darmos no praso o nosso trabalho, não ha tempo de consultar os sabios; damos os nomes ás que não podemos capitular pelos livros, que possuimos.

Monoecia syngonosia.-O nome generico é tirado da estreitesa, que tern a flôr feminina logo abaixo do calix, dividindo-o do ovario. Conhecemos tres especies, todas acima da Serra do Mar, em campos descobertos, mas abundantes, onde domina mais arêa; todas têm gavinhas simples, caule fino sulcado, folhas quasi rentes pedatipartidas em tres lacinias lineari-agudas, mucronuladas, inteirissimas, seccas, reticuladas. pedunculos solitarios de uma flôr.

As especies são tiradas da forma da raiz, e do fructo.

Espelina, em S. Paulo, Tomba. em Minas (Perianthopodus espelina. P.)-Raiz até de cinco palmos de comprimento, afinaindo cada vez mais para a ponta, tendo na parte superior proximamente uma pollegada de diametro, procurando o centro da terra por poucas circunvoluçoes: é pallida por fóra, o parenchyma quasi branco. mui quebradiço, preso por algumas fibras finas longitudinaes: gosto amargoso amygdalaceo.

Espelina (Perianthopodus tomba. P.)-E' vista principalmente em S. Paulo: os fructos são quasi carmezim, meio compridos, rombudos: a raiz é quasi um fio, que se engrossa formando 
varias tuberas seguidas ertre esta raiz fina, e commum; tem até quatro d'estas tuberas, que se profundam quasi perpendicularmente, oblongas, e as da ponta maiores: pelo mais sĩo do caracter da espelina.

Estas duas especies são tomadas uma pela outra indifferentemente, debaixo dos mais faustosos auspicios nos casos de envenenamentos de qualquer natureza: provas irrefragaveis tinhamos para longa dissertação, se o objecto do presente papel não fosse a qualidade cathartica, pela qual respondemos (bem como por tudo o que affirmamos sem citar alguem); a dóse ordinaria é uma oitava, mas nós temos visto obrar com meia chicara de ligeiro cozimento de uma oitava em uma libra de agua: pensamos que não ha inconveniente por excesso na dóse. Obram tambem emeticamente. Usa-se muito em clysteres, nos casos de molestias que têm por causa virus venereo, e escorbutico, e entĩo é só purgativa no mais alto gráo; purga sem grande irritação; mas de serosidade passa o sangue, cuja hemorrhagia se chega a dar cuidado, facilmente se atalha por meio de comida de qualquer herva oleracea, feita pelo modo ordinario, quasi sempre com angú.

Puxga do Caxijó, em Cuyabá (Perianthopodus Carijo. P.) - Tem o fructo dous terços de capacidade menor que as antecedentes; de côr proxirna á de zarcão (em madura); tem a raiz muitas tuberas seguidas, e prests por uma fibra cada vez mais, e a intersecção cada vez mais comprida: as tuberas são como de um palmo, de figura linear: pelo mais como as antecedentes.

Esta raiz foi mostrada pelos indios como possuidora de todas as virtudes; ella tem um effeito seguro nos envenenamentos por picadas de cobras, sempre como cathartica: não vimos effeito emetico; uma oitava, proximamente, varias vezes vimos applical sem inconveniente, e usamos sempre que podemos obter qualquer das tres especies com preferencia a qualquer purgante.

Abobrinha do mato: 'Tayuia do quiabo. em Minas e S. Paulo, Gónúr. em Minas. (Wilbrandia hibiscoides W.)-Rauz de cipó, dividida em poucos galhos, mas finos, espalhados horisontalmente; d'este sahem tibras, que acabam em 
tuberas ir:agulares de sess pollegadas de comprimeato, e duas, e mais de diamotro na grossura.

Picroja do Ciajó em S. Panlo, Annia Pinta: Capilio do matto em Minas: (Cayaponia globosa. C.)E. um cipj fino com follas como de pepino, que cobre pequenas arvores de mattos inferiores, com o fructo redondo. vermelho, de dez sementes com pouca differença, ovadas, esbranquiçadas.

As sementes d'esta planta são usadas, com grande vantagem, como coitraveneno de cobras, antivenereo, emenagogo; já. vimos hemorrhargias produzidas por clysteres d'estas sementes: meia fructa purgga muito bem, porém dão até duas em casos urgentes de envenenamento de cobris.

Daroga de Caiapó (Demorphylla eliptica. D.)-Tem o mesmo habito qne a antecedente, e dá em logares mais seccos. Os fructos são meio compridos, e amarellos; as sementes são miulas que as antecedentes, desiguaes, acabando em poata, com a margem estreita, marginada por uma linha branca.

Esta especie é preferida pelos praticos d'estas applicações, ambas tem applicação veterinaria contria a peste: di-se as sementes de seis fiuctos com milho aos bois, e cavallos, o que lhes produz copiosas dejecções.

Bucha le Paulita: Puega de Joño paes: (Luffa? Momsrdica operculata. L.)-Esta planta, que (além de outras dissemelhanças) differe da Luffa, por ter as antheras coadinadis, e dia ilomordica, pelo fructo oblo:igo operculado (quando a Momordica tem capsula, que se abre com violencia por um lado) viri a fizer min genero aparte. Usa-se da infusio da polpa do tructo recente (o que é em commum com as da familia) em frio, como se vê no Putriotı, ou em agua quente, o que abrevia a operação, sem prejuizo do resultado. Toma-se as colleres até lazer obra: as sementes têm a mesma propriedade que as antecedentes, em pouco menor grío.

13uchiuha (Luffu? Momordics purgans. Mart.)-E' sem duvida outra especie do geilero acima, que poico differe no habito, e tem os fructos tres quartos mais pequenos: ella tem mais acrimonia, e obra em menor dóse que a Bucha de Paulista; tres grãos do extracto é drastico. 


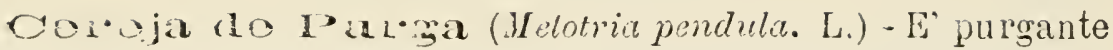
como Cuyıponia, na mesma dóse em numeru de sementes, não obstante serem cinco sextos menores

Desta raiz é que se usa no centro de Miıs Geraes, para supp ir o Tombı, lli mesma dóse em pó, e cozimento, por bebida, e clysteres nos casos de molestias renereas, cutaneas, hydropesia, etc., etc.

E' um dos enumerados como Leroy: nĩo nos consta, porém, que appliquem como antidoto, o que se deve ensaiar com a maior pirobabilidale do bom resultado. Ha una outra especie.

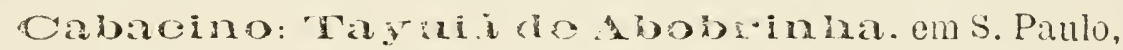
sertĩo da Bahia, e Pernambuco. (Demnephylla pendulinu)-Folhas te cinco lacinils em caule de cinco sulcos, con gavinhas partidas em diras partes desiguaes; os fructos de figura oval, de uma a luas pollegarlas na sua maior grauleza, de dez ou doze sementes postas ao longo, dependuiados, e emam murcham, e se tornam amarellos. A raiz co.ista de tub ras lineares pendentes de fibras que nascem todas de uma excrescencia do collo.

Onde se encontra esta plant، (que não é muito abundante) dizem os moradores, que d'esta casta é que mais procuram.

Ella é pleferida nas molestias de pelle, e é d'esta casta que se pretend: ter tomado um escravo do Searlor vergueiro, que the Pugira para não hir para o Hospital dos Lazaros, depois de desenganado pela Gente da Llec, e volton quando se achou são, depois de continuo uso de bebila dis folhas d'este cabacinlo.

A dóse da raiz ó proximannente uma oitava a luas em secca. tres ou quatro sementes, e ainula a iatusióo di polpa de meio fructo.

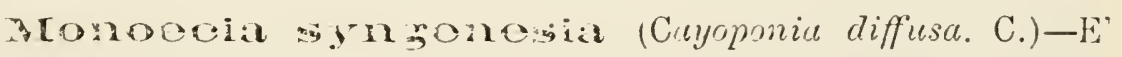
um cipo muito grande, que cobre is vezes as grumles arvores: tem os ramos de sete sulcos, folhas de majs de palmo, com tres lobulos, dos quaes o do meio è mais comprido, e acaba em ponta fina; as raizes são tambem muito compridas, e de grallos no principio como cipó, que se espallıa por debaixo da terra.

As raizes são purgantes, em bebida ou clyster, frescas, raspadas, e seccas, reduzidas a pó; a clóse é regulada como duas oitavas. Uma fructa que terí o tamanho de um ovo de pomba, e i ama- 
rello parda em secca, regula para um purgante forte em casos de envenenamento por picada de cobra, e outros em commum com a familia.

Cabaco amarogoso (Lagenaria vulgaris sering $C u$ curbita lagenaria L.) Ha muitas variedades d'este genero, mais ou menos amarg'sas; usa-se da polpa em clysteres pelas curadeiras nas abstrucções, e cores palidas; é drastico forte: já vimos fallecer um certo Cirurgião Sauta Anna, em Sorocaba, por uma hemorrhagia que lhe sobreveio depois de ter deitado muito mucs por dous dias, e depois muco sanguinoso pelo abuso na dóse de uma d'estas applicações: tambem vimos vomitos, e dejecções pelo equivoco de se misturar alguns grelos de cabaço com os de abobora em um guisado.

Esta especie tem a maior propensão para dar variedades: a qualidade amargosa vai-se perdendo quanto maior é o fructo, até ser abobora d'ağua adocicada; ou antes pela degeneração l'esta é que se engenlra claterina que parece ser o principio activo em toda a familia: os cabaços, que temos observado, e tentado em clysteres na dóse de duas oitavas de polpa recente, são ovados verticalmente, e de seis pollegardas proximamente de diametro.

\section{rayuí: Tayuí do pimonta: Abobora do} Matto: Abobrinha: (Bryonia cordatifolia Godoy) no Patriota com a nota de Marcg.) - A que temos presente coincide com a breve descripção de Godoy somente da folha: como n'este momento não ha flôres, forçoso é estarmos pelo genero: accrescentamos no entanto que a da provincia de S. Paulo tem o cipó com sete sulcos; as gavinhas partidas até o meio em tres, e as vezes quatro partes: as folhas têm uma decurrencia estreita até o meio do peciolo: sĩo velutinas, asperas, cordatoseptem-lobadas, remota e brevissimamente dentadas: os fiuctos em cachos, oblongos de quatro ou seis linhas de comprimento.

D’esta pequena observacĩo se conclue que nĩo tem logar a supposição de Merat e de Lens citados por Justiniano, de que - Tayuíi é a Momoídica purgans de Mart.

As raizes d'esta planta, que são muito abundantes de cipó com poucos galhos espalhados, sĩo de antiquissimo uso como purgantes, cujo effeito, se excede a espectação, os sertanejo ${ }_{S}$ 
atalham com caldo de cangica (e por consequencia nós o faremos com qualquer mucilagem): são igualmente estas raizes as que se vendem em toda a parte com o nome de Turbith: a dóse é de meia á duas oitavas.

Ha um Sycios, cujo fructo é nuito amargoso, que tambem tem applicação como purga de Cayapó no sertão; e dizem que purga na dóse de uma fructa.

Tayuiá miudo. (Alternasemina tayuiá. A)-Tem cipó com cotovellos, com gavinhas simplices; as folhas são profundamente cordiformes com ponta aguda, e margem dentada: é planta pequena do campo.

Bem perto é este genero do Melothria: é usado proximamente como as Cerejas de purga; e a planta como alterante.

Abobora do Matto, em Goyaz. (Druparia racemosa. D.)-Na Villa de Meia Ponte, mostrou-se-nos esta planta, de que usam, como nós do Tayuiá: é planta pequena, e por isso rara já por perto das povoações.

Póde-se enumerar a Bryonia alba, e Cucumis colocynthis, que se deve transplantar.

Cucurbitoe Species varioe. - No supplemento á Therapeutica de Richter por Jorge Richter lemos que Mongeny applicava contra o verme solitario tres onças de abobora em jejum, acomparıhado de duas onças de mel á cada hora das tres seguintes; Hufeland accrescenta que se deve continuar por dez dias.

Todas as especies de abobora cultas, são abundantes de oleo nas sementes; e por isso devem ser enumeradas como laxantes; além do effeito de toda a substancia crua, que se observa nos animaes. Este effeito póde ser considerado com mais amplitude em toda a familia, e suas affins: entre estas podemos enumerar as seguintes.

Mamão (Carica papaya L.)

- Taracatici (Attazia payos Lour. Jacaratia Brasiliana Pison.

- Taracatiá (Attazia Jobini (h) A.) As sementes d'estas tres especies são anthelminticas na dose de uma oitava, repetidos dias. 
Tabota, Cipó Jaboti, no Pará; Andirova. na Bahia; Fava do Samto Ignacio em algumas partes (Ferillea trilobata D. Cand F. scandens B. L. F. hederacea Poir Nhandiroba Marcgr.) - Nos Manuscriptos dos Jesuitas um inarcgrave no Joumal Universel des Sciences Medicales, citando ao Jamaicenses, em Berlin na collecção dos remedios novos do anno de 1825 , em Baviere, etc.; tem-se feito notavel a utilidade d'este vegetal, que Jorg. Rict. propõe cultivar-se 110 Meio dia da Europa. Nada ha a accrescentar ao que refere Justiniano das experiencias feitas no Hospital da Misericordia da Corte, senão que esperamos conhecer a planta descripta por Marcgrave para tirar-nos o equivoco, que nos for possive sobre a descripção, pois parece-nos que a mesma estampa de Turpin foi feita sobre exemplar secco, o que pouco prejudicará a Terapeutica, pois que as sementes de todas as especies, que temos noticia d'este genero, e analogos. servem umas por outras.

A que conhecemos temos por outro genero do mesmo grupo; e por isso damos uma descripção breve, visto que o tempo já não nos dá para os detalhes, que desejamos.

Dioecia pentandroia (L.)-Esta planta tem inteiramente o habito do Tayuiá (bryonia?), mas não se póde examinar a flôr sem tomal-a por uma Passiflorea. Tal é o effeito que produz a vista dos estames, que vistos de cima parece que não tem antheras por ser a fenda antherifera da parte de baixo; e o receptaculo muito saliente com o rudimento da corôa. Na Fexillea Jussieu suppoz na flôr masculina germens abortivos; e na flòr feminina estames abortivos, o que nĩo nos parece muito natural, sobretudo que hajam germes excentricos aos estames; e tantos, posto que abortivos; antes nos parece que este grupo está entre as cucurbitaceas, e passifloreas; e desde que se separaram estes ultimos grupos, que Linneo tinha juntos apparece em Jussieu-Cucurbitacea dubie; em Sprengel Passi. Horece; em Hil. Nhandirobec; em D. C. Cucurbitacece tudo para a Feuillea: parece-nos que, enriquecendo-se um pouco o gr upo, os sabios virão a acceitar proposta de S. Hilaire para uma Familia separada.

Guapeva: Hava de s. Ignacio, em S. Paulo, (Hypanthera guapeva. H.)-Tem as raizes, de cipó muito abun- 
dantes, amargosas (que se deve experimentar como Tayuiá): o caule, e folhas de gosto gomoso cucurbitaceo e no fim piperaceo: as amendoas antes de tomarem ranço tem o amargo simples da quassia. Tem os mesmos usos sabidos da Andirova. Temos a accrescentrar doze casos seguidos de cura Icterica em Africanos com purgantes de Guapeva na dóse de duas sementes: todos sararam com um a dous purgantes: pensamos que será de utilidade nas erysipelas. Aos cavallos se dá nove sementes, e não lhes faz vomitar.

Castania: Castanha de Bugre. (Anissosperma passiflora. A.)-As sementes tem applicaçĩo vulgar com o nome tambem de Fava de S. Ignacio. Dá se tres, ou quatro sementes nas opilações, etc., sempre purga.

\section{MELIACEAS}

Marinheiro: Utuaruba. (Guarea trichilioides. L.) in Spr.-Mostrou-se-nos na Villa de Uberava em Minas, um pedaço de casca de um gemio, de comprido; e tres dedos de largo, como a dóse para um purgante (o entrecasco posto de infusão) para limpar a barriga das mulheres (diziam): para o centro tomam em clyster: em todo o caso é purgante forte; mas que póde ser de utilidade em menor dóse.

Marindeiro de folna larga: Marianinha de Lonla laria: Tuaiussu: Tuanpoca : (Toichilia glabra T. havanensis Jacq.)-Usa-se como a antecedente, é anti-siphylitica, em clyster.

Maringeiro de follha minda. (Trickilia cathartica Hart. Jito Pis.) -E' das raizes que os curadores dos Indios tinham para expelir os maleficios, dando.porções arbitrarias da casca raspada: toma-se como meia onça da raiz recente.

Cajarana é uma grande arvore, que tem o habito da cedreta com as folhas pinnadas com impar, os foliosos ovatolonceolados com meio acumem inteirissimos, lisos. Usa-se nos mesmos casos, e pelo mesmo modo que o Marinheiro. 
Supacaya (Lecythis ollaria L ?)

Lecythis Zabucajo (Aublet), e outras especies; o oleo das sementes em grande dóse.

Andirora (no Pará Xylocarpus Carapa Schereb:) o oleo das sementes em grande dóse.

Mas vegetaes ha n'esta familia analogos aos antecedentes, que todos pódem ter applicação como catharticos, sendo todas as sementes mui ricas de oleo, de que alguma experiencia temos de ser innocentes.

\section{BIGNONIACEAS}

Caroba (Jacaiandi caroliniana Pers. Bygnonia cceruloea L.)

Caroba. (Jacarandá brasiliana Pers. Bygnonia Lam. Jacaranda procera Juss? Bygnonia copaia Aublet.)-Esta especie, e a oblongifolia, e a cutilifolia de Humboldt não enumeramos por não estar bem certos se se encontram no Brasil (o que é muito provavel) posto que temos mais que sufficiente numero de especies d'este genero, e outros: taes são.

Caroba do matto (em S. Paulo Jaracandá paulis tana J.)

Caroba do campo (em Goyaz, e Matto-Grosso Jacarandá rufa J.)

Carovinha do campo: Sene (em S. Paulo, e Minas Jacaranda pteroides. J.) Todas as especies se usa das folhas, e do entrecasco das arvores interna, e externamente : e fazem purgar mais ou menos. E' de muito uso em todo o sertão uma ou outra especie, e as que vamos continuando a enumerar: regulam tres oitavas das folhas, ou do entrecasco das que são arvores.

Caroba; Sene do campo. (Bygnonia nodosa. B.)Nasce pelos campos seccos. Usa-se das folhas como sene, duas oitavas para purgante. 
Ipê: Ipeuva: Piuva, em S. Paulo, Para tudo, em Matto-Grosso. Páo de arco (Bygnonia aurea. B.)0 entrecasco d'esta arvore é usado ccmo a caroba em muitas partes do interior, e em dóse de uma onça de substancia, em cozimento, purga.

Taruman: no Rio de Janeiro Ipê, Taruman: na Bahia Páo de arco (Bygnonia Aluviclis? Aubl.)-Não temos um exemplar para determinar esta especie, que é a enumerada na Corographia Brasileira, como secernente renario.

Usa-se das folhas em forte cozimento, e tambem do entrecasco como a antecedente.

O nome de Ipé é commum a muitas Bygnonias; muitas mais especies tem uso em varios sentidos; e póde-se affirmar que a familia tem propriedade anti-siphylitica.

\section{LEGUMINOSAS}

Angelim: (Geofroya inermes Swartz Andira D. C.)-Esta e varias especies são anthelminticas na dóse de meio, á um escropulo das amendoas.

Cumary. (Dipteres odorata? W.)-As sementes dão oleo, que se póde empregar em laxantes.

. Tatay : Totay : Copal: (Jetaiba Pis. Hymenec cour baril L.)-Usa-se do entrecasco em infusão.

Voronona: (Inquirii Pis. Mimosa pudica L) -Um pugillo das folhas orçado de uma a duas onças, ou uma oitava de raiz, são tidas por purgantes nas Antilhas.

Mendoim: Mrandoby. (Arachis hypogae L)-Oleo conhecido, que tambem se póde empregar.

ramarinos: 'Tamaxindos. (Tamarindus indica L.)

Caaroba Pis. (Ceratonia siliqua)

Canafistula. (Cassia brasiliana. Lam. C. gradis L. Cathartocarpus bacillaris. Pers.) 
Canafistula: Quapicobaba. (Cassillaris Spreng Cathartocarpus bacillaris Pers.)

Canaristula. (Cassia fistula L. Cathartocarpus fistula Pers.)-Estes cinco vegetaes indigenas, e aclimatados existem com abundancia no Brasil: usa-se de todos de duas a quatro onças, quasi sempre com algum sal quando é applicado por professores. Da Caaroba póde-se usar tambem das folhas em cozimento, ou infusâo, segundo a indicação de Pison.

Sene do campo. (Cassia.)-Suffructicosa, caule ramoso de dous, ou tres palmos; folhas viscosas pinnadas de muitos pares; foliolos quasi redondos menores os das extremidades; flores nas extremidades, siliquas planas de tres sementes pouco mais ou menos.

Alcassús bravo: Boigordo. (Cassia.)-A raiz d'este vegetal (que é notavel por tingir de amarello, cuja côr tem no parenchima, e é por fóra) além de outras propriedades purga na dóse de meia onça proxiraamente, de que se tira a substancia feculosa por cozimento, infusão, e dissolução em agoardente.

Sene do campo. (Cassia eathartica. Mart.)-Não temos esta descripção.

Deve contar-se com a Cassia lanceolata. Forst. C. abovata, Collad. C. cegipciaca. W. que se cultivam na Italia, onde são tambem espontaneas, e de onde nos vem misturadas: igualmente com a Cassia marylandica de que se usa na America do Norte indigena de Nova-York, que todas se devem transplantar. De resto, este genero está inteiramente inobservado, bem como toda a familia. de que apenas se entrevê a utilidade; sendo de esperar que varias castas de Timbó, como o Glycine precatorius, e outros; a maior parte das folhas das cassias, a polpa do Timbouva ou Timburi, Mimosa de que ha duas especies conhecidas; as cascas das Acassias; e sobretudo as cotiledones da maioria da familia tenham a mais util applicação, e se tornem preciosos ramos de commercio, quando os encarregados dos destinos do Brasil prestarem sua attenção tambem para este lado 


\section{DILENIACEAS}

Cipó de carijó. (Tetracera ablongata. D. C.)

Cipó de carijó. (Tetracera volubilis. Spr.)

Cipó de carijó. (Darilla rugosa. Poir.)-Estas tres raizes são apontadas como drastico, e applicadas na mania $\mathrm{n}_{\mathrm{a}}$ dóse de meia oitava em pó.

Vismia lacifera. (Mart.)

Vismia micrantha. (Mart.)

Vismia laccifora. (Mart.)-Estas tres especies da fámilia das Hypericineas dĩo a gomma caopiá de Pison ou lacra cuja dóse se sabe ser de oito grãos o termo medio nos caso em que se applica a gomma gutta.

Torminalia arogentea. (Mart.)-A gomma risina na dóse proximamente de meio escropulo em logar da gomma gutta: ella pertence á familia das combretaceas.

A' esta familia devem pertencer os Mirabolanos, de tanta voga em outro tempo, e que se deixou por fraco; mas que se póde substituir pela casca do fructo de uma Bucida? que temos em arvore com o habito da curatella americana, folhas penninerves oblongas, retusas cotanilhosas por baixo; fructos drupaceos, ovados, cotanilhosas, sementes celindraceas reluzentes.

Poaia. (Polygala poaya. Mart.) -N'esta familia das polygaleas estí a Securidaca, cujas folhas se deve observar para servir de sene como servem algumas especies entre os lavradore da Europa; e consta de Rossier.

Fava de santo Ignacio. (Sterculia balaghas.)-No Patriota o fructo é cathartico desfeito em agua na dóse de uma oitava.

Monduim do Matto. (Sterculia:)-Cumem-se os fructos que são empregnados do oleo, e podem servir como outro qualquer purgante d'esta ordem dos obeosos.

Baboza. (Aloe) -0 extracto é applicavel como o Azebre, que dá a Aloe ferox D. C. (A. perfoliata. L.) 
Dorradinlaa: orellaa de I.ato, no Pará e Matto Grosso. Matta cama. na Bahia. Purga de paes. (Caataya. Pis. Stemodia arenaria. Humb. St. parreflora. R. Br.) - Toda a planta na dóse de uma oitara para menos. A mesma propriedade tem outras especies que não podemos dizer positivamente.

Cabelio do nogro.-E' uma especie de Erythroxilon com folhas oblongas grandes, de côr de couve (glaucus) cuja raiz faz purgar.

Deve-se tental este effeito em outras especie d'este genero, bem como a arvore que em S. Paulo clıamam, Massaranduva, e outra, que em Paquetá se chama Suputiava, porque outras especies tem uso no sertão, o que nos assegura que se póde tentar sem risco.

\section{Cipó summa bianco.}

Cipó summa vermelho.-Estas duas especies tem um effeito cathartico muito seguro, e applicação muito antiga em S. Paulo nus casos de boubas, e molestias de pelle: a dóse é a casca de um palmo da raiz. Secca-se tambem a mesma casca da raiz, e se applica por dias seguidos na dóse de uma oitava.

Promettemos uma descripção circumstanciada quanro nos vier á mão as peças para isso necessarias, se esta planta não estiver capitulada: no entanto só podemos affirmar que ella nos parece ser da familia das Asperifolias, talvez uma Tournefortia: é cipó de grande extensão com folhas alternas ovaes, com acumen lisas, e a margem brandamente serrada: raizes muito abundantes, notareis (a segunda especie) pelo seu parenchima côr de rosa.

Horra de santa Iaria. (Chenopodium ambrosioides, L.)-As sementes na dóse de uma oitava proximamente envolvidas em algum oleo, são muito usadas como anthelminticas.

Collophora atisis. (Mart.)- No Pará dá um leite usado como anthelmintico.

Ficus radiala. (W. F. anthelmintica. Rich. D. C. Mar.) 
Gameleira. Figueiıa branca. (Ficus.)-Esta, e muitas outras especies tem o leite, que é gomma resina, mais ou menos cathartico para as cachexias.

Sabugueiro. (Sambucas nigra. L.)-Temos por um laxante. Rosier diz. Les feuilles recentes purgent per; fs. 312. Usa-se quasi sempre guisadas as folhas para a cêa.

Losas brancas.-E outras especies conhecidas de todos, como se fossem indigenas (Rosk, epec. var.)

Pecogueiro. (Amygdalus persicu L. in Spr)-As folhas, e flores na dóse de meia onça em cozimento seguindo os AA.

Fumo: Tabaco: Petemni: (Nicotianna tabacum.)Tem o effeito purgativo. Is praticos regulam o meio; em bebida rara vez; poucas em clyster; em fumigaçoes aos afixixiados, e em unguento com mais frequencia. Notamos que as constipações de ventre são menos frequentes nos que fumam.

Didynamia angiosperma. (R.o Pardo, e S. Paulo) com flores labiadas ruivas em espiga, folhas felpudas estreitas na base, raiz tuberosa, que obra catharticamente.

Boounva: Bicuiba redonda. (Myristica officinalis. Mart.)

Bocunva: Bicuiba. (Myistica bicuiba. Schoth.) -0 gerue está dentro de uma substancia sebacea, que corresponde as cotyledones, cujas propriedades entre outras é ser laxante como todas as substancias pingues; indica-se duas oncas.

Cacáo. (Theobroma cacao. L. e Th. bicolor. Humb)-Tambem pelas propriedades pingues póde ter applicação como laxante.

Sesamun oxientale.-Oleo que é muito brando.

Barthollesia excelsa.-O oleo como o antecedente para o uso da mesa, e para brandissimas applicações.

O oleo das palmas todas (que se pódem enumerar trinta, e mais) enumeramos só pelá propriedade pingue. que tem de commum, e como tal laxante.

Mur.ici. (Buchosice sp. var.)-Muitas especies ha n'este genero com os nomes de fructa de perdir. pão de semana, e outros, que todos dĩo drupas, cujo sareocarpo, segundo Pison 
faz purgar, bem assim outras especies d'esta familia das malpighiaceas.

Araticum. (Annono spr. var.) Muitas especies temos d'este genero, cujas sementes fazem vomitar, e purgar na dóse de uma, ou duas que se mastiguem; o que induz a tentar-se as sementes das atas, e fructas de conde.

- Imbir ou Umbú. (Purruna guienensis. Aubl.)Parece-nos que se deve reduzir a esta capitulação uma arvore enumerada por Justiniano, em sua These, como com fructos laxantes. Do mesmo lugar transcrevemos as seguintes de que não temos conhecimento.

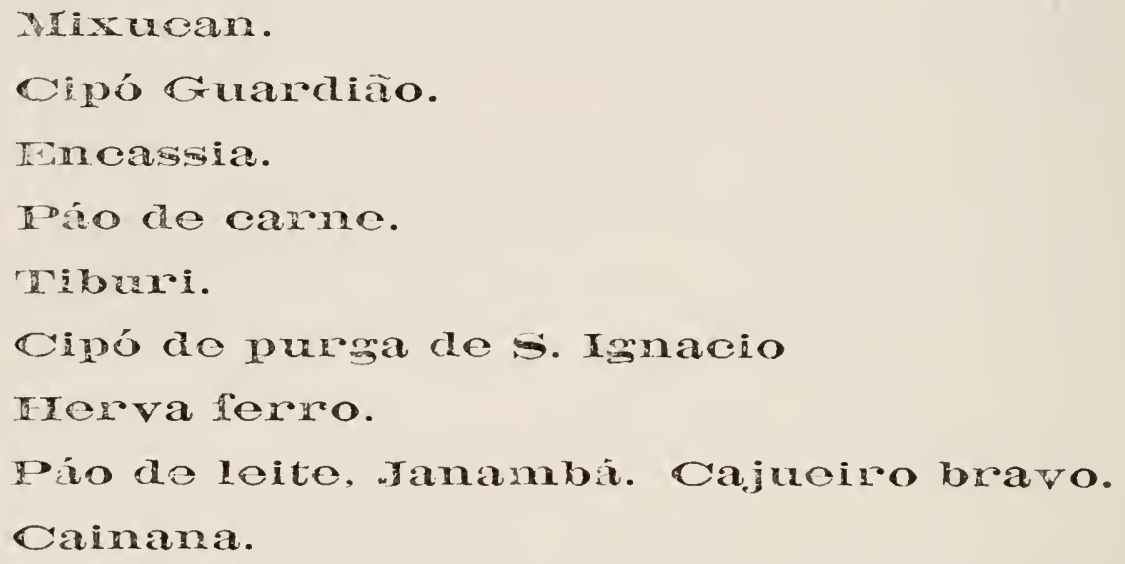

As ervas oleraceas em geral: algumas em particular como o carurú, Amarantinus viridis L., espinafres, e outras acclimatadas, devem ser contadas para a medicina prophilatica como laxantes.

Plantas verdes em geral. - O livrinho das arvores principal ${ }^{-}$ mente, tem uma humidade adstringente, que quasi sempre é purgante : esta propriedade muitas perdem pela desecação. Todos os agentes, que temos enumerado d'e-ta especie devem-se observar seccos, e em extracto, etc., pois pensamos que o alcali tem muito grande parte no seu effeito, combinando-se com o acido do estomago, e intestinos, e que, volatisado o alcali, ou neutralisado pelo calor, e principios do ar, deve obrar differen-

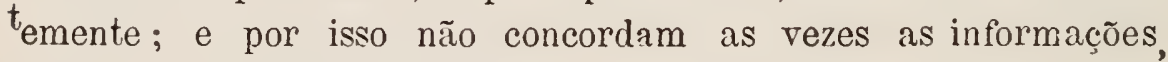
com as experiencias: a analyse porém d'estas substancias em todos os estados virá um dia a estabelecer o meio de tirar o partido de que são susceptiveis. 
Fructos sumarentos.-A maioria dos fructos sumarentos, obram como uma dissolução de saes, que de certa quantidade para cima, soltam o ventre: podia-se fazer d'este genero um grande catalogo.

Potassa.-D'este elemento da maioria dos vegetaes,se tiram muitas composições, que satịfazem o nosso objecto.

Soda.-Igualmente este sal póde-se ter de plantas brasileiras.

Tartaro.-E outros saes de que abundam tantos vegetaes.

Assucar. - Laxante como os outros saes, só com differença de gráo, e sempre applicavel como coadjuvante, além de tantas propriedades.

Não se deve omittir a cataia, ou herva de bicho (Polygonum hydropiper) e muitas plantas estimulantes, e outras mucilaginosas, etc. etc. etc., que tem applicação em clysteres. Podiam-se enumerar mais de cem d'estes agentes. 



\title{
PLANTAS MONOCOTYLEDONEAS BRASILEIRAS EMPREGADAS NA MEDICINA
}

\author{
PELO \\ DR. EMILIO JOAQUIM DA SILVA MAIA
}

Palmeiras. (Palmo).-Esta preciosa e rica familia que depois das Grammineas é, sem duvida alguma, a que maiores serviços presta ao homem, existe em abundancia no Brasil, onde pelo seu sublime aspecto e magnifica vegetação muito concorre para o ornamento e riqueza do nosso abençoado paiz. Quanto não é magestosa e encantadora a vista de um nosso Guaguaçú (Attalea spesiosa Mart)? Quanto nos não é util e vantajosa uma Carnauba (Corypha cerifera Mart.) ou uma Piassaba (Attalea funifera Mart.)?

Martius a quem se deve um importantissimo trabalho sobre esta familia natural, obra além d'isto mui notavel pela belleza das estampas e por ser terminada por um apendix de Mohl sobre a estructura anatomica d'estes vegetaes, nos tem feito conhecer para mais de cem especies Brasileiras, quasi todas offerecendo em algumas ou em todas as suas partes, productos uteis á medicina, ás artes, e á economia domestica. Este celebre viajante, cujo nome será sempre mui grato aos amigos das sciencias naturaes e do Brasil, sendo o naturalista, que explorando com toda a coragem e denodo algumas de nossas Provincias do Norte, nos tem feito melhor conhecer estes vegetaes, será o nosso guia n'esta occasião, sobretudo para os seus nomes scientificos. 
As palmeiras sendo, como nota mui judiciosamente A. Richard, a familia que contém as arvores mais elevadas, e as que tem fructos mais proficuos, habitam quasi todas, a excepção de duas ou tres, os paizes equatoriaes, beneficiando estes logares com a sua presença. Ellas são die dimensões mui differentes, e como observa o Sr. Riedel no manual do agricultor Brasileiro « se encontram de anãs até gigantes e de meia pollegada até 3 palmos de diametro, »

Os antigos não conheciam senão tres especies de palmeiras, porém tendo bem estudado sua fecundação já tinham notado que estas arvores eram dioicas, isto é, que seus orgãos sexuaes achavam-se distinctos em cada individuo, o que bem se collige de algumas de suas obras, que chegaram até nós, como as de Theo. phrasto e Plinio. Elles vieram naturalmente á este conhesimento, pelo costume que tinham os Arabes não só de cultivarem unicamente individuos femeas, indo depois buscar no matto as flores dos machos para saccudir sobre ás d'aquellas, e assim as fecundarem, como igualmente porque nas suas guerras não procuravam destruir o inimigo senão os individuos machos, pois d'esta maneira vinham arruinar completamente esta util plantação, como o que thes faziam grande damno. Foram certamente estas idéas? dos antigos, a respeito dos sexos das $\mathrm{pal}^{-}$ meiras, que levaram o immortal Linnêo a estabelecer seu ingenhoso systema de classificação botanica, tendo melhor que seus predecessores estudado as flores de todos os vegetaes.

Agora seria a occasião de expôr os outros caracteres botanicos, que separam esta familia de todos os outros do grupo das monocotyledoneas; porém como já temos dito mais de uma vez, não sendo o nosso fim n'estes artigos de materia medica brasileira, señ̃o chamar a attenção do publico e de todos os nossos collegas sobre as immensas applicaç̃es medicas que se podem fazer de uma infinidade de nossas plantas, por isso nada mais diremos a este respeito, e nos limitaremos n'estas generalidade sobre as palmeiras a aquillo, que julgarmos poder interessar a todos os nossos leitores em geral.

As palmeiras não só são notareis pela elegancia de suas formas, como tambem pelos immensos serviços que prestam aos habitantes dos paizes onde ellas se acham. Certamente immensos 
são os beneficios que o homear póde encontrar n'estes bellos vegetaes, nada ha n'elles, que se não possa approveitar, e só n'elles como diz De Lens se póde achar todo o necessario para a conservação da existencia e saude do homem. No decurso d'este artigo faremos ver alguns dos recursos que a medicina brusileira póde ahi achar, e por agora seja-nos no entretanto permittido notar de passagem alguns dos muitos outros prestimos

Estes vegetaes tendo um tronco direito, cylindrico, as vezes bastante elevado, e despido de follhas em uma grande parte do seu cunprimento, mas contendo no seu apice estas em forma de tufo e extendidas a maneira de um leque, nos appresentam assin uma sombra extensa e bastante agradavel bos nussos climas ardentes. Com effeito quanto não é suave o repouso debaixo de urn coqueiro (Cocos nucifera L.)! Quanto a imaginação se não deleita á sombra de um Buriti (Mauritia vinifera Mart.), evitando-se por este modo os effeitos as vezes terriveis da insolação debaixo dos tropicos! Na Asia a especie-Colypha umbraculifera L. - i tăo proveitosa a este respeito, que pela immensa extensão de suas folhas, póde nesmo abrigar debaixo de si muitas dezenas de homens.

Algumas outras palmeiras pela cureza e consistencia do seu leuho, o qual se póde prestar para o fabrico de certas obras de carpintaria, nos offerecem igualmente uma exceilente madeira de construcção. Ėatre nós já muito uso se fez d'estas madeiras, sendo mesmo ji al:rumas objecto de commercio; taes são os nossos Ayris oil Iris (Astrocarium ayri Mart.), os nossos Patis (Corus batryophora Mart.), as nossas Guarirobas (Cocos o'eracea Mart.) e outras. Alguns d'estes lenhos passam mesmo por ser inalteraveis pelos vermes e o nosso destruidor cupinr.

Muitos outros indiviluos d'esta familia, possuindo um seiva mui abundante e assucarada, a qual se póde obter mui facilmente. furando-se a arvore alguns pés acima do terreno, nos appresentam assim uma bebida deliciosa e refrigerante, de grande recurso nos paizes quentes; d'esta mesma seiva, póde-se pela formentaçăo fazer um excellente vinho, e pela desecação obter uma especie de mel agradavel, e is vezes jassucar. Muitas de nossas palmeiras contém esta seiva em grande quantidade, e 
entre outros nomearemos os Buritis, e as Carnaubas de que já fallamos, e a Pindova chamada pelos Indigenas Ndaja-assú. (Attalea compacta Mart.)

As folhas destes vegetaes tem igualmente muitas applicaçres domesticas, ellas, sendo bastante fortes, tibrosas, e de grande duração, servem para cobrir casas, e fazer ranchos, esteiras, balaios, cestos, redes, chapéos \&c., e de tudo isto se faz um uso quasi diario entre nós. Para cobrir casas servem as folhas de qualquer palmeira, porém n'esta Provincia do Rio de Janeiro usa-se de preferencia das folbas do Pati ou Patioba já ncmeado; para o fabrico de esteiras e cestos os filamentos das follhas do Buritis sĩo os mais usados, ainda que as fazem-se tambem dos de outras muitas especies: os filamentoz que se extrahem das folhas das especies (Bactris Acanthocarpa Mart., e B. maraja Mart.), e outras do mesmo genero, que tem o nome vulgar de tucum, de tucum bravo, são muito empregados sobretudo para fazerem-se rêdes. Segundo o testemunho do Sr. Riedel, os Indios de Matto-Grosso preferem as folhas do Guaguaçu, de que já fallámos para a factura de suas casas ou ranchos, e os do Rio das Amazonas as da palmeira Baxiuba (Iriatea ventricosa Mart.) Pelo crescimento successivo das palmeiras indo pouco a pouco morrendo as primeiras follıas, e separando-se então pela decomposição, que nellas tem lugar, a parte cellular da fibrosa, e persistindo esta em algumas eșpe cies enroscando-se sobre o tronco da arvore, torna-se pelo decur'so do tempo bastante dura, vindo d'este modo muito a convir para a fabrica ção de muitos objectos uteis ao homem: taes sĩo os filamentos, que nos fornece a Piassaba, já citada, da qual ji muito uso se fez entre nós, para o fabrico de vassouras, cordas, e amarras que são indestructiveis n'agua. Hoje quem não sabe, que já existem muitos navios brasileiros cujos cabos, cordas, e amarras sĩo todos de piassabas! Quem não conhece que estes filamentos sendo mui fortes, e consistentes duram tambem por muitos annos!

o renovo final, que brota em algumas outras especies d'esta familia, appresentando folhas ainda não desenvolvidas, que são tenras e mucilaginosas, vem a ser um excellente alimento de que já muito gasto se faz no Brasil, preparando-se de mil maneiras, tal è o que vulgarmente chamamos palmito, e sabido 
é de todos, que habitam a terra de Santa Cruz, o quanto esta comila é deliciosa. As arvores de que mais vul rarmente se extrahe entre nós este palmito são as seguintes, a Guariroba, hoje a mais usada no Rio de Janeiro, e que tambem tem o nome de palmito amargoso, a Jussara ou Issara (Euterpe oleracea, Mart.), que nós chamaremos palmito do Pará, pois é a arvore usada por excellencia n'aquella provincia para isto, a Pindova já acima nomeada, e outras. Os Indios Bororós, habitantes da provincia de Matto Grosso, se nutrem quasi especialmente de uma especie de palmito, a que lão o nome de Bacava (Differentes especies do genero C. Enozarpus), com elle estes Indios preparam uma especie de pão mui duro, de que muito se servem, guardando-o para quando lhes falta o palmito fresco; asseguram-me algumas pessoas que já tem estado n'aquella provincia e comido d'este pão, que elle não é desagradavel ao paladar.

0 interior de quasi todas as palmeiras contém uma medulla muito nutriente, a qual alguns selvagens a comem mesmo crua; e é com a medulla de algumas outras especies, que na Asia se prepara o sagú, farinha já muito conhecida. Nós tambem possuimos algumas palmeiras de cuja medulla já em algumas provincias se prepara farinha. a qual se come sobre tudo em forma de mingáos; assim nas provincias de Mattn-Grosso, e Ceará, prepara-se esta da Carnauba já fallada, e no Pará especialmente dit Bubunha (Guilielma speciosa, Mart.)

Estes precioscs vegetaes acham-se t.ımbem quasi sempre cohertos de numerosissimos fructos, os quaes sendo on amargosos, ou acidos, ou mucilaginosos, apresentam além d'isto uma grande variedade na estructura e fórma. Com effeito, immensa é a differença que existe entre os nossos cocos de catharrhos (Acrocomia sclero carpa, Mart.) Cocos da quaresma (Cocos oleracea, Mart.) Baba de boi (Cocns flexuosa, Mart.) Guiriri ou Guri (Diplothemium lithorale, Mart), e Cocos da Bahia, etc., etc. Estes e outros muitos fructos das palmeiras são comestiveis e de um gosto agradavel: de uns comem-se a parte externa, de outros a interna. A casca de muitos d'estes fructos serve tambem para - fabrico de cordas, do caroço de outros podem-se extrahir oleos com serventia para a luz, para preparar alimentos, para a medicina e outros usos, em fim, de alguns bebe-se o liquido, 
vulgarmente chamado agua de coco, que se achando no interior do fructo vem a produzir o albumem.

Existe ainda n'esta rica familia um producto, que pela sua singularidade e importancia não podemos deixar de fallar d'elle, este é a cêra vegetal, fornecida pela uitilissima Carnauba, já acima mencionada. Esta cêra que cobre a superficie das novas folhas, e que se apresenta debaixo do aspecto de um pó glutinoso, não mui abundante, tem quasi a consistencia e mesmo o cheiro da cêra fornecida pelas abelhas, ainda que a sua côr seja differente Ella é susceptivel dos mesmos usos e applicaç̃es da cêra ordinaria, e por isso já entre nós se fabricam velas com este producto, as quaes as vezes apparecem aqui ro mercado d'esta côrte; todavia convém dizer, que estas são sempre inferiores ás fabricadas com a cêra ordinaria, tanto na côr como na duração e consistencia; mas se combinar uma cêra com a outra, o que pode-se mui bem fazer, as velas sabirão boas em todos os sentidos. O Sr. Brande. chimico Inglez, já analysou esta singular cêra, recebendo parte de uma porção d'ella enviada do Brasil pelo Sr. Conde das Galveas a Lord Granville, em Londres, e esta analyse acha-se no Investigador Portuguez, tomo $2^{\circ}$, pag. 33 .

Taes sĩo, em resumo, os immensos beneficios que nos rendem as palmeiras, e como quasi todas habitam o Brasil, ellas muito concorrem para a riqueza do nosso solo, e a belleza de nossos campos e bosques. Certamente se exceptuarmos as Gramineas, nenhuma familia é tão util ao genero humano como esta. E' só n'ella, como acabamos de vêr, que o homem poderá ao mesmo tempo encontrar sombra saudavel, habitaçào commoda, vestidos, cama, nutrição sã e abundante, leite, vinho, mel, assucar, e, em fim, cêra para as suas precisões. Todavia estes não são $O S$ unicos serviços que as palmeiras pódem fazer a humanidade, ellas ainda offerecem prestimos á arte de curar.

Segundo o que já fica dito, é facil de prever alguma das applicações medicas que se pódem fazer de alguns dos productos d'estes uteis vegetaes; assim, contando quasi todos uma seiva mais ou menos abundante, que é refrigerante, logo que sahe da arvore, uma farinha bastante nutriente, e oleos mais os menos energicos, devem servir em todos os casos onde estes meios 
são reclamados. No entretanto, em geral, podemos dizer que as palmeiras são antes plantas economicas do que medicinaes, sendo além d'isto estes seus usos medicos ainda mui limitarlos entre nós. Todavia vamos dizer o que tem chegado ao nosso conhecimento a este respeito.

Cocos.-Este genero de palmeiras, que conserva o nome dado pelos indigenas dos paizes onde elle cresce, além de muitas outras especies, encerra duas que, existindo em abundancia no Brasil, tem igualmente grandes applicações medicas. Taes são as especies (C. nucifera, L. e C. oleracea, Mart., das quaes pasaamos a dizer alguma cousa.

A primeira é o nosso coqueiro ordinario, bastante conhecido de todos, e impropriamente chamado n'esta Corte coqueiro da Bahia, naturalmente por ser esta a provincia que importa mior quantidade de fructos d'esta palmeira no mercado do Rio de Janeiro. Este precioso vegetal, que não é indigena do Brasil, mas que já se acha muito generalisado entre nós, nas visinhanças do mar, contendo entre si 20 e tantos productos differentes, cada um com prestimos diversos, vem a ser sem duvida alguma o maior presente que a natureza deu ao homem, e pelo que com justa razão deu-se-lhe o nome de Rei dos vegetaes. Além da seiva e da medulla que pódem prestar alguns pequenos serviços medicos, como já dissemos, é sobretudo no fructo d'este utilissimo vegetal que encontraremos productos de grande utilidade a sciencia de curar. Não obstante, as suas raizes feitas em cozimento, passam tambem na provincia da Bahia por gosarem um pouco de propriedades adstringentes, e portanto b as para os casos onde estes medicamentos convém, porém não sabemos até que ponto isto é verdadeiro.

Este fructo, que é certamente a parte mais importante do coqueiro, e que tem o volume de um pequeno mellão, e a fúrma um pouco triangular, contém, além da casca, que é lenhosa, um outro involucro externo que é tibroso, e que serve para o fabrico de cordas etc. Na India obtem-se por distillação d'esta parte lenhosa um oleo empyreumatico, que passa entre os habitantes d'aquelle paiz como o remedio mais energico contra as dures de dentes, como se vê do Jornal de Pharmacia, vol. 3, pag. 466. A amendoa, que se acha dentro d'esta casca lenhosa, 
- que é branca, compacta, e bastante dura, além de ser agradavel alimento, mas um pouco indigesto, presta-se para a preparação de emulszes e loochs, como já se pratica nas Autilhas, onde ella, por assim dizer, substitue as amendoas doces, e este uso seria muito á desejar que se praticisse igualmente no Brasil, onde estes fructos são tâo vulgares.

E' d'esta amendoa que se póde extrahir um oleo, que gozando de propriedades adocantes, sedativas e emollientes muito convém á medicina. Os habitantes das ilhas do mar pacifico untam-se com elle, o qual tambem muito serve para a preparação de alimentos. Na India elle é mesmo muito usado para o fabrico dos emplastros, como nos assegura Ainslie.

O povo, em algumas provincias do Norte do Brasil, serve-se tambem muito d'elle para combater qualquer dor fomentando com este oleo a parte doente, bem como o empregam com successo contra algumas feridas: o que tudo temos ouvido dizer a pessoas, que tem residido n'aquellas provincias. Maıtius, na sua bella obra sobre Palmeiras do Brasil, certifica igualmente - que acabamos de dizer, para prova do que, transcrevemos 28 suas proprias palavras a este respeito. « Dolorem sedat et prœcipue ortum a frigida causa et mire vulneribus opitulatur. " Além d'estes usos medicos, elle passa tambem por ser um excellente remedio em fomentação contra a contracção dos tendj̃es, em clyster contra as hemorrhoidas, e misturado com o oleo de cravo e em fomentação contra algumas paralysias das extremidades, segundo informações que temos recebido. Por nossa propria observação por ora nada polemos dizer a este respeito, porém julgamos necessario fallar d'estas applicacões, feitas pelo vulgo, do oleo extrahido do coco, tanto porque muitos d'estes usos estão em harmonia com as propriedades d'este - leo, como porque chamando d'esta maneira a attenção do pu blico medico sobre este objecto, elle poderá vir a ser melhor esclarecido.

Logo que o coco chega ao volume que lhe é natural, contém no seu interior um liquido branco, chamado entre nós agua de coco, e que podemos fazer sahir para fora, furando um dos tres pequenos buracos que se acham na base do fructo. Este liquido, que é de um gosto agro-doce, bastante agradavel, é uma bebida re- 
frigerante muito util nos nossos climas, e que passa mesmo por ser mui saudavel para o peito. As senhoras nas Autilhas lavam tambem o rosto com elle, por o julgarem bum para amaciar a pelle, assegurando alguns viajantes que realmente ellas tiram d'i-to grande proveito Martius diz que elle é diurectico, o que no entretanto nunca notamos, apezar de termos muitas vezes bebido d'esta agua: todavia, segundo nos affirma Mr. Lesson, ella parece ter alguma influencia solire o systema urinario, assim diz este escriptor na su 2 Viagem Medica, pag. 65: "que esta beberagem causa uma viva comirhão na urethra, provoca uma purgação que tinge a roupa de preto. $\gg$ A vista do que, seria muito a desejar, que se verificasse entre nós esta singular propriedade d'este liquido, do qual a medicina póde a este respeito vir a aproveitar-se. C vulgo no Brasil já muito se serve d'e'le como do collyrio em muitas inflammaçes de ollus, e tem. se-ıos assegurado, que quasi sempre é com inteiro successo. Na analyse que Mr. Trommsdorff fez da agua do coco, a achou composto de agua, assucar, gomma, carbonatos e hydrochloratos salinus, e outros saes, para o que vêde o Juurnal da Pharmacie. Tum. 2, pag. 97.

De todas as appl:caç⿸es medicas, que já se fazem das diversas partes do fructo do coqueiro, a mais util, e aquella que apresenta resultados mais felizes e em maior n"mero. é a da amendoa ou da sua agua como anthelmintica, sobretudo contra a solitaria. Porém nos immensos casos que temos ouvido a este respeito, requer-se como condicão indispensavel para se ubter este fim, que a amendoa esteja já um pouco corrupta; a agua, que ella contém, em fermentação, addicionando-lhe ao mesmo tempo um pouco de um espirito qualquer. Entre outros fuctos passamos a referir os dous seguintes, que não deixam duvida alguma.

Ha anno e meio pouco mais ou menos, entrou no Hospital de S Francisco de Paula, um homem qụe, segundo a exposição que fez dos seus incommıdos, e segundo os symptomas que entĩo apresentava, mostrava padecer pela presenca de um tœuia no seu canal intestinal. Elle communicou tambem ter já tomado infructuosamente muitos remedios receitados por diversos facultativos d'esta Côrte. Vendo então os praticos daquelle 
Hospital, que o doente não expulsava vérme algum, apezar d'elles terem empregado os meios reclamados em iguaes circumstancias, e além d'isto lembrando-se das outras medicações porque o enfermo tinha pas:ado, resolveram-se lançar mão de tratamento empirico, que tinham ouvido gabar muito. N'esta conformidade mandaram vir um coco, furaram-lhe os tes buracos da base, e acabaram de encher de aguardente, depois enterraram este coco por espaço de 15 dias, deixando ficar de fóra os lugares dos buracos, o que tudo foi executado fielmente pelo enfermeiro da casa. Passados os 15 dias, achando-se já o coco um pouco corrupto ou podre, como vulgarmente se diz, e a agua fermentada, pri cipia_ ram a dar pela manhã ao doente uma colher de sôpa d'este liquido já assim alterado, depois de alguns dias passaram a duas colheres, e assim foram indo, até que, com grande admiração, virãu-ıo expulsar uma soliıaria bastante comprida. Este caso foi-nos referido pelo medico da casa o Dr. De Simoni, e pelo Cirurgião da mesma o Sr. J. Alves de Moura.

o segundo caso nol-o contou o Pharmaceutico Luiz Antonio da Costa Mattos. Uma preta, escrava de uma senhora do seu conhecimento, moradora na rua do Alecrim, (hoje do Hospicio), padecendo ha muito tempo de um tœenia, contra o qual se tinha empre. gado, sem resultado algum, muitos remedios, foi tratada por esta medicacão empirica com completo successo. Para isto tendo-se mandado vir um coco já podre. o que se conheceu pelo máo cheiro, que exhalava quando fni aberto, se principiou a dar á doente de duas em duas horas uma colher de sôpa da massa que já se achava alterada dentro do coco, e em cima dava-se outra colher de vinho generoso; no outro dia depois d'esta applicacão teve lugar a sahida de uma solitaria de 10 braças de c.impirdo. Como este caso, temos ouvido outros muitos referidos por pessuas do povo.

A'vista dos dous factos que deixamos expostos, alguem poderá suspaitır, que a expulsão da solitaria foi talvez devida ao uso da bibida al coolica, que ao mesmo tempo tomaram estes doentes; porim a isto diremos, que nada d'isto devemos suppor, tanto por ser p quena a quantidade de espirito de que elles usavam, como porque nos diver:os tratamentos porque tinham passado já haviam tomado tinturas e outras bebidas espirituosas sem 
resultado algum, sendo além d'isto estes doentes habituados a bebidas alcoolicas. No entretanto, attendendo á magnitude do objecto, e á grande divergencia, que existe no modo d'esta applicacão, serí muito conveniente, que algum nosso collega occupando-se especialmente d'este objecto, determine até que ponto elle é efficaz, e qual a melhor maneira de fazermos a appli-

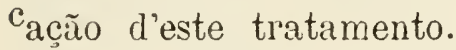

Assim, segundo o que deixamos expendido, e segundo a asserção de alguns viajantes, é de crêr que a agua do coco, ou o mesmo coco, tendo antes passado por alguma preparacĩo, póde vir a ser um excellente remedio anthelmintico, do que os praticos poderão tirar grande proveito. Martius, que bastante se occupou com os usos medicos de nosso coqueiro, quando falla da agua do fructo, certifica esta sua propriedade medica, baseando-se no testemunho de Recicho. Eis como elle se exprime n'esta materia: « d'este Recho, si octo unciarum pondere addito sale, matutino tempore assumatur, utilissimum est necandis vermibus. »

Taes são os usos medicos do coqueiro de que temos conhecimento, os quaes, posto que por ora mal estudaros, nos poderão todavia muito aproveitar na falta de outros mielhores. Possam estas e outras razões fazerem com que alguns praticos Brasileiros, qiie estejam em melhores circumstancias, estudem melhor estes usos publicando o resultado de suas investigações.

A segunda especie de coqueiro de que temos a fallar é o C. olvracea. Este bello vegetal, conhecido entre nós pelos nomes de Guarivaba, ou Palmito amargoso ou Iraiba, segundo Pison, além de muitas serventias, que tem na economia domestica, é igualmente util nas febres intermittentes, onde muito aproveita, segundo tenho ouvido dizer. A parte empregada é o mesmo palmito dado em cozimento. Nós anda não tivemos nccasião de o empregar, e por isso nada podemos certificar sobre esta sua propriedade antifebril: porém sabemos que o Dr. Silva, Professor da escola de medicina d'esta Côrțe, já o tem empregado felizmente como tal, pois este é um dos remedios de que fallo r na sua aula o anno passado. Assim muito conviria á sciencia que este senhor publicasse o resultado de suas observaçōes a este respeito.

Corypha.- Este genero que é notavel por suas lindas 
folhas, é o que contém a nossa preciosa Carnauba ( $C$. ceriferc. Mart), de tão grande recurso nas provincias do Ceará, Piauhy, Mitto-Grosso, etc Esta util arvore não só presta grandes beneficios na economia domestica, dos habitantes dos logares onde ella nasce, alguns dos quaes já foram por nós apontados, como é de graude auxilio á medicina d'aquelles povos. Assim, a cêra que el'e produz póde entrar em todas as preparações pharmaceuticas oarle entra a nossa cêra, e a amendoa do seu fructo e as suas raizes gosam de muita reputação como antivenereas

E' da sua raiz, sobretudo, que se faz grande uso como remedio anti-syphilitico, principalmente na provincia do Ceará. Ella \&́ ahi empregada em coz:mento na dóse de uma onca de raiz para libra e meia d'agua, até ficar reduzido a uma libra, a qual porcão a dão por dia em tres doses. Todas as pessoas que têrn habitado aquella provincia nos asseguram a efficacia d'este medicamento para combater todas as mulestias venereas; e elle ahi passa tambem como mui util na gotta e no rheumatismo Ainda ha pouco tivemos occasião de receber do Ceará, do Sr. Manoel Josí de Albuquerque, uma carta com a remessa de alguns productos botanicos, onde elle, elogiando muito esta raiz, nos relata alguns casos de curas semelhantes obtidos por ella. Nós a vamos pôr em pratica, e em tempo opportuno communicaremos o nosso juizo sobre esta materia.

Elais.-E' a este genero que pertence a arvore de que Pison falla com o nome de Pindova (E. Butyracea. Kunth). Nome ainda hoje conservado ao mesmo vegetal na proviacia de Pernambuco, porém que é preciso não confundir com a Pindova do Ric e Bahia, tambem conhecida pelos nossos sertanejus pelo nome de Indaiaçú que é de um ge.ıero differente (Attulea compacta. Mart.) A Pindova de Pison contém um fructo cuja amendoa é bom alimento, e d'esta póde-se extrahir um oleo, ou manteiga, d'onde vem o nome da especie, que é emolliente e adoçante, e como tal empregado pelo vulgo sobretudo nas contracç̃as dos tendões, onde elle aproveita, segundo temos ouvido dizer. Do alto d'esta arvore corre uma gomma transpare um cheiro mui agradavel, que póde inteiramente substituir a gomma-arabica nos immensos casos om que ella é usada na arte 
de curar, como nos certifica Pison. E' igualmente a este genero que pertence o nosso coco de dendê (Elais Guineensis. L), cujo oleo do fructo as vezes é tambem usado pelo vulgo como medicamento.

Estas são as palmeiras que nos pódem prestar algumas serventias medicas: outras muitas ainda existirão, porém das quaeś até hoje ainda não temos conhecimento algum. Todavia não devemos terminar este artigo sem lembrar, que os fructos do Burity, do Guriri ou Guı'i contém oleos, de que o povo já entre nós se serve como emolliente e adoçante, e que podem muito convir' á medicina.

De tudo que fica dito claramente se vê, que sendo por muitas consideraç̃es grande a importancia d'esta familia, nos occupou por mais tempo que nenhuma outra de que até hoje temos fallado, e que por isso não nos deixando ella n'este artigo espaço algum para fallarmos de outras familias monocotyledoneas, continuaremos com as outras nos artigos seguintes. 



\section{EXAME BOTANICO}

DA PLANTA INDIGENA DO BRASIL, VULGARMENTE CHAMADA

TATAJIBA

Lendo a informação que dá o padre José Ribeiro a respeito da Tatajiba nâo pude assentir ás razões, com que se propõe provar não ser ella-nem o Morus alba, do Dr. Linneo, como pareceu ao Dr. Pison, nem o Morus tinctcria, como traduzio o Dr. Brotero, por serem ambas classificadas na Monoicia Tetandria, e ser esta da Dioicia Manandria, de um genero, e especie desconbecidos até agora pelos Botanicos, que tem lido.

o defeito de leitura, e observação tem sem duvida induzido ao autor a aventurar uma semelhante asserção a respeitu de uma arvore tão celebre no novo, como no antigo mundo pelo commercio, e utilidade da sua madeira em tinturaria, e cujo conhecimento remonta sem duvida á época dos primeiros estabelecimentos dos Europeos na America. Ella tem sido successira mente o objecto das indagações, e observações da maior parte dos Botanicos, que tem pa sado ás differentes colonias d'America. Vejam-se Marcgrave-1. 3. c. 14-Plumier-Icones-199-tt. 240Stoanne-Histor.-Jamaic, tt. 158-Plucknet 396-tt. 239-fig. 3.Brown-Jamaic. 339.-Ray Dendrol--666-Linneo Genera e spec. Rant edit, Gmelin-Miller-Diccion.-Jacquin-Amer. 247 tt. 180.

Nenhum d'elles hesitou um só momento que ella não fosse uma especie de Amoreira, mormente os modernos depois da completa descripção que della fez o celebre Jacquin na sua historia das plantas da America, que não deixa nada a desejar, e que 
confrontada uma e muitas vezes com as flores, e fructos tão vulgares n'este paiz a achei sempre conforme pela exactidão e reracidade do autor bem conhecidas, e assis sufficientes a esteiar a reducção que d'ella fizera o Dr. Brotero fundado em tão respeitaveis autoridades.

As durilas que oppõe deduzidas da classe são de nenhum momento, pois que a variução, ou differenca de serem umas especie; hermaphoditas, outras menoicas, dioicas, ou prolygamas, não foi jimais uma nota caracteristica exclusiva de um genero, o que é tão frequente, e particularmente na familiı das Urti eas, e, portanto, no genero-Morus-do qual as especies umas são monoicas como a Alba indica, e tartarica. outras dioicas como a nigra, canadensis, e tinturia, e outras emfin polygamas como a rubra, a mesma nigra, e outras.

Quanto á ordem, numero dos estames, fórma dó calix, e mais partes da fructificaça ha manifesto defeito de observação, pois que alı́m d'aqcellas dos botanicos já citados, e as minhas proprias anteriormente feitas, e todas em contrario. ell as repeti ainda agora outra vez para melhor me certificar, que não houvesse alguma aberração, ou differença entre plantas produzidas em outro paiz; e destacando dos esqueletos que vieram um amentilho masculino, e outro feminino, expondo-os ao vapor quente do acido autico eu os vi desabrolharem-se, e separarem se distinctamente cada flosculo de um, e outro sexo em ambos os amentilhos.

Os flosculos masculinos appareceram com os calices formados de quatro fuliolos ovaes, concavos, e patentes.

Os estarnes quatro, e oppostos, insertos junto á base do calix cada um intortilhado, e preso dentro da cavidade de cada um dos foliolos calycinos, em cuja expansão saltam elasticamente, e se levantam os filamentos filiformes, mais compridos o dobro que o calix, com as antheras dydymas, e biloculares: no cento apparece o rudimento do pistillo esteril.

Da mesma manelra as flores femininas, nas quaes visivelmente se soparou cada flosculo composto de calix de quatro foliolos obovados, convexo-concaros, depressos no topo, conniventes, e cerrados entre si, cobrindo o pistillo fertil, cujo germen ellyptico 
compresso tem um só estylete filiforme, longuissimo, e que rompe por entre os foliolos calycinos coalizados entre si, e peristente.

O fructo é um grupo, ou pinha globulosa formada pela aggregação dos flosculos, cujos calix depois da fecundação tornando-se succulentos, cariosos, e bacciformes encerrain uma só seme.ite lenticular, e ernarginada a um lado do topo no lorar da insersão do estylete, pelo que parecem cordiformes. Notam-se, bem como nos mais fructos desta natureza, alguns flosculos definhados, e abortivos.

Quanto á differença de ter o pistillo um só estylete em vez de dous, é esta uma nota que apenas póde distinguir a especie, sendo - numero tão sujeito a variar.

Daqui se vê, que o autor tomou a parte pelo todo, e contou por flosculo iuteiro cada lacinia do calix com o seu estame, e da mesma maneira as flores femininas onde os quatro toliolos the pareceram outros tantos flosculos, e não achando em cada um a sua competerite semente os julgou abortivos, quando não são mais que si nples diviszes do calix.

Portinuto, á vista dos caracteres familiares genericos e especificos, que se acham inteiramente conformes com os de Linneo, Jussieu, Gertner, Lamarck, e Venteant, e averados pela autopsia de tantos Botanicos respeitaveis, a tatajiba será sempre a amoreira dos tintureiros.

Pretende o vulgo, que ha duas especies, que eu creio meras variedades, unicamente pela differenca do porte e grandeza, e mais ou menos espinhosas, o que pende do t rreno, e talvez da differença dos sexos; pois que foi para mim notavel encoitrar sempre flores masculinas sómente nas arvores grandes, e femininas en arbustos muito ramosos, baixos, porém de uma folhagem mais brilhante, mais verde, maior, e mais bem nutrida. Entretanto eu não avanco isto senão como primeiras vistas apenas de um só paiz, e ainda não generalisadas.

Finalmente, fica claro quão racionavel era a tentativa de ensaiar ou tirar partido das suas folhas para a nutrição do bicho da seda, e dos seus troncos para a multiplicação por enxercia da amoreira branca, e outras igualmente exoticas, e que lhe são tão superiores para aquelle fim como as especies indica e tartarica, cujas sementes se podiam solicitar de Bombay, e melhor ainda de Bengala, de onde 
aqui vieram já algumas que não nasceram por arruinadas. Analogia com estas especies, e a superioridade, que tem na grandeza, a tatajiba promette com probabilidade successos vantajosos que determinarĩo um dia a olhal-a deste lado com attenção, e promover mesmo a sua cultura, utilisando os terrenos perdidos. cansados, e inuteis, em que ella vem de preferencia, e sobretudo para os cercados em logar dos espinheiros, a que ella se presta commodamente pelo seu prompto crescimento, formidaveis espinhos e tecido, ramagem impenetravel, logo que pelo talhe se tornem cespitosas.

Não duvido que estas lembranças sejam caracterisadas de chochas e abortivas, mas, infelizmente para nossa industria, ninguem as contradirá de facto. Rio de Janeiro, 30 de Agosto de 1812.-Joìo Gomes do, Silveira Mendonça.

Mámoel Moreira de Figueiredo. 


\title{
OBRAS DO DR. MELLO MORAES
}

\author{
(NATURAL DA CIDADE DAS ALAGOAS)
}

Materia Medica Homœopathica, 2 vols. em $8 .^{\circ}, 2 .^{2}$ edição......

168000

Repertorio de Medicina Homœopathica, l vol. em $8 .{ }^{\circ} . . . \ldots$.

Nova Pratica Elementar da Homœopathia, l vol. em $32 . . .$. .

Guia Pratica da Homœpathia, l vol..................

Physiologia das Paixões, 3 vols. em $8 . \ldots \ldots \ldots \ldots \ldots \ldots \ldots$

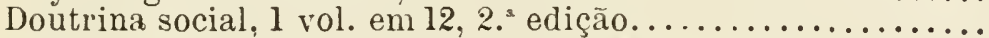

Elementos de Litteratura, I vol. em $8 .{ }^{\circ} \ldots \ldots \ldots \ldots \ldots \ldots . . . . .$.

Ensaio Chorographico do Imperio do Blazil, i vol.............

Os portuguezes perante o mundo, I vol. em $8 . . \ldots \ldots \ldots \ldots$.

O Educador da Mocidade Brazileira, 1 vol. em $8.0^{\circ} \ldots \ldots \ldots . .$.

Memorias diarias da guerra do Brazil, l vol. em $4 . \ldots \ldots \ldots$.

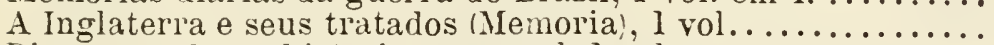

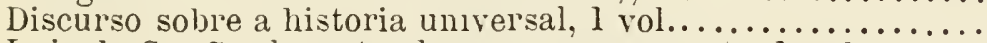

Luiz de Camóes levantando o seu monumento, i vol.........

Os Tumulos, poema pelo Visconde da Pedra Branca, publicadó

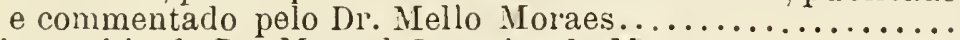

Biographia do Dr. Manoel Joaquim de Menezes..............

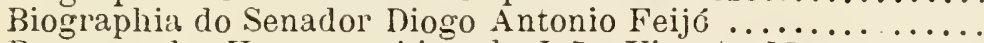

Propaganda Homœopathica de João Vicente Martins e do

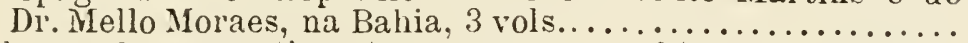

These sobre os sentimentos moraes, para obter o gráo de doutor em medicina na Bahia, 1 vol. em $4 .^{\circ}$, com 56 pags.....

0 Instituto de S. Vicente de Paulo, as Irmãs de Caridade e os

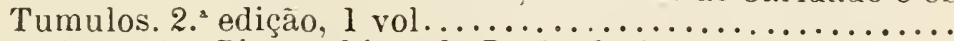

A pontamentos Biographicos do Barão de Cayrú, i vol.........

Biographia do Conselheiro Joaquim Marcellino de Brito......

Necrologia do Senador Diogo Antonio Feijó, l vol. em $8 . \cdots$

Corographia Historica, Chronographica, Genealogica, Nobi-

liaria e Politica do Imperio do Brasil, 亏े vols. em $8.0 . .$. .

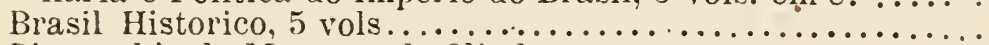

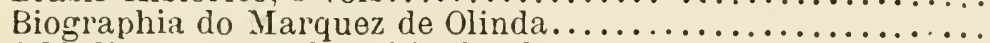

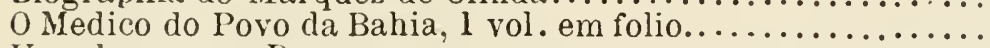

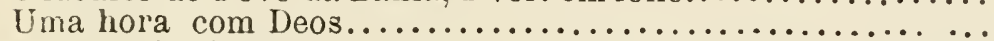

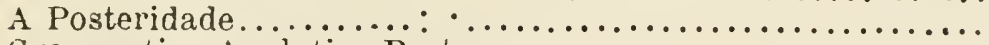

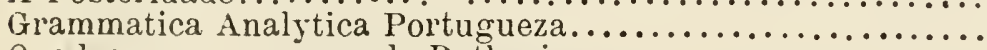

Quadro

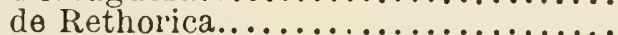

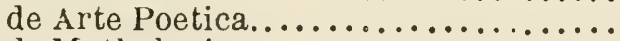

de Mythologia.......................
$6 \$ 000$

$4 \$ 000$

$2 \$ 000$

105000

$2 \$ 000$

$5 \$ 000$

$3 \$ 000$

$6 \$ 000$

$6 \$ 000$

$5 \$ 000$

19000

$1 \$ 000$

$2 \$ 000$

28000

15000

19000

$6 \$ 000$

23000

35000

$2 \$ 000$

15000

25000

$60 \$ 000$

$60 \$ 000$

19000

$30 \$ 000$

$1 \$ 000$

$1 \$ 000$

15000

18000

18000

19000 
Diccionario de Medicina Homœopathica, 1 vol............ 188000

Historia do Brasil-Reino e Brasil Imperı. 2 vols. in-folio..... 158000

o Brasil Social e Politico, ou n que fomos e o que somos...... 28000

A vida e a morte do Conselheiro Francisco Freire Allemão.. 18000

Historia da Homœopathia no Brasil, l vol............... 19000

Deos, a Natureza, o Universo, e o homem, i vol............. $5 \$ 000$

A Febre Amarella, o typho, as epidemias e a peste, l vol..... 18000

A independencia e o Imperio do Brasil, 1 vol............. 58000

Nos prélos:

Chronica geral e minuciosa do Imperio do Brasil, 4 vols,

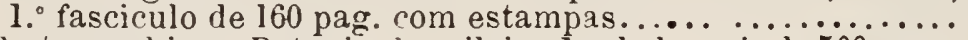

Phytographia ou Botanica brazileira,l vol. de mais de 500 pags.

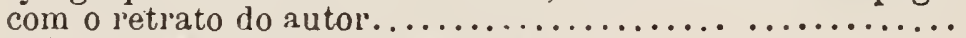

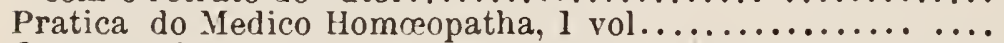

o Tombo das terras e bens dos Jesuitas, 1 tom.............

Historia do Gabinete de 31 de $\mathrm{Ag}$ sto de 1864 que durou até 12 de Maio de 1865, - a Guerra do Paraguay e os serviços valiosos do Duque de Caxias.

Promptos para entrar nos prelos:

Historia da Conjuração Mineira, denominada do Tira-dentes, de 1786 a 1792 seguida do Processo desde as denuncias de 11 de Abril de 1789 por Joaquim Silverio dos Reis, Pamplona \& Basilio Malheiros, até o martyrio na forca do Alferes Joaquim José da Silva Xavier, o Tira-dentes, no campo de s. Domingos, no dia 21 de Abril de 1792.

Historia da Revolucão de 6 de Março de 1817 em Pernambuco. Historia da Republica do Equador em 2 de Julho de 1824. Historia do Sete de Novembro de 1837, chamada a Sabinada na Bahia.

Historia das Fortiflcações do Brasil desde a primeira na Bahia em 1538.

Ineditos:

Diccionario de Aredicina, Cirurgia e Historia Natural.

Trp. do-A POSTOLO-rua Nova do Ouvidor ng. $14 \cdot 16$ 
Ao leitor..................................... I

Historia da Flora Fluminense................... VII

Dê-se protecção á lavoura..................... XV

Destruição das mattas e florestas e seus males incalculaveis. XXIX

Florestas e mattas virgens do Brasil e seus beneficios em

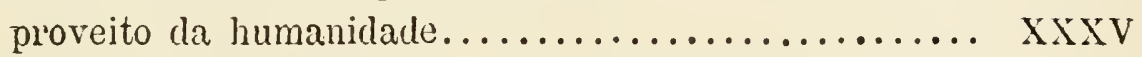

Notas biographicas de Fr. José Marianno da Conceiçĩo Velloso................................. XLI

Notas biographicas de Fr. Francisco Solano.......... XLV

Clima do Brasil............................ XLVII

Clima do Rio de Janeiro...................... XLVIII

Sociedade Auxiliadora da Industria Nacional......... XLIX

Jardim do Campo da Acclamação................ LIII

Córtes das madeiras.-Officio do Dezembargador Francisco

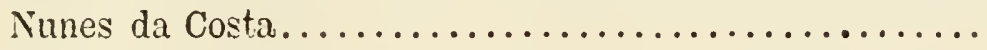

Regimento dos córtes das madeiras em virtude da carta

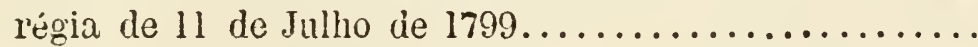

officio de Manoel Joaquim José da Cruz, de 3 de Outubro de 1818, sobre o regimento para os córtes das madeiras...

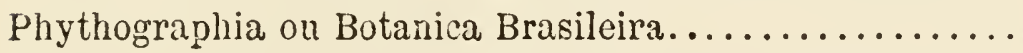
Plantas medicinaes da provincia do Espirito-Santo....... Vegetaes que servem para uso caseiro na provincia de Pernambuco .................................

Plantas que podem produzir evacuações purgativas....... Plantas monocotyledoneas brasilgiras empregadas na me-

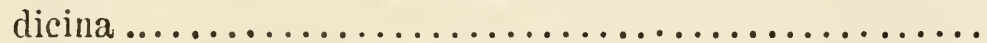

Exame botanico da planta indigena do Brasil, vulgarmente chamada-Tatajiba .......................... 





QK263. Mew York Botanical Garden Library

Mello Moraes C. 2

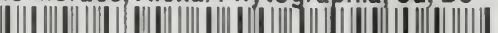

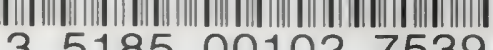

35185001027539 
